\title{
Site Observational Work Plan FOR THE UMTRA PROJECT SITE AT RIVERTON, WYOMING
}

\author{
RECEIV:- \\ OCT $1 \cdot 4 \%$ \\ osr?
}

September 1994 


\section{DISCLAIMER}

Portions of this document may be illegible in electronic image products. Images are produced from the best available original document. 
This report has been reproduced from the best available copy. Available in paper copy and microfiche.

Number of pages in this report: 298

DOE and DOE contractors can obtain copies of this report from:

Office of Scientific and Technical Information

P.O. Box 62

Oak Ridge, TN 37831

(615) 576-8401

This report is publicly available from:

\author{
National Technical Information Service \\ Department of Commerce \\ 5285 Port Royal Road \\ Springfield, VA 22161 \\ (703) 487-4650
}

\title{
DISCLAIMER
}

This report was prepared as an account of work sponsored by an agency of the United States Government. Neither the United States Government nor any agency thereof, nor any of their employees, makes any warranty, express or implied, or assumes any legal liability or responsibility for the accuracy, completeness, or usefulness of any information, apparatus, product, or process disclosed, or represents that its use would not infringe privately owned rights. Reference herein to any specific commercial product, process, or service by trade name, trademark, manufacturer, or otherwise does not necessarily constitute or imply its endorsement, recommendation, or favoring by the United States Government or any agency thereof. The views and opinions of authors expressed herein do not necessarily state or reflect those of the United States Government or any agency thereof. 


\section{SITE OBSERVATIONAL WORK PLAN FOR THE UMTRA PROJECT SITE AT \\ RIVERTON, WYOMING}

September 1994

Prepared for

U.S. Department of Energy

UMTRA Project Office

Albuquerque, New Mexico

Prepared by

Jacobs Engineering Group Inc.

Albuquerque, New Mexico 


\section{EXECUTIVE SUMMARY}

The site observational work plan (SOWP) for the Riverton, Wyoming, Uranium Mill Tailings Remedial Action (UMTRA) Project Site is the first document for the UMTRA Ground Water Project to address site-specific activities to meet compliance with the U.S. Environmental Protection Agency (EPA) proposed ground water standards (52 FR 36000 (1987)). In support of the activities the regulatory framework and drivers are presented along with a discussion of the relationship of this SOWP to other UMTRA Ground Water Project programmatic documents.

A combination of the two compliance strategies that will be recommended for this site are no remediation with the application of alternate concentration levels $(A C L)$ and natural flushing in conjunction with institutional controls. ACLs are to be applied to constituents that occur at concentrations above background levels but which are essential nutrients and occur within nutritional ranges and/or have very low toxicity and high dietary intake rates compared to the levels detected in the ground water. The essential premise of natural flushing is that ground water movement and natural attenuation processes will reduce the detected contamination to background levels within 100 years. These two recommended compliance strategies were evaluated by applying Riverton site-specific data to the compliance framework developed in the UMTRA Ground Water programmatic environmental impact statement (PEIS) (DOE, 1994a).

There are three aquifers beneath the site: a surficial unconfined aquifer, a middle semiconfined aquifer, and a deeper confined aquifer. The site conceptual model demonstrates that the milling-related contamination at the site has affected both the surficial and semiconfined aquifers, although the leaky shale aquitard separating these units limits the downward migration of contamination into the semiconfined aquifer. The semiconfined aquifer is separated from the underlying confined aquifer by a shale aquitard. The confined aquifer has not been contaminated by milling-related constituents. Contaminant distribution is controlled largely by ground water movement, which is generally to the southeast towards the Little Wind River. Ground water from the surficial and semiconfined aquifers ultimately discharges into the Little Wind River.

The Baseline Risk Assessment for the Riverton site identified 10 potential contaminants of concern: arsenic, lead-210, manganese, molybdenum, polonium-210, sulfate, thorium230, uranium, and vanadium. The risk assessment determined that risks to human health can be mitigated by applying institutional controls to restrict access to contaminated ground water in the vicinity of the site. Additional data are needed to evaluate ecological risks.

The identified data gaps and associated data needs are related to the distribution of hydraulic conductivities within the aquifers; seasonal variations in hydraulic gradients; effects of the aquifer matrix on the attenuation and transport of contaminants; definition of background ground water quality entering the site from the west and near the Little Wind River; impacts to surface water and sediments; and the feasibility of institutional controls. 


\section{TABLE OF CONTENTS}

Section

Page

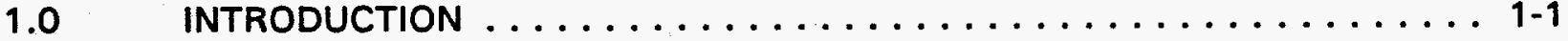

$1.1 \quad$ Ground water compliance strategy . . . . . . . . . . . 1-1

1.2 Relationship to other programmatic documents ......... 1-2

$1.3 \quad$ Content of SOWP revisions ................... 1-2

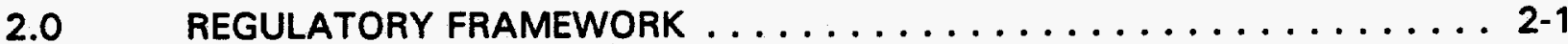

$2.1 \quad$ Uranium Mill Tailings Radiation Control Act . . . . . . . . . . . 2-1

2.1.1 EPA ground water compliance standards . . . . . . 2-1

2.1.2 Cooperative agreements . . . . . . . . . . . 2-4

2.2 National Environmental Policy Act . . . . . . . . . . . . 2-4

3.0 CONCEPTUAL SITE MODEL $\ldots \ldots \ldots \ldots \ldots \ldots \ldots \ldots \ldots \ldots \ldots \ldots$

3.1 Summary of site conceptual model $\ldots \ldots \ldots \ldots \ldots \ldots \ldots \ldots$ 3-1

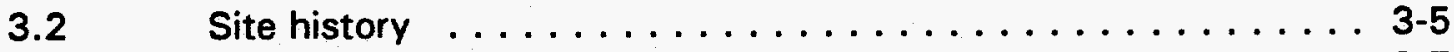

$3.3 \quad$ Surrounding land and water uses $\ldots \ldots \ldots \ldots \ldots \ldots \ldots \ldots \ldots$

3.3.1 Land uses . . . . . . . . . . . . . 3-7

$3.3 .2 \quad$ Water uses $\ldots \ldots \ldots \ldots \ldots \ldots \ldots \ldots \ldots$ 3-7

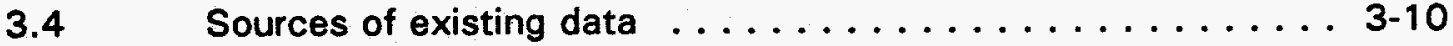

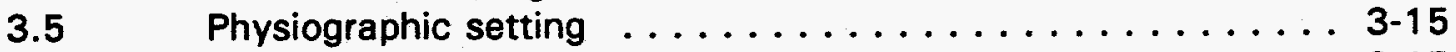

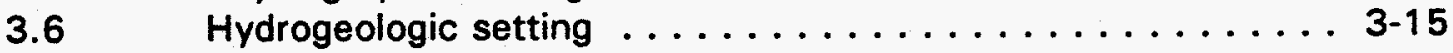

3.6.1 Surficial aquifer . . . . . . . . . . . . 3-17

3.6.2 Semiconfined aquifer . . . . . . . . . . . 3-20

3.6.3 Confined aquifer ................ 3-20

$3.7 \quad$ Ground water quality . . . . . . . . . . . . . 3-23

3.7.1 Background ground water quality ........ 3-23

$3.8 \quad$ Nature and extent of contamination ............. 3-27

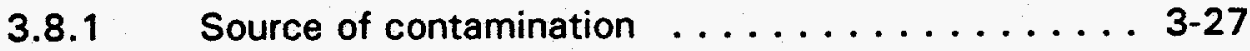

3.8.2 Contaminants of concern ............ 3-27

3.8.3 Extent of contamination . . . . . . . . . . 3-28

3.9 Contaminant fate and transport $\ldots \ldots \ldots \ldots \ldots \ldots \ldots . \ldots \ldots$

3.9.1 Contaminant flushing . . . . . . . . . . . 3-34

3.9.2 Contaminant attenuation ........... . . .36

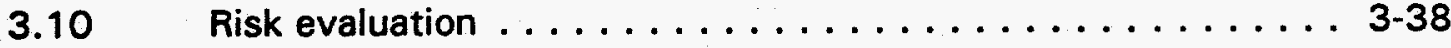

3.10.1 Potential public health impacts .......... 3-38

3.10.2 Potential environmental impacts . . . . . . . 3 3-40

3.11 Evaluation of interim remedial action needs $\ldots \ldots \ldots \ldots . . . .35$

4.0 GROUND WATER COMPLIANCE STRATEGY SELECTION . . . . . . . . 4-1

4.1 Ground water compliance strategy selection process . . . . . . 4-1

4.2 Site-specific ground water compliance strategy ........ 4-3

4.3 Identification of deviations, contingencies, and decision

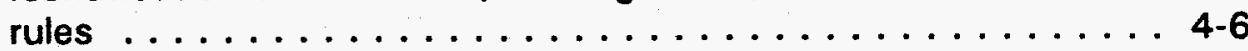


TABLE OF CONTENTS (Continued)

Section

5.0

COLLECTION AND ASSESSMENT OF DATA $\ldots \ldots \ldots \ldots \ldots \ldots \ldots \ldots$ 5-1

5.1

Statement of data needs $\ldots \ldots \ldots \ldots \ldots \ldots \ldots \ldots \ldots$ 5-1

$5.1 .1 \quad$ Aquifer testing $\ldots \ldots \ldots \ldots \ldots \ldots \ldots \ldots \ldots \ldots \ldots$

5.1 .2 Topographic surveying $\ldots \ldots \ldots \ldots \ldots \ldots \ldots \ldots$ 5-1

5.1.3 Monitoring well installation and ground water

sampling . . . . . . . . . . . . . . . . . . 5-1

5.1.4 Surface water and sediment sampling . . . . . . . 5-1

5.1.5 Ground water level elevation monitoring ....... 5-2

5.1.6 Geochemical analysis of ground water and

aquifer matrix ................... 5-2

5.1.7 Toxicological literature review ........... 5-2

5.1.8 Computer modeling of ground water flow

regime ...................... 5-2

$5.1 .9 \quad$ Feasibility of executing institutional controls $\ldots \ldots \ldots$
Data collection objectives $\ldots \ldots \ldots \ldots \ldots \ldots \ldots \ldots \ldots \ldots \ldots$

$5.2 .1 \quad$ Aquifer testing $\ldots \ldots \ldots \ldots \ldots \ldots \ldots \ldots \ldots \ldots \ldots$

5.2 .2 Topographic surveys .............. 5-2

5.2.3 Monitoring well installation and ground water

sampling .................... 5-3

5.2.4 Surface water and sediment sampling . . . . . . . 5-3

5.2.5 Ground water level elevation monitoring ....... 5-3

5.2.6 Geochemical analysis of ground water and aquifer matrix ................. . . . . .

5.2.7 Toxicological literature review .......... 5-4

5.2.8 Computer modeling of ground water flow regime ...................... 5-4

5.2.9 Feasibility of institutional controls . . . . . . . . 5-4

$5.3 \quad$ Data quality objectives $\ldots \ldots \ldots \ldots \ldots \ldots \ldots \ldots \ldots \ldots$

$5.3 .1 \quad$ Aquifer testing $\ldots \ldots \ldots \ldots \ldots \ldots \ldots \ldots \ldots$

5.3 .2 Topographic surveys .............. 5-5

5.3.3 Monitor well installation . . . . . . . . . . 5-5

5.3.4 Ground water level measurements .......... 5-5

5.3.5 Surface water and sediment sampling . . . . . . . 5-6

5.3.6 Water quality sampling and analysis ......... 5-6

5.3.7 Geochemical analysis of aquifer matrix ....... 5-6

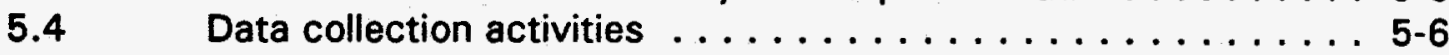

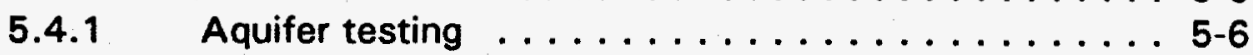

5.4.2 Topographic surveying .............. 5-8

5.4.3 Monitoring well installation and ground water

sampling . . . . . . . . . . . . . . . . 5-9

5.4.4 Surface water and sediment sampling ........ 5-9

5.4.5 Ground water level monitoring ... . . . . . . 5-10

5.4.6 Geochemical analysis of aquifer materials and ground water ............... 5-10 
TABLE OF CONTENTS (Continued)

Section

Page

5.4.7 Toxicological literature review ......... 5-10

5.4.8 Computer modeling of ground water flow and contaminant transport .............. 5-11

5.4.9 Feasibility of executing institutional controls . . . . 5-11

5.5 Results of collection activities ............. 5-12

$6.0 \quad$ LIST OF CONTRIBUTORS $\ldots \ldots \ldots \ldots \ldots \ldots \ldots \ldots \ldots \ldots \ldots$

7.0 REFERENCES $\ldots \ldots \ldots \ldots \ldots \ldots \ldots \ldots \ldots \ldots \ldots \ldots \ldots \ldots \ldots$

APPENDIX A APPENDIX B1 APPENDIX B2 APPENDIX C
MONITOR WELL LITHOLOGIC AND CONSTRUCTION LOGS CONTAMINANTS OF CONCERN IN DOMESTIC WELLS CONTAMINANTS OF CONCERN IN MONITOR WELLS SURFACE WATER AND SEDIMENT ANALYTICAL RESULTS 
LIST OF FIGURES

Figure

3.1 Riverton site location map, Riverton, Wyoming . . . . . . . . . . . 3-2

3.2 Land use and water well location map, Riverton, Wyoming, site . . . . . . 3-3

3.3

Diagram of the conceptual site model, Riverton, Wyoming . . . . . . . . . . 3-4

3.4

Extent of surface contamination, Riverton, Wyoming, site . . . . . . . . . 3-6

3.5

Monitor well locations, Riverton, Wyoming, site . . . . . . . . . . . . 3-11

3.6

1993 Surface water and sediment sampling locations, Riverton,

Wyoming, site . . . . . . . . . . . . . . . . . . . 3-14

3.7 Geologic cross section, Riverton, Wyoming, site . . . . . . . . . . 3-16

3.8 Ground water elevations in the surficial aquifer, Riverton, Wyoming,

site ............................ 3-18

3.9 Hydrograph of onsite wells, Riverton, Wyoming, site . . . . . . . . 3-19

3.10 Ground water elevations in the semiconfined sandstone aquifer,

Riverton, Wyoming, site . . . . . . . . . . . . . . . . . . . 3-21

3.11 Ground water elevations in the confined sandstone aquifer, Riverton,

Wyoming, site ........................... 3-22

3.12 1987 and 1993 molybdenum concentrations in the surficial aquifer,

Riverton, Wyoming, site . . . . . . . . . . . . . . . . . . . . . 3-29

3.13 1987 and 1993 sulfate concentrations in the surficial aquifer,

Riverton, Wyoming, site . . . . . . . . . . . . . . . . 3-30

3.14 1987 and 1993 uranium concentrations in the surficial aquifer,

Riverton, Wyoming, site . . . . . . . . . . . . . . . . . . 3-31

3.15 Sulfate concentrations in the semiconfined aquifer, Riverton,

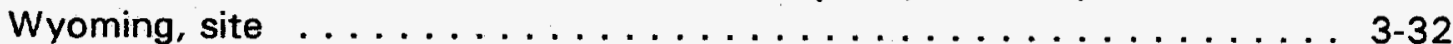

3.16 Sulfate plume development after tailings pile relocation, Riverton,

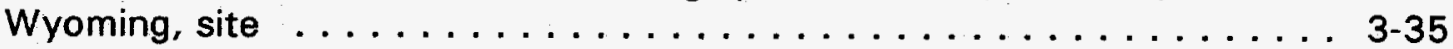

3.17 Potential exposure pathways, Riverton, Wyoming, site . . . . . . . . 3-39

4.1 Compliance selection framework, Riverton, Wyoming, site . . . . . . 4-2

5.1 Existing and proposed well, boring, and surface water/sediment

sampling locations, Riverton, Wyoming, site 


\section{LIST OF TABLES}

Table

2.1 Maximum concentrations of inorganic constituents for ground water protection at UMTRA Project sites . . . . . . . . . . . . . 2-3

3.1 Domestic wells, details, and sampling dates, Riverton, Wyoming, site . . . 3-8

3.2 Monitor well information, Riverton, Wyoming, site . . . . . . . . . 3-12

3.3 Statistical summary of filtered ground water quality in the surficial, semiconfined, and confined aquifers at the Riverton, Wyoming, site (1987 to 1994 water quality data) . . . . . . . . . . . . . . . . . . 3-24

3.4 Occurrence of constituents in the Little Wind River surface water, June 1993 sampling event, Riverton, Wyoming, site . . . . . . . . . 3-41

3.5 Occurrence of constituents in the Little Wind River sediments, June 1993 sampling event, Riverton, Wyoming, site . . . . . . . . . . . . 3-42

3.6 Occurrence of constituents in surface water from water bodies in the

3.7 Occurrence of constituents in sediments from water bodies in the site vicinity, June 1993 sampling event, Riverton, Wyoming, site . . . . . . . 3-44

4.1 Application of constituents to compliance selection framework for the Riverton, Wyoming, site . . . . . . . . . . . . . . . . . 4-4 


\section{LIST OF ACRONYMS AND ABBREVIATIONS}

\begin{tabular}{|c|c|}
\hline Acronym & Definition \\
\hline$a c$ & acre \\
\hline $\mathrm{ACL}$ & alternate concentration level \\
\hline As & arsenic \\
\hline ASTM & American Society for Testing Materials \\
\hline $\begin{array}{l}\text { BLRA } \\
{ }^{\circ} \mathrm{C}\end{array}$ & $\begin{array}{l}\text { baseline risk assessment } \\
\text { degrees Celsius }\end{array}$ \\
\hline C \& NW & $\begin{array}{l}\text { degrees Celsius } \\
\text { Chicago \& Northwestern }\end{array}$ \\
\hline $\mathrm{cm}$ & centimeter \\
\hline dia. & diameter \\
\hline DOE & U.S. Department of Energy \\
\hline DQO & data quality objective \\
\hline EA & environmental assessment \\
\hline $\begin{array}{l}\mathrm{EC}_{50} \\
\text { elev. }\end{array}$ & $\begin{array}{l}\text { sublethal concentrations affecting } 50 \text { percent of test organisms } \\
\text { elevation }\end{array}$ \\
\hline $\begin{array}{l}\text { EPA } \\
{ }^{\circ} \mathrm{F}\end{array}$ & $\begin{array}{l}\text { U.S. Environmental Protection Agency } \\
\text { degrees Fahrenheit }\end{array}$ \\
\hline FR & Federal Register \\
\hline $\mathrm{ft}^{3}$ & foot \\
\hline $\begin{array}{l}\mathrm{ft}^{2} \\
\mathrm{gal}\end{array}$ & $\begin{array}{l}\text { cubic foot } \\
\text { gallon }\end{array}$ \\
\hline $\begin{array}{l}\text { gal } \\
\text { GWPP }\end{array}$ & $\begin{array}{l}\text { gallon } \\
\text { Groundwater Project Plan }\end{array}$ \\
\hline $\begin{array}{l}\text { GWPP } \\
\text { ha }\end{array}$ & $\begin{array}{l}\text { Groundwater Project Plan } \\
\text { hectare }\end{array}$ \\
\hline $\mathrm{IAH}$ & $\begin{array}{l}\text { hectare } \\
\text { International Association of Hydrogeologists }\end{array}$ \\
\hline ID & $\begin{array}{l}\text { International Association of Hydrogeologists } \\
\text { identification }\end{array}$ \\
\hline JEG & $\begin{array}{l}\text { identification } \\
\text { Jacobs Engineering Group Inc. }\end{array}$ \\
\hline $\mathrm{km}$ & $\begin{array}{l}\text { Jacobs Engineering Group Inc. } \\
\text { kilometer }\end{array}$ \\
\hline$L$ & $\begin{array}{l}\text { kilometer } \\
\text { liter }\end{array}$ \\
\hline $\mathrm{LC}_{50}$ & $\begin{array}{l}\text { liter } \\
\text { lethal concentrations affecting } 50 \text { percent of test organisms }\end{array}$ \\
\hline LOAEL & $\begin{array}{l}\text { lethal concentrations affecting } 50 \text { percent of test organisms } \\
\text { lowest observed adverse effect levels }\end{array}$ \\
\hline $\mathrm{m}^{3}$ & meter \\
\hline $\begin{array}{l}\mathrm{m}^{3} \\
\mathrm{MCL}\end{array}$ & cubic meter \\
\hline $\begin{array}{l}\mathrm{MCL} \\
\mathrm{mg} / \mathrm{kg}\end{array}$ & $\begin{array}{l}\text { maximum concentration limit } \\
\text { milligrams per kilogram }\end{array}$ \\
\hline $\mathrm{mg} / \mathrm{L}$ & $\begin{array}{l}\text { milligrams per kilogram } \\
\text { milligrams per liter }\end{array}$ \\
\hline $\mathrm{mi}$ & mile \\
\hline Mn & manganese \\
\hline Mo & molybdenum \\
\hline MSL & mean sea level \\
\hline NEPA & National Environmental Policy Act \\
\hline NOAA & National Oceanic and Atmospheric Administration \\
\hline NOAEL & no observed adverse effect levels \\
\hline NRC & U.S. Nuclear Regulatory Commission \\
\hline 0 & oxygen \\
\hline
\end{tabular}




\section{LIST OF ACRONYMS AND ABBREVIATIONS (Concluded)}

$\begin{array}{ll}\text { Acronym } & \text { Definition } \\ \text { pCi/g } & \text { picocuries per gram } \\ \text { PEIS } & \text { programmatic environmental impact statement } \\ \text { QA } & \text { quality assurance } \\ \text { RAP } & \text { remedial action plan } \\ \text { RRM } & \text { residual radioactive material } \\ \text { S } & \text { sulfur } \\ \text { SOP } & \text { standard operating procedure } \\ \text { SOWP } & \text { site observational work plan } \\ \text { TAC } & \text { Technical Assistance Contractor } \\ \text { TAGR } & \text { Technical Approach to Ground Water Restoration } \\ \text { TDS } & \text { total dissolved solids } \\ \text { TER } & \text { Technical Evaluation Report } \\ \text { UMTRA } & \text { Uranium Mill Tailings Remedial Action } \\ \text { UMTRCA } & \text { Uranium Mill Tailings Radiation Control Act } \\ \text { USGS } & \text { U.S. Geological Survey } \\ \text { V } & \text { vanadium } \\ \text { WDEQ } & \text { Wyoming Department of Environmental Quality } \\ \text { WRTEQC } & \text { Wind Rivers Tribes' Environmental Quality Commission } \\ \text { WSAP } & \text { Water Sampling and Analysis Plan } \\ \text { Yd } & \text { cubic yard }\end{array}$




\subsection{INTRODUCTION}

The Riverton, Wyoming, Uranium Mill Tailings Remedial Action (UMTRA) Project site observational work plan (SOWP) is the first document for the UMTRA Ground Water Project to address site-specific activities to meet compliance with U.S. Environmental Protection Agency (EPA) proposed ground water standards (52 FR $36000(1987)$ ) at this UMTRA Project site.

This SOWP, Revision 0 presents a summary of site hydrogeological data and presents a conceptual model of the milling-related ground water contamination and the aquifer system. The SOWP defines 1) the potential environmental and health risks, 2) data gaps in the conceptual model, and 3) identifies appropriate site-specific compliance strategies. Relevant data in support of the recommended compliance strategies are also presented, along with a plan for collecting and assessing additional required data.

Section 2.0 of this SOWP describes the requirements for meeting standards at UMTRA Project sites. Section 3.0 provides site-specific data and the related conceptual model. Section 4.0 provides the justification for the recommended ground water compliance strategies for the Riverton site. Section 5.0 provides the justification and process for collection and assessment of additional required data. Section 6.0 provides a list of the references cited. The appendixes include data on monitor wells and lithography, ground water, surface water, and sediment quality.

\subsection{GROUND WATER COMPLIANCE STRATEGY}

The ground water compliance strategy recommended for the Riverton site consists of a combination of two compliance strategies for the 24 hazardous constituents identified: 1) no remediation with application of alternate concentration limits (ACL) and 2) natural flushing with institutional controls.

No remediation is the recommended compliance strategy for 14 of the constituents that are potential candidates for the ACLs list of constituents. Application of ACLs is appropriate for these 14 constituents because they are essential nutrients and the concentrations at which they occur in the ground water are within nutritional ranges and/or because they have very low toxicity and relatively high dietary intake ranges in comparison to the levels detected in the ground water.

Natural flushing is the second recommended compliance strategy and is proposed for the remaining 10 constituents that are not $A C L$ candidates. The hydrogeologic and geochemical data collected from the Riverton site and preliminary ground water and geochemical modeling indicate that natural ground water movement and geochemical processes will decrease the contaminant concentrations to background levels, maximum concentration limits (MCL), or ACLs within 100 years. During that period of time, effective monitoring and institutional controls will need to be maintained to prevent domestic use of ground water in the affected aquifer. 
Programmatic documents that provide guidance for this SOWP include the U.S. Department of Energy (DOE) UMTRA Groundwater Project Plan (GWPP) (DOE, 1992), Programmatic Environmental Impact Statement for the Uranium Mill Tailings Remedial Action Ground Water Project (PEIS) (DOE, 1994a), and the Technical Approach to Ground Water Restoration (TAGR) (DOE, 1993a). The GWPP states the mission need and objectives for the UMTRA Ground Water Compliance Program and provides an overall technical and management approach for conducting the program. The PEIS provides an objective programmatic decision-making framework for conducting the UMTRA Ground Water Project, assesses the potential programmatic impacts of conducting the project, provides a method for determining the site-specific ground water compliance strategies, and provides data and information that can be used to prepare site-specific National Environmental Policy Act (NEPA) of 1969 (42 USC $\$ 4321$ et seq.) more efficiently. The TAGR provides technical guidance for conducting the ground water program.

Preliminary results from the baseline risk assessment (BLRA), including the identified constituents of potential concern, were used in this SOWP to evaluate hazards resulting from milling-related constituents in ground water at the site (DOE, 1994b).

The environmental impacts from the recommended ground water action presented in this SOWP will be assessed in a site-specific environmental assessment $(E A)$ prepared by the DOE that will meet the requirements of the NEPA. The site-specific EA will be based on the framework in the approved PEIS. A record of decision on the PEIS framework is anticipated in 1995. The preferred alternative from the PEIS for conducting the UMTRA Ground Water Project will be published as a record of decision in the Federal Register.

\subsection{CONTENT OF SOWP REVISIONS}

This SOWP, Revision 0 presents a summary of existing data, describes the conceptual model, proposes a compliance strategy based on this information, and identifies data needed to further support the selected strategy. Upon approval of this SOWP, a 1-year field program will be initiated to satisfy the data needs. A program will also be devised to evaluate and calibrate the rate of natural flushing and assess the effectiveness of institutional controls.

The results of these activities will be discussed in the annual water sampling and analysis plans and the annual site environmental report. The final SOWP will be prepared to present the comprehensive results of data gathering and pilot testing, and provide the final plan for compliance with general design parameters. The final revision will be prepared after review by affected stakeholders and comment resolution. 
It is the intent of the DOE to provide copies of the SOWPS to the U.S. Nuclear Regulatory Commission (NRC) and to the potentially affected public, states, or Indian tribes for comment. Public meetings will also be conducted during the SOWP process to ensure close coordination and consultation with the potentially affected stakeholders. These interactions should result in an expedited and more informative decision-making process for the Riverton site. 


\subsection{REGULATORY FRAMEWORK}

This section identifies the requirements for recommending a ground water compliance strategy for the Riverton site to achieve compliance with Subpart B of the EPA "Health and Environmental Protection Standards for Uranium and Thorium Mill Tailings" (40 CFR Part 192 (1994)), the EPA proposed 1987 standards (52 FR 36000), and the 1994 draft final rule (EPA, 1994).

\subsection{URANIUM MILL TAILINGS RADIATION CONTROL ACT}

The U.S. Congress passed the Uranium Mill Tailings Radiation Control Act (UMTRCA) (42 USC $\$ 7901$ et seq.) in 1978 in response to public concerns about the potential health hazards from exposure to uranium mill tailings over long periods of time. The UMTRCA authorized the DOE to stabilize, dispose of, and control uranium mill tailings and other contaminated materials at uranium mill processing sites.

The UMTRCA has three titles that apply to uranium processing sites. Title I of the Act designates 24 inactive processing sites that will undergo remediation; directs the EPA to promulgate standards; mandates remedial action in accordance with standards prescribed by the EPA; directs the NRC, states, and Indian tribes to concur in the remedial actions; directs the NRC to license the disposal sites for long-term care; and directs the DOE to enter into cooperative agreements with the affected states and Indian tribes. Title II applies to active uranium mills, and Title III applies to certain uranium mills in New Mexico. The UMTRA Project has responsibility for administering only Title I of the UMTRCA.

In 1988, Congress passed the Uranium Mill Tailings Remedial Action Amendments Act (Amendments Act; 42 USC $\$ 7923$ et seq.), authorizing the DOE to extend without limitation the time needed to complete ground water remediation activities at the processing sites. Section 108 of the UMTRCA requires that the DOE comply with the proposed EPA standards in the absence of final standards.

\subsubsection{EPA ground water compliance standards}

The UMTRCA requires that the EPA promulgate standards for protecting human health and the environment from hazardous constituents associated with the processing of uranium and the resulting residual radioactive materials (RRM).

On January 5, 1983, the EPA published standards (40 CFR Part 192 (1994)) for the disposal and cleanup of RRMs. On September 3, 1985, the Tenth Circuit Court of Appeals set aside the ground water provisions of 40 CFR $5192.20(a)(2)(3)(1994)$ and remanded them to the EPA. The EPA proposed new standards to replace the remanded sections in the Federal Register on September 24, 1987 (52 FR 36000). 
The proposed standards address two ground water contamination scenarios. The first addresses future ground water contamination that may occur from tailings piles after disposal, and the second addresses the cleanup of contamination that occurred at the processing sites before disposal of the tailings piles (52 FR 36000 (1987)). Protection of the ground water at the disposal sites is being addressed in the UMTRA Surface Project. The UMTRA Ground Water Project addresses the contamination that occurred at the processing sites and is regulated by Subparts B and C of the proposed standards.

Subpart B, "Standards for Cleanup of Land and Buildings Contaminated with Residual Radioactive Materials from Inactive Uranium Processing Sites" (52 FR 36000 (1987)), requires that remedial action at processing sites be conducted to ensure that the amounts of RRMs in ground water meet any one of the three criteria:

- Background levels - concentrations of constituents in nearby ground water that was not affected by processing activities.

- Maximum concentration limits - the EPA's maximum limits for concentration of certain hazardous constituents in ground water, as proposed for the UMTRA Project. The MCLs for inorganic constituents that apply to the UMTRA Project sites are given in Table 2.1.

- Alternate concentration limits - an alternate limit for a hazardous constituent that does not pose a substantial present or potential hazard to human health or the environment, as long as the limit is not exceeded.

Under certain specific conditions, the DOE may apply supplemental standards in lieu of background levels, MCLs, or ACLs (52 FR 36000 (1987)). Subpart B of the proposed standards defines "limited-use" ground water as ground water that is not a current or potential source of drinking water because the concentration of total dissolved solids (TDS) is in excess of 10,000 milligrams per liter (mg/L); or because widespread, ambient contamination not due to activities involving RRMs from a designated processing site exists that cannot be cleaned up using treatment methods reasonably employed in public water supply systems; or because the quantity of water available is less than 150 gallons (gal) 1570 liters [L]) per day (40 CFR \$192.11(e) (1.994); 52 FR 36000 (1987)).

When supplemental standards apply, implementing agencies shall apply any remedial actions for the restoration of contaminated ground water by RRMs that is required to assure, at a minimum, protection of human health and the environment. In addition, when limited-use ground water applies, supplemental standards shall ensure that current and reasonably projected uses of the affected ground water are preserved (EPA, 1994). 
Table 2.1 Maximum concentrations of inorganic constituents for ground water protection at UMTRA Project sites ${ }^{a}$

\begin{tabular}{|c|c|}
\hline Constituent & Maximum concentration ${ }^{b}$ \\
\hline Arsenic & 0.05 \\
\hline Barium & 1.0 \\
\hline Cadmium & 0.01 \\
\hline Chromium & 0.05 \\
\hline Lead & 0.05 \\
\hline Mercury & 0.002 \\
\hline Molybdenum & 0.1 \\
\hline Nitrate (as N) & $10.0^{\mathrm{C}}$ \\
\hline Selenium & 0.01 \\
\hline Silver & 0.05 \\
\hline Combined radium-226 and radium-228 & $5 \mathrm{pCi} / \mathrm{L}$ \\
\hline Combined uranium-234 and uranium-238 & $30 \mathrm{pCi} / \mathrm{L}^{\mathrm{d}}$ \\
\hline $\begin{array}{l}\text { Gross alpha-particle activity (excluding radon } \\
\text { and uranium) }\end{array}$ & $15 \mathrm{pCi} / \mathrm{L}$ \\
\hline
\end{tabular}

${ }^{2} 40$ CFR $\$ 264.94$ (1994), 52 FR 36007 (1987).

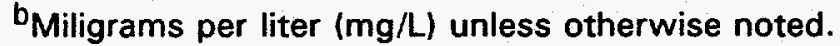

$\mathrm{C}^{\mathrm{C}}$ Equivalent to $44 \mathrm{mg} / \mathrm{L}$ nitrate as nitrate.

Equivalent to $0.044 \mathrm{mg} / \mathrm{L}$.

pCi/L - picocuries per liter. 
Subpart B also provides for selecting natural flushing as a means to meet the proposed standards. Natural flushing means allowing natural ground water processes to reduce the contamination in ground water to the standards (background levels, MCLs, or ACLs). Natural flushing must allow standards to be met within 100 years. In addition, ground water must not be currently, or projected to become, a source of drinking water during the period of natural flushing (40 CFR \$192.12(c)(4) (1994); 52 FR 36000 (1987)). Institutional controls (measures that restrict access to contamination, protect human health, and satisfy beneficial uses of ground water) must be established and maintained during the period of natural flushing.

Subpart C, "Implementation," provides guidance for implementing methods and procedures to provide reasonable assurance that the provisions of Subpart $B$ are satisfied. Subpart $C$ requires that the conditions of Subpart $B$ should be met on a site-specific basis using information gathered from site characterization and monitoring. Subpart $C$ also requires the plan to meet the conditions of Subpart B, which should be stated in the compliance strategy plan or remedial action plan (RAP) that contains the proposed compliance strategy, a demonstration of effectiveness, and a monitoring program.

\subsubsection{Cooperative agreements}

The UMTRCA requires that remedial action be accomplished with the full participation of the affected states (Section 103, State Cooperative Agreements) and Indian tribes (Section 105, Indian Tribe Cooperative Agreements) on whose lands the uranium mill tailings are located. The UMTRCA also directed the DOE to enter into cooperative agreements with the states and Indian tribes. A cooperative agreement for the Surface Project with the state of Wyoming was executed December 23, 1983 (Cooperative Agreement Number DE-FCO4-83AL19454, as amended) (DOE, 1983). Indian tribal land was not involved in the UMTRA Surface Project.

\subsection{NATIONAL ENVIRONMENTAL POLICY ACT}

Implementation of the UMTRCA represents a major federal action subject to the requirements of NEPA of 1969 (42 USC $\$ 4321$ et seq.). The Council on Environmental Quality's regulations that implement the NEPA are codified in 40 CFR $\$ \$ 1500-1508$ (1994). The regulations require that each federal agency develop its own implementing procedures (40 CFR $\$ 1507.3$ (1994)). The DOE NEPA regulations are contained in "National Environmental Policy Act Implementing Procedures" (10 CFR Part 1021 (1994)). DOE guidance is provided in Recommendations for the Preparation of Environmental Assessments and Environmental Impact Statements (DOE, 1993b).

Pursuant to the NEPA, the DOE drafted a PEIS in 1994 for the UMTRA Ground Water Project to analyze the potential impacts of implementing four programmatic alternatives for conducting ground water compliance at the UMTRA Project processing sites. The preferred alternative will be selected by 
the DOE, following a public participation effort, and published in a record of decision. All subsequent actions on the UMTRA Ground Water Project must comply with this record of decision.

The environmental impacts from implementing the proposed compliance strategies presented in the final Riverton SOWP will be addressed in an EA that will meet the requirements of the NEPA and tier off applicable issues discussed in the PEIS. 


\subsection{CONCEPTUAL SITE MODEL}

This section presents the conceptual site model and describes the history of the former milling operations and surface remediation, the surrounding land uses, the physiographic and hydrogeologic settings and the ground water quality and geochemical properties of the aquifer as they control the fate and transport of the contaminants, and the risks associated with the contaminants. A summary of the site conceptual model is presented below. The details are presented in subsequent subsections.

\subsection{SUMMARY OF SITE CONCEPTUAL MODEL}

The former Riverton uranium processing site encompasses about 190 acres (ac) (76.9 hectares [ha]) on a level, alluvial terrace between the Wind River and the Little Wind River, approximately 2.3 miles (mi) (3.7 kilometers [km]) southwest of Riverton, Wyoming (Figures 3.1 and 3.2). The uranium mill at the Riverton site operated from 1958 until mid-1963. The storage of uranium ore and seepage from the tailings pile following the sulfuric acid and alkaline leaching processes resulted in the contamination of the ground water with arsenic, lead-210, manganese, molybdenum, nickel, polonium-210, sulfate, thorium-230, uranium, and vanadium. The tailings pile and associated contaminated soils were removed in 1988 and 1989.

Ground water occurs in an unconfined surficial aquifer, an underlying semiconfined sandstone aquifer, and a deeper confined sandstone aquifer. These aquifers are recharged primarily by inflow from the Wind River to the northwest. The ground water in the surficial aquifer is the most contaminated, and some contamination exists in the semiconfined aquifer. No contamination has been detected in the deep confined aquifer. Potable water in the Riverton area is withdrawn from the Wind River and from the confined sandstone aquifer. Ground water from the surficial and semiconfined aquifers appears to discharge into the Little Wind River. Figure 3.3 is a representation of the site conceptual model.

Ground water analyses indicate that the contaminated ground water extends from the former tailings pile area all the way to the Little Wind River, approximately $\mathbf{4 2 0 0}$ feet (ft) (1500 meters [m]) southeast of the northwestern corner of the former tailings pile. Data on water quality and flow in the Little Wind river suggest that the river will dilute the discharging ground water to below concentrations that present risks to wildlife or the environment. The contaminated ground water plume does not appear to extend beyond the river.

Data collected between 1987 and 1994 suggest that the natural ground water flow, probably enhanced by infiltration from irrigation canals along the upgradient side of the former mill site, is flushing contaminants out of the affected aquifers into the Little Wind River. Based on ground water modeling, the mass of contaminated ground water should be flushed to the river in 100 years. It is anticipated that geochemical reactions as well as dilution and 

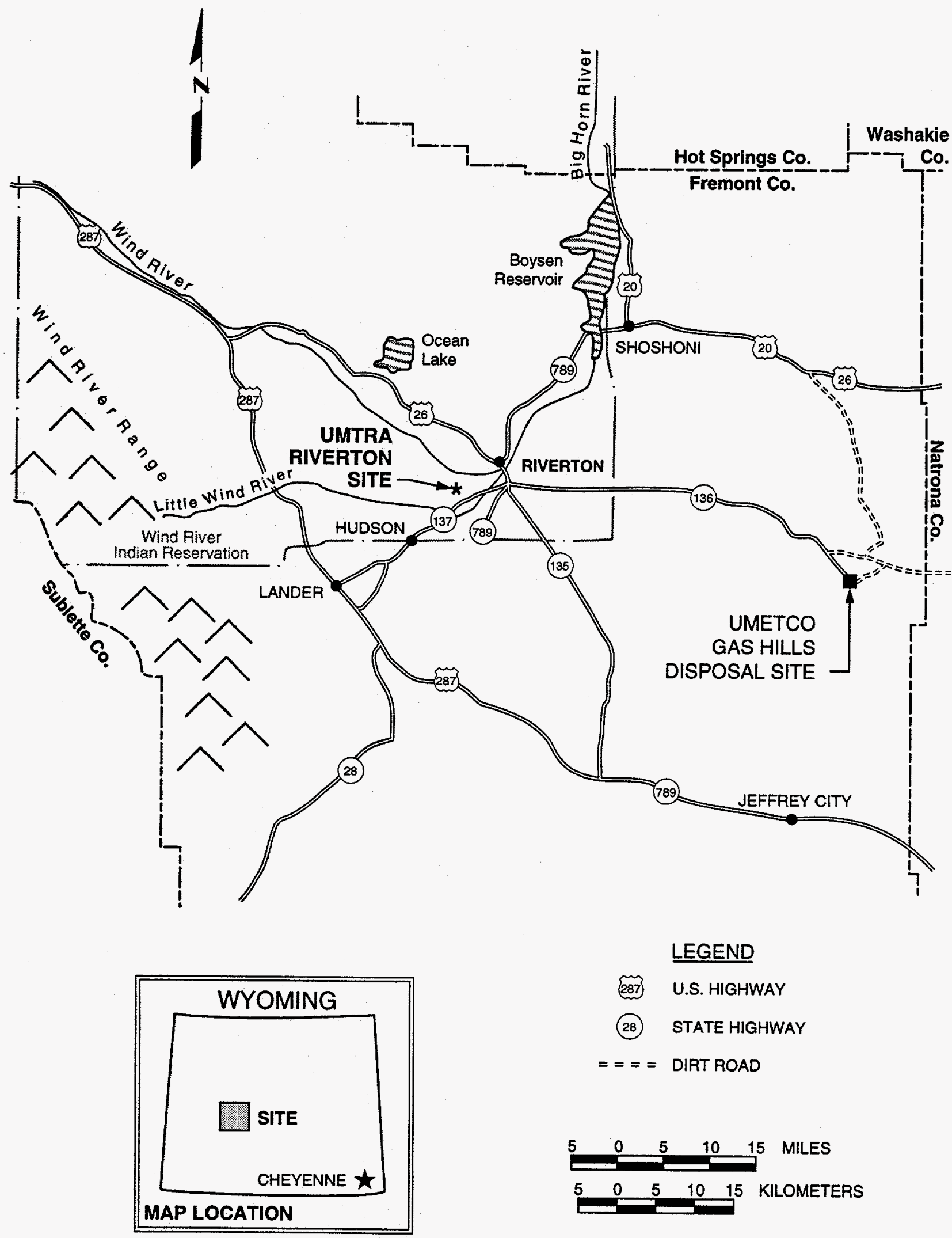

FIGURE 3.1

RIVERTON SITE LOCATION MAP RIVERTON, WYOMING 


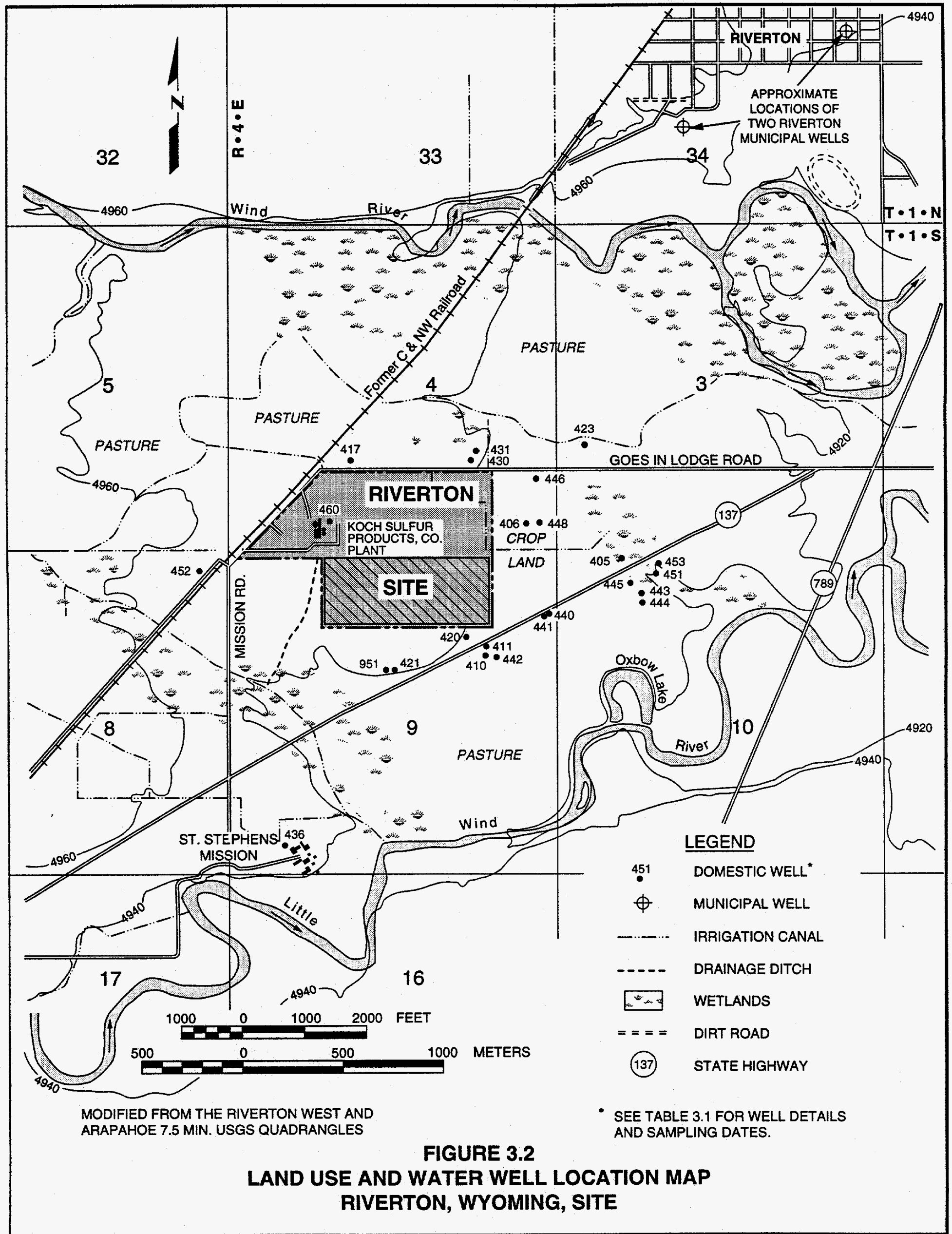


ON THE SURFACE:

- Approximately 1.5 million cubic yards of contaminated materials were taken to a disposal site in Gas Hills located 55 miles east-southeast of Riverton. Surface remedial action was completed in 1989.

- The primary source of domestic water in the Riverton area is from an area of the Wind River Formation that is not contaminated.
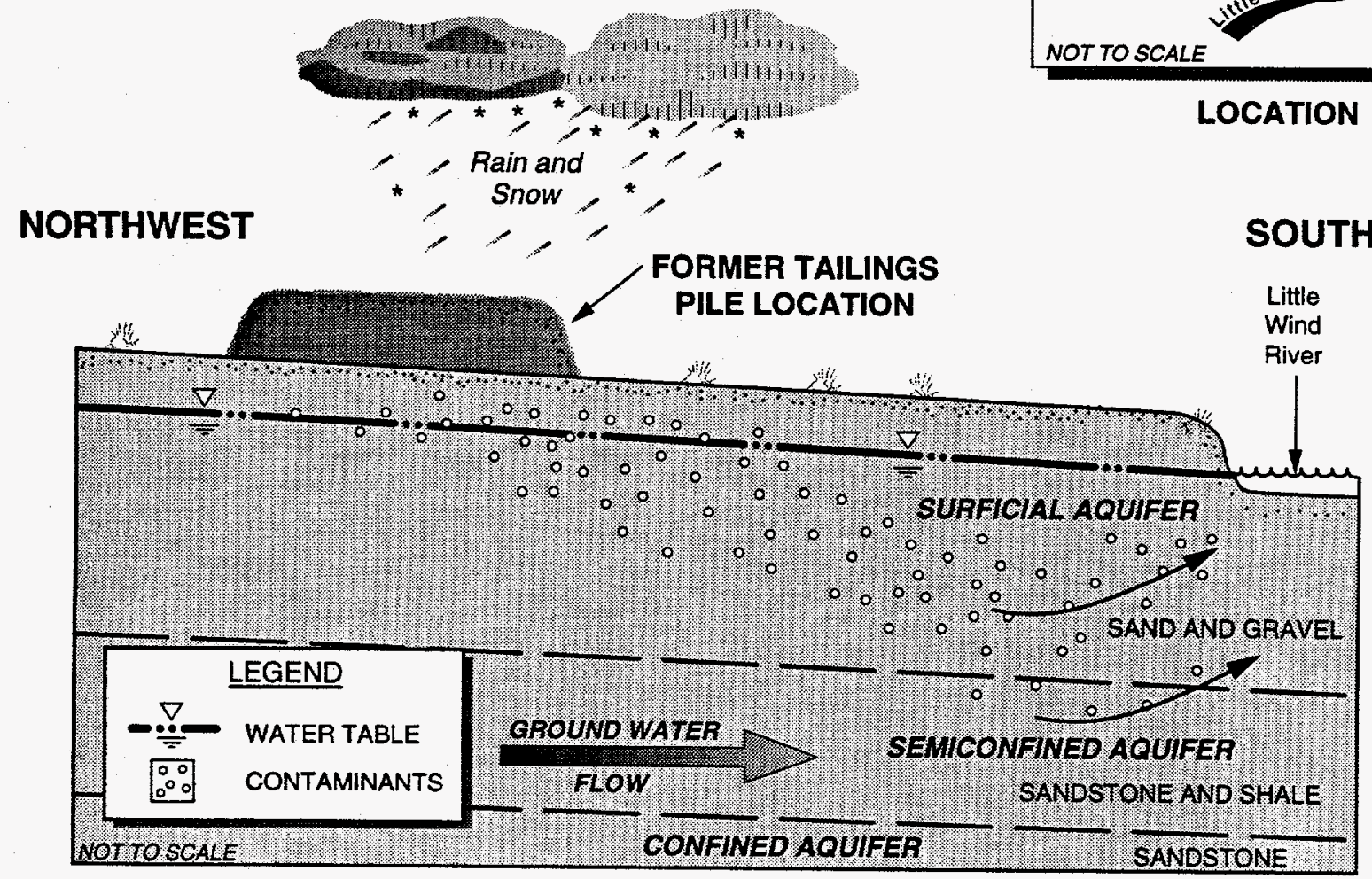

RIVERTON SITE CROSS SECTION

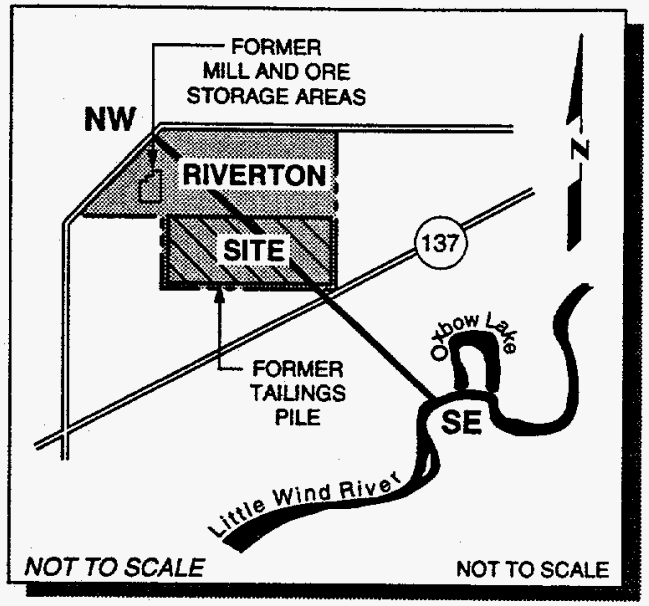

LOCATION MAP

\section{SOUTHEAST}

WIND

RIVER

FORMATION

\section{BELOW THE SURFACE:}

- Ground water occurs in the shallow sand, gravel, and in the deeper rock of the Wind River Formation under the site. The surficial aquifer is contaminated.

- The underlying sandstone and shale semiconfined aquifer is contaminated to a limited extent.

- Ground water discharges into the Little Wind River.

- The deep confined sandstone aquifer is not contaminated

FIGURE 3.3

DIAGRAM OF THE CONCEPTUAL SITE MODEL RIVERTON, WYOMING, SITE 
dispersion are also effective in reducing the concentrations beneath and downgradient of the site. Institutional controls implemented to prevent use of the contaminated ground water during the remediation period will avoid risks to human health.

\subsection{SITE HISTORY}

The surficial and semiconfined ground water aquifers underlying the Riverton site became contaminated as a result of the former uranium milling processes and disposal practices. The BLRA identified the following contaminants of concern: arsenic, lead-210, manganese, molybdenum, nickel, polonium-210, sulfate, thorium-230, uranium, and vanadium. This section discusses the activities at the site resulting in the ground water degradation and the steps taken to remove the surface source of contamination. It also describes the activities in the vicinity of the site and uses of the ground water.

The Riverton site, including the former mill site and tailings pile area, is located approximately $2.3 \mathrm{mi}(3.7 \mathrm{~km})$ southwest of the center of Riverton on the north side of Highway 137 (Rendezvous Road) in Fremont County, Wyoming (Figure 3.1). The site is on private land within the boundaries of the Wind River Indian Reservation (Northern Arapaho and Shoshone Indian tribes). It is located in Township 1 South, Range 4 East, Sections 4 and 9 (Figure 3.2).

The mill at the Riverton tailings site was constructed in 1958 and was operated initially by Fremont Minerals, Inc., and Susquehanna Western, Inc., to treat a variety of uranium ores extracted from the surrounding area. A sulfuric acid plant that used sulfur made from sour gas was also part of the mill facilities. The uranium mill was closed in mid-1963. The sulfuric acid plant is still being operated by Koch Sulfur Products.

The mill operations included both sulfuric acid and alkaline leach circuits to provide flexibility for the many types of uranium ore received. Clarified solutions from the acid leaching process were fed to a solvent extraction circuit using an amine-decanol-kerosene extractant. The extractant was subsequently stripped with caustic soda to precipitate the uranium. Consequently sulfate, uranium, and trace elements (such as molybdenum) should be present in ground water beneath the tailings. During its 5 years of operation, approximately 900,000 tons $(800,000$ tonnes) of ore were processed at the mill. The waste solids from the milling of the uranium ores were transferred to a tailings pile located adjacent to and southeast of the mill (Figure 3.4).

The rectangular tailings pile covered about $70 \mathrm{ac}(30 \mathrm{ha})$ and contained approximately 1 million cubic yards $\left(y d^{3}\right)\left(800,000\right.$ cubic meters $\left.\left[\mathrm{m}^{3}\right]\right)$ of tailings. An additional $70 \mathrm{ac}(30 \mathrm{ac})$ of the land surface to the north of the tailings pile were also contaminated from ore storage. Dispersion of the tailings by wind resulted in soil contamination on about 50 additional ac ( 20 ha) outside the site boundaries, especially to the southeast (Figure 3.4). 


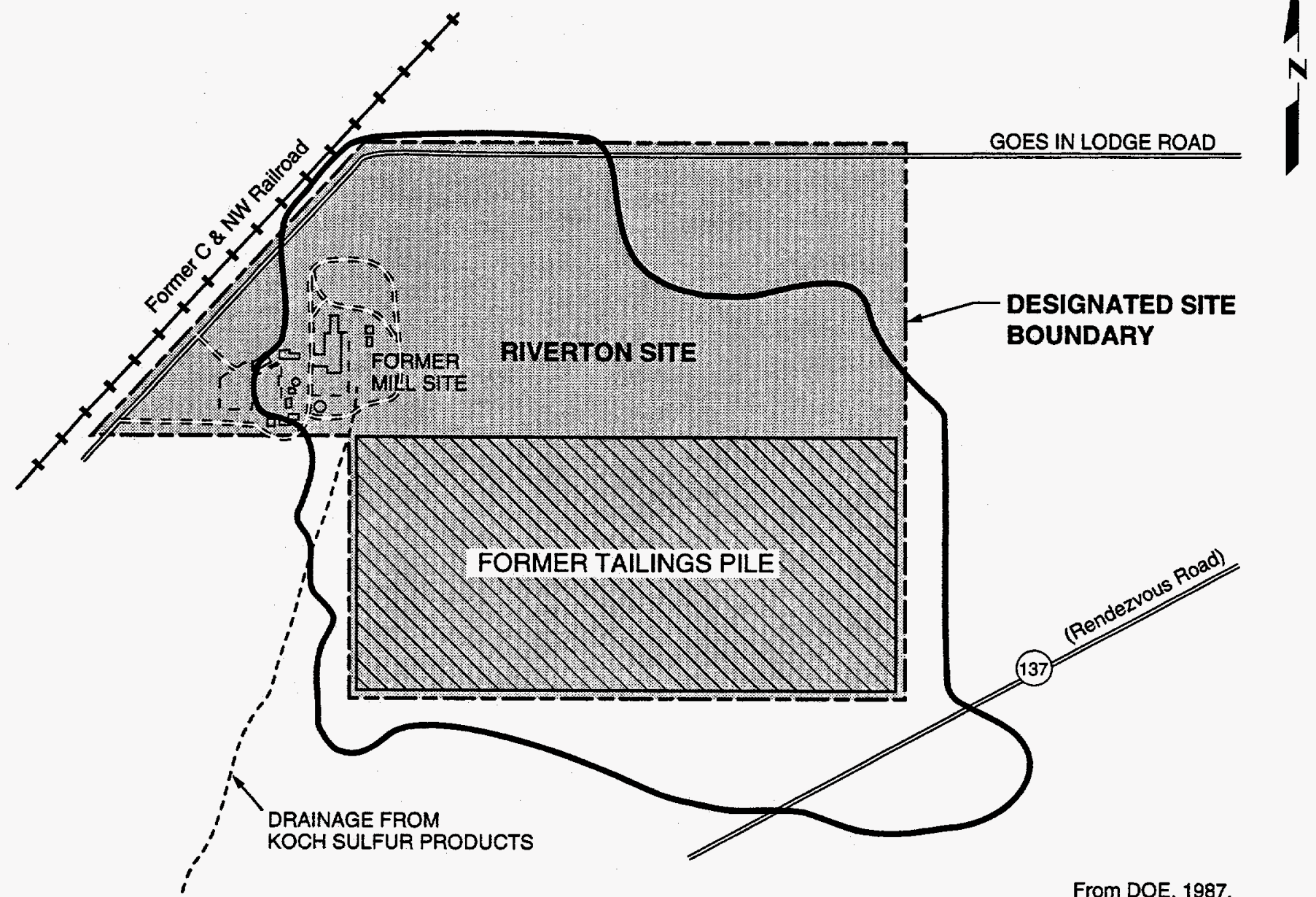

From DOE, 1987.

\section{LEGEND}

EXTENT OF 5 pCi/g LIMIT

IN THE 0 to 6-INCH LAYER

$===$ DIRT ROAD

- - DRAINAGE DITCH

(137) STATE HIGHWAY

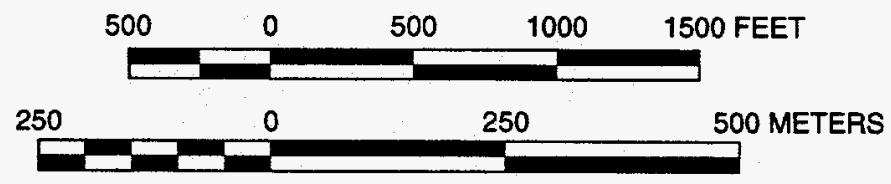

FIGURE 3.4

EXTENT OF SURFACE CONTAMINATION RIVERTON, WYOMING, SITE 
Between 1988 and 1990, the uranium mill was demolished and the tailings pile and contaminated soils were removed from the site and surrounding area. The soils were excavated until the radium concentrations were less than 5.0 picocuries per gram (pCi/g) in the first 6 inches (15 centimeters $[\mathrm{cm}]$ ) in accordance with UMTRA guidelines (DOE, 1989; 40 CFR \$192.12 (1994)) (Figure 3.4). Approximately 1.8 million $\mathrm{yd}^{3}\left(1.4\right.$ million $\left.\mathrm{m}^{3}\right)$ of contaminated material were removed from the site and disposed at Umetco's Gas Hill Disposal Site (Figure 3.1). The excavation was backfilled with clean fill. The finished land surface was graded to form a crown and planted with rye grass. Surface remediation was completed in November 1989.

\subsection{SURROUNDING LAND AND WATER USES}

\subsubsection{Land uses}

The current predominant land use in the vicinity of the site is agricultural. Much of the area is used as pasture for cattle and horses. Hay is the primary crop in the area, while some of the residences have vegetable gardens.

\subsubsection{Water uses}

The city of Riverton is located approximately $2 \mathrm{mi}(3 \mathrm{~km})$ northeast of the former milling site. The city draws water from one of the irrigation canals fed by the Wind River during the summer growing season (May through September). It pumps water from wells during the rest of the year. There are a total of 12 active city wells located between 1.5 and $9 \mathrm{mi}(2$ and $15 \mathrm{~km})$ from the site. Only two of these wells are within $2 \mathrm{mi}(3.2 \mathrm{~km})$ of the site (Figure 3.2). The Riverton municipal wells are completed in the confined aquifers of the Wind River Formation and are commonly 400 to $900 \mathrm{ft}(120$ to $270 \mathrm{~m})$ deep (Anderson and Kelly, 1976). The city has total water rights from the wells of 4.5 million gal ( 17 million $L$ ) per day. In 1993, the city pumped a total of approximately 3.3 million gal $(12.5$ million $L)$ per day from the municipal well field from January to April and from November to December (Saban, 1994).

Water used for livestock and domestic purposes in the vicinity of the site is withdrawn from drilled wells. The locations of known residential wells are shown on Figure 3.2. Information on the wells, including total depths, casing depths, supply aquifers, and the uses of the water, is presented on Table 3.1. All the wells used for potable water are at least $100 \mathrm{ft}(60 \mathrm{~m})$ deep and are completed in the confined sandstone aquifer.

St. Stephen's Mission is located south of Highway 137, approximately $3200 \mathrm{ft}$ $(975 \mathrm{~m}$ ) southeast of the site (Figure 3.2). St. Stephen's has a well (436) completed in the confined sandstone aquifer that is used for potable and domestic water. A shallow alluvial well that refills with water from an irrigation canal is used for watering the recreational fields (Brown, 1994). 
Table 3.1 Domestic wells, details, and sampling dates, Riverton, Wyoming, site

\begin{tabular}{|c|c|c|c|c|}
\hline $\begin{array}{c}\text { Domestic wells } \\
\text { TAC ID \# }\end{array}$ & $\begin{array}{l}\text { Date(s) } \\
\text { sampled }\end{array}$ & $\begin{array}{l}\text { Total/casing } \\
\text { depth (ft) }\end{array}$ & Aquifer & $\begin{array}{l}\text { Water } \\
\text { use }^{b}\end{array}$ \\
\hline 405 & $\begin{array}{l}1981,1983 \\
1984(2 X), 1985 \\
1990,1991(3 X) \\
1992(2 \times), 1993\end{array}$ & $274 / ?$ & $\begin{array}{l}\text { Confined sandstone } \\
\text { bedrock }\end{array}$ & Potable \\
\hline 406 & $\begin{array}{l}\text { 1981, 1990, } \\
\text { 1991(3X), } \\
1992(2 X), 1993\end{array}$ & $350 / ?$ & $\begin{array}{l}\text { Confined sandstone } \\
\text { bedrock }\end{array}$ & Potable \\
\hline 410 & $\begin{array}{l}\text { 1982, 1983, } \\
\text { 1984(3X), } \\
1990(2 X), \\
1992(2 X), 1993\end{array}$ & $100 / ?$ & $\begin{array}{l}\text { Confined sandstone } \\
\text { bedrock }\end{array}$ & Domestic \\
\hline 411 & $\begin{array}{l}1985,1988 \\
1990,1991(3 X) \\
1992(2 x), 1993\end{array}$ & $270 / 261$ & $\begin{array}{l}\text { Confined sandstone } \\
\text { bedrock }\end{array}$ & Domestic \\
\hline 417 & $\begin{array}{l}1981,1990,1991 \\
1992,1993\end{array}$ & $400 / 350$ & $\begin{array}{l}\text { Confined sandstone } \\
\text { bedrock }\end{array}$ & Potable? \\
\hline 420 & $\begin{array}{l}1981,1983 \\
1984(3 X), 1985 \\
1990(2 X) \\
1991(3 X) \\
1992(2 X)\end{array}$ & $273 / 228$ & $\begin{array}{l}\text { Confined sandstone } \\
\text { bedrock }\end{array}$ & Potable \\
\hline 421 & 1981,1985 & $200 / ?$ & $\begin{array}{l}\text { Confined sandstone } \\
\text { bedrock }\end{array}$ & Potable \\
\hline 423 & $\begin{array}{l}1984,1985,1988 \\
1990,1991(3 X) \\
1992(2 X), 1993\end{array}$ & $290 / ?$ & $\begin{array}{l}\text { Confined sandstone } \\
\text { bedrock }\end{array}$ & Potable \\
\hline 430 & $\begin{array}{l}1981,1983 \\
1984(2 X), 1985, \\
1990,1991(2 X), \\
1992(2 X), 1993\end{array}$ & $284 / 320$ & $\begin{array}{l}\text { Confined sandstone } \\
\text { bedrock }\end{array}$ & Potable \\
\hline 431 & $\begin{array}{l}1984,1985 \\
1992,1993\end{array}$ & $\begin{array}{l}\text { Approximately } \\
15 / ? \text { (installed } \\
\text { with backhoe) }\end{array}$ & Surficial & Stock \\
\hline 436 & $\begin{array}{l}1982,1991(3 X) \\
1892(2 X), 1993\end{array}$ & $525 / ?$ & $\begin{array}{l}\text { Confined sandstone } \\
\text { bedrock }\end{array}$ & Potable \\
\hline 440 & $\begin{array}{l}1984,1985(2 X) \\
1988,1990(2 X),\end{array}$ & $267 / ?$ & $\begin{array}{l}\text { Confined sandstone } \\
\text { bedrock }\end{array}$ & Potable? \\
\hline 441 & 1985 & $100 / ?$ & $\begin{array}{l}\text { Confined sandstone } \\
\text { bedrock }\end{array}$ & N/A \\
\hline 442 & 1994 & $405 / ?$ & $\begin{array}{l}\text { Confined sandstone } \\
\text { bedrock }\end{array}$ & Domestic \\
\hline 443 & 1994 & $397 / 356.5$ & $\begin{array}{l}\text { Confined sandstone } \\
\text { bedrock }\end{array}$ & Potable \\
\hline
\end{tabular}


Table 3.1 Domestic wells, details, and sampling dates, Riverton, Wyoming, site (Concluded)

\begin{tabular}{|c|c|c|c|c|}
\hline $\begin{array}{c}\text { Domestic wells" } \\
\text { TAC ID \# }\end{array}$ & $\begin{array}{l}\text { Date(s) } \\
\text { sampled }\end{array}$ & $\begin{array}{l}\text { Total/casing } \\
\text { depth (ft) }\end{array}$ & Aquifer & $\begin{array}{c}\text { Water } \\
\text { use }\end{array}$ \\
\hline 444 & 1994 & $375 / 365$ & $\begin{array}{l}\text { Confined sandstone } \\
\text { bedrock }\end{array}$ & Domestic \\
\hline 445 & 1994 & $35 / ?$ & Surficial & Stock \\
\hline 446 & 1994 & $410 / 370$ & $\begin{array}{l}\text { Confined sandstone } \\
\text { bedrock }\end{array}$ & Potable \\
\hline 448 & 1985 & $405 / ?$ & $\begin{array}{l}\text { Confined sandstone } \\
\text { bedrock }\end{array}$ & Potable \\
\hline 451 & 1994 & $360 / 338$ & $\begin{array}{l}\text { Confined sandstone } \\
\text { bedrock }\end{array}$ & Potable \\
\hline 452 & 1994 & $? / ?$ & $?$ & Potable \\
\hline 453 & 1994 & $? / ?$ & $?$ & Potable \\
\hline 460 & 1993 & $450 / ?$ & $\begin{array}{l}\text { Confined sandstone } \\
\text { bedrock }\end{array}$ & Process \\
\hline 951 & $1988,1992(2 X)$ & $273 / 246$ & $?$ & Potable? \\
\hline
\end{tabular}

${ }^{a}$ See Figure 3.2 for well locations.

bWater uses: Potable $=$ Drinking and other uses.

Domestic = Bathing, washing dishes and other uses, but not drinking.

Stock = Watering livestock, irrigation, but not drinking or domestic.

Irrigate $=$ Crop irrigation but no drinking or domestic.

? $\quad=$ Information needs to be collected or confirmed. Where water use is not certain, suggest potable to be conservative.

Process $=$ Industrial use.

Water use from interviews with resident or inferred from well characteristics. 
The Koch Sulfur Products Company plant is located near the northwest corner of the Riverton site. This facility previously made acid for the uranium process mill and is still in production. This facility uses the same water supply well that supplied the former uranium mill. This well is reportedly $345 \mathrm{ft}(105 \mathrm{~m})$ deep and produces an average of $110 \mathrm{gal}(416 \mathrm{~L}$ ) per minute (Slack, 1994). Approximately 70 gal $(265 \mathrm{~L})$ per minute of used process water from this facility flows into a retention pond south of the plant and then into an unlined drainage ditch that runs to the south under Highway 137 and into the Little Wind River (Figure 3.2). The remainder of the process water is recycled.

\subsection{SOURCES OF EXISTING DATA}

Ground water quality sampling has been performed at the Riverton site since the mid-1970s (FBD, 1983; FBDU, 1981; GECR, 1983; LBL, 1984; DOE, 1987). The Water Sampling and Analysis Plan (WSAP) (DOE, 1994C) summarizes much of the data. During 1993 and 1994, DOE conducted a BLRA to evaluate the potential impacts to human health and the environment (DOE, 1994b). The Technical Evaluation Report (TER) prepared by the NRC (NRC, 1989) to summarize or present was also reviewed. As stated in the TER, the NRC requires that DOE assess the need for further remedial action to bring the ground water into compliance with EPA standards for Title I sites "in a timely manner."

Most monitor wells installed during the pre-1990 investigations were decommissioned during the surface remedial actions at the site. There are 26 monitor wells presently available for sampling. These are identified on Figure 3.5 as monitor wells 100 through 113 near the former mill site; monitor wells 701 through 703, 705, and 707 through 709 near the Little Wind River; monitor well 706 on the south side of the river; monitor wells 710 through 715 along the former Chicago \& Northwestern (C \& NW) railroad right-of-way northwest of the site; and monitor wells 716 through 730 within and downgradient of the site. Monitor well 704, south of Highway 137, is no longer available for sampling because of a dispute with the landowner.

Selected monitor wells from each of these groups have been sampled during the last several years and will continue to be sampled in the future to monitor changes in ground water quality and water levels. Construction details for these wells are presented on Table 3.2. Data on the decommissioned wells are given in DOE, 1987.

Surface water and sediment samples were collected during previous investigations at the locations shown on Figure 3.6. A qualitative ecological survey that included visual observations of plants and wildife was also conducted in the vicinity of the site. No plant or animal tissue samples were collected or analyzed during this survey. 


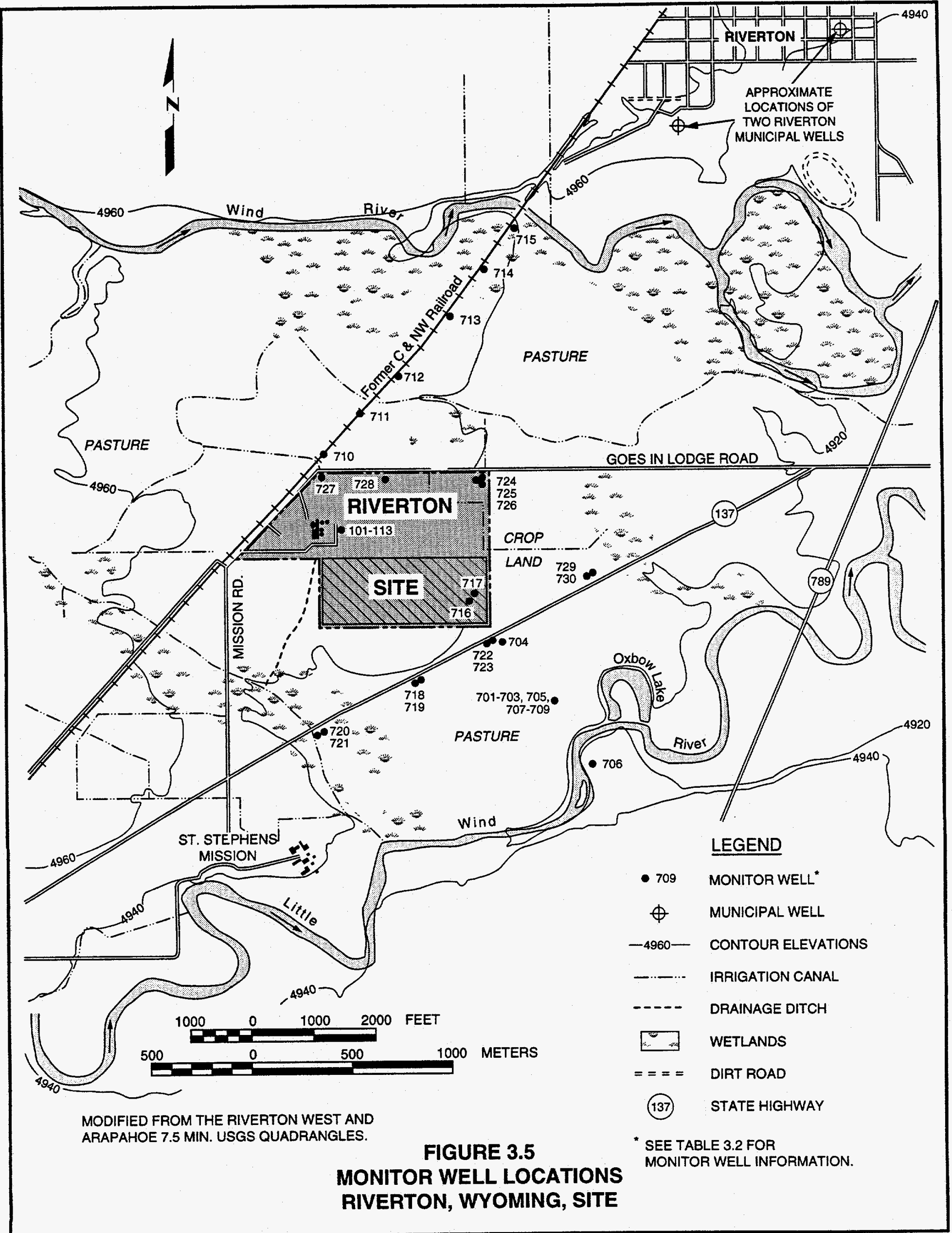


Table 3.2 Monitor well information, Riverton, Wyoming, site

\begin{tabular}{|c|c|c|c|c|c|c|c|c|}
\hline $\begin{array}{l}\text { ID } \\
\#\end{array}$ & $\begin{array}{c}\text { Ground } \\
\text { Elev. }\end{array}$ & $\begin{array}{l}\text { Bore } \\
\text { Depth }\end{array}$ & $\begin{array}{l}\text { Bore } \\
\text { Dia. }\end{array}$ & $\begin{array}{c}\text { Casing } \\
\text { Elev. }\end{array}$ & $\begin{array}{c}\text { Casing } \\
\text { Dia. }\end{array}$ & $\begin{array}{c}\text { Screened } \\
\text { Interval }\end{array}$ & $\begin{array}{l}\text { Filter } \\
\text { Pack }\end{array}$ & Aquifer \\
\hline 100 & 4946.1 & 17.0 & 11.0 & 4646.21 & 6.0 & $6.0-14.0$ & $4.0-17.0$ & Surficial \\
\hline 101 & 4946.2 & 17.5 & 6.0 & 4946.58 & 2.0 & $10.5-15.5$ & $5.5-17.5$ & Surficial \\
\hline 102 & 4946.3 & 17.5 & 6.3 & 4946.30 & 2.0 & $10.0-15.0$ & $6.5-17.0$ & Surficial \\
\hline 103 & 4946.0 & 17.0 & 6.3 & 4946.43 & 2.0 & $10.0-15.0$ & $6.5-17.0$ & Surficial \\
\hline 104 & 4945.3 & 15.5 & 6.3 & 4945.90 & 2.0 & $8.5-13.5$ & $6.5-15.5$ & Surficial \\
\hline 105 & 4946.3 & 17.5 & 6.3 & 4946.79 & 2.0 & $10.5-15.5$ & $6.0-17.5$ & Surficial \\
\hline 106 & 4946.2 & 100.0 & 6.0 & 4945.88 & 2.0 & $49.5-54.5$ & $35.0-56.5$ & Semiconfined \\
\hline 107 & 4946.0 & 67.0 & 6.0 & 4945.98 & 2.0 & 49.554 .5 & $36.5-56.5$ & Semiconfined \\
\hline 108 & 4946.2 & 56.0 & 6.0 & 4946.02 & 2.0 & $48.5-53.5$ & $35.5-56.5$ & Semiconfined \\
\hline 109 & 4945.8 & 58.0 & 6.0 & 4946.08 & 2.0 & $49.0-54.0$ & $40.0-56.0$ & Semiconfined \\
\hline 110 & 4946.2 & 72.0 & 6.0 & 4946.44 & 2.0 & $61.3-66.5$ & $59.0-72.0$ & Confined \\
\hline 111 & 4946.1 & 56.0 & 9.8 & 4946.87 & 6.0 & 39.054 .0 & 36.056 .0 & Semiconfined \\
\hline 112 & 4946.2 & 32.0 & 10.0 & 4947.27 & 6.0 & $8.5-28.5$ & $5.0-32.0$ & Surficial \\
\hline 113 & 4946.2 & 34.0 & 6.0 & 4946.40 & 2.0 & $21.0-26.0$ & $5.0-34.0$ & Surficial \\
\hline 701 & 4930.2 & 228.0 & 6.0 & 4930.80 & 2.0 & $25.4-30.4$ & $23.0-31.0$ & Semiconfined \\
\hline 702 & 4930.2 & 215.0 & 6.0 & 4931.00 & 2.0 & $39.2-44.2$ & $35.5-45.5$ & Semiconfined \\
\hline 703 & 4930.2 & 214.0 & 6.0 & 4930.70 & 2.0 & $93.0-98.0$ & $87.0-98.0$ & Confined \\
\hline 705 & 4930.1 & 50.0 & 10.0 & 4930.80 & 6.0 & $38.0-48.0$ & $35.5-50.0$ & Semiconfined \\
\hline 706 & 4931.1 & 21.5 & 6.0 & 4932.00 & 2.0 & $14.5-19.5$ & $12.8-21.5$ & Surficial \\
\hline 707 & 4930.4 & 18.0 & 6.0 & 4931.00 & 2.0 & $9.8-14.8$ & $7.5-16.8$ & Surficial \\
\hline 709 & 4930.2 & 111.0 & 10.0 & 4930.70 & 6.0 & $85.0-105.0$ & $84.0-111.0$ & Confined \\
\hline 710 & 4947.2 & 20.0 & 6.0 & 4947.90 & 2.0 & $11.2-16.2$ & $8.0-20.0$ & Surficial \\
\hline 711 & 4943.5 & 21.5 & 6.0 & 4944.50 & 2.0 & $10.8-15.8$ & $6.0-21.5$ & Surficial \\
\hline 712 & 4943.5 & 19.5 & 6.0 & 4944.50 & 2.0 & $10.6-15.6$ & $10.0-19.5$ & Surficial \\
\hline 713 & 4941.6 & 16.5 & 6.0 & 4942.70 & 2.0 & $9.5-14.5$ & $4.5-16.5$ & Surficial \\
\hline 714 & 4941.2 & 18.0 & 6.0 & 4942.10 & 2.0 & $11.0-16.0$ & $10.0-18.0$ & Surficial \\
\hline 715 & 4938.5 & 18.5 & 6.0 & 4939.40 & 2.0 & $11.5-16.5$ & $6.8-18.5$ & Surficial \\
\hline 716 & 4936.4 & 12.5 & 6.0 & 4939.12 & 2.0 & $7.5-12.5$ & $5.5-12.5$ & Surficial \\
\hline
\end{tabular}


Table 3.2 Monitor well information, Riverton, Wyoming, site (Concluded)

\begin{tabular}{rcccccccl}
\hline $\begin{array}{c}\text { ID } \\
\#\end{array}$ & $\begin{array}{c}\text { Ground } \\
\text { Elav. }\end{array}$ & $\begin{array}{c}\text { Bore } \\
\text { Depth }\end{array}$ & $\begin{array}{c}\text { Bore } \\
\text { Dia. }\end{array}$ & $\begin{array}{c}\text { Casing } \\
\text { Elev. }\end{array}$ & $\begin{array}{c}\text { Casing } \\
\text { Dia. }\end{array}$ & $\begin{array}{c}\text { Screened } \\
\text { Interval }\end{array}$ & $\begin{array}{c}\text { Filter } \\
\text { Pack }\end{array}$ & Aquifer \\
\hline 717 & 4936.4 & 50.0 & 6.0 & 4938.80 & 2.0 & $37.5-47.5$ & $29.0-49.5$ & Semiconfined \\
718 & 4937.0 & 18.0 & 6.0 & 4937.18 & 2.0 & $13.0-18.0$ & $10.0-18.0$ & Surficial \\
719 & 4936.8 & 40.0 & 6.0 & 4936.94 & 2.0 & $28.0-38.0$ & $23.0-40.0$ & Semiconfined \\
720 & 4937.9 & 10.5 & 6.0 & 4940.46 & 2.0 & $5.5-10.5$ & $3.5-10.5$ & Surficial \\
721 & 4937.9 & 49.0 & 6.0 & 4940.47 & 2.0 & $37.0-47.0$ & $27.0-49.0$ & Semiconfined \\
722 & 4935.2 & 18.0 & 6.0 & 4935.35 & 2.0 & $6.0-16.0$ & $4.0-18.0$ & Surficial \\
723 & 4935.0 & 49.0 & 6.0 & 4935.26 & 2.0 & $35.5-45.5$ & $31.0-47.5$ & Semiconfined \\
724 & 4939.4 & 16.0 & 6.0 & 4941.36 & 2.0 & $11.0-16.0$ & $6.0-16.0$ & Surficial \\
725 & 4939.4 & 38.0 & 6.0 & 4941.36 & 2.0 & $24.5-34.5$ & $19.5-36.5$ & Semiconfined \\
726 & 4939.5 & 133.0 & 6.0 & 4942.00 & 2.0 & $121.0-131$ & $80.0-133.0$ & Confined \\
727 & 4949.5 & 40.0 & 6.0 & 4951.69 & 2.0 & $27.0-37.0$ & $21.5-39.0$ & Semiconfined \\
728 & 4943.9 & 24.0 & 6.0 & 4946.01 & 2.0 & $12.0-22.0$ & $9.0-24.0$ & Surficial \\
729 & 4932.1 & 17.0 & 6.0 & 4932.07 & 2.0 & $9.0-14.0$ & $8.0-14.0$ & Surficial \\
730 & 4932.5 & 40.0 & 6.0 & 4932.48 & 2.0 & $28.0-38.0$ & $21.0-40.0$ & Semiconfined \\
\hline
\end{tabular}




\section{تIIS 'ONIWOAM 'NOLIEAIY SNOIL $\forall 007$ פNI7dW IN}

$\lambda \forall M H O H H \exists \perp \forall \perp S$

(48)

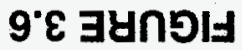

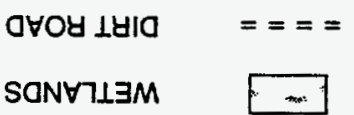

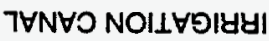

$\cdots-\cdot-$

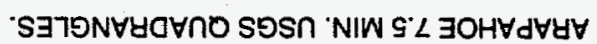

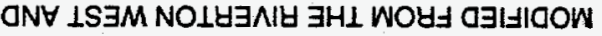

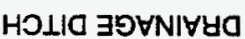

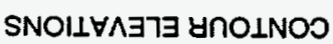

$7 า \exists M$ TళdIOINกW

- $0967-$

$\oplus$

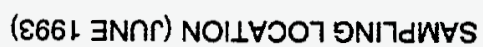

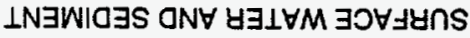

$\phi 272$ S4ヨ1ヨW
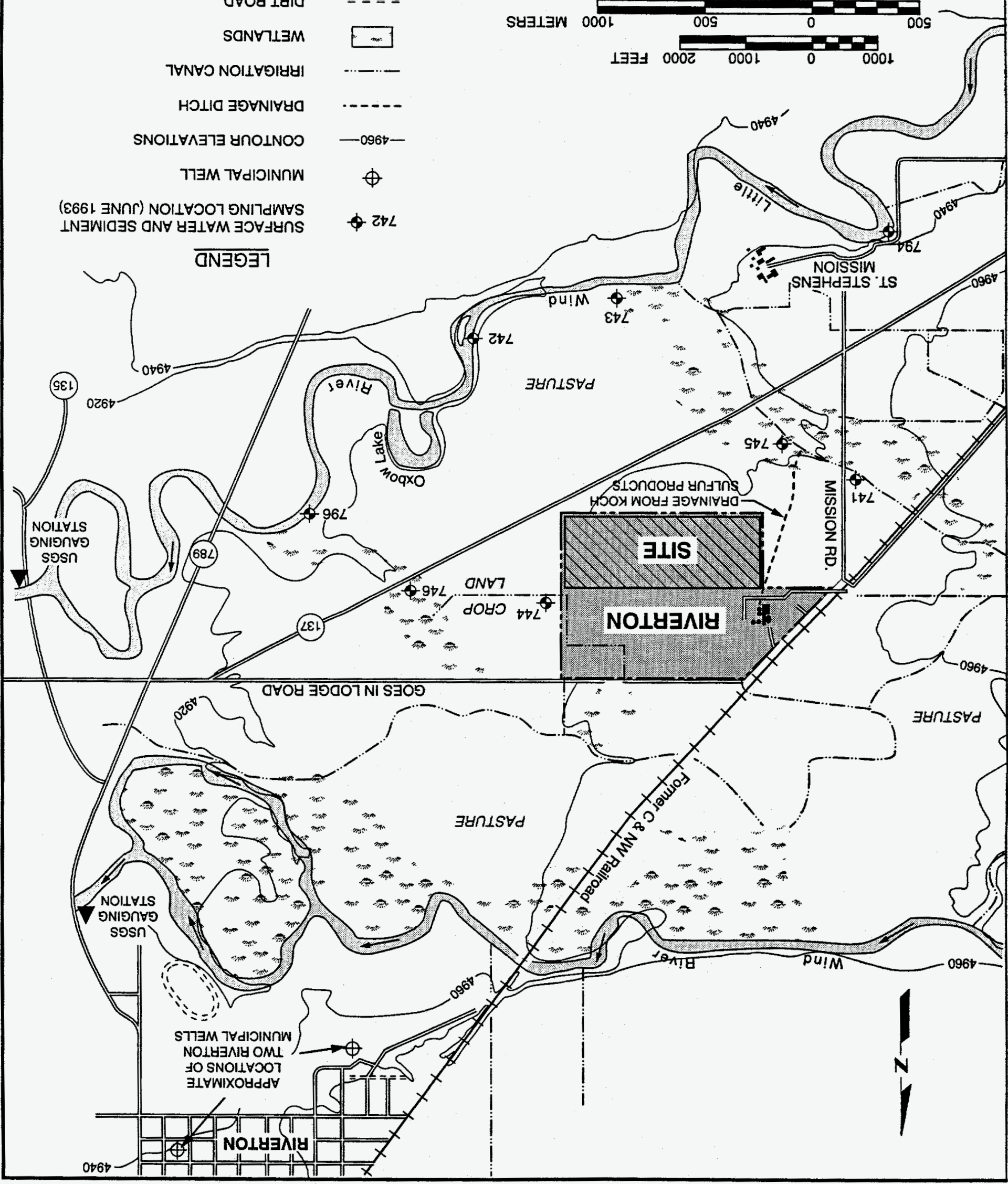


\section{PHYSIOGRAPHIC SETTING}

The former Riverton uranium mill tailings site is located on a nearly level alluvial terrace between the Wind River (approximately $4000 \mathrm{ft}[1000 \mathrm{~m}]$ to the north) site and the Little Wind River (approximately $3000 \mathrm{ft}[900 \mathrm{~m}]$ to the southeast) (Figure 3.2). These two rivers join approximately $2.5 \mathrm{mi}(4.0 \mathrm{~km})$ east of the site. The land surface elevation at the site averages approximately $4950 \mathrm{ft}$ $(1510 \mathrm{~m})$ above mean sea level (MSL) and slopes at less than 0.5 percent to the southeast.

The climate in the Riverton area is semiarid to arid (DOE, 1987) and is influenced both by cold air masses from Canada and by the prevailing, warm westerly winds. The highest and lowest temperatures recorded in Riverton from 1951 to 1980 were 104 degrees Fahrenheit $\left({ }^{\circ} \mathrm{F}\right)\left(40\right.$ degrees Celsius $\left.\left[{ }^{\circ} \mathrm{C}\right]\right)$ and $-46^{\circ} \mathrm{F}\left(-43^{\circ} \mathrm{C}\right)$, and an average of 207 days per year have minimum temperatures less than or equal to $32^{\circ} \mathrm{F}\left(0^{\circ} \mathrm{C}\right)$, and an average of 37 days per year have maximum temperatures of $90^{\circ} \mathrm{F}\left(32^{\circ} \mathrm{C}\right)$ or greater. The average annual precipitation during the 30-year period from 1951 to 1980 was 8 inches $(20 \mathrm{~cm})$. The greatest amount of precipitation and ground water infiltration occurs in April, May, and June in the form of late spring snows, snow melt, and showers.

A man-made, unlined drainage channel carries discharge water from the sulfur processing plant on the western side of the site. This channel joins the regional irrigation canal system and natural wetlands areas before the canal passes under Highway 137 where the system joins the Little Wind River approximately $3500 \mathrm{ft}(1100 \mathrm{~m})$ due south of the property. A second wetlands area is located to the east of the site. Drainage from this wetland passes under Highway 137 approximately $2500 \mathrm{ft}(760 \mathrm{~m})$ east of the southeast corner of the property. A former meander in the Little Wind River has been cut off, leaving an oxbow lake southeast of the site.

A system of irrigation canals are located along the northern and eastern sides of the property. These canals carry water from the Wind River to the northwest and discharge into the wetlands area east of the site. The irrigation system operates from June to October. The flow in the canal where it enters the site and where it exits the site was approximately 1 cubic foot $\left(\mathrm{ft}^{3}\right)\left(0.028 \mathrm{~m}^{3}\right)$ per second in June 1994.

\subsection{HYDROGEOLOGIC SETTING}

There are five hydrogeologic units of interest underlying the Riverton site. They are, in descending order, a surficial, unconfined alluvial and sandstone aquifer; a leaky shale aquitard; a semiconfined sandstone aquifer; a second, more impermeable shale aquitard; and a confined sandstone aquifer (Figure 3.7). The rock units comprise the upper units of the Eocene age Wind River Formation. 


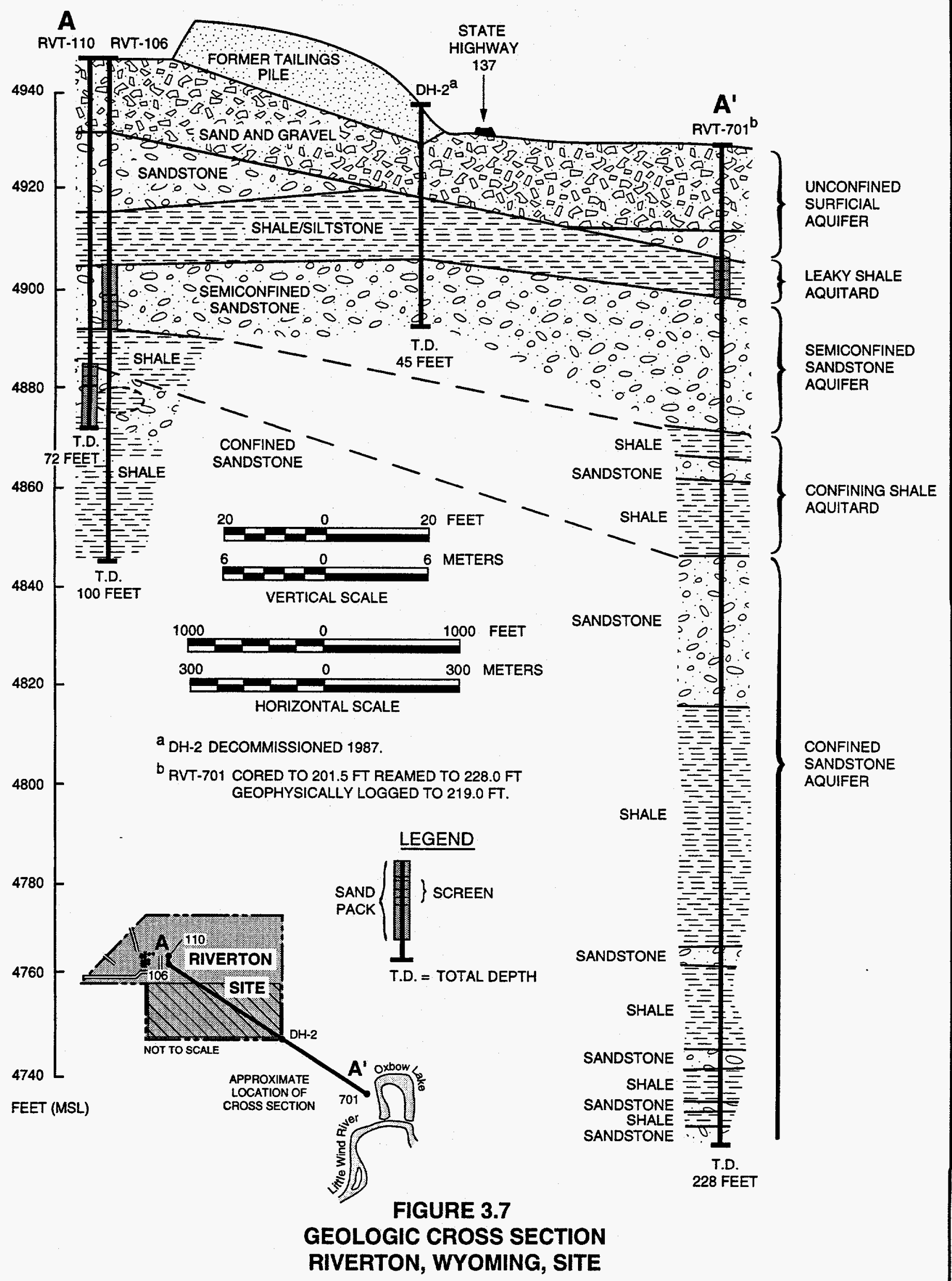


Analysis of deuterium and oxygen-18 isotopes in the ground water indicate that samples taken from all three aquifers in the vicinity of the site are isotopically similar (White et al., 1984). White postulates that from the slightly depleted ratios of deuterium and oxygen-18, the source of ground water for all three aquifers is the Wind River Mountains to the west. This suggests that there is a common source of recharge and communication between these three units upgradient from the site.

\subsubsection{Surficial aquifer}

The surficial unconfined aquifer consists of 15 to $20 \mathrm{ft}(5$ to $6 \mathrm{~m}$ ) of alluvial sand and gravel underlain by a discontinuous layer of sandstone. The sandstone layer exists both north and south of the former tailings pile, but pinches out and is absent for approximately $1500 \mathrm{ft}(500 \mathrm{~m})$ south of the southern edge of the pile. There is no aquitard between the alluvial sediments and this sandstone layer.

The water table in the surficial aquifer in March 1993 ranged from approximately $7.5 \mathrm{ft}(2.3 \mathrm{~m})$ below the ground surface (elevation $4936 \mathrm{ft}$ [1504 m] MSL) at the middle of the northern edge of the property (monitor well 728) to about $5.5 \mathrm{ft}(1.7 \mathrm{~m}$ ) below ground surface (elevation $4930 \mathrm{ft}[1503 \mathrm{~m}] \mathrm{MSL}$ ) near the southeast corner of the site (monitor well 716). The ground water flow was east-southeast with a gradient of approximately 0.0024 , as shown in Figure 3.8.

In June 1994, the ground water level in both the surficial and semiconfined aquifers (monitor wells 728 and 727 , respectively) at the northern edge of the site had risen $2 \mathrm{ft}(0.6 \mathrm{~m}$ ) above the March 1993 level (Table 3.2), while the water level in both aquifers near the middle and at the southeastern corner were about the same as in March 1993 (Figure 3.9). The ground water flow in June 1994 was almost due south and the gradient beneath the site increased by about 30 percent to 0.0034 (Figure 3.8 ). The rise in the water table is interpreted to be in response to infiltration from the nearby irrigation canal. A similar rise was seen in a well completed in the semiconfined aquifer at the northwest corner of the property, indicating hydraulic connection between the surficial and semiconfined aquifers in this area. Infiltration from the canals may also form hydraulic boundaries limiting the movement of ground water to the east during the irrigation season.

Ground water in the surficial aquifer discharges predominantly to the Little Wind River. When the irrigation canals are not in use, some of the ground water in the surficial aquifer may also discharge into the wetlands to the east. When the irrigation canals are in use, the water level in the wetlands may be high enough to reverse the flow direction and recharge the surficial aquifer.

A 24-hour, 5-gal (19-L) per minute aquifer pumping test was conducted in the surficial aquifer in monitor well RVT-112 near the northwest corner of the former tailings pile as part of the EA (DOE, 1987). Measurable drawdown was not observed in either the semiconfined or confined aquifers during the test. The 


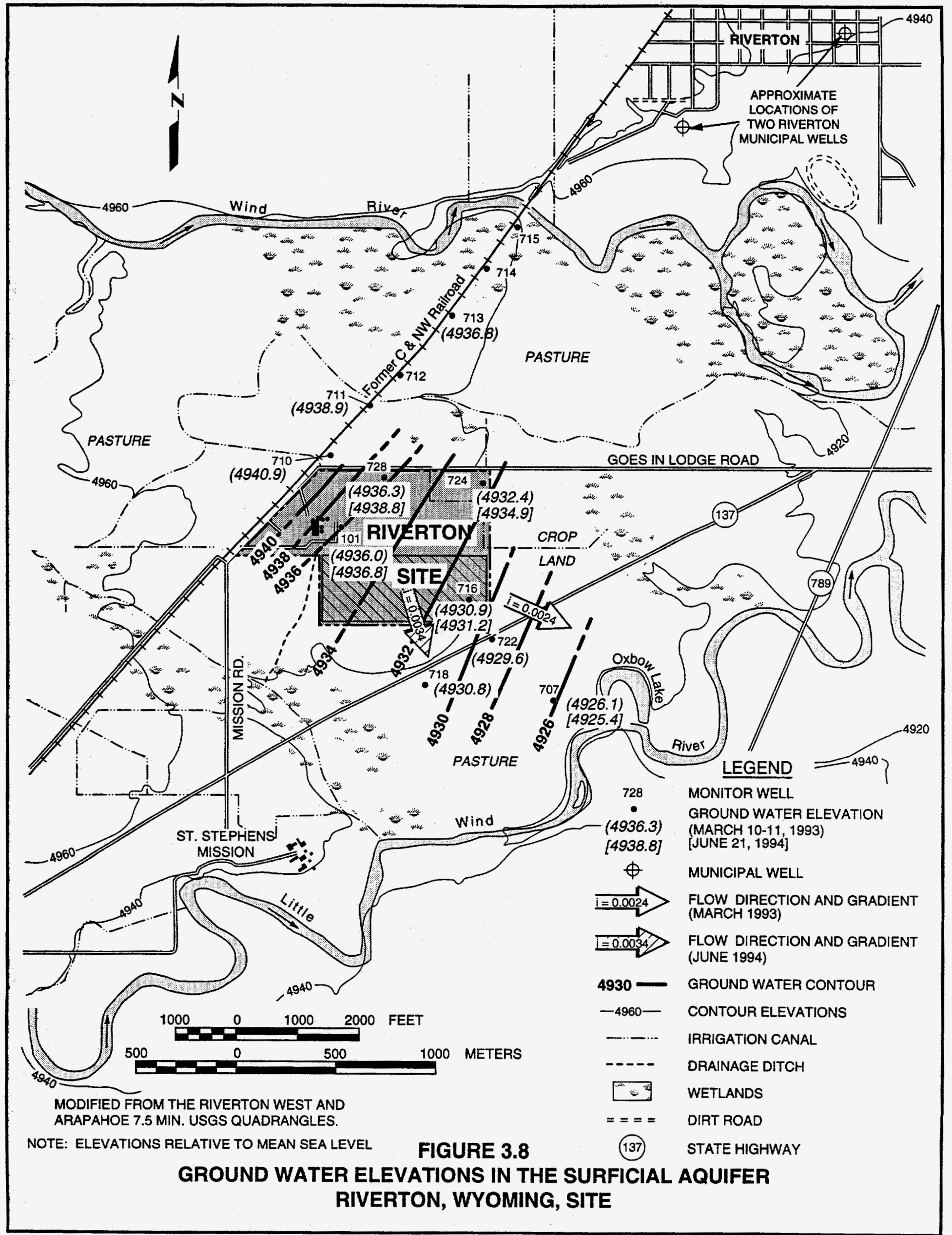




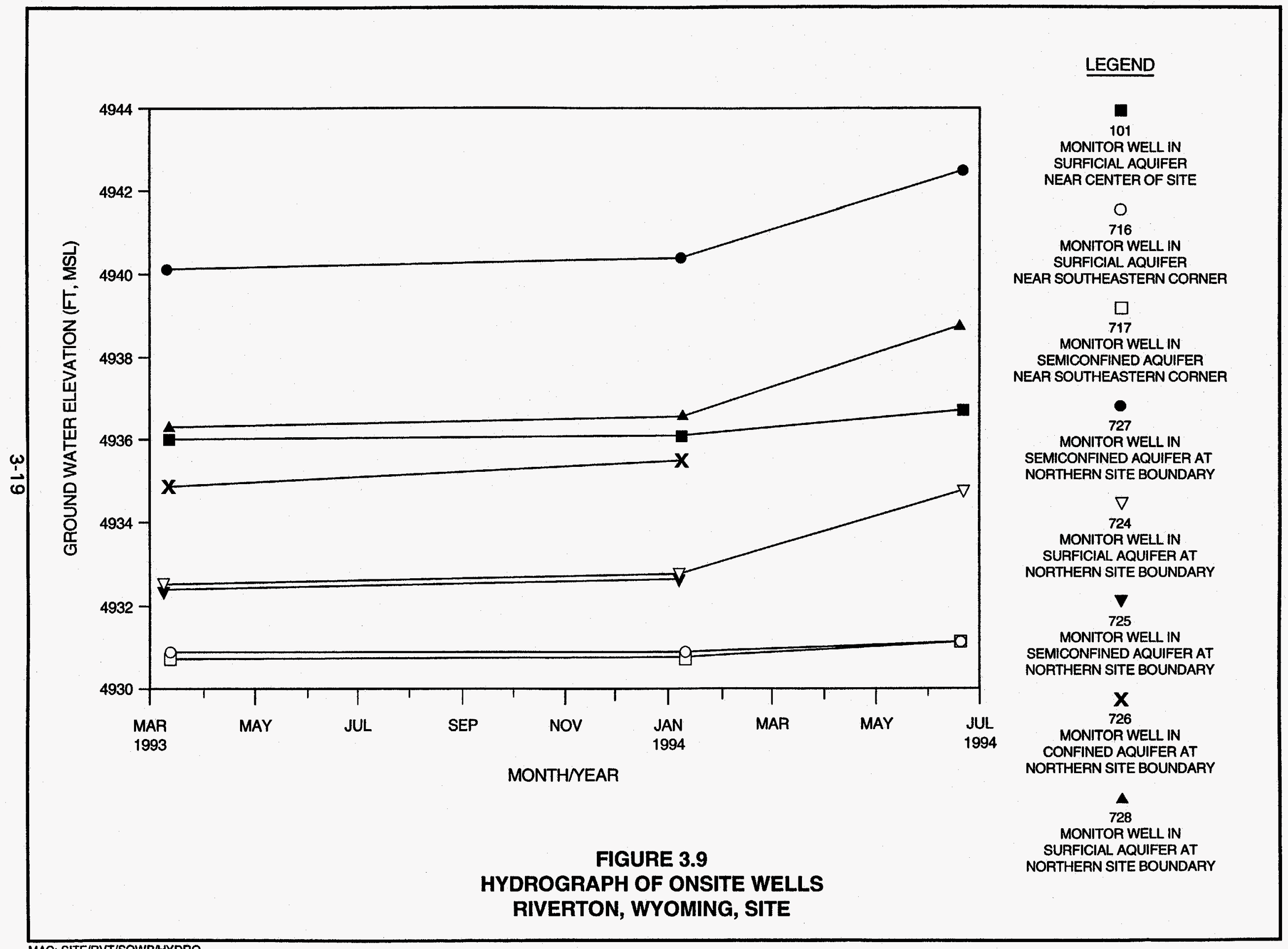


test demonstrated a hydraulic conductivity of approximately $56 \mathrm{ft}(17 \mathrm{~m})$ per day. Using a porosity of 0.30 (DOE, 1987) for the alluvium and unconfined sandstone and the March 1993 gradient of 0.0024 , the calculated ground water flow velocity is approximately $160 \mathrm{ft}(55 \mathrm{~m})$ per year. During the irrigation season, the steeper gradient of 0.0034 could increase the flow velocity to $230 \mathrm{ft}(80 \mathrm{~m})$ per year. At these rates, one pore volume of water will move from beneath the upgradient edge of the former tailings pile to the Little Wind River in 20 to 30 years. Approximately four pore volumes will flush beneath the site within 100 years.

\subsubsection{Semiconfined aquifer}

A semiconfining shale unit underlies the surficial aquifer. This leaky aquitard ranges in thickness from 5 to $10 \mathrm{ft}(2$ to $3 \mathrm{~m})$. A semiconfined sandstone unit underlies this shale layer. This unit ranges in thickness from 15 to $30 \mathrm{ft}$ ( 5 to $9 \mathrm{~m}$ ) and is continuous throughout the Riverton site. The shale aquitard does not appear to completely separate the two units hydraulically, as the piezometric heads in the surficial and semiconfined aquifers are nearly identical in most areas, as shown in Figure 3.10 and in the hydrographs in Figure 3.9.

A 24-hour, 18-gal (68-L) per minute aquifer test in the semiconfined sandstone yielded a calculated hydraulic conductivity of about $30 \mathrm{ft}(10 \mathrm{~m})$ per day. No significant water level changes were noted in monitor wells in the surficial aquifer during this test.

Using a porosity of 15 percent (typical of sandstones according to Freeze and Cherry, 1987) and the March 1993 gradient of 0.0024 , it is projected that the ground water will move with an approximate velocity of $175 \mathrm{ft}(60 \mathrm{~m})$ per year. The ground water in the semiconfined sandstone also appears to discharge into the Little Wind River, although additional data will be needed to confirm this assumption. At this rate, approximately one pore volume of ground water will flush through semiconfined aquifer every 25 years.

\subsubsection{Confined aquifer}

Approximately 10 to $25 \mathrm{ft}(3$ to $8 \mathrm{~m}$ ) of shale aquitard with discontinuous sandstone lenses underlies the semiconfined sandstone. The confined sandstone aquifer underlies the shale aquitard. The sandstone is at least $50 \mathrm{ft}$ $(15 \mathrm{~m})$ thick. Water level data from the monitor wells completed in the confined sandstone indicate that ground water flow in this unit is to the south with a gradient of approximately 0.002 (Figure 3.11). No aquifer tests have been performed in the confined aquifer.

Water levels observed in the monitor wells do not conclusively define the vertical ground water gradient between the aquifers. For example, in the well cluster south of the site near the Little Wind River, the piezometric head in deep monitor well 703 (4928.31 ft MSL) exhibits an upward gradient from the lower confined sandstone aquifer to the shallower aquifers (4926.05 ft MSL) in 


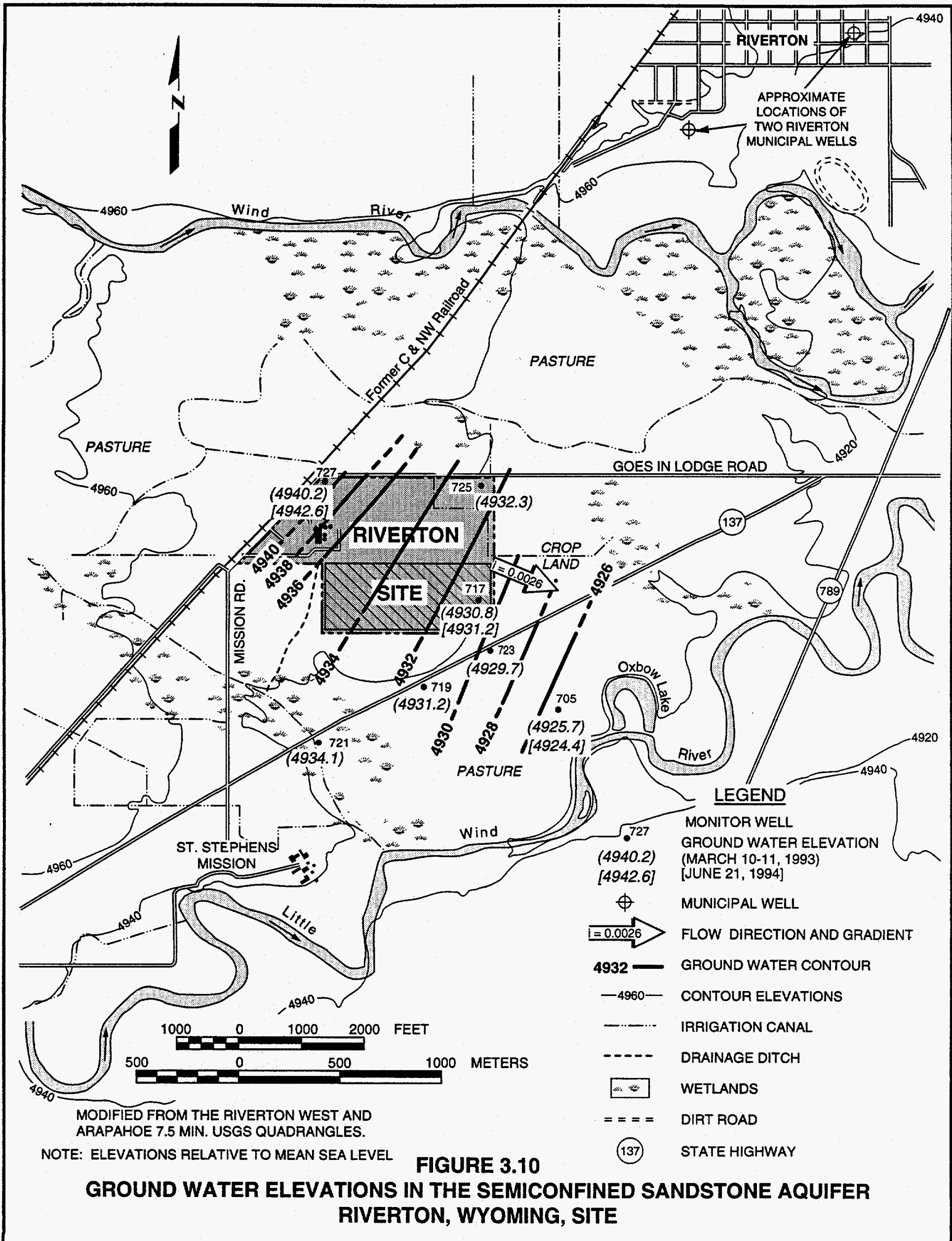




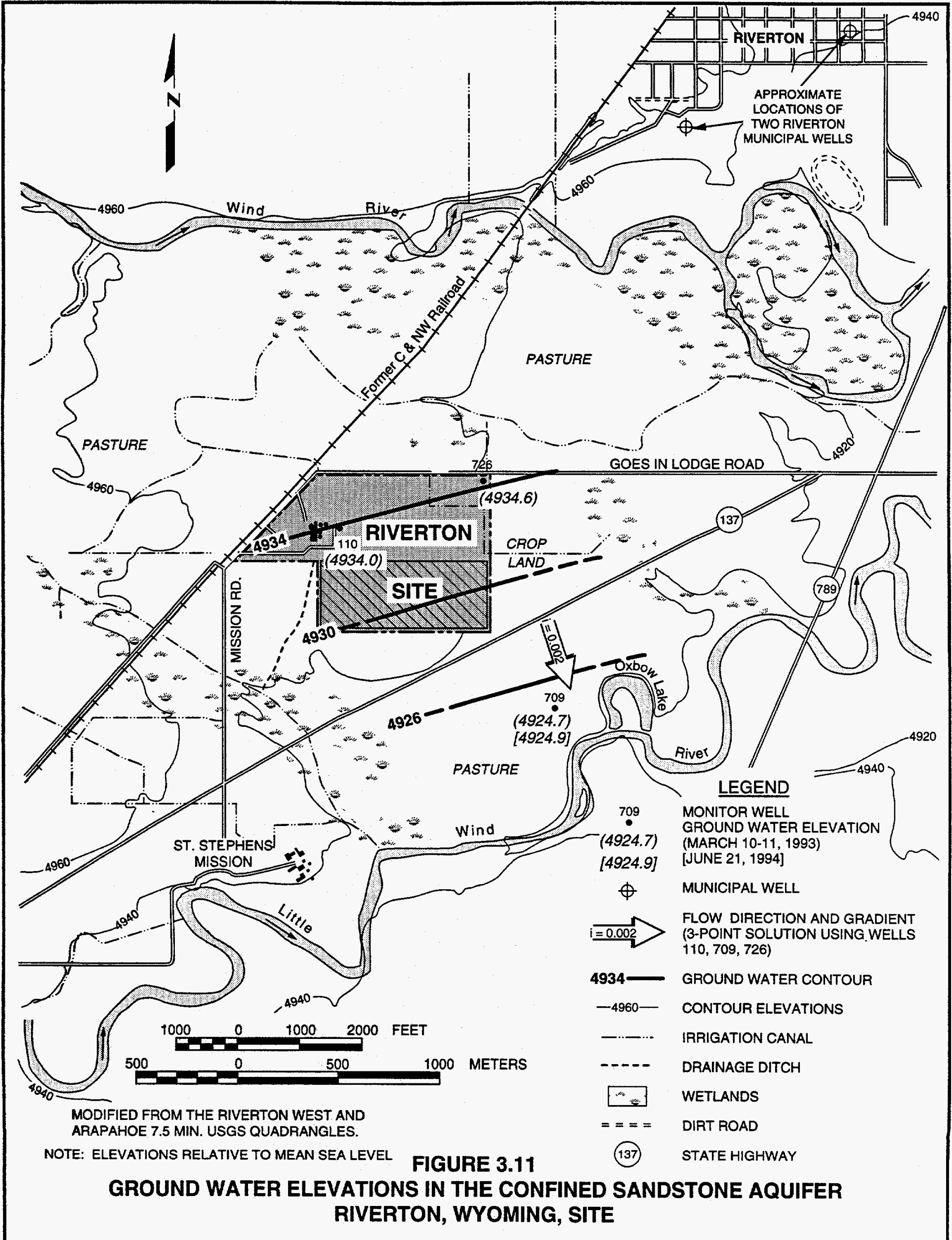


monitor well 707). In contrast, the piezometric head in the nearby deep monitor well 709 (4924.65 ft MSL) exhibits a downward gradient even though it is screened at approximately the same depth. While vertical gradients between the surficial and semiconfined aquifers and the confined sandstone aquifer have not been conclusively defined, none of the deep monitor wells have ever shown any impacts associated with the former milling operations.

\subsection{GROUND WATER QUALITY}

This section discusses the natural, background ground water quality and the contamination resulting from the former milling operations.

\subsubsection{Background ground water quality}

Background ground water quality is the quality of ground water if uranium milling activities had not taken place. Table 3.3 lists the ranges and median background concentrations of the milling-related constituents measured in the surficial, semiconfined, and confined aquifers.

\section{Surficial aquifer}

Monitor wells 710 and 711 (Figure 3.8 ) represent background ground water quality based on their position upgradient from the former processing site and the low concentrations or absence of milling-related constituents in ground water samples. Background ground water quality in the surficial aquifer is a moderately oxidizing, calcium-sulfate-bicarbonate water characterized by nearneutral $\mathrm{pH}$, ranging from 7.1 to 7.6 , and low TDS.

\section{Semiconfined aquifer}

The background wells are located upgradient from the remediated tailings pile, but are still within the site along the northern perimeter of the site boundary (Figure 3.10 ) in an area that was contaminated with wind-blown material (Figure 3.4). Therefore, additional background water quality data may be needed.

Background ground water quality of the semiconfined aquifer, which can be described as a moderately oxidizing, sulfate-bicarbonate-calcium sodium type with a slightly basic $\mathrm{pH}$, was determined from monitor wells 725 and 727 .

\section{Confined aquifer}

Background ground water quality of the confined aquifer was determined from monitor well 726 located northwest and upgradient of the remediated tailings pile. Ground water in the confined aquifer is a moderately oxidizing sodiumsulfate water characterized by low TDS and high $\mathrm{pH}$ (9.3 to 9.9). 


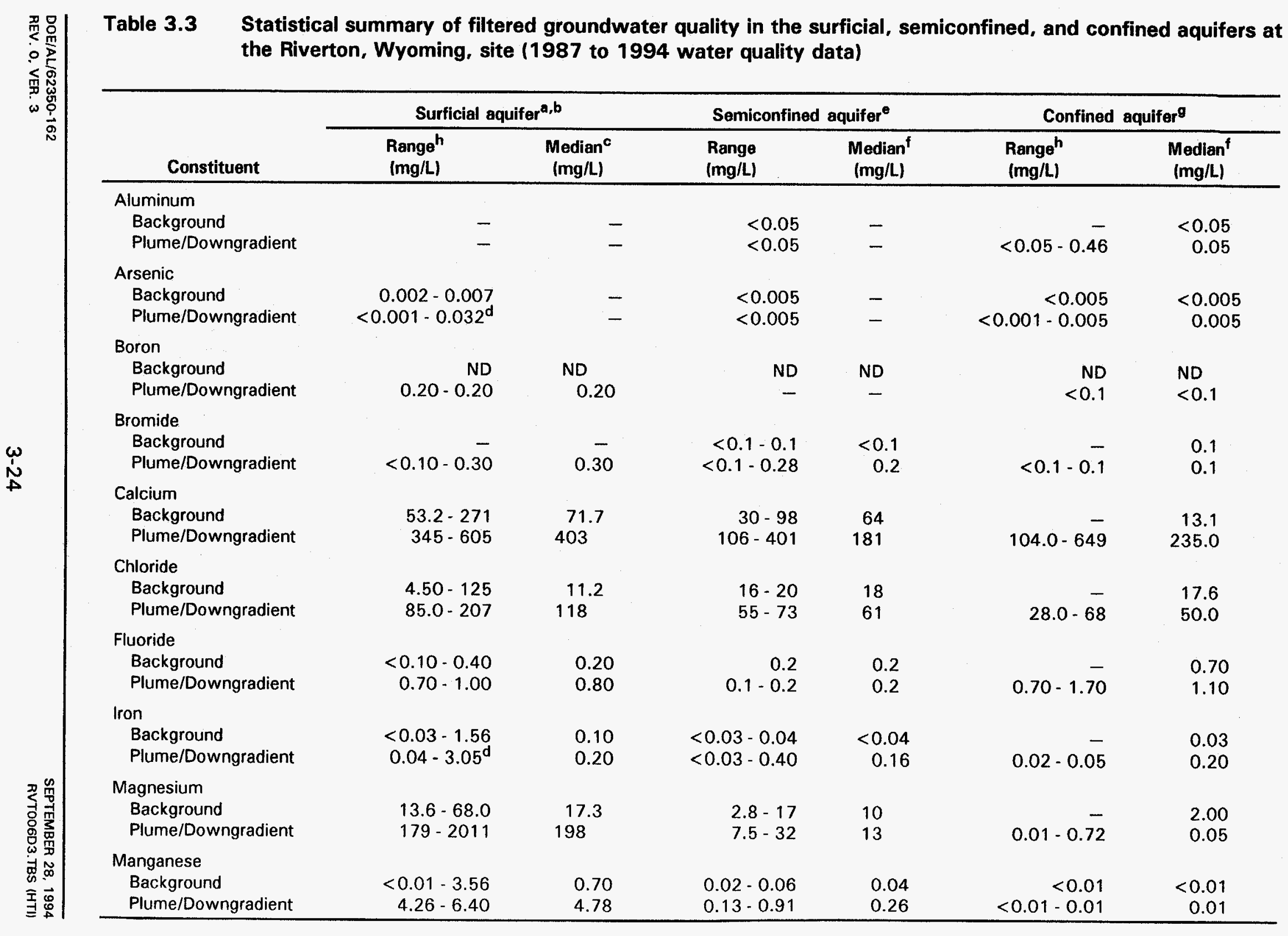




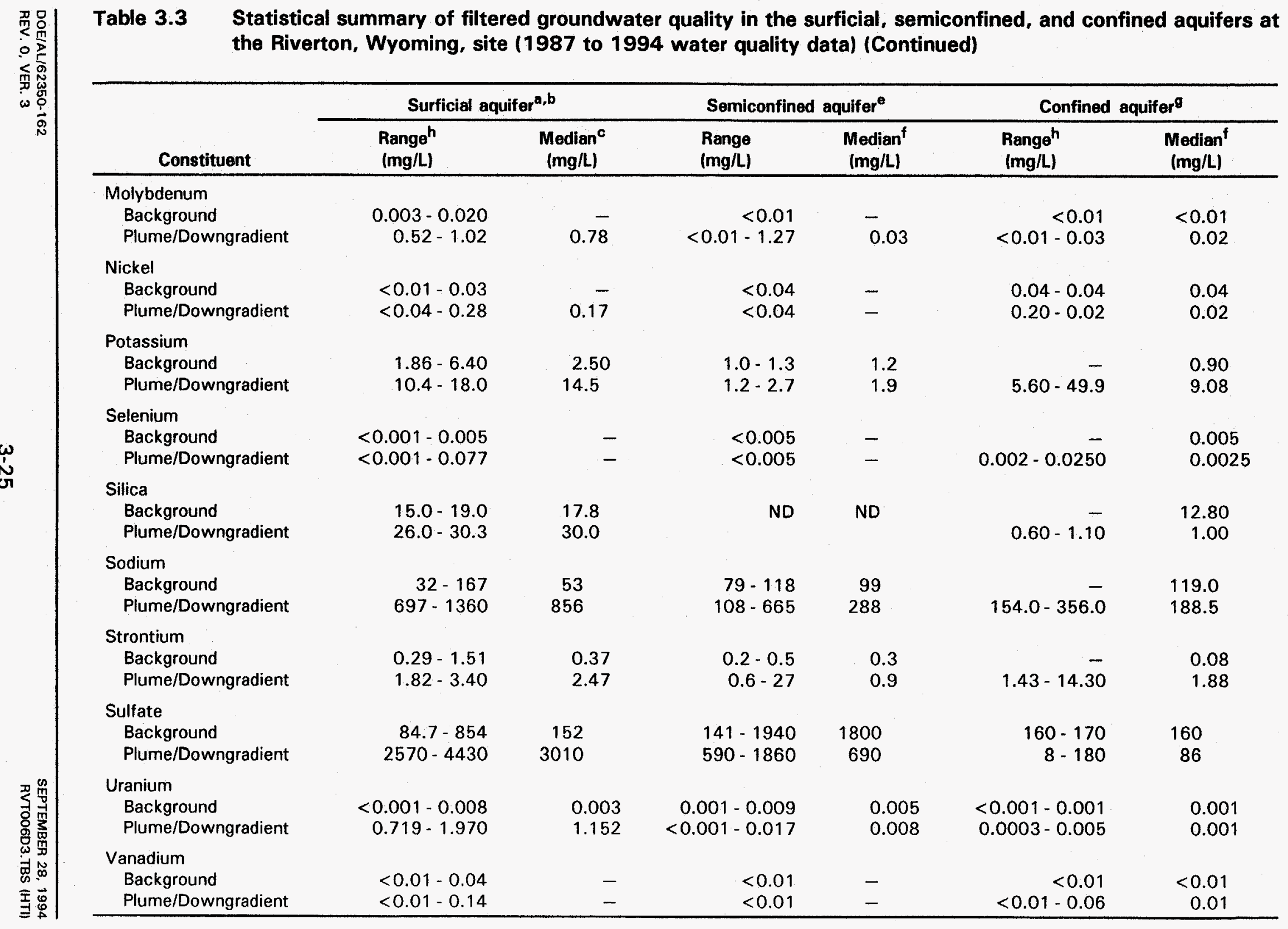


Statistical summary of filtered groundwater quality in the surficial, semiconfined, and confined aquifers at the Riverton, Wyoming, site (1987 to 1994 water quality data) (Concluded)

\begin{tabular}{|c|c|c|c|c|c|c|}
\hline \multirow[b]{2}{*}{ Constituent } & \multicolumn{2}{|c|}{ Surficial aquifer $r^{a, b}$} & \multicolumn{2}{|c|}{ Semiconfined aquifer ${ }^{\circ}$} & \multicolumn{2}{|c|}{ Confined aquifer ${ }^{g}$} \\
\hline & $\begin{array}{l}\text { Range } \\
\text { (mg/L) }\end{array}$ & $\begin{array}{c}\text { Medianc } \\
\text { (mg/L) }\end{array}$ & $\begin{array}{l}\text { Range } \\
\text { (mg/L) }\end{array}$ & $\begin{array}{c}\text { Medianf } \\
\text { (mg/L) }\end{array}$ & $\begin{array}{l}\text { Range } \\
\text { (mg/L) }\end{array}$ & $\begin{array}{c}\text { Median } \\
\text { (mg/L) }\end{array}$ \\
\hline \multicolumn{7}{|l|}{ Zinc } \\
\hline Background & $<0.005-0.021$ & - & $0.008-0.012$ & 0.010 & - & 0.007 \\
\hline Plume/Downgradient & $<0.005-0.019^{d}$ & - & $0.008-0.013$ & 0.010 & $<0.005-0.024$ & 0.0055 \\
\hline \multicolumn{7}{|l|}{ Radionuclides } \\
\hline \multicolumn{7}{|l|}{ Lead-210 } \\
\hline Background & $0.00-0.90$ & 0.15 & $0.3-1.5$ & 0.9 & - & 3.00 \\
\hline Plume/Downgradient & $0.20-4.00$ & 3.00 & $0.0-1.5$ & 0.7 & $1.50-1.50$ & 1.50 \\
\hline \multicolumn{7}{|l|}{ Polonium-210 } \\
\hline Background & $0.10-0.30$ & 0.20 & 0.0 & 0.0 & 0 & 1.20 \\
\hline Plume/Downgradient & $0.10-2.40$ & 0.90 & $0.0-0.6$ & 0.1 & $1.00-1.10$ & 1.00 \\
\hline \multicolumn{7}{|l|}{ Thorium-230 } \\
\hline Background & $0.00-3.80$ & 0.20 & $0.1-1.6$ & 0.9 & - & 0.4 \\
\hline
\end{tabular}

a Surficial aquifer background ground water quality represented by monitor wells 710 and 711 .

b Surficial aquifer groundwater quality in the centroid of the plume represented by monitor well 707.

${ }^{c}$ The median or 50th percentile of the sample data cannot be determined unless more than 50 percent of the data are above detection. A dash (-) in the median column indicates the median cannot be calculated.

d Maximum observed concentrations in unfiltered samples exceeded those obtained for filtered samples for these

constituents in monitor well 707.

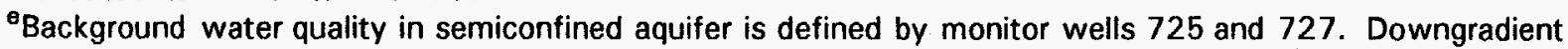

groundwater impacted by milling is represented by monitor wells 108, 717, 719, and 723 .

The median is the 50th percentile of the data. Based on two data values, the median is only the arithmetic average.

For four data values, the median is the average of the two middle values. A dash $(-)$ in the median column indicates the median cannot be calculated.

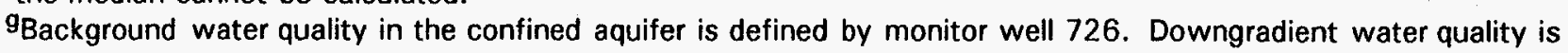

represented by monitor well 709 . Elevated $\mathrm{pH}$ in monitor well 709 may indicate grout contamination; this well is used

because there are no other wells in the confined aquifer downgradient from the site.

${ }^{h} \mathrm{~A}$ dash $(-)$ in the range column indicates only one measurement is available and is presented on the median column.

ND - no data available.

Note: Only constituents measured above background concentrations in the surficial aquifer are presented in this table. 


\subsection{NATURE AND EXTENT OF CONTAMINATION}

Ground water quality data indicate that both the surficial and semiconfined aquifers have been impacted by milling activities (Table 3.3). This conclusion is based on the presence of milling-related contaminants at elevated concentrations. Because of their elevated concentrations, indicator parameters such as uranium, molybdenum, and sulfate are used to track plume migration.

\subsubsection{Source of contamination}

Ground water contamination was primarily caused by seepage of original mill process waters and tailings pore fluids into the underlying surficial aquifer. Isotopic analysis of pore fluid from the top meter of the tailings pile showed enrichment of oxygen-18 and hydrogen-2 from evaporation, indicating that infiltration and flow of precipitation through the tailings was insignificant relative to this seepage (White et al., 1984). The milling process consisted of both sulfuric acid and alkaline leach processes, resulting in a composite alkaline-acidic tailings pile. The mixed acidic and alkaline leachate (high in sulfate, carbonate species, uranium, and major anions and cations) seeped into the ground water, impacting ground water quality. The mobility of the indicator parameters (defined above) was enhanced under the existing alkaline conditions. Furthermore, because the base of the tailings pile rested within several feet of the water table, it is believed that fluctuations in water levels may have periodically flooded the tailings.

\subsubsection{Contaminants of concern}

In general, a constituent was placed on the list of contaminants of concern when the site was the likely source of the contamination and the average constituent concentrations measured in contaminated wells exceeded the average background levels at the 0.05 level of statistical significance. Inorganic constituents exceeding background concentrations in the surficial aquifer are aluminum, arsenic, boron, bromide, calcium, chloride, fluoride, iron, magnesium, manganese, molybdenum, nickel, potassium, selenium, silica, sodium, strontium, sulfate, uranium, vanadium, and zinc. Several of the chemical species detected above background were deleted from the list of contaminants of concern because they are essential nutrients and were detected at levels within nutritional ranges. These constituents are calcium, chloride, fluoride, iron, potassium, and zinc. Some of the remaining contaminants were removed from the list of contaminants of concern on the basis of very low toxicity and relatively high dietary intake compared to the values detected.

For the surficial aquifer, these screening criteria eliminated all the contaminants but the following contaminants of concern: arsenic, manganese, molybdenum, nickel, sulfate, uranium, vanadium, and several radioactive progeny of the uranium decay series, including lead-210, polonium-210, and thorium-230. The contaminants of concern for the semiconfined aquifer are manganese, 
molybdenum, sulfate, and uranium. No contaminants of concern were detected in the confined aquifer.

\subsubsection{Extent of contamination}

The extent and distribution of milling-related contamination with the respect to the surficial, semiconfined, and confined aquifers and the surface water and sediments is presented subsequently.

The centroid of the contaminant plume is currently located offsite near the Little Wind River, suggesting that the original pulse of contamination is moving with the ground water flow. This evidence provides a partial basis for the selection of natural flushing as the proposed remedial compliance strategy.

\section{Surficial aquifer}

Ground water contamination in the surficial aquifer downgradient from the former processing site (monitor well 707) is characterized by elevated concentrations of molybdenum, sulfate, and uranium. Figures $3.12,3.13$, and 3.14 show the concentrations of molybdenum, sulfate, and uranium, respectively, in surficial ground water. The analytical data are presented in Appendix B2. The other contaminants are not present in sufficient, widespread concentrations to be depicted. The figures indicate contamination migration southeast toward the Little Wind River.

\section{Semiconfined aquifer}

Ground water in the semiconfined aquifer is also contaminated directly beneath and downgradient from the processing site. The potentiometric surface of the semiconfined aquifer is presently about the same as that of the surficial aquifer in the vicinity of the abandoned mill site. When the mill was in operation, however, the drainage from the tailings pile would have mounded the ground water in the surficial aquifer, resulting in a downward vertical gradient. This vertical hydraulic gradient has resulted in the contamination of the semiconfined aquifer. Milling-related contamination in the semiconfined aquifer is represented by water quality data from monitor wells $108,717,719$, and 723

(Appendix B2). The most recent sampling in March 1993 showed that concentrations of calcium, chloride, iron, manganese, molybdenum, sodium, strontium, sulfate, and uranium are elevated with respect to background, although they are generally lower than those detected in the surficial aquifer (Table 3.3). Sulfate concentrations in the semiconfined aquifer are shown in Figure 3.15. These contours indicate that the contamination in the semiconfined aquifer is also moving offsite southeast toward the Little Wind River. Detected concentrations of the other constituents were not sufficiently well distributed to create similar figures. 


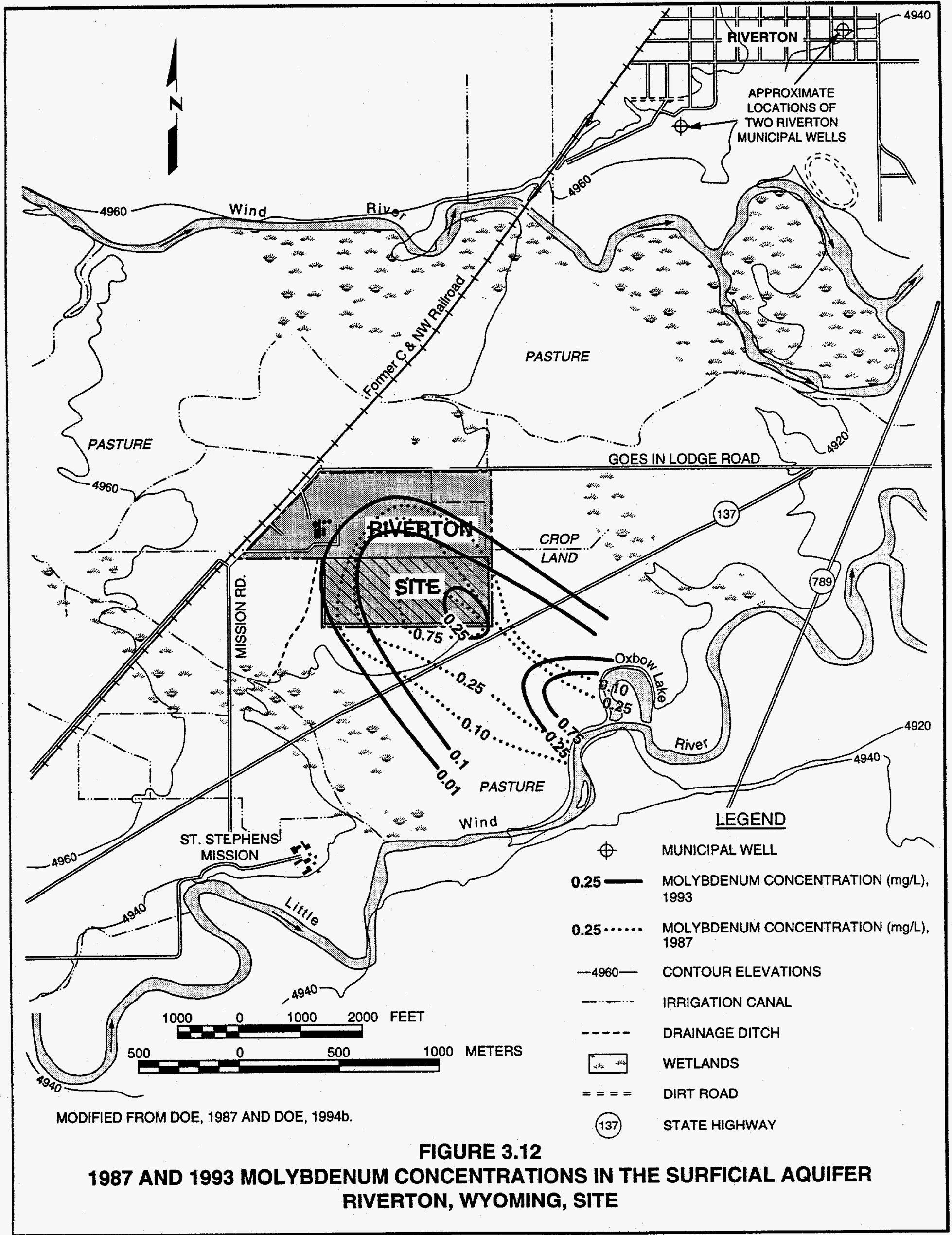




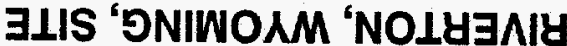

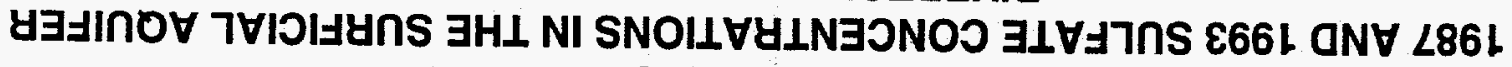

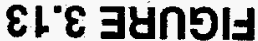

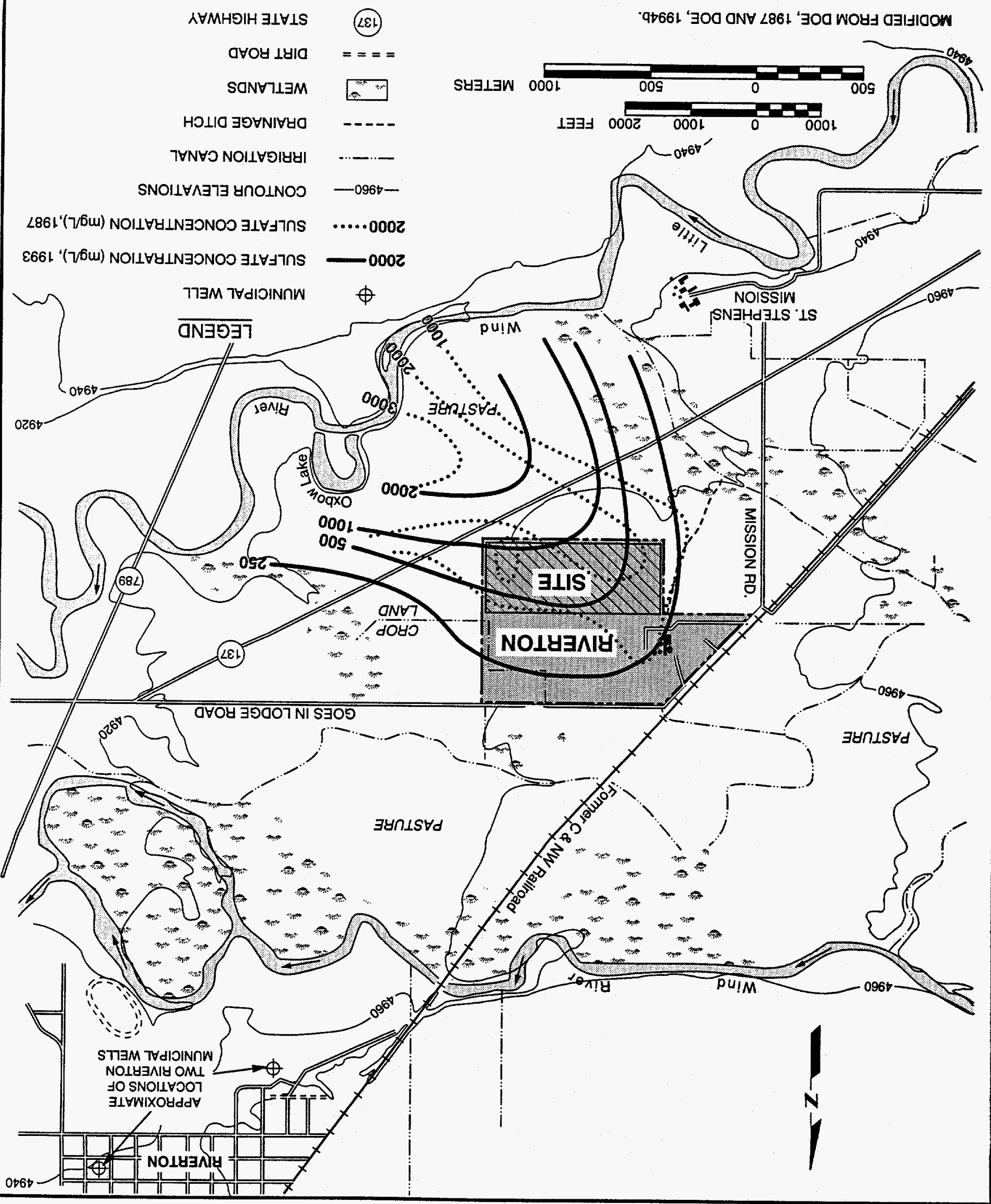




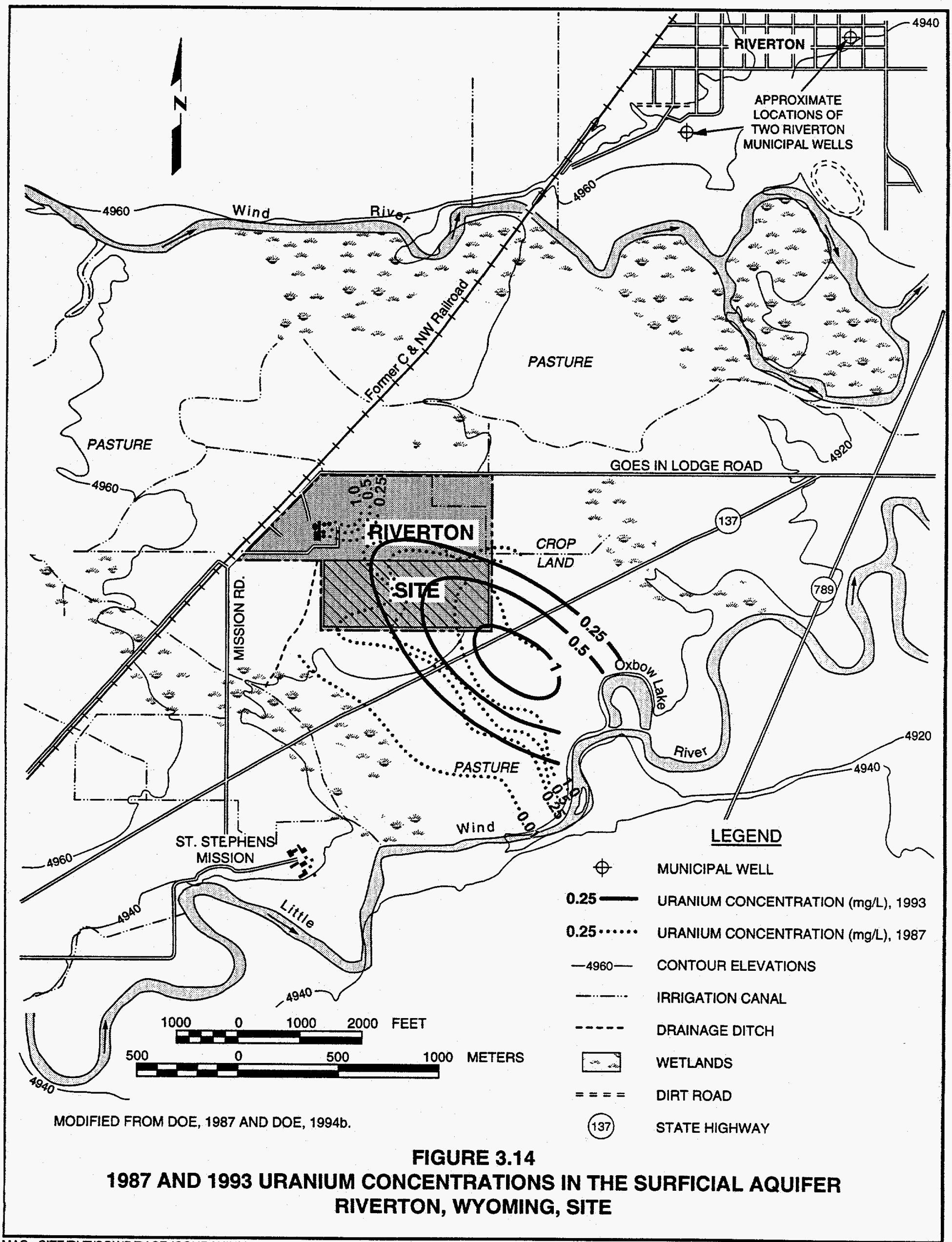




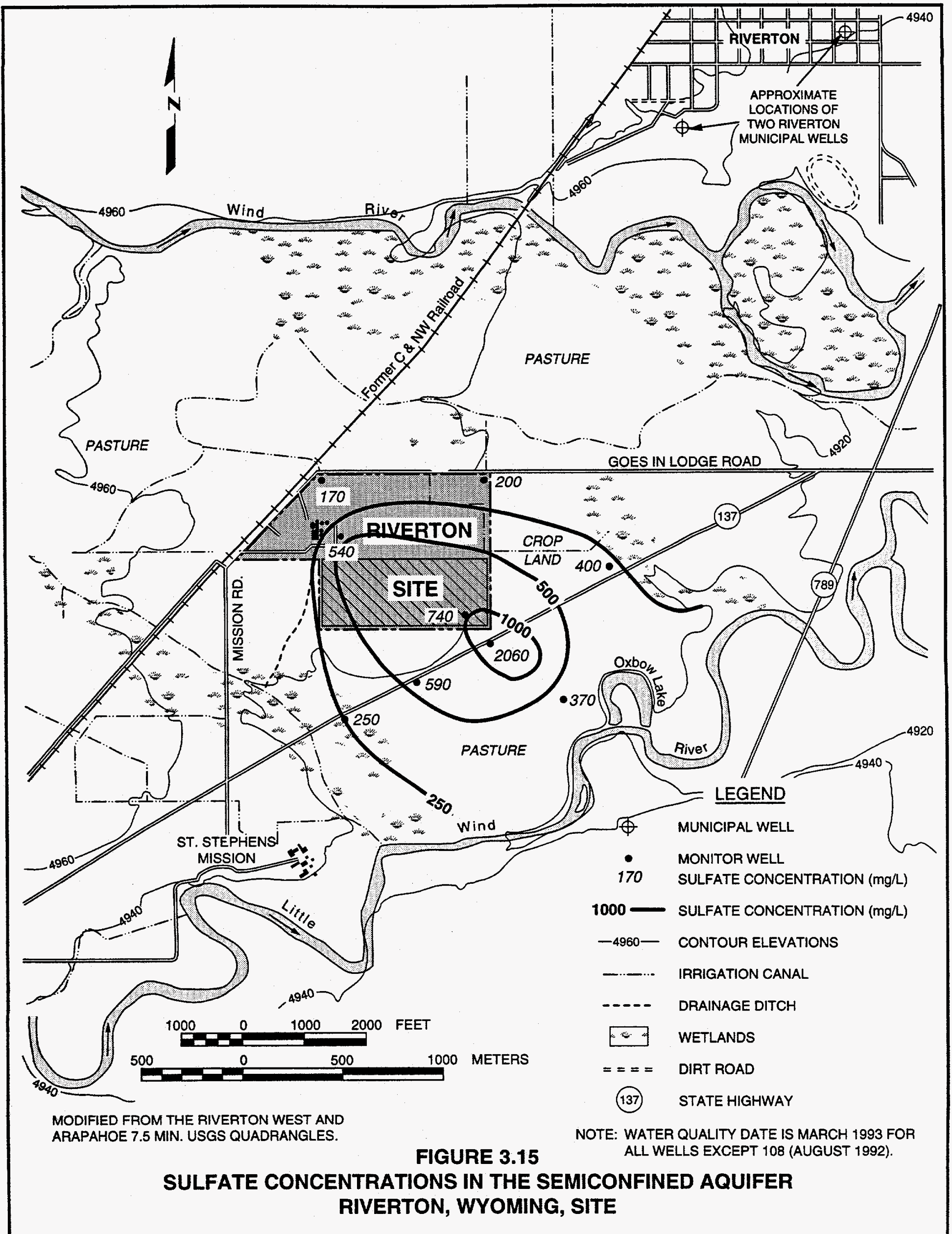




\section{Confined aquifer}

Ground water quality data from upgradient, onsite, and downgradient monitor wells (monitor wells 726,110 , and 709 , respectively) indicate that this aquifer has not been affected by milling activities.

\section{Surface water and sediments}

Elevated concentrations of uranium (Appendix C) were detected in both the surface water and sediment samples collected from the Little Wind River in June 1993 at location 742 (Figure 3.6). The uranium concentrations in the surface water measured at this location $10.025 \mathrm{mg} / \mathrm{L}$ ) were approximately one order of magnitude higher than the upstream background location $794(0.002 \mathrm{mg} / \mathrm{L})$, but still well below the MCL for drinking water standards $(0.044 \mathrm{mg} / \mathrm{L})$. Similarly, the uranium concentration in the sediments at location 742 was five times higher than at the background location $(10.0 \mathrm{mg} / \mathrm{kg}$ versus $2.0 \mathrm{mg} / \mathrm{kg})$. Approximately $4500 \mathrm{ft}(1372 \mathrm{~m})$ farther downstream (location 796), uranium concentrations in both the surface water and sediments decline to background levels. Based on the distribution of contaminant concentration, it is anticipated that the Little Wind River will dilute discharging contaminated ground water to near background concentrations downgradient of the site.

Surface water and sediment samples collected from the contaminant plume area (location 741); from irrigation canals upgradient of the wetlands areas east (746) and west (745) of the site; from an irrigation canal at the eastern edge of the site (location 744); and from an oxbow lake south of the site near the Little Wind River (location 743) were analyzed for calcium, iron, lead, magnesium, manganese, molybdenum, and uranium. Although water quality criteria for protection of aquatic life are not available for all of these constituents, the concentrations detected in surface samples did not exceed those that are available.

The water sampled at location 743 was probably a combination of ground water discharged from the north and water recharged from the river. The samples indicated elevated concentrations of calcium, magnesium, manganese, and uranium. The concentration of uranium was only $0.013 \mathrm{mg} / \mathrm{L}$, well below the $\mathrm{MCL}$ of $0.044 \mathrm{mg} / \mathrm{L}$ for drinking water. The sediments sampled at this location indicated elevated concentrations of iron, lead, manganese, and uranium.

The water sampled at location 744 was predominantly water that flowed into the canal from the Wind River and does not represent ground water discharge. The samples indicated a slightly elevated concentration of uranium $(0.016 \mathrm{mg} / \mathrm{L})$. Additional investigations are needed to further assess the sources of contamination at this location.

The water sampled at location 746 showed significantly higher concentrations of calcium and magnesium. The sediments sampled at this location indicated higher than background concentrations of lead and magnesium. The lead 
contamination in the sediments may be due to accumulations from automobile exhaust and runoff from Highway 137.

The selection of natural flushing as the remedial strategy for the Riverton site is based on the conceptual site model, the discharge of contaminated ground water into the Little Wind River, and the expected attenuation mechanisms of the various constituents. This section discusses the movement and attenuation of the contaminants of concern.

\subsubsection{Contaminant flushing}

Contaminants present in the surficial aquifer are moving with the ground water downgradient from the processing site to the Little Wind River. Since uranium ore processing was begun in 1958, ground water movement has transported the centroid of ground water contamination southeast to the vicinity of monitor well 707 , located approximately $3000 \mathrm{ft}(900 \mathrm{~m})$ from the tailings pile area.

A ground water flow and contaminant transport model, prepared in the EA (DOE, 1987), was used to predict changes in the sulphate concentrations in the surficial aquifer over time (Figure 3.16). The model assumed that the sulfate moved with the ground water. The effects of dispersion and attenuation were not addressed. As shown in Figure 3.16, the model predicted that the sulfate plume would be flushed from the system in approximately 45 years (from 1987), assuming no continuing source.

Comparison of the 1987 and 1993 data showing the concentrations of molybdenum, sulfate, and uranium in the surficial aquifer (Figures 2.12, 3.13, and 3.14, respectively) confirms that the center of the contamination has moved from beneath the site towards the Little Wind River. The configuration of the three plumes are different due to variation in the rates at which the different constituents move. These differences are controlled by their concentrations and their individual interactions with the aquifer matrix.

The calibrated steady-state flow model used in this evaluation was developed with the Trescott (1976) code. Calibration was performed by adjusting hydraulic conductivity data in certain areas to match an interpreted contour map with the model results. These adjustments were needed because of the lack of hydraulic conductivities in these areas. Future modeling of the surficial aquifer will require the verification of hydraulic conductivities.

Because ground water discharges to the Little Wind River, surface water quality is of major concern before implementing the natural flushing strategy. As noted earlier, samples collected from the Little Wind River in 1993 exhibited elevated concentrations of uranium immediately downgradient of the site, but farther downstream (location 796) the uranium concentrations decline to background levels. It is therefore interpreted that the Little Wind River will be able to dilute 


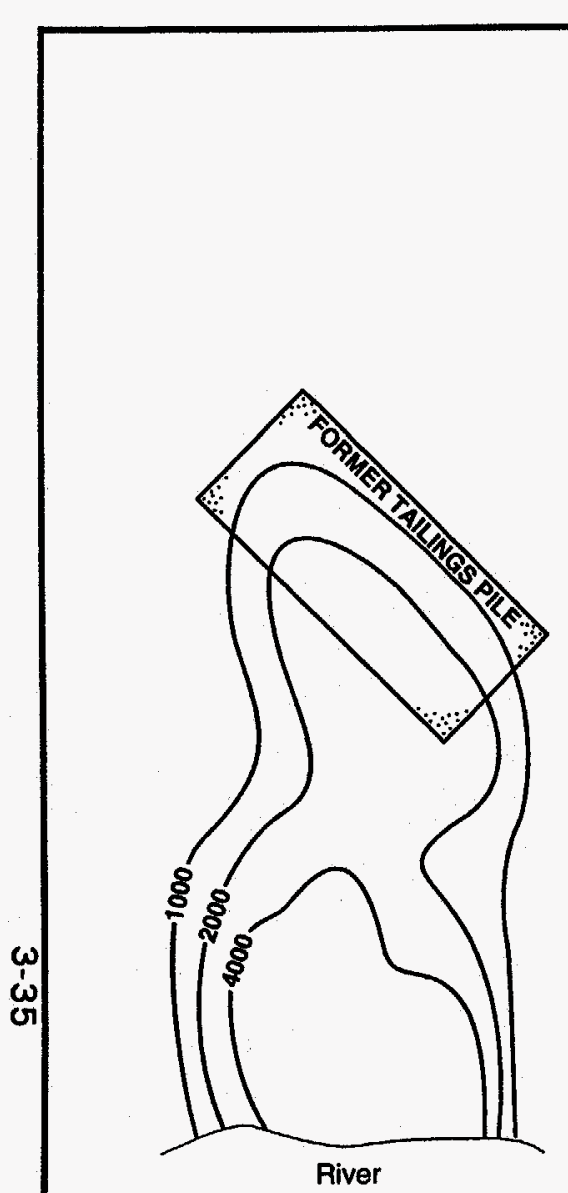

$T_{0}$
$(1987)$

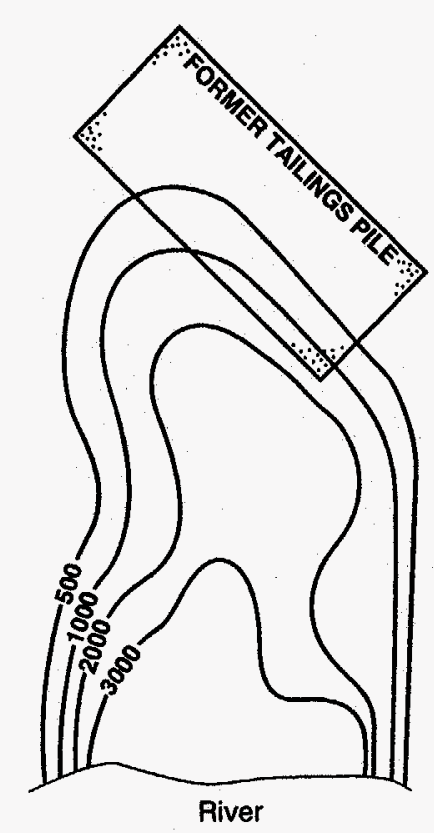

To $_{0} 5$ YRS. (1992)

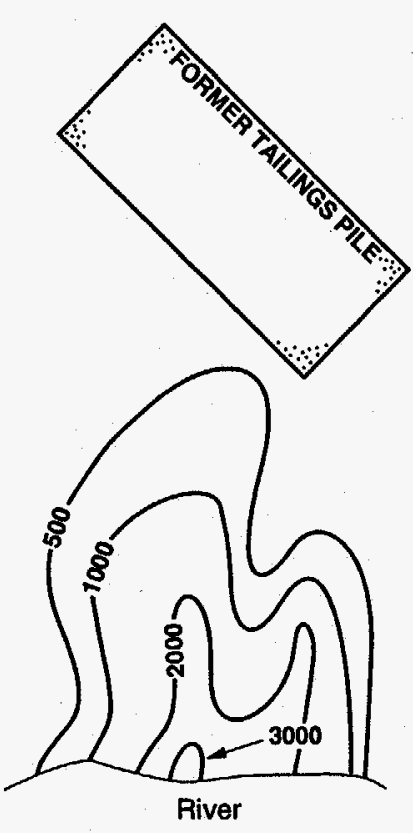

$T_{0}+15$ YRS. (2002)
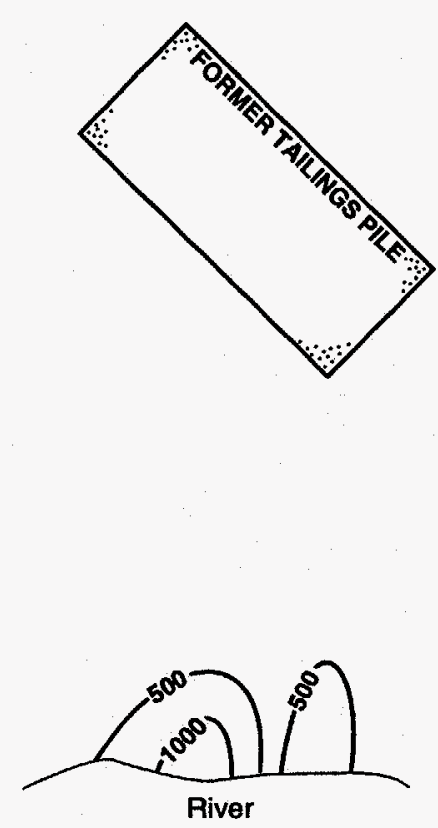

$T_{0}+25$ YRS. (2012)
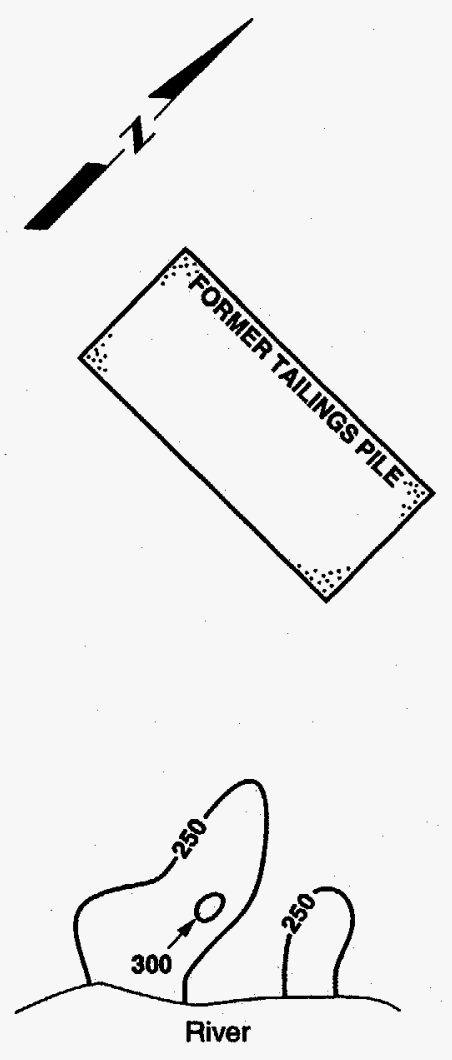

$T_{0}+45$ YRS. (2032)

NOTE: CONTOURS IN MILLIGRAMS/LITER

MODIFIED FROM DOE, 1987 SIMULATED SULFATE PLUME CONCENTRATIONS.

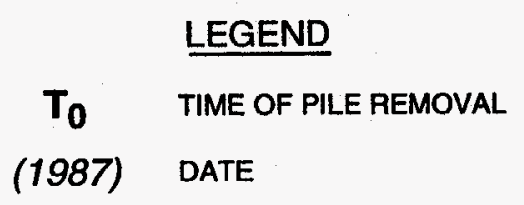

FIGURE 3.16

SULFATE PLUME DEVELOPMENT AFTER TAILINGS PILE RELOCATION RIVERTON, WYOMING, SITE

MAC: SITERELATED/RVT/SOWP/SULFPLUMDEV 
the discharging ground water to near background concentrations. Additional monitoring is needed to assess the impacts of possible ground water discharge on the wetlands east of the site and on the oxbow lake to the southeast.

\subsubsection{Contaminant attenuation}

Geochemical sinks in the aquifer are responsible for additional reduction of contaminants in ground water. Sorption onto the aquifer matrix and precipitation are the primary sinks. Dispersion and dilution will also be effective in reducing concentration of contaminants.

Geochemical computer modeling, using the software packages MINTEQA2 (Allison et al., 1991) and PHREEOE (Parkhurst et al., 1980), was used to calculate saturated mineral phases and species in ground water. Water quality data exhibiting the highest constituent concentration (monitor well 707) was used as input for the model. The modeling calculations show that ground water accessed by monitor well 707 is slightly oversaturated with barite and gypsum and moderately oversaturated with the uranium phase schoepite, hydroxides, and oxyhydroxides of iron and manganese, jarosite (iron sulfate), nickel hydroxide, barium arsenate, and calcium and magnesium vanadate phases. Kinetically favorable uranium, vanadium, nickel, arsenic, manganese, and sulfate phases will precipitate onto the aquifer matrix, thus removing some of these constituents from ground water and reducing their concentrations. This information was used to evaluate the fate and behavior of individual contaminants of concern in the surficial and semiconfined aquifers. The radionuclides are not addressed because of their limited mobility and low concentrations (slightly above detection limits) in the downgradient wells.

\section{Arsenic}

Arsenic is associated with sulfide minerals common to uranium ore and is liberated during the leaching process. Low concentrations of arsenic are present in ground water downgradient from the site as an arsenate oxyanion. Arsenic is moderately mobile in an oxidizing aqueous environment as an arsenate species. Generally the mobility increases as the oxidation state of arsenic decreases, whereby As(III) species generally sorb onto the aquifer matrix less readily than As(V) species (Rai and Zachara, 1984). Based on the concentrations found in ground water beneath the Riverton site (maximum of $0.032 \mathrm{mg} / \mathrm{L}$ ), it may be assumed that the main attenuation mechanism for arsenic removal is probably adsorption onto aquifer materials, particularly ferric oxyhydroxides and organic matter (Rai and Zachara, 1984; Leckie et al., 1980).

\section{Manganese}

Manganese is found in sulfide and oxide minerals in the uranium ore and gangue material and is mobilized during the leaching process. The mobility of manganese is primarily controlled by the redox state of the aquifer. Manganese, present in surficial ground water in the $\mathrm{Mn}(\mathrm{II})$ valence state, is predominantly 
$\mathrm{Mn}^{2}+$ complexed with sulfate and carbonate species in the aquifer. Oxide and hydroxide manganese mineral phases are saturated in the most contaminated areas. The precipitation of these phases will remove manganese from ground water. Additional removal of manganese through sorption and coprecipitation with iron phases may also be occurring in the area of contamination.

\section{Molybdenum}

Molybdenum is found in select sulfide minerals associated with uranium ore and is mobilized during the leaching process. Alkaline conditions which favor the mobility of molybdenum as the oxyanion $\mathrm{MoO}_{4}{ }^{2-}$ (Rai and Zachara, 1984) were reported by Peterson (1985) to be present in the bottom of the tailings pile. Molybdenum is particularly high in onsite monitor well 108 (up to $1.3 \mathrm{mg} / \mathrm{L}$ ) located at the northwest corner of the remediated tailings pile (Figure 3.6). Molybdenum in downgradient monitor wells was detected at concentrations slightly above the analytical detection limit, indicating molybdenum is being attenuated from ground water down the flow path.

\section{Nickel}

Nickel is found in discrete nickel sulfides and as a trace constituent in many sulfide minerals and is mobilized during the leaching process. Nickel is present in ground water predominantly as a nickel cation or complexed with carbonate and sulfate. Nickel hydroxide is oversaturated with respect to ground water and, if kinetically favorable, will precipitate. Nickel also coprecipitates and sorbs onto ferric oxyhydroxide phases (Rai and Zachara, 1984). Precipitation and sorption onto the aquifer matrix are probably responsible for the removal of nickel from ground water.

\section{Sulfate}

Sulfate is derived from the sulfuric acid leaching process and from the dissolution and oxidation of sulfide minerals during the leaching process. Sulfate is present in ground water predominantly as a $\mathrm{SO}_{4}{ }^{2-}$ ion or is complexed with calcium, magnesium, or sodium. Barite and gypsum mineral phases are oversaturated in the ground water and precipitation of sulfate minerals partially control sulfate concentrations in ground water. Sorption onto aquifer materials may also be responsible for the removal of some sulfate from ground water.

\section{Uranium}

Uranium minerals are dissolved and oxidized during the leaching process. Residual uranium is found in the ground water because of inefficient recovery of uranium during the solvent extraction circuit. Under moderately oxidizing conditions, uranium exists as uranyl carbonate complexes. Schoepite is the only probable uranium mineral phase that is thermodynamically saturated in the ground water in the contaminated region of the aquifer. Therefore, partial removal of uranium from precipitation reactions can be expected. Additionally, 
sorption of uranium onto the aquifer matrix should occur especially onto iron oxyhydroxides (Kent et al., 1988; Hsi and Langmuir, 1985) and humic material (Nakashima, 1992; Mohan et al., 1991).

\section{Vanadium}

Vanadium is associated with uranium minerals and clays in the uranium mineralized zone. It is mobilized along with a host of trace elements during the leaching phase of the operation. Field redox and $\mathrm{pH}$ data suggest that vanadium is present as V(V) oxyanion complexes in ground water beneath the site. Vanadium mineral phases are oversaturated in contaminated ground water with respect to calcium and magnesium vanadate minerals. Sorption onto aquifer materials may also control the concentration of vanadium in ground water.

\subsection{RISK EVALUATION}

The draft risk assessment followed the basic approach prescribed by the EPA. The first step was to evaluate ground water data collected at the site over the last 5 years. The surficial aquifer was evaluated quantitatively because of the higher contamination levels. The less contaminated semiconfined aquifer was evaluated qualitatively. The potential exposure pathways for humans, livestock, and wildife are shown in Figure 3.17.

\subsubsection{Potential public health impacts}

Contaminants from uranium processing have been detected in the surficial and semiconfined aquifers. Door-to-door surveys of residences near the Riverton processing site were completed in March 1993 and January 1994. No known drinking water wells tap the contaminated ground water in the surficial and semiconfined aquifers, although one shallow well is occasionally used for livestock. Ground water from deeper aquifers in the vicinity is used for drinking water and is not contaminated. Therefore, the risk assessment evaluated the potential future use of the contaminated ground water from the surficial aquifer for drinking and livestock.

The risk assessment estimated how much of the contaminants of concern people would be exposed to if a drinking well were installed in the contaminated ground water. Since the contaminant concentrations vary each time a well is sampled and because people vary in weight and water consumption, the risk assessment used probability distributions to determine the amounts of contaminants that probably would be ingested using a hypothetical well at the site. The probability distributions describe how likely it is for a particular event to happen. For example, based on population surveys, probability distributions can describe what percentage of people drink a half-gallon of water each day and what percentage drink only one cup of water each day. 


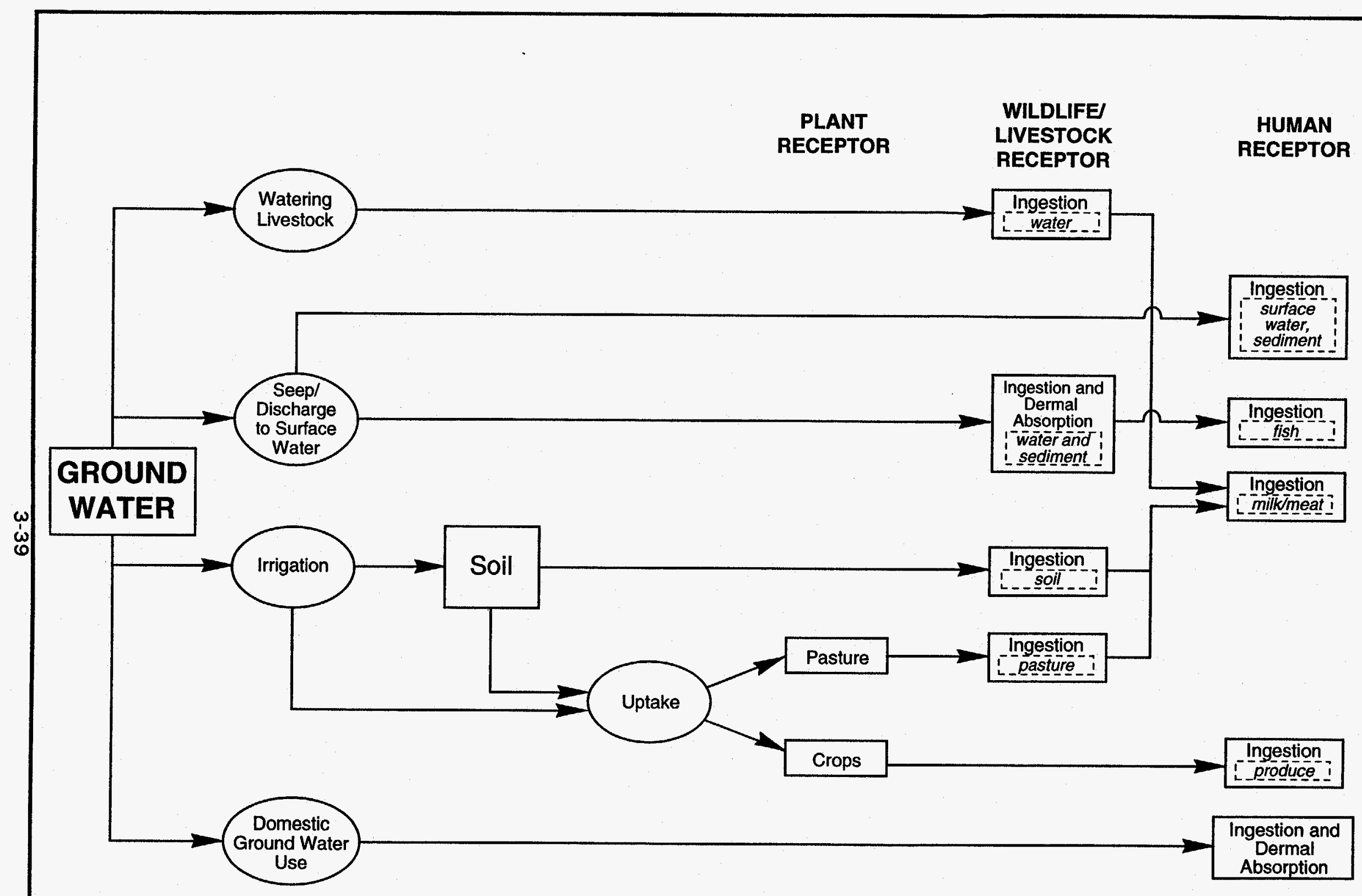

FIGURE 3.17

POTENTIAL EXPOSURE PATHWAYS

RIVERTON, WYOMING, SITE 
The estimated amounts of contaminants that could be ingested by consuming tap water were then compared to the toxic effects these contaminant levels could cause. Sulfate is the most significant health hazard in the ground water at the Riverton mill site. Sulfate is of special concern for infants, because at the levels found at the site, sulfate-induced severe diarrhea could lead to dehydration in infants more quickly than it would in children or aduits. Although no one currently drinks the contaminated ground water, the sulfate levels in the ground water exceed levels that have been reported elsewhere to cause severe dehydration when ingested by infants.

Using the uppermost aquifer as a source of drinking water would cause an unacceptable risk of $3 \times 10^{-4}$ for uranium and $4 \times 10^{-4}$ for arsenic, exceeding the EPA National Contingency Plan guideline of a maximum of $1 \times 10^{-4}$ lifetime excess cancer risk. Potential noncarcinogenic health effects from exposure to uranium would also be of concern, as would exposure to molybdenum and manganese. Although these exposures are not in the range that cause lethal effects, exposures probably would result in adverse health effects such as neurologic changes (manganese) and biochemical imbalances (molybdenum and manganese).

Based on this analysis, the use of contaminated ground water for nondrinking water purposes (i.e., watering livestock, irrigating crops, or bathing) would not result in adverse health effects to humans.

Since the levels of arsenic, manganese, molybdenum, sulfate, and uranium in the surficial aquifer between the former processing site and the Little Wind River could cause adverse health effects if the ground water is used for drinking, access to contaminated ground water must be controlled. Institutional controls prohibiting the use of the ground water from the surficial and semiconfined aquifer should be planned and implemented as soon as possible in the vicinity of the Riverton site.

\subsubsection{Potential environmental impacts}

Contaminated ground water could potentially impact the environment. Based on monitor wells near the river and surface water and sediment quality data, it appears that contaminated ground water has reached the Little Wind River and wetlands areas near the site. With ground water near the surface, plant roots can probably reach the contamination.

Comparing mean ground water concentrations with water concentrations protective of plants indicates that manganese and molybdenum are at concentrations that could adversely affect plants. Thus, plants that may have roots in contact with ground water-saturated soil or plants that are irrigated with ground water could be affected by levels of these contaminants of potential concern in ground water. 
No data are currently available to evaluate the effects of contaminated ground water exposure on terrestrial wildlife species.

The surface water concentrations for iron detected in samples from the Little Wind River exceed available surface water quality criteria for the protection of aquatic life. However, for most constituents analyzed in surface waters, the results for samples from the downstream location differed little from concentrations in samples from the background location (Table 3.4). The surface water and sediment sampling locations are shown in Figure 3.6. The downstream location, 796 , is approximately $9000 \mathrm{ft}(2740 \mathrm{~m})$ downriver from the background location, 794. The uranium concentration measured at sampling location 742 is approximately one order of magnitude higher than the background concentration and could represent an ecological concern. This sampling location is closest to the highest contaminant levels detected in ground water (monitor well 707) in the surficial aquifer. Further downstream, at sampling location 796, uranium concentrations decline to background levels.

Table 3.4 Occurrence of constituents in the Little Wind River surface water, June 1993 sampling event, Riverton, Wyoming, site

\begin{tabular}{lccc}
\hline $\begin{array}{c}\text { Constituent of } \\
\text { concern }\end{array}$ & $\begin{array}{c}\text { Location 794 } \\
\text { (background) }\end{array}$ & Location 742 & Location 796 \\
\hline Calcium & 41 & 41 & 42 \\
Lead & 0.004 & 0.004 & 0.004 \\
Iron & 2.0 & 1.4 & 3.1 \\
Magnesium & 14 & 14 & 14 \\
Manganese & 0.09 & 0.12 & 0.14 \\
Molybdenum & ND & ND & ND \\
Uranium & 0.002 & 0.025 & 0.002 \\
\hline
\end{tabular}

All concentrations reported in $\mathrm{mg} / \mathrm{L}$. ND - not detected.

An evaluation of sediment data from the Little Wind River showed that downstream concentrations exceeded background concentrations, with the highest concentrations observed at sampling location 742 (Table 3.5). This is the same location where higher uranium values were observed in surface waters. Sediment quality values were available only for lead. Lead concentrations in the sediment did not exceed sediment quality guidelines.

In other water bodies in the site vicinity, which include wetlands, a stream, and drainage ditches, the surface water concentrations did not exceed water quality values. However, water quality values are not available for several constituents. 
Table 3.5 Occurrence of constituents in the Little Wind River sediments, June 1993 sampling event, Riverton, Wyoming, site

\begin{tabular}{lccc}
\hline $\begin{array}{c}\text { Constituent of } \\
\text { concern }\end{array}$ & $\begin{array}{c}\text { Location 794 } \\
\text { (background) }\end{array}$ & Location 742 & Location 796 \\
\hline Iron & 5900 & 21,000 & 8500 \\
Lead & 4.5 & 14 & 3.9 \\
Manganese & 170 & 620 & 210 \\
Molybdenum & ND & ND & 4.0 \\
Uranium & 2.0 & 10 & 2.3 \\
\hline
\end{tabular}

All concentrations reported in milligrams per kilogram $(\mathrm{mg} / \mathrm{kg})$.

ND - not detected.

Thus, it is not certain whether any of these concentrations threaten aquatic organisms. At most, the concentrations exceeded maximum background concentrations by a factor of 2 to 2.5 (Table 3.6). No clear trend is associated with surface water concentrations in these areas. The locations of highest values varied for the different constituents.

The sediment data collected from these water bodies in the vicinity are shown in Table 3.7. Comparing sediment data from these areas with sediment quality guidelines shows the lead concentration at sampling location 746 exceeds the National Oceanic and Atmospheric Administration (NOAA) sediment quality values (NOAA, 1990). Because this sampling location is only a few feet from Highway 137, these concentrations are probably due to automobile exhaust fumes rather than site-related activities. Sediment quality guidelines were not available for any other constituents detected in sediments. Manganese and molybdenum concentrations did not exceed background concentrations. Concentrations of the other constituents exceeded maximum background concentrations by a factor of 1.5 at most. No clear trend is associated with sediment concentrations in these water bodies. The locations of highest concentrations varied for the different constituents.

Potential exposure to livestock that ingest ground water from a stock tank or pond was evaluated by comparing mean ground water concentrations to water concentrations determined for livestock protection. Based on the sulfate concentrations in ground water, the results showed that adverse effects could occur because the mean concentration of sulfate in ground water was three times greater than the guidance values.

Water and sediment quality criteria and/or guideline values were insufficient to comprehensively evaluate the impact of ground water, surface water, and sediments on ecological receptors. Therefore, this qualitative, screening-level 


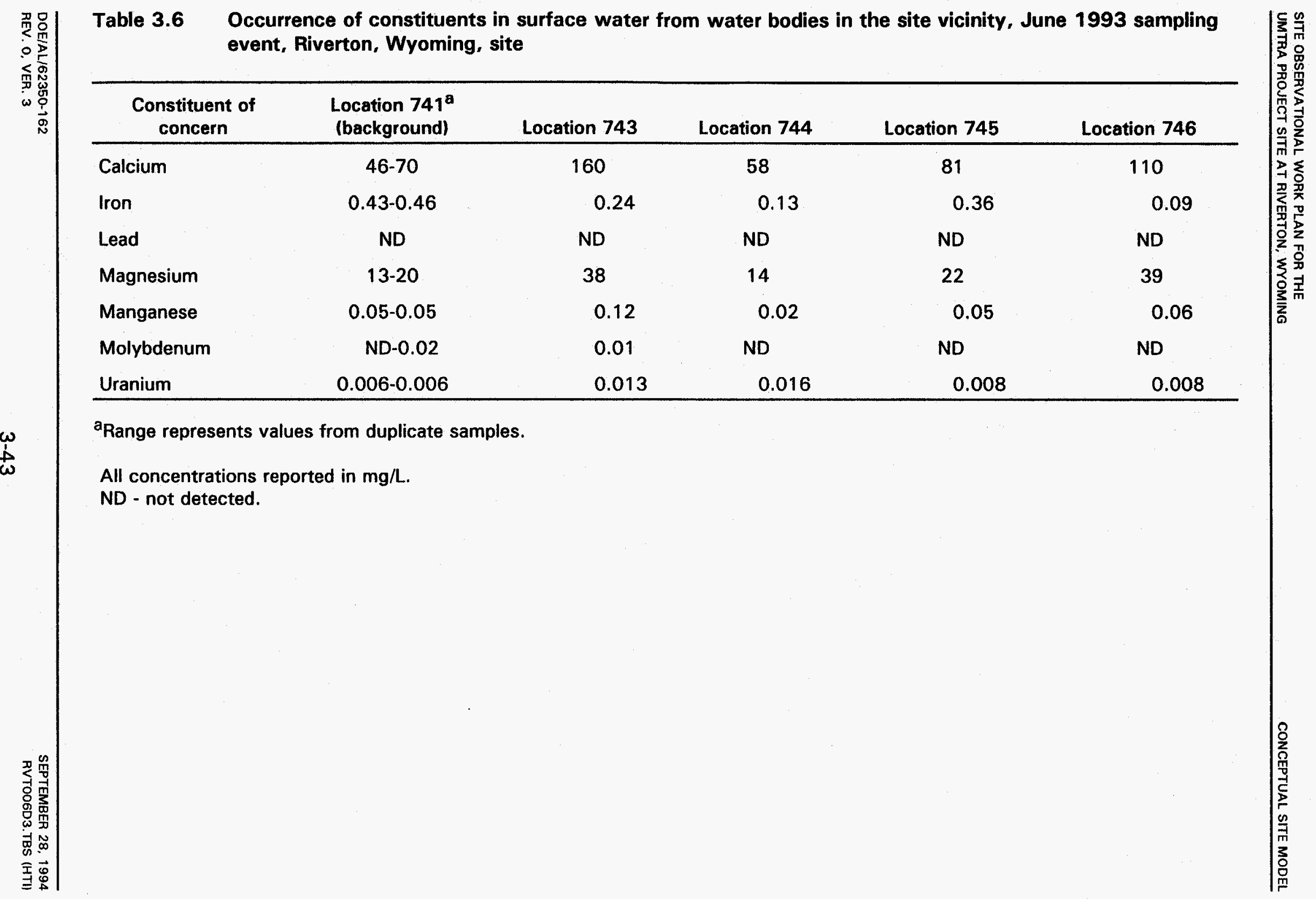




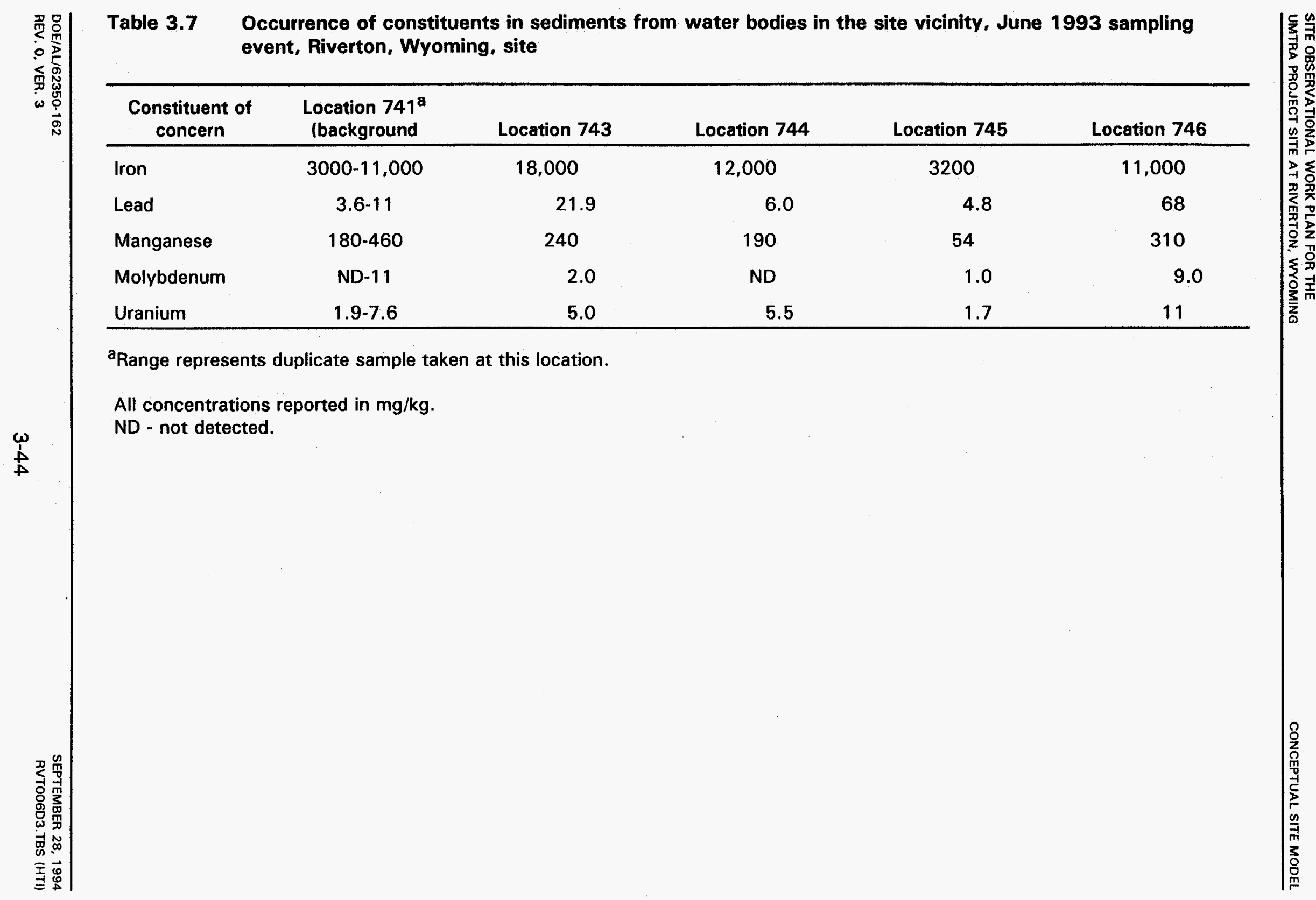


assessment of ecological risk could evaluate only some constituents detected at the site.

\subsection{EVALUATION OF INTERIM REMEDIAL ACTION NEEDS}

No current dangers to human health or the environment have been identified. However, because of the possibility of wells being installed in the contaminated ground water, institutional controls should be implemented immediately to prevent the use of contaminated ground water from the surficial and semiconfined aquifers. Controls should also be established to prevent downwards contamination migration into the confined aquifer from improperly installed wells. 


\subsection{GROUND WATER COMPLIANCE STRATEGY SELECTION}

This section identifies the proposed ground water compliance strategies for the Riverton site; explains the application of site-specific data to the ground water compliance selection framework; identifies data deficiencies as a result of applying the ground water compliance selection framework; and analyzes possible deviations from the conceptual model, contingencies (selection of a different compliance strategy(ies)), and decision rules (criteria) for application of contingencies.

\subsection{GROUND WATER COMPLIANCE STRATEGY SELECTION PROCESS}

Proposed ground water compliance decisions at the Riverton site were made by using the compliance selection framework shown in Figure 4.1. This compliance selection framework was developed in the UMTRA Ground Water PEIS (DOE, 1994a). The proposed ground water compliance strategy is selected by applying site-specific data to this compliance selection framework.

The compliance selection framework provides for the selection of one or more of three ground water compliance strategies based upon site-specific data. The three strategies developed in the UMTRA Ground Water PEIS are defined as follows:

- No remediation - Application of the no remediation strategy would mean that compliance with the proposed standards would be met without altering the ground water or cleaning it up in any way. This could be applied at sites that have no contamination above MCLs or background levels, or at sites that have contamination above MCLs or background levels but qualify for supplemental standards or ACLs.

- Natural flushing - Natural flushing would allow the natural ground water movement and geochemical processes to decrease the contaminant concentrations to levels within regulatory limits within a given time period. This could be applied at sites where ground water compliance would be achieved with the application of natural flushing within 100 years, where effective monitoring and institutional controls could be maintained, and the ground water is not currently and is not projected to be a drinking water source.

- Active ground water remediation - Active ground water remediation would require the application of engineered ground water remediation methods such as gradient manipulation, ground water extraction and treatment, and in situ ground water treatment to achieve compliance with the proposed standards.

This SOWP has made the determination that proposed EPA standards will be met by applying a combination of two compliance strategies for the 24 hazardous constituents identified: 1) no remediation with application of ACLs 
CHARACTERIZE PLUME AND

HYDROLOGICAL CONDITIONS USING

EXISTING DATA AND NEW DATA AS

REQUIRED

\section{$\mathrm{BO} 2 \mathrm{2}$ \\ IS GROUND WATER CONTAMINATION PRESENT IN EXCESS OF MAXIMUM CONCENTAATION LIMITS OR BACKGROUND?}

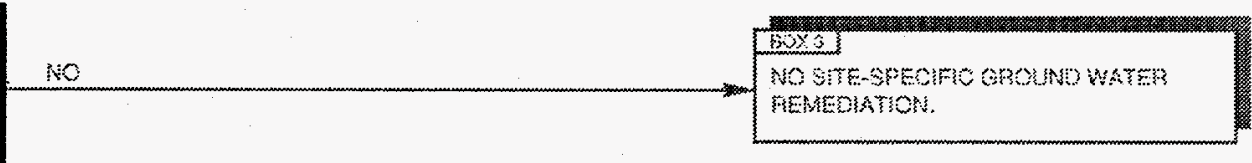

\section{YES}

\section{BOX 4 \\ DOES CONTAMINATED GROUND WATER QUALIFY FOA SUPPLEMENTAL \\ STANDARDS DUE TO CLASS III GROUND WATER?}

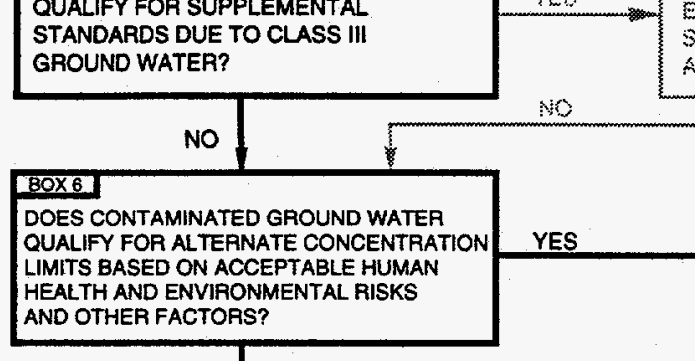

NO

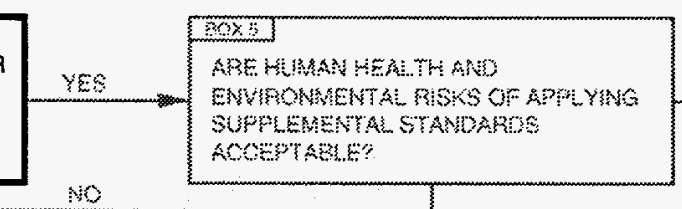
ACE
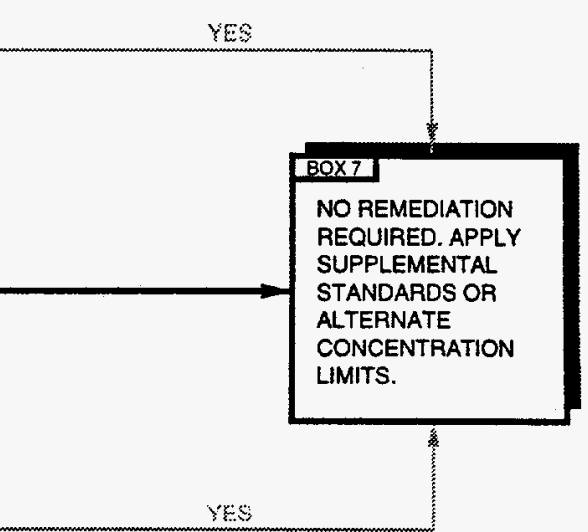

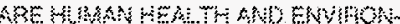

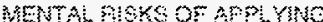

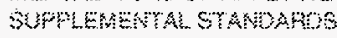

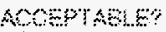

ENVIRONM

REMEDIATION?

\section{(2)}

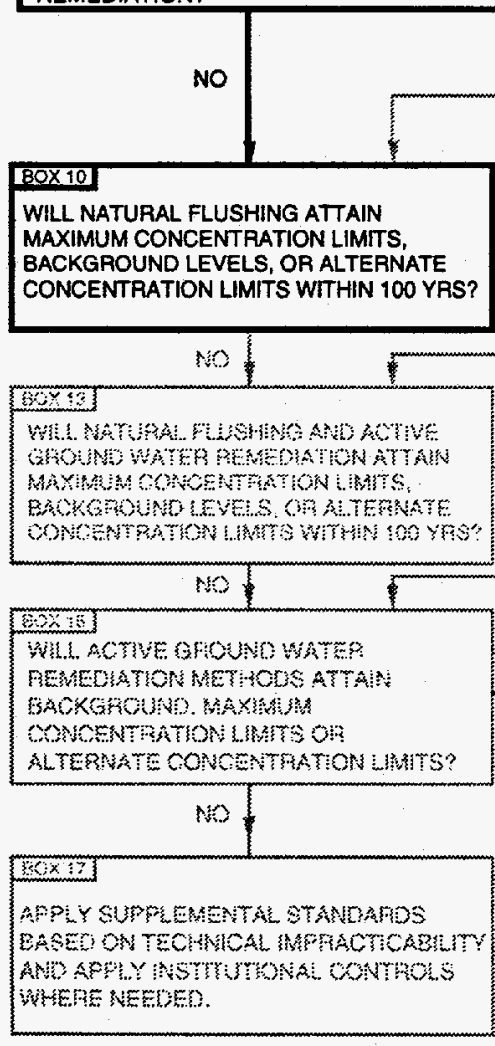

$\because 0$
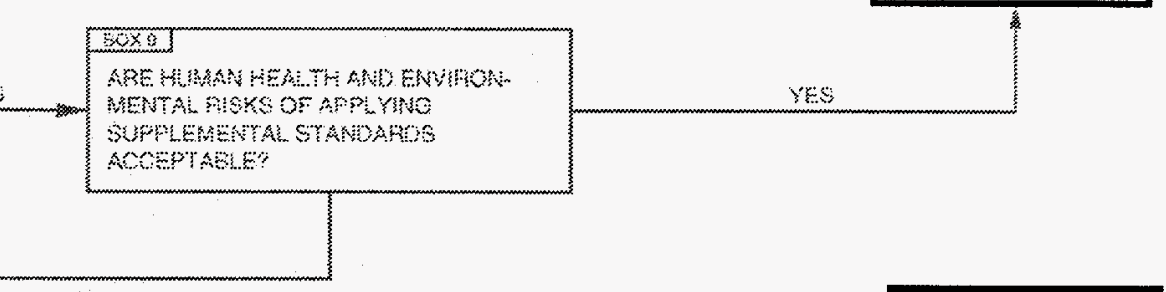

BOX11

CAN INSTITUTIONAL CONTROLS BE

YES MAINTAINED DURING THE FLUSHING PERIOD AND IS NATURAL FLUSHING PROTECTIVE OF HUMAN HEALTH AND THE ENVIRONMENT?

\section{NO THE ENVIRONMENT?}

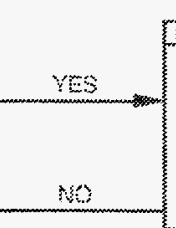

$30 x \& 4$

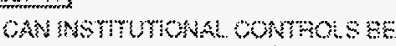

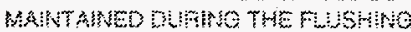

PFHOD ANO

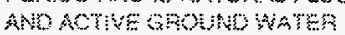

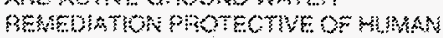

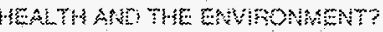

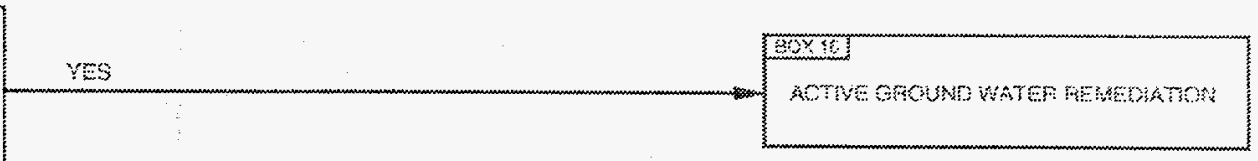

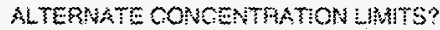
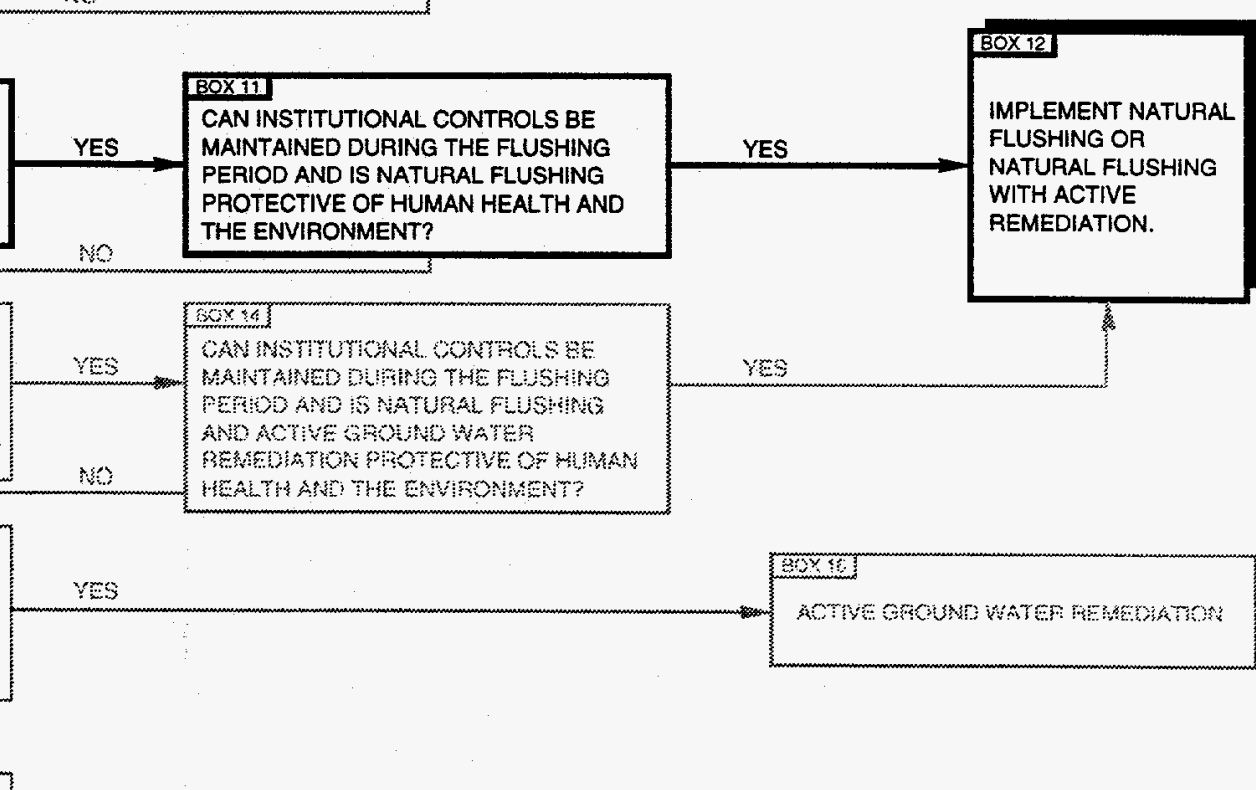

COMPLIANCE SELECTION FRAMEWORK RIVERTON, WYOMING, SITE

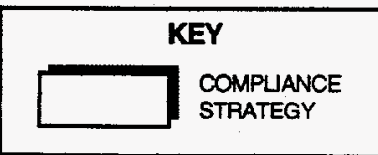

\section{FIGURE 4.1}


and 2) natural flushing. The following section describes the decision-making process for compliance at the Riverton site.

\subsection{SITE-SPECIFIC GROUND WATER COMPLIANCE STRATEGY}

This section describes how the PEIS decision-making framework was used to evaluate and select the proposed compliance strategies for ground water remediation at the Riverton site. Figure 4.1 illustrates the process while Table 4.1 shows the results of the process. The steps involved in applying the constituents to the compliance selection framework are as follows:

1 and 2. The first two steps (boxes 1 and 2 in Figure 4.1 ) confirm that the ground water quality data show that the milling activities have resulted in ground water contamination that exceeds background levels or MCLs. Twenty-four contaminants that exceed background levels have been identified at the site and are listed in column 1 of Table 4.1.

3. The third step (box 4 in Figure 4.1) determines whether compliance with the proposed standards could be achieved by applying supplemental standards based on the existence of Class III (limited-use) ground water. The quality and quantity of the natural ground water at the Riverton site, as evidenced by the background ground water quality data and the results of the aquifer tests, do not meet the requirements for a limited-use aquifer (column 2 of Table 4.1). Therefore, supplemental standards do not protect human health and the environment.

4. The fourth step (box 6 in Figure 4.1) determines whether ACLs would apply. Fourteen of the constituents are potential candidates for ACLs because they are essential nutrients and the levels at which they occur in the ground water are within nutritional ranges and/or because they have very low toxicity and relatively high dietary intake ranges in comparison to the levels detected in the ground water. The remaining 10 constituents are not potential $A C L$ candidates and are indicated in column 3 of Table 4.1 as the constituents considered in the compliance strategy.

5. The fifth step (box 8 in Figure 4.1) determines if contaminated ground water qualifies for supplemental standards due to excessive environmental harm. There are no reasons why remediation of the ground water would cause more environmental harm than benefit. Therefore, the contaminated ground water will not qualify for supplemental standards (column 4 of Table 4.1 ).

6. The sixth step (Box 10 of Figure 4.1) evaluates if natural flushing would bring the 10 constituents of concern within $M C L$ or background levels within 100 years. The hydrogeologic and 


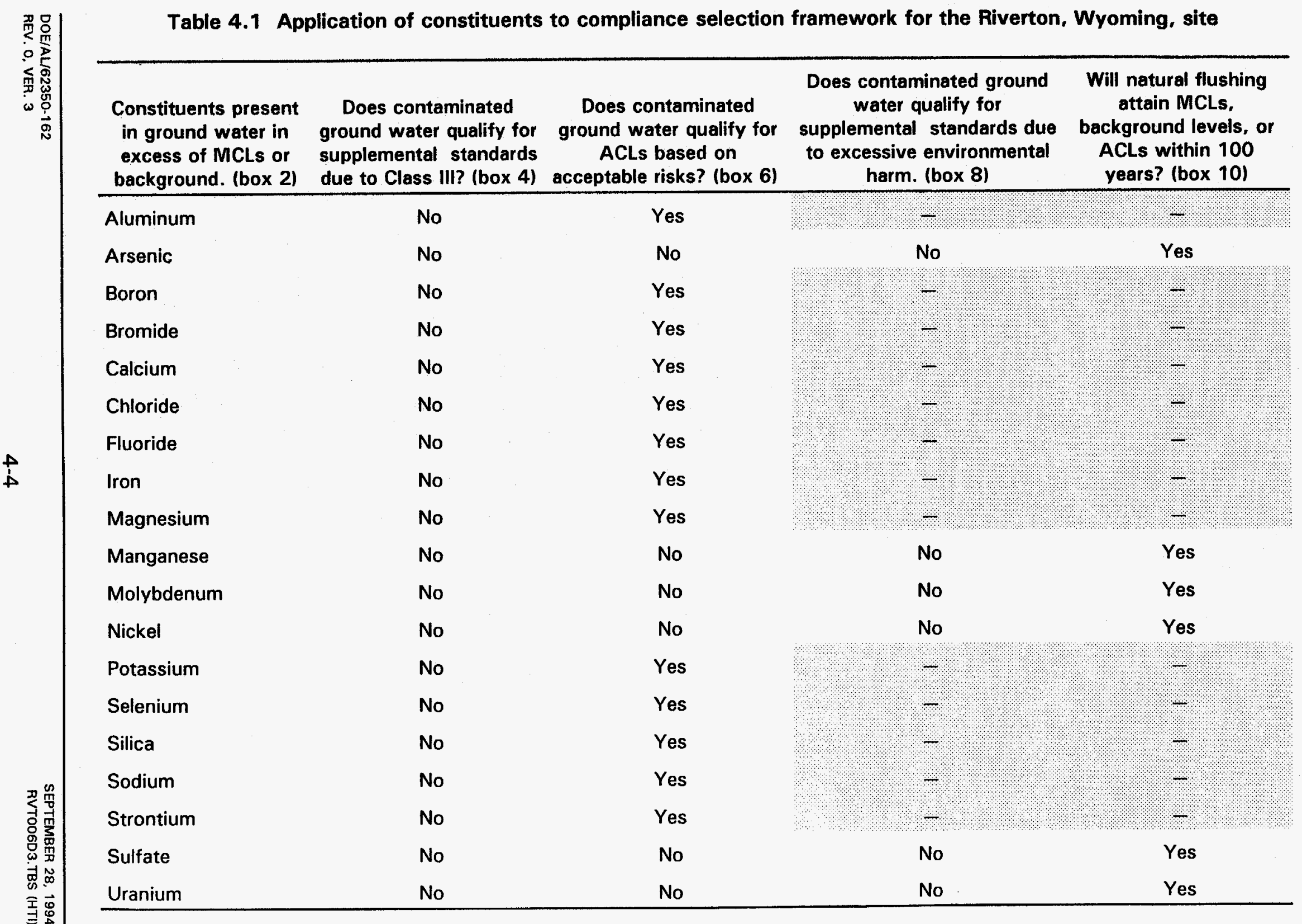


Table 4.1 Application of constituents to compliance selection framework for the Riverton, Wyoming, site (Concluded)

\begin{tabular}{lcccc}
\hline $\begin{array}{c}\text { Constituents present } \\
\text { in ground water in } \\
\text { excess of MCLs or } \\
\text { background. (box 2) }\end{array}$ & $\begin{array}{c}\text { Does contaminated } \\
\text { ground water qualify for } \\
\text { supplemental standards } \\
\text { due to Class III? (box 4) }\end{array}$ & $\begin{array}{c}\text { Does contaminated } \\
\text { ground water qualify for } \\
\text { ACLs based on } \\
\text { acceptable risks? (box 6) }\end{array}$ & $\begin{array}{c}\text { Does contaminated ground } \\
\text { water qualify for } \\
\text { supplemental standards due } \\
\text { to excessive environmental } \\
\text { harm. (box 8) }\end{array}$ & $\begin{array}{c}\text { Will natural flushing } \\
\text { attain MCLs, } \\
\text { background levels, or } \\
\text { ACLs within 100 } \\
\text { years? (box 10) }\end{array}$ \\
\hline Vanadium & No & No & No \\
Zinc & No & Yes & Yes \\
\hline Radionuclides & & & No & No \\
\hline Lead-210 & No & No & No & Yes \\
Polonium-210 & No & No & No & Yes \\
Thorium-230 & No & & Yes
\end{tabular}

Note: Shading indicates that the process is complete for that constituent. 
geochemical data collected from the Riverton site and preliminary contaminant transport and ground water flow modeling indicate that natural ground water flushing appears to be an applicable strategy (column 5 of Table 4.1). That is, natural ground water movement and geochemical processes will decrease the contaminant concentrations to background levels within 100 years. During that period of time, effective monitoring and institutional controls will need to be maintained so ground water in the affected aquifer will not be used as a source of domestic water (box 11 in Figure 4.1).

7. The last step is the implementation of natural flushing (box 12 in Figure 4.11.

\subsection{IDENTIFICATION OF DEVIATIONS, CONTINGENCIES, AND DECISION RULES}

The natural flushing ground water compliance strategy proposed for the Riverton site is based on the evaluation of the existing conceptual model. Additional sitespecific information must be collected to confirm the conceptual model and finalize the applicability of a natural flushing/institutional control scenario to achieve compliance with regulatory standards, as well as to mitigate risks to human health and the environment. Proposed additional data collection will focus on site-specific hydrogeologic and geochemical conditions, ground water quality, surface water flows, and impacts of ground water discharge to surface water quality. Additional work also will be needed to assess the feasibility of institutional controls.

Deviations from the existing site model may be identified during data collection and/or evaluation. As the magnitude of such deviations will control the nature of future site activities and the final selection of the ground water compliance strategy, decision rules and contingencies must be addressed.

Decision rules will focus on identifying whether additional data collection efforts confirm the conceptual site model or identify deviations/variations that would compromise the proposed compliance strategy. For example, if calculated hydraulic conductivity values combined with retardation factors will not allow the contaminant plume to migrate at a rate of at least $40 \mathrm{ft}(12 \mathrm{~m})$ per year so that it will cover the $4000 \mathrm{ft}(1219 \mathrm{~m})$ from the northern edge of the plume to the Little Wind River in 100 years, or if ground water recharge to the Little Wind River severely degrades surface water quality, decision rules to modify or abandon the natural flushing scenario would be imposed. Similarly, if institutional controls on ground water usage can not be obtained or enforced, the feasibility of the natural flushing strategy will need to be reevaluated. In this event, alternative strategies will be recommended. Based on the constituents, concentration, and configuration of ground water contamination at the Riverton site, alternative compliance strategies under consideration include:

- Enhanced natural flushing. 
- Natural flushing combined with localized ground water extraction.

- Ground water extraction.

The ground water system's flushing capabilities may be enhanced by introducing additional water through existing irrigation canals and/or new infiltration systems to increase the rate of ground water movement.

Localized extraction of ground water, particularly in areas exhibiting extremely elevated constituent levels and/or along the outermost edges of the plume, could be initiated to enhance the performance of a natural flushing scenario. The physical removal and/or reduction of contaminant concentrations and plume size will assist the natural flushing process by immediately improving the ground water quality and reducing the time required for total plume migration to the Little Wind River.

If the combination of enhanced natural flushing and selective ground water extraction and treatment do not remediate the ground water, more extreme water extraction systems may be needed. The length of time and the costs required to physically capture and collect the total volume of contaminated ground water at the Riverton site will need to be determined.

All compliance strategies discussed (proposed and alternative) must be performed in conjunction with the execution of institutional controls on ground water usage in the vicinity of the Riverton site. Because implementing any of these strategies addresses the reduction and/or the removal of contaminant concentrations through time, controlling ground water usage will mitigate the immediate and/or long-term risks to both public health and the environment. 


\subsection{COLLECTION AND ASSESSMENT OF DATA}

Existing site conditions, as defined by previous investigations conducted at the Riverton site, support a preliminary selection of an appropriate ground water remediation strategy. While the existing site data support the strategy of naturally flushing constituents of concern to the Little Wind River, additional site-specific data are needed to confirm the applicability and feasibility of this compliance option. This section identifies the data needs, the related data collection objectives and activities, and the governing data quality objectives (DOO).

\subsection{STATEMENT OF DATA NEEDS}

The following are the data needs based on the conceptual model and an evaluation of existing data.

\subsubsection{Aquifer testing}

Additional data are needed on the variability of the hydraulic conductivity of the surficial and semiconfined aquifers downgradient of the site.

\subsubsection{Topographic surveying}

A topographic profile across the Little Wind River is required to establish topographic reference for elevations, water levels, and ground water flow. Surveys of water levels in the wetlands to the east are needed to assess if contaminated ground water could be discharging there.

\subsubsection{Monitoring well installation and ground water sampling}

Water quality data are needed to determine if the discharge from the Koch Sulfur Products Co. plant has impacted the quality of ground water along the western boundary of the site. Background water quality in the surficial and semiconfined aquifers upgradient of the site and on the south side of the Little Wind River is needed to confirm that the river serves as a hydraulic barrier against the migration of the contaminant plume. In addition, existing monitor wells will continue to be sampled to monitor changes in ground water quality.

\subsubsection{Surface water and sediment sampling}

Surface water quality and contaminant concentrations in sediments from the Little Wind River, the oxbow lake, and nearby wetlands areas are required to assess the impact of ground water discharge into the river and wetlands. The most recent surface water and sediment sampling event was conducted during a high-flow period at the Little Wind River and the wetlands areas. The samples were analyzed for a limited suite of analytes. This suite was selected prior to development of the baseline risk assessment. The risk assessment identified several additional contaminants of potential environmental concern. Samples 
should be collected during a low-flow period when the impacts of contaminated ground water discharging to surface water bodies will be the most noticeable.

\subsubsection{Ground water level elevation monitoring}

Ground water level elevation data are required to evaluate the effect of infiltrating irrigation canal water on the ground water gradient and to more adequately evaluate the vertical ground water gradients between the aquifers.

\subsubsection{Geochemical analysis of ground water and aquifer matrix}

Geochemical analysis of the aquifer matrix is required to determine the interaction between the constituents in ground water and the material comprising the aquifer in order to assess contaminant migration and attenuation.

\subsubsection{Toxicological literature review}

Toxicological data are needed for those contaminants of potential concern that have no state or federal water quality or sediment quality guidelines.

\subsubsection{Computer modeling of ground water flow regime}

A quantitative evaluation of the ground water flow regime and the fate and transport of contaminants (computer modeling) is needed to complement previous evaluations and to determine and monitor the effectiveness of the natural flushing remedial strategy.

\subsubsection{Feasibility of executing institutional controls}

Additional information is required to assess the feasibility of implementing institutional controls for ground water usage in the vicinity of the Riverton site.

\subsection{DATA COLLECTION OBJECTIVES}

\subsubsection{Aquifer testing}

Only one aquifer pumping test was conducted in the surficial aquifer and only one test was conducted in the semiconfined aquifer. Both tests were performed in wells upgradient of the former tailings site. To better evaluate the variability of the aquifer and the resulting fate and transport of the contaminants, hydraulic conductivity data from both the surficial and semiconfined aquifers downgradient of the site are required.

\subsubsection{Topographic surveys}

It is presumed that the Little Wind River is the local base level for the ground water regime in the surficial and semiconfined aquifers downgradient of the site, and that contaminated ground water from beneath the site will not cross under 
the river. The detection of sulfate and uranium in monitor well 706 to the south of the river at concentrations above the concentrations in monitor wells 710 and 711 raises questions regarding this supposition. Therefore, additional information on the water elevation in the Little Wind River is needed. There is also a question whether the ground water flows into the wetlands east of the site during the non-irrigation season and/or if irrigation water actually created the wetlands and is recharging the aquifer. Data on the elevation of the water in the wetlands areas are needed to address these uncertainties.

\subsubsection{Monitoring well installation and ground water sampling}

Process water coming from the Koch Sulfur Products Co. plant meets their permit requirements for surface water discharges. The sulfate concentration in water infiltrating from the drainage ditch, however, may affect the ground water quality along the western, upgradient edge of the site. Information on the quality of the Koch Sulfur Products Co. plant discharge and the ground water entering the site from the west is therefore needed to determine if the plant is contributing to ground water contamination.

Existing data documenting background water quality in the semiconfined aquifer indicate that constituents found onsite are also detected downgradient of the site. Because the samples were obtained from monitor wells located along the northern boundary of the site, additional background water quality samples are needed from an upgradient location established far enough away to preclude influence of past or present site activities.

Ground water sampling is proposed to confirm that site contamination has not migrated across the Little Wind River and that the presence of low uranium concentrations south of the river can be attributed to background conditions.

\subsubsection{Surface water and sediment sampling}

Potential environmental impacts from ground water migration into the Little Wind River, the oxbow lake, and nearby wetlands areas must be determined as part of the natural flushing compliance strategy. Surface water and sediment sampling during low-flow periods will more adequately define the potential for ecological impact (i.e., surface water, sediment, and biota contamination).

\subsubsection{Ground water level elevation monitoring}

The ground water level elevations in some of the monitor well clusters need to be confirmed to resolve inconsistencies in the interpretation of vertical gradients between aquifers. An assessment of ground water level changes due to infiltration from irrigation canals, as well as changes in the water levels in the Little Wind River and the wetlands east of the site, is also needed to develop an accurate hydrologic model of the site. 


\subsubsection{Geochemical analysis of ground water and aquifer matrix}

The geochemistry of both the ground water and aquifer matrix is required in order to determine the sorption potential of the aquifer. No such data currently exist in the Riverton site data base. This information is required to quantify the interaction of solute during transport through the aquifer (i.e., distribution coefficients, retardation coefficients, and contaminant specific velocities).

\subsubsection{Toxicological literature review}

An in-depth literature review to obtain toxicological data for contaminants of potential concern which have no state or federal water quality or sediment quality guidelines is needed to more adequately define specific contaminant impacts, if any, on public health and/or the environment.

Examples of the information that will be obtained include acute (short-term) effects and chronic (long-term) effects. The type of measurement endpoints that could be obtained include lethal concentrations $\left(\mathrm{LC}_{50}\right.$ - concentration of a chemical in water that results in death to 50 percent of the test organisms); sublethal concentrations $\left(E C_{50}\right.$ - concentration of a chemical in water that results in sublethal effects to 50 percent of the test organisms); lowest observed adverse effect levels (LOAEL); and no observed adverse effect levels (NOAEL). The data will be evaluated with respect to conditions in the river and wetlands and will enhance the understanding of the potential ecological impacts, if any, from exposure to these contaminants of potential concern.

\subsubsection{Computer modeling of ground water flow regime}

After completing the field activities, computer modeling of the ground water flow and contaminant transport regimes will be conducted. The models will integrate all the information available from the Riverton site and will allow quantitative evaluation of the feasibility of achieving a natural flushing ground water compliance strategy within the 100-year timeframe.

\subsubsection{Feasibility of institutional controls}

Institutional controls, in the form of restricted ground water usage of the surficial and semiconfined aquifers in the vicinity of the Riverton site, must be imposed to ensure the immediate and long-term mitigation of risks to human health and the environment. The legal, regulatory, and environmental constraints and basis for implementation of institutional controls must first be determined.

\subsection{DATA QUALITY OBJECTIVES}

DOOs are quantitative and qualitative statements made to ensure that data of known and appropriate quality are obtained during an investigation. To ensure that the data gathered during investigation activities are adequate to support 
stakeholder decisions, a clear definition of the quality objectives and the method by which decisions will be made will be established. The DQOs for each previously proposed task are presented in this section.

\subsubsection{Aquifer testing}

Step tests will first be performed to select the most suitable pumping rate for the aquifer test and to include losses due to well inefficiency in the calculations of aquifer characteristics. The long-term aquifer pumping test will then be performed. Data loggers and pressure transducers (in the pumping and observation wells) used in accordance with the manufacturer's instructions will rapidly record reliable drawdown and recovery data for the analysis. Periodic manual measurements will be made to verify the accuracy of the data logger readings. The step tests and aquifer tests will be designed, performed, and analyzed according to various standards, such as American Society for Testing Materials (ASTM) Standard D4050-91, Standard Test Method (Field Procedure) for Withdrawal and Injection Well Tests for Determining Hydraulic Properties of Aquifer Systems, and UMTRA Project standard operating procedure (SOP) 16.15, "Pumping Tests for Aquifers" (JEG, n.d.).

A potential problem with analyzing the aquifer tests is the possibility of obtaining multiple, equally good solutions that cannot be discriminated amongst (Horne, 1994). To help alleviate this problem, each test will be analyzed during both the drawdown and recovery phases to cross-check the results.

Slug tests may be performed to assess variations in hydraulic conductivities across the site. Slug tests will be performed in accordance with ASTM Standard D4044-91, (Field Procedures) for Instantaneous Change In Head (Slug Tests) for Determining Hydraulic Properties of Aquifers, and UMTRA Project SOP 16.1.3, "Slug Testing" (JEG, n.d.).

\subsubsection{Topographic surveys}

The elevations of the monitor wells and the topographic profile and survey will all be conducted by professional surveyors licensed in the state of Wyoming. The surveys will be done in accordance with 2 nd order topographic surveying accuracy criteria.

\subsubsection{Monitor well installation}

The monitor wells will be installed in accordance with UMTRA Project SOPs 16.1.1, "Monitor Well Installation," and 16.1.2, "Well Development" (JEG, n.d.) to ensure that the wells will be adequate for the intended purpose.

\subsubsection{Ground water level measurements}

Changes in ground water elevations due to infiltration from the irrigation canals will be measured with data loggers in onsite monitor wells. The data loggers 
read changes in water levels to $0.01 \mathrm{ft}(0.003 \mathrm{~m})$. The loggers will be installed, operated, and maintained in accordance with the manufacturer's specifications. The loggers will be operated for at least 1 year to measure seasonal variations. Ground water elevations in other wells will also be measured to $0.01 \mathrm{ft}$ $(0.003 \mathrm{~m})$ in accordance with the manufacturer's specifications.

\subsubsection{Surface water and sediment sampling}

Surface water and sediment samples will be collected during a low-flow period when the dilution effects associated with high-flow conditions are expected to be minimal (e.g., late summer and fall). The samples will be collected in accordance with EPA Region IV SOPs and Quality Assurance Manual (EPA, 1991) and analyzed for the complete list of the constituents of concern identified in the risk assessment as exceeding background ground water quality (DOE, 1994b). The flow in the Little Wind River will be determined relative to the U.S. Geological Survey (USGS) gauging station downstream of the site (Figure 3.6).

\subsubsection{Water quality sampling and analysis}

The new and existing monitor wells will be sampled at least once per year. Samples will be collected, preserved, and shipped according to the UMTRA Project SOPS (JEG, n.d.). Because these results will be compared to and used with earlier results, the laboratory $Q A$ level needs to be the same. Thus, a laboratory quality assurance (OA) level corresponding to DOE Level $C$ will be used for the chemical analyses of the samples.

\subsubsection{Geochemical analysis of aquifer matrix}

Alluvial and rock samples will be collected in accordance with UMTRA Project SOPs 14.4.1, "Soil and Rock Core Borehole and Test Pit Logging" and 14.5.1, "Procedures for Handling and Shipping of Geotechnical Samples." The samples will be analyzed using standard testing procedures such as ASTM Method 4319, Distribution Ratios by the Short-Term Batch Method, and standard laboratory QA procedures will generate data suitable for this activity.

\subsection{DATA COLLECTION ACTIVITIES}

The following discussion describes the methods of data collection to meet each of the data needs.

\subsubsection{Aquifer testing}

A 4-inch $(10-\mathrm{cm})$ diameter, screened pumping well $(737)$ will be installed to test the surficial aquifer in the vicinity of existing monitor wells 705, 707, and 709 located near the Little Wind River (Figure 5.1). This well will be installed to the top of the semiconfining unit separating the surficial and the semiconfined sandstone aquifers. Existing monitor well 705 is a 6 -inch $(15.25-\mathrm{cm})$ well 


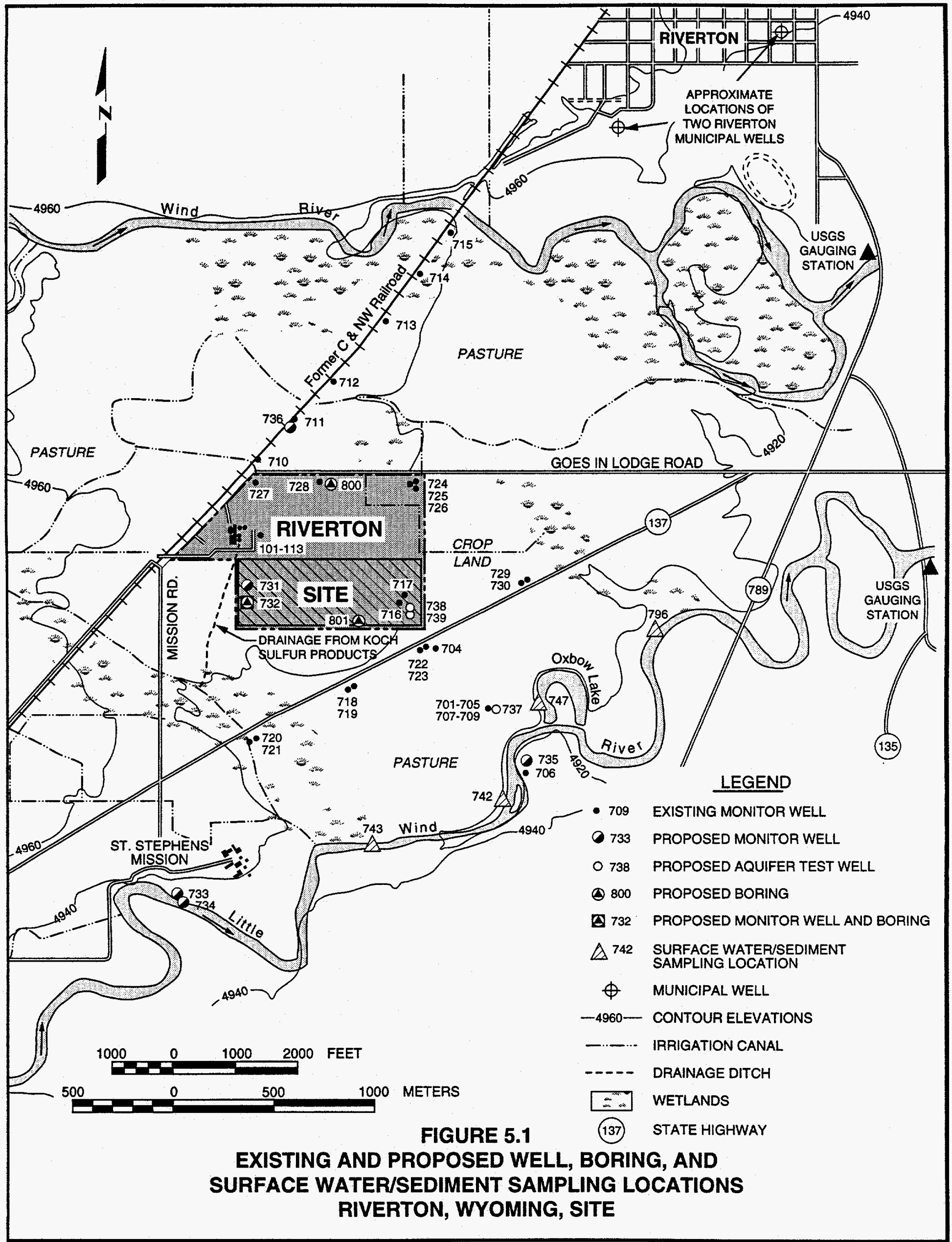


screened in the semiconfined sandstone and will be pumped to test the semiconfined aquifer after completion of the surficial aquifer test.

Step drawdown tests will be performed in each well prior to conducting the long-term pumping tests to assess the well efficiencies and to select appropriate pumping rates for the actual aquifer pumping tests. Water levels in all wells will be allowed to recover to static water levels before the aquifer test begins. The aquifer pumping tests will be performed by pumping each of the wells for a period of at least 24 hours at a constant rate followed by at least 24 hours of recovery until the water is back to static level. Changes in ground water levels in the surficial aquifer pumping well and observation wells 705, 707, and 709 will be monitored during the pumping test in the surficial aquifer. The change in water levels in the semiconfined aquifer pumping well (705), the observation wells $(707$ and 709$)$, and the 4-inch $(10-\mathrm{cm})$ surficial aquifer pumping well will be recorded during the aquifer test in the semiconfined aquifer. Water levels in background wells outside of the zone of influence will be monitored to identify regional trends that need to be accounted for during the tests. The hydraulic conductivities of the aquifers between the pumping and the monitor wells will be calculated.

Should the results of these tests differ by more than a factor of two from those obtained from the 1984 aquifer tests conducted onsite, another set of aquifer tests will be conducted in the vicinity of monitor wells 716 and 717 located near the southeast corner of the site.

Similarly, slug tests will be conducted in selected wells if needed to better define the areal variability of the aquifer as determined by the differences in the results of the pumping tests. Slug tests will be performed in the observation wells used in the pumping tests to calibrate the slug test results with the aquifer test. Then slug tests may be performed on monitor well clusters 718 and 719,722 and 723 , and 729 and 730 .

\subsubsection{Topographic surveying}

A topographic profile will be constructed from monitor well 702 across the Little Wind River to monitor well 706 on the south bank of the river and up to the top of the escarpment south of the river. The elevations of the river will be referenced to MSL so that future changes in river stage can be calculated based on the USGS reading. A survey of the edge of the wetlands east of the site will also be completed.

The elevation of clustered monitor wells 101 through 113 and 701 through 603. 705 , and 707 through 709 will be surveyed to confirm the elevation of the datum elevations used to calculate the ground water elevations. 


\subsubsection{Monitoring well installation and ground water sampling}

The quality of the wastewater being discharged by the Koch Sulfur Products Co. plant and its potential effects on the ground water along the western edge of the former mill tailings site will be evaluated by reviewing records provided by the company to the state of Wyoming.

The impacts of the discharged wastewater infiltrating the ground water will be assessed by collecting and analyzing ground water samples from two monitor wells (731 and 732) to be installed along the western boundary of the site. Each well will be 4 inches $(10 \mathrm{~cm})$ in diameter. One well will be screened in the surficial aquifer to straddle the water table and the second well will be screened within the semiconfined aquifer.

A 4-inch $(10-\mathrm{cm})$ monitor well $(735)$ will be installed in the semiconfined aquifer next to monitor well 706 to the south of the Little Wind River to assess the migration of ground water contamination below the river. Two 4-inch $(10-\mathrm{cm})$ monitor wells (733 and 734) will be installed in the surficial and semiconfined aquifers near the Little Wind River upstream of the potential zone of impact to help establish background water quality for existing monitor well 706 and the new monitor well (735) to be installed into the semiconfined aquifer.

\subsubsection{Surface water and sediment sampling}

Water and sediment samples will be collected at a time of low-flow conditions after the end of the irrigation season llocations 742, 743, 747, and 796 in Figure 5.1). No samples will be collected during or immediately after a precipitation event. The samples will be collected in accordance with the UMTRA Project SOPS (JEG, n.d.) and analyzed for the complete list of the constituents of concern identified in the risk assessment as exceeding background ground water quality.

The quantity of flow in the Little Wind River available to dilute contamination from the ground water discharge will be based on USGS records from the gauging station located approximately $2.5 \mathrm{mi}(4 \mathrm{~km})$ downstream on the Little Wind River from monitor wells 701 through 709 (Figure 5.1). The probable zone of discharge along the river will be visually inspected to assist in calculating the cross-sectional area of discharge.

The water levels in the wetlands area will be surveyed during both the irrigation season and the non-irrigation season. Attempts will be made to identify ground water seepage locations. Surface water and sediment samples will be collected at these locations. Painted stakes will be driven into the ground at the sampling location, and the points will be surveyed as part of the topographic surveying of the wetlands. 


\subsubsection{Ground water level monitoring}

To evaluate the effects of the irrigation canal on the ground water levels, data loggers will be installed in monitor wells 724 and 728 in the surficial aquifer and monitor wells 725 and 727 in the semiconfined aquifer near the irrigation canal along the northern boundary of the site (Figure 5.1). Data loggers will also be installed in surficial monitor wells 101, 716, and 718 to record changes in three locations south of the canal. The data loggers will record water levels every 4 hours. Manual measurements will be made of water levels in the semiconfined aquifer (monitor well 108) and the confined aquifer (monitor wells 110 and 709) at least four times per year.

If the amount of surface flow entering and leaving the site needs to be quantified to develop the flow model, measurements will be made using weirs in the existing flow-control structure on the north side of Goes In Lodge Road near the northwest corner of the site and in the existing flow-control structure in the section of canal along the eastern boundary of the site. In situ measurements of seepage from the bottom of the canal will also be made using a "constant head seepage meter" (IAH, 1990).

\subsubsection{Geochemical analysis of aquifer materials and ground water}

Subsurface core samples will be collected at three locations (boring locations 732, 800, and 801 in Figure 5.11. These locations were chosen to represent the aquifer matrix. Split-spoon sampling techniques will be used to collect samples at $5-\mathrm{ft}(1.5-\mathrm{m})$ intervals from the ground surface to the base of the alluvium. If the sampling technique fails due to the unconsolidated nature of alluvial materials, test pits will be dug and samples collected in the excavated holes.

Samples of the aquifer matrix will be analyzed for organics, inorganics (mineralogy), and sorption potential. Batch sorption tests will be performed by a contract laboratory to determine contaminant specific distribution coefficients. Complete mineralogical characterization will also be performed at the laboratory.

Isotopic samples will be collected from the two new monitor wells (731 and 732) along the western boundary, two surface water locations along the drainage ditch from the sulfur plant, and from two surface background locations.

\subsubsection{Toxicological literature review}

Several of the contaminants of potential ecological concern identified in the BLRA (DOE, 1994b) have no tribal, state, or federal water quality or sediment quality guidelines. A literature review will be conducted using commercially available databases, such as AQUIRE and DIALOG, to obtain ecotoxicological data and information specific to these contaminants of potential ecological concern and the organisms that are likely to be exposed. If the data are not 
sufficient to establish quality guidelines, efforts will be undertaken to fill this data need.

\subsubsection{Computer modeling of ground water flow and contaminant transport}

A two-layered, three-dimensional hydrologic flow model simulating the existing ground water flow pattern will be developed (probably using the software package MODFLOW, according to ASTM standard currently under development). This model will incorporate the existing data on the hydrogeology and boundary conditions. It will be calibrated to emulate the existing "steady state" conditions. The computer model will identify data gaps and uncertainties.

A contaminant transport and decay model (probably MT3D) will then be incorporated into the flow model and calibrated with the 1987 and 1993 water quality information. The transport model will be used to generate representative retardation and decay criteria needed to make the plume migration simulation correspond to the actual changes in contaminant distributions. These generated values will be compared to the retardation and decay factors suggested by analysis of the aquifer matrix samples. If the values appear appropriate, they will be used in the predictive model. If not, this data gap will be identified. The ground water flow and contaminant transport and decay models will be used to predict the feasibility of the natural flushing strategy. The model will also be used to identify appropriate future sampling needs and schedules to ensure the compliance strategy is working as predicted.

\subsubsection{Feasibility of executing institutional controls}

All federal, state, and local agencies responsible for regulatory guidance and enforcement of ground water usage in the vicinity of the Riverton site will be identified to determine the possibility of, and procedures for, executing ground water usage restrictions. As of 1993, the Wind Rivers Tribes' Environmental Quality Commission (WRTEQC) was negotiating with the state of Wyoming to define their role in administering ground water activities on the reservation. The status and results of these negotiations will be determined.

As institutional controls are intended to restrict ground water usage and prohibit cross-contamination of aquifers in the area of concern, all wells (public and private), and the associated property owners, located within 100 yds $(91.4 \mathrm{~m})$ of the probable maximum extent of the contaminant plume will be identified through the WRTEOC and the state of Wyoming Department of Environmental Quality (WDEO). 


\subsection{RESULTS OF COLLECTION ACTIVITIES}

Upon completion of data collection and analytical testing, data evaluation and report preparation activities will be initiated. Data evaluation activities will include, but not be limited to:

- Synthesis of ground water level measurements, calculation of ground water elevations, and preparation of contour maps.

- Synthesis of aquifer pumping test data.

- Implementation of computer modeling and resultant calculation of hydraulic conductivities, ground water flow path, vertical and horizontal gradients, ground water flow velocity, contaminant fate and transport, and surface water and ground water interactions.

- Tabulation of analytical results obtained from surface water and sediment sampling, ground water sampling, and geochemical sampling.

- Implementation of risk-based analysis of contaminant data with respect to receptors.

- The hydrogeologic data resulting from the well tests will be used, along with the estimates of rate of contaminant transport, to predict the quantity and concentrations of the contaminants being discharged to the river. A mass balance during low-flow periods will be calculated to evaluate the potential environmental impact on the river water and sediments. These predictions will be compared to surface water and sediment samples collected during low-flow periods as part of the continuing sampling activities.

Upon completion of data evaluation activities, a report will be compiled and delivered that will include a discussion of all field activities, a description of the instrumentation used, the location of the surveys, copies of all field measurement data, copies of field logs, the method of interpretation, and a summary of the results relative to the data collection objective. The results and reports will be incorporated in the SOWP, Revision 1. As the focus and overall objective of this report is to confirm or deny the applicability of the proposed conceptual compliance strategy, all recommendations, deviations, and contingencies regarding the site remediation will be identified, as will any additional data needs. 


\subsection{LIST OF CONTRIBUTORS}

The following individuals contributed to the preparation of this document.

\begin{tabular}{ll}
\hline Name & Contribution \\
\hline S. Wright & Document coordination \\
D. Tarbox & Primary authorship \\
R. Bowen, P. Briggs, L. Morisi & Document review \\
A. Groffman & Geochemistry \\
D. Tarbox & Hydrogeology \\
C. Day & Environmental \\
J. Bartel & Technical editing \\
K. Granillo, L. Keith & Text processing \\
E. Bond, T. Gagliano, J. Gates, & Graphic design \\
B. Harvey, S. Suniga, J. Wimmer & \\
\hline
\end{tabular}




\subsection{REFERENCES}

Allison et al. (J. D. Allison, D. S. Brown, and K. J. Novo-Gradac), 1991. MINTEOA2/PRODEFA2, A Geochemical Assessment Model For Environmental Systems: Version 3.0 User's Manual, EPA/600/3-91/021.

Anderson and Kelly, 1976. "Water Supply Study, City of Riverton, Wyoming".

Brown, Rollie, 1994. Facility Maintenance, St. Stephen's Mission, Riverton, Wyoming, personal communication to David Tarbox, Characterization and Remedial Design Department, Jacobs Engineering Group Inc., JEGI/JEG/0994-0015, UPDCC File Loction No. 7.19.2.2, Albuquerque, New Mexico, June 20, 1994.

DOE (U.S. Department of Energy), 1994a. Programmatic Environmental Impact Statement for the Uranium Mill Tailings Remedial Action Ground Water Project, DOE/EIS0198, Rev. 3, April 1994, draft, prepared by the U.S. Department of Energy, UMTRA Project Office, Albuquerque Operations Office, Albuquerque, New Mexico.

DOE (U.S. Department of Energy), 1994b. Baseline Risk Assessment of Ground Water Contamination at the Uranium Mill Tailings Site Near Riverton, Wyoming, DOE/AL/62350-65, prepared by the U.S. Department of Energy, UMTRA Project Office, Albuquerque Operations Office, Albuquerque, New Mexico.

DOE (U.S. Department of Energy), 1994c. UMTRA Project Water Sampling and Analysis Plan, Riverton, Wyoming, DOE/AL/62350-117, prepared by the U.S. Department of Energy, UMTRA Project Office, Albuquerque Operations Office, Albuquerque, New Mexico.

DOE (U.S. Department of Energy), 1993a. Technical Approach to Groundwater Restoration, DOE/AL/62350-20F, November 1993, prepared by the U.S. Department of Energy, UMTRA Project Office, Albuquerque Operations Office, Albuquerque, New Mexico.

DOE (U.S. Department of Energy), 1993b. Recommendations for the Preparation of Environmental Assessments and Environmental Impact Statements, May 1993, Office of NEPA Oversight, U.S. Department of Energy, Washington, D.C.

DOE (U.S. Department of Energy), 1992. UMTRA Groundwater Program Plan, May 1992, draft, prepared by the U.S. Department of Energy, UMTRA Project Office, Albuquerque Operations Office, Albuquerque, New Mexico.

DOE (U.S. Department of Energy), 1989. Technical Approach Document, UMTRA-DOE/AL 050425.0002, Revision II, December 1989, Uranium Mill Tailings Remedial Action Project, Albuquerque, New Mexico. 
DOE (U.S. Department of Energy), 1987. Environmental Assessment for Remedial Action at the Riverton Uranium Mill Tailings Site, Riverton, Wyoming, DOE/EA-0254, prepared by the U.S. Department of Energy, UMTRA Project Office, Albuquerque Operations Office, Albuquerque, New Mexico.

DOE (U.S. Department of Energy), 1983. Cooperative Agreement Between the United States Department of Energy and the State of Wyoming, DOE Cooperative Agreement Number DE-FC04-83AL19454, December 23, 1983, as amended, Uranium Mill Tailings Remedial Action Project, U.S. Department of Energy, Albuquerque Operations Office, Albuquerque, New Mexico.

EPA (U.S. Environmental Protection Agency), 1994. Draft Final Rule, Groundwater Standards for Remedial Actions at Inactive Uranium Processing Sites, UMTRA Project Document Control Center file location number 0.13.5.1, 1994, prepared by the U.S. Environmental Protection Agency, Washington, D.C.

EPA (U.S. Environmental Protection Agency), 1991. Region IV Standard Operating Procedures and Quality Assurance Manual, Atlanta, Georgia.

FBD (Ford, Bacon, \& Davis, Inc.), 1983. Evaluation of Alternate Disposal Sites for the Riverton, Wyoming, UMTRA Site, UC-451-320, UMTRA-SNL/68 8605, unpublished report prepared by FBD, Salt Lake City, Utah, for the U.S. Department of Energy, UMTRA Project Office, Albuquerque Operations Office, Albuquerque, New Mexico.

FBDU (Ford, Bacon, \& Davis Utah, Inc.), 1981. Engineering Assessment of Inactive Uranium Mill Tailings, Riverton Site, Riverton, Wyoming, DOE/UMT0106, FBDU360-19, UC70, prepared by FBDU, Salt Lake City, Utah, for the U.S. Department of Energy, UMTRA Project Office, Albuquerque Operations Office, Albuquerque, New Mexico.

Freeze, R. A., and J. A. Cherry, 1979. Ground Water, Prentice-Hall, Inc., Englewood Cliffs, New Jersey.

GECR (Geochemistry and Environmental Chemistry Research, Inc.), 1983. "Data for the Geochemical Investigation of UMTRAP Designated Site at Riverton, Wyoming," prepared by GECR for the U.S. Department of Energy, UMTRA Project Office, Albuquerque Operations Office, Albuquerque, New Mexico.

Hsi, C. D. and D. Langmuir, 1985. "Adsorption of Uranyl onto Ferric Oxyhydroxides: Application of the Surface Complexation Site-Binding Model," Geochim. Cosmochim. Acta, Vol. 49, pp. 1931-1941.

Horne, R. N., 1994. "Advances in Computer-Aided Well-Test Interpretation," Journal of Petroleum Technology, v. 46, no. 7, pp. 599-607. 
IAH (International Association of Hydrogeologists), 1990. "Groundwater Recharge - A Guide to Understanding and Estimating Natural Recharge," International Contribution to Hydrogeology, Vol 8, p. 182, International Association of Hydrogeologists.

JEG (Jacobs Engineering Group Inc.), n.d., standard operating procedures, prepared by Jacobs Engineering Group Inc., Albuquerque, New Mexico, for the U.S. Department of Energy, UMTRA Project Office, Albuquerque Operations Office, Albuquerque, New Mexico.

Kent et al. (D. B. Kent, V. S. Tripathy, N. B. Ball, J. O. Leckie, and M. D. Siegel), 1988. Surface-Complexation Modeling of Radionuclide Adsorption in Subsurface Environments, prepared for the Division of High-Level Waste Management Office of Nuclear Material Safety and Safeguards, U.S. Nuclear Regulatory Commission, Washington, D.C., NUREG/CR-4807 SAND86-7175.

LBL (Lawrence Berkeley Laboratory, University of California), 1984. "Hydrology and Geochemistry of the Uranium Mill Tailings Pile at Riverton, Wyoming," draft report for the U.S. Department of Energy, UMTRA Project Office, Albuquerque Operations Office, Albuquerque, New Mexico.

Leckie et al. (J. O. Leckie, M. M. Benjamin, K. Hayes, G. Kaufman, and S. Altmann), 1980. Adsorption/Coprecipitation of Trace Elements From Water With Iron Oxide, EPRI CS-1513, EPRI, Palo Alto, California.

Mohan et al. (M. S. Mohan, J. D. Ilger, and R. A. Zingarol, 1991. "Speciation of Uranium in a South Texas Lignite: Additional Evidence for a Mixed Mode of Occurrence," in Energy and Fuels, American Chemical Society, 5, pp., 568-573.

Nakashima, S., 1992. "Complexation and Reduction of Uranium by Lignite," The Science of the Total Environment, 117/118, Elsevier Science Publishers B.V., Amsterdam, pp. 425-437.

NOAA (National Oceanic and Atmospheric Administration), 1990. The potential for biological effects of sediment-sorbed contaminants tested in the national status and trends program, NOAA Technical Memo, NOS OMA 52.

NRC (U.S. Nuclear Regulatory Commission), 1989. Final Technical Evaluation Report for the Proposed Remedial Action at the Riverton Tailings Site, Riverton, Wyoming, April 18, 1989, File No. 0.2.2.5, U.S. Nuclear Regulatory Commission, Division of Low-Level Waste Management and Decommissioning, Washington, D.C.

Parkhurst et al. (D. L. Parkhurst, D. C. Thorstenson, and N. L. Plummer), 1980.

"PHREEQE - A Computer Program For Geochemical Calculations," U.S.

Geological Survey WRI 80-96. 
Peterson, S., 1985. Letter to W.C. Damm, U.S.N.R.C., dated July 2, 1985, File Location Number 7.1.8.2, Available in the UMTRA Project Document Control Center, UMTRA Project Office, Albuquerque Operations Office, Albuquerque, New Mexico.

Rai, D., and J. M. Zachara, 1984. Chemical Attenuation Rates, Coefficients and Constants in Leachate Migration, Volume 1: A Critical Review, EPRI-EA-3356, Volume 1, Battelle, Pacific Laboratories, Richland, Washington.

Saban, Ron, 1994. Water Treatment Plant Superintendent, city of Riverton, Wyoming, personal communication to David Tarbox, Characterization and Remedial Design Department, Jacobs Engineering Group Inc., JEGI/JEG/0994-0015, UPDCC File Location No. 0.2.8, Albuquerque, New Mexico, February 7, 1994.

Slack, Dennis, 1994. Plant Manager, Koch Sulfur Products Company, Riverton, Wyoming, personal communication to David Tarbox, Characterization and Remedial Design Department, Jacobs Engineering Group Inc., JEGI/JEG/0994-0015, UPDCC File Location No. 7.19.2.2, Albuquerque, New Mexico, June 21, 1994.

Trescott, P. C., 1976. Documentation of Finite Difference Model for Simulation of ThreeDimensional Ground-Water Flow, U.S. Geological Survey Open File Report 75-438, U. S. Department of the Interior, Washington, D.C.

White et al. (A. F. White, J. M. Delany., T. N. Narasimhan, and A. Smith), 1984. "Ground Water Contamination From an Inactive Uranium Mill Tailings Pile; 1. Application of a Chemical Mixing Model," Water Resources Research, Vol. 20, No. 11, pp. 1743-1752.

\section{CODE OF FEDERAL REGULATIONS}

10 CFR Part 1021, Compliance with the National Environmental Policy Act, U.S. Department of Energy (1994).

40 CFR Part 192, Health and Environmental Protection Standards for Uranium and Thorium Mill Tailings, U.S. Environmental Protection Agency (1994).

40 CFR Part 264, "Standards for Owners and Operators of Hazardous Waste Treatment, Storage, and Disposal Facilities," U.S. Environmental Protection Agency (1994).

40 CFR Part 1500, Purpose, Policy, and Mandate, (Regulations for Implementing the Procedural Provisions of the National Environmental Policy Act), Council on Environmental Quality (1994). 


\section{FEDERAL REGISTER}

52 FR 36000, Standards for Remedial Actions at Inactive Uranium Processing Sites;

Proposed Rule, September 24, 1987.

\section{UNITED STATES CODE}

42 USC \$4321, et seq. National Environmental Policy Act, January 1, 1970.

42 USC \$7901, et seq. Uranium Mill Tailings Radiation Control Act, November 8, 1978.

42 USC \$7923, et seq. Comprehensive National Energy Policy Act, October 24, 1992. 
APPENDIX A

MONITOR WELL LITHOLOGIC AND CONSTRUCTION LOGS 
PROJECT RIVERTON SITE, WYO.: UMTRA

Page 1 of 1

\begin{tabular}{|c|c|c|}
\hline \multirow{2}{*}{\multicolumn{2}{|c|}{ JOB NO. RVTO1 DATE $10 / 04 / 83$}} & \\
\hline & & \\
\hline SURFACE ELEVATION & 4946.10 & WELL OWNER P. DARR \\
\hline H OF SEAL & 4.00 & BORING TYPE ROTARY W/ REVERT \\
\hline WELL CASING TIPE & 6-IN.SCHED. 40 PVC & $N 24100.70 \quad E 24050.70$ \\
\hline COMPLETION & ALLUVIUM (PUMP TEST) & MSL, GROUND SURFACE \\
\hline
\end{tabular}

LOG OF WELL BORING NO. 100

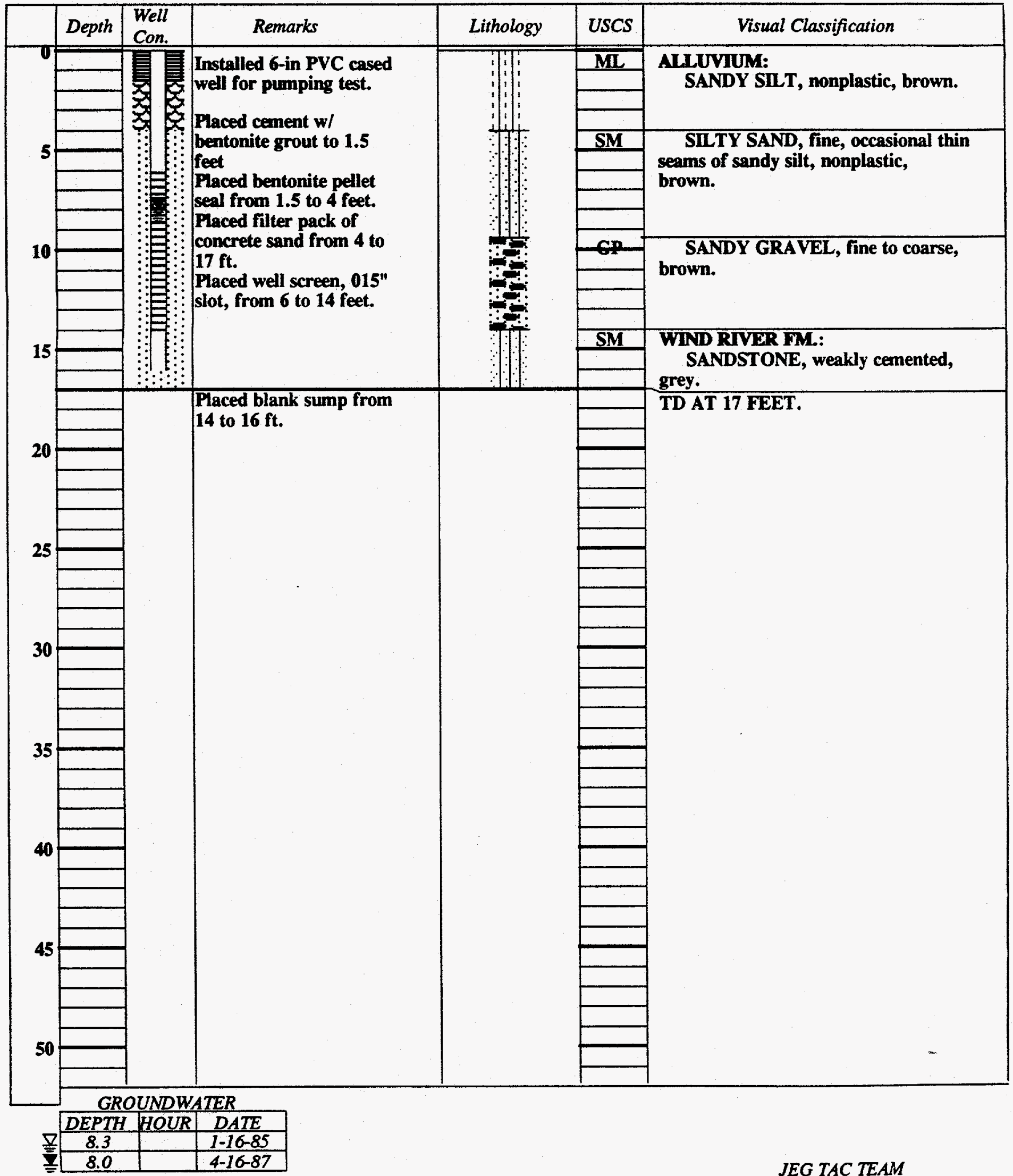




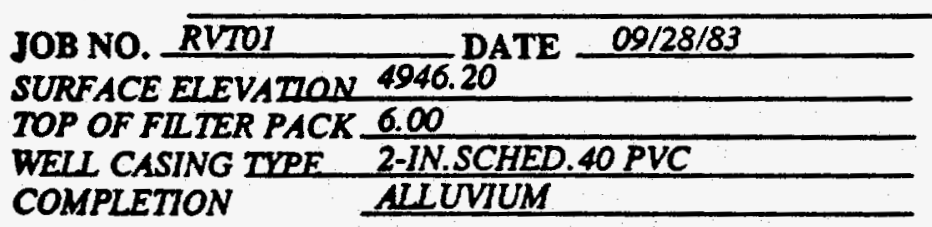

LOG OF WELL BORING NO.

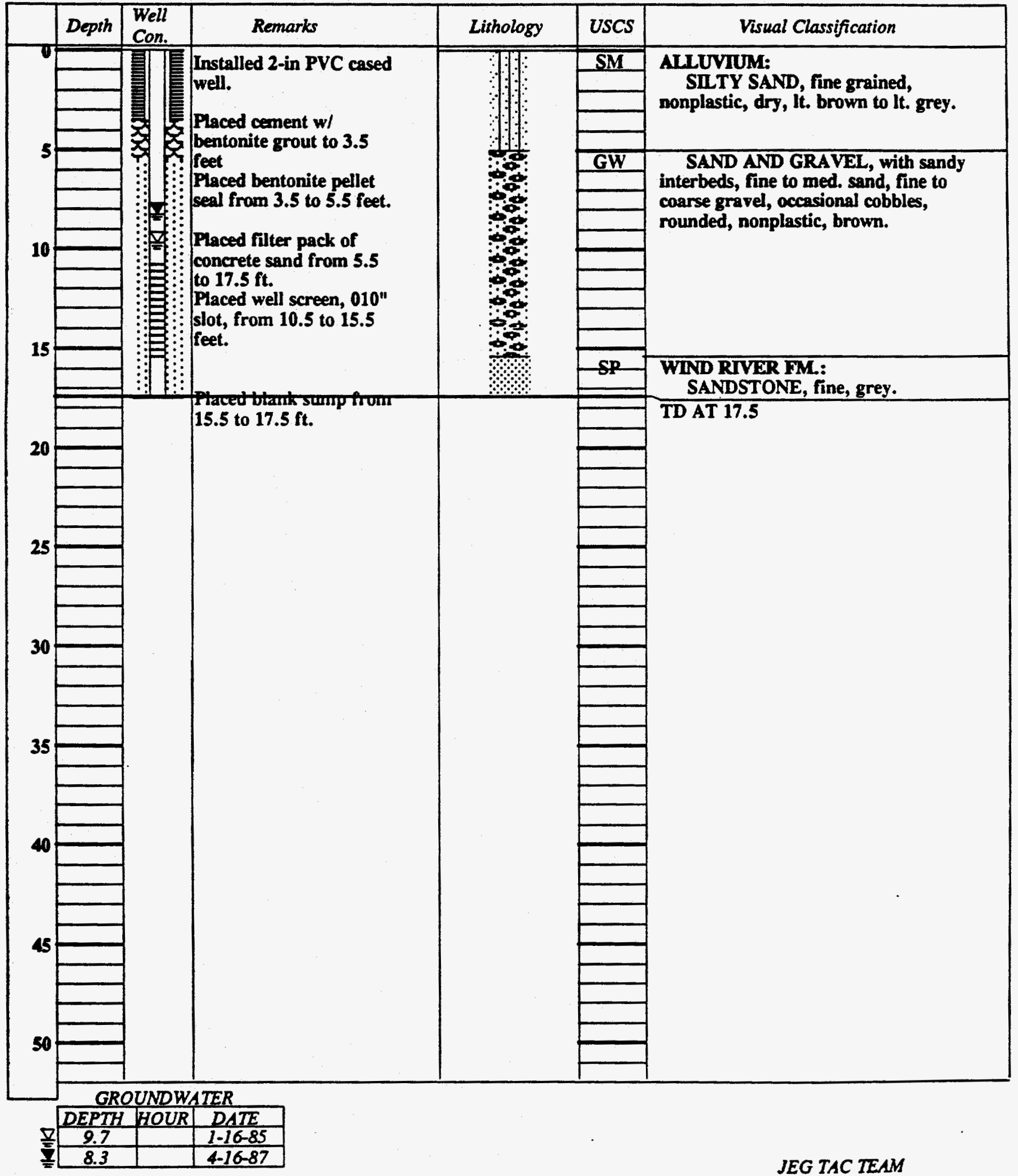


PROJECT RIVERTON SITE, WYO.: UMTRA

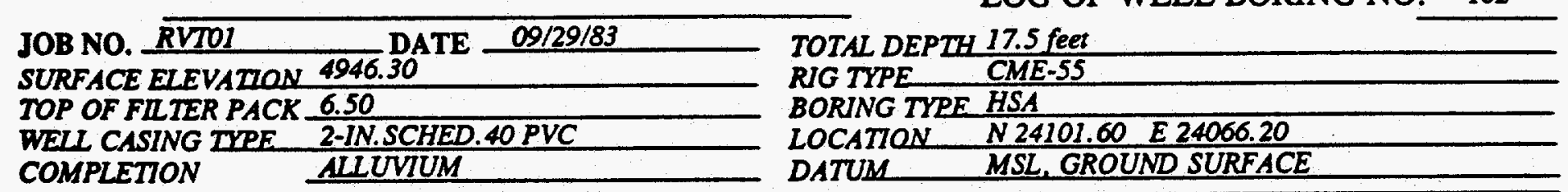

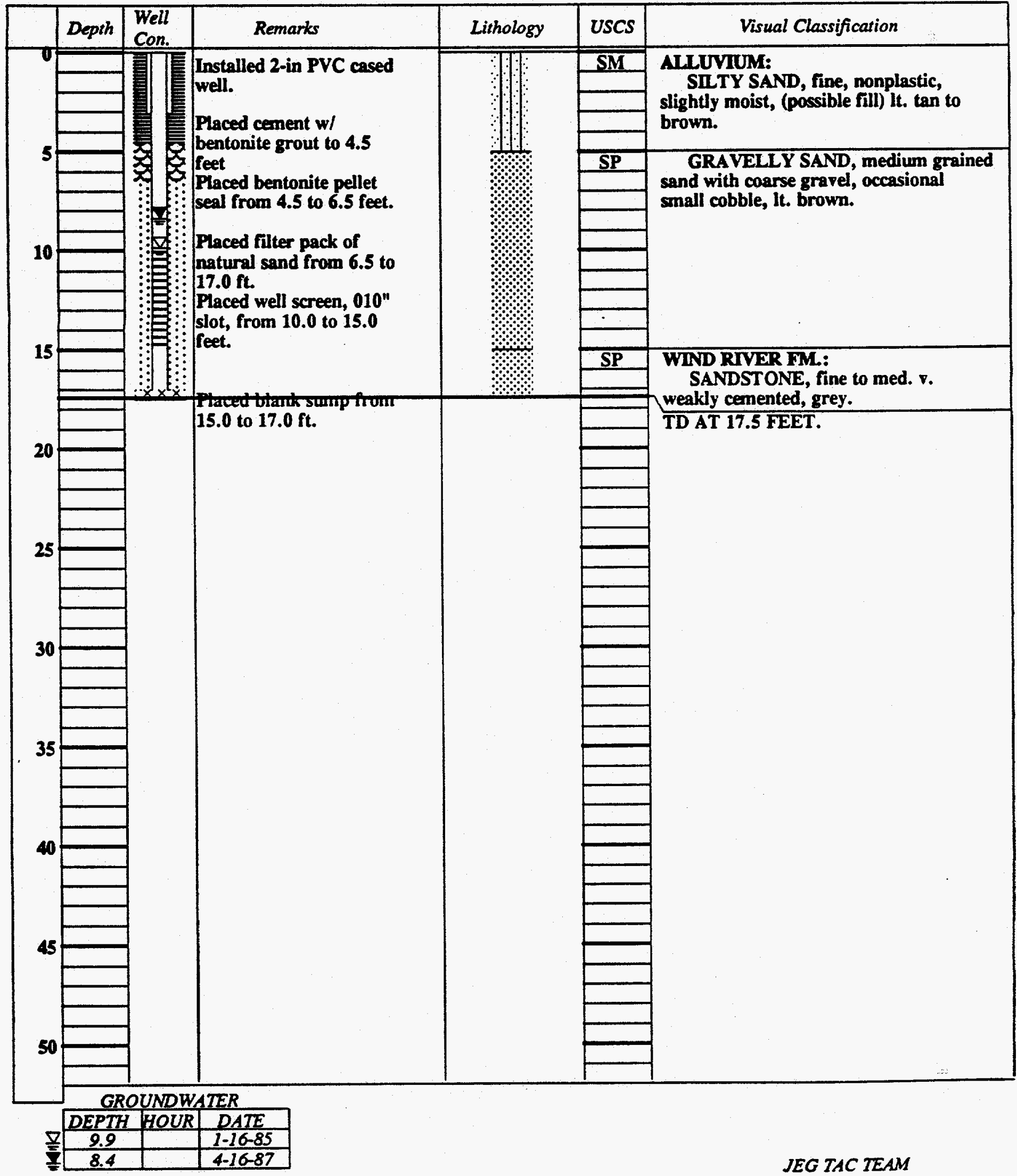




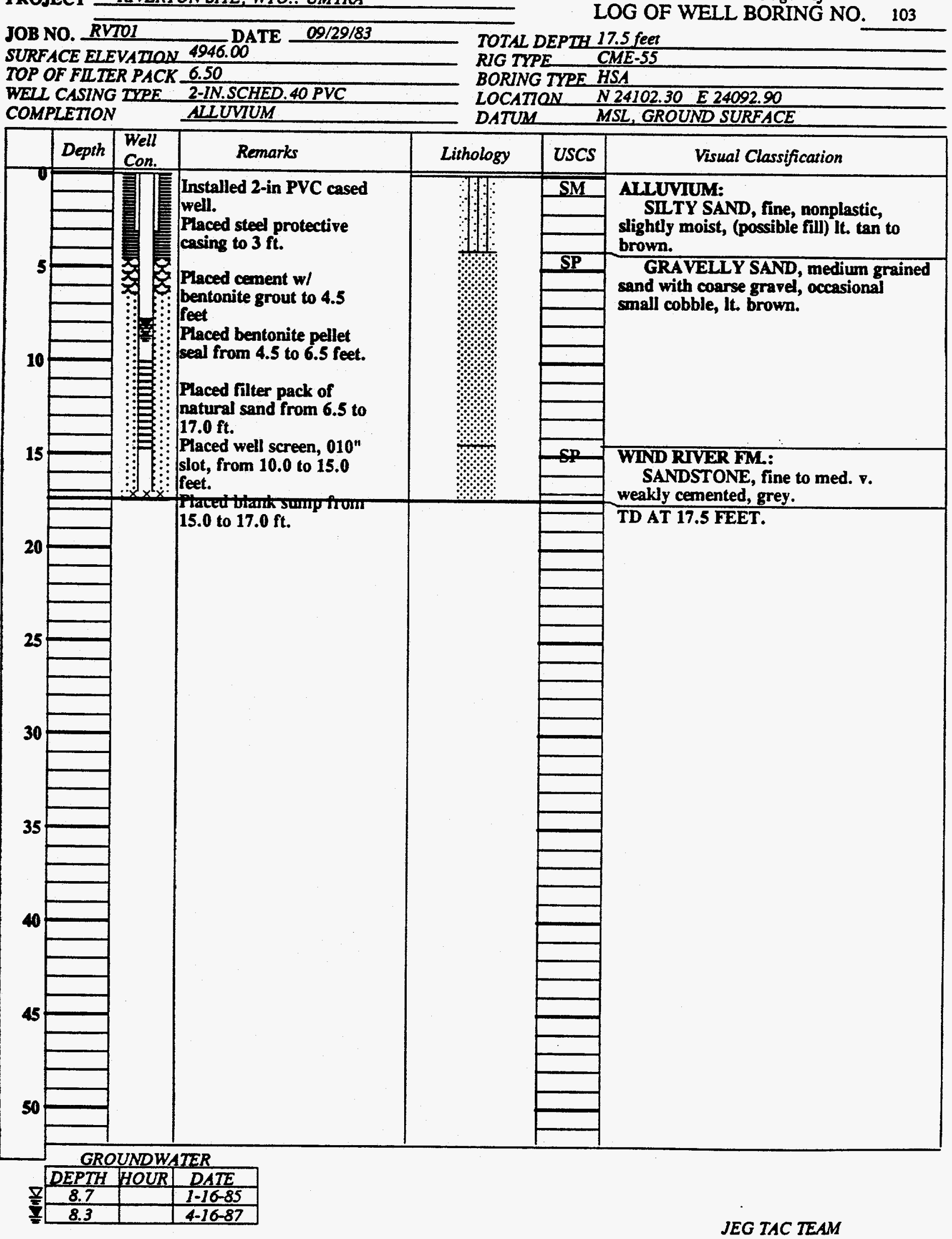


PROJECT RIVERTON SITE, WYO.: UMTRA

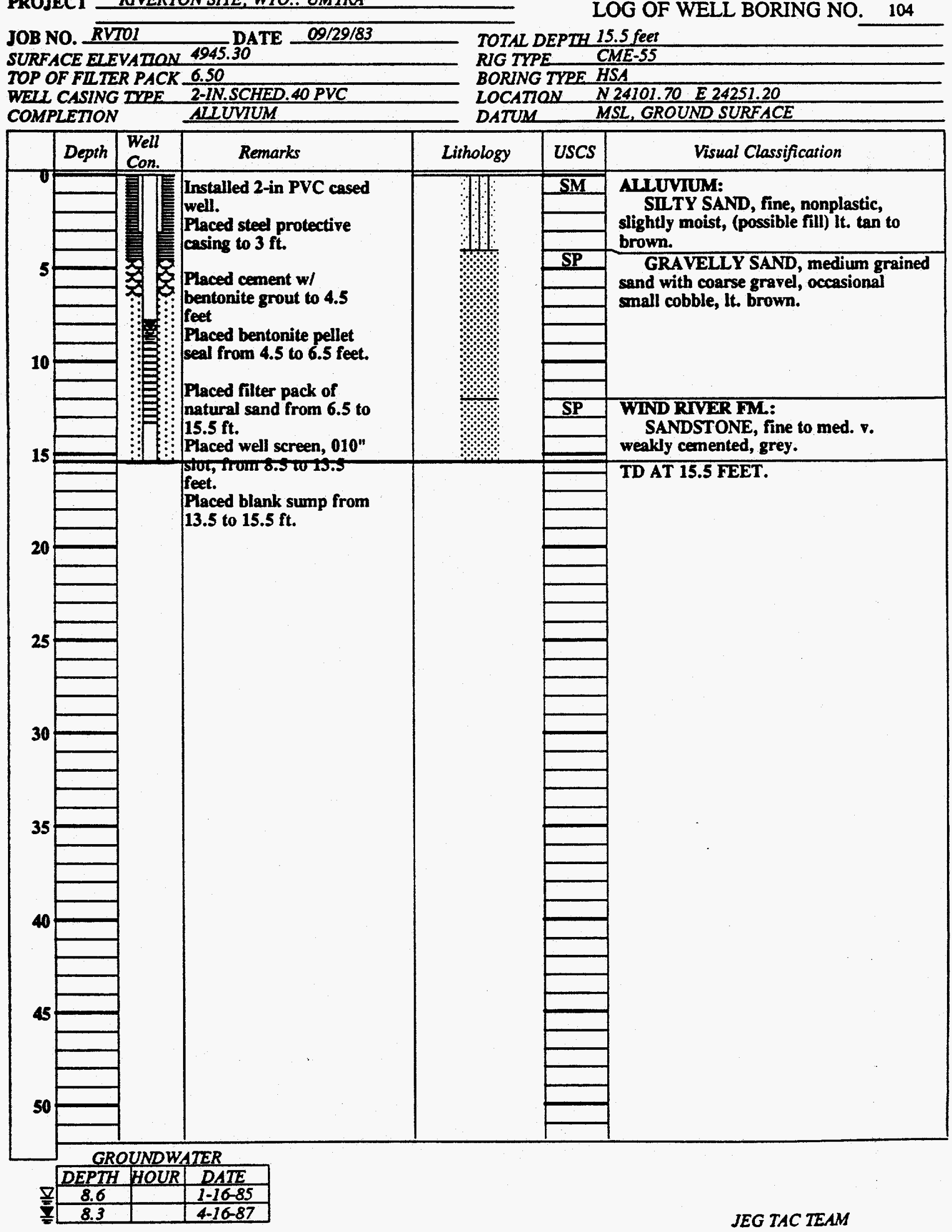




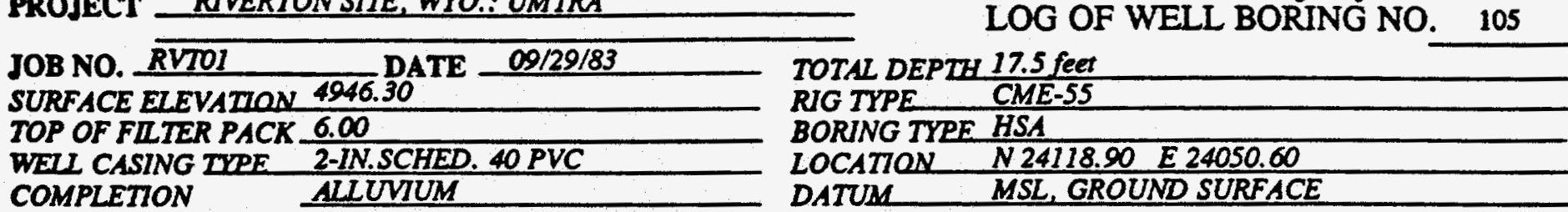

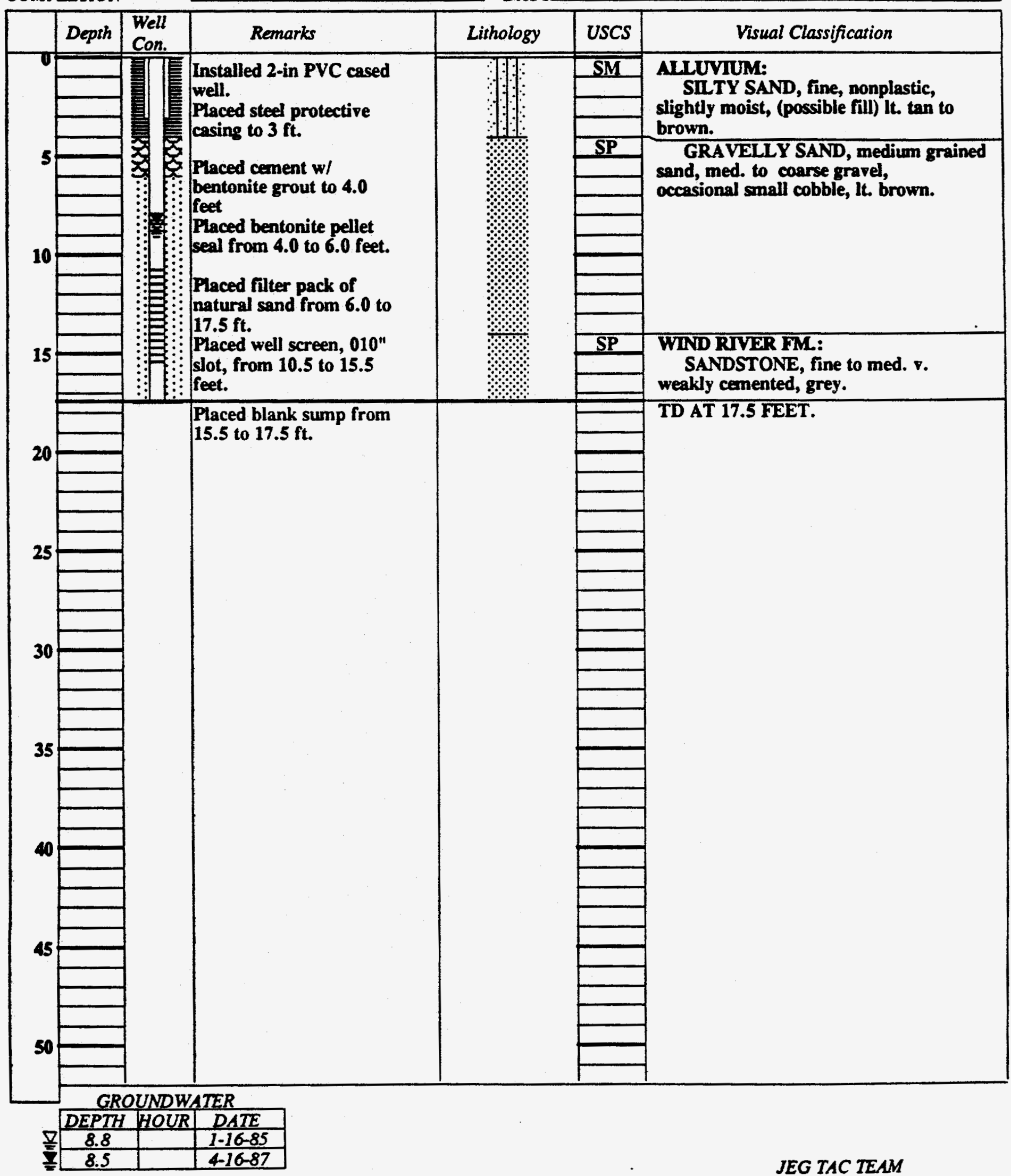


FROJECT RIVRTON SITE, WYO.: UMTRA

Page 1 of 2

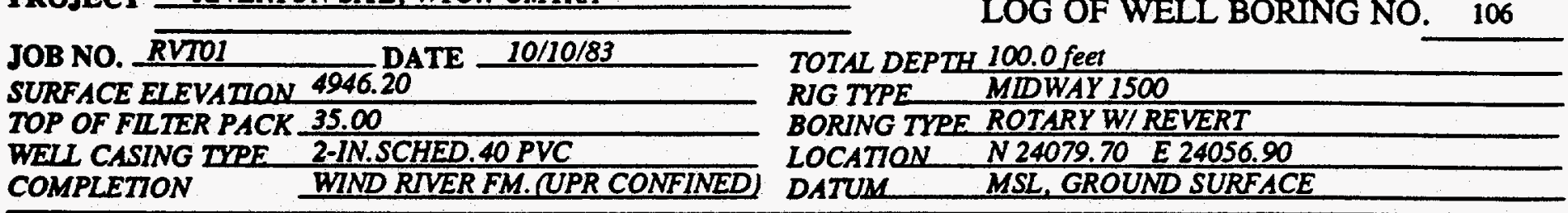

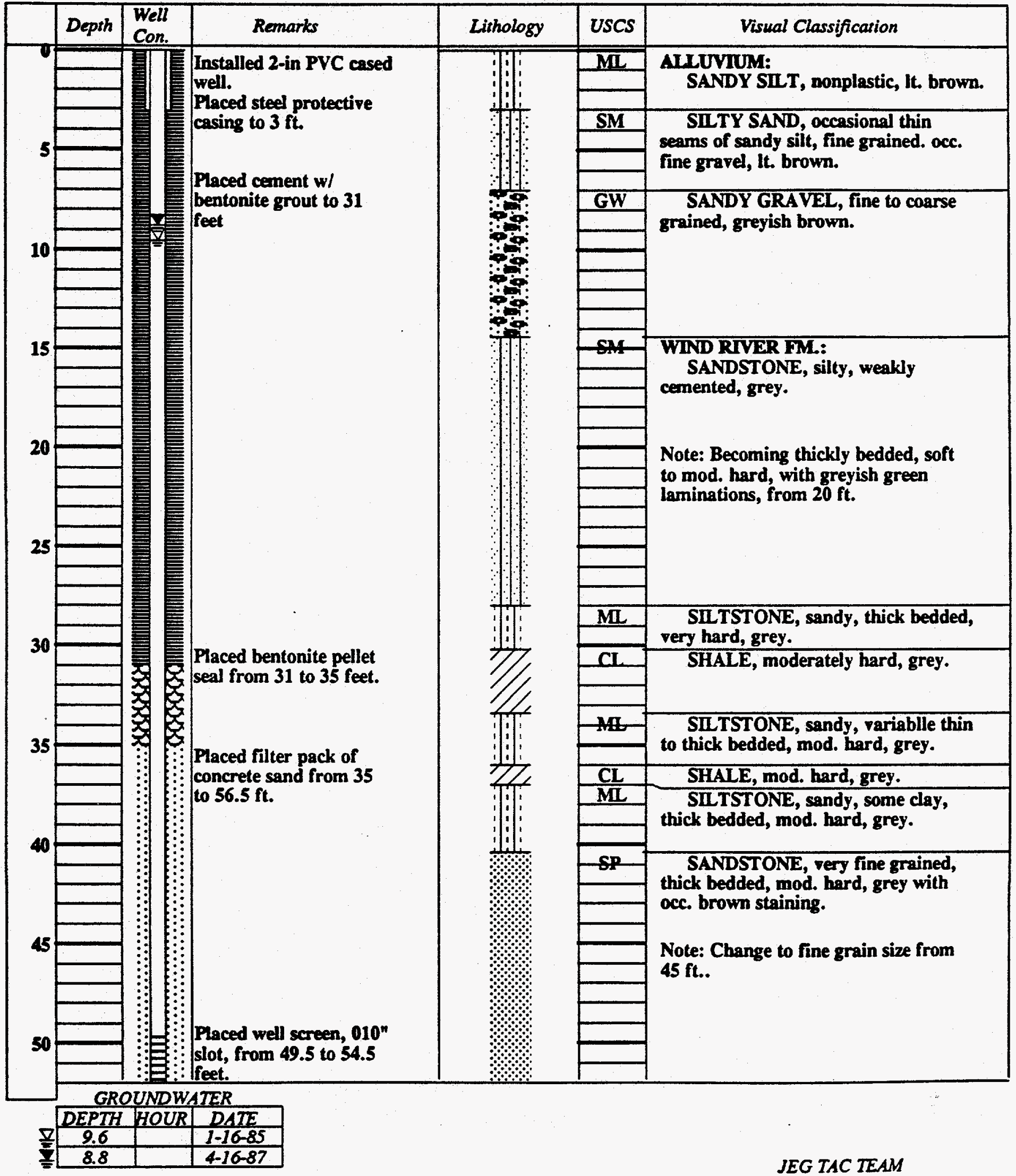


PROJECT RIVETON SITE, WYO.: UMTRA

JOB NO. RVTO1 DATE 10/10/83

Page $^{2}$ of 2

SURFACE ELEVATION 4946.20

100,0 fed

TOP OF FIL TER PACK 35.00

WELL CASING TYRE 2-IN.SCHED.40 PVC

COMPLETION WND RIVER FM.UPRR CONFINED

TOTAL DEPTH 100.0 feet

RIG TYPE MDWAY 1500

BORING TYRE ROTARY W/ REVERT

LOCATION N24079.70 E 24056.90

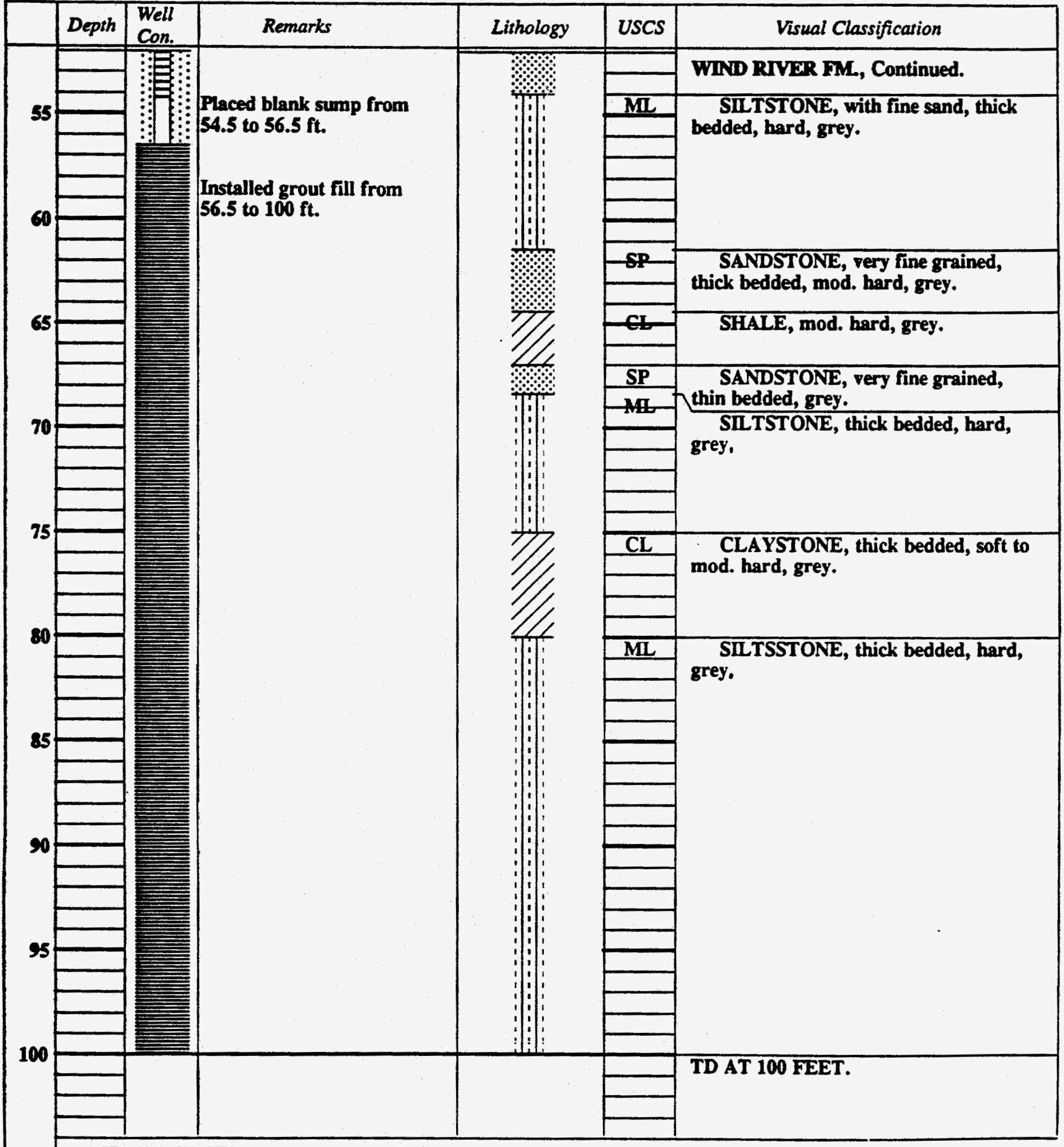

GROUNDWATER

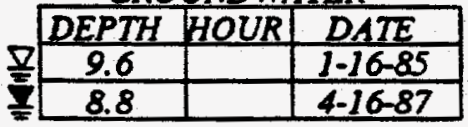

JEG TAC TEAM 
PROJECT RIVERTON SITE, WYO.: UMTRA

PageI of 2

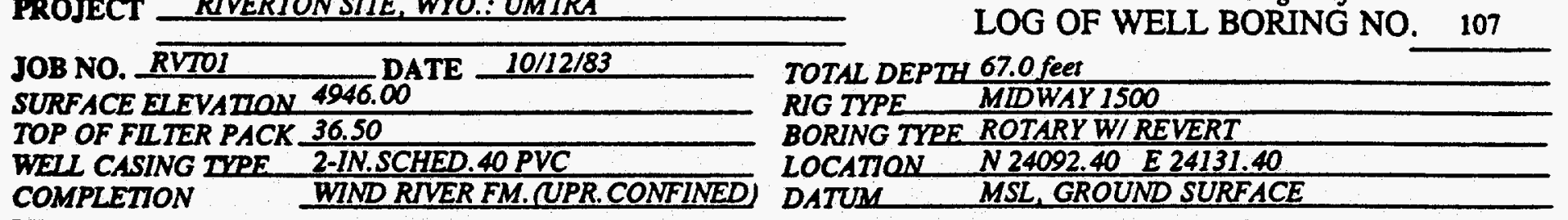

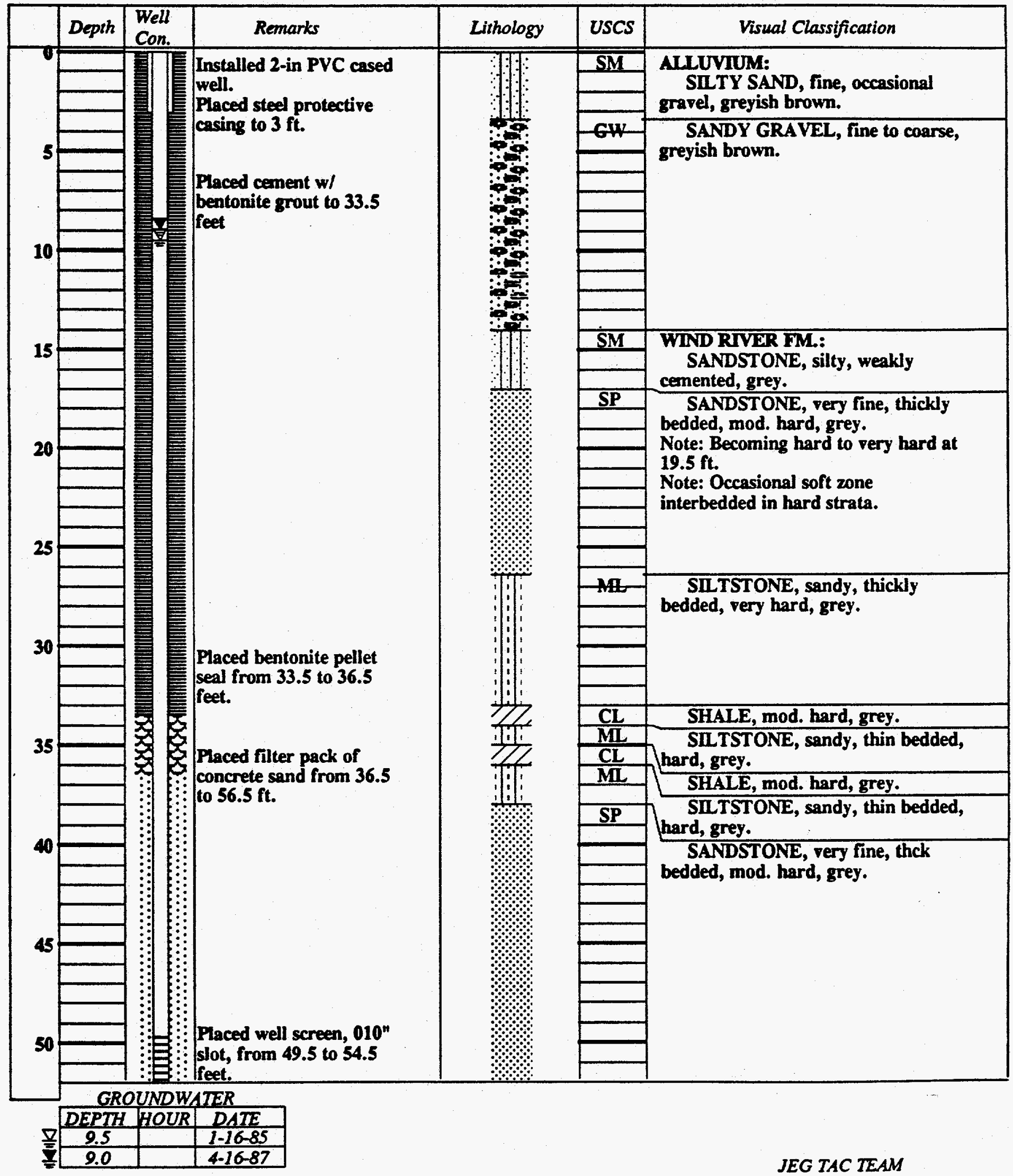


PROJECT RIVERTON SITE, WYO.: UMTRA

Page $^{2}$ of 2

\begin{tabular}{|c|c|c|c|}
\hline & (2) & & OF WELL BC \\
\hline B NO. & $10 / 12 / 83$ & $\boldsymbol{z}$ & $20 \% .0$ \\
\hline URFACE & ELEVATION 4946.00 & RIG TYPE & MDWAY 1500 \\
\hline$=$ & PACK 36.50 & BORING TYRE & ROTARY WI REVERT \\
\hline VELL C & 2-IN.SCHED. 40 PVC & LOCATTON & $N 24092.40 \quad E 24131.40$ \\
\hline COMPLE & WND RVER FM. UPR. CONFINED & DATUM & MSL, GROUND SURFACE \\
\hline
\end{tabular}

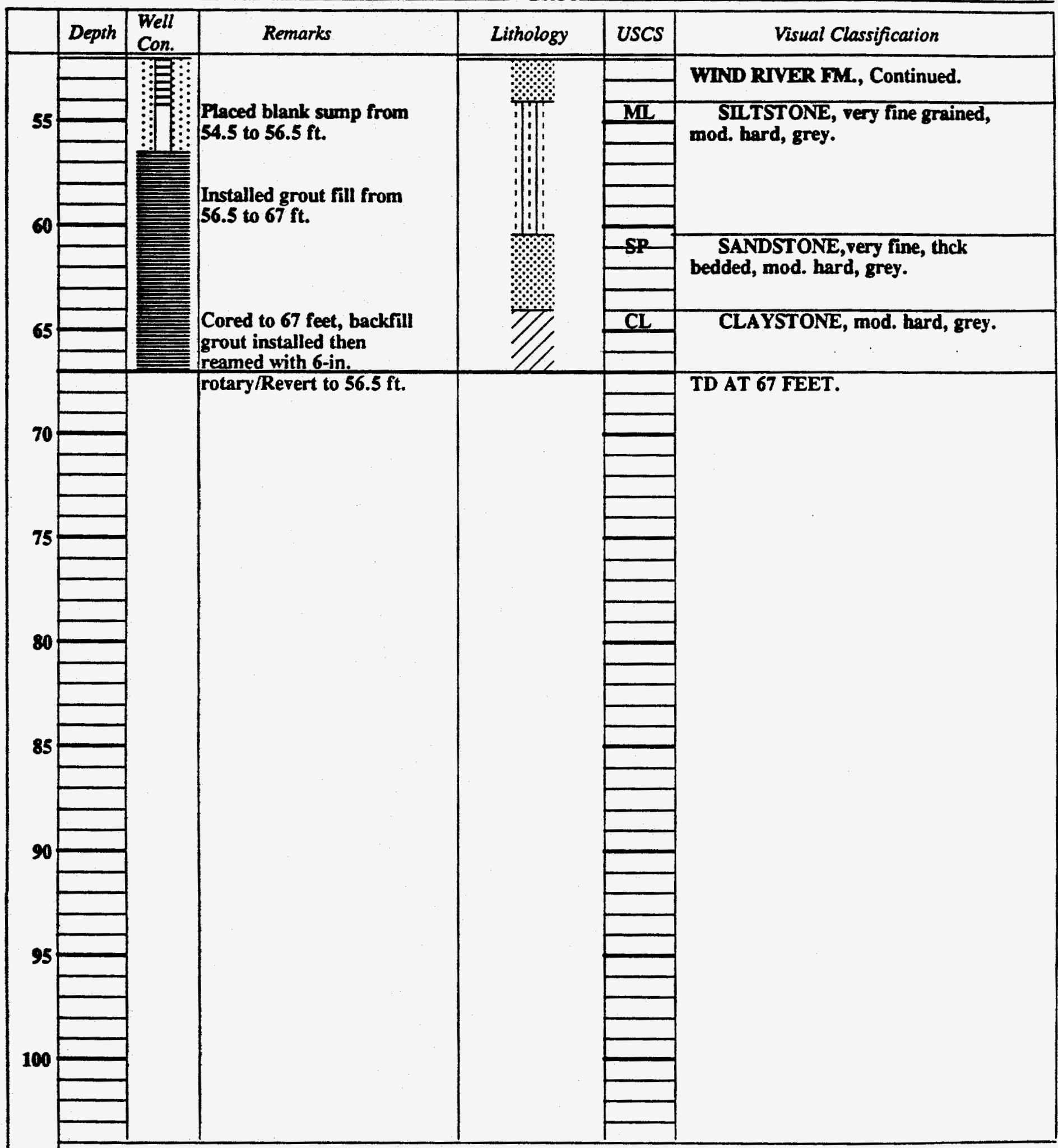

GROUNDWATER

DEPTH HOUR DATE

\begin{tabular}{|c|c|c|}
\hline 9.5 & & $1-16-85$ \\
\hline 9.0 & & $4-16-87$ \\
\hline
\end{tabular}


FROJECT RIVERTON SITE, WYO.: UMTRA

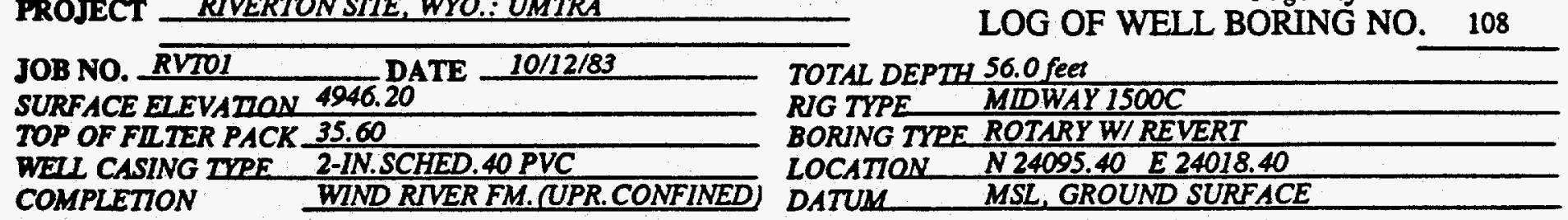

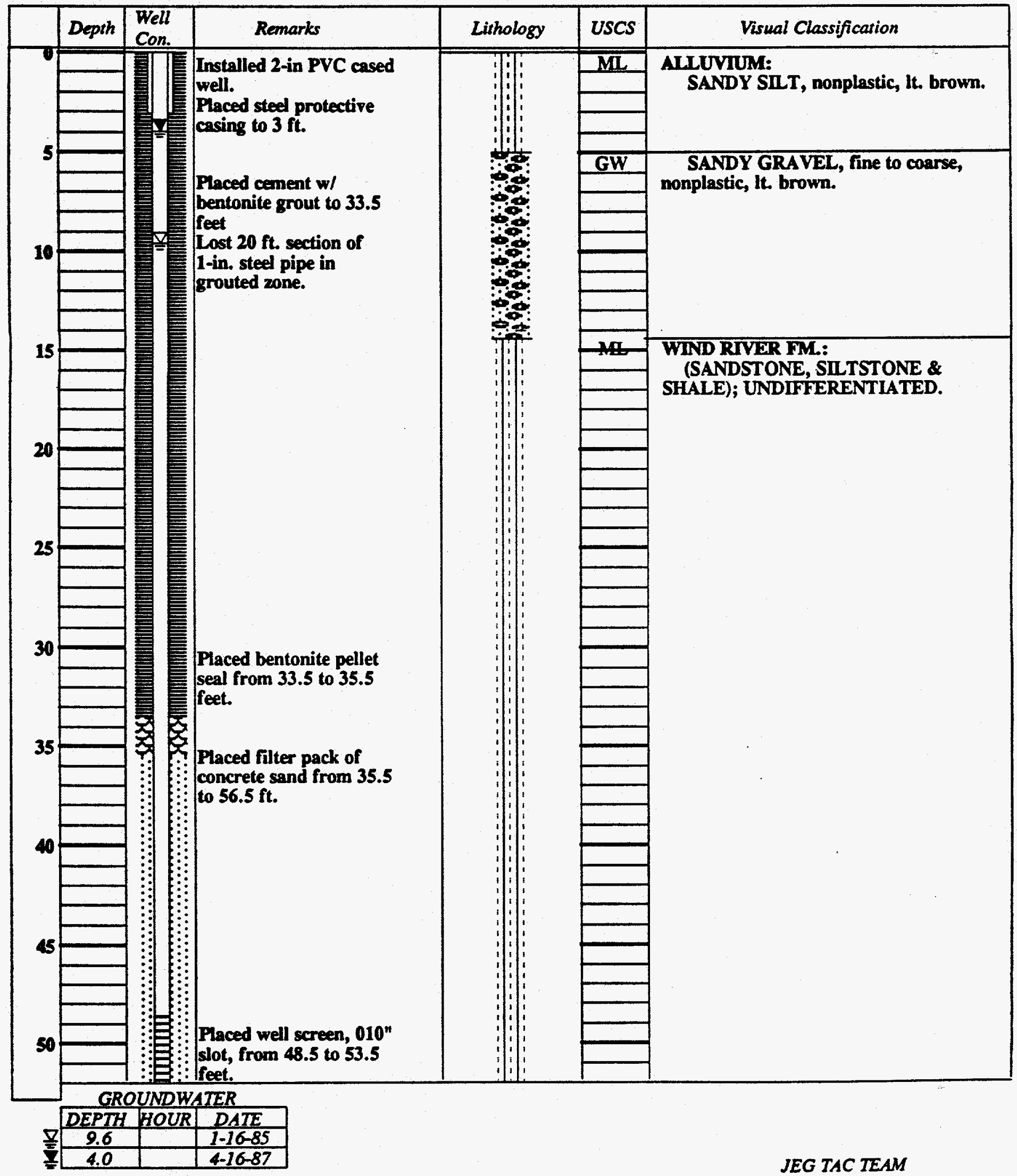


PROJECT RIVERTON SITE, WYO.: UMTRA

JOB NO. RVTO1

SURFACE ELEVATION 4946.20

TOP OF FILIER PACK 35.60

WELL CASING TYPE 2-IN.SCHED.40 PVC

COMPLETION WIND RIVER FM.(UPR. CONFINED)

DATE $10 / 12 / 83$

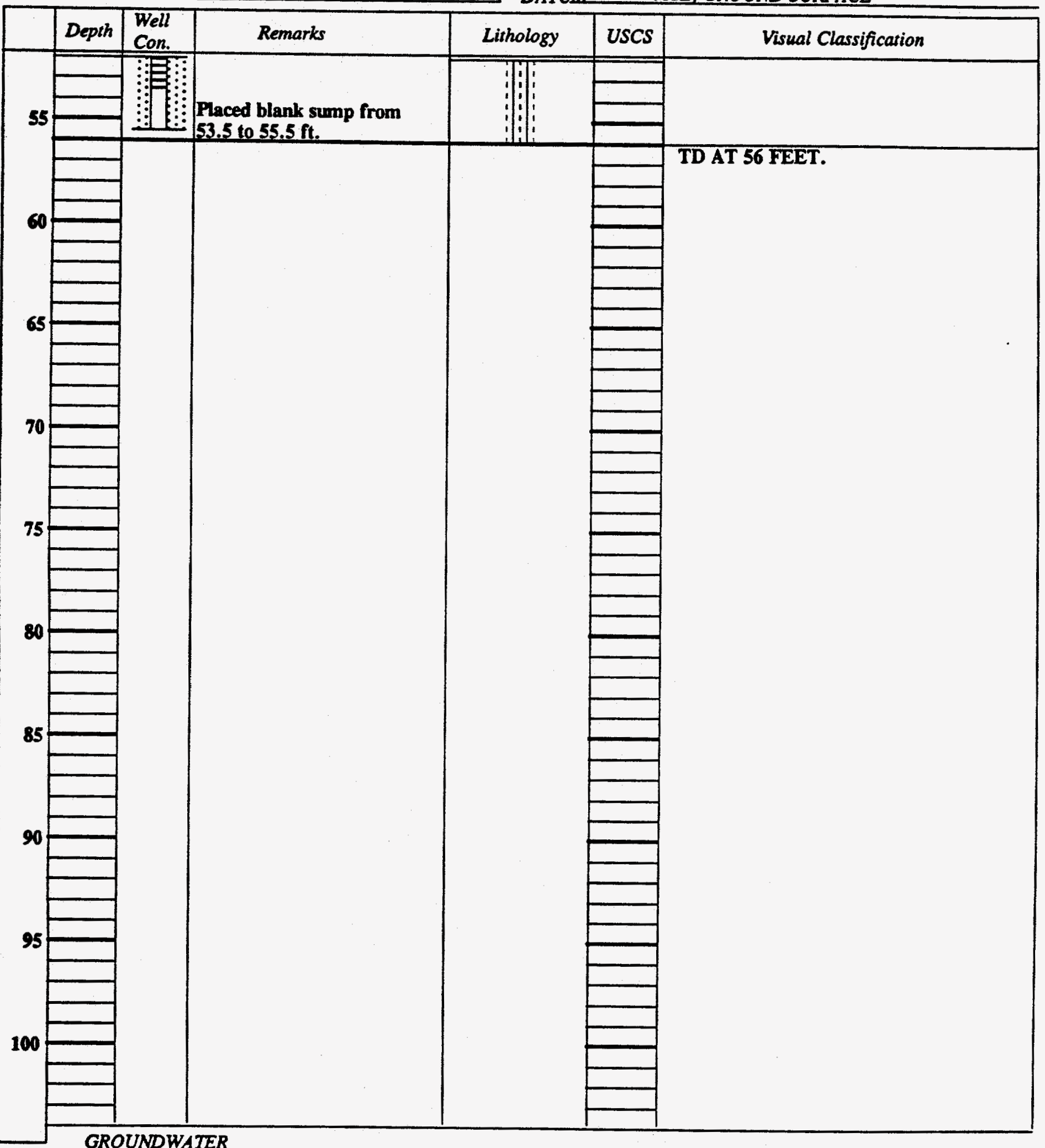

RIG TYPE MDWAY 1500C

BORING TYRE ROTARY W/ REVERT

LOCATION N 24095.40 E 24018.40

DATUM MSL, GROUND SURFACE 


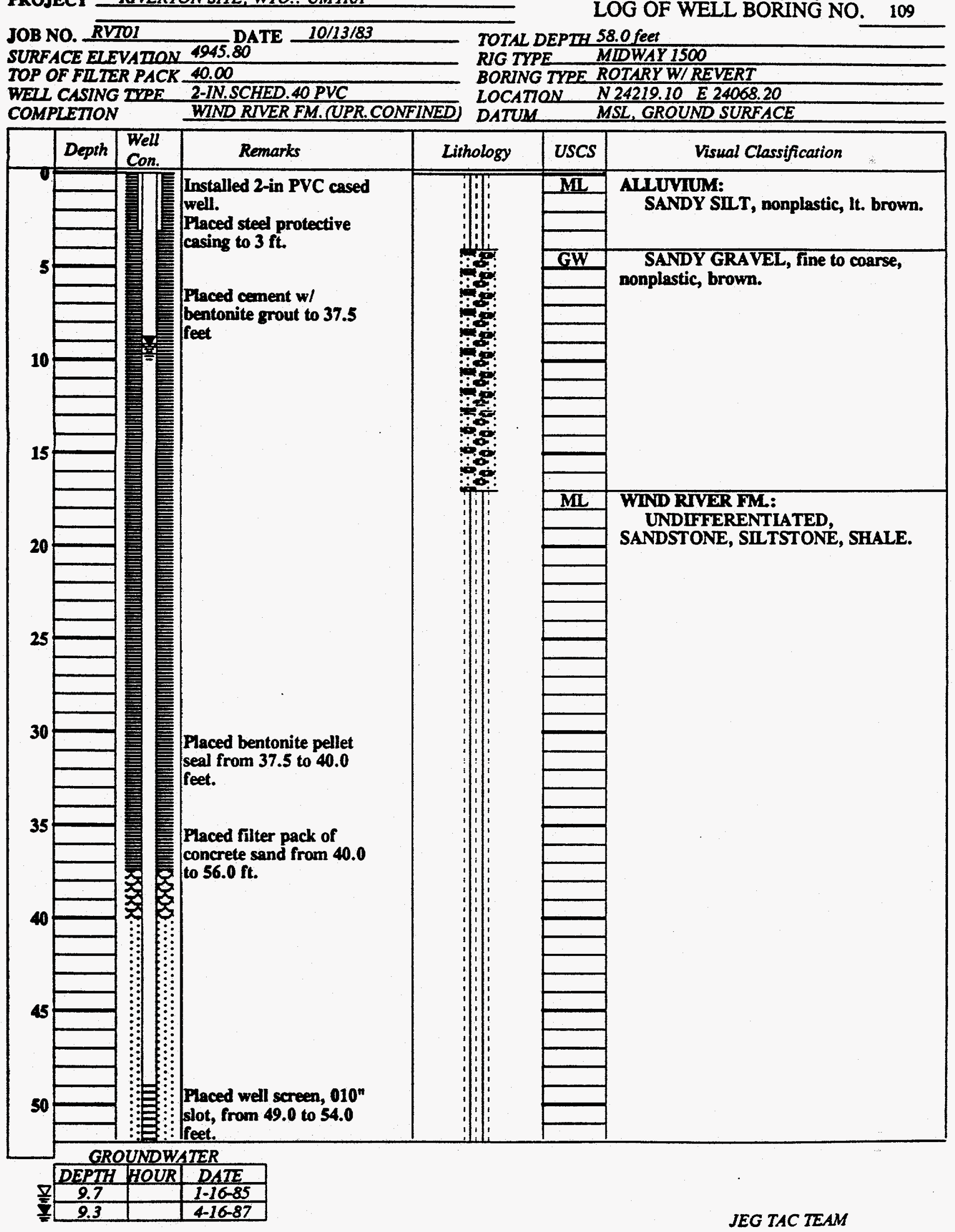


PROJECT RIVERTON SITE, WYO.: UMTRA

JOB NO. RVTOI

DATE $10 / 13 / 83$

SURFACE ELEVATON 4945.80

TOP OF FILTER PACK 40.00

WEIL CASING TYPE 2-IN.SCHED.40 PVC

COMPLETION WIND RIVER FM.(UPR.CONFINED
Page $^{2}$ of 2

LOG OF WELL BORING NO. 109

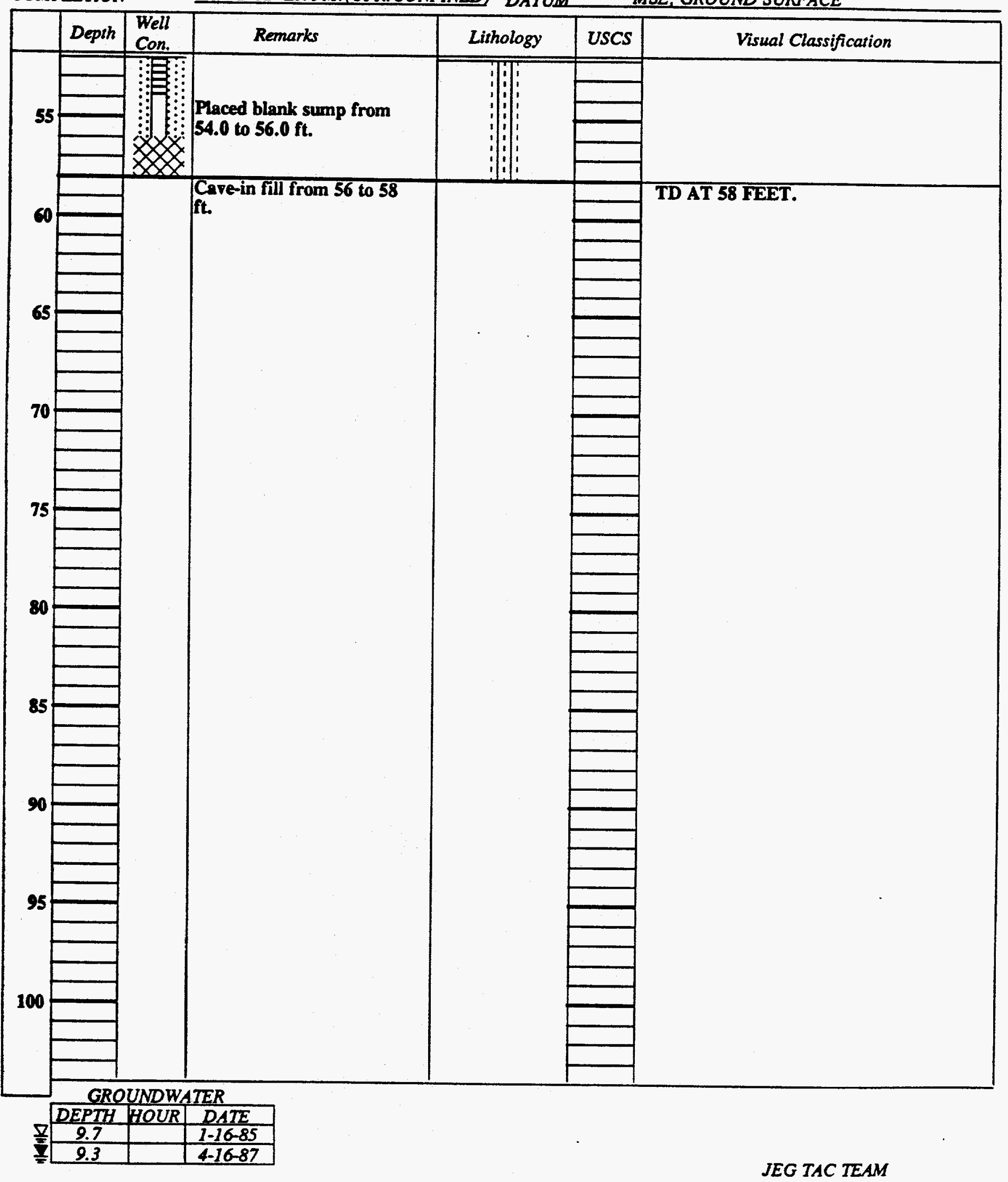




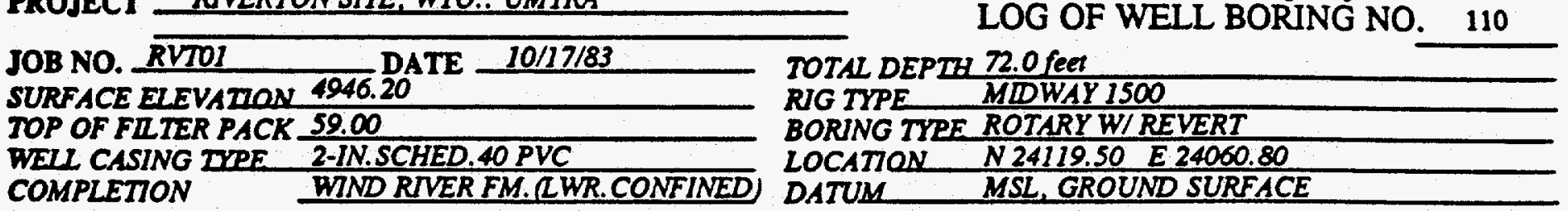

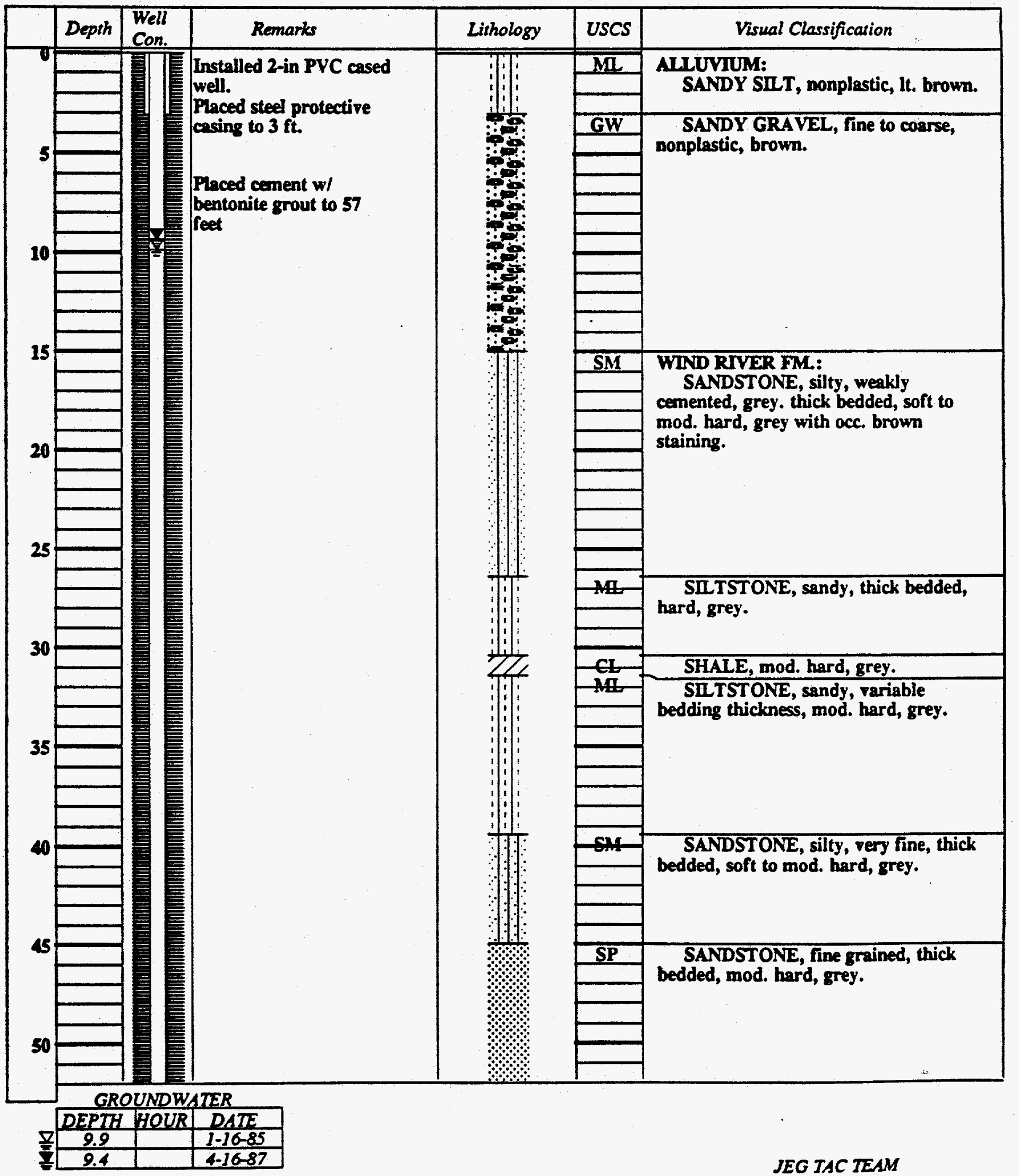




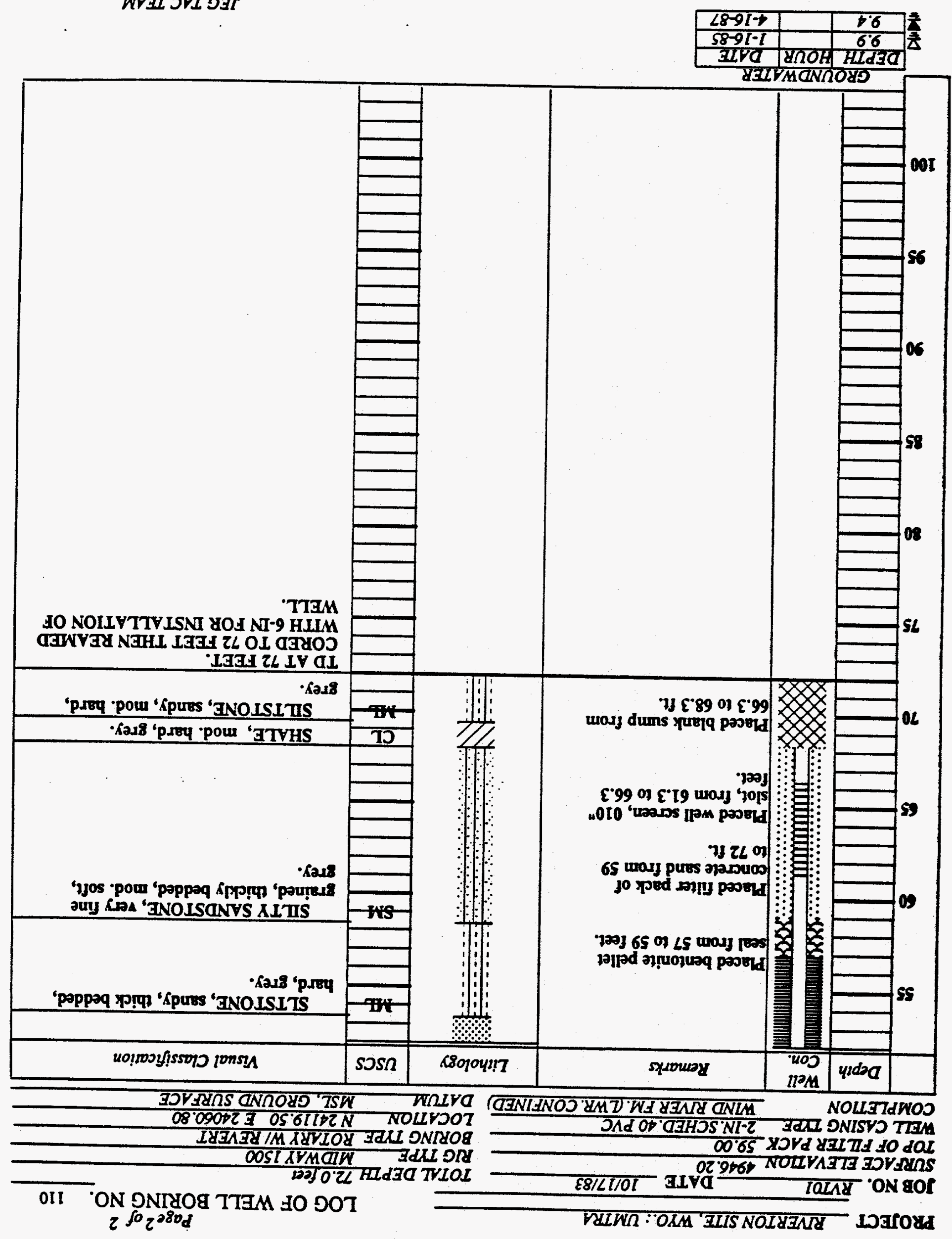




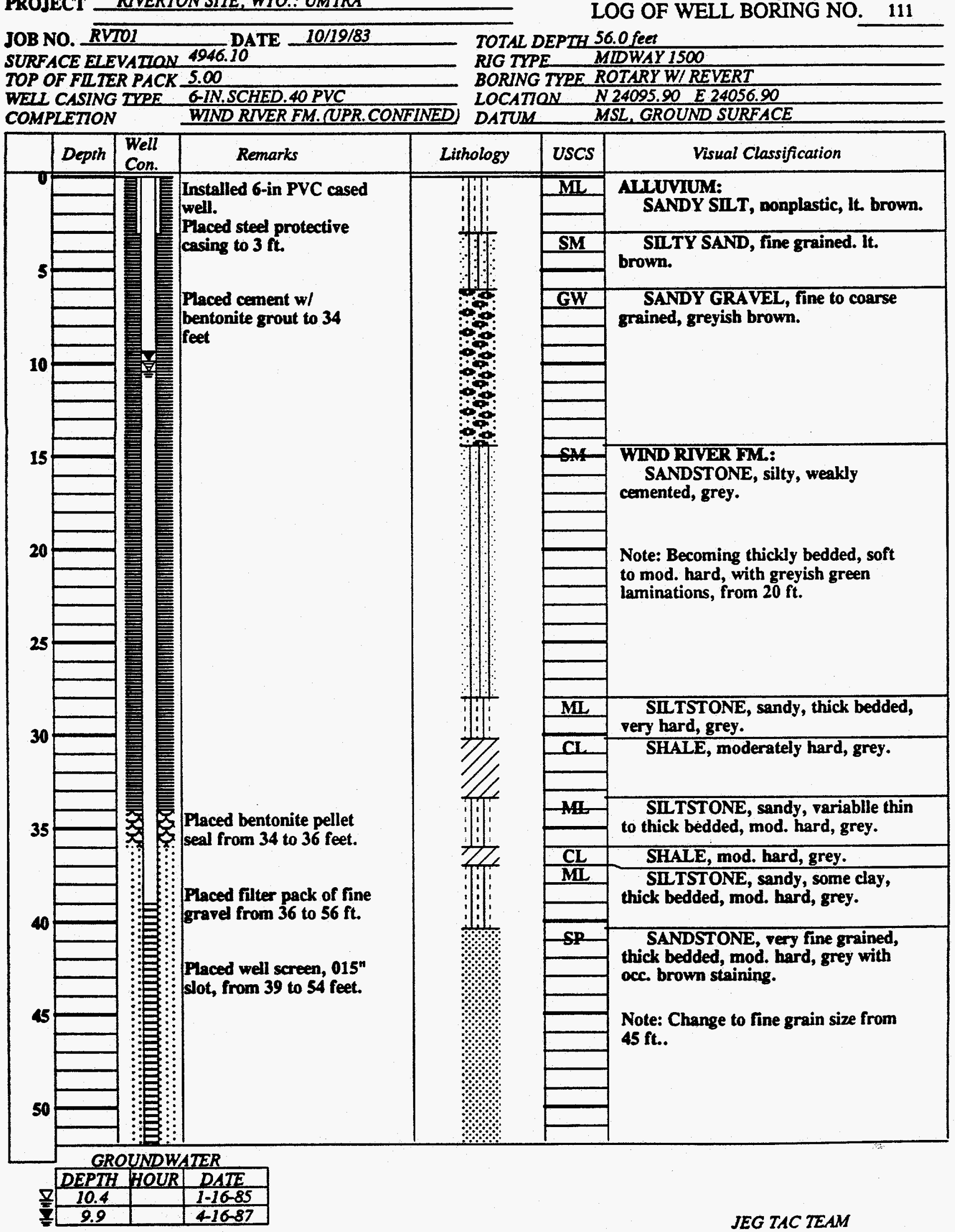


JOB NO. RVTOI DATE 10/19/83

LOG OF WELL BORING NO. 111

SURFACE ELEVATION

4946.10

TOP OF FILTER PACK 5.00

WELL CASING TUPE G-IN.SCHED.40 PVC

COMPLETION WIND RIVER FM.UPR. CONFINED

TOTAL DEPTH 56.0 feet

RIG TYPE MDWAY 1500

BORING TYPE ROTARY W/ REVERT

LOCATION N24095.90 E24056.90

\begin{tabular}{|l|l|l|l|l|l|l|}
\hline & Depth & $\begin{array}{l}\text { Well } \\
\text { Con. }\end{array}$ & Remarks & Lithology & USCS & Visual Classification \\
\hline
\end{tabular}

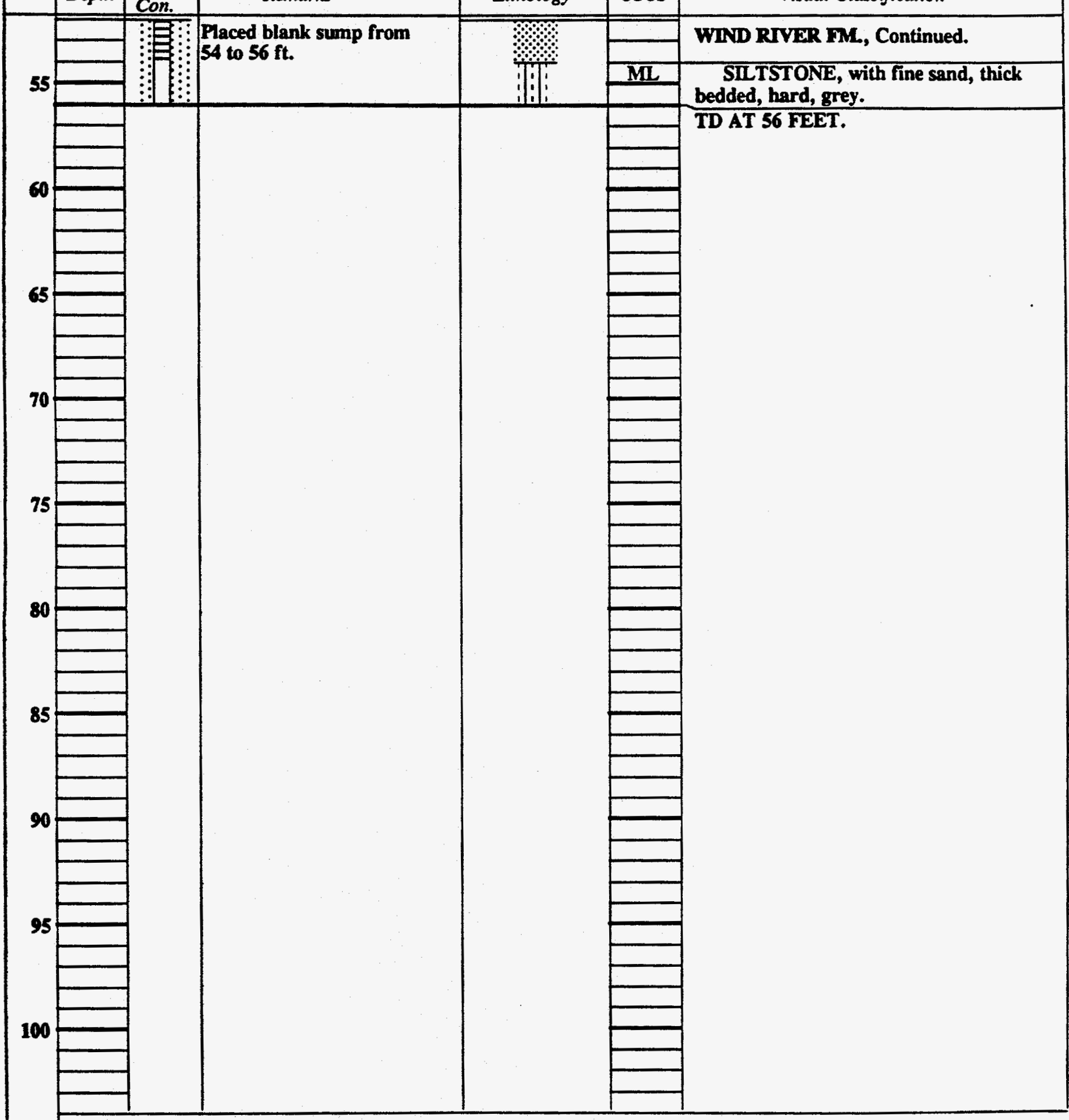

GROUNDWATER

\begin{tabular}{|c|c|c|}
\hline DEPTH & HOUR & DATE \\
\hline 10.4 & & $1-16-85$ \\
\hline 9.9 & & $4-16-87$ \\
\hline
\end{tabular}




\begin{tabular}{|c|c|}
\hline \multirow{2}{*}{\multicolumn{2}{|c|}{ JOB NO. $\frac{\overline{R V T O 1}}{\text { DATE } 10 / 12 / 83}$}} \\
\hline SURFACE ELEVATION & \\
\hline DEPTH OF SEAL & 5.00 \\
\hline WELL CASING TYPE & 6-IN. SCHED. 40 PVC \\
\hline COMPLETION & ALLUVIUM / WIND RIVER FM. \\
\hline
\end{tabular}

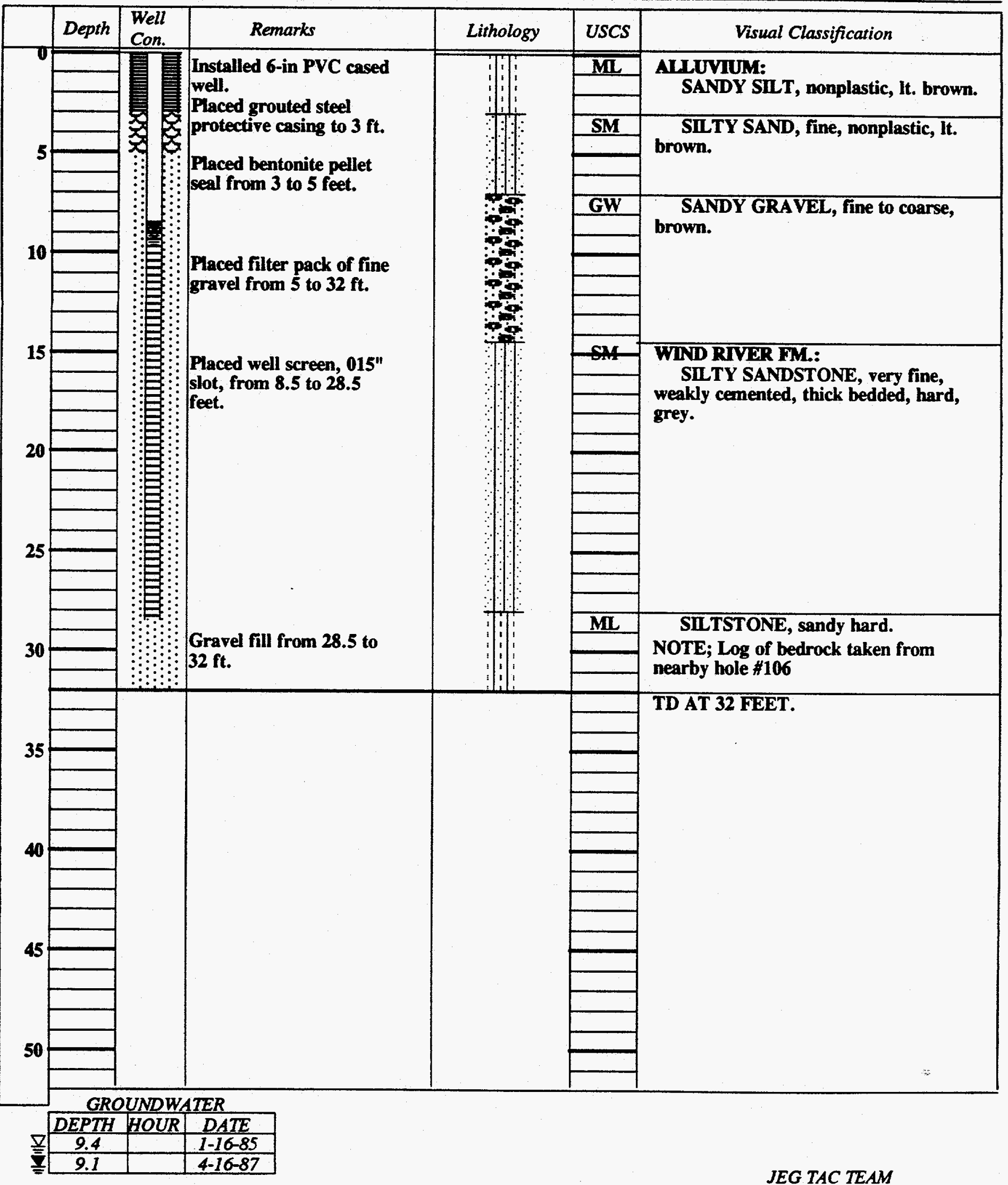


PROJECT RIVERTON SITE, WYO.: UMTRA

Page 1 of 1

\begin{tabular}{ll}
\cline { 2 - 2 } JOB NO. RVTOI & \multicolumn{1}{c}{ DATE $10 / 20 / 83$} \\
SURFACE ELEVATION & 4946.20 \\
DEPTH OF SEAL & 5.00 \\
WELL CASING TUPE & $2.1 N$. SCHED.40 PVC \\
COMPLETION & WND RIVER FM. (UPR. CONFINED)
\end{tabular}

TOTAL DEPLH 34.0 feet

WELL OWNER P. DARR

BORING TYRE ROTARY W/REVERT

LOCATION N24089.40 E 24040.30

DATUM MSL, GROUND SURFACE

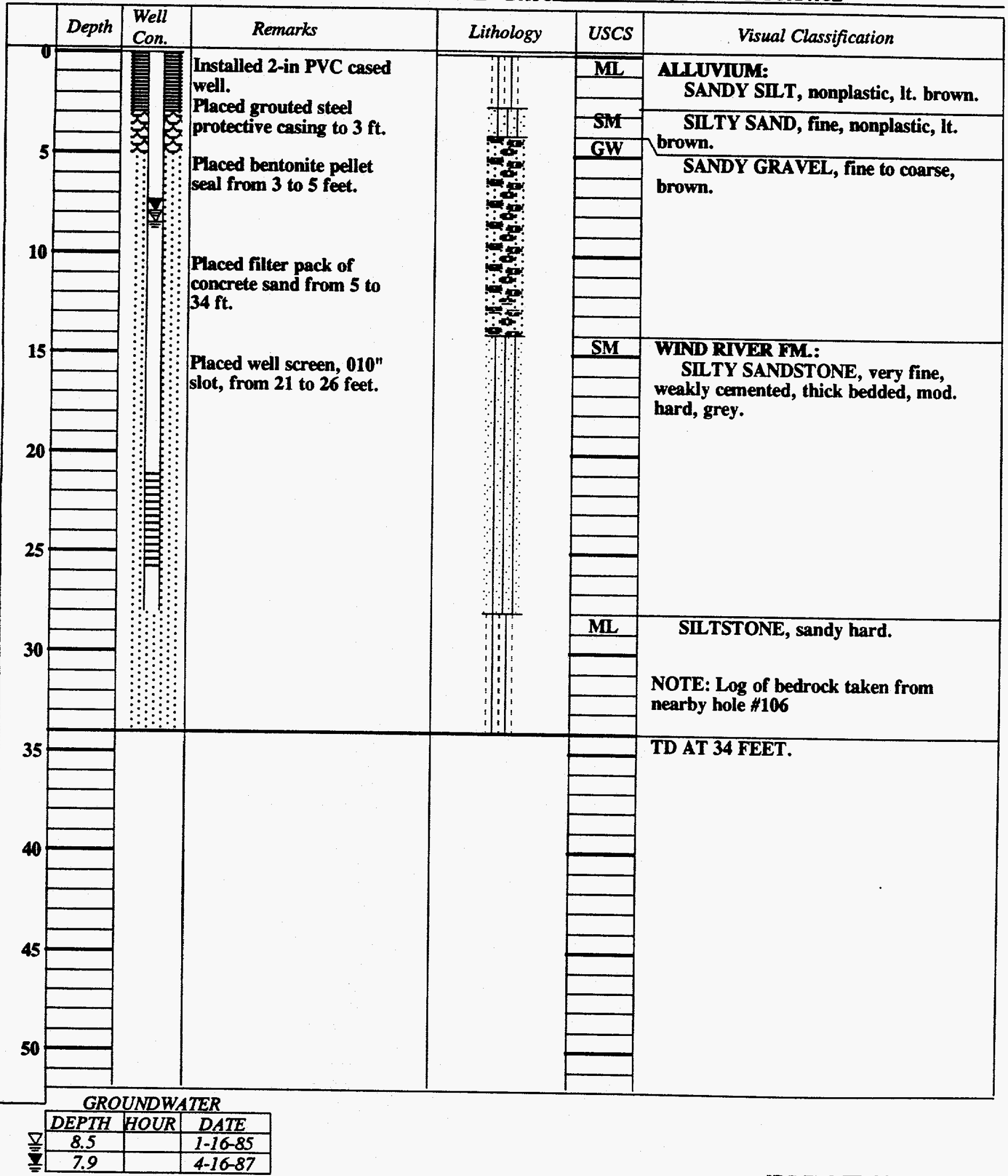




\begin{tabular}{|c|c|c|c|}
\hline & & & \\
\hline OB NO. $\overline{R V T O 1}$ & $11 / 21 / 84$ & TOTAL DEPTH & 228.0 feet \\
\hline $\begin{array}{l}\text { SURFACE ELEVATION } \\
\text { TOP OF FILTER PACK }\end{array}$ & $\frac{4930.20}{23.00}$ & RIG TYPE & FAIIING CF 1500 \\
\hline WELL CASING TIPE & 2.01.SCHED. 40 PVC & LOCATION & $N 21007.20$ E 27725.90 \\
\hline COMPLETION & WND RNER FM. (RWR AQUITARD) & DATUM & MSL, GROUND SURFACE \\
\hline
\end{tabular}

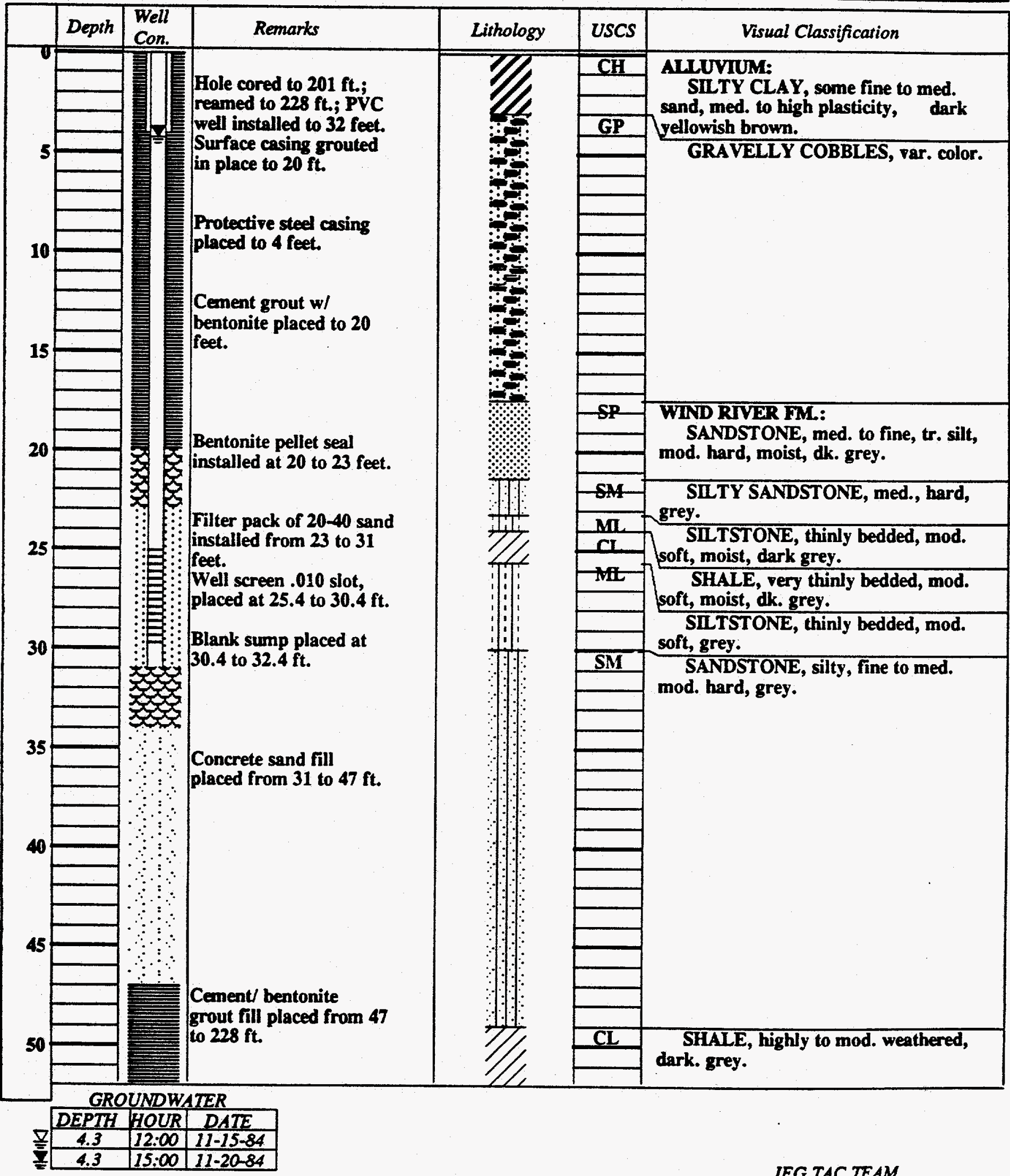


PROJECT RIVERTON SITE, WYO.: UMTRA

JOB NO. RVTO1 DATE 11/21/84

Page ${ }^{2}$ of 5

SURFACE ELEVATION 4930.20

TOP OF FILTER PACK 23.00

WEUL CASING TIPE 2.0-1.SCHED.40 PVC

COMPLETION WND RIVER FM.RWR AQUITARD

TOTAL DEPTH 228.0 feet

RIG TYPE FAILING CF 1500

BORING TYRE NX CORE, ROTARY REAM

LOCATION N 21007.20 E 27725.90

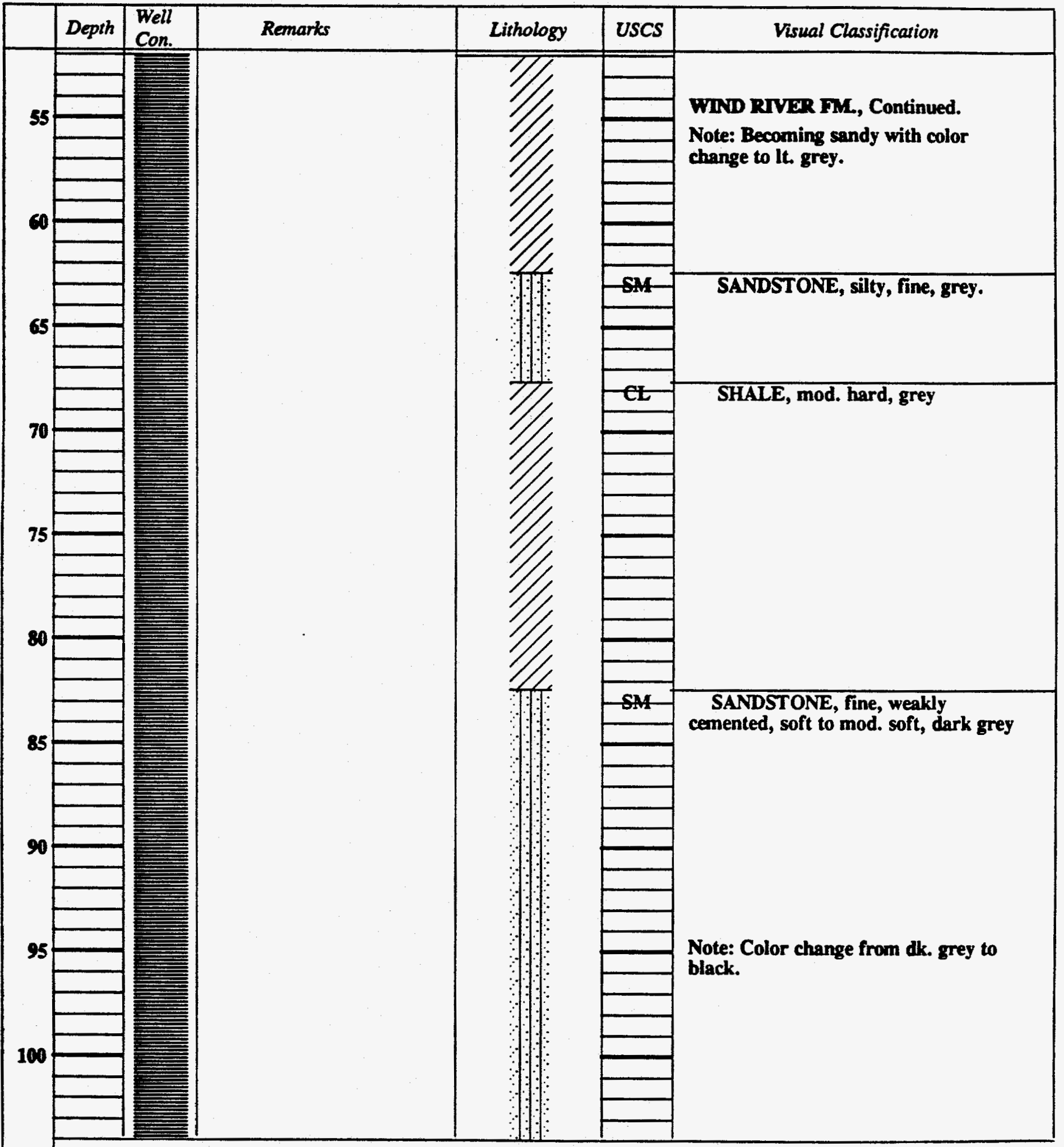

GROUNDWATER

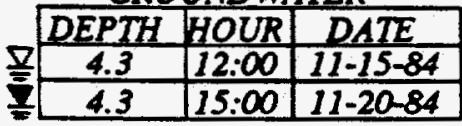




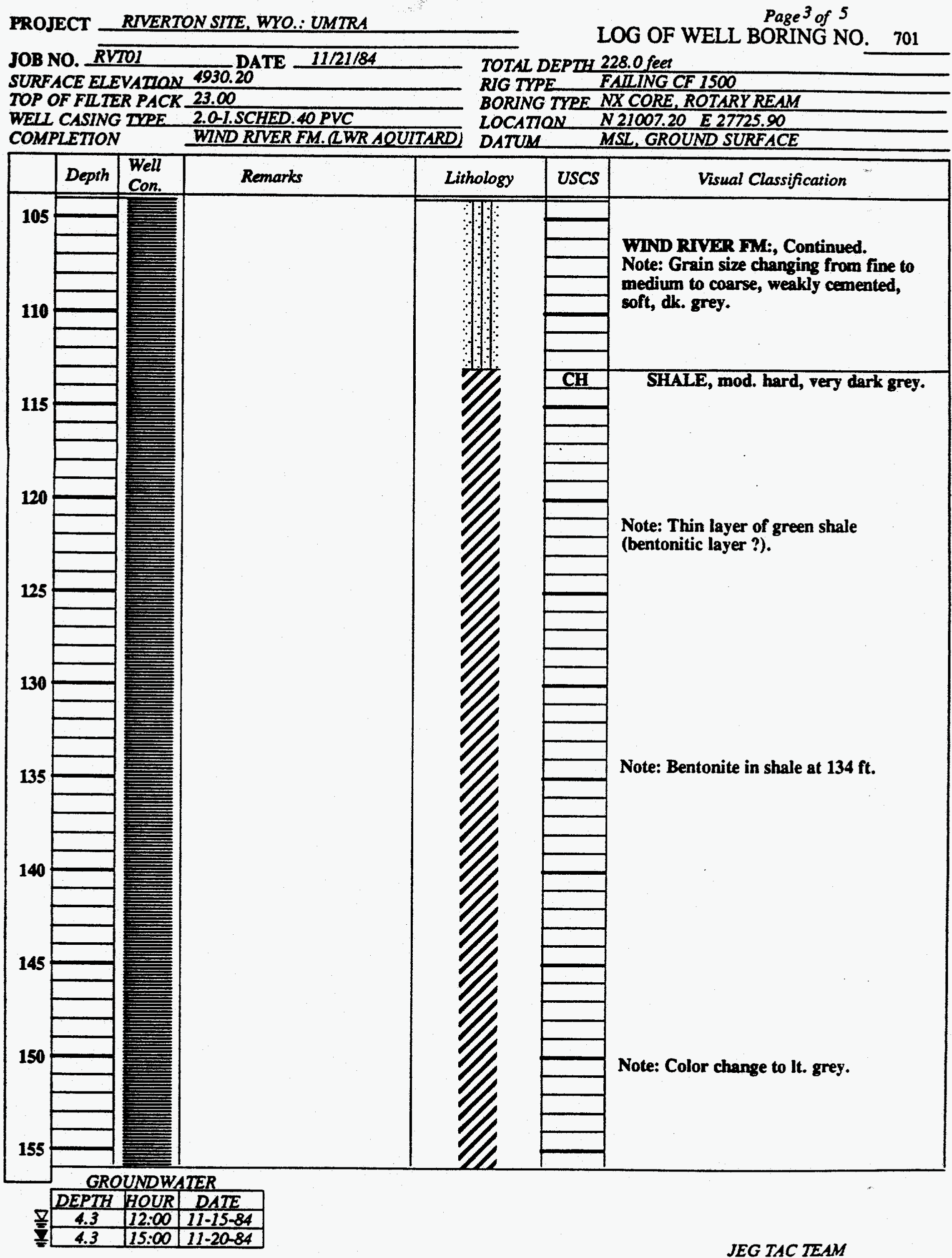




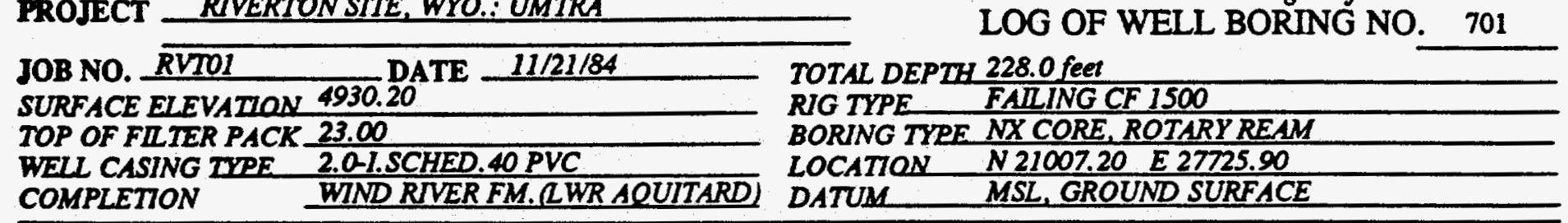

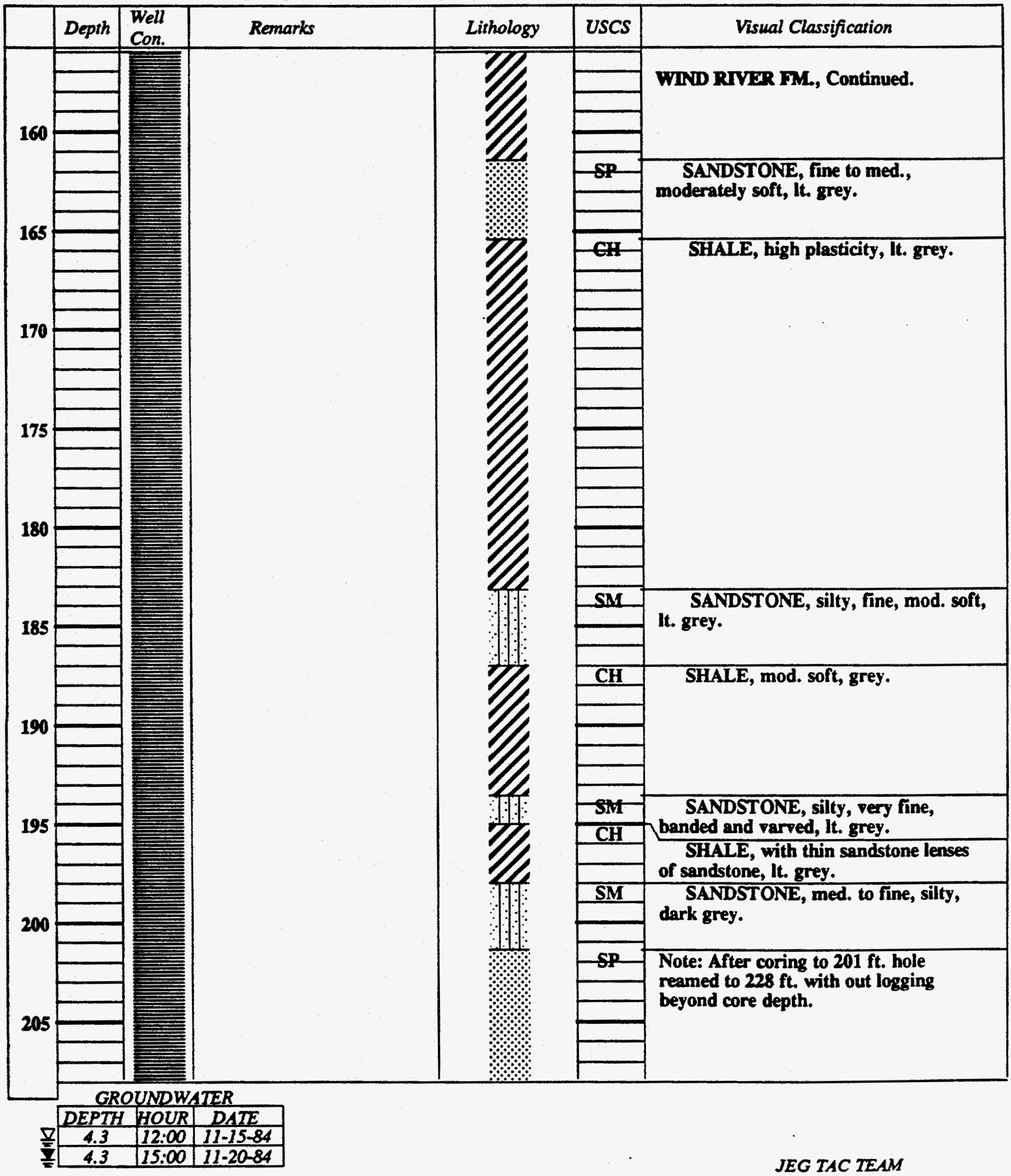


PROJECT RIVERTON SITE, WYO.: UMTRA

JOB NO. RVTOI DATE 11/21/84

LOG OF WELL BORING NO. 701

SURFACE ELEVATION 4930.20

TOP OF FILTER PACK 23.00

WELL CASING TYPE 2.01.SCHED.40 PVC

COMPLETION

WND RIVER FM.RWR AOUITARD

TOTAL DEPTH 228.0 feet

RIG TYPE FALING CF 1500

BORING TYPE NX CORE, ROTARY REAM

LOCATION N21007.20 E 27725.90

DATUM MSL, GROUND SURFACE

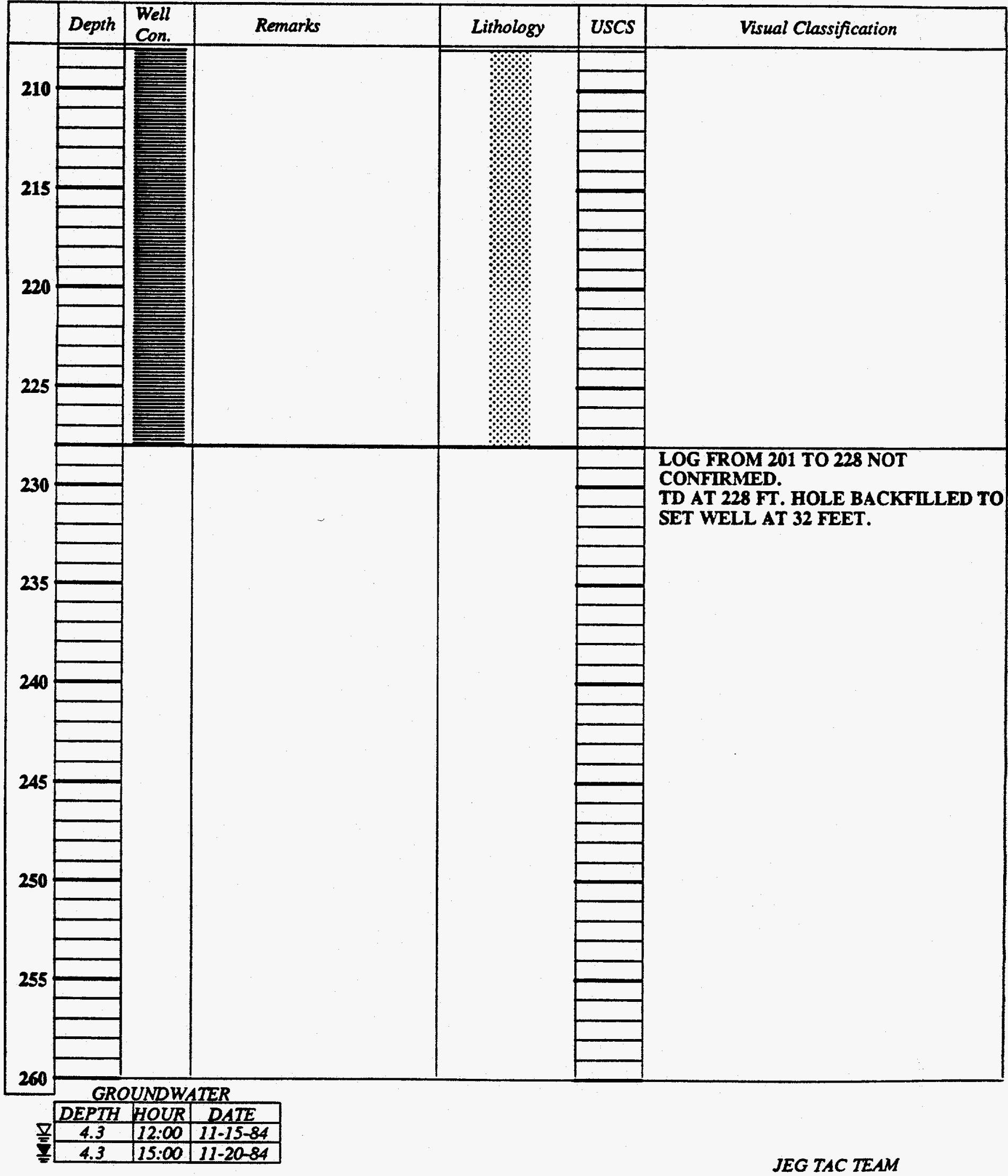




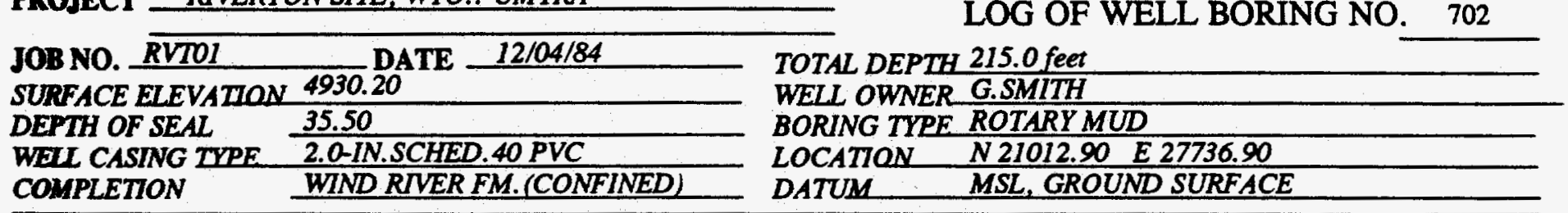

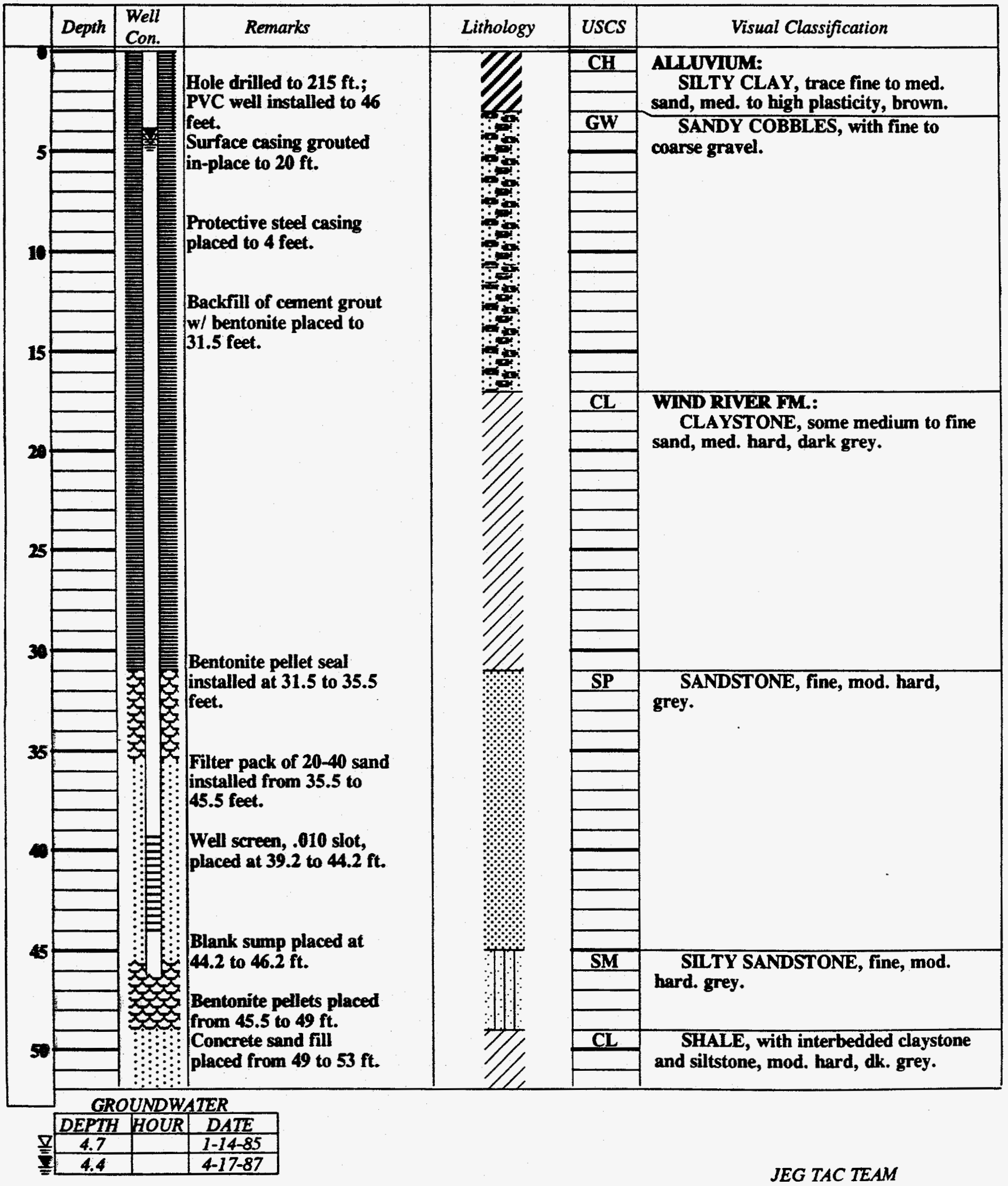




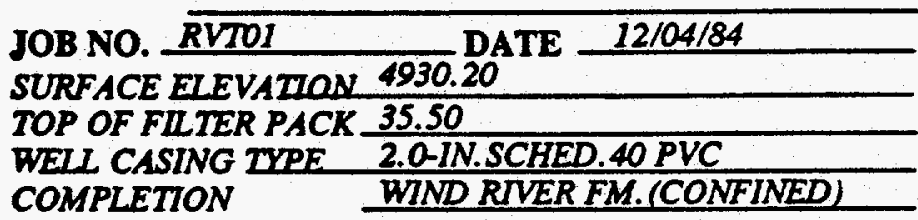

LOG OF WELL BORING NO.

TOTAL DEPTH 215.0 feet

RIG TIPE FAIIING CF 1500

BORING TYRE ROTARY MUD

LOCATION N 21012.90 E 27736.90

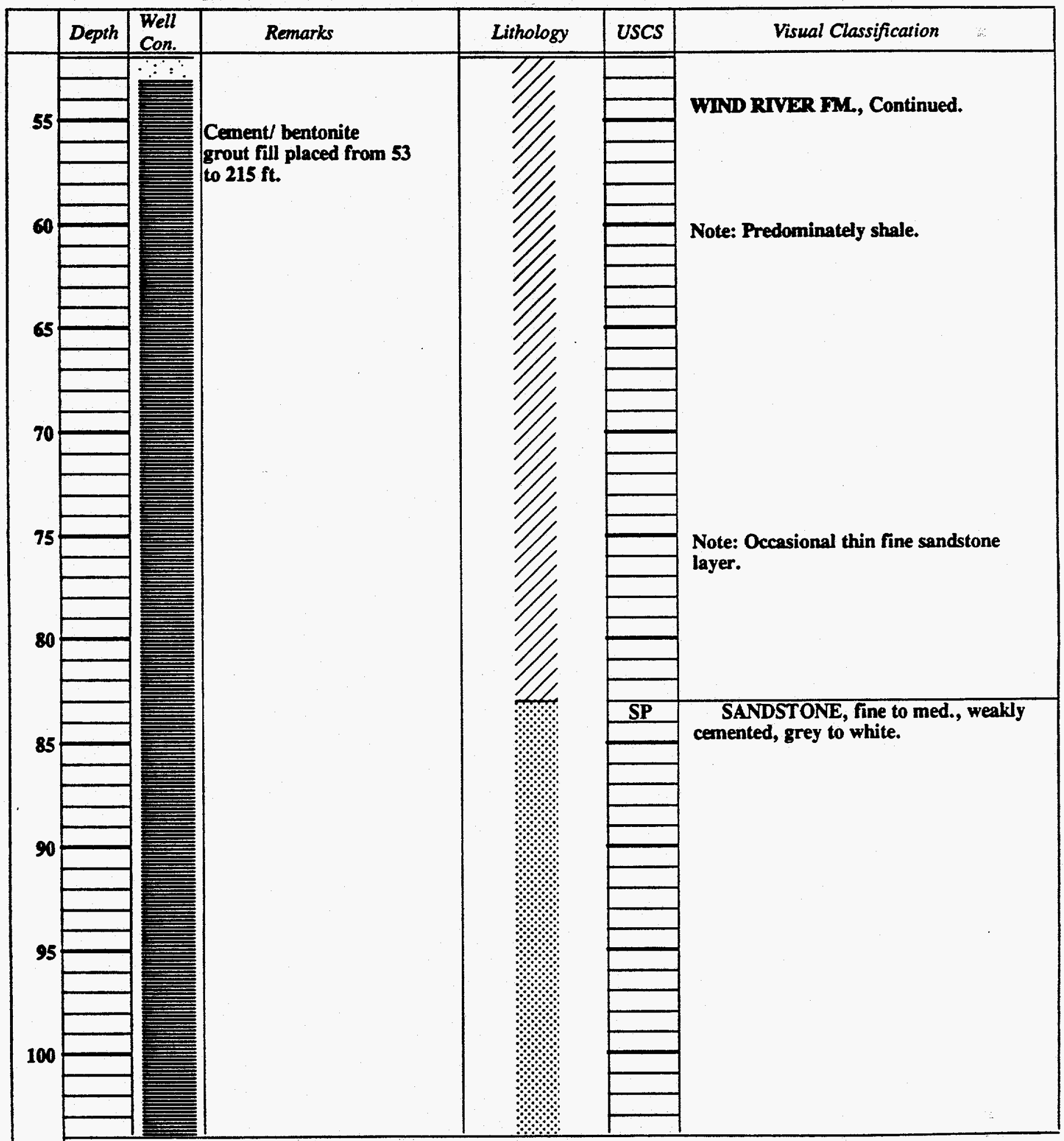

GROUNDWATER

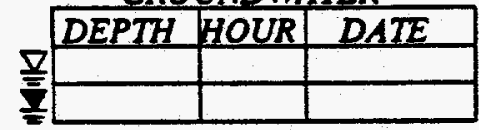


PROJECT RIVERTON SITE, WYO.: UMTRA

JOB NO. RVTO1 DATE 12/04/84

SURFACE ELEVATION 4930.20

TOP OF FILTER PACK 35.50

WEIL CASING TYPE 2.0-IN.SCHED.40 PVC COMPLETION WIND RNER FM.(CONFINED)
TOTAL DEPTH 215.0 feet

RIG TYPE FAILING CF 1500

BORING TYRE ROTARY MUD

LOCATION N21012.90 E 27736.90

DATUM MSL, GROUND SURFACE

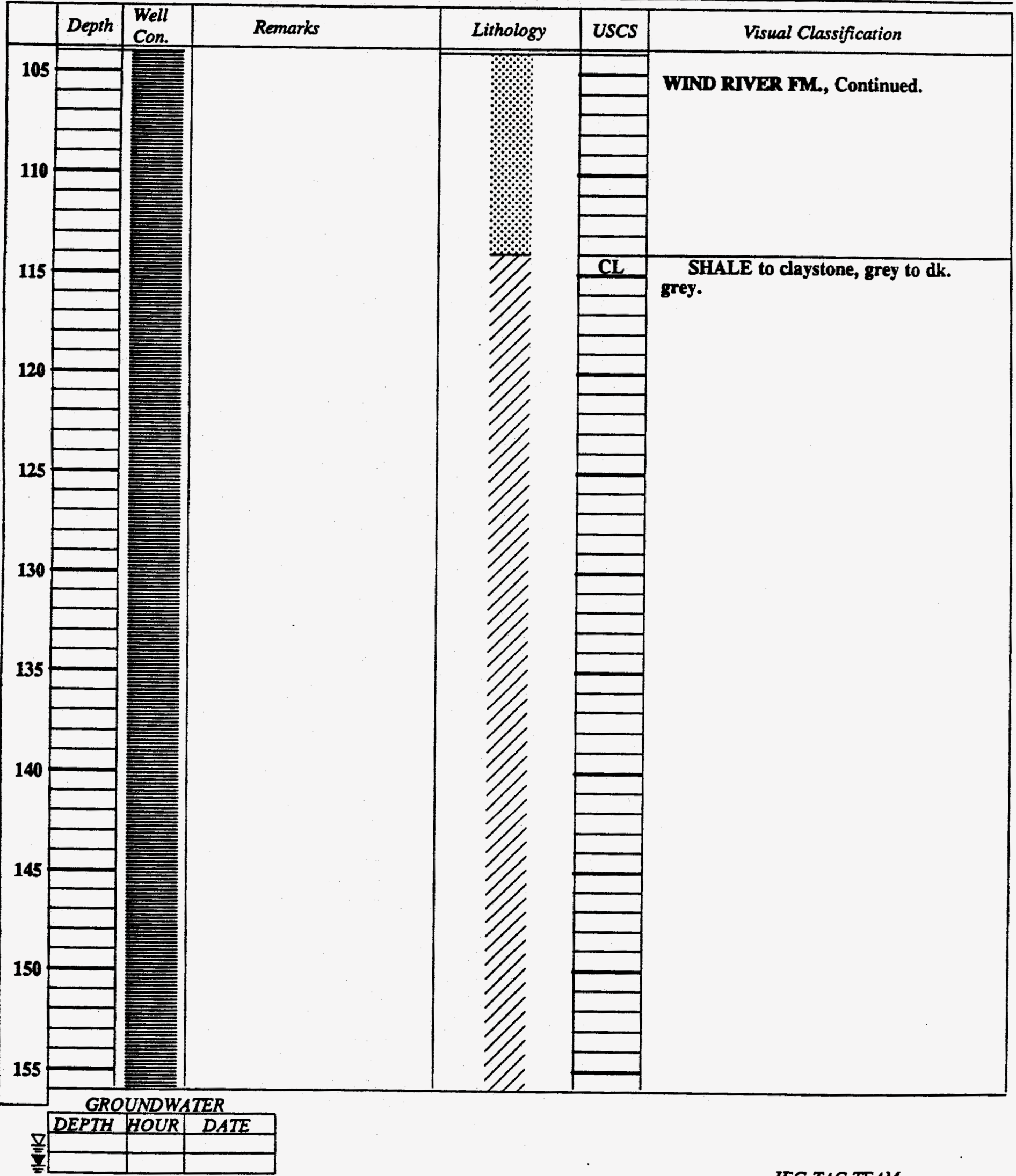




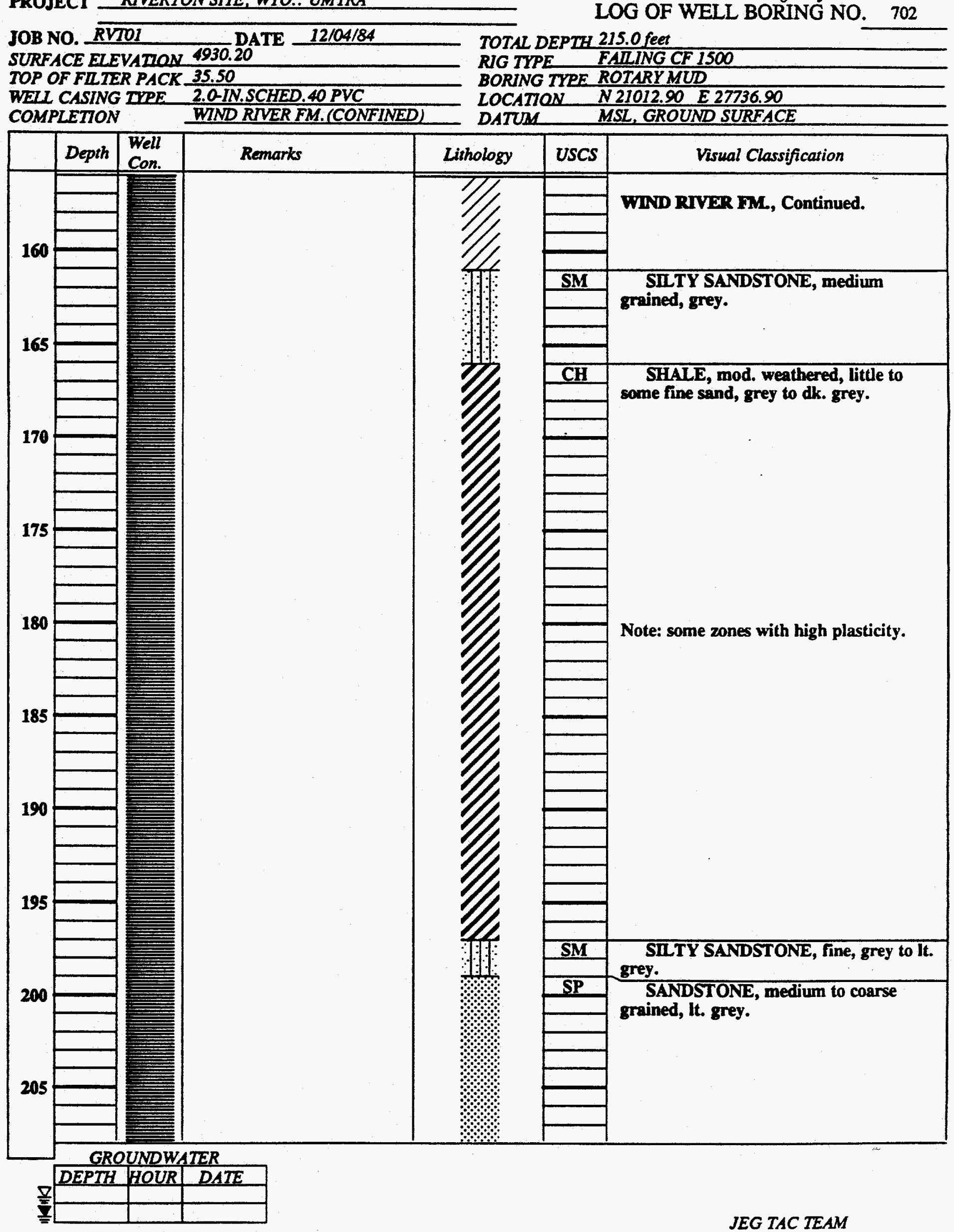


PROJECT RIVERTON SITE, WYO.: UMTRA

Page $^{3}$ of $S$

JOB NO. RVTO1

LOG OF WELL BORING NO. 702

DATE $12 / 04 / 84$

SURFACE ELEVATION 4930.20

TOP OF FIITER PACK 35.50

WEUL CASING TYPE 2.0-IN.SCHED.40 PVC

COMPLETION WIND RIVER FM.(CONFINED)

COMPLETION WIND RIVER FM.(CONFINED)

TOTAL DEPTH 215.0 feet

RIG TYPE FAIIING CF 1500

BORING TYRE ROTARYMUD

LOCATION N21012.90 E 27736.90

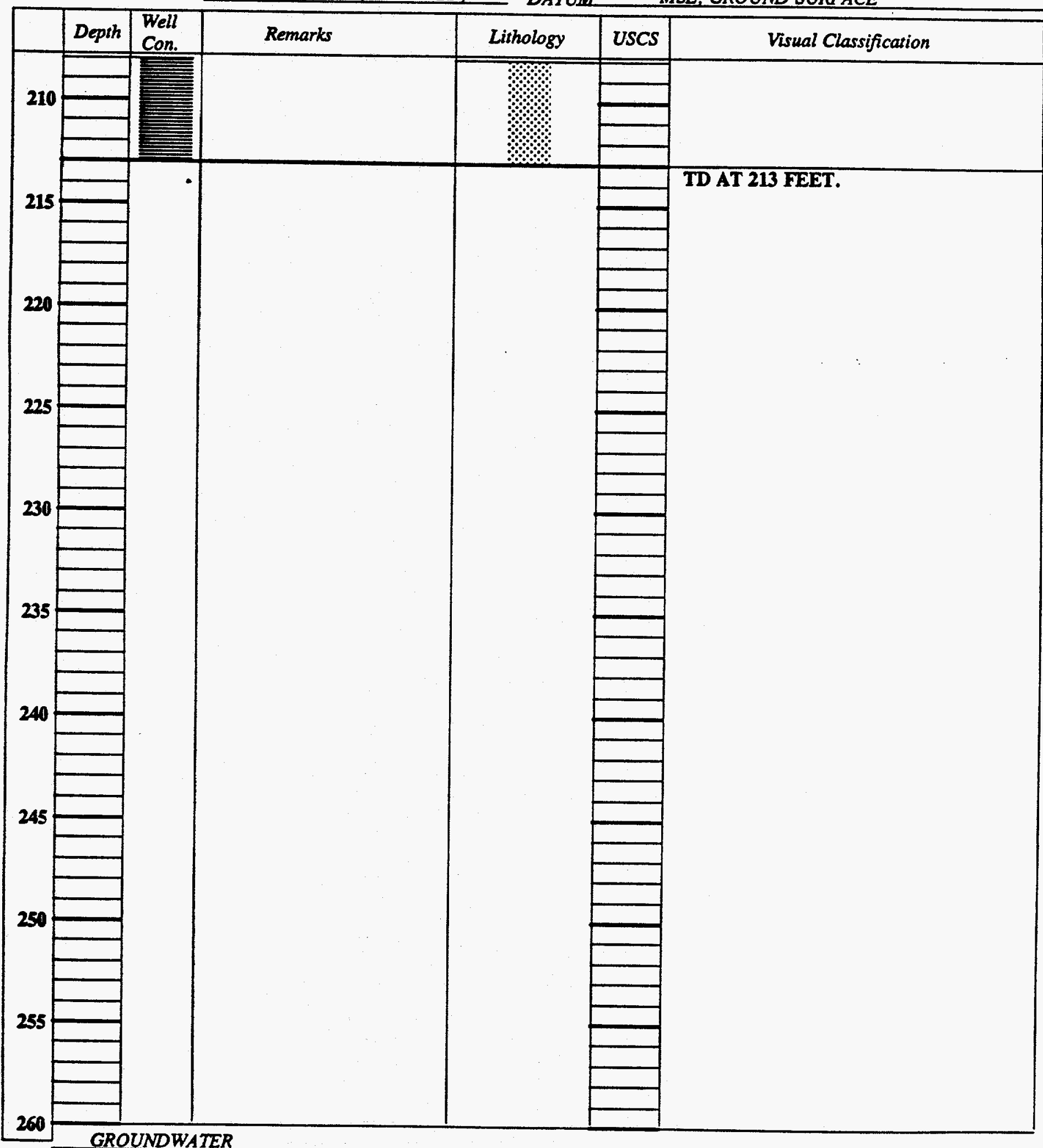

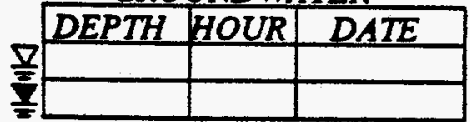




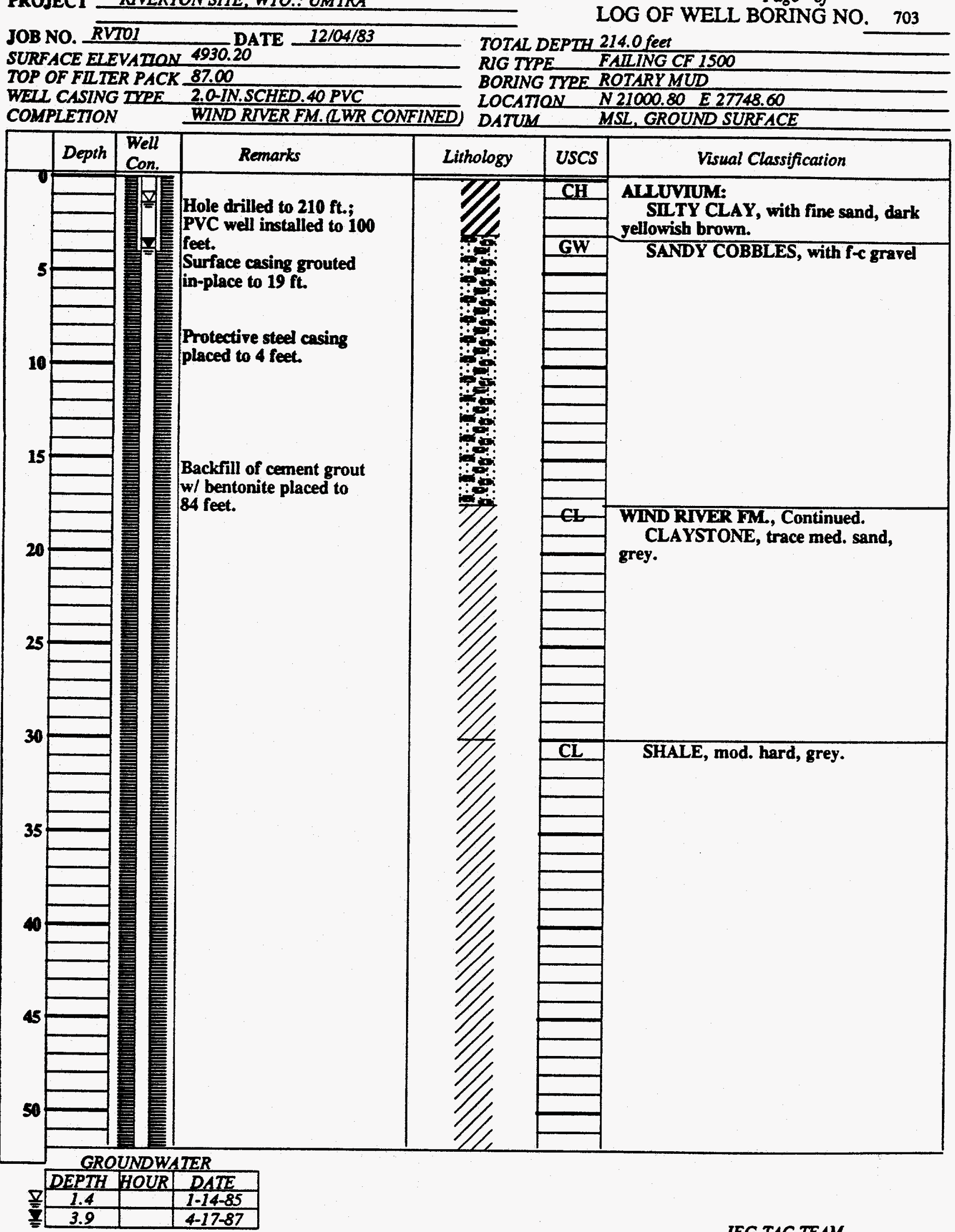




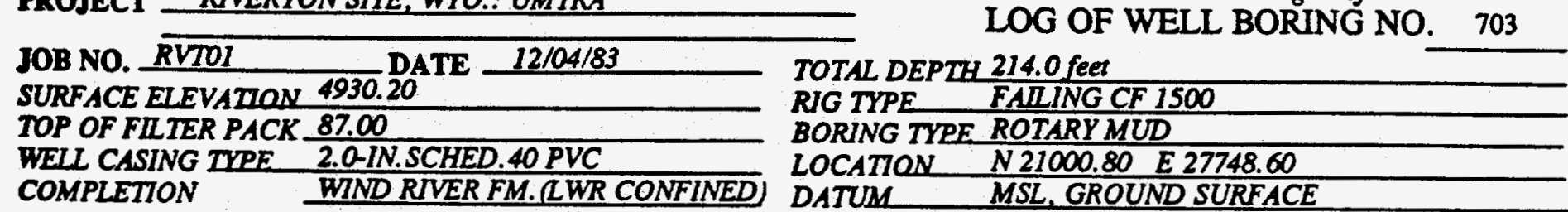

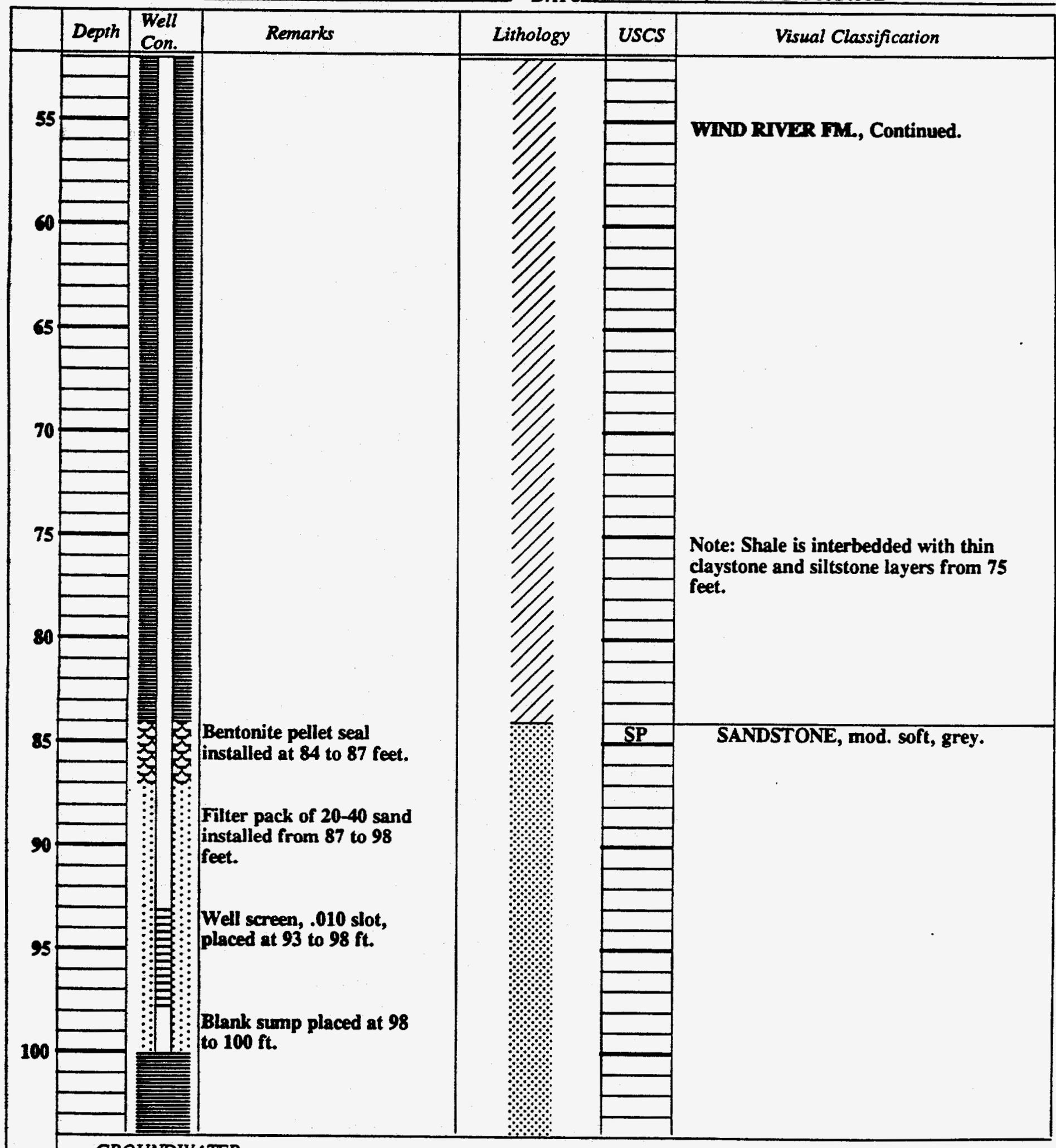

\begin{tabular}{|c|c|c|}
\hline DEPTH & HOUR & $D A T E$ \\
\hline 1.4 & & $1-14-85$ \\
\hline 3.9 & & $4-17-87$ \\
\hline
\end{tabular}




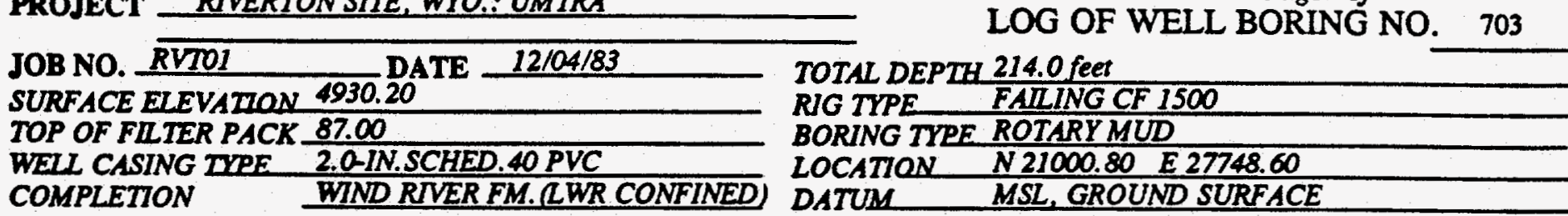

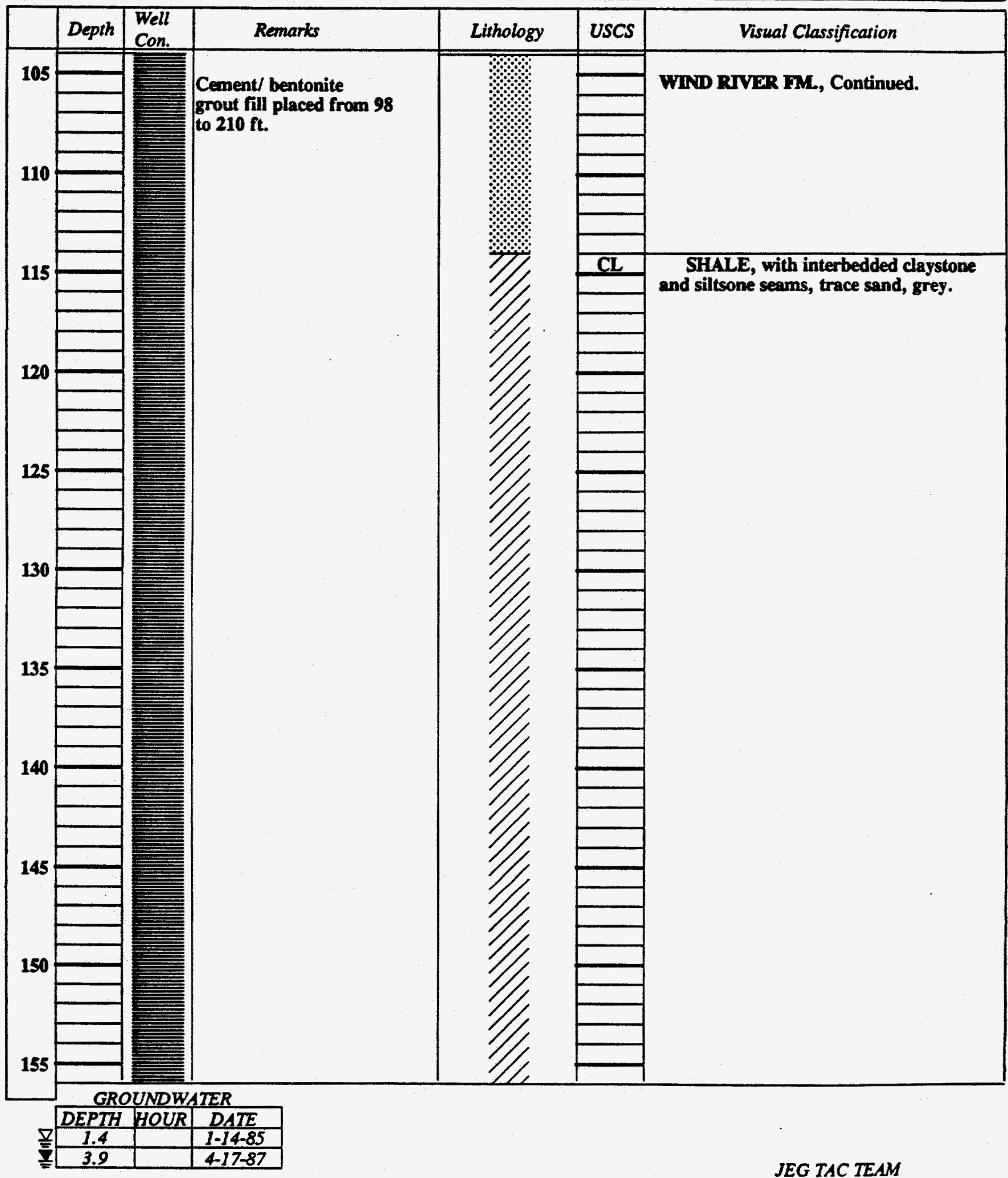


FROJECT RIVERTON SITE, WYO.: UMTRA

JOB NO. RVTO1 DATE 12/04/83

LOG OF WELL BORING NO

703

SURFACE ELEVATION 4930.20

TOTAL DEPTH 214.0 feet

TOP OF FILTER PACK 87.00

WELL CASING TIPE 2.0-IN.SCHED.40 PVC

RIG TYPE FAIIING CF 1500

COMPLETION WIND RIVER FM. RWR CONFINED

BORING TYPE ROTARYMUD

LOCATION N21000.80 E 27748.60

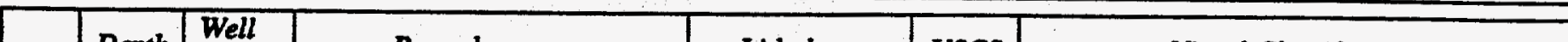

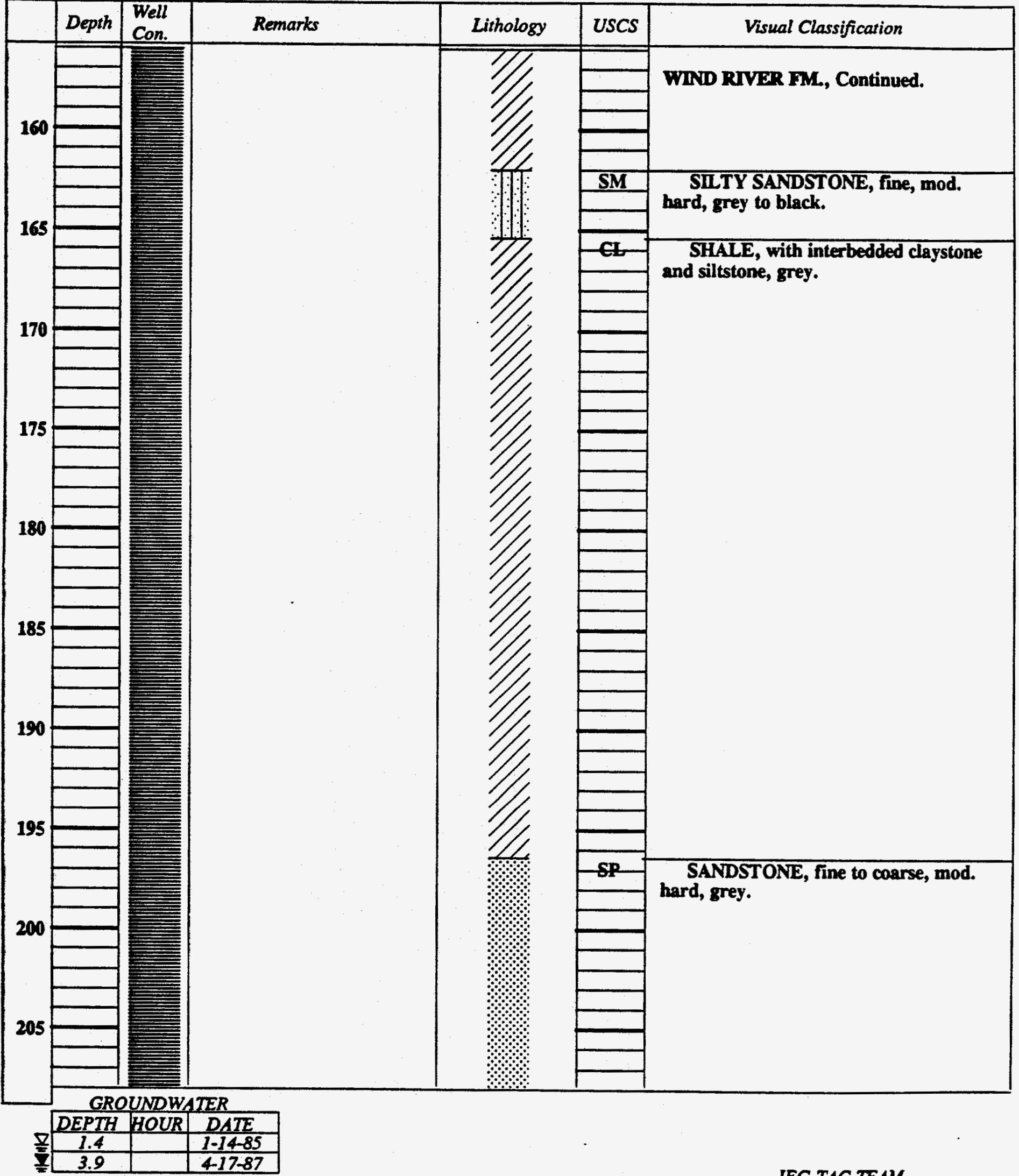


PROJECT RIVERTON SITE WYO.: UMTRA

JOB NO. RVTO1 DATE 12/04/83

LOG OF WELL BORING NO. 703

SURFACE ELEVATION 4930.20

TOP OF FILTER PACK 87.00

WEIL CASING THPE 2.0.IN.SCHED.40 PVC

COMPLETION

WIND RIVER FM.(LWR CONFINED

TOTAL DEPTH 214.0 feet

RIG TYPE FAIIING CF 1500

BORING TYEE ROTARY MUD

LOCATION N21000.80 E 27748.60

DATUM MSL, GROUND SURFACE

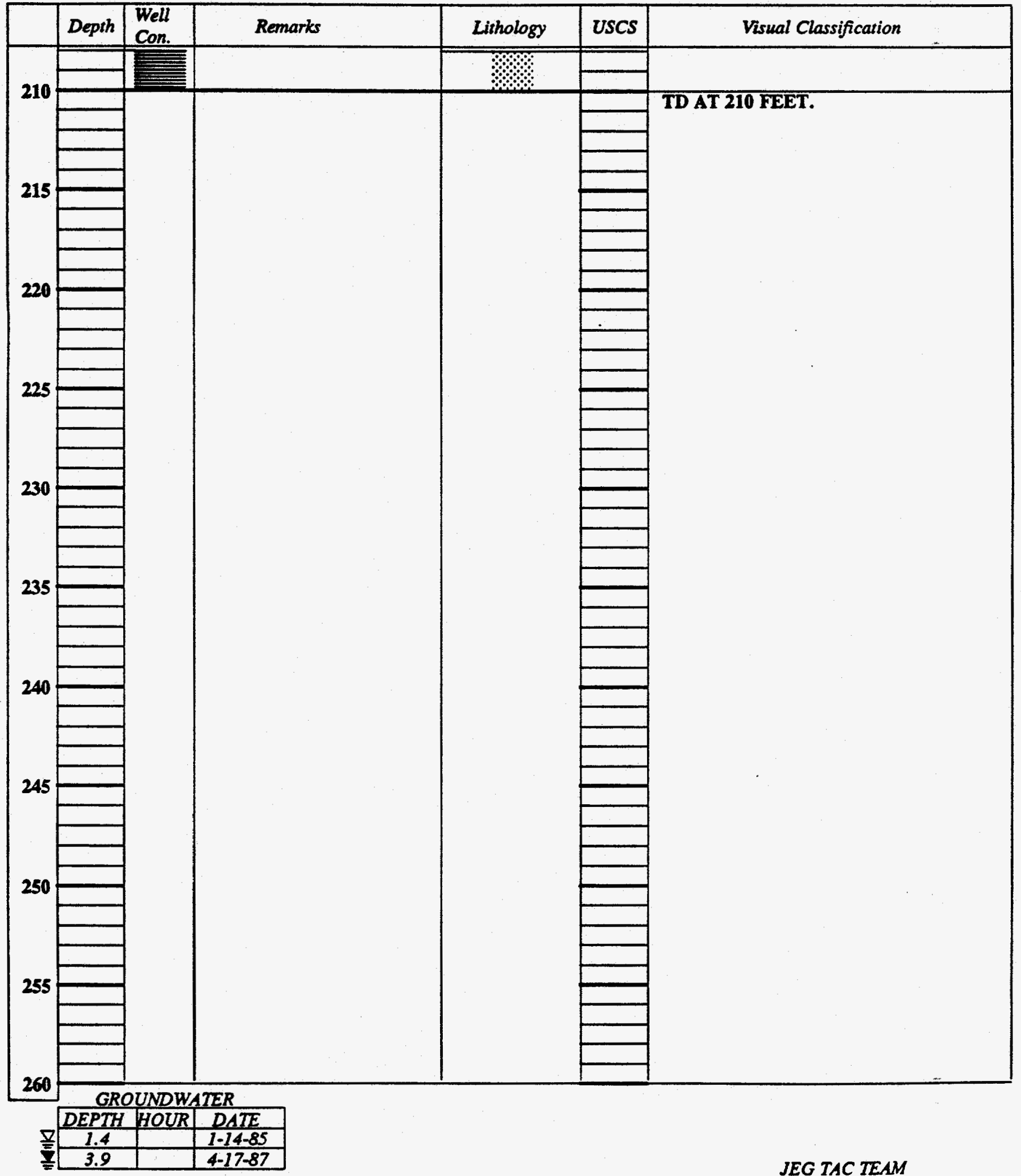




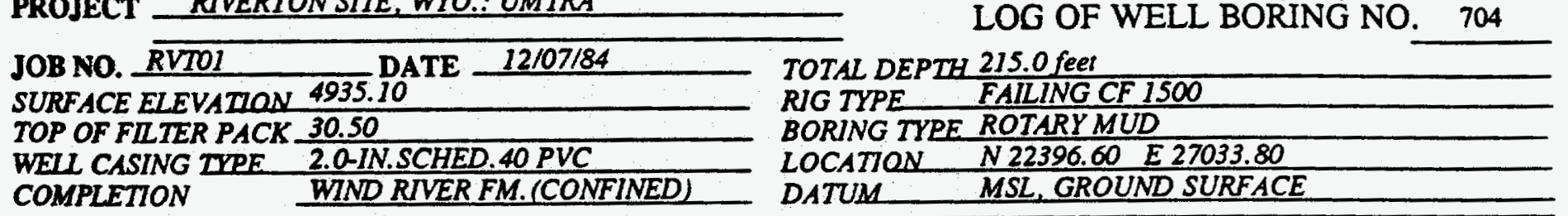

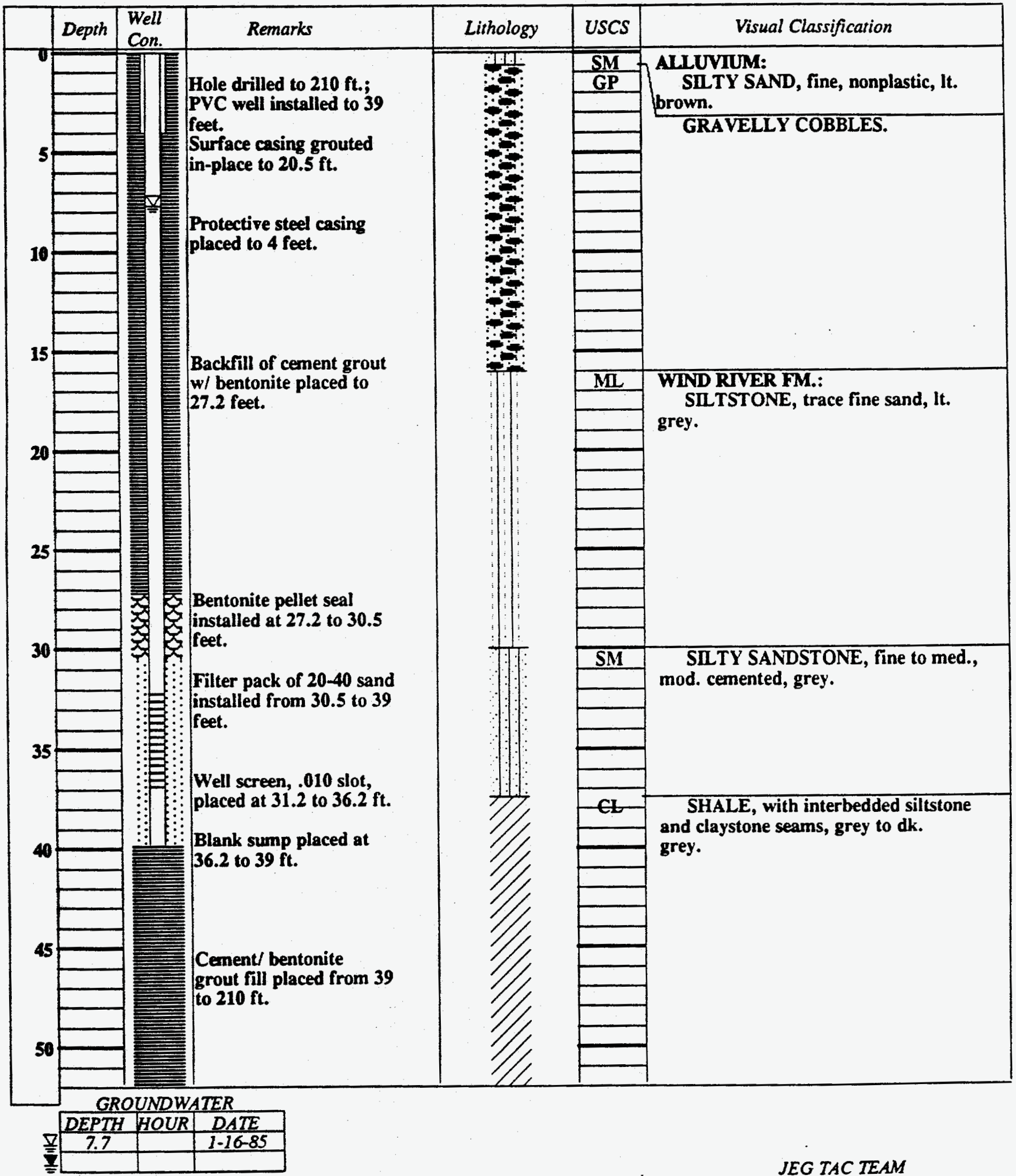




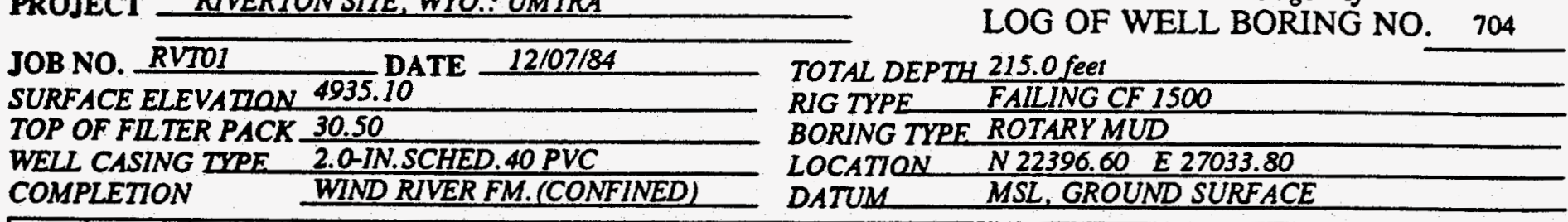

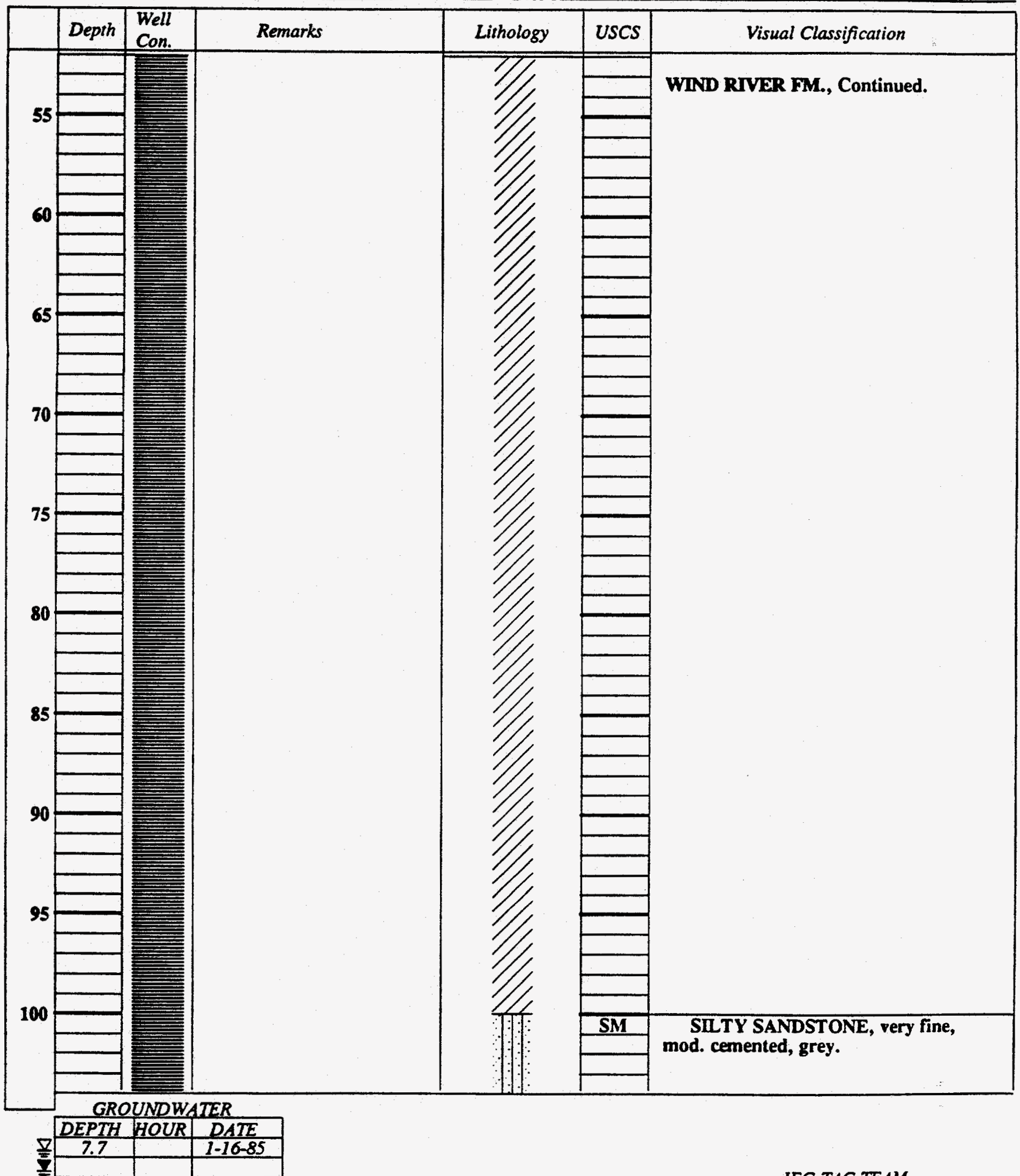


JOB NO. RVTOI

DATE $12 / 07 / 84$

TOTAL DEPTH 215.0 feet

SURFACE ELEVATION 4935.10

TOP OF FILTER PACK 30.50

WELL CASING TYPE 2.0-IN.SCHED.40 PVC

COMPLETION WIND RIVER FM.(CONFINED)

RIG TYPE FAILING CF 1500

BORING TYRE ROTARY MUD

\begin{tabular}{|l|l|l|l|l|l|l|}
\hline & Depth & $\begin{array}{l}\text { Well } \\
\text { Con. }\end{array}$ & Remarks & Lithology & USCS & Visual Classification \\
\hline
\end{tabular}

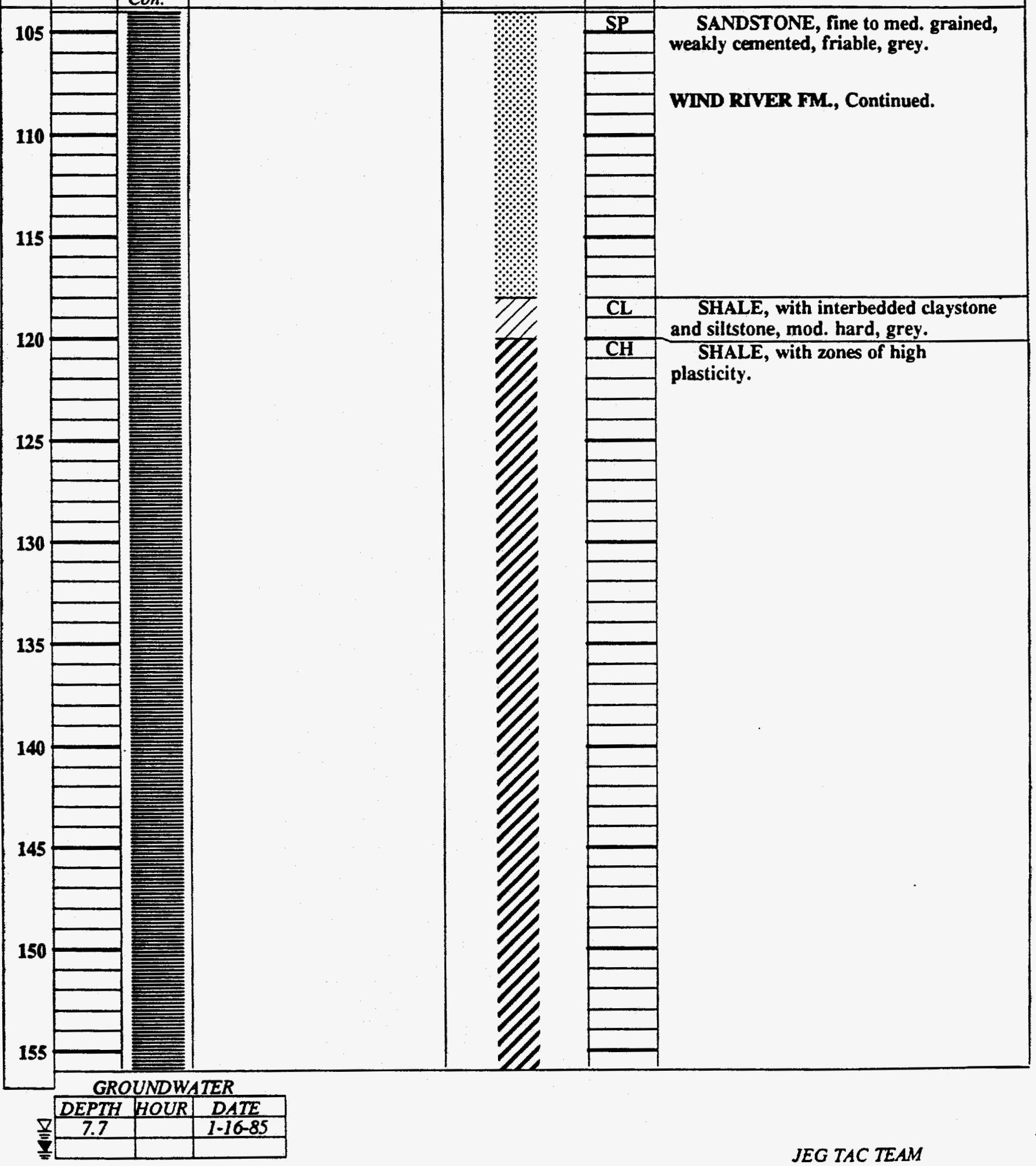




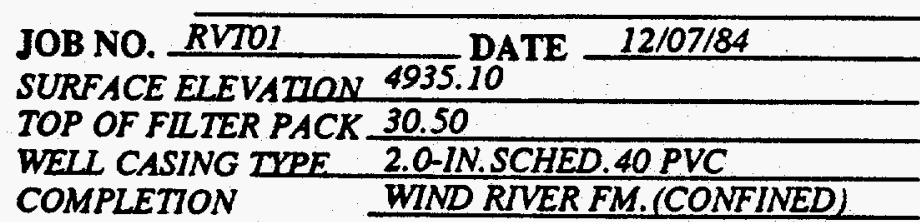

TOTAL DEPTH 215.0 feet

RIG TYPE FAILING CF 1500

BORING TYPE ROTARYMUD

LOCATION N 22396.60 E 27033.80

DATUM MSL GROUND SURFACE

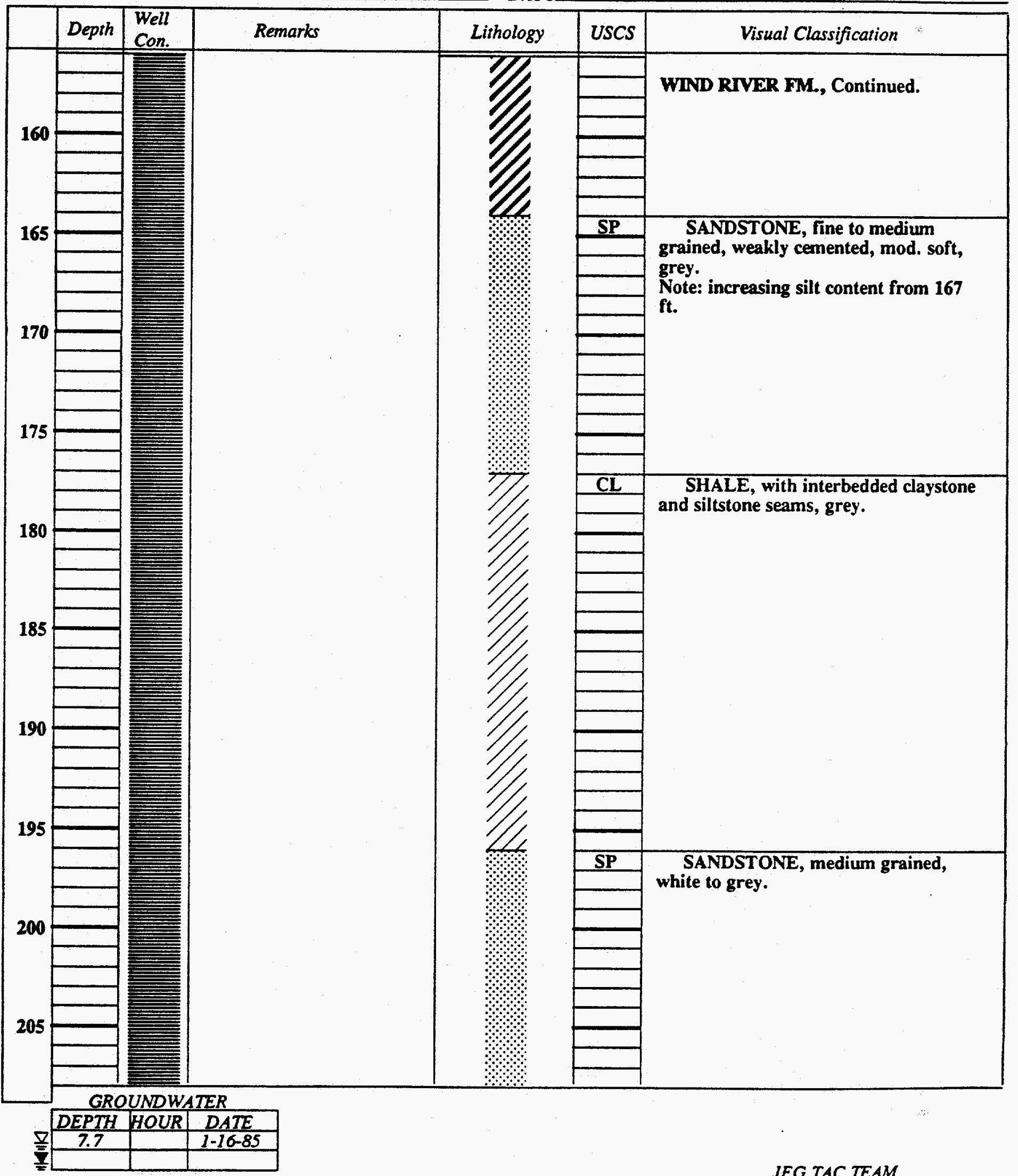


PROJECT RIVERTON SITE, WYO.: UMTRA

JOB NO. RVTO1 DATE 12/07/84

SURFACE ELEVATION 4935.10

TOP OF FILIER PACK 30.50

WELL CASING TYPE 2.0-IN.SCHED.40 PVC

COMPLETION WINDRIVER FM.(CONFINED)

LOG OF WELL BORING NO. 704

Page 5 of 5

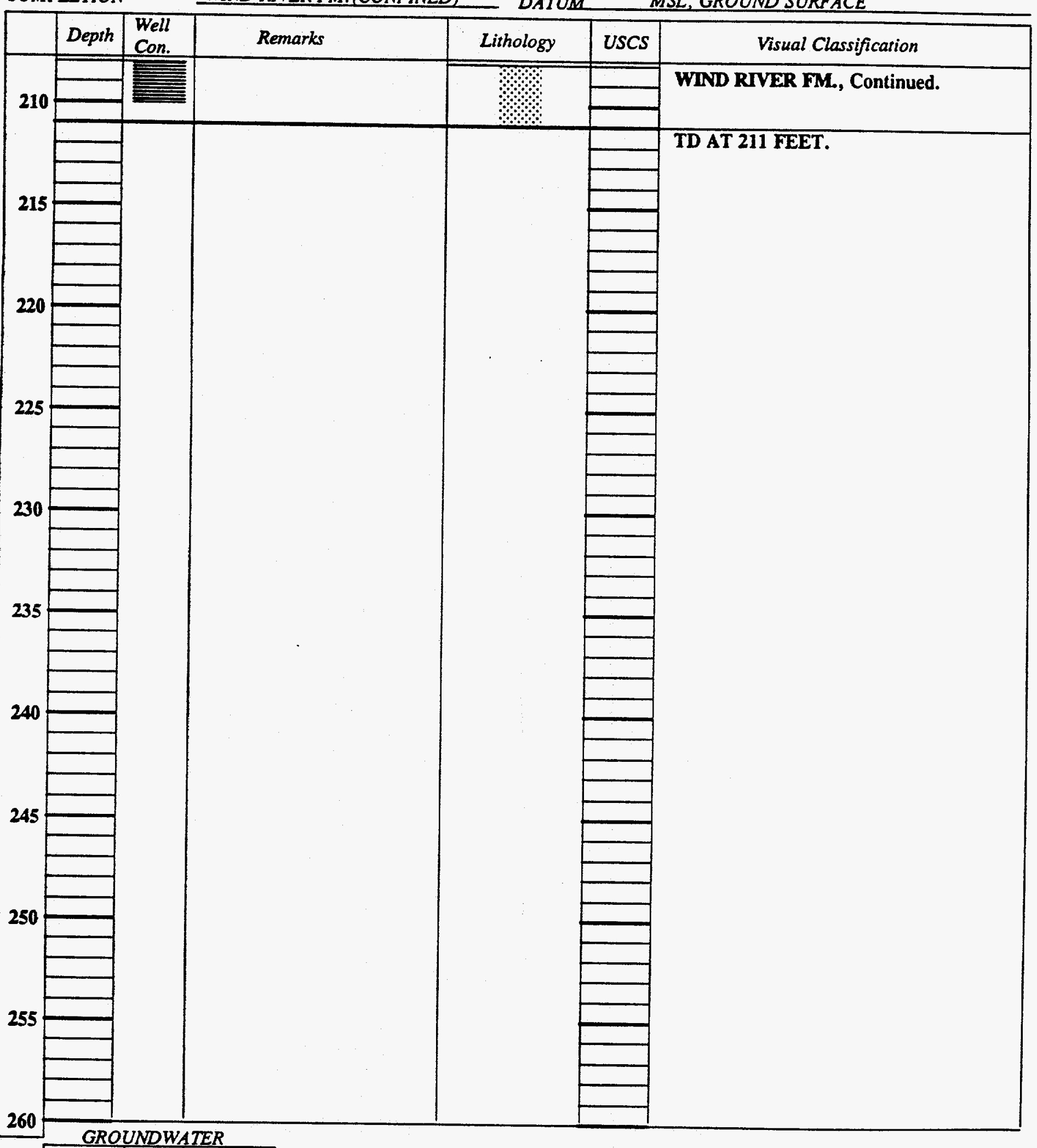

\begin{tabular}{|c|c|c|}
\hline DEPTH & HOUR & DATE \\
\hline 7.7 & & $1-16-85$ \\
\hline & & \\
\hline & & \\
\hline
\end{tabular} 
PROJECT RIVERTON SITE, WYO.. UMTRA

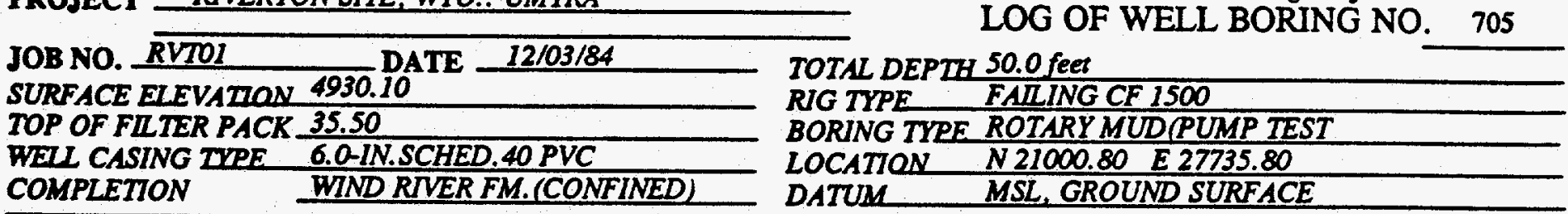

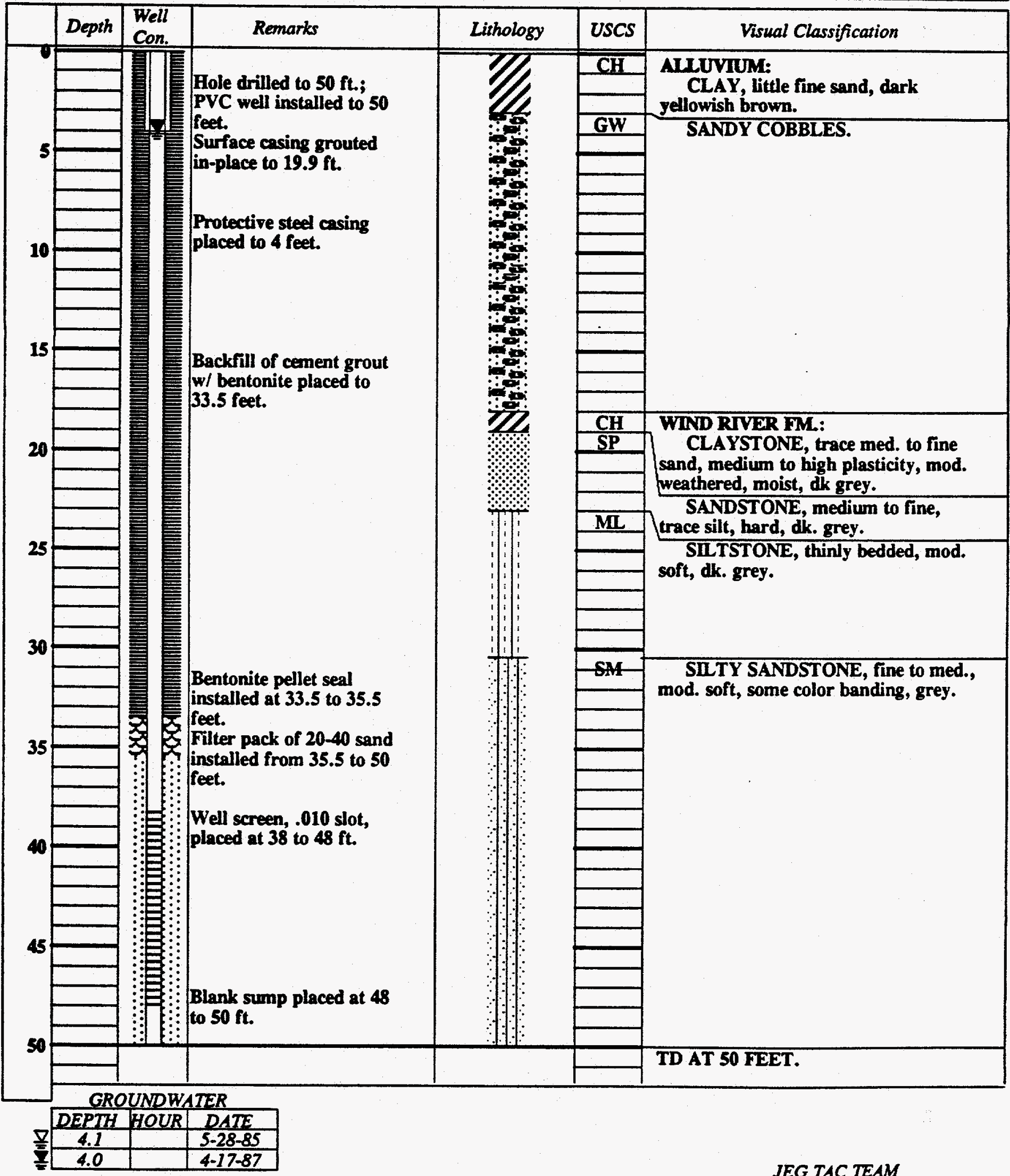


PROJECT RIVERTON SITE, WYO.: UMTRA

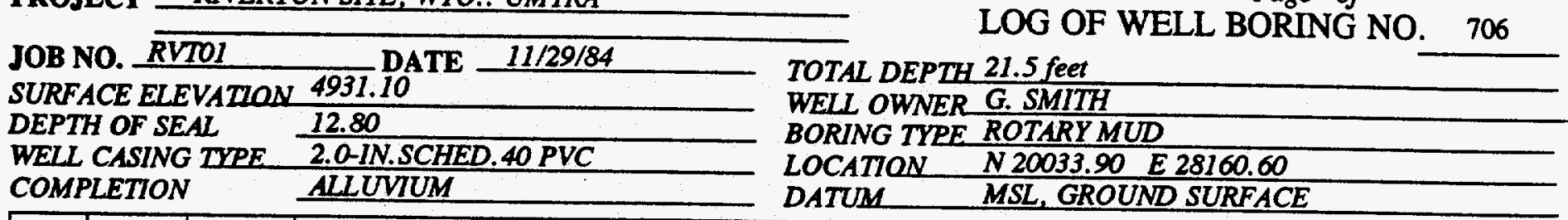

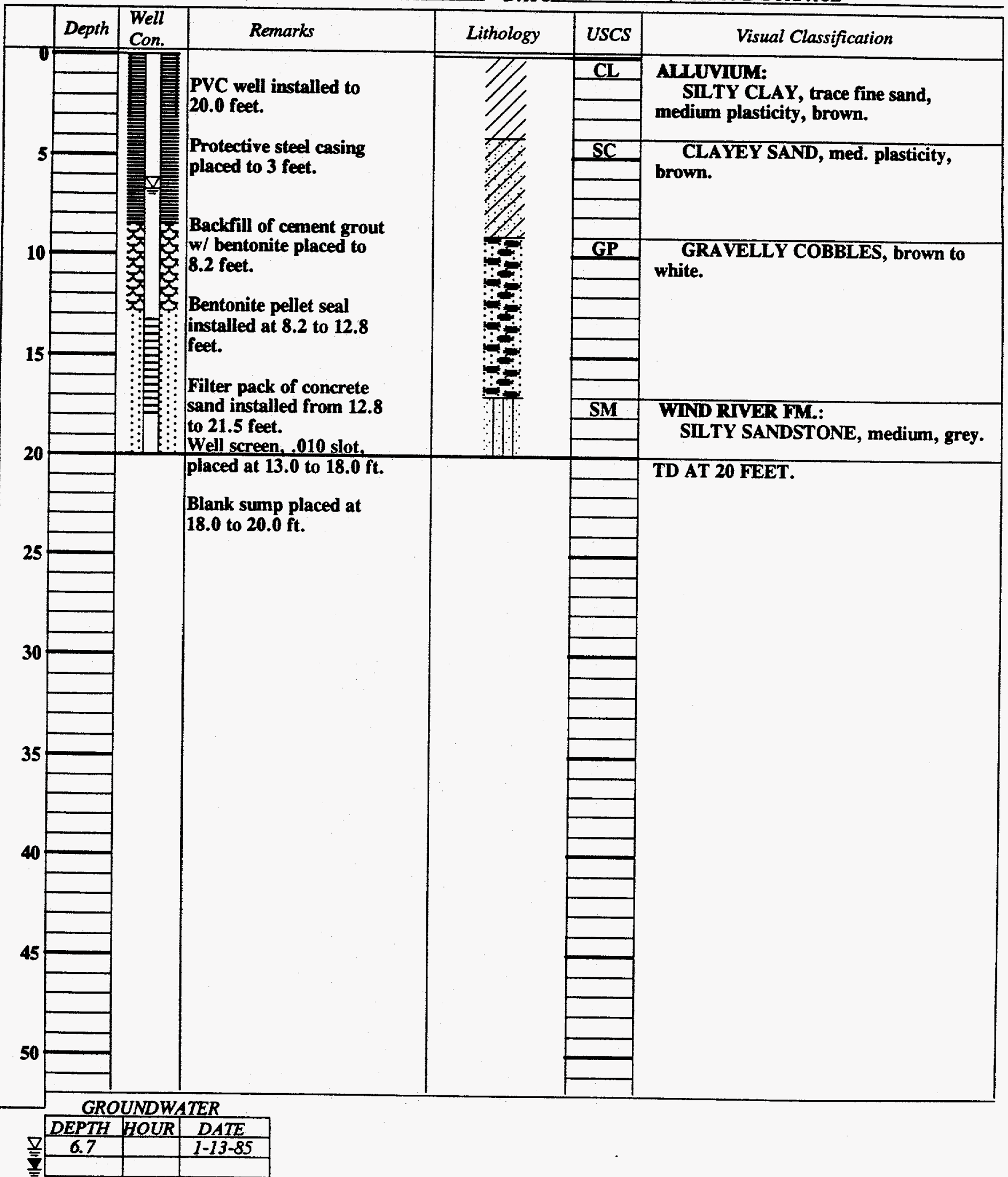




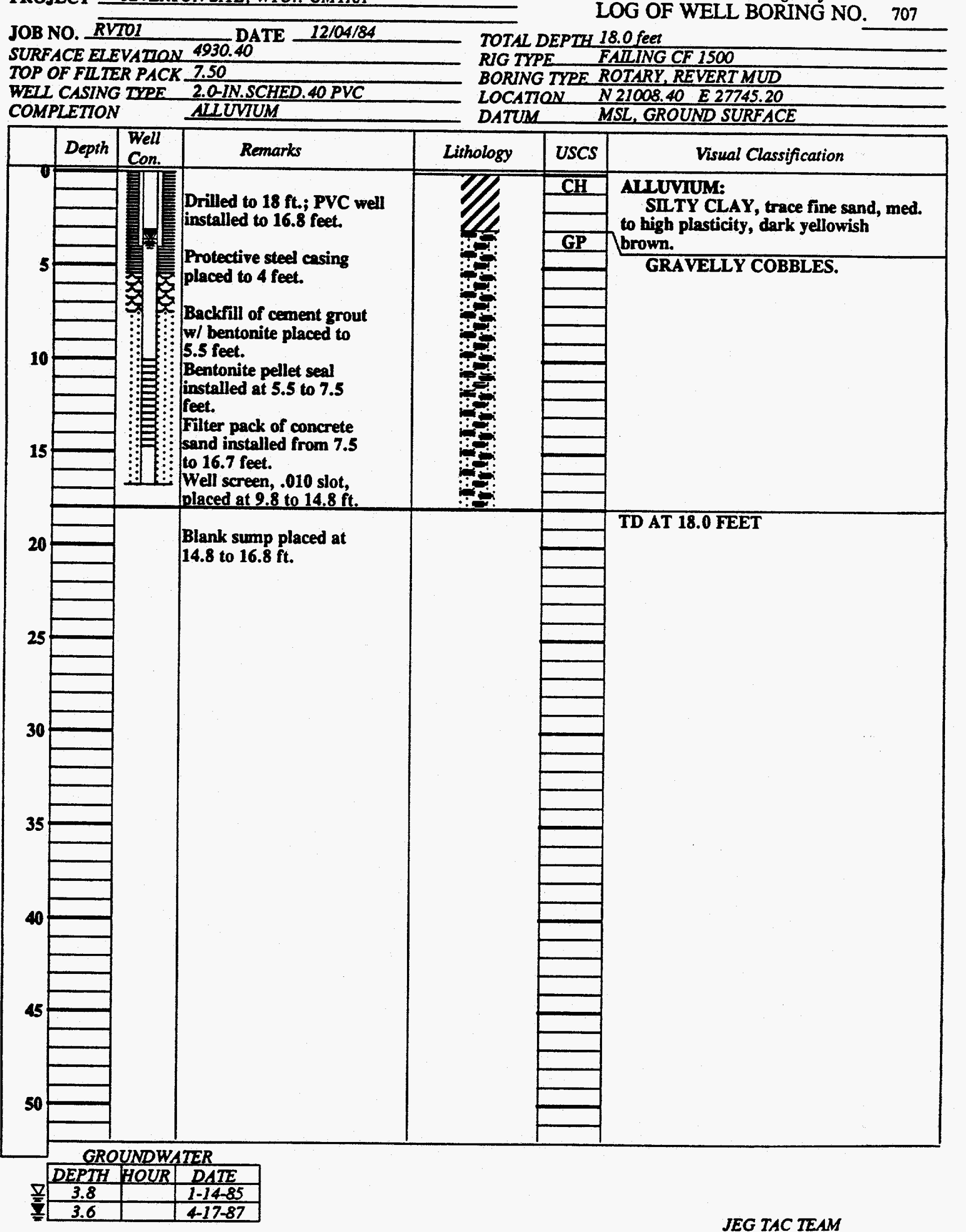




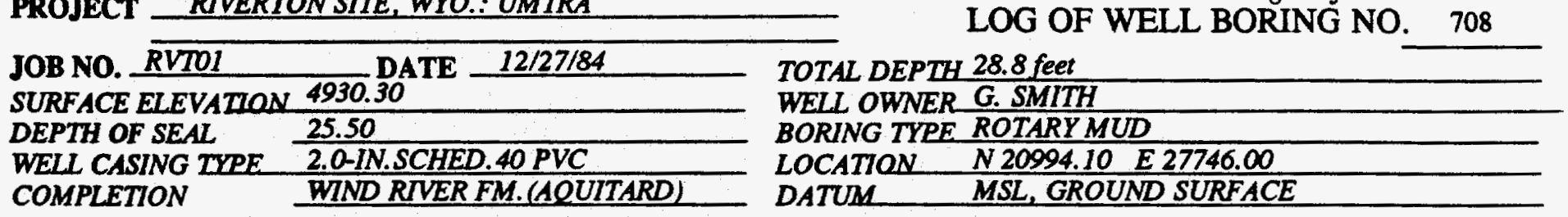

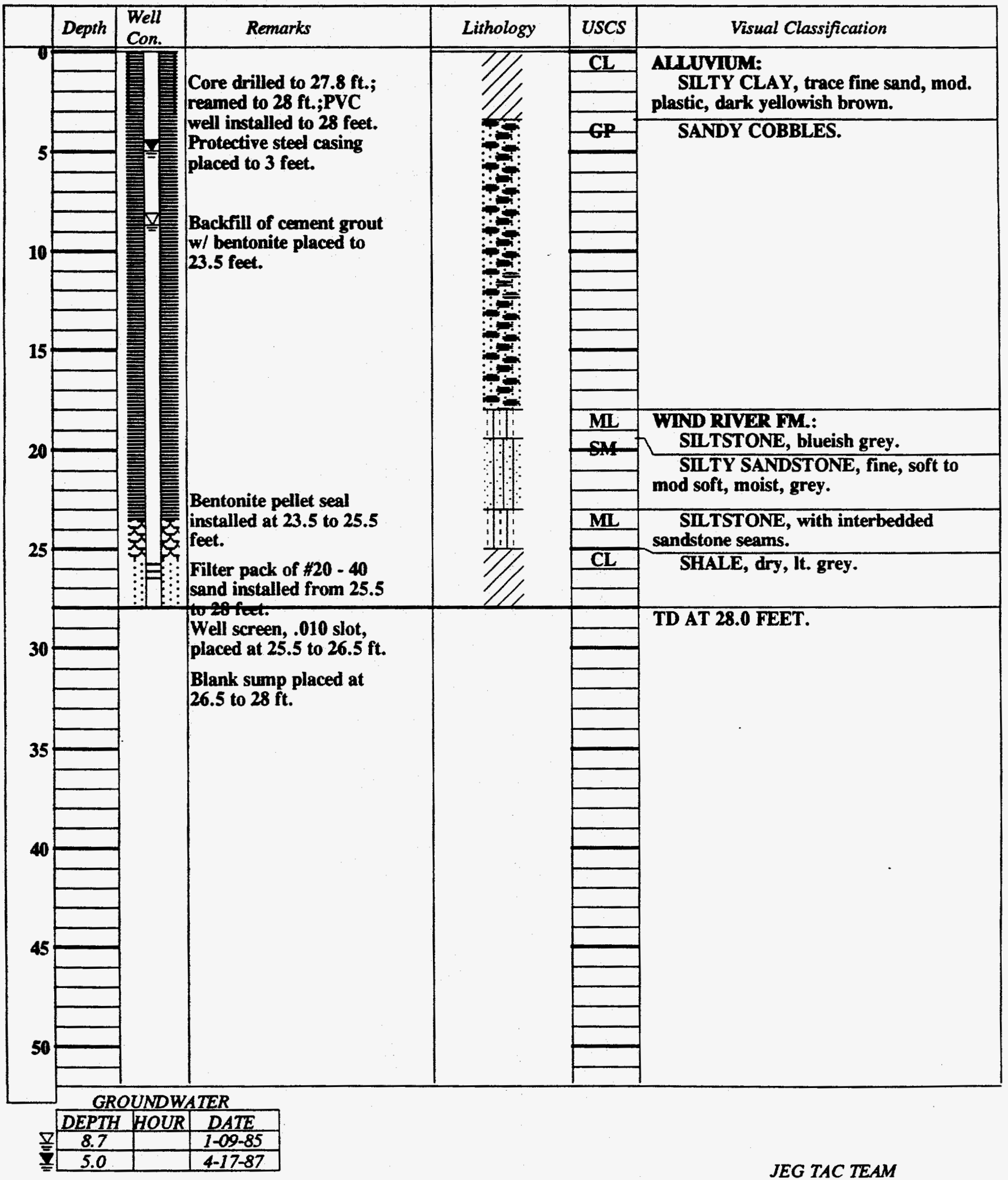


PROJECT RIVERTON SITE, WYO.. UMTRA

JOB NO. $\frac{\text { RVTOI }}{\text { DATE } \frac{12 / 27 / 84}{19}}$
SURFACE ELEVATION 4930.20
TOP OF FILTER PACK $\frac{84.00}{6.0 \text { IN.SCHED.40 PVC }}$
WELI CASING TIPE
COMPLETION

LOG OF WEI BORING NO.

Page 1 of 3

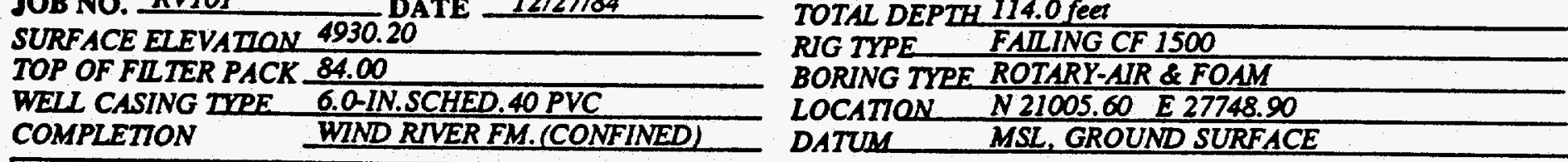

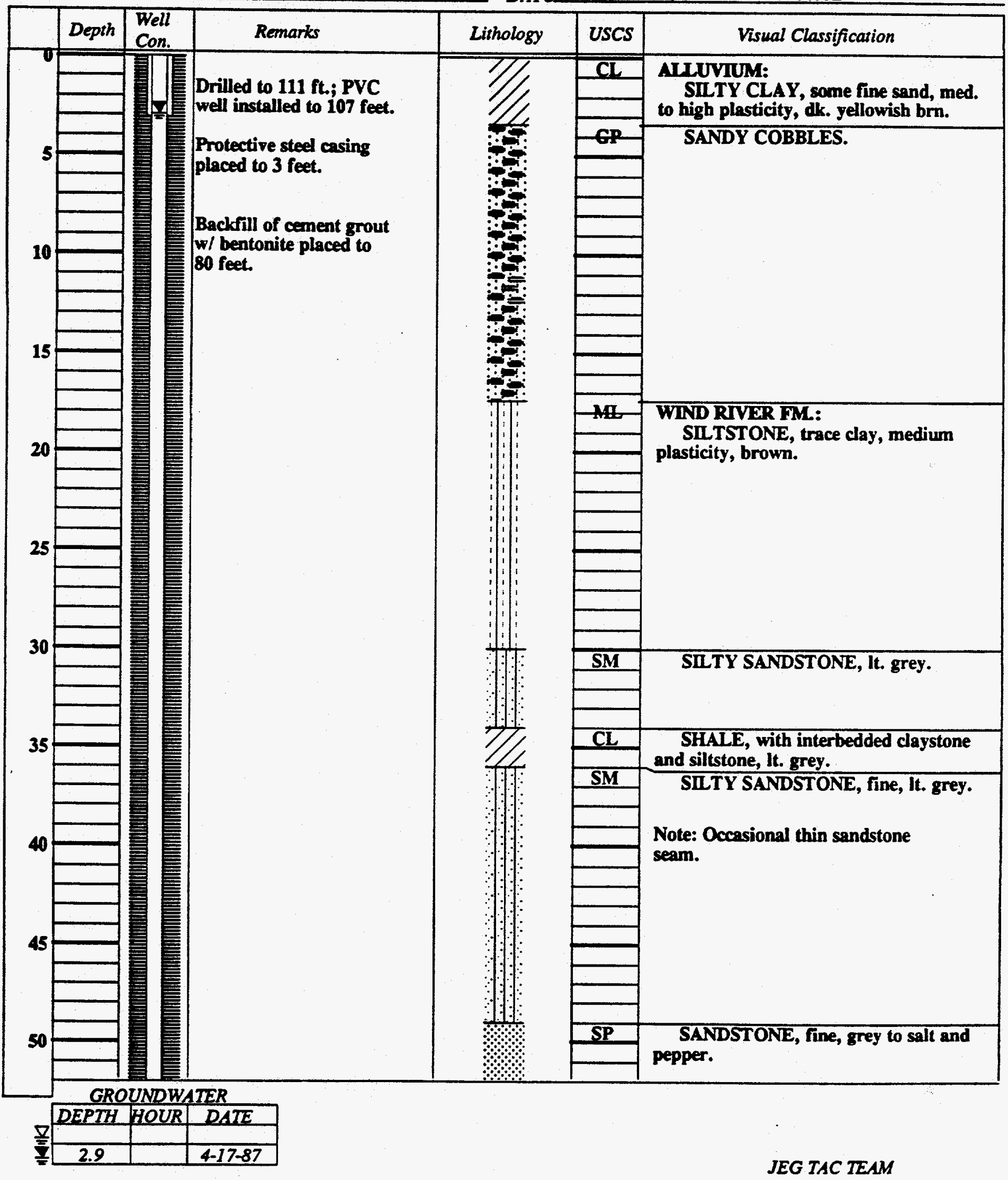


PROJECT RIVERTON SITE, WYO.: UMTRA

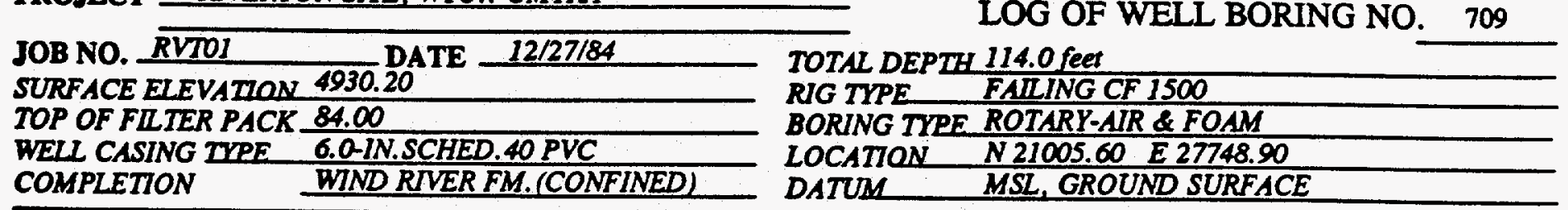

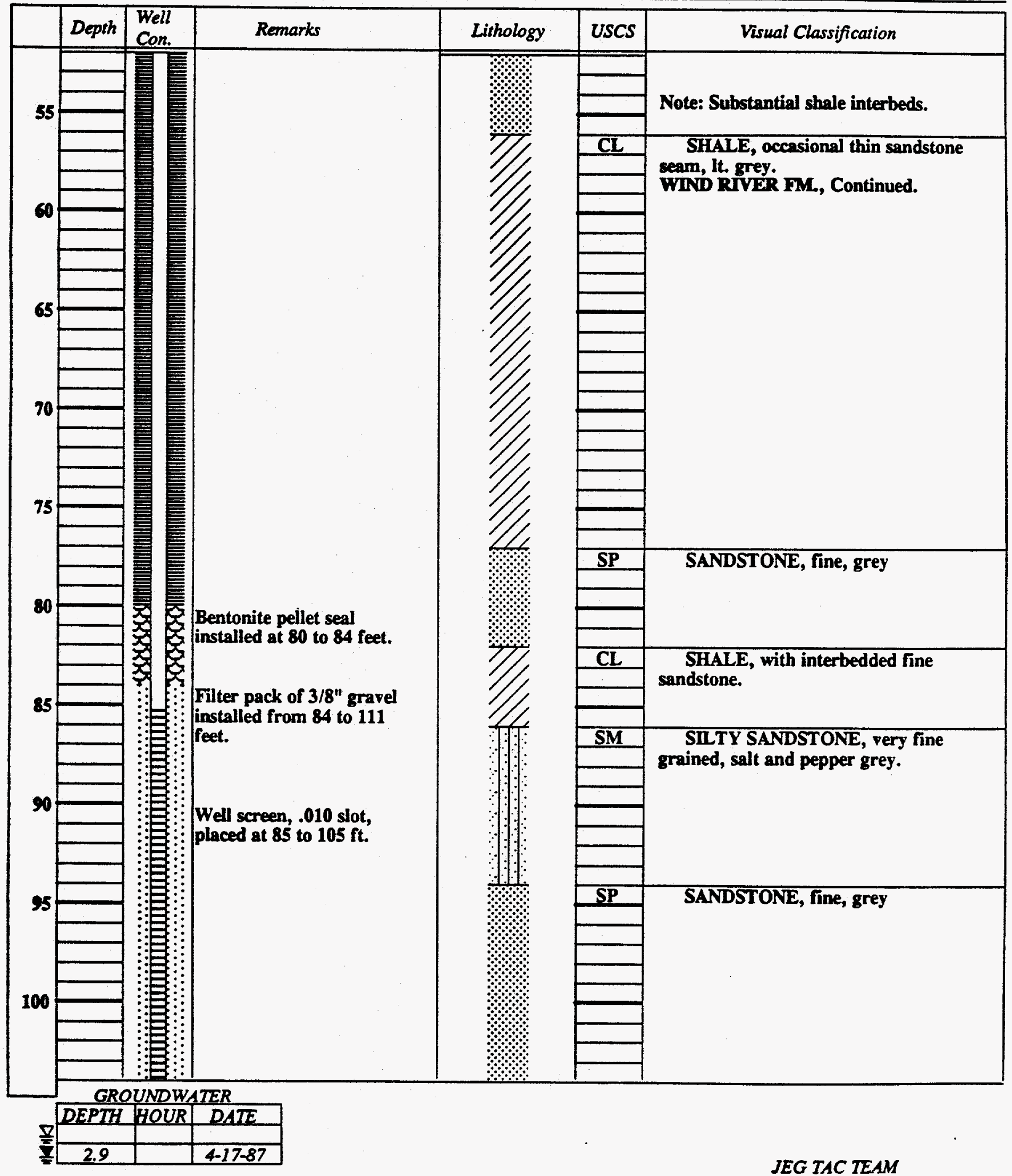




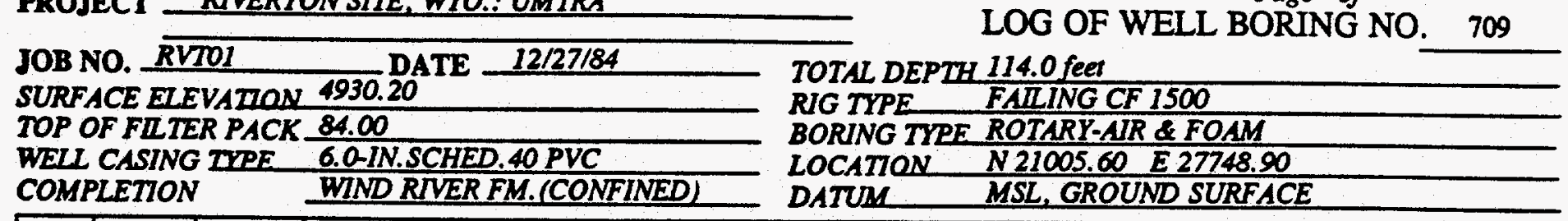

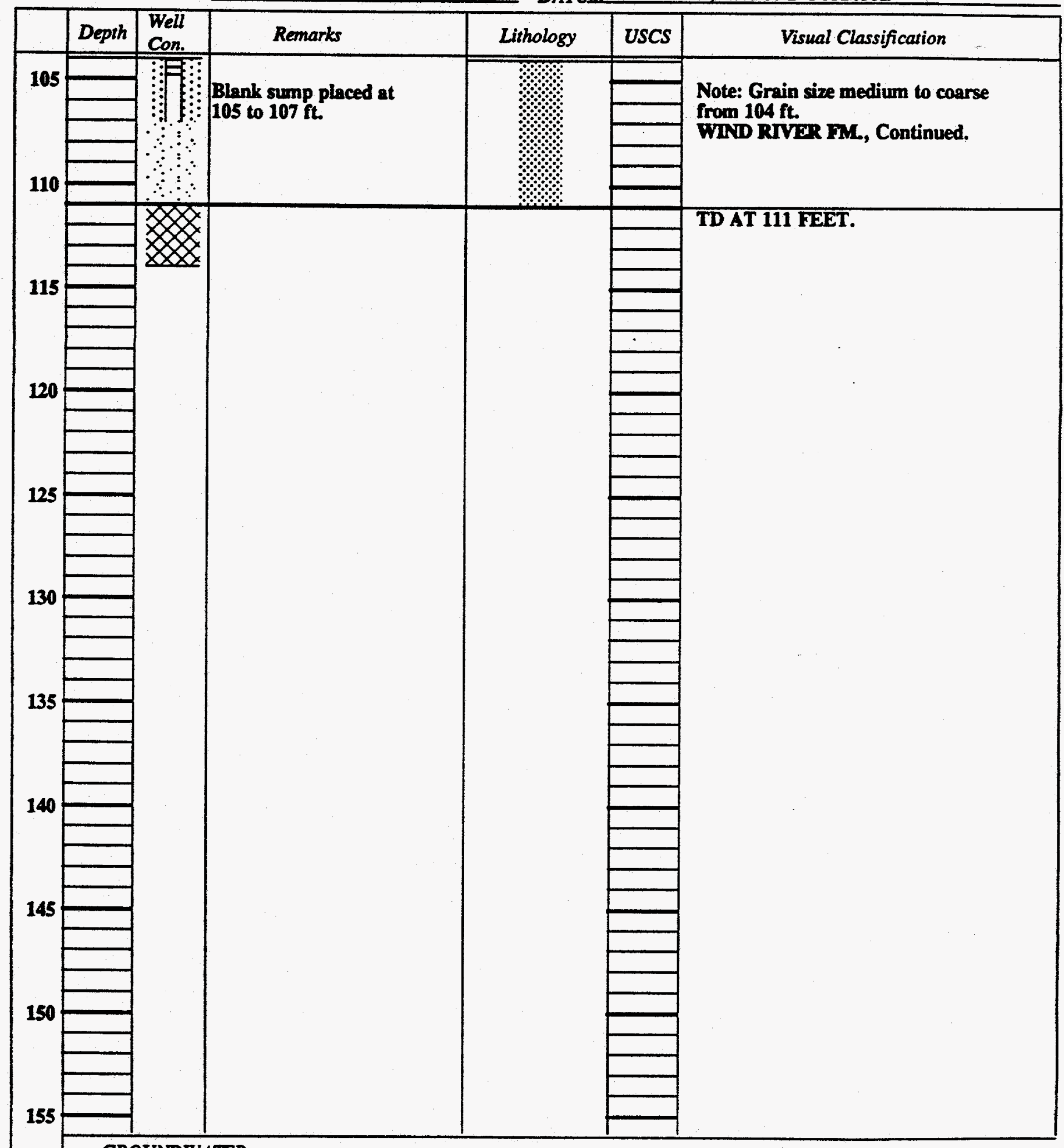

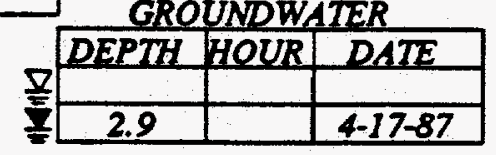


FROJECT RIVERTON SITE, WYO.: UMTRA

JOB NO. RVTO1 DATE 11/29/84

SURFACE ELEVATION 4947.20
TOP OF FILTER PACK $\frac{8.50}{2.0 I N . S C H E D .40 \text { PVC }}$
WEL CASING TYPE.
COMPLETION

TOTAL DEPTH 20.0 feet

LOG OF WELL BORING NO. 710

RIG TYPE MDWAY 15M

BORING TYRE ROTARY W/ REVERT

LOCATION N25355.60 E 23982.60

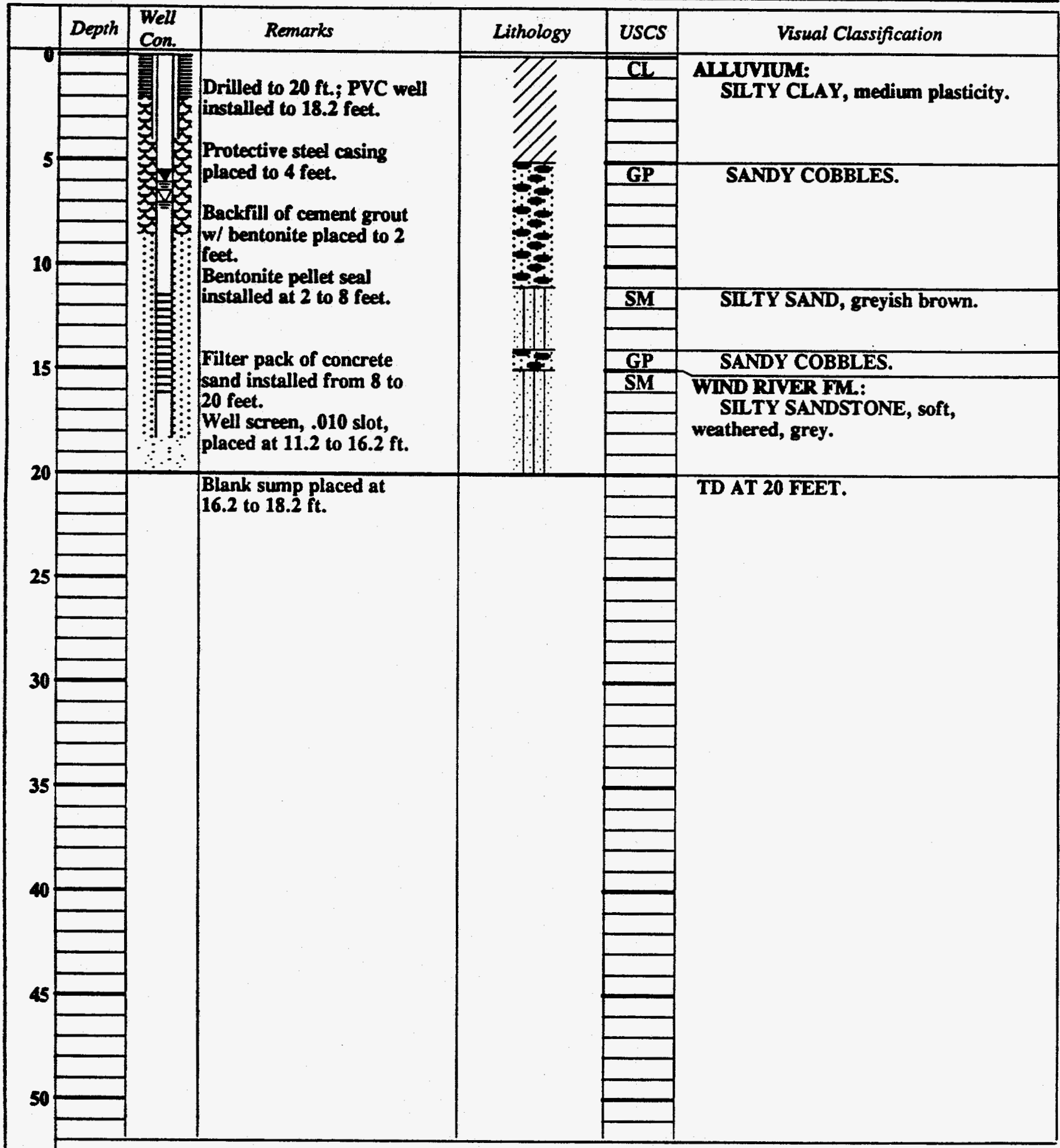

GROUNDWATER

\begin{tabular}{|c|c|c|}
\hline DEPTH & HOUR & DATE \\
\hline 7.0 & & $1-19-85$ \\
\hline 6.1 & & $4-17-87$ \\
\hline
\end{tabular}


PROJECT RIVERTON SITE, WYO.: UMTRA

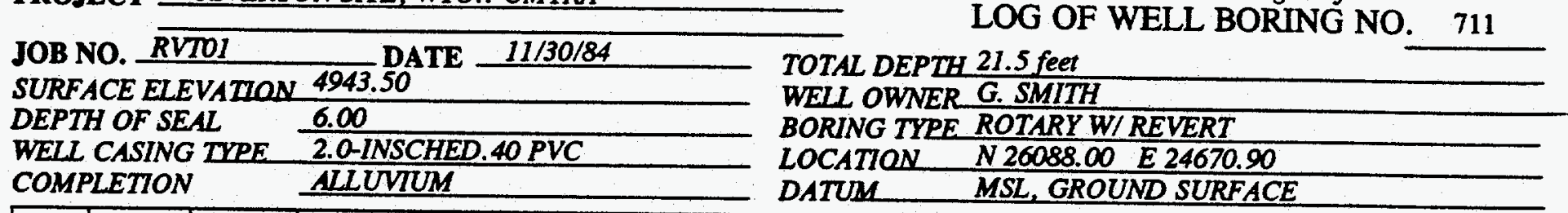

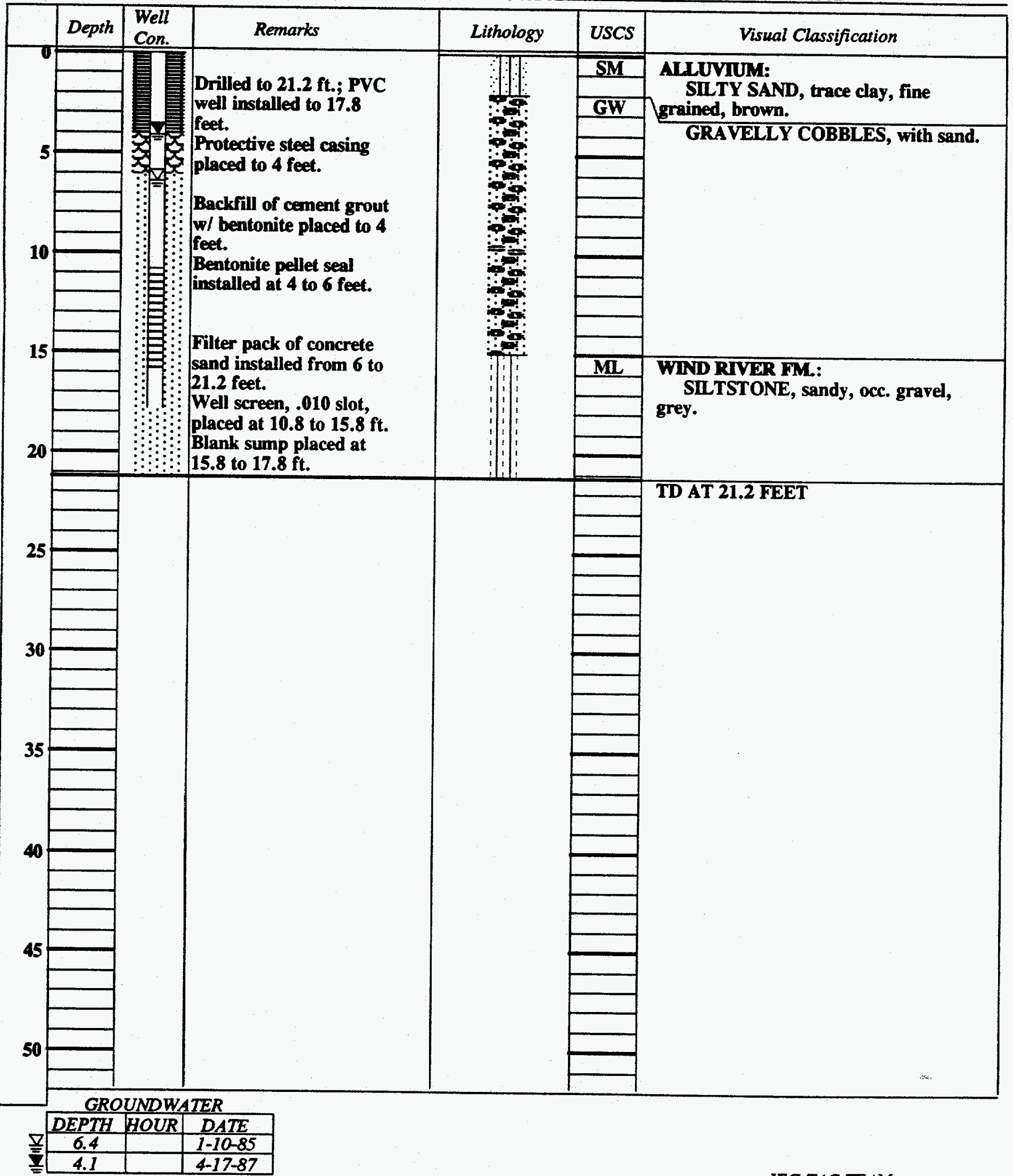




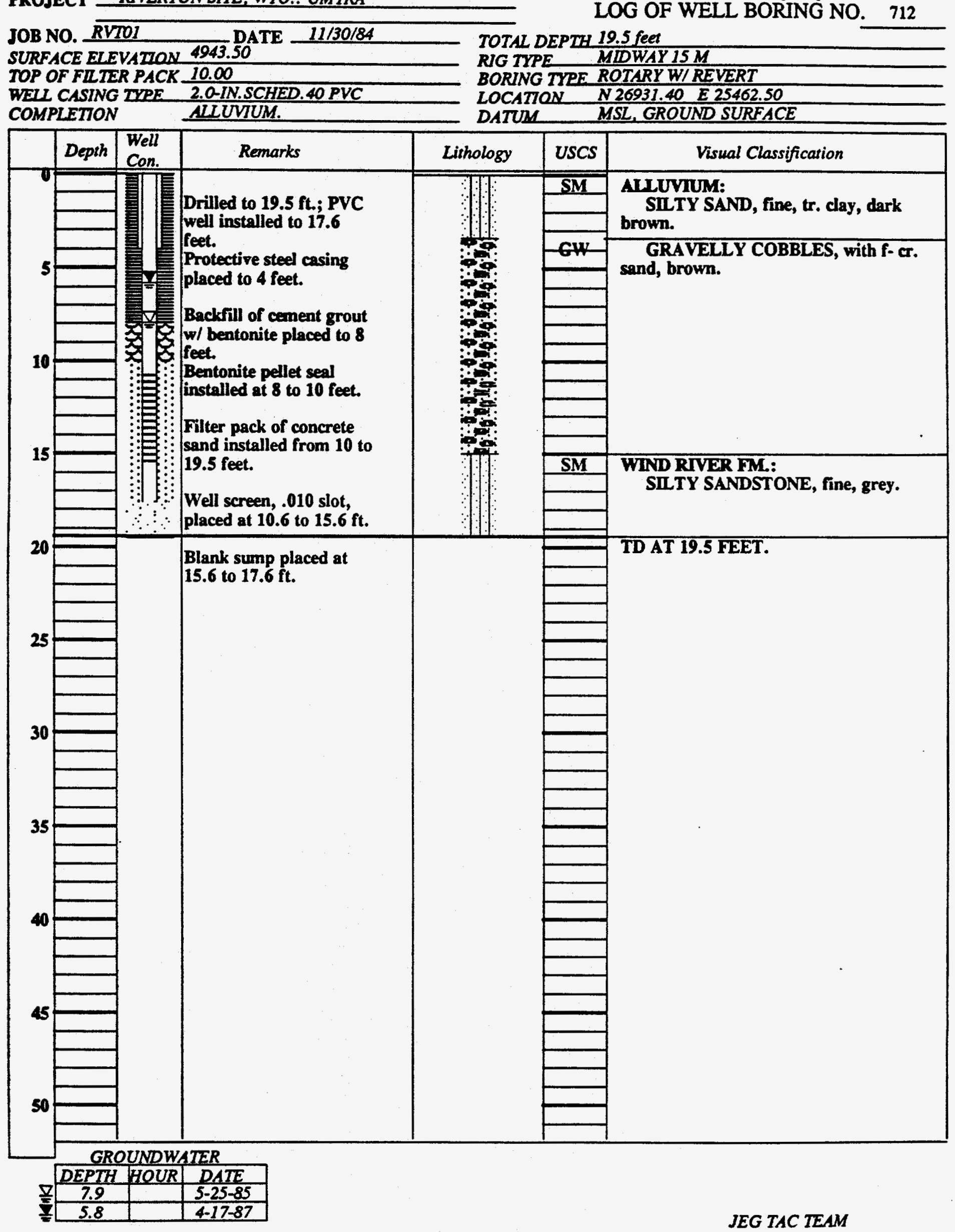




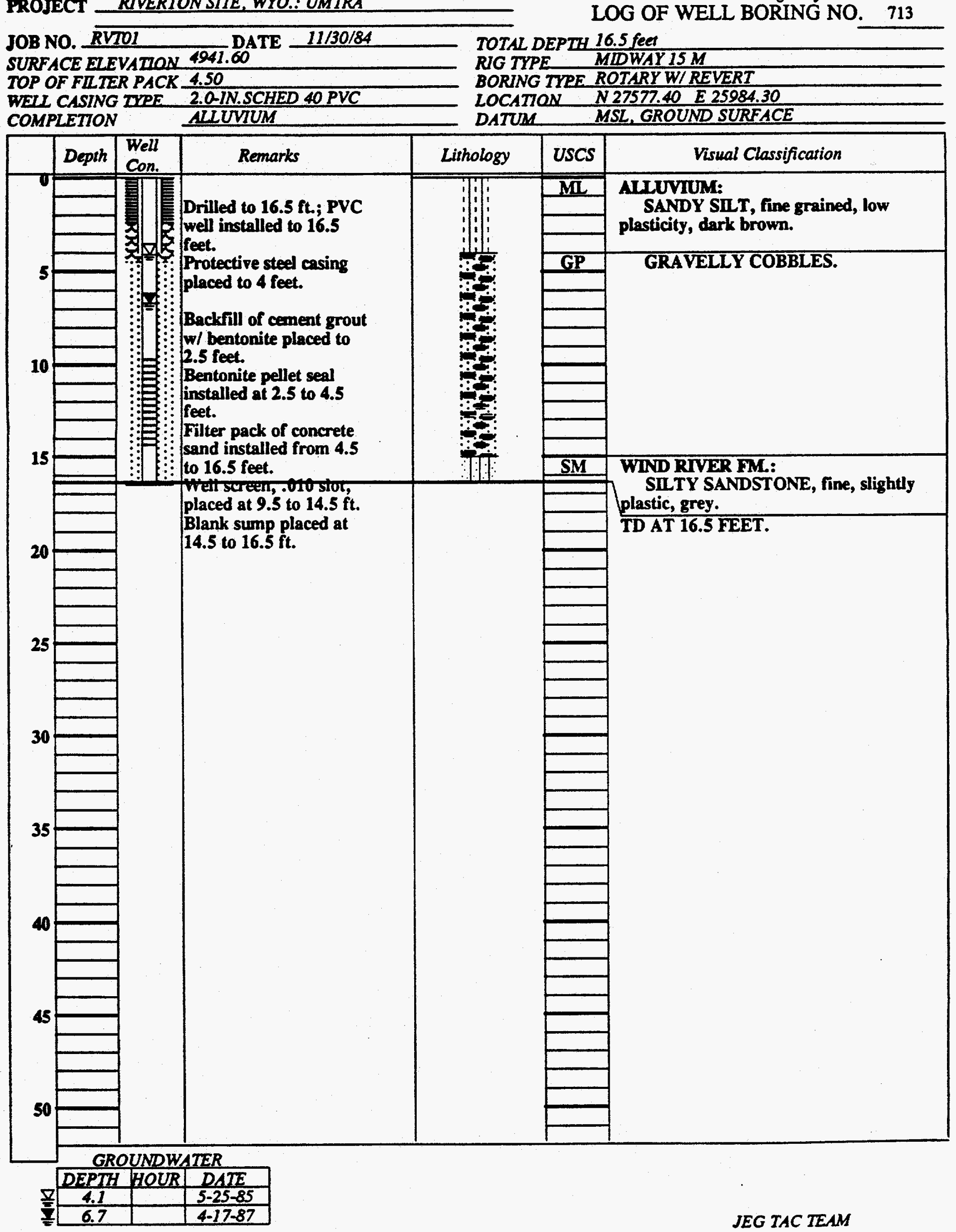


FOJECT RIVERTON SITE, WYO.: UMTRA

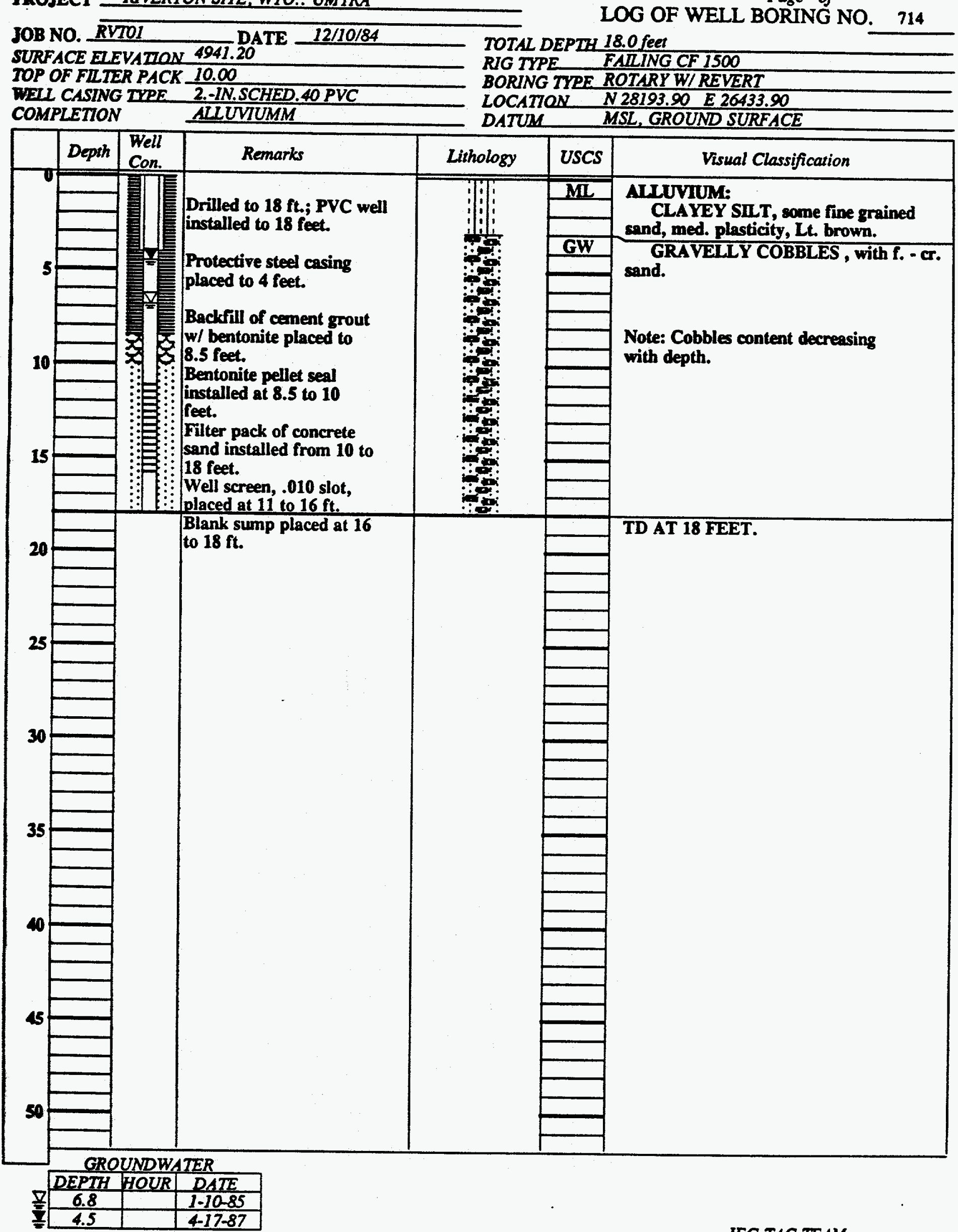

LOG OF WELL BORING NO

RIG TYPE FAILING CF 1500

BORING TYRE ROTARY W/ REVERT

DLCATION N28193 OO E 2643390

WELL CASING ITEE 2.-IN.SCHED.40 PVC

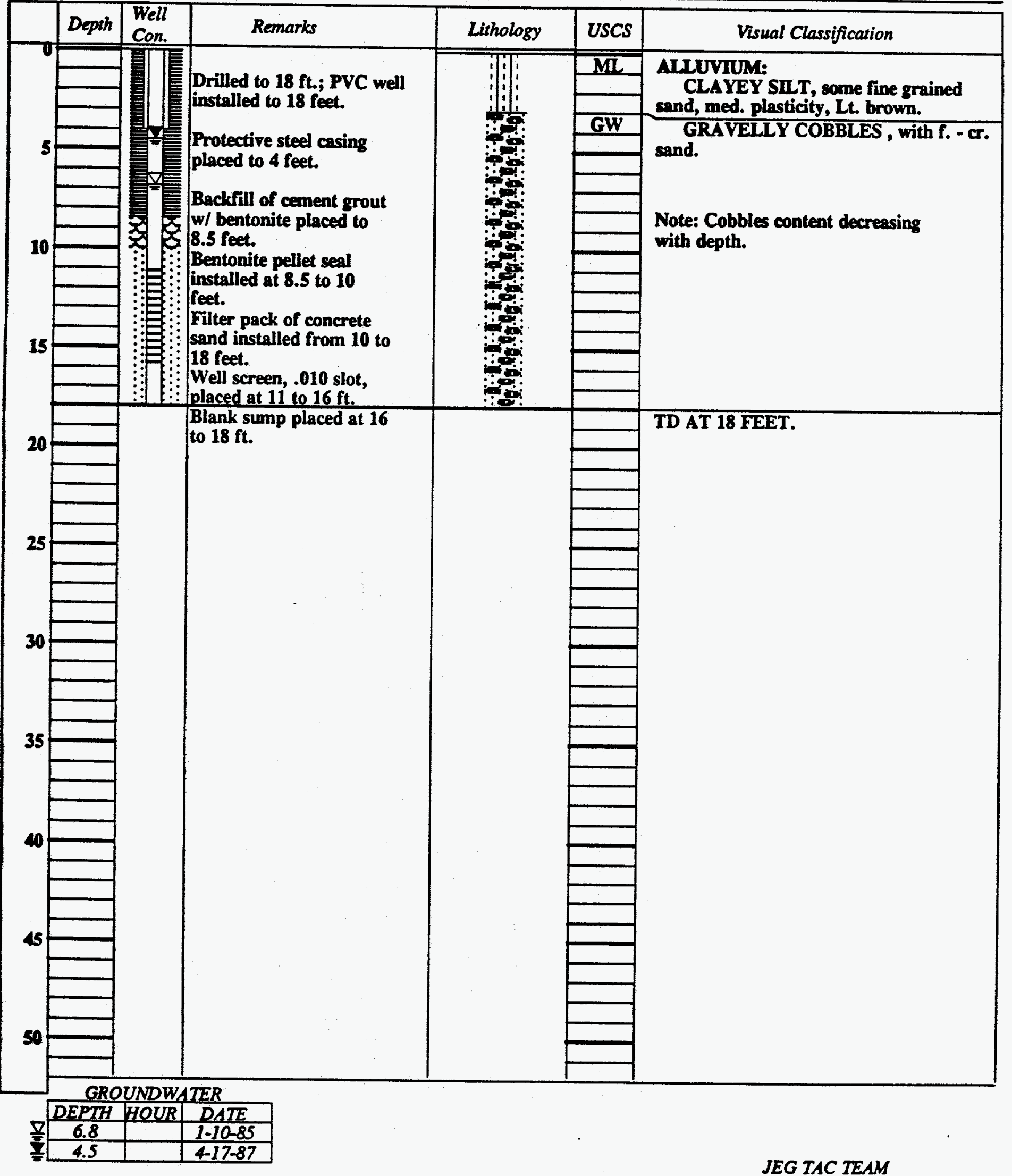


PROJECT RIVERTON SITE, WYO.: UMTRA

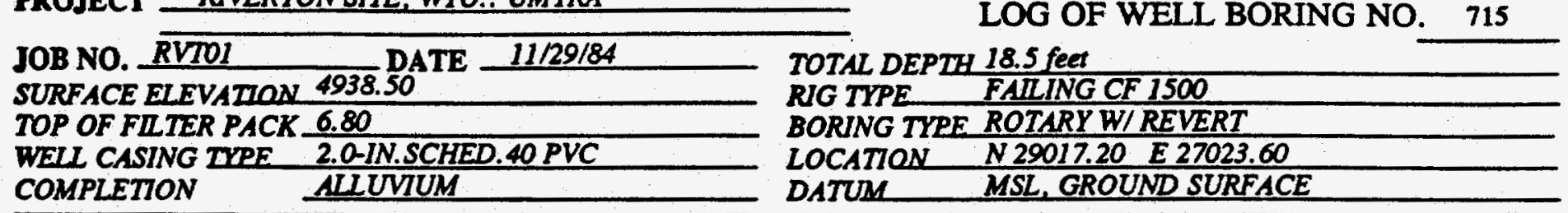

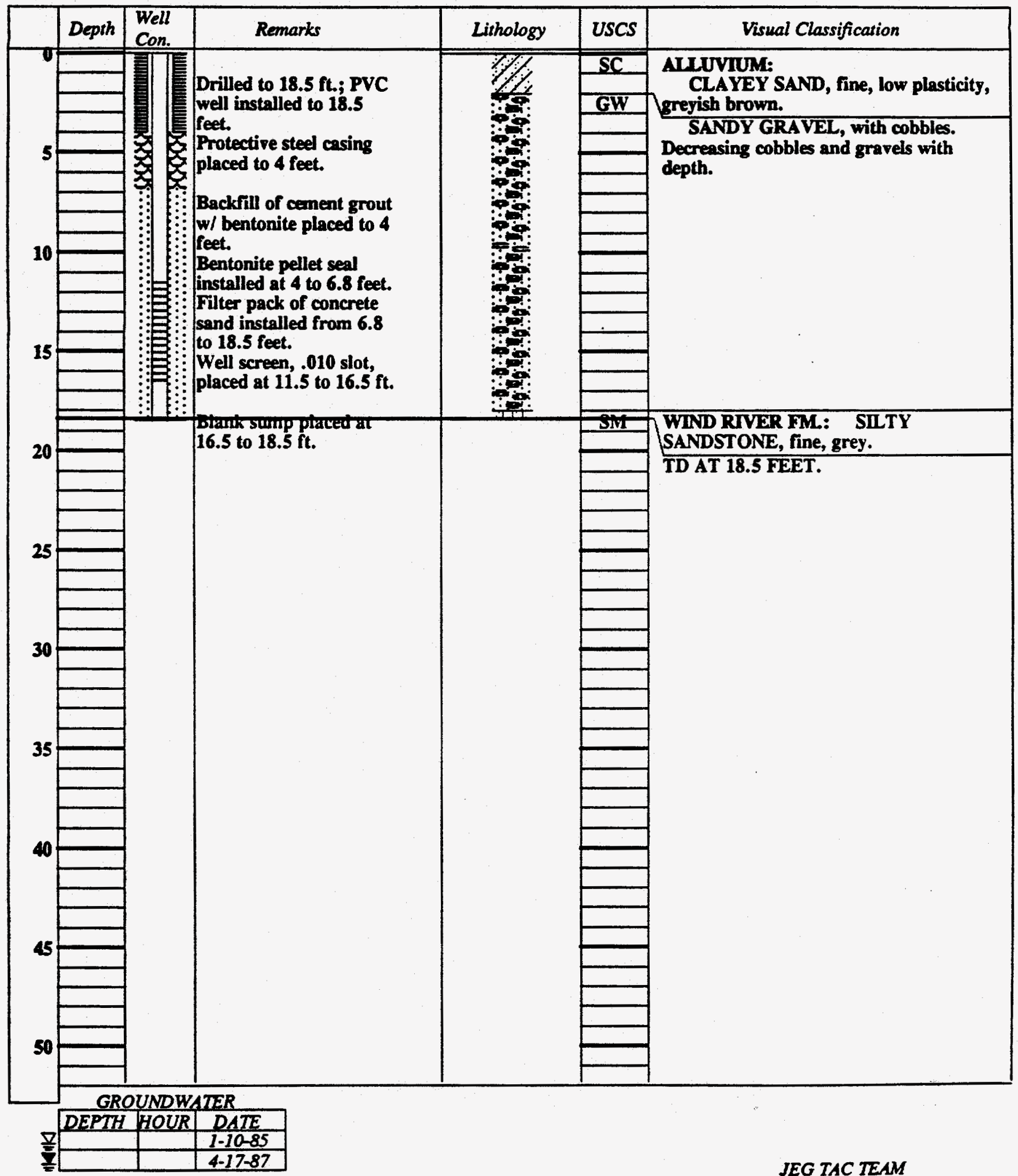




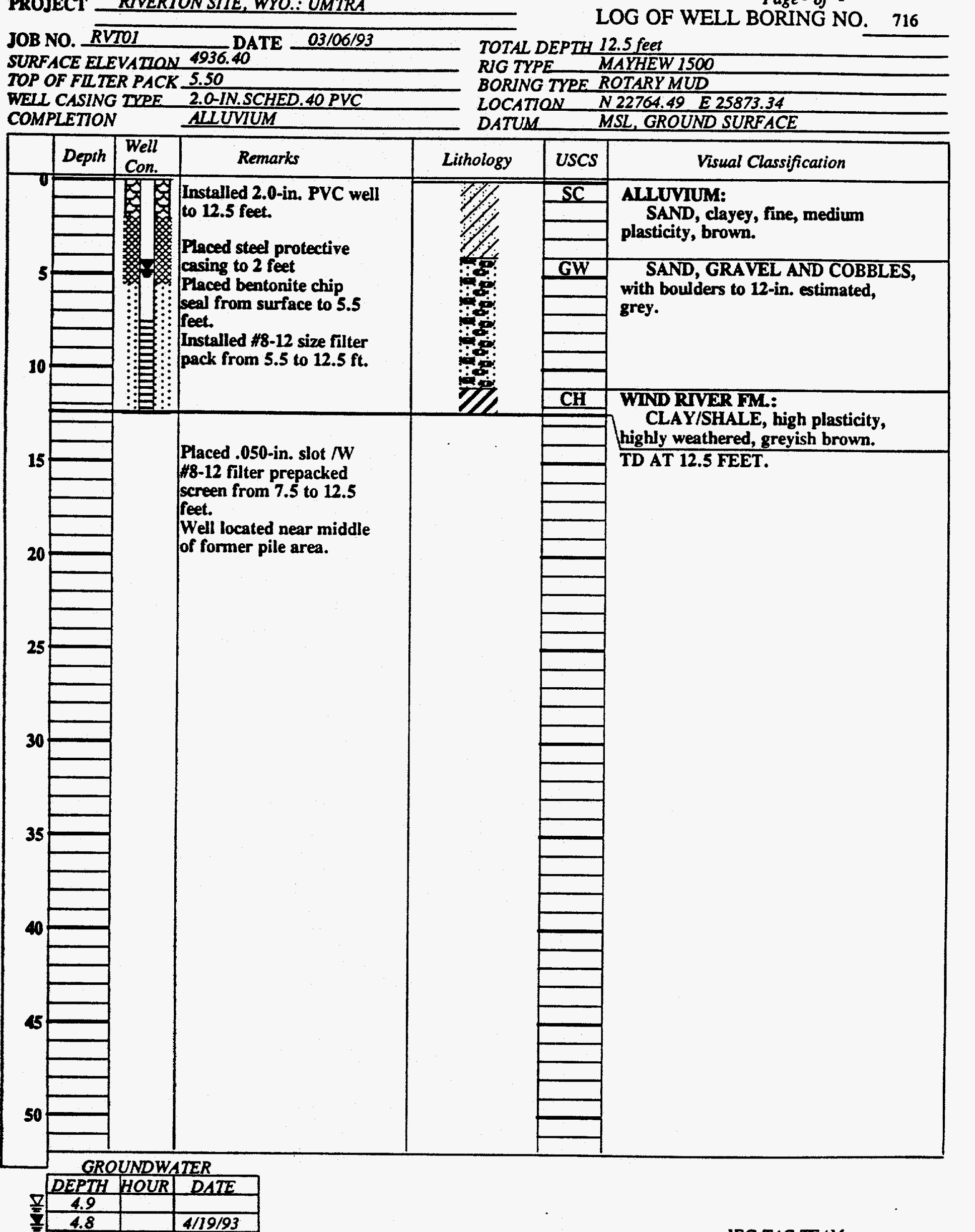


PROJECT RIVERTON SITE, WYO.: UMTRA

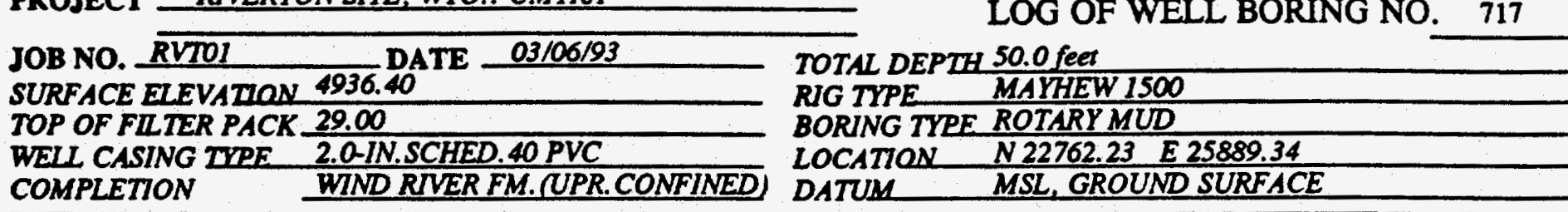

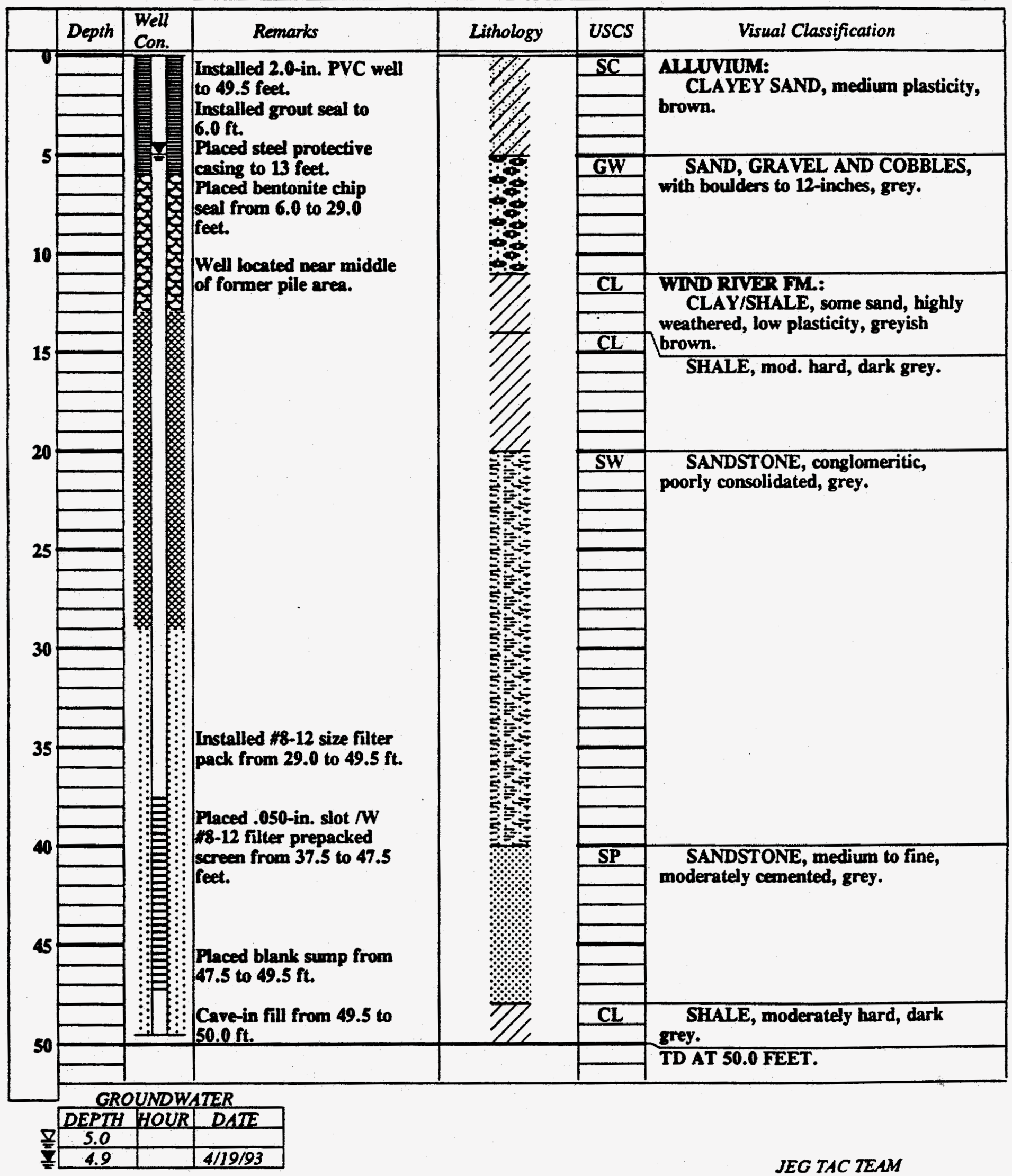


JOB NO. RVTOI DATE 03/02/93

SURFACE ELEVATON 4937.00

TOP OF FILTER PACK 10.00

WEUL CASING TIPE 2.0IN.SCHED.40 PVC

COMPLETION ALLUVIUM.

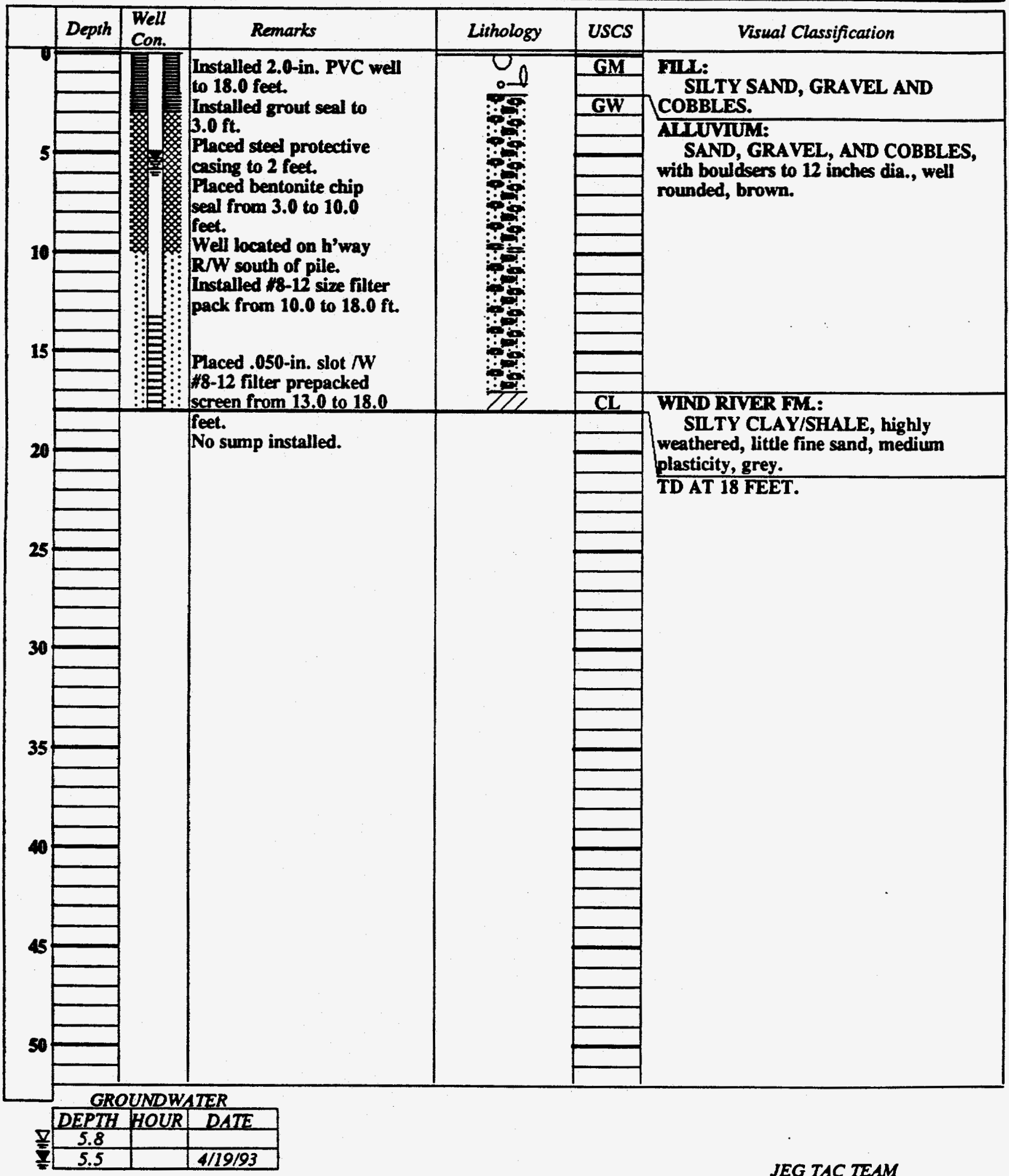

TOTAL DEPTH 18.0 feet

RIG TYPE MAYHEW 1500

BORING TYRE ROTARY MUD

LOCAT7ON N 21673.56 E 25406.28

DATUM MSL GROUND SURFACE 
PROJECT RIVERTON SITE, WYO.: UMTRA

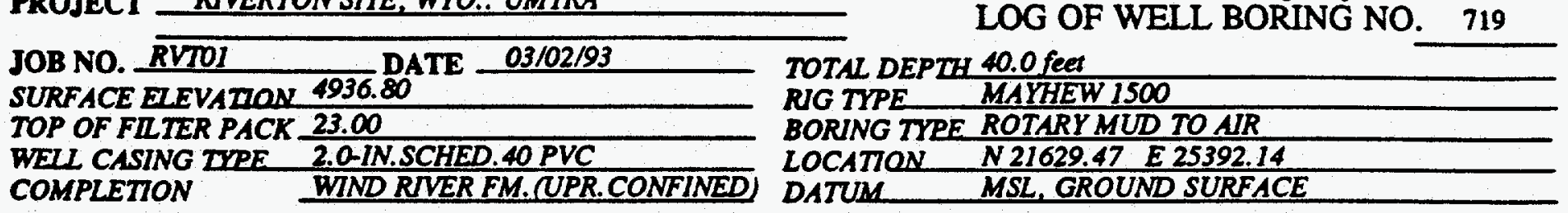

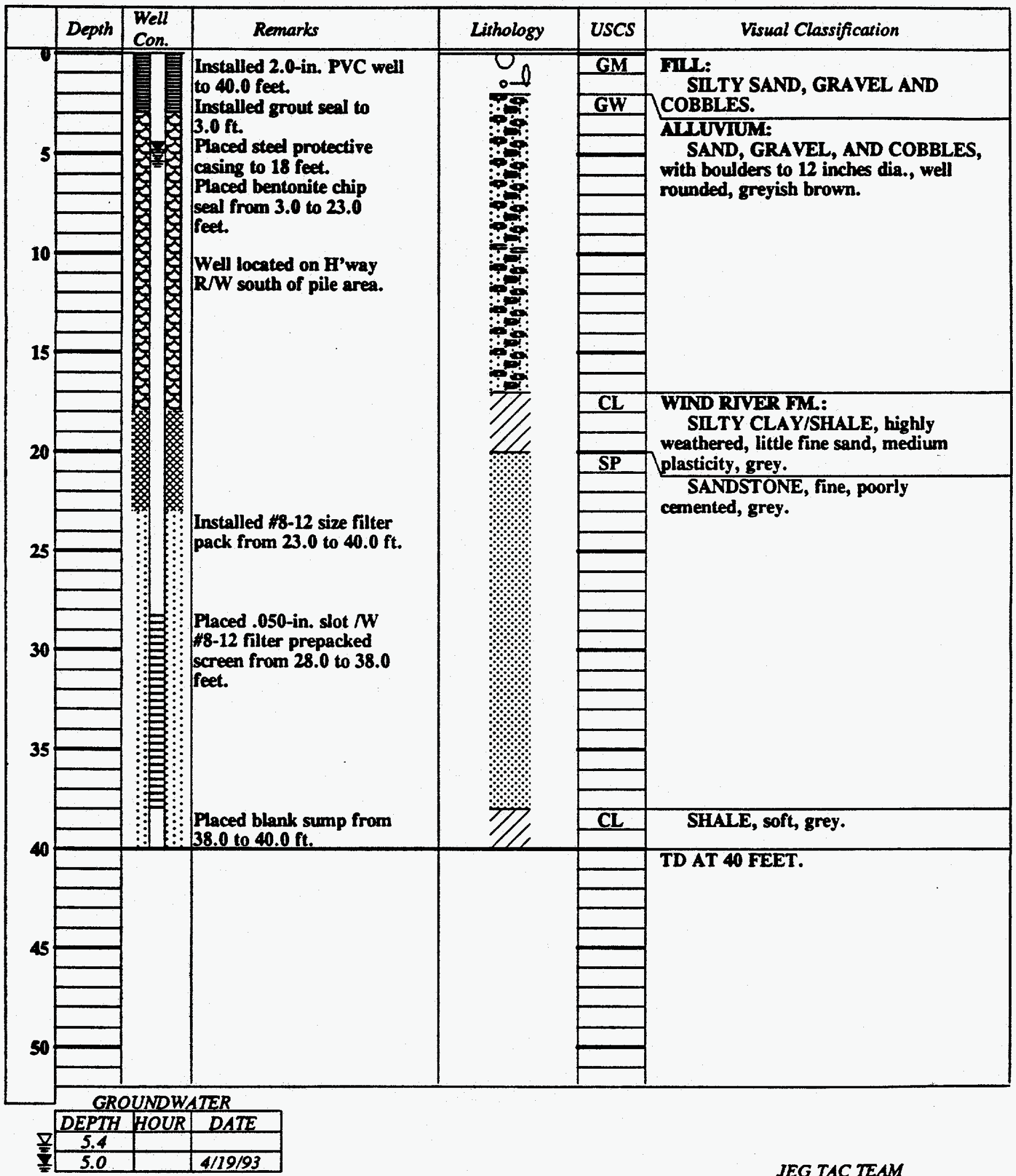




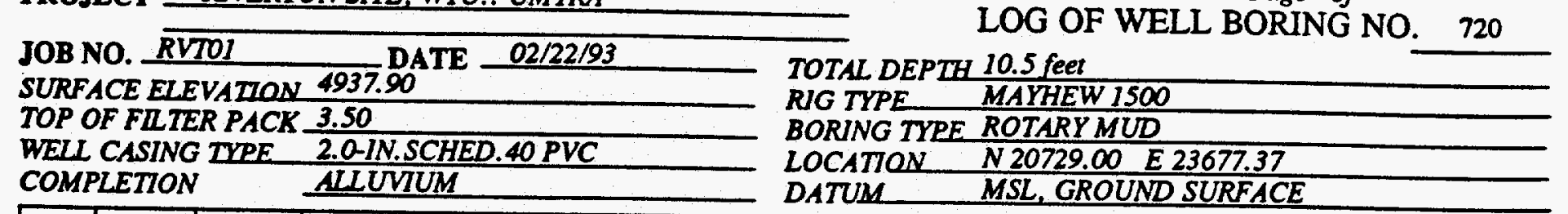

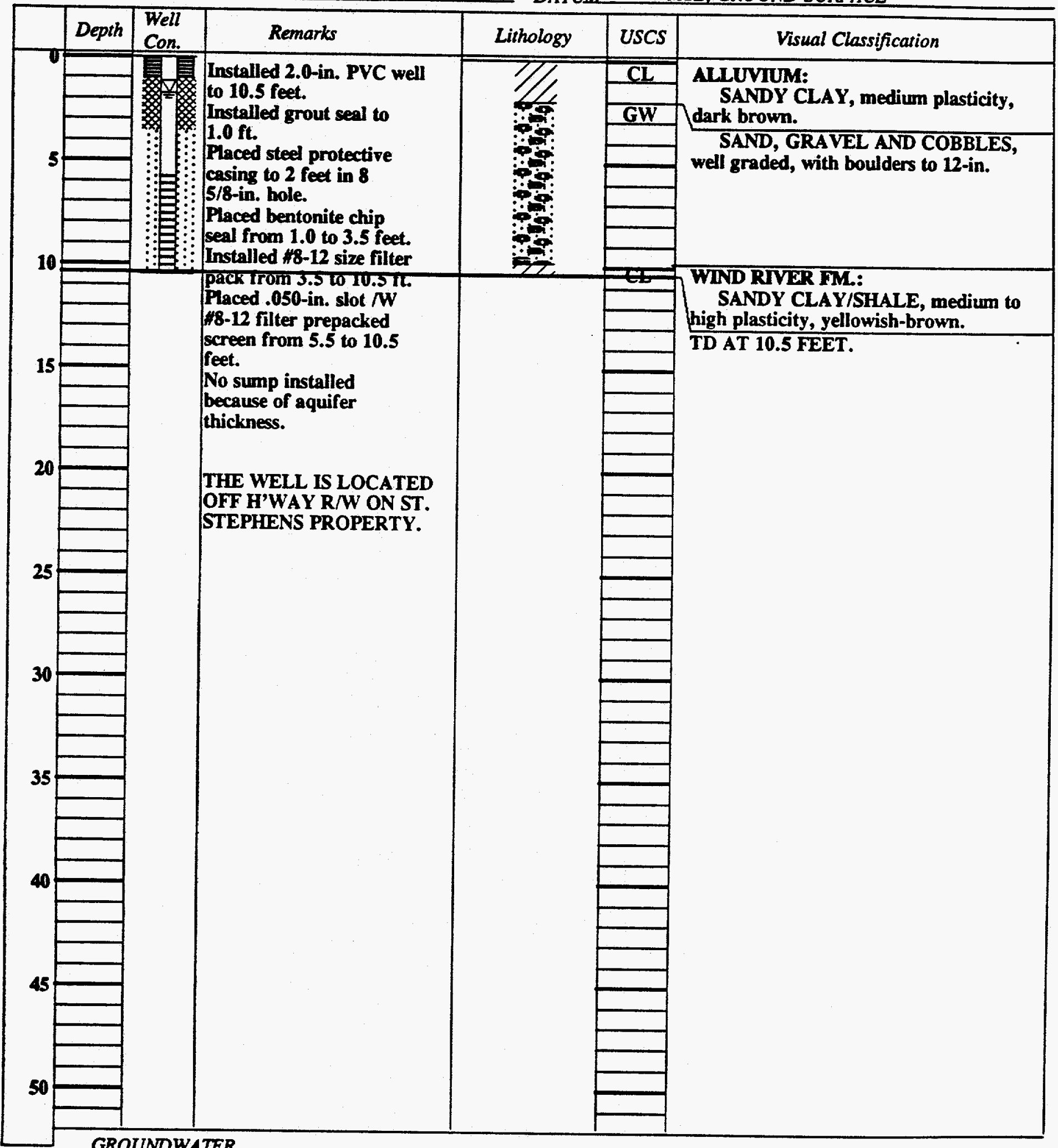

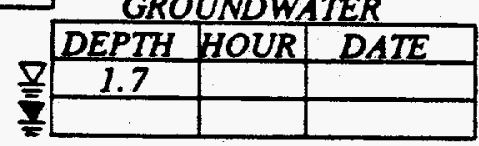




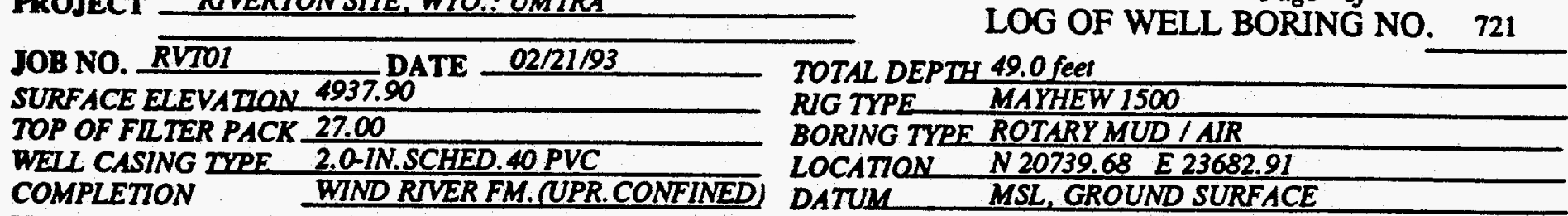

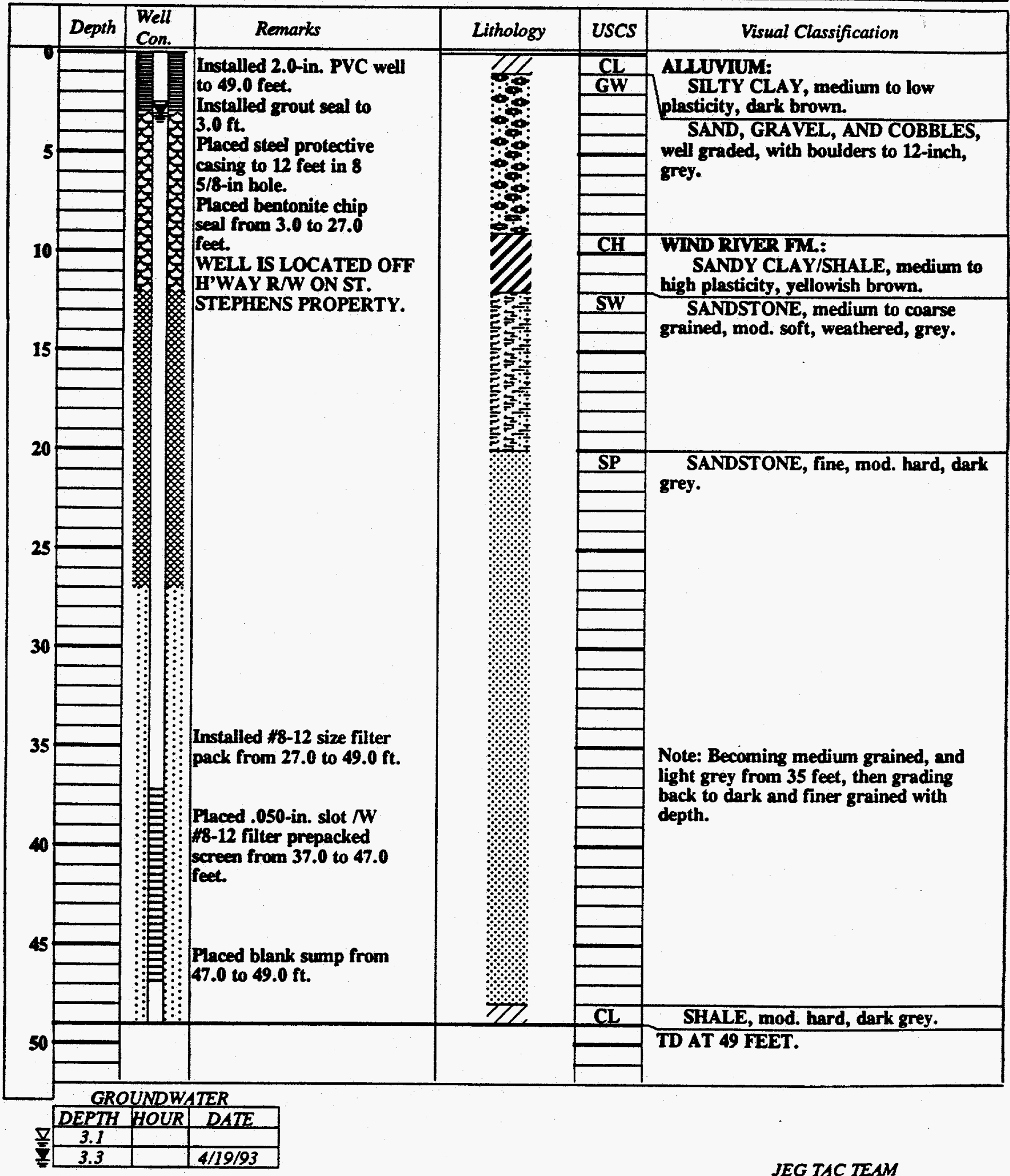




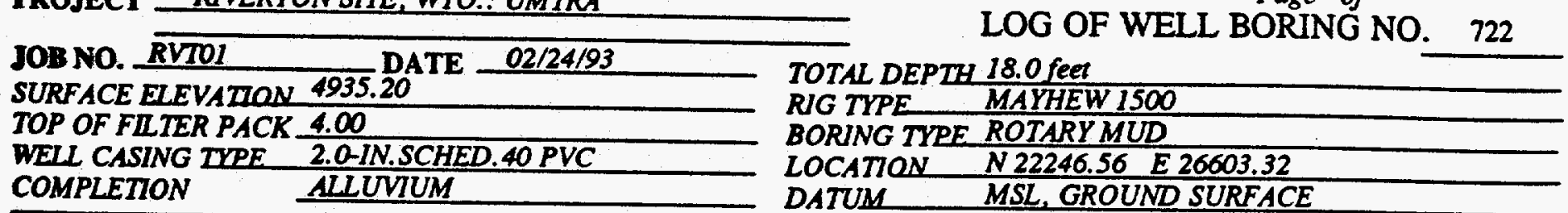

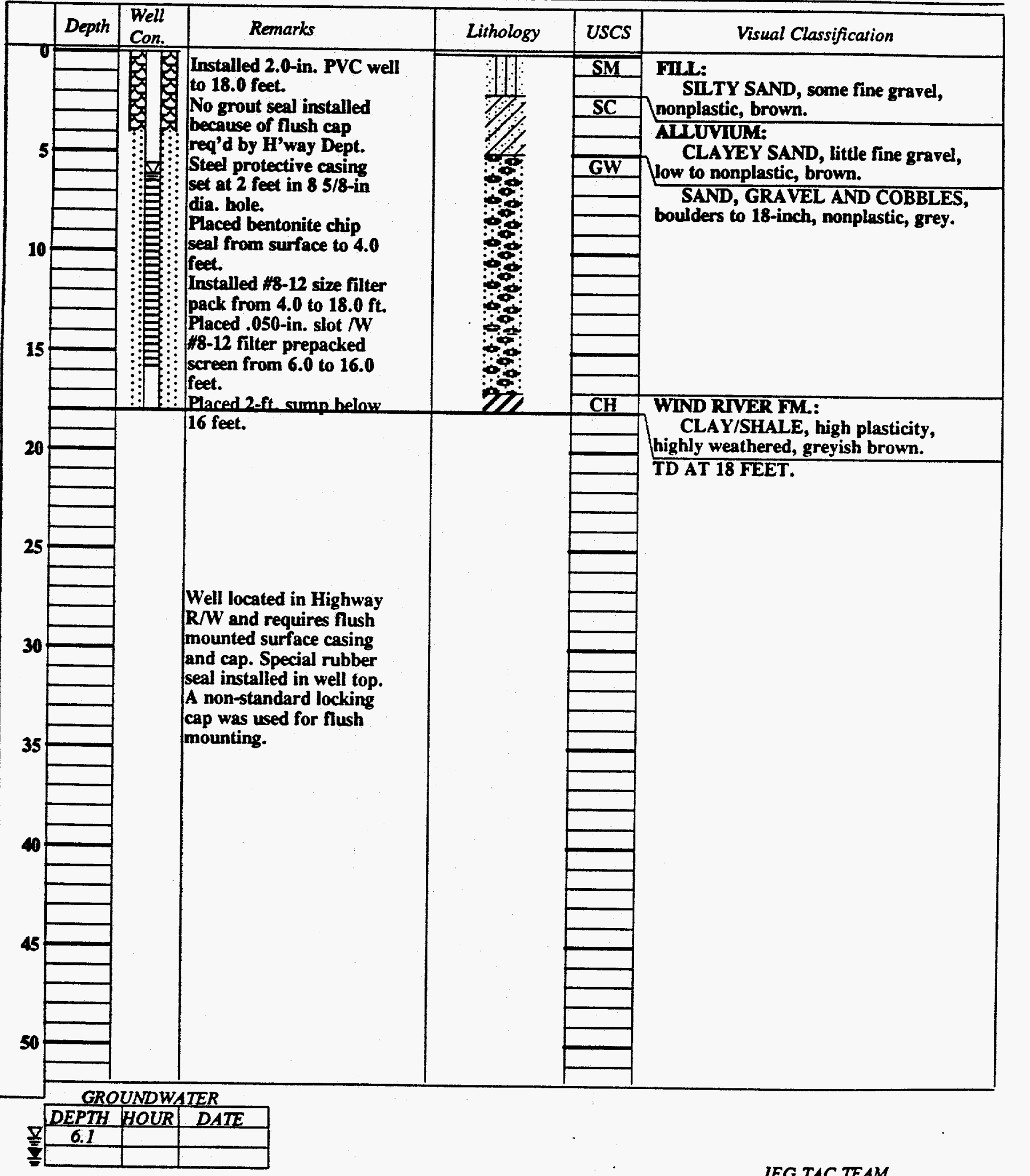


PROJECT RIVERTON SITE, WYO.: UMTRA

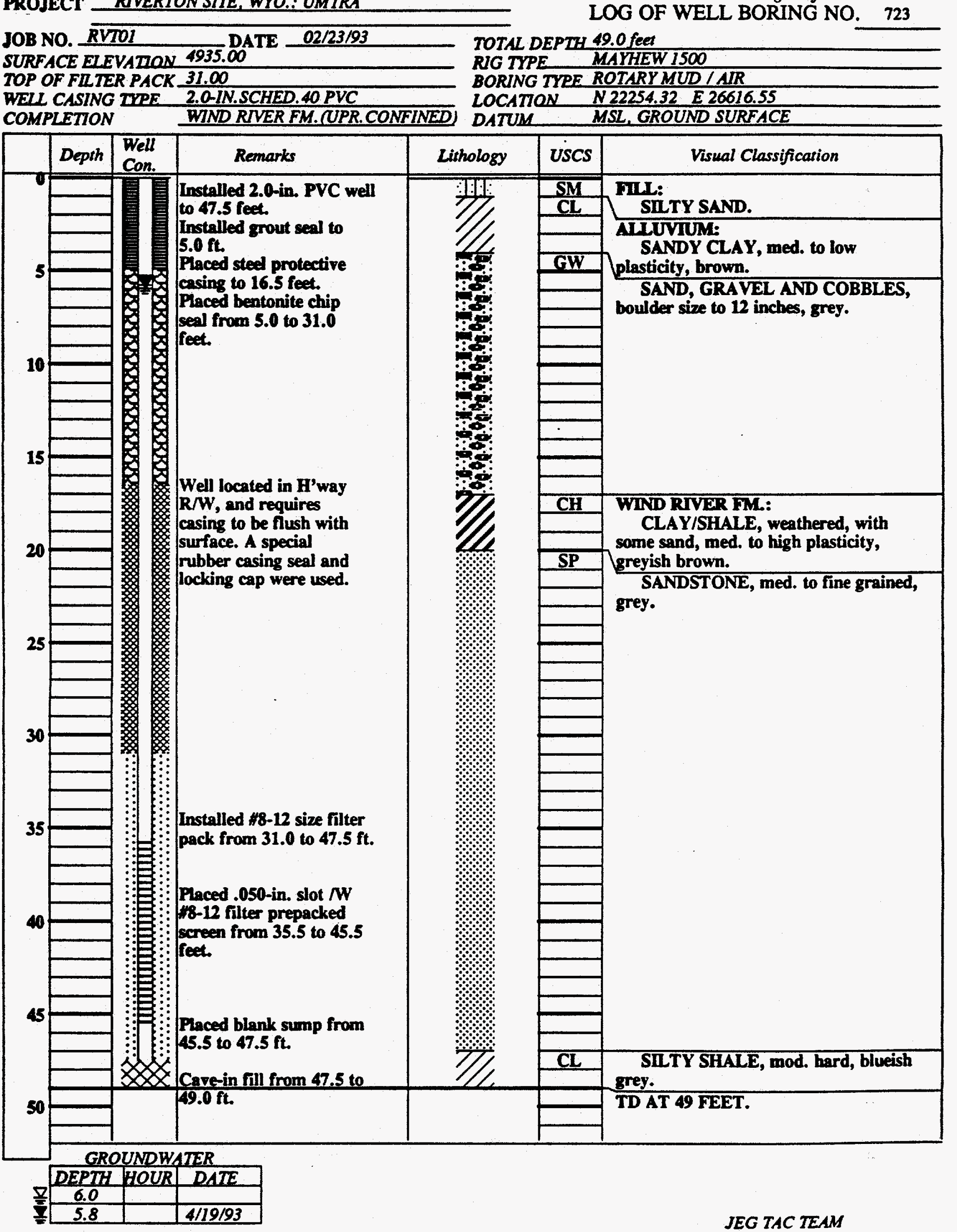




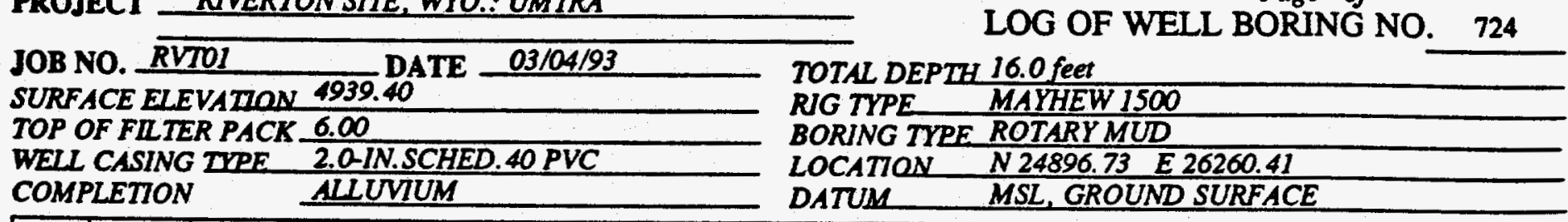

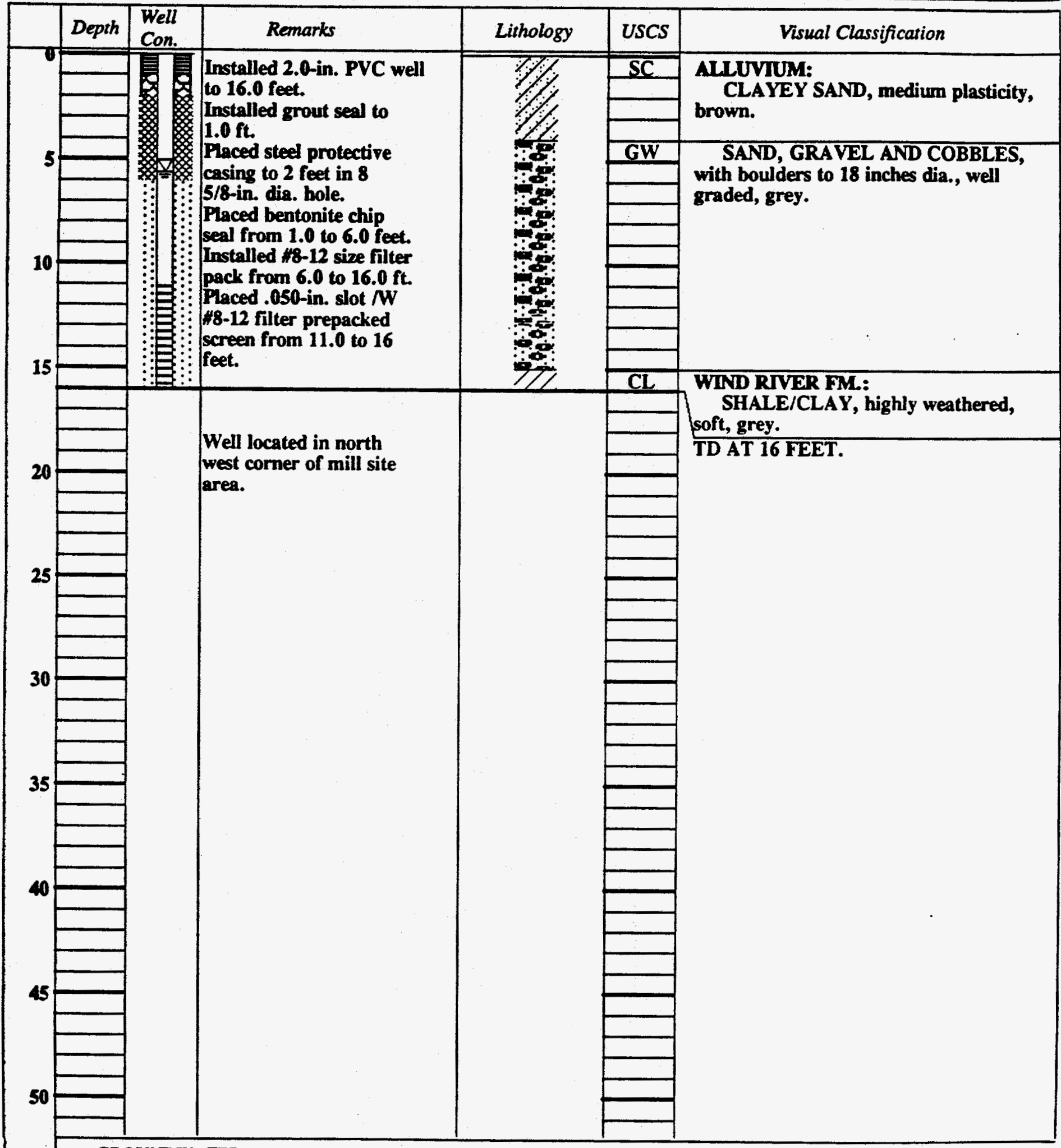

GROUNDWATER

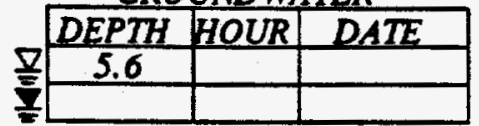




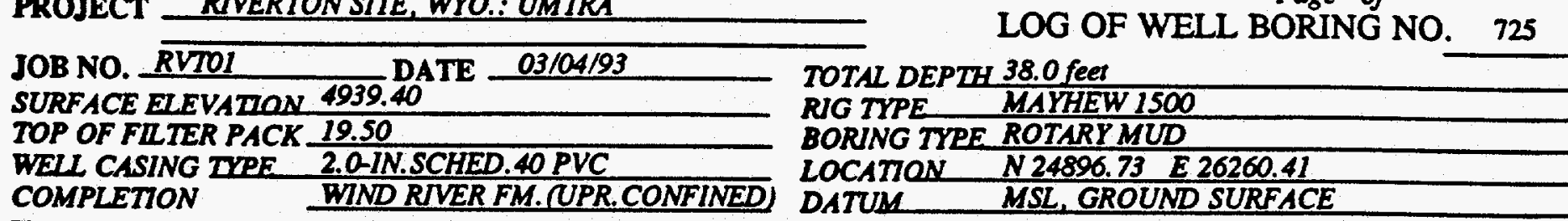

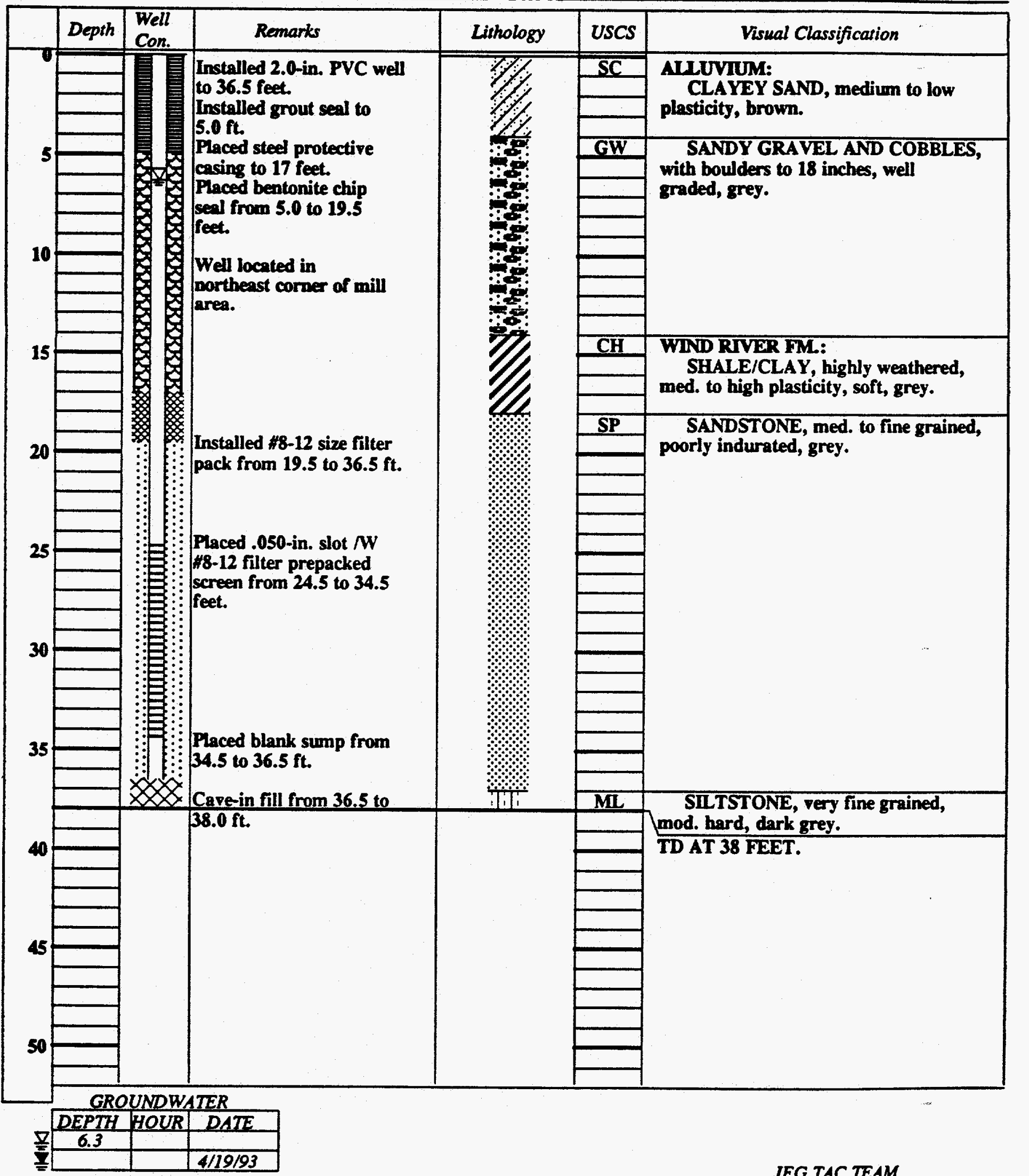




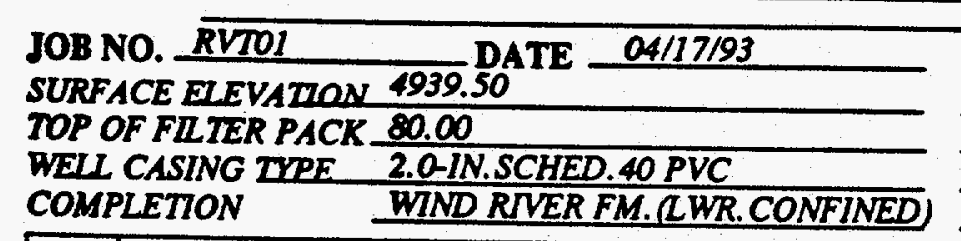

TOTAL DEPTH 133.0 feet

LOG OF WELL BORING NO. 726

RIG TYPE MAYHEW 1500

BORING TYRE ROTARY MUD TO AIR

LOCATION N24904.00 E 26251.00

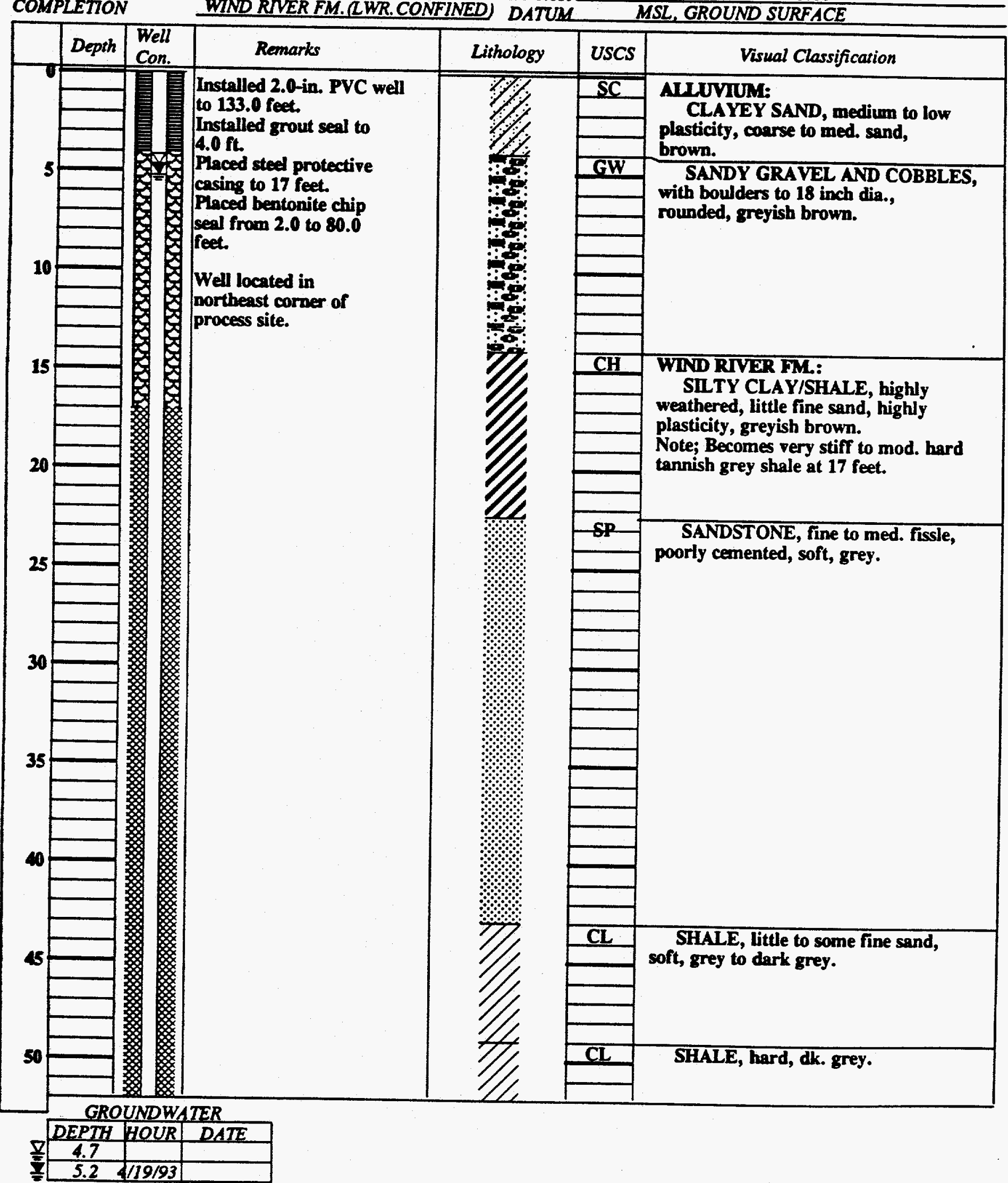


PROJECT RIVERTON SITE, WYO.: UMTRA

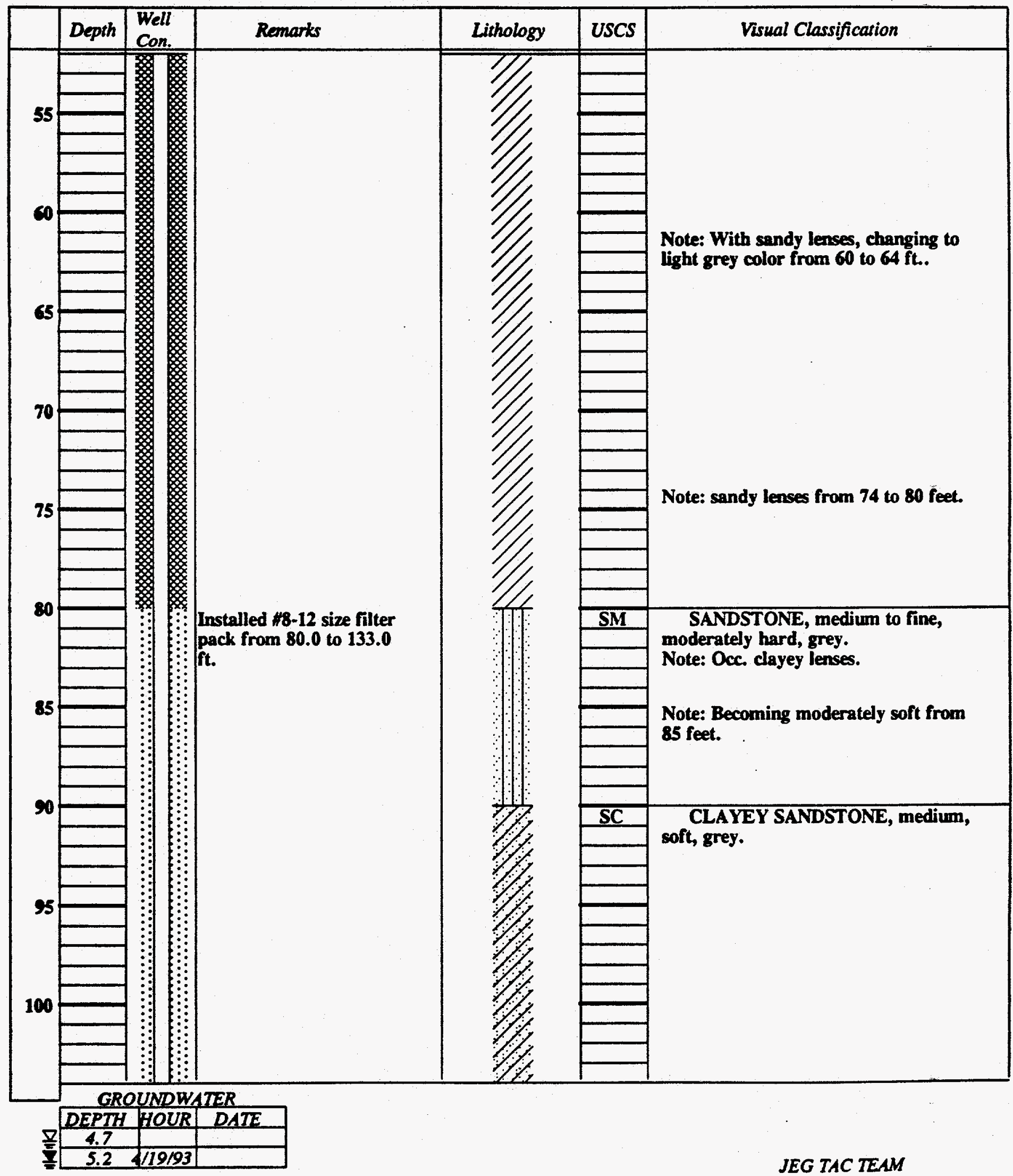


PROJECT RIVERTON SITE, WYO.: UMTRA

JOB NO. RVTO1 DATE 04/I7/93

LOG OF WELL BORING NO.

726

\begin{tabular}{|c|c|}
\hline $\begin{array}{l}\text { OB NO. KVIUI } \\
\text { URFACE ELEVATION 4939.50 }\end{array}$ & 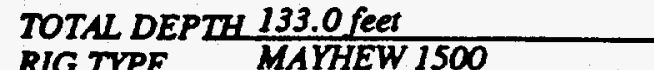 \\
\hline $2 K 80.0$ & RG TYPE MATRCW ISW \\
\hline 2.O-IN.SCHED. & $N 24904.00$ E 26251.00 \\
\hline WIND RIVER FM. (2WR.CONFINED) & MSL, GROUND SURFACE \\
\hline
\end{tabular}

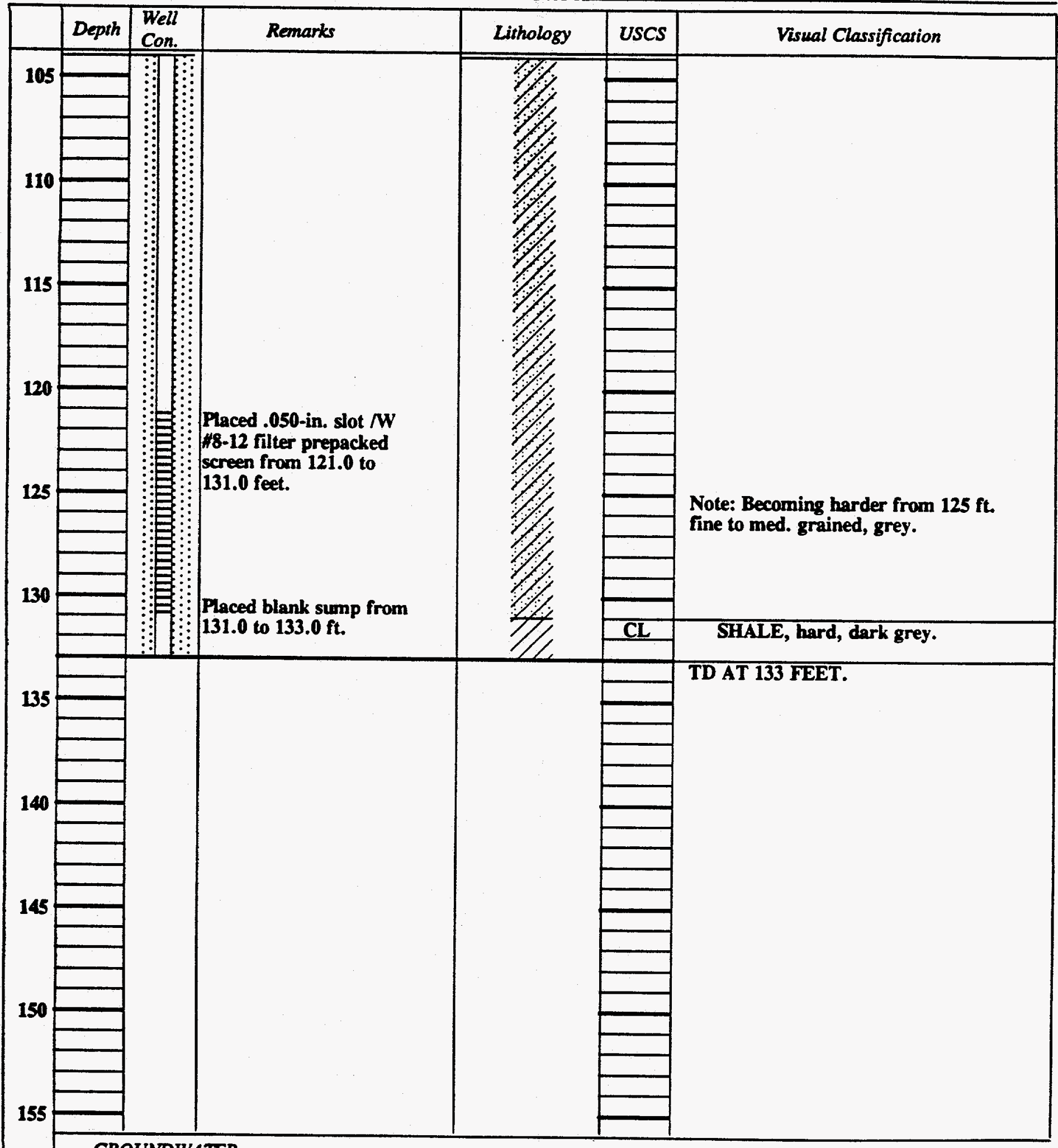

GROUNDWATER

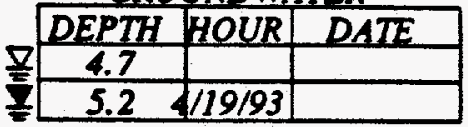




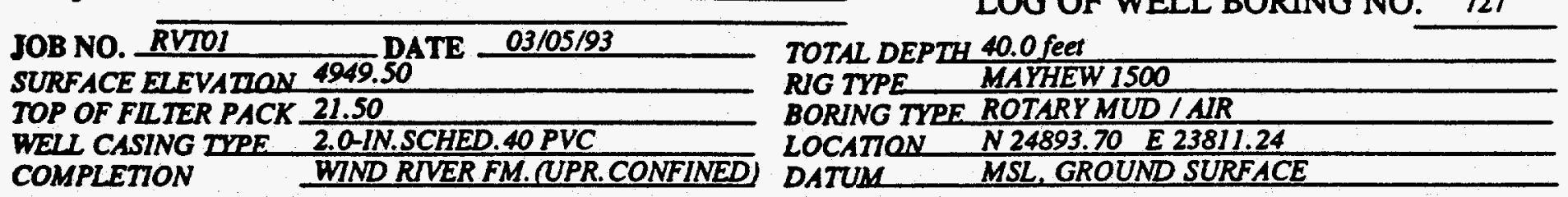

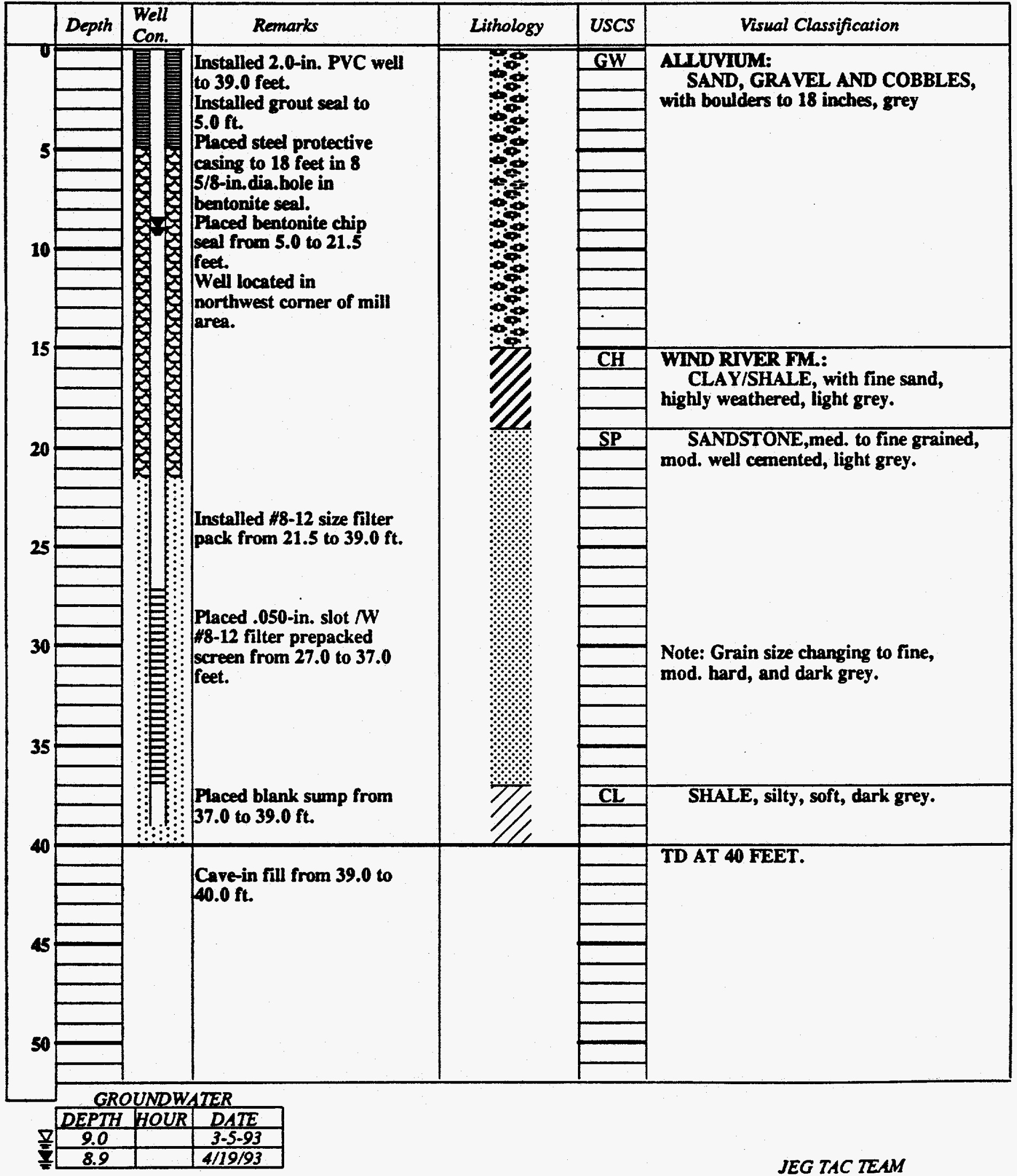




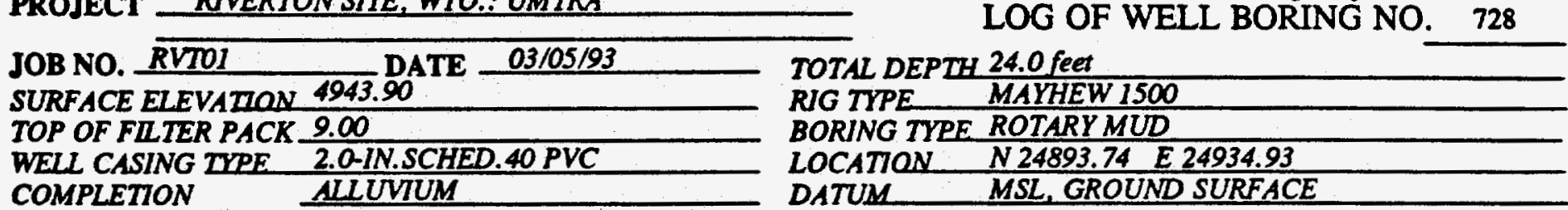

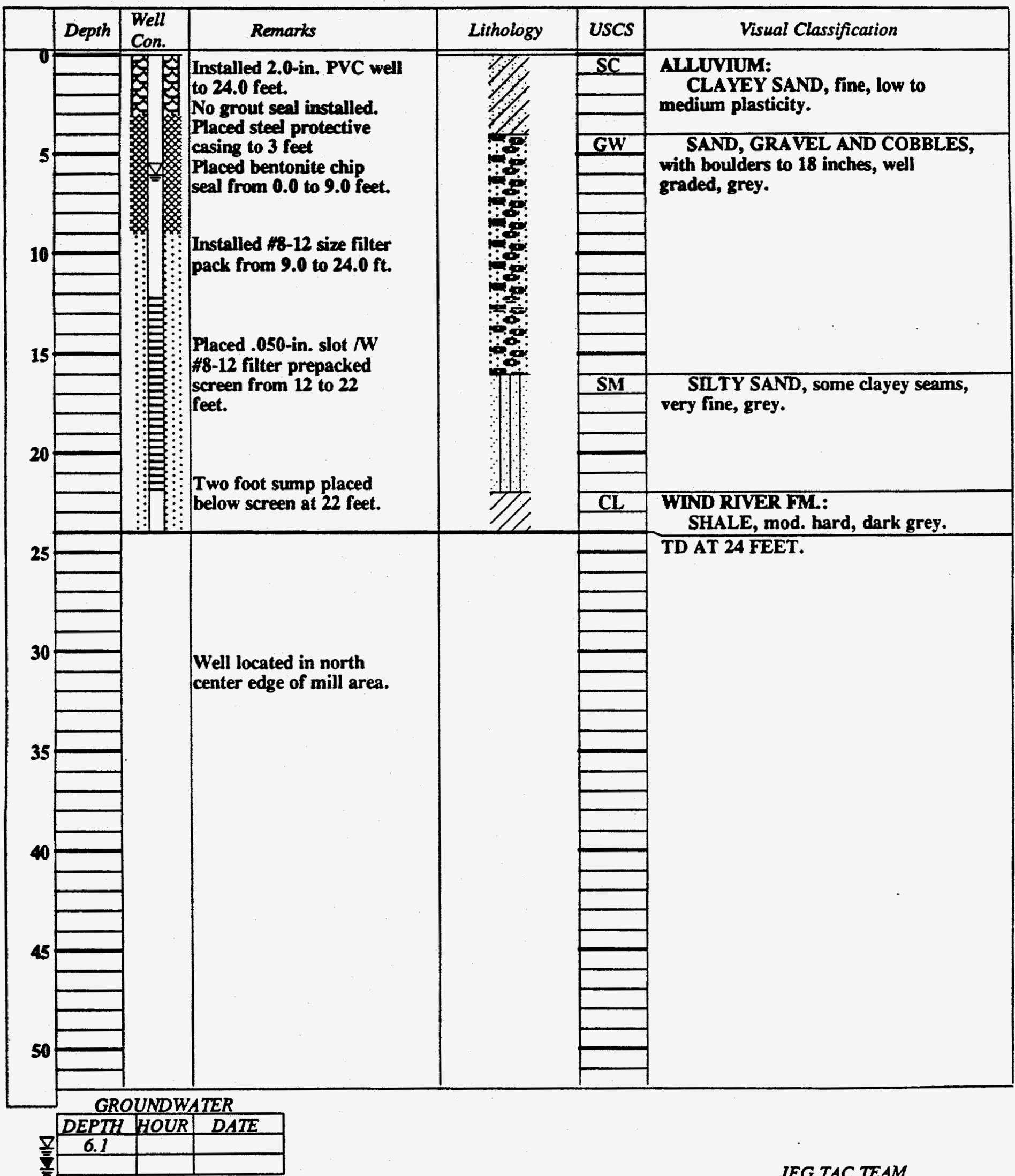


PROJECT RIVERTON SITE, WYO.: UMTRA

JOB NO. RVTO1 DATE 03/17/93

SURFACE ELEVATZON 4932.10

TOTAL DEPTH 17.0 feet

TOP OF FILTER PACK 8.00

WEIL CASING TIPE 2.0-IN.SCHED.40 PVC

RIG TIPE MAYHEW 1500

COMPLETION ALLUVIUM

BORING TYPE ROTARY MUD

LOCATION N23228.03 E 28349.91

DATUM

MSL, GROUND SURFACE

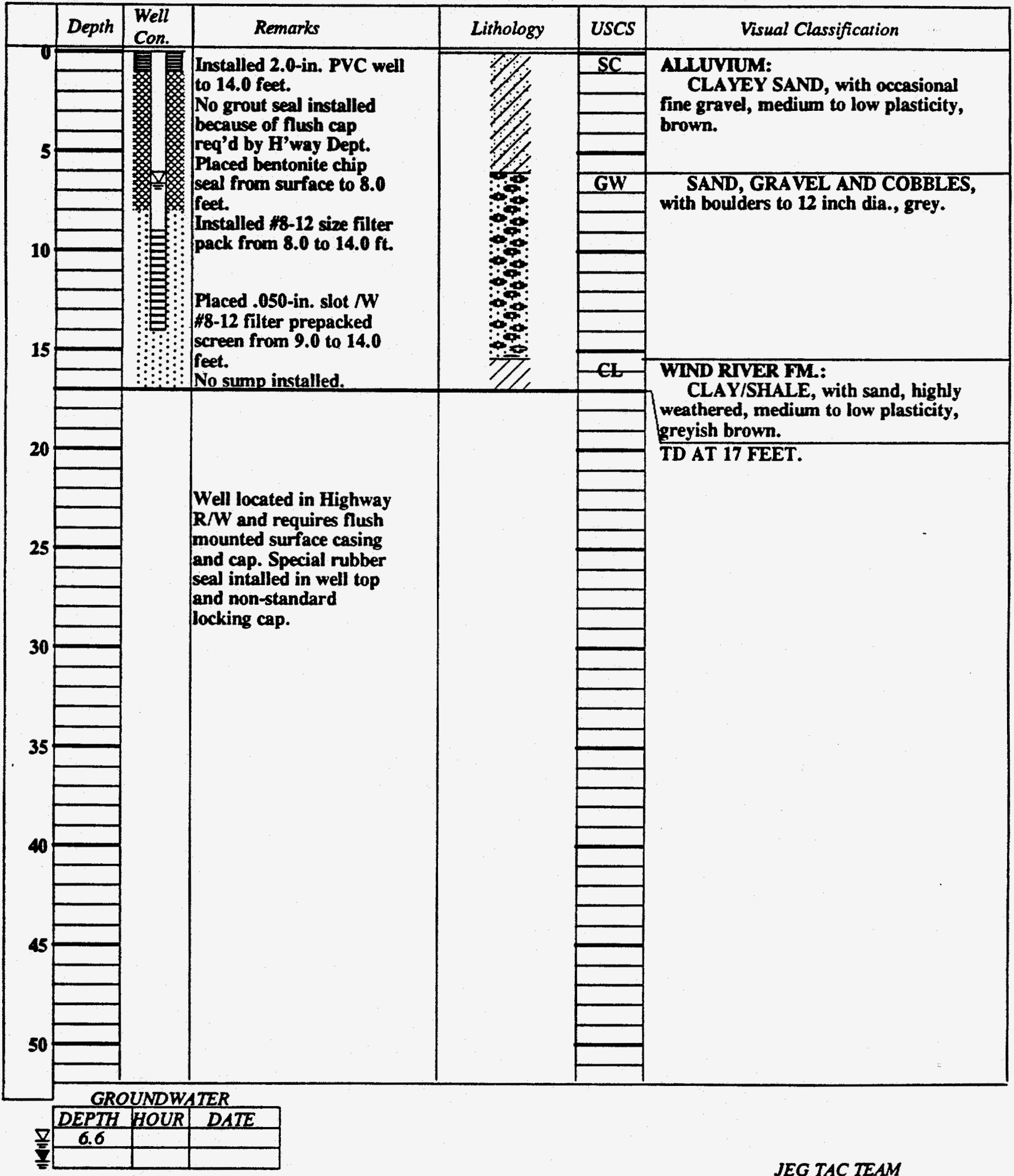


FROJECT RIVERTON SITE, WYO.: UMTRA

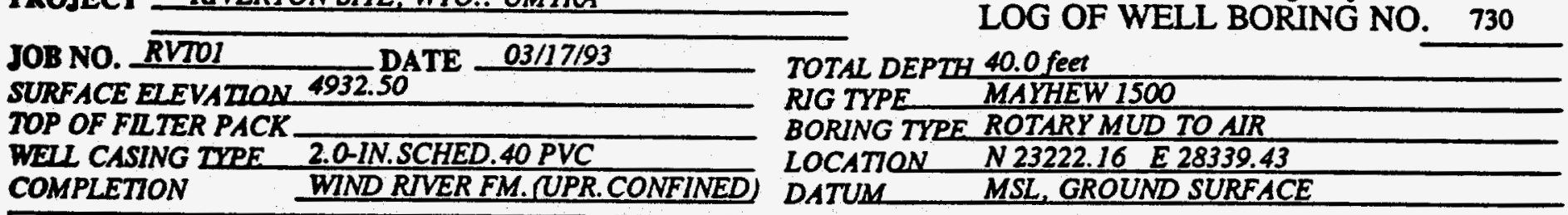

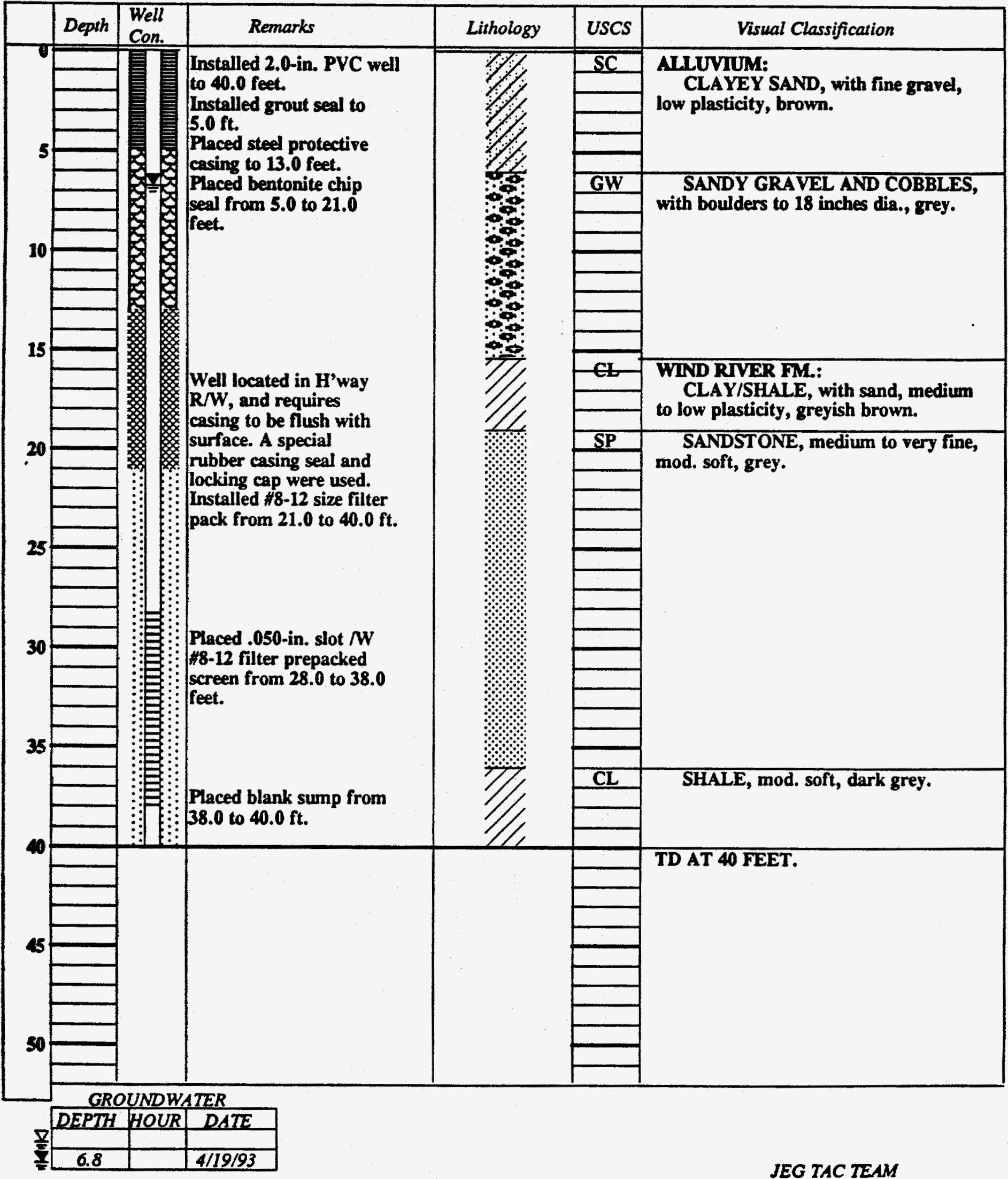




\section{APPENDIX B1}

\section{CONTAMINANTS OF CONCERN IN DOMESTIC WELLS}


GROUNDHATER QUALITY DATA BY LOCATION

SITE: RVTO1 RIVERTON

LOCATION: 0401 DOMESTIC WELL

MORTH COORDINATE: 18004.0 FT

EAST COORDINATE: $\quad 21347.6$ FT

06/12/81 TO 01/10/94

REPORT DATE: 09/07/94

FORMATION OF CONPLETION: NO RECOVERY OF DATA FOR CLASSIFYING (NR)

HYDRAULIC FLOW RELATIONSHIP: UNKMOWN (N)

\begin{tabular}{|c|c|c|c|c|c|c|c|}
\hline PARAMETER NAME & LOS DATE & $\begin{array}{l}\text { SAMPLE } \\
\text { ID }\end{array}$ & $\begin{array}{l}\text { UNITS OF } \\
\text { MEASURE }\end{array}$ & PVI & $\begin{array}{l}\text { PARAMETER } \\
\text { VALUE FLAGS }\end{array}$ & $\begin{array}{l}\text { DETECTION } \\
\text { LIMIT }\end{array}$ & $\begin{array}{l}\text { PARAMETER } \\
\text { UNCERTAINTY }\end{array}$ \\
\hline ARSENIC & $05 / 29 / 85$ & 0001 & MG/L & $<$ & 0.01 & 0.01 & - \\
\hline MOL YBDENUM & $05 / 29 / 85$ & 0001 & MG/L & $<$ & 0.01 & 0.01 & - \\
\hline SULFATE & $05 / 29 / 85$ & 0001 & MG/L & & 118.00 & 0.1 & - \\
\hline URAN IUM & $05 / 29 / 85$ & 0001 & $M G / L$ & & 0.0037 & 0.003 & - \\
\hline VANADIUM & $05 / 29 / 85$ & 0001 & $M G / L$ & $<$ & 0.01 & 0.01 & - \\
\hline
\end{tabular}

PARAMETER VALUE INDICATOR (PVI): < - LESS THAN DETECTION LIMIT

SAMPLE ID CODES:

0001 - FILTERED SAMPLE (.45 MICRONS) 
GROUNDWATER QUALITY DATA BY LOCATION

SITE: RVTO1 RIVERTON

LOCATION: 0402 DOMESTIC WELL

NORTH COORDINATE: 20004.0 FT

EAST COORDINATE: $\quad 27707.6$ FT

$06 / 12 / 81$ TO $01 / 10 / 94$

REPORT DATE: 09/07/94

FORMATION OF COMPLETION: NO RECOVERY OF DATA FOR CLASSIFYING (NR) HYDRAULIC FLOW RELATIONSHIP: UNKNOWN (N)

\begin{tabular}{|c|c|c|c|c|c|c|c|}
\hline PARAMETER NAME & LOG DATE & $\begin{array}{c}\text { SAMPLE } \\
\text { ID }\end{array}$ & $\begin{array}{l}\text { UNITS OF } \\
\text { MEASURE }\end{array}$ & PVI & $\begin{array}{l}\text { PARAMETER } \\
\text { VALUE FLAGS }\end{array}$ & $\begin{array}{l}\text { DETECTION } \\
\text { LIMIT }\end{array}$ & $\begin{array}{l}\text { PARAMETER } \\
\text { UNCERTAINTY }\end{array}$ \\
\hline ARSENIC & $05 / 29 / 85$ & 0001 & HG/L & $<$ & 0.01 & 0.01 & - \\
\hline MANGANESE & $05 / 29 / 85$ & 0001 & MG/L & $<$ & 0.01 & 0.01 & - \\
\hline MOLYBDENUM & $05 / 29 / 85$ & 0001 & $M G / L$ & $<$ & 0.01 & 0.01 & - \\
\hline NICKEL & $05 / 29 / 85$ & 0001 & $M G / L$ & $<$ & 0.04 & 0.04 & - \\
\hline SULFATE & $05 / 29 / 85$ & 0001 & $M G / L$ & & 112.00 & 0.1 & - \\
\hline URANIUM & $05 / 29 / 85$ & 0001 & $M G / L$ & & $0.0021 \mathrm{~J}$ & 0.003 & - \\
\hline VANADIUM & $05 / 29 / 85$ & 0001 & $M G / L$ & $<$ & 0.01 & 0.01 & - \\
\hline
\end{tabular}

PARAMETER VALUE INDICATOR (PVI):

< - LESS THAN DETECTION LIMIT

SAMPLE TD CODES:

0001 - FILTERED SAMPLE (.45 MICRONS)

OTHER PARAMETER VALUE FLAGS:

J - ESTIMATED VALUE 
GROUNDWATER QUALITY DATA BY LOCATION

SITE: RVT01 RIVERTON

LOCATION: 0403 DOMESTIC WELL

NORTH COOROINATE: 23844.0 FT

EAST COORDINATE: $\quad 33407.6$ FT

06/12/81 TO 01/10/94

REPORT DATE : 09/07/94

FORMATION OF COMPLETION: NO RECOVERY OF DATA FOR CLASSIFYING (NR)

HYDRAULIC FLOW RELATIONSHIP: UNKNOWN (N)

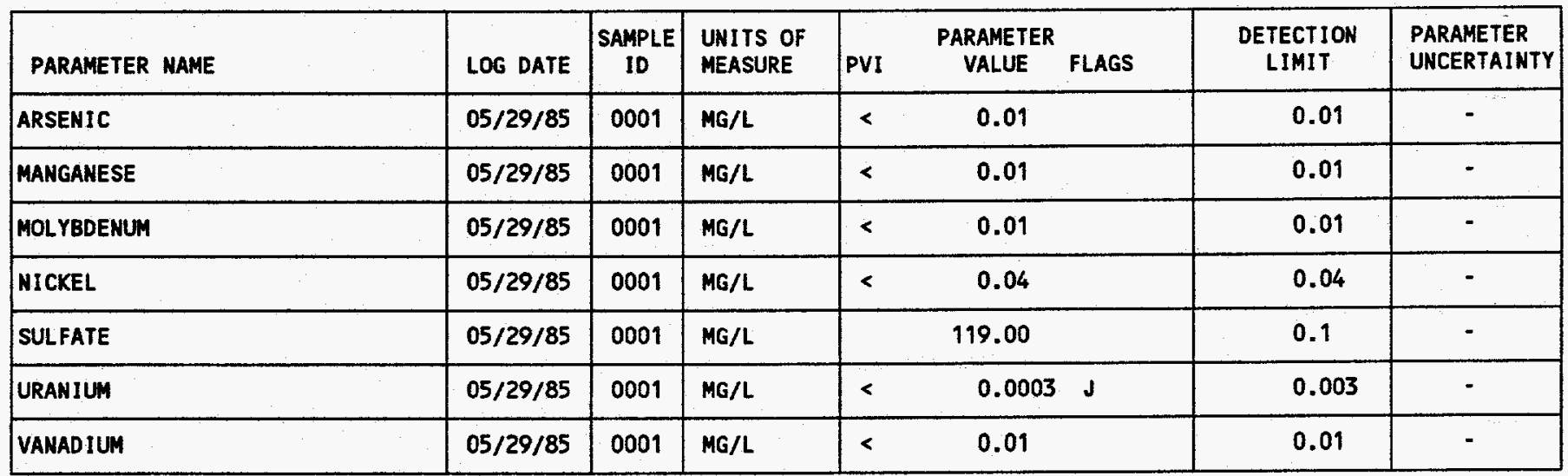

PARAMETER VALUE INDICATOR (PVI): < - LESS THAN DETECTION LIMIT

SAMPLE ID CODES:

0001 - FILTERED SAMPLE (.45 MICRONS)

OTHER PARAMETER VALUE FLAGS:

J. ESTIMATED VALUE 
GROUNDWATER QUALITY DATA BY LOCATION

SITE: RVTO1 RIVERTON

LOCATION: 0404 DOMESTIC WELL

NORTH COORDINATE: 23890.5 FT

EAST COORDINATE: $\quad 27836.5$ FT

06/12/81 TO $01 / 10 / 94$

REPORT DATE: $09 / 07 / 94$

FORMATION OF COMPLETION: NO RECOVERY OF DATA FOR CLASSIFYING (NR) HYDRAULIC FLOW RELATIONSHIP: UNKNOWN (N)

\begin{tabular}{|c|c|c|c|c|c|c|c|}
\hline PARAMETER NAME & LOG DATE & $\begin{array}{c}\text { SAMPLE } \\
\text { ID }\end{array}$ & $\begin{array}{l}\text { UNITS OF } \\
\text { MEASURE }\end{array}$ & PVI & $\begin{array}{l}\text { PARAMETER } \\
\text { VALUE FLAGS }\end{array}$ & $\begin{array}{l}\text { DETECTION } \\
\text { LIMIT }\end{array}$ & $\begin{array}{l}\text { PARAMETER } \\
\text { UNCERTAINTY }\end{array}$ \\
\hline ARSENIC & $05 / 28 / 85$ & 0001 & $M G / L$ & $<$ & 0.01 & 0.01 & - \\
\hline MANGANESE & $05 / 28 / 85$ & 0001 & MG/L & $<$ & 0.01 & 0.01 & - \\
\hline MOL YBDENUM & $05 / 28 / 85$ & 0001 & $M G / L$ & $<$ & 0.01 & 0.01 & - \\
\hline NICKEL & $05 / 28 / 85$ & 0001 & MG/L & $<$ & 0.04 & 0.04 & - \\
\hline SULFATE & $05 / 28 / 85$ & 0001 & MG/L & & 158.00 & 0.1 & - \\
\hline URANIUM & $05 / 28 / 85$ & 0001 & $M G / L$ & $<$ & $0.0003 \mathrm{~J}$ & 0.003 & - \\
\hline VANADIUM & $05 / 28 / 85$ & 0001 & $M G / L$ & $<$ & 0.01 & 0.01 & - \\
\hline
\end{tabular}

PARAMETER VALUE INDICATOR (PVI): < - LESS THAN DETECTION LIMIT

SAMPLE ID CODES:

0001 - FILTERED SAMPLE (.45 MICRONS)

OTHER PARAMETER VALUE FLAGS:

$J$ - ESTIMATED VALUE 
GROUNDWATER QUALITY DATA BY LOCATION

SITE: RVT01 RIVERTON

LOCATION: 0405 DOMESTIC MELL - BLOMBERG

NORTH COORDINATE: 23680.0 FT

EAST COORDINATE: $\quad 28510.0$ FT

$06 / 12 / 81$ TO $01 / 10 / 94$

REPORT DATE: 09/07/94

FORMATION OF COMPLETION: NO RECOVERY OF DATA FOR CLASSIFYING (NR) HYDRAULIC FLOW RELATIONSHIP: UNKNOWN (N)

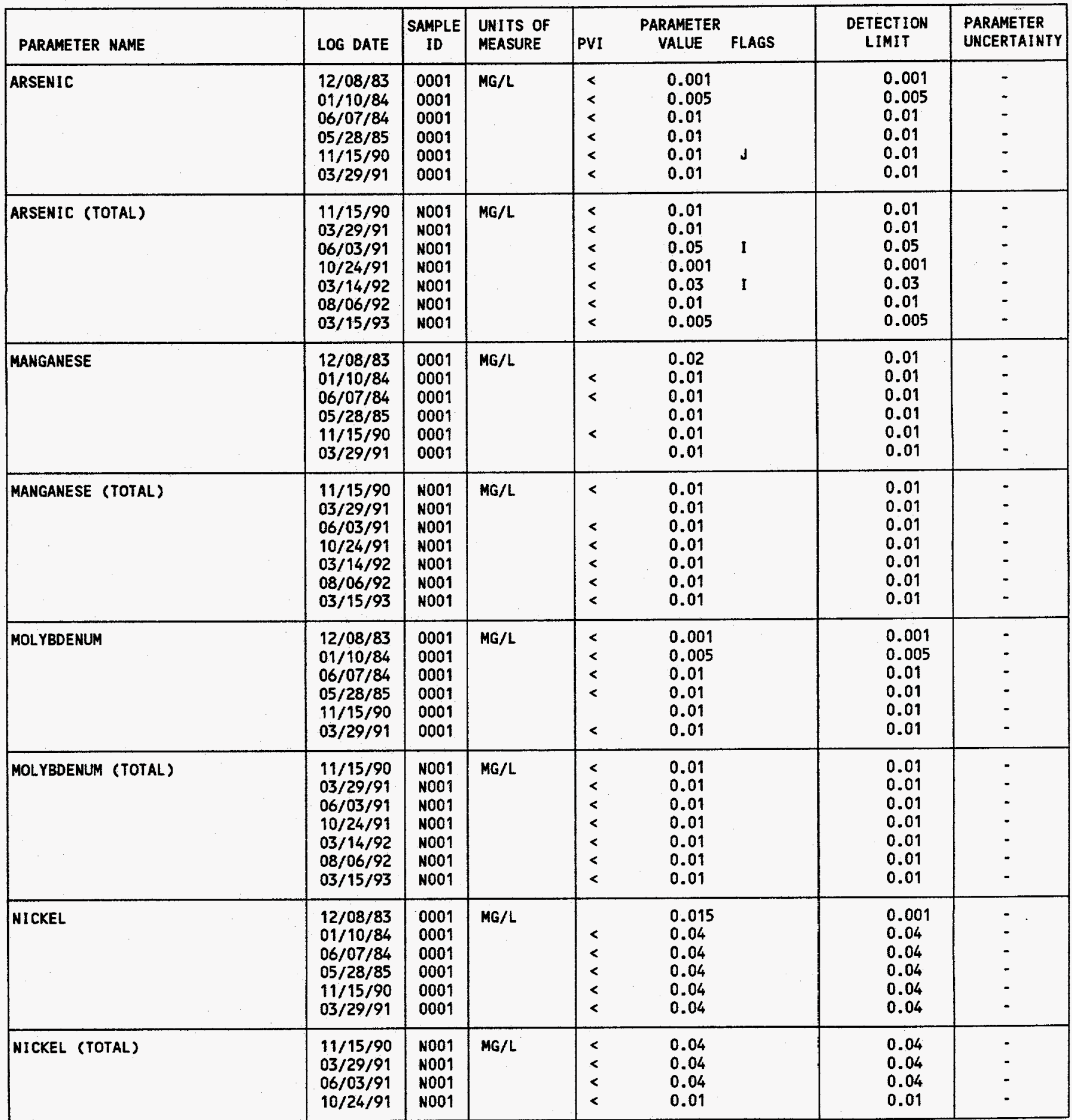

PARAMETER VALUE INDICATOR (PVI): < - LESS THAN DETECTION LIMIT

SAMPLE ID CODES:

0001 - FILTERED SAMPLE (.45 MICRONS)

OTHER PARAMETER VALUE FLAGS:

N001 - UNFILTERED SAMPLE

I - INCREASED DETECTION LIMIT DUE TO REQUIRED DILUTION

$J$ - estimated VALUE 


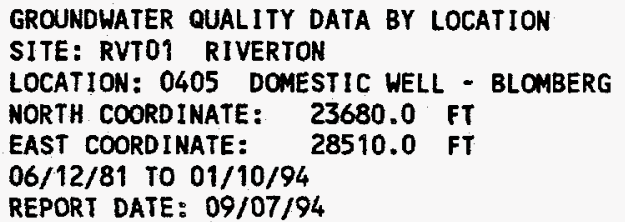

FORMATION OF COMPLETION: NO RECOVERY OF DATA FOR CLASSIFYING (NR) HYDRAULIC FLOW RELATIONSHIP: UNKNOWN (N)

\begin{tabular}{|c|c|c|c|c|c|c|c|}
\hline PARAMETER NAME & LOG DATE & $\begin{array}{l}\text { SAMPLE } \\
\text { ID }\end{array}$ & $\begin{array}{l}\text { UNITS OF } \\
\text { MEASURE }\end{array}$ & PVI & $\begin{array}{l}\text { PARAMETER } \\
\text { VALUE FLAGS }\end{array}$ & $\begin{array}{l}\text { DETECTION } \\
\text { LIMIT }\end{array}$ & $\begin{array}{l}\text { PARAMETER } \\
\text { UNCERTAINTY }\end{array}$ \\
\hline NICKEL (TOTAL) & $\begin{array}{l}03 / 14 / 92 \\
08 / 06 / 92 \\
03 / 15 / 93\end{array}$ & $\begin{array}{l}\text { N001 } \\
\text { N001 } \\
\text { N001 }\end{array}$ & MG/L & $\begin{array}{l}< \\
<\end{array}$ & $\begin{array}{l}0.04 \\
0.04 \\
0.04\end{array}$ & $\begin{array}{l}0.04 \\
0.04 \\
0.04\end{array}$ & : \\
\hline SULFATE & $\begin{array}{l}06 / 12 / 81 \\
12 / 08 / 83 \\
01 / 10 / 84 \\
06 / 07 / 84 \\
05 / 28 / 85 \\
11 / 15 / 90 \\
03 / 29 / 91\end{array}$ & $\begin{array}{l}0001 \\
0001 \\
0001 \\
0001 \\
0001 \\
0001 \\
0001\end{array}$ & $M G / L$ & & $\begin{array}{l}264.00 \\
263.00 \\
250.00 \\
117.00 \\
264.00 \\
277 . \\
339 .\end{array}$ & $\begin{array}{c}- \\
0.1 \\
- \\
0.1 \\
0.1 \\
0.1 \\
10 .\end{array}$ & $\begin{array}{l}: \\
: \\
: \\
-\end{array}$ \\
\hline SULFATE (TOTAL) & $\begin{array}{l}11 / 15 / 90 \\
06 / 03 / 91 \\
10 / 24 / 91 \\
03 / 14 / 92 \\
08 / 06 / 92 \\
03 / 15 / 93\end{array}$ & $\begin{array}{l}\text { NO01 } \\
\text { NOO? } \\
\text { N001 } \\
\text { NO01 } \\
\text { N001 } \\
\text { N001 }\end{array}$ & $M G / L$ & & $\begin{array}{l}276 . \\
297 \\
245 \\
315 \\
277 \\
260\end{array}$ & $\begin{array}{c}0.1 \\
0.1 \\
0.1 \\
40 . \\
30 . \\
1\end{array}$ & : \\
\hline URANIUM & $\begin{array}{l}12 / 08 / 83 \\
01 / 10 / 84 \\
06 / 07 / 84 \\
05 / 28 / 85 \\
11 / 15 / 90 \\
03 / 29 / 91\end{array}$ & $\begin{array}{l}0001 \\
0001 \\
0001 \\
0001 \\
0001 \\
0001\end{array}$ & $M G / L$ & $\begin{array}{l}< \\
<\end{array}$ & $\begin{array}{l}0.0003 \\
0.002 \\
0.0008 \\
0.0003 \\
0.0003 \\
0.005\end{array}$ & $\begin{array}{l}0.0003 \\
- \\
0.0003 \\
0.003 \\
0.0003 \\
0.001\end{array}$ & $\begin{array}{l}- \\
- \\
- \\
-\end{array}$ \\
\hline URANIUM (TOTAL) & $\begin{array}{l}11 / 15 / 90 \\
03 / 29 / 91 \\
06 / 03 / 91 \\
10 / 24 / 91 \\
03 / 14 / 92 \\
08 / 06 / 92 \\
03 / 15 / 93\end{array}$ & $\begin{array}{l}\text { NO01 } \\
\text { N001 } \\
\text { N001 } \\
\text { N001 } \\
\text { N001 } \\
\text { NO01 } \\
\text { N001 }\end{array}$ & $M G / L$ & $\begin{array}{l}< \\
< \\
< \\
< \\
< \\
<\end{array}$ & $\begin{array}{l}0.0003 \\
0.001 \\
0.001 \\
0.0003 \\
0.001 \\
0.001 \\
0.001\end{array}$ & $\begin{array}{l}0.0003 \\
0.001 \\
0.001 \\
0.0003 \\
0.001 \\
0.001 \\
0.001\end{array}$ & $\begin{array}{l}- \\
- \\
- \\
-\end{array}$ \\
\hline VANADIUM & $\begin{array}{l}12 / 08 / 83 \\
01 / 10 / 84 \\
06 / 07 / 84 \\
05 / 28 / 85 \\
11 / 15 / 90 \\
03 / 29 / 91\end{array}$ & $\begin{array}{l}0001 \\
0001 \\
0001 \\
0001 \\
0001 \\
0001\end{array}$ & MG/L. & $\begin{array}{l}< \\
< \\
< \\
< \\
<\end{array}$ & $\begin{array}{l}0.004 \\
0.004 \\
0.01 \\
0.01 \\
0.01 \\
0.01\end{array}$ & $\begin{array}{l}0.004 \\
0.004 \\
0.01 \\
0.01 \\
0.01 \\
0.01\end{array}$ & $\begin{array}{l}- \\
- \\
-\end{array}$ \\
\hline VANADIUM (TOTAL) & $\begin{array}{l}11 / 15 / 90 \\
03 / 29 / 91 \\
06 / 03 / 91 \\
10 / 24 / 91 \\
03 / 14 / 92 \\
08 / 06 / 92 \\
03 / 15 / 93\end{array}$ & $\begin{array}{l}\text { N001 } \\
\text { N001 } \\
\text { N001 } \\
\text { N001 } \\
\text { N001 } \\
\text { N001 } \\
\text { N001 }\end{array}$ & $M G / L$ & $\begin{array}{l}< \\
< \\
< \\
< \\
< \\
< \\
<\end{array}$ & $\begin{array}{l}0.01 \\
0.01 \\
0.01 \\
0.01 \\
0.01 \\
0.01 \\
0.01\end{array}$ & $\begin{array}{l}0.01 \\
0.01 \\
0.01 \\
0.01 \\
0.01 \\
0.01 \\
0.01\end{array}$ & $\begin{array}{l}- \\
: \\
- \\
-\end{array}$ \\
\hline
\end{tabular}

PARAMETER VALUE INDICATOR (PVI): < - LESS THAN DETECTION LIMIT 
GROUNDWATER QUALITY DATA BY LOCATION

SITE: RVTO1 RIVERTON

LOCATION: 0406 DOMESTIC WELL - CLARK/KNOWLES

MORTH COORDINATE: $\quad 24280.0$ FT

EAST COORDINATE: $\quad 27300.0$ FT

06/12/81 TO 01/10/94

REPORT DATE: $09 / 07 / 94$

FORMATION OF COMPLETION: NO RECOVERY OF DATA FOR CLASSIFYING (NR) HYDRAULIC FLOW RELATIONSHIP: UNKNOWN (N)

\begin{tabular}{|c|c|c|c|c|c|c|c|c|}
\hline PARAMETER NAME & LOG DATE & $\begin{array}{c}\text { SAMPLE } \\
\text { ID }\end{array}$ & $\begin{array}{l}\text { UNITS OF } \\
\text { MEASURE }\end{array}$ & PVI & $\begin{array}{l}\text { PARAMETER } \\
\text { VALUE }\end{array}$ & FLAGS & $\begin{array}{l}\text { DETECTION } \\
\text { LIMIT }\end{array}$ & $\begin{array}{l}\text { PARAMETER } \\
\text { UNCERTAINTY }\end{array}$ \\
\hline ARSENIC & $\begin{array}{l}11 / 19 / 90 \\
03 / 29 / 91\end{array}$ & $\begin{array}{l}0001 \\
0001\end{array}$ & $M G / L$ & $\begin{array}{l}< \\
<\end{array}$ & $\begin{array}{l}0.01 \\
0.01\end{array}$ & $\begin{array}{l}\text { GJ } \\
\mathbf{G}\end{array}$ & $\begin{array}{l}0.01 \\
0.01\end{array}$ & - \\
\hline ARSENIC (TOTAL) & $\begin{array}{l}11 / 19 / 90 \\
03 / 29 / 91 \\
06 / 03 / 91 \\
10 / 24 / 91 \\
03 / 14 / 92 \\
08 / 05 / 92 \\
03 / 15 / 93\end{array}$ & $\begin{array}{l}\text { No01 } \\
\text { N001 } \\
0001 \\
N 001 \\
N 001 \\
N 001 \\
N 001\end{array}$ & MG/L & $\begin{array}{l}< \\
< \\
< \\
< \\
< \\
<\end{array}$ & $\begin{array}{l}0.01 \\
0.01 \\
0.05 \\
0.012 \\
0.03 \\
0.01 \\
0.005\end{array}$ & $\begin{array}{l}\mathbf{G} \\
\mathbf{G} \\
\mathbf{G I} \\
\mathbf{I}\end{array}$ & $\begin{array}{l}0.01 \\
0.01 \\
0.05 \\
0.001 \\
0.03 \\
0.01 \\
0.005\end{array}$ & $\begin{array}{l}- \\
- \\
- \\
- \\
- \\
-\end{array}$ \\
\hline MANGAHESE & $\begin{array}{l}11 / 19 / 90 \\
03 / 29 / 91\end{array}$ & $\begin{array}{l}0001 \\
0001\end{array}$ & $\mathrm{MG} / \mathrm{L}$ & $\begin{array}{l}< \\
<\end{array}$ & $\begin{array}{l}0.01 \\
0.01\end{array}$ & $\begin{array}{l}\mathbf{G} \\
\mathbf{G}\end{array}$ & $\begin{array}{l}0.01 \\
0.01\end{array}$ & - \\
\hline MANGANESE (TOTAL) & $\begin{array}{l}11 / 19 / 90 \\
03 / 29 / 91 \\
06 / 03 / 91 \\
10 / 24 / 91 \\
03 / 14 / 92 \\
08 / 05 / 92 \\
03 / 15 / 93\end{array}$ & $\begin{array}{l}\text { No01 } \\
\text { No01 } \\
0001 \\
\text { No01 } \\
\text { No01 } \\
\text { No01 } \\
\text { No01 }\end{array}$ & $M G / L$ & $\begin{array}{l}< \\
< \\
< \\
< \\
< \\
< \\
<\end{array}$ & $\begin{array}{l}0.01 \\
0.01 \\
0.01 \\
0.01 \\
0.01 \\
0.01 \\
0.01\end{array}$ & $\begin{array}{l}\mathbf{G} \\
\mathbf{G} \\
\mathbf{G}\end{array}$ & $\begin{array}{l}0.01 \\
0.01 \\
0.01 \\
0.01 \\
0.01 \\
0.01 \\
0.01\end{array}$ & $\begin{array}{l}- \\
- \\
- \\
- \\
- \\
-\end{array}$ \\
\hline HOL YBDENUM & $\begin{array}{l}11 / 19 / 90 \\
03 / 29 / 91\end{array}$ & $\begin{array}{l}0001 \\
0001\end{array}$ & $M G / L$ & $\begin{array}{l}< \\
<\end{array}$ & $\begin{array}{l}0.01 \\
0.01\end{array}$ & $\mathbf{G}$ & $\begin{array}{l}0.01 \\
0.01\end{array}$ & - \\
\hline MOLYBDENUM (TOTAL) & $\begin{array}{l}11 / 19 / 90 \\
03 / 29 / 91 \\
06 / 03 / 91 \\
10 / 24 / 91 \\
03 / 14 / 92 \\
08 / 05 / 92 \\
03 / 15 / 93\end{array}$ & $\begin{array}{l}\text { No01 } \\
\text { N001 } \\
\text { O001 } \\
\text { No01 } \\
\text { No01 } \\
\text { No01 } \\
\text { No01 }\end{array}$ & $M G / L$ & $\begin{array}{l}< \\
< \\
< \\
< \\
< \\
< \\
<\end{array}$ & $\begin{array}{l}0.01 \\
0.01 \\
0.01 \\
0.01 \\
0.01 \\
0.01 \\
0.01\end{array}$ & $\begin{array}{l}\mathbf{G} \\
\mathbf{G} \\
\mathbf{G}\end{array}$ & $\begin{array}{l}0.01 \\
0.01 \\
0.01 \\
0.01 \\
0.01 \\
0.01 \\
0.01\end{array}$ & $\begin{array}{l}- \\
- \\
- \\
- \\
- \\
-\end{array}$ \\
\hline NICKEL & $\begin{array}{l}11 / 19 / 90 \\
03 / 29 / 91\end{array}$ & $\begin{array}{l}0001 \\
0001\end{array}$ & $M G / L$ & $<$ & $\begin{array}{l}0.04 \\
0.04\end{array}$ & $\begin{array}{l}G \\
G\end{array}$ & $\begin{array}{l}0.04 \\
0.04\end{array}$ & - \\
\hline NICKEL (TOTAL) & $\begin{array}{l}11 / 19 / 90 \\
03 / 29 / 91 \\
06 / 03 / 91 \\
10 / 24 / 91 \\
03 / 14 / 92 \\
08 / 05 / 92 \\
03 / 15 / 93\end{array}$ & $\begin{array}{l}\text { No01 } \\
\text { No01 } \\
0001 \\
\text { N001 } \\
\text { N001 } \\
\text { No01 } \\
\text { No01 }\end{array}$ & $M G / L$ & $\begin{array}{l}< \\
< \\
< \\
< \\
< \\
< \\
<\end{array}$ & $\begin{array}{l}0.04 \\
0.04 \\
0.04 \\
0.01 \\
0.04 \\
0.04 \\
0.04\end{array}$ & $\begin{array}{l}\mathbf{G} \\
\mathbf{G} \\
\mathbf{G}\end{array}$ & $\begin{array}{l}0.04 \\
0.04 \\
0.04 \\
0.01 \\
0.04 \\
0.04 \\
0.04\end{array}$ & $\begin{array}{l}- \\
- \\
- \\
- \\
- \\
- \\
-\end{array}$ \\
\hline SULFATE & $\begin{array}{l}07 / 21 / 81 \\
11 / 19 / 90 \\
03 / 29 / 91\end{array}$ & $\begin{array}{l}0001 \\
0001 \\
0001\end{array}$ & $M G / L$ & & $\begin{array}{l}229.00 \\
297 . \\
358 .\end{array}$ & G & $\begin{array}{c}-\overline{-} \\
10 .\end{array}$ & $\begin{array}{l}- \\
-\end{array}$ \\
\hline SULFATE (TOTAL) & $\begin{array}{l}11 / 19 / 90 \\
06 / 03 / 91 \\
10 / 24 / 91 \\
03 / 14 / 92 \\
08 / 05 / 92 \\
03 / 15 / 93\end{array}$ & $\begin{array}{l}\text { No01 } \\
0001 \\
\text { N001 } \\
\text { No01 } \\
\text { No01 } \\
\text { No01 }\end{array}$ & $M G / L$ & & $\begin{array}{l}295 . \\
286 \\
345 \\
226 . \\
312 . \\
275\end{array}$ & $\begin{array}{l}\mathbf{G} \\
\mathbf{G}\end{array}$ & $\begin{array}{c}0.1 \\
0.1 \\
0.1 \\
40 . \\
30 . \\
1\end{array}$ & $\begin{array}{l}- \\
- \\
- \\
- \\
-\end{array}$ \\
\hline URANIUM & $11 / 19 / 90$ & 0001 & $M G / L$ & & 0.0004 & $\mathbf{G}$ & 0.0003 & - \\
\hline
\end{tabular}

PARAMETER VALUE INDICATOR (PVI): < - LESS THAN DETECTION LIMIT

SAMPLE ID CODES:

OTHER PARAMETER VALUE FLAGS:

0001 - FILTERED SAMPLE (.45 MICRONS)

N001 - UNFILTERED SAMPLE

G - PH > 9, POSSIBLE GROUT CONTAMINATION

I - INCREASED DETECTION LIMIT DUE TO REQUIRED DILUTION

$J$ - ESTIMATED VALUE 
GROUNDWATER QUALITY DATA BY LOCATION

SITE: RVTOI RIVERTON

LOCATION: 0406 DOMESTIC WELL - CLARK/KNOWLES

NORTH COORDINATE: 24280.0 FT

EAST COORDINATE: $\quad 27300.0$ FT

$06 / 12 / 81$ TO $01 / 10 / 94$

REPORT DATE: 09/07/94

FORMATION OF COMPLETION: NO RECOVERY OF DATA FOR CLASSIFYING (NR) HYDRAULIC FLOW RELATIONSHIP: UNKNOWN (N)

\begin{tabular}{|c|c|c|c|c|c|c|c|c|}
\hline PARAMETER NAME & LOG DATE & $\begin{array}{c}\text { SAMPLE } \\
\text { ID }\end{array}$ & $\begin{array}{l}\text { UNITS OF } \\
\text { MEASURE }\end{array}$ & PVI & $\begin{array}{l}\text { ARAMETER } \\
\text { VALUE }\end{array}$ & FLAGS & $\begin{array}{l}\text { DETECTION } \\
\text { LIMIT }\end{array}$ & $\begin{array}{l}\text { PARAMETER } \\
\text { UNCERTAINTY }\end{array}$ \\
\hline URANIUM & $03 / 29 / 91$ & 0001 & $M G / L$ & & 0.010 & G & 0.001 & - \\
\hline URANIUM (TOTAL) & $\begin{array}{l}11 / 19 / 90 \\
03 / 29 / 91 \\
06 / 03 / 91 \\
10 / 24 / 91 \\
03 / 14 / 92 \\
08 / 05 / 92 \\
03 / 15 / 93\end{array}$ & $\begin{array}{l}\text { No01 } \\
\text { No01 } \\
0001 \\
\text { No01 } \\
\text { No01 } \\
\text { No01 } \\
\text { No01 }\end{array}$ & MG/L & $\begin{array}{l}< \\
< \\
< \\
< \\
<\end{array}$ & $\begin{array}{l}0.0003 \\
0.002 \\
0.014 \\
0.0003 \\
0.001 \\
0.001 \\
0.001\end{array}$ & $\begin{array}{l}\mathbf{G} \\
\mathbf{G} \\
\mathbf{G}\end{array}$ & $\begin{array}{l}0.0003 \\
0.001 \\
0.001 \\
0.0003 \\
0.001 \\
0.001 \\
0.001\end{array}$ & $\begin{array}{l}- \\
- \\
- \\
- \\
- \\
-\end{array}$ \\
\hline VANADIUM & $\begin{array}{l}11 / 19 / 90 \\
03 / 29 / 91\end{array}$ & $\begin{array}{l}0001 \\
0001\end{array}$ & $M G / L$ & $<$ & $\begin{array}{l}0.01 \\
0.02\end{array}$ & $\begin{array}{l}G \\
G\end{array}$ & $\begin{array}{l}0.01 \\
0.01\end{array}$ & - \\
\hline VANADIUM (TOTAL) & $\begin{array}{l}11 / 19 / 90 \\
03 / 29 / 91 \\
06 / 03 / 91 \\
10 / 24 / 91 \\
03 / 14 / 92 \\
08 / 05 / 92 \\
03 / 15 / 93\end{array}$ & $\begin{array}{l}\text { No01 } \\
\text { N001 } \\
0001 \\
\text { N001 } \\
\text { N001 } \\
\text { N001 } \\
\text { N001 }\end{array}$ & $M G / L$ & $\begin{array}{l}< \\
< \\
< \\
< \\
< \\
< \\
<\end{array}$ & $\begin{array}{l}0.01 \\
0.01 \\
0.01 \\
0.01 \\
0.01 \\
0.01 \\
0.01\end{array}$ & $\begin{array}{l}\mathbf{G} \\
\mathbf{G} \\
\mathbf{G}\end{array}$ & $\begin{array}{l}0.01 \\
0.01 \\
0.01 \\
0.01 \\
0.01 \\
0.01 \\
0.01\end{array}$ & $\begin{array}{l}- \\
- \\
- \\
- \\
- \\
-\end{array}$ \\
\hline
\end{tabular}

PARAMETER VALUE INDICATOR (PVI): < - LESS THAN DETECTION LIMIT

SAMPLE ID CODES:

OTHER PARAMETER VALUE FLAGS:

0001 - FILTERED SAMPLE (.45 MICRONS)

G - PH > 9, POSSIBLE GROUT CONTAMINATION

N001 - UNFILTERED SAMPLE 
GROUNDWATER QUALITY DATA BY LOCATION

SITE: RVTO1 RIVERTON

LOCATION: 0409 DOMESTIC WELL

NORTH COORDINATE: 23330.0 FT

EAST COORDINATE: $\quad 28455.5$ FT

06/12/81 To 01/10/94

REPORT DATE: 09/07/94

FORMATION OF COMPLETION: NO RECOVERY OF DATA FOR CLASSIFYING (NR) HYDRAULIC FLOW RELATIONSHIP: UNKNOWN (N)

\begin{tabular}{|c|c|c|c|c|c|c|c|}
\hline PARAMETER NAME & LOG DATE & $\underset{\text { ID }}{\text { SAMPLE }}$ & $\begin{array}{l}\text { UNITS OF } \\
\text { MEASURE }\end{array}$ & PVI & $\begin{array}{l}\text { PARAMETER } \\
\text { VALUE FLAGS }\end{array}$ & $\begin{array}{l}\text { DETECTION } \\
\text { LIMIT }\end{array}$ & $\begin{array}{l}\text { PARAMETER } \\
\text { UNCERTAINTY }\end{array}$ \\
\hline ARSENIC & $05 / 30 / 85$ & 0001 & $M G / L$ & $<$ & 0.01 & 0.01 & - \\
\hline MANGANESE & $05 / 30 / 85$ & 0001 & $M G / L$ & $<$ & 0.01 & 0.01 & - \\
\hline MOL YBDENUM & $05 / 30 / 85$ & 0001 & MG/L & $<$ & 0.01 & 0.01 & - \\
\hline NICKEL & $05 / 30 / 85$ & 0001 & $M G / L$ & $<$ & 0.04 & 0.04 & - \\
\hline SULFATE & $05 / 30 / 85$ & 0001 & $M G / L$ & & 370.00 & 0.1 & - \\
\hline VANADIUM & $05 / 30 / 85$ & 0001 & $M G / L$ & $<$ & 0.01 & 0.01 & - \\
\hline
\end{tabular}

PARAMETER VALUE INDICATOR (PVI):

< - LESS THAN DETECTION LIMIT

SAMPLE IO CODES

0001 - FILTERED SAMPLE (.45 MICRONS) 
GROUNDWATER QUALITY DATA BY LOCATION

SITE: RVTO1 RIVERTON

LOCATION: 0410 DOMESTIC WELL - RUTH BIGLAKE

NORTH COORDINATE: 22320.0 FT

EAST COORDINATE: $\quad 26800.0$ FT

$06 / 12 / 81$ TO $01 / 10 / 94$

REPORT DATE : 09/07/94

FORMATION OF COMPLETION: BLACKSANDS (BS)

HYDRAULIC FLOW RELATIONSHIP: UNKNOWN (N)

\begin{tabular}{|c|c|c|c|c|c|c|c|c|}
\hline PARAMETER NAME & LOG DATE & $\begin{array}{c}\text { SAMPLE } \\
\text { ID }\end{array}$ & $\begin{array}{l}\text { UNITS OF } \\
\text { MEASURE }\end{array}$ & PVI & $\begin{array}{l}\text { PARAMETER } \\
\text { VALUE }\end{array}$ & FLAGS & $\begin{array}{l}\text { DETECTION } \\
\text { LIMIT }\end{array}$ & $\begin{array}{l}\text { PARAMETER } \\
\text { UNCERTAINTY }\end{array}$ \\
\hline ARSENIC & $\begin{array}{l}12 / 08 / 83 \\
01 / 10 / 84 \\
03 / 28 / 84 \\
06 / 07 / 84 \\
03 / 30 / 90 \\
11 / 15 / 90 \\
03 / 28 / 91\end{array}$ & $\begin{array}{l}0001 \\
0001 \\
0001 \\
0001 \\
0001 \\
0001 \\
0001\end{array}$ & MG/L & $\begin{array}{l}< \\
< \\
< \\
< \\
< \\
<\end{array}$ & $\begin{array}{l}0.001 \\
0.005 \\
0.001 \\
0.01 \\
0.01 \\
0.01 \\
0.01\end{array}$ & GJ & $\begin{array}{l}0.001 \\
0.005 \\
0.001 \\
0.01 \\
0.01 \\
0.01 \\
0.01\end{array}$ & $\begin{array}{l}- \\
- \\
- \\
-\end{array}$ \\
\hline ARSENIC (TOTAL) & $\begin{array}{l}03 / 30 / 90 \\
11 / 15 / 90 \\
03 / 28 / 91 \\
06 / 03 / 91 \\
10 / 23 / 91 \\
03 / 16 / 92 \\
08 / 05 / 92 \\
03 / 16 / 93 \\
03 / 16 / 93\end{array}$ & $\begin{array}{l}\text { N001 } \\
\text { N001 } \\
\text { N001 } \\
\text { N001 } \\
\text { NO01 } \\
\text { N001 } \\
\text { NO01 } \\
\text { N001 } \\
\text { NO02 }\end{array}$ & $M G / L$ & $\begin{array}{l}< \\
< \\
< \\
< \\
< \\
< \\
< \\
< \\
<\end{array}$ & $\begin{array}{l}0.01 \\
0.01 \\
0.01 \\
0.05 \\
0.001 \\
0.005 \\
0.01 \\
0.005 \\
0.005\end{array}$ & $\begin{array}{l}G \\
1\end{array}$ & $\begin{array}{l}0.01 \\
0.01 \\
0.01 \\
0.05 \\
0.001 \\
0.005 \\
0.01 \\
0.005 \\
0.005\end{array}$ & $\begin{array}{l}- \\
- \\
- \\
- \\
- \\
- \\
- \\
-\end{array}$ \\
\hline MANGANESE & $\begin{array}{l}12 / 08 / 83 \\
01 / 10 / 84 \\
03 / 28 / 84 \\
06 / 07 / 84 \\
03 / 30 / 90 \\
11 / 15 / 90 \\
03 / 28 / 91\end{array}$ & $\begin{array}{l}0001 \\
0001 \\
0001 \\
0001 \\
0001 \\
0001 \\
0001\end{array}$ & $M G / L$ & $\begin{array}{l}< \\
< \\
<\end{array}$ & $\begin{array}{l}0.03 \\
0.01 \\
0.01 \\
0.01 \\
0.01 \\
0.02 \\
0.03\end{array}$ & G & $\begin{array}{l}0.01 \\
0.01 \\
0.01 \\
0.01 \\
0.01 \\
0.01 \\
0.01\end{array}$ & $\begin{array}{l}- \\
- \\
- \\
-\end{array}$ \\
\hline MANGANESE (TOTAL) & $\begin{array}{l}03 / 30 / 90 \\
11 / 15 / 90 \\
03 / 28 / 91 \\
06 / 03 / 91 \\
10 / 23 / 91 \\
03 / 16 / 92 \\
08 / 05 / 92 \\
03 / 16 / 93 \\
03 / 16 / 93\end{array}$ & $\begin{array}{l}\text { NO01 } \\
\text { N001 } \\
\text { NO01 } \\
\text { NO01 } \\
\text { NO01 } \\
\text { NO01 } \\
\text { NO01 } \\
\text { NO01 } \\
\text { NO02 }\end{array}$ & $M G / L$ & $\begin{array}{l}< \\
< \\
<\end{array}$ & $\begin{array}{l}0.01 \\
0.02 \\
0.02 \\
0.01 \\
0.01 \\
0.01 \\
0.01 \\
0.01 \\
0.01\end{array}$ & G & $\begin{array}{l}0.01 \\
0.01 \\
0.01 \\
0.01 \\
0.01 \\
0.01 \\
0.01 \\
0.01 \\
0.01\end{array}$ & $\begin{array}{l}- \\
- \\
- \\
- \\
- \\
-\end{array}$ \\
\hline MOLYBDENUM & $\begin{array}{l}12 / 08 / 83 \\
01 / 10 / 84 \\
03 / 28 / 84 \\
06 / 07 / 84 \\
03 / 30 / 90 \\
11 / 15 / 90 \\
03 / 28 / 91\end{array}$ & $\begin{array}{l}0001 \\
0001 \\
0001 \\
0001 \\
0001 \\
0001 \\
0001\end{array}$ & $M G / L$ & $\begin{array}{l}< \\
< \\
< \\
< \\
<\end{array}$ & $\begin{array}{l}0.001 \\
0.005 \\
0.001 \\
0.01 \\
0.01 \\
0.02 \\
0.01\end{array}$ & G & $\begin{array}{l}0.001 \\
0.005 \\
0.001 \\
0.01 \\
0.01 \\
0.01 \\
0.01\end{array}$ & $\begin{array}{l}- \\
- \\
- \\
-\end{array}$ \\
\hline MOLYBDENUM (TOTAL) & $\begin{array}{l}03 / 30 / 90 \\
11 / 15 / 90 \\
03 / 28 / 91 \\
06 / 03 / 91 \\
10 / 23 / 91 \\
03 / 16 / 92 \\
08 / 05 / 92 \\
03 / 16 / 93 \\
03 / 16 / 93\end{array}$ & $\begin{array}{l}\text { NO01 } \\
\text { NO01 } \\
\text { NO01 } \\
\text { N001 } \\
\text { NO01 } \\
\text { NO01 } \\
\text { NO01 } \\
\text { NO01 } \\
\text { NO02 }\end{array}$ & $M G / L$ & $\begin{array}{l}< \\
< \\
< \\
< \\
< \\
< \\
<\end{array}$ & $\begin{array}{l}0.01 \\
0.01 \\
0.01 \\
0.01 \\
0.01 \\
0.01 \\
0.01 \\
0.01 \\
0.01\end{array}$ & G & $\begin{array}{l}0.01 \\
0.01 \\
0.01 \\
0.01 \\
0.01 \\
0.01 \\
0.01 \\
0.01 \\
0.01\end{array}$ & $\begin{array}{l}- \\
- \\
- \\
- \\
- \\
-\end{array}$ \\
\hline NICKEL & $\begin{array}{l}12 / 08 / 83 \\
01 / 10 / 84\end{array}$ & $\begin{array}{l}0001 \\
0001\end{array}$ & MG/L & $<$ & $\begin{array}{l}0.022 \\
0.04\end{array}$ & & $\begin{array}{l}0.001 \\
0.04\end{array}$ & - \\
\hline
\end{tabular}

PARAMETER VALUE INDICATOR (PVI): < - LESS THAN DETECTION LIMIT

SAMPLE ID CODES:

OTHER PARAMETER VALUE FLAGS:

G - PH > 9, POSSIBLE GROUT CONTAMINATION
I - INCREASEO DETECTION LIMIT DUE TO REQUIRED DILUTION

0001 - FILTERED SAMPLE (.45 MICRONS)

NOO1 - UNFILTERED SAMPLE

NOO2 - UNFILTERED REPLICATE SAMPLE

$\downarrow$ - estimated VALUe 
GROUNDWATER QUALITY DATA BY LOCATION

SITE: RVTO1 RIVERTON

LOCATION: 0410 DOMESTIC WELL - RUTH BIGLAKE

NORTH COORDINATE: 22320.0 FT

EAST COORDINATE: $\quad 26800.0$ FT

06/12/81 TO 01/10/94

REPORT DATE: $09 / 07 / 94$

FORMATION OF COMPLETION: BLACKSANDS (BS)

HYDRAULIC FLOW RELATIONSHIP: UNKHOWN (N)

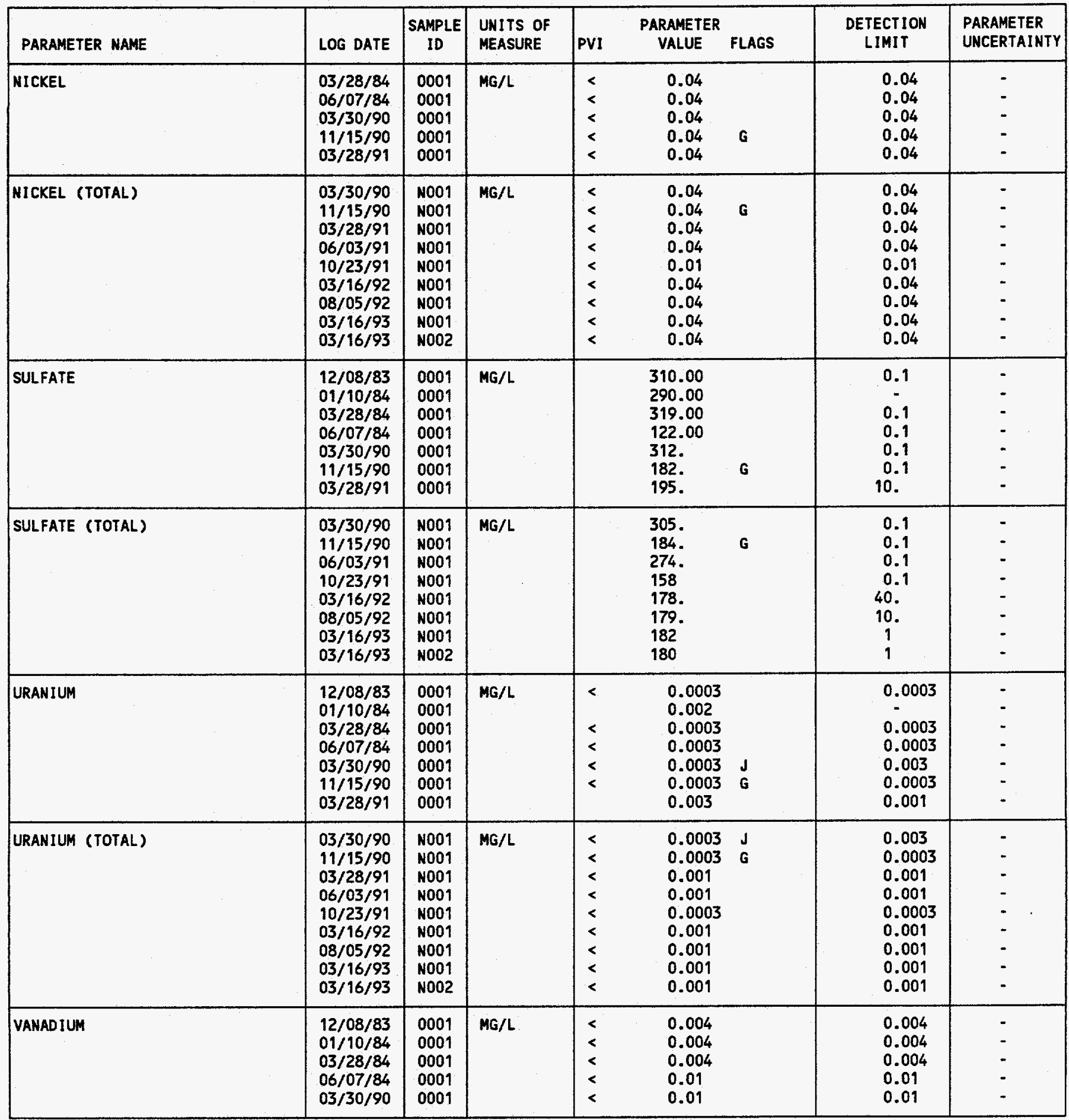

PARAMETER VALUE INDICATOR (PVI): < - LESS THAN DETECTION LIMIT

SAMPLE ID CODES:

0001 - FILTERED SAMPLE (.45 MICRONS)

OTHER PARAMETER VALUE FLAGS:

M001 - UNFILTERED SAMPLE

$G$ - PH > 9, POSSIBLE GROUT CONTAMINATION

NOO2 - UNFILTERED REPLICATE SAMPLE

$J$ - ESTIMATED VALUE 
GROUNDWATER QUALITY DATA BY LOCATION

SITE: RVTO1 RIVERTON

LOCATION: 0410 DOMESTIC WELL - RUTH BIGLAKE

NORTH COORDINATE: 22320.0 FT

EAST COORDINATE: 26800.0 FT

06/12/81 TO 01/10/94

REPORT DATE: $09 / 07 / 94$

FORMATION OF COMPLEIION: BLACKSANDS (BS)

HYDRAULIC FLOW RELATIONSHIP: UNKNOWN (N)

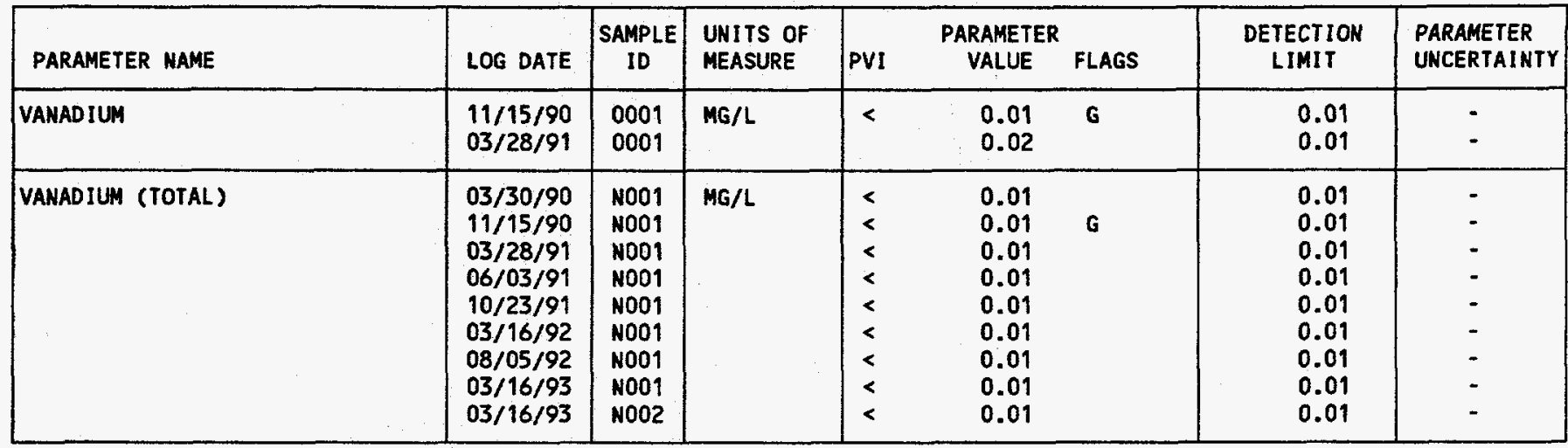

PARAMETER VALUE INDICATOR (PVI): < - LESS THAN DETECTION LIMIT

SAMPLE ID COOES:

OTHER PARAMETER VALUE FLAGS:

G - PH > 9, POSSIBLE GROUT CONTAMINATION

SAMPLE - FILTERED SAMPLE ( 45 MICRONS)

N001 - UNFILTERED SAMPLE

NOO2 - UNFILTERED REPLICATE SAMPLE 


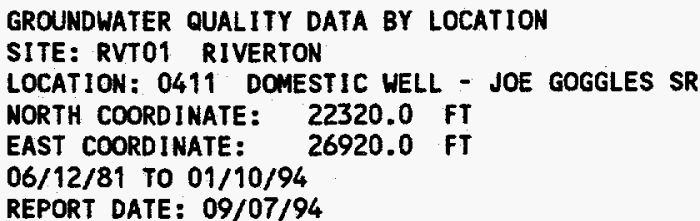

FORMATION OF COMPLETION: NO RECOVERY OF DATA FOR CLASSIFYING (NR) HYORAULIC FLOW RELATIONSHIP: UNKNOWN (N)

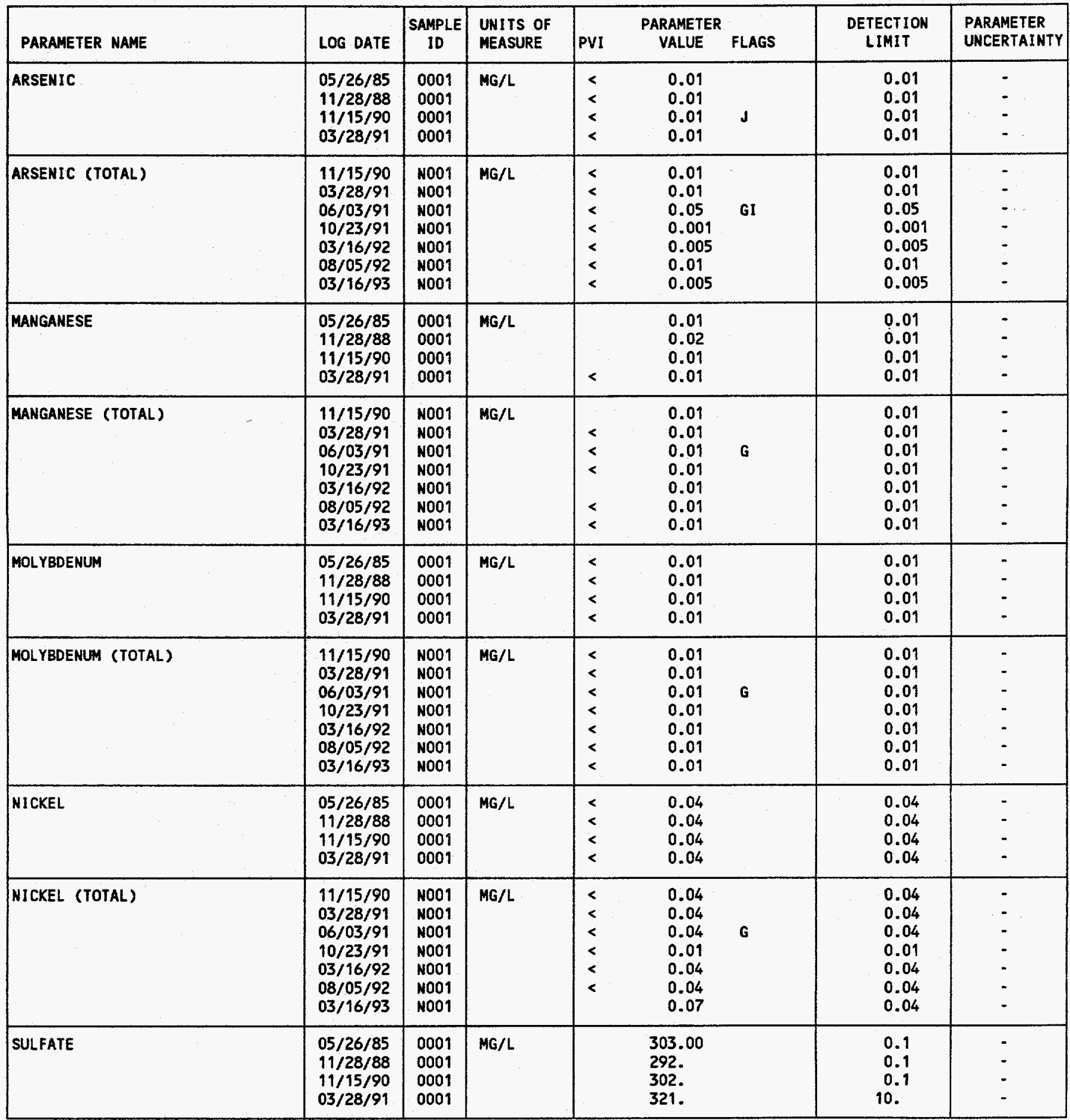

PARAMETER VALUE INDICATOR (PVI): < - LESS THAN DETECTION LIMIT

OTHER PARAMETER VALUE FLAGS:

G - PH > 9, POSSIBLE GROUT CONTAMINATION

I - INCREASED DETECTION LIMIT DUE TO REQUIRED DILUTION

$J$ - ESTIMATED VALUE
SAMPLE ID CODES:

0001 - FILTERED SAMPLE (.45 MICRONS) N001 - UNFILTERED SAMPLE 


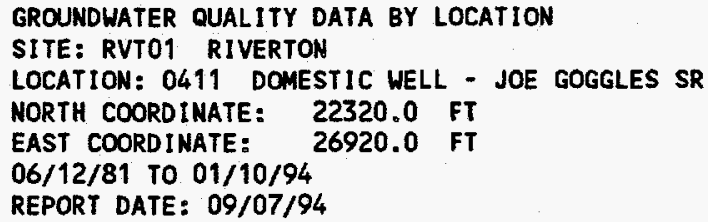

FORMATION OF COMPLETION: NO RECOVERY OF DATA FOR CLASSIFYING (NR) HYDRAULIC FLOW RELATIONSHIP: UNKNOWN (N)

\begin{tabular}{|c|c|c|c|c|c|c|c|c|}
\hline PARAMETER NAME & LOG DATE & $\begin{array}{c}\text { SAMPLE } \\
\text { ID }\end{array}$ & $\begin{array}{l}\text { UNITS OF } \\
\text { MEASURE }\end{array}$ & PVI & $\begin{array}{l}\text { ARAMETER } \\
\text { VALUE }\end{array}$ & FLAGS & $\begin{array}{l}\text { DETECTION } \\
\text { LIMIT }\end{array}$ & $\begin{array}{l}\text { PARAMETER } \\
\text { UNCERTAINTY }\end{array}$ \\
\hline SULFATE (TOTAL) & $\begin{array}{l}11 / 15 / 90 \\
06 / 03 / 91 \\
10 / 23 / 91 \\
03 / 16 / 92 \\
08 / 05 / 92 \\
03 / 16 / 93\end{array}$ & $\begin{array}{l}\text { N001 } \\
\text { N001 } \\
\text { N001 } \\
\text { N001 } \\
\text { N001 } \\
\text { N001 }\end{array}$ & $M G / L$ & & $\begin{array}{l}313 . \\
252 . \\
267 \\
344 . \\
318 . \\
304\end{array}$ & G & $\begin{array}{c}0.1 \\
0.1 \\
0.1 \\
40 . \\
30 . \\
1\end{array}$ & $\begin{array}{l}- \\
- \\
- \\
-\end{array}$ \\
\hline URANIUM & $\begin{array}{l}05 / 26 / 85 \\
11 / 28 / 88 \\
11 / 15 / 90 \\
03 / 28 / 91\end{array}$ & $\begin{array}{l}0001 \\
0001 \\
0001 \\
0001\end{array}$ & $M G / L$ & $<$ & $\begin{array}{l}0.0003 \\
0.0003 \\
0.0003 \\
0.001\end{array}$ & J & $\begin{array}{l}0.003 \\
0.003 \\
0.0003 \\
0.001\end{array}$ & $\begin{array}{l}- \\
-\end{array}$ \\
\hline URANIUM (TOTAL) & $\begin{array}{l}11 / 15 / 90 \\
03 / 28 / 91 \\
06 / 03 / 91 \\
10 / 23 / 91 \\
03 / 16 / 92 \\
08 / 05 / 92 \\
03 / 16 / 93\end{array}$ & $\begin{array}{l}\text { N001 } \\
\text { N001 } \\
\text { N001 } \\
\text { N001 } \\
\text { N001 } \\
\text { N001 } \\
\text { N001 }\end{array}$ & $M G / L$ & $\begin{array}{l}< \\
< \\
<\end{array}$ & $\begin{array}{l}0.0003 \\
0.001 \\
0.001 \\
0.0003 \\
0.001 \\
0.001 \\
0.001\end{array}$ & G & $\begin{array}{l}0.0003 \\
0.001 \\
0.001 \\
0.0003 \\
0.001 \\
0.001 \\
0.001\end{array}$ & $\begin{array}{l}- \\
- \\
- \\
-\end{array}$ \\
\hline VANADIUM & $\begin{array}{l}05 / 26 / 85 \\
11 / 28 / 88 \\
11 / 15 / 90 \\
03 / 28 / 91\end{array}$ & $\begin{array}{l}0001 \\
0001 \\
0001 \\
0001\end{array}$ & $M G / L$ & $\begin{array}{l}< \\
< \\
<\end{array}$ & $\begin{array}{l}0.01 \\
0.01 \\
0.01 \\
0.01\end{array}$ & & $\begin{array}{l}0.01 \\
0.01 \\
0.01 \\
0.01\end{array}$ & :- \\
\hline VANADIUM (TOTAL) & $\begin{array}{l}11 / 15 / 90 \\
03 / 28 / 91 \\
06 / 03 / 91 \\
10 / 23 / 91 \\
03 / 16 / 92 \\
08 / 05 / 92 \\
03 / 16 / 93\end{array}$ & $\begin{array}{l}\text { N001 } \\
\text { N001 } \\
\text { N001 } \\
\text { N001 } \\
\text { N001 } \\
\text { N001 } \\
\text { N001 }\end{array}$ & $M G / L$ & $\begin{array}{l}< \\
< \\
< \\
< \\
< \\
< \\
<\end{array}$ & $\begin{array}{l}0.01 \\
0.01 \\
0.01 \\
0.01 \\
0.01 \\
0.01 \\
0.01\end{array}$ & G & $\begin{array}{l}0.01 \\
0.01 \\
0.01 \\
0.01 \\
0.01 \\
0.01 \\
0.01\end{array}$ & $\begin{array}{l}: \\
: \\
: \\
-\end{array}$ \\
\hline
\end{tabular}

PARAMETER VALUE INDICATOR (PVI): < - LESS THAN DETECTION LIMIT

SAMPLE ID CODES:

OTHER PARAMETER VALUE FLAGS:

0001 - FILTERED SAMPLE (.45 MICRONS)

G - PH > 9, POSSIBLE GROUT CONTAMINATION

NOOI - UNFILTERED SAMPLE

J - estimated value 
GROUNDWATER QUALITY DATA BY LOCATION

SITE: RVTO1. RIVERTON

LOCATION: 0412 DOMESTIC WELL

MORTH COORDINATE: 24394.0 FT

EAST COORDINATE: 28447.6 FT

06/12/81 TO 01/10/94

REPORT DATE: $09 / 07 / 94$

FORMATION OF COMPLETION: NO RECOVERY OF DATA FOR CLASSIFYING (NR) HYDRAULIC FLOW RELATIONSHIP: UNKNOWN (N)

\begin{tabular}{|c|c|c|c|c|c|c|c|}
\hline PARAMETER NAME & LOG DATE & $\begin{array}{c}\text { SAMPLE } \\
\text { ID }\end{array}$ & $\begin{array}{l}\text { UNITS OF } \\
\text { MEASURE }\end{array}$ & PVI & $\begin{array}{l}\text { PARAMETER } \\
\text { VALUE FLAGS }\end{array}$ & $\begin{array}{l}\text { DETECTION } \\
\text { LIMIT }\end{array}$ & $\begin{array}{l}\text { PARAMETER } \\
\text { UNCERTAINTY }\end{array}$ \\
\hline ARSENIC & $\begin{array}{l}06 / 05 / 85 \\
06 / 05 / 85 \\
06 / 05 / 85 \\
06 / 05 / 85 \\
06 / 05 / 85\end{array}$ & $\begin{array}{l}0001 \\
0002 \\
0003 \\
0004 \\
0005\end{array}$ & $M G / L$ & $\begin{array}{l}< \\
< \\
< \\
< \\
<\end{array}$ & $\begin{array}{l}0.01 \\
0.01 \\
0.01 \\
0.01 \\
0.01\end{array}$ & $\begin{array}{l}0.01 \\
0.01 \\
0.01 \\
0.01 \\
0.01\end{array}$ & $\begin{array}{l}- \\
- \\
. \\
-\end{array}$ \\
\hline MANGANESE & $\begin{array}{l}06 / 05 / 85 \\
06 / 05 / 85 \\
06 / 05 / 85 \\
06 / 05 / 85 \\
06 / 05 / 85\end{array}$ & $\begin{array}{l}0001 \\
0002 \\
0003 \\
0004 \\
0005\end{array}$ & $M G / L$ & $\begin{array}{l}< \\
< \\
< \\
< \\
<\end{array}$ & $\begin{array}{l}0.01 \\
0.01 \\
0.01 \\
0.01 \\
0.01\end{array}$ & $\begin{array}{l}0.01 \\
0.01 \\
0.01 \\
0.01 \\
0.01\end{array}$ & $\begin{array}{l}- \\
- \\
- \\
-\end{array}$ \\
\hline MOLYBDENUM & $\begin{array}{l}06 / 05 / 85 \\
06 / 05 / 85 \\
06 / 05 / 85 \\
06 / 05 / 85 \\
06 / 05 / 85\end{array}$ & $\begin{array}{l}0001 \\
0002 \\
0003 \\
0004 \\
0005\end{array}$ & MG/L & $\begin{array}{l}< \\
< \\
< \\
< \\
<\end{array}$ & $\begin{array}{l}0.01 \\
0.01 \\
0.01 \\
0.01 \\
0.01\end{array}$ & $\begin{array}{l}0.01 \\
0.01 \\
0.01 \\
0.01 \\
0.01\end{array}$ & $\begin{array}{l}- \\
- \\
- \\
-\end{array}$ \\
\hline NICKEL & $\begin{array}{l}06 / 05 / 85 \\
06 / 05 / 85 \\
06 / 05 / 85 \\
06 / 05 / 85 \\
06 / 05 / 85\end{array}$ & $\begin{array}{l}0001 \\
0002 \\
0003 \\
0004 \\
0005\end{array}$ & MG/L & $\begin{array}{l}< \\
< \\
< \\
< \\
<\end{array}$ & $\begin{array}{l}0.04 \\
0.04 \\
0.04 \\
0.04 \\
0.04\end{array}$ & $\begin{array}{l}0.04 \\
0.04 \\
0.04 \\
0.04 \\
0.04\end{array}$ & $\begin{array}{l}- \\
- \\
- \\
-\end{array}$ \\
\hline SULFATE & $\begin{array}{l}06 / 05 / 85 \\
06 / 05 / 85 \\
06 / 05 / 85 \\
06 / 05 / 85 \\
06 / 05 / 85\end{array}$ & $\begin{array}{l}0001 \\
0002 \\
0003 \\
0004 \\
0005\end{array}$ & $M G / L$ & & $\begin{array}{l}166.00 \\
164.00 \\
164.00 \\
164.00 \\
164.00\end{array}$ & $\begin{array}{l}0.1 \\
0.1 \\
0.1 \\
0.1 \\
0.1\end{array}$ & $\begin{array}{l}- \\
- \\
- \\
- \\
-\end{array}$ \\
\hline URANIUM & $\begin{array}{l}06 / 05 / 85 \\
06 / 05 / 85 \\
06 / 05 / 85 \\
06 / 05 / 85 \\
06 / 05 / 85\end{array}$ & $\begin{array}{l}0001 \\
0002 \\
0003 \\
0004 \\
0005\end{array}$ & $M G / L$ & & $\begin{array}{l}0.0122 \\
0.012 \\
0.0121 \\
0.0125 \\
0.0121\end{array}$ & $\begin{array}{l}0.003 \\
0.003 \\
0.003 \\
0.003 \\
0.003\end{array}$ & $\begin{array}{l}- \\
- \\
- \\
-\end{array}$ \\
\hline VANADIUM & $\begin{array}{l}06 / 05 / 85 \\
06 / 05 / 85 \\
06 / 05 / 85 \\
06 / 05 / 85 \\
06 / 05 / 85\end{array}$ & $\begin{array}{l}0001 \\
0002 \\
0003 \\
0004 \\
0005\end{array}$ & $M G / L$ & $\begin{array}{l}< \\
< \\
< \\
< \\
<\end{array}$ & $\begin{array}{l}0.01 \\
0.01 \\
0.01 \\
0.01 \\
0.01\end{array}$ & $\begin{array}{l}0.01 \\
0.01 \\
0.01 \\
0.01 \\
0.01\end{array}$ & $\begin{array}{l}- \\
- \\
- \\
-\end{array}$ \\
\hline
\end{tabular}

PARAMETER VALUE INDICATOR (PVI): < - LESS THAN DETECTION LIMIT

SAMPLE ID COOES:

0001 - FILTERED SAMPLE (.45 MICRONS)

0002 - FILTERED REPLICATE SAMPLE (.45 MICRONS)

0003 - FILTERED REPLICATE SAMPLE (.45 MICRONS)

0004 - FILTERED REPLICATE SAMPLE (.45 MICRONS) 
GROUNDWATER QUALITY DATA BY LOCATION

SITE: RVT01 RIVERTON

LOCATION: 0413 DOMESTIC WELL

NORTH COORDINATE: 23844.0 FT

EAST COORDINATE: $\quad 23657.6$ FT

06/12/81 TO $01 / 10 / 94$

REPORT DATE : 09/07/94

FORMATION OF COMPLETION: NO RECOVERY OF DATA FOR CLASSIFYING (NR) HYDRAULIC FLOW RELATIONSHIP: UNKNOWN (N)

\begin{tabular}{|l|c|c|l|l|l|c|c|}
\hline PARAMETER NAME & LOG DATE & $\begin{array}{l}\text { SAMPLE } \\
\text { ID }\end{array}$ & $\begin{array}{l}\text { UNITS OF } \\
\text { MEASURE }\end{array}$ & PVI & $\begin{array}{l}\text { PARAMETER } \\
\text { VALUE }\end{array}$ & $\begin{array}{c}\text { DETECTIONS } \\
\text { LIMIT }\end{array}$ & $\begin{array}{l}\text { PARAMETER } \\
\text { UNCERTAINTY }\end{array}$ \\
\hline ARSENIC & $05 / 30 / 85$ & 0001 & MG/L & $<$ & 0.01 & 0.01 & - \\
\hline MANGANESE & $05 / 30 / 85$ & 0001 & MG/L & $<$ & 0.01 & 0.01 & - \\
\hline MOLYBDENUM & $05 / 30 / 85$ & 0001 & MG/L & $<$ & 0.01 & 0.01 & - \\
\hline NICKEL & $05 / 30 / 85$ & 0001 & MG/L & $<$ & 0.04 & 0.04 & - \\
\hline SULFATE & $05 / 30 / 85$ & 0001 & MG/L & & 1270.00 & 0.1 & - \\
\hline URANIUM & $05 / 30 / 85$ & 0001 & MG/L & $<$ & $0.0003 \mathrm{~J}$ & 0.003 & - \\
\hline VANADIUM & $05 / 30 / 85$ & 0001 & MG/L & & 0.08 & - \\
\hline
\end{tabular}

PARAMETER VALUE INDICATOR (PVI): < - LESS THAN DETECTION LIMIT

SAMPLE ID COOES

0001 - FILTERED SAMPLE (.45 MICRONS)

OTHER PARAMETER VALUE FLAGS:

$\checkmark$ - ESTIMATED VALUE 
GROUNDWATER QUALITY DATA BY LOCATION

SITE: RVTO1 RIVERTON

LOCATION: 0415 DOMESTIC WELL

NORTH COORDINATE: 23970.0 FT

EAST COORDINATE: 25152.0 FT

06/12/81 TO 01/10/94

REPORT DATE: 09/07/94

FORMATION OF COMPLETION: NO RECOVERY OF DATA FOR CLASSIFYING (NR) HYDRAULIC FLOW RELATIONSHIP: UNKNOWN (N)

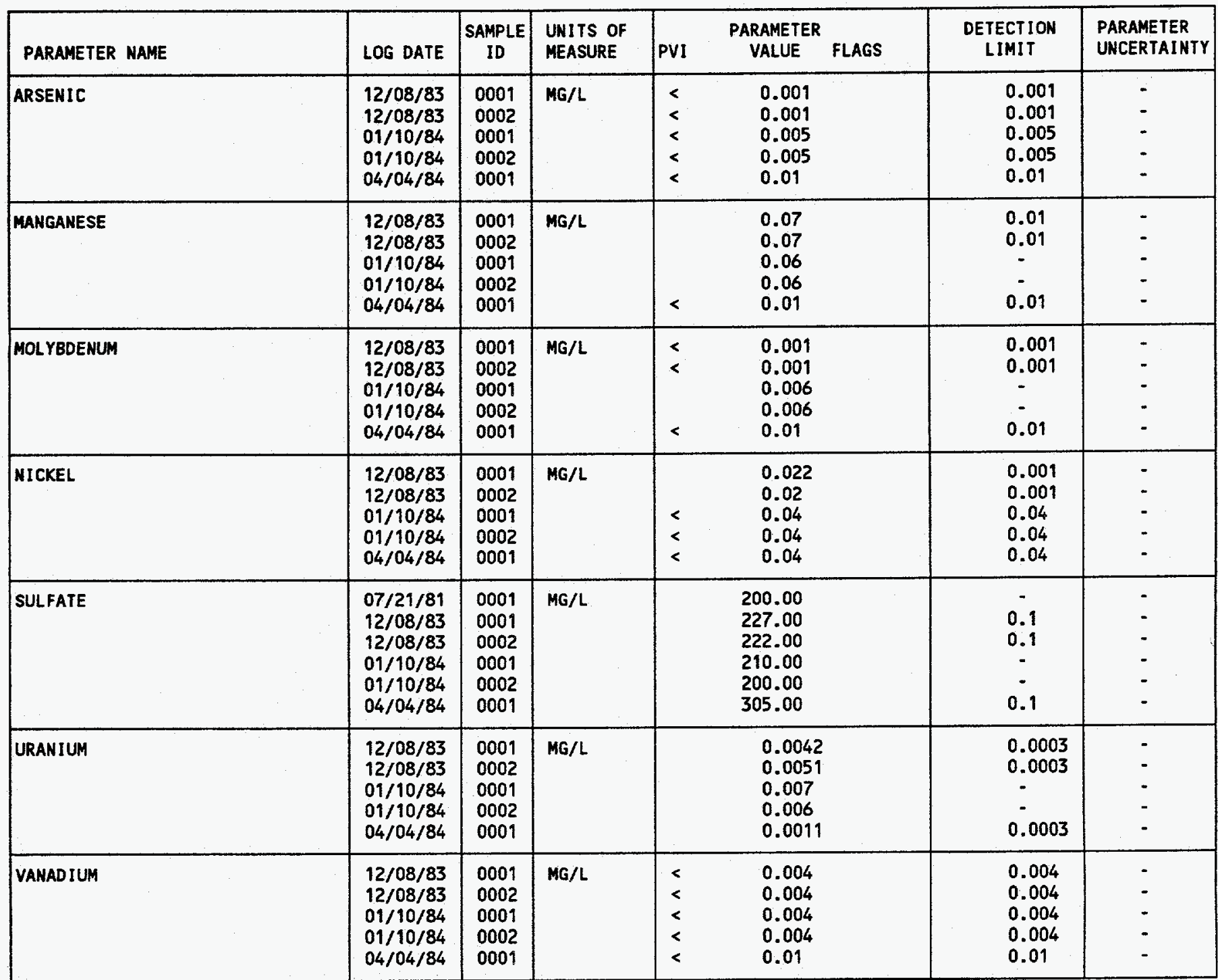

PARAMETER VALUE INDICATOR (PVI): < - LESS THAN DETECTION LIMIT 
GROUNDWATER QUALITY DATA BY LOCATION

SITE: RVTO1 RIVERTON

LOCATION: 0417 DOMESTIC WELL - MELVIN HUTCHINSON

NORTH COORDINATE: 25300.0 FT

EAST COORDINATE: $\quad 24400.0$ FT

$06 / 12 / 81$ TO $01 / 10 / 94$

REPORT DATE: 09/07/94

FORMATION OF COMPLETION: NO RECOVERY OF DATA FOR CLASSIFYING (NR)

HYDRAULIC FLOW RELATIONSHIP: UNKNOWN (N)

\begin{tabular}{|c|c|c|c|c|c|c|c|}
\hline PARAMETER NAME & LOG DATE & $\begin{array}{c}\text { SAMPLE } \\
\text { ID }\end{array}$ & $\begin{array}{l}\text { UNITS OF } \\
\text { MEASURE }\end{array}$ & PVI & $\begin{array}{l}\text { PARAMETER } \\
\text { VALUE FLAGS }\end{array}$ & $\begin{array}{l}\text { DETECTION } \\
\text { LIMIT }\end{array}$ & $\begin{array}{l}\text { PARAMETER } \\
\text { UNCERTAINTY }\end{array}$ \\
\hline ARSENIC & $\begin{array}{l}11 / 19 / 90 \\
03 / 29 / 91\end{array}$ & $\begin{array}{l}0001 \\
0001\end{array}$ & $M G / L$ & $\begin{array}{l}< \\
<\end{array}$ & $\begin{array}{l}0.01 \\
0.01\end{array}$ & $\begin{array}{l}0.01 \\
0.01\end{array}$ & - \\
\hline ARSENIC (TOTAL) & $\begin{array}{l}11 / 19 / 90 \\
03 / 29 / 91 \\
08 / 06 / 92 \\
03 / 15 / 93\end{array}$ & $\begin{array}{l}\text { N001 } \\
\text { N001 } \\
\text { N001 } \\
\text { N001 }\end{array}$ & $M G / L$ & $\begin{array}{l}< \\
< \\
<\end{array}$ & $\begin{array}{l}0.01 \\
0.01 \\
0.01 \\
0.005\end{array}$ & $\begin{array}{l}0.01 \\
0.01 \\
0.01 \\
0.005\end{array}$ & $\begin{array}{l}- \\
- \\
-\end{array}$ \\
\hline MANGANESE & $\begin{array}{l}11 / 19 / 90 \\
03 / 29 / 91\end{array}$ & $\begin{array}{l}0001 \\
0001\end{array}$ & $M G / L$ & & $\begin{array}{l}0.13 \\
0.08\end{array}$ & $\begin{array}{l}0.01 \\
0.01\end{array}$ & - \\
\hline MANGANESE (TOTAL) & $\begin{array}{l}11 / 19 / 90 \\
03 / 29 / 91 \\
08 / 06 / 92 \\
03 / 15 / 93\end{array}$ & $\begin{array}{l}\text { No01 } \\
\text { N001 } \\
\text { N001 } \\
\text { No01 }\end{array}$ & $M G / L$ & $<$ & $\begin{array}{l}0.13 \\
0.07 \\
0.42 \\
0.01\end{array}$ & $\begin{array}{l}0.01 \\
0.01 \\
0.01 \\
0.01\end{array}$ & $\begin{array}{l}- \\
- \\
-\end{array}$ \\
\hline MOLYBDENUM & $\begin{array}{l}11 / 19 / 90 \\
03 / 29 / 91\end{array}$ & $\begin{array}{l}0001 \\
0001\end{array}$ & $M G / L$ & $<$ & $\begin{array}{l}0.03 \\
0.01\end{array}$ & $\begin{array}{l}0.01 \\
0.01\end{array}$ & $\dot{-}$ \\
\hline MOLYBDENUM (TOTAL) & $\begin{array}{l}11 / 19 / 90 \\
03 / 29 / 91 \\
08 / 06 / 92 \\
03 / 15 / 93\end{array}$ & $\begin{array}{l}\text { N001 } \\
\text { N001 } \\
\text { No01 } \\
\text { N001 }\end{array}$ & $M G / L$ & $\begin{array}{l}< \\
< \\
< \\
<\end{array}$ & $\begin{array}{l}0.01 \\
0.01 \\
0.01 \\
0.01\end{array}$ & $\begin{array}{l}0.01 \\
0.01 \\
0.01 \\
0.01\end{array}$ & $\begin{array}{l}- \\
- \\
=\end{array}$ \\
\hline NICKEL & $\begin{array}{l}11 / 19 / 90 \\
03 / 29 / 91\end{array}$ & $\begin{array}{l}0001 \\
0001\end{array}$ & MG/L & $<$ & $\begin{array}{l}0.04 \\
0.04\end{array}$ & $\begin{array}{l}0.04 \\
0.04\end{array}$ & - \\
\hline NICKEL (TOTAL) & $\begin{array}{l}11 / 19 / 90 \\
03 / 29 / 91 \\
08 / 06 / 92 \\
03 / 15 / 93\end{array}$ & $\begin{array}{l}\text { No01 } \\
\text { No01 } \\
\text { N001 } \\
\text { NO01 }\end{array}$ & $M G / L$ & $\begin{array}{l}< \\
< \\
< \\
<\end{array}$ & $\begin{array}{l}0.04 \\
0.04 \\
0.04 \\
0.04\end{array}$ & $\begin{array}{l}0.04 \\
0.04 \\
0.04 \\
0.04\end{array}$ & $\begin{array}{l}- \\
- \\
-\end{array}$ \\
\hline SULFATE & $\begin{array}{l}07 / 21 / 81 \\
11 / 19 / 90 \\
03 / 29 / 91\end{array}$ & $\begin{array}{l}0001 \\
0001 \\
0001\end{array}$ & $M G / L$ & & $\begin{array}{l}149.00 \\
143 . \\
128 .\end{array}$ & $\begin{array}{c}0.1 \\
10 .\end{array}$ & $\begin{array}{l}- \\
\text { - }\end{array}$ \\
\hline SULFATE (TOTAL) & $\begin{array}{l}11 / 19 / 90 \\
08 / 06 / 92 \\
03 / 15 / 93\end{array}$ & $\begin{array}{l}\text { No01 } \\
\text { No01 } \\
\text { N001 }\end{array}$ & MG/L & & $\begin{array}{r}144 . \\
97 . \\
120\end{array}$ & $\begin{array}{c}0.1 \\
10 . \\
1\end{array}$ & $\begin{array}{l}- \\
-\end{array}$ \\
\hline URANIUM & $\begin{array}{l}11 / 19 / 90 \\
03 / 29 / 91\end{array}$ & $\begin{array}{l}0001 \\
0001\end{array}$ & $M G / L$ & & $\begin{array}{l}0.0405 \\
0.019\end{array}$ & $\begin{array}{l}0.0003 \\
0.001\end{array}$ & - \\
\hline URANIUM (TOTAL) & $\begin{array}{l}11 / 19 / 90 \\
03 / 29 / 91 \\
08 / 06 / 92 \\
03 / 15 / 93\end{array}$ & $\begin{array}{l}\text { N001 } \\
\text { N001 } \\
\text { N001 } \\
\text { N001 }\end{array}$ & MG/L & & $\begin{array}{l}0.0385 \\
0.018 \\
0.018 \\
0.013\end{array}$ & $\begin{array}{l}0.0003 \\
0.001 \\
0.001 \\
0.001\end{array}$ & $\begin{array}{l}- \\
- \\
-\end{array}$ \\
\hline VANADIUM & $\begin{array}{l}07 / 21 / 81 \\
11 / 19 / 90 \\
03 / 29 / 91\end{array}$ & $\begin{array}{l}0001 \\
0001 \\
0001\end{array}$ & $M G / L$ & $<$ & $\begin{array}{l}0.009 \\
0.01 \\
0.01\end{array}$ & $\begin{array}{l}- \\
0.01 \\
0.01\end{array}$ & $\dot{-}$ \\
\hline VANADIUM (TOTAL) & $\begin{array}{l}11 / 19 / 90 \\
03 / 29 / 91 \\
08 / 06 / 92 \\
03 / 15 / 93\end{array}$ & $\begin{array}{l}\text { No01 } \\
\text { N001 } \\
\text { N001 } \\
\text { N001 }\end{array}$ & $M G / L$ & $\begin{array}{l}< \\
<\end{array}$ & $\begin{array}{l}0.01 \\
0.01 \\
0.02 \\
0.01\end{array}$ & $\begin{array}{l}0.01 \\
0.01 \\
0.01 \\
0.01\end{array}$ & $\begin{array}{l}- \\
- \\
-\end{array}$ \\
\hline
\end{tabular}

PARAMETER VALUE INDICATOR (PVI): < - LESS THAN DETECTION LIMIT 
GROUNDWATER QUALITY DATA BY LOCATION

SITE: RVTO1 RIVERTON

LOCATION: 0417 DOMESTIC WELL - MELVIN HUTCHINSON

NORTH COORDINATE: 25300.0 FT

EAST COORDINATE: $\quad 24400.0$ FT

06/12/81 TO 01/10/94

REPORT DATE: $09 / 07 / 94$

FORMATION OF COMPLETION: NO RECOVERY OF DATA FOR CLASSIFYING (NR) HYDRAULIC FLOW RELATIONSHIP: UNKNOWN (N)

\begin{tabular}{|c|c|c|c|c|c|c|c|c|}
\hline PARAMETER NAME & LOG DATE & $\begin{array}{c}\text { SAMPLE } \\
\text { ID }\end{array}$ & $\begin{array}{l}\text { UNITS OF } \\
\text { MEASURE }\end{array}$ & PVI & $\begin{array}{l}\text { PARAMETER } \\
\text { VALUE }\end{array}$ & FLAGS & $\begin{array}{l}\text { DETECTION } \\
\text { LINIT }\end{array}$ & $\begin{array}{l}\text { PARAMETER } \\
\text { UNCERTAINTY }\end{array}$ \\
\hline
\end{tabular}

PARAMETER VALUE IHDICATOR (PVI): < - LESS THAN DETECTION LIMIT SAMPLE ID CODES: 
GROUNDWATER QUALITY DATA BY LOCATION SITE: RVTO1 RIVERTON

LOCATION: 0420 DONESTIC WELL - MOSS

NORTH COORDINATE: 22440.0 FT

EAST COORDINATE: 22250.0 FT

06/12/81 TO 01/10/94

REPORT DATE: 09/07/94

FORMATION OF COMPLETION: NO RECOVERY OF DATA FOR CLASSIFYING (NR) HYORAULIC FLOW RELATIONSHIP: UNKNOWN (N)

\begin{tabular}{|c|c|c|c|c|c|c|c|c|}
\hline PARAMETER NAME & LOG DATE & $\begin{array}{c}\text { SAMPLE } \\
\text { ID }\end{array}$ & $\begin{array}{l}\text { UNITS OF } \\
\text { MEASURE }\end{array}$ & PVI & $\begin{array}{l}\text { PARAMETER } \\
\text { VALUE }\end{array}$ & FLAGS & $\begin{array}{l}\text { DETECTION } \\
\text { LIMIT }\end{array}$ & $\begin{array}{l}\text { PARAMETER } \\
\text { UNCERTAINTY }\end{array}$ \\
\hline ARSENIC & $\begin{array}{l}12 / 08 / 83 \\
12 / 08 / 83 \\
01 / 10 / 84 \\
01 / 10 / 84 \\
03 / 28 / 84 \\
06 / 07 / 84 \\
05 / 26 / 85 \\
04 / 01 / 90 \\
11 / 19 / 90 \\
03 / 28 / 91\end{array}$ & $\begin{array}{l}0001 \\
0002 \\
0001 \\
0002 \\
0001 \\
0001 \\
0001 \\
0001 \\
0001 \\
0001\end{array}$ & $M G / L$ & $\begin{array}{l}< \\
< \\
< \\
< \\
< \\
< \\
< \\
<\end{array}$ & $\begin{array}{l}0.001 \\
0.001 \\
0.005 \\
0.005 \\
0.001 \\
0.01 \\
0.01 \\
0.01 \\
0.01 \\
0.01\end{array}$ & GJ & $\begin{array}{l}0.001 \\
0.001 \\
0.005 \\
0.005 \\
0.001 \\
0.01 \\
0.01 \\
0.01 \\
0.01 \\
0.01\end{array}$ & $\begin{array}{l}- \\
- \\
- \\
- \\
- \\
- \\
- \\
-\end{array}$ \\
\hline ARSENIC (TOTAL) & $\begin{array}{l}04 / 01 / 90 \\
04 / 01 / 90 \\
04 / 01 / 90 \\
04 / 01 / 90 \\
04 / 01 / 90 \\
11 / 19 / 90 \\
03 / 28 / 91 \\
06 / 03 / 91 \\
10 / 23 / 91 \\
03 / 13 / 92 \\
08 / 06 / 92\end{array}$ & $\begin{array}{l}\text { NO01 } \\
\text { N002 } \\
\text { NO03 } \\
\text { NO04 } \\
\text { NO05 } \\
\text { NO01 } \\
\text { NO01 } \\
\text { NO01 } \\
\text { N001 } \\
\text { N001 } \\
\text { N001 }\end{array}$ & $M G / L$ & $\begin{array}{l}< \\
< \\
< \\
< \\
< \\
< \\
< \\
< \\
< \\
<\end{array}$ & $\begin{array}{l}0.01 \\
0.01 \\
0.01 \\
0.01 \\
0.01 \\
0.01 \\
0.01 \\
0.05 \\
0.001 \\
0.03 \\
0.01\end{array}$ & $\begin{array}{l}G \\
G \\
\text { GI } \\
I\end{array}$ & $\begin{array}{l}0.01 \\
0.01 \\
0.01 \\
0.01 \\
0.01 \\
0.01 \\
0.01 \\
0.05 \\
0.001 \\
0.03 \\
0.01\end{array}$ & $\begin{array}{l}- \\
- \\
- \\
- \\
- \\
- \\
- \\
-\end{array}$ \\
\hline MANGANESE & $\begin{array}{l}12 / 08 / 83 \\
12 / 08 / 83 \\
01 / 10 / 84 \\
01 / 10 / 84 \\
03 / 28 / 84 \\
06 / 07 / 84 \\
05 / 26 / 85 \\
04 / 01 / 90 \\
11 / 19 / 90 \\
03 / 28 / 91\end{array}$ & $\begin{array}{l}0001 \\
0002 \\
0001 \\
0002 \\
0001 \\
0001 \\
0001 \\
0001 \\
0001 \\
0001\end{array}$ & $M G / L$ & $\begin{array}{l}< \\
< \\
< \\
<\end{array}$ & $\begin{array}{l}0.03 \\
0.02 \\
0.01 \\
0.02 \\
0.01 \\
0.01 \\
0.01 \\
0.01 \\
0.01 \\
0.01\end{array}$ & . & $\begin{array}{l}0.01 \\
0.01 \\
- \\
0.01 \\
0.01 \\
0.01 \\
0.01 \\
0.01 \\
0.01\end{array}$ & $\begin{array}{l}- \\
- \\
- \\
- \\
- \\
-\end{array}$ \\
\hline MANGANESE (TOTAL) & $\begin{array}{l}04 / 01 / 90 \\
04 / 01 / 90 \\
04 / 01 / 90 \\
04 / 01 / 90 \\
04 / 01 / 90 \\
11 / 19 / 90 \\
03 / 28 / 91 \\
06 / 03 / 91 \\
10 / 23 / 91 \\
03 / 13 / 92 \\
08 / 06 / 92\end{array}$ & $\begin{array}{l}\text { N001 } \\
\text { N002 } \\
\text { N003 } \\
\text { N004 } \\
\text { N005 } \\
\text { N001 } \\
\text { N001 } \\
\text { N001 } \\
\text { N001 } \\
\text { N001 } \\
\text { NO01 }\end{array}$ & $M G / L$ & $\begin{array}{l}< \\
< \\
< \\
< \\
<\end{array}$ & $\begin{array}{l}0.01 \\
0.01 \\
0.01 \\
0.01 \\
0.01 \\
0.02 \\
0.02 \\
0.02 \\
0.01 \\
0.01 \\
0.01\end{array}$ & $\begin{array}{l}\text { G } \\
\text { G } \\
\text { G }\end{array}$ & $\begin{array}{l}0.01 \\
0.01 \\
0.01 \\
0.01 \\
0.01 \\
0.01 \\
0.01 \\
0.01 \\
0.01 \\
0.01 \\
0.01\end{array}$ & $\begin{array}{l}- \\
- \\
- \\
- \\
- \\
- \\
-\end{array}$ \\
\hline MOLYBDENUM & $\begin{array}{l}12 / 08 / 83 \\
12 / 08 / 83 \\
01 / 10 / 84 \\
01 / 10 / 84 \\
03 / 28 / 84 \\
06 / 07 / 84 \\
05 / 26 / 85 \\
04 / 01 / 90\end{array}$ & $\begin{array}{l}0001 \\
0002 \\
0001 \\
0002 \\
0001 \\
0001 \\
0001 \\
0001\end{array}$ & $M G / L$ & $\begin{array}{l}< \\
< \\
< \\
< \\
< \\
<\end{array}$ & $\begin{array}{l}0.001 \\
0.04 \\
0.005 \\
0.005 \\
0.001 \\
0.01 \\
0.01 \\
0.01\end{array}$ & & $\begin{array}{l}0.001 \\
0.001 \\
0.005 \\
0.005 \\
0.001 \\
0.01 \\
0.01 \\
0.01\end{array}$ & $\begin{array}{l}- \\
: \\
: \\
- \\
-\end{array}$ \\
\hline
\end{tabular}

PARAMETER VALUE INDICATOR (PVI): < - LESS THAN DETECTION LIMIT

OTHER PARAMETER VALUE FLAGS:

G - PH > 9, POSSIBLE GROUT CONTAMINATION

1 - INCREASED DETECTION LIMIT DUE TO REQUIRED DILUTION

」 - ESTIMATED VALUE
SAMPLE ID CODES:

0001 - FILTERED SAMPLE (.45 MICRONS)

0002 - FILTERED REPLICATE SAMPLE (.45 MICRONS)

NOO1 - UNFILTERED SAMPLE

NOO2 - UNFILTERED REPLICATE SAMPLE

NOO3 - UNFILTERED REPLICATE SAMPLE

N004 - UNFILTERED REPLICATE SAMPLE

NO05 - UNFILTERED REPLICATE SAMPLE 
GROUNDWATER QUALITY DATA BY LOCATION

SITE: RVTO1 RIVERTON

LOCATION: 0420 DOMESTIC WELL - MOSS

NORTH COORDINATE: 22440.0 FT

EAST COORDINATE: 22250.0 FT

06/12/81. TO 01/10/94

REPORT DATE: 09/07/94

FORMATION OF COMPLETION: NO RECOVERY OF DATA FOR CLASSIFYING (NR)

HYDRAULIC FLOW RELATIONSHIP: UNKNOWN (N)

\begin{tabular}{|c|c|c|c|c|c|c|c|c|}
\hline PARAMETER NAME & LOG DATE & $\begin{array}{c}\text { SAMPLE } \\
\text { ID }\end{array}$ & $\begin{array}{l}\text { UNITS OF } \\
\text { MEASURE }\end{array}$ & PVI & $\begin{array}{l}\text { PARAMETER } \\
\text { VALUE }\end{array}$ & FLAGS & $\begin{array}{l}\text { DETECTION } \\
\text { LIMIT }\end{array}$ & $\begin{array}{l}\text { PARAMETER } \\
\text { UNCERTAINTY }\end{array}$ \\
\hline MOLYBDENUM & $\begin{array}{l}11 / 19 / 90 \\
03 / 28 / 91\end{array}$ & $\begin{array}{l}0001 \\
0001\end{array}$ & $M G / L$ & $<$ & $\begin{array}{l}0.01 \\
0.01\end{array}$ & G & $\begin{array}{l}0.01 \\
0.01\end{array}$ & - \\
\hline MOLYBDENUM (TOTAL) & $\begin{array}{l}04 / 01 / 90 \\
04 / 01 / 90 \\
04 / 01 / 90 \\
04 / 01 / 90 \\
04 / 01 / 90 \\
11 / 19 / 90 \\
03 / 28 / 91 \\
06 / 03 / 91 \\
10 / 23 / 91 \\
03 / 13 / 92 \\
08 / 06 / 92\end{array}$ & $\begin{array}{l}\text { NOO1 } \\
\text { NOO2 } \\
\text { N003 } \\
\text { NO04 } \\
\text { N005 } \\
\text { N001 } \\
\text { N001 } \\
\text { N001 } \\
\text { N001 } \\
\text { N001 } \\
\text { N001 }\end{array}$ & MG/L & $\begin{array}{l}< \\
< \\
< \\
< \\
< \\
< \\
< \\
< \\
< \\
<\end{array}$ & $\begin{array}{l}0.01 \\
0.01 \\
0.01 \\
0.01 \\
0.01 \\
0.01 \\
0.01 \\
0.01 \\
0.01 \\
0.01 \\
0.01\end{array}$ & $\begin{array}{l}G \\
G \\
G\end{array}$ & $\begin{array}{l}0.01 \\
0.01 \\
0.01 \\
0.01 \\
0.01 \\
0.01 \\
0.01 \\
0.01 \\
0.01 \\
0.01 \\
0.01\end{array}$ & $\begin{array}{l}- \\
- \\
- \\
- \\
- \\
- \\
- \\
- \\
-\end{array}$ \\
\hline MICKEL (TOTAL) & $\begin{array}{l}04 / 01 / 90 \\
04 / 01 / 90 \\
04 / 01 / 90 \\
04 / 01 / 90 \\
04 / 01 / 90 \\
11 / 19 / 90 \\
03 / 28 / 91 \\
06 / 03 / 91 \\
10 / 23 / 91 \\
03 / 13 / 92 \\
08 / 06 / 92\end{array}$ & $\begin{array}{l}\text { NOO1 } \\
\text { N002 } \\
\text { N003 } \\
\text { N004 } \\
\text { N005 } \\
\text { N001 } \\
\text { N001 } \\
\text { N001 } \\
\text { NO01 } \\
\text { N001 } \\
\text { NO01 }\end{array}$ & $M G / L$ & $\begin{array}{l}< \\
< \\
< \\
< \\
< \\
< \\
< \\
< \\
< \\
<\end{array}$ & $\begin{array}{l}0.04 \\
0.04 \\
0.04 \\
0.04 \\
0.04 \\
0.04 \\
0.04 \\
0.04 \\
0.01 \\
0.04 \\
0.04\end{array}$ & $\begin{array}{l}G \\
G \\
G\end{array}$ & $\begin{array}{l}0.04 \\
0.04 \\
0.04 \\
0.04 \\
0.04 \\
0.04 \\
0.04 \\
0.04 \\
0.01 \\
0.04 \\
0.04\end{array}$ & $\begin{array}{l}- \\
- \\
- \\
- \\
- \\
- \\
- \\
- \\
-\end{array}$ \\
\hline SULFATE (TOTAL) & $\begin{array}{l}04 / 01 / 90 \\
04 / 01 / 90 \\
04 / 01 / 90\end{array}$ & $\begin{array}{l}\text { NO01 } \\
\text { N002 } \\
\text { N003 }\end{array}$ & $M G / L$ & & $\begin{array}{l}286 . \\
283 . \\
283 .\end{array}$ & & $\begin{array}{l}0.1 \\
0.1 \\
0.1\end{array}$ & : \\
\hline
\end{tabular}

PARAMETER VALUE INDICATOR (PVI): < - LESS THAN DETECTION LIMIT

SAMPLE ID CODES:

0001 - FILTERED SAMPLE (.45 MICRONS)

OTHER PARAMETER VALUE fLAGS:

O002 - FILTERED REPLICATE SAMPLE (.45 MICRONS)

G - PH > 9, POSSIBLE GROUT CONTAMINATION

NOO1 - UNFILTERED SAMPLE

NOO2 - UNFILTERED REPLICATE SAMPLE

NOO3 - UNFILTERED REPLICATE SAMPLE

NOO4 - UNFILTERED REPLICATE SAMPLE

NO05 - UNFILTERED REPLICATE SAMPLE 


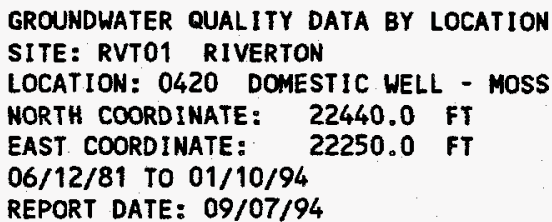

FORMATION OF COMPLETION: NO RECOVERY OF DATA FOR CLASSIFYING (NR) HYORAULIC FLOW RELATIONSHIP: UNKNOWN (N)

\begin{tabular}{|c|c|c|c|c|c|c|c|c|}
\hline PARAMETER NAME & LOG DATE & $\begin{array}{c}\text { SAMPLE } \\
\text { ID }\end{array}$ & $\begin{array}{l}\text { UNITS OF } \\
\text { MEASURE }\end{array}$ & PVI & $\begin{array}{l}\text { PARAMETER } \\
\text { VALUE }\end{array}$ & FLAGS & $\begin{array}{l}\text { DETECTION } \\
\text { LIMIT }\end{array}$ & $\begin{array}{l}\text { PARAMETER } \\
\text { UNCERTAINTY }\end{array}$ \\
\hline SULFATE (TOTAL) & $\begin{array}{l}04 / 01 / 90 \\
04 / 01 / 90 \\
11 / 19 / 90 \\
06 / 03 / 91 \\
10 / 23 / 91 \\
03 / 13 / 92 \\
08 / 06 / 92 \\
03 / 17 / 93\end{array}$ & $\begin{array}{l}\text { N004 } \\
\text { N005 } \\
\text { N001 } \\
\text { N001 } \\
\text { N001 } \\
\text { N001 } \\
\text { N001 } \\
\text { N001 }\end{array}$ & $M G / L$ & & $\begin{array}{l}284 . \\
284 . \\
272 . \\
250 \\
242 \\
318 \\
268 . \\
292\end{array}$ & $\begin{array}{l}\mathbf{G} \\
\mathbf{G}\end{array}$ & $\begin{array}{l}0.1 \\
0.1 \\
0.1 \\
0.1 \\
0.1 \\
40 . \\
30 . \\
1\end{array}$ & $\begin{array}{l}- \\
- \\
- \\
- \\
- \\
-\end{array}$ \\
\hline URANIUM & $\begin{array}{l}12 / 08 / 83 \\
12 / 08 / 83 \\
01 / 10 / 84 \\
01 / 10 / 84 \\
03 / 28 / 84 \\
06 / 07 / 84 \\
05 / 26 / 85 \\
04 / 01 / 90 \\
11 / 19 / 90 \\
03 / 28 / 91\end{array}$ & $\begin{array}{l}0001 \\
0002 \\
0001 \\
0002 \\
0001 \\
0001 \\
0001 \\
0001 \\
0001 \\
0001\end{array}$ & $M G / L$ & $\begin{array}{l}< \\
< \\
< \\
< \\
< \\
< \\
<\end{array}$ & $\begin{array}{l}0.0003 \\
0.0005 \\
0.002 \\
0.005 \\
0.0003 \\
0.0003 \\
0.0003 \\
0.0003 \\
0.0003 \\
0.003\end{array}$ & $\begin{array}{l}\mathbf{J} \\
\mathbf{J} \\
\mathbf{G} \\
\mathbf{G}\end{array}$ & $\begin{array}{l}0.0003 \\
0.0003 \\
0.002 \\
- \\
0.0003 \\
0.0003 \\
0.003 \\
0.003 \\
0.0003 \\
0.001\end{array}$ & $\begin{array}{l}- \\
- \\
- \\
= \\
= \\
= \\
= \\
=\end{array}$ \\
\hline URANIUM (TOTAL) & $\begin{array}{l}04 / 01 / 90 \\
04 / 01 / 90 \\
04 / 01 / 90 \\
04 / 01 / 90 \\
04 / 01 / 90 \\
11 / 19 / 90 \\
03 / 28 / 91 \\
06 / 03 / 91 \\
10 / 23 / 91 \\
03 / 13 / 92 \\
08 / 06 / 92 \\
03 / 17 / 93\end{array}$ & $\begin{array}{l}\text { N001 } \\
\text { NO02 } \\
\text { N003 } \\
\text { N004 } \\
\text { N005 } \\
\text { N001 } \\
\text { N001 } \\
\text { N001 } \\
\text { NO01 } \\
\text { N001 } \\
\text { N001 } \\
\text { N001 }\end{array}$ & $M G / L$ & $\begin{array}{l}< \\
< \\
< \\
< \\
< \\
< \\
< \\
< \\
<\end{array}$ & $\begin{array}{l}0.0004 \\
0.0003 \\
0.0003 \\
0.0003 \\
0.0003 \\
0.0003 \\
0.001 \\
0.001 \\
0.0004 \\
0.001 \\
0.001 \\
0.001\end{array}$ & $\begin{array}{l}\text { J } \\
\mathbf{J} \\
\mathbf{J} \\
\mathbf{J} \\
\mathbf{J} \\
\mathbf{G} \\
\mathbf{G} \\
\mathbf{G}\end{array}$ & $\begin{array}{l}0.003 \\
0.003 \\
0.003 \\
0.003 \\
0.003 \\
0.0003 \\
0.001 \\
0.001 \\
0.0003 \\
0.001 \\
0.001 \\
0.001\end{array}$ & $\begin{array}{l}- \\
- \\
- \\
- \\
- \\
- \\
- \\
- \\
- \\
-\end{array}$ \\
\hline VANADIUM & $\begin{array}{l}12 / 08 / 83 \\
12 / 08 / 83 \\
01 / 10 / 84 \\
01 / 10 / 84 \\
03 / 28 / 84 \\
06 / 07 / 84 \\
05 / 26 / 85 \\
04 / 01 / 90 \\
11 / 19 / 90 \\
03 / 28 / 91\end{array}$ & $\begin{array}{l}0001 \\
0002 \\
0001 \\
0002 \\
0001 \\
0001 \\
0001 \\
0001 \\
0001 \\
0001\end{array}$ & $M G / L$ & $\begin{array}{l}< \\
< \\
< \\
< \\
< \\
< \\
< \\
< \\
< \\
<\end{array}$ & $\begin{array}{l}0.004 \\
0.004 \\
0.004 \\
0.004 \\
0.004 \\
0.01 \\
0.01 \\
0.01 \\
0.01 \\
0.01\end{array}$ & $\begin{array}{l}\mathbf{G} \\
\mathbf{G}\end{array}$ & $\begin{array}{l}0.004 \\
0.004 \\
0.004 \\
0.004 \\
0.004 \\
0.01 \\
0.01 \\
0.01 \\
0.01 \\
0.01\end{array}$ & $\begin{array}{l}- \\
- \\
- \\
- \\
- \\
- \\
- \\
- \\
- \\
-\end{array}$ \\
\hline VANADIUM (TOTAL) & $\begin{array}{l}04 / 01 / 90 \\
04 / 01 / 90 \\
04 / 01 / 90 \\
04 / 01 / 90 \\
04 / 01 / 90 \\
11 / 19 / 90 \\
03 / 28 / 91 \\
06 / 03 / 91 \\
10 / 23 / 91\end{array}$ & $\begin{array}{l}\text { No01 } \\
\text { No02 } \\
\text { N003 } \\
\text { N004 } \\
\text { N005 } \\
\text { N001 } \\
\text { No01 } \\
\text { No01 } \\
\text { No01 }\end{array}$ & $M G / L$ & $\begin{array}{l}< \\
< \\
< \\
< \\
< \\
< \\
< \\
< \\
<\end{array}$ & $\begin{array}{l}0.01 \\
0.01 \\
0.01 \\
0.01 \\
0.01 \\
0.01 \\
0.01 \\
0.01 \\
0.01\end{array}$ & $\begin{array}{l}\mathbf{G} \\
\mathbf{G} \\
\mathbf{G}\end{array}$ & $\begin{array}{l}0.01 \\
0.01 \\
0.01 \\
0.01 \\
0.01 \\
0.01 \\
0.01 \\
0.01 \\
0.01\end{array}$ & $\begin{array}{l}- \\
- \\
- \\
- \\
- \\
- \\
-\end{array}$ \\
\hline
\end{tabular}

PARAMETER VALUE INDICATOR (PVI): < - LESS THAN DETECTION LIMIT

SAMPLE IO CODES:

OTHER PARAMETER VALUE FLAGS:

G - PH > 9, POSSIBLE GROUT CONTAMINATION

$\checkmark$ - ESTIMATED VALUE

0001 - FILTERED SAMPLE (.45 MICRONS)

0002 - FILTERED REPLICATE SAMPLE (.45 MICRONS)

N001 - UNFILTERED SAMPLE

NOO2 - UNFILTERED REPLICATE SAMPLE

NO03 - UNFILTERED REPLICATE SAMPLE

N004 - UNFILTERED REPLICATE SAMPLE

N005 - UNFILTERED REPLICATE SAMPLE 
GROUNDWATER QUALITY DATA BY LOCATIOH

SITE: RVTO1 RIVERTON

LOCATION: 0420 DOMESTIC WELL - MOSS

NORTH COORDINATE: 22440.0 FT

EAST COORDINATE: 22250.0 FT

06/12/81 TO 01/10/94

REPORT DATE : $09 / 07 / 94$

FORMATION OF COMPLETION: NO RECOVERY OF DATA FOR CLASSIFYING (NR) HYDRAULIC FLOW RELATIONSHIP: UNKNOWN (N)

\begin{tabular}{|l|c|c|l|l|l|c|c|}
\hline PARAMETER NAME & LOG DATE & $\begin{array}{c}\text { SAMPLE } \\
\text { ID }\end{array}$ & $\begin{array}{l}\text { UNITS OF } \\
\text { MEASURE }\end{array}$ & PVI & $\begin{array}{c}\text { PARAMETER } \\
\text { VALUE }\end{array}$ FLAGS & $\begin{array}{c}\text { DETECTION } \\
\text { LIMIT }\end{array}$ & $\begin{array}{l}\text { PARAMETER } \\
\text { UNCERTAINTY }\end{array}$ \\
\hline VANADIUM (TOTAL) & $03 / 13 / 92$ & N001 & MG/L & $<$ & 0.01 & - \\
$08 / 06 / 92$ & N001 & & $<$ & 0.01 & 0.01 & 0.01 \\
\hline
\end{tabular}

PARAMETER VALUE INDICATOR (PVI): < - LESS THAN DETECTION LIMIT

SAMPLE ID CODES:

HOO1 - UNFILTERED SAMPLE 
GROUNDWATER QUALITY DATA BY LOCATION

SITE: RVTO1 RIVERTON

LOCATION: 0421 DOMESTIC WELL - HARRIS

NORTH COORDINATE: 21900.0 FT

EAST COORDINATE: 25000.0 FT

06/12/81 TO 01/10/94

REPORT DATE : 09/07/94

FORMATION OF COMPLETION: NO RECOVERY OF DATA FOR CLASSIFYING (NR) HYDRAULIC FLOW RELATIONSHIP: UNKNOWN (N)

\begin{tabular}{|c|c|c|c|c|c|c|c|}
\hline PARAMETER NAME & LOG DATE & $\begin{array}{c}\text { SAMPLE } \\
\text { ID }\end{array}$ & $\begin{array}{l}\text { UNITS OF } \\
\text { MEASURE }\end{array}$ & PVI & $\begin{array}{l}\text { PARAMETER } \\
\text { VALUE FLAGS }\end{array}$ & $\begin{array}{l}\text { DETECTION } \\
\text { LIMIT }\end{array}$ & $\begin{array}{l}\text { PARAMETER } \\
\text { UNCERTAINTY }\end{array}$ \\
\hline ARSENIC & $05 / 26 / 85$ & 0001 & MG/L & $<$ & 0.01 & 0.01 & - \\
\hline MANGANESE & $05 / 26 / 85$ & 0001 & $M G / L$ & $<$ & 0.01 & 0.01 & - \\
\hline MOLYBDENUM & $05 / 26 / 85$ & 0001 & $M G / L$ & $<$ & 0.01 & 0.01 & - \\
\hline MICKEL & $05 / 26 / 85$ & 0001 & $M G / L$ & $<$ & 0.04 & 0.04 & - \\
\hline SULFATE & $\begin{array}{l}07 / 21 / 81 \\
05 / 26 / 85\end{array}$ & $\begin{array}{l}0001 \\
0001\end{array}$ & $M G / L$ & & $\begin{array}{l}212.00 \\
233.00\end{array}$ & 0.1 & $\begin{array}{l}- \\
-\end{array}$ \\
\hline URANIUM & $05 / 26 / 85$ & 0001 & $M G / L$ & $<$ & $0.0003 \mathrm{~J}$ & 0.003 & - \\
\hline VANADIUM & $05 / 26 / 85$ & 0001 & $M G / L$ & $<$ & 0.01 & 0.01 & - \\
\hline
\end{tabular}

PARAMETER VALUE INDICATOR (PVI):

$<$ - LESS THAN DETECTION LIMIT

SAMPLE ID CODES:

0001 - FILTERED SAMPLE (.45 MICRONS)

OTHER PARAMETER VALUE FLAGS:

J - ESTIMATED VALUE 
GROUNDWATER QUALITY DATA BY LOCATION

SITE: RVTO1 RIVERTON

LOCATION: 0422 DOMESTIC WELL

NORTH COORDINATE: 24990.0 FT

EAST COORDINATE: $\quad 22810.0$ FT

06/12/81 TO $01 / 10 / 94$

REPORT DATE: 09/07/94

FORMATION OF COMPLETION: NO RECOVERY OF DATA FOR CLASSIFYING (NR)

HYDRAULIC FLOW RELATIONSHIP: UNKNOWN (N)

\begin{tabular}{|c|c|c|c|c|c|c|c|}
\hline PARAMETER NAME & LOG DATE & $\begin{array}{l}\text { SAMPLE } \\
\text { ID }\end{array}$ & $\begin{array}{l}\text { UNITS OF } \\
\text { MEASURE }\end{array}$ & PVI & $\begin{array}{l}\text { PARAMETER } \\
\text { VALUE FLAGS }\end{array}$ & $\begin{array}{l}\text { DETECTION } \\
\text { LIMIT }\end{array}$ & $\begin{array}{l}\text { PARAMETER } \\
\text { UNCERTAINTY }\end{array}$ \\
\hline ARSENIC & $\begin{array}{l}04 / 04 / 84 \\
05 / 28 / 85\end{array}$ & $\begin{array}{l}0001 \\
0001\end{array}$ & MG/L & $<$ & $\begin{array}{l}0.01 \\
0.01\end{array}$ & $\begin{array}{l}0.01 \\
0.01\end{array}$ & - \\
\hline MANGANESE & $\begin{array}{l}04 / 04 / 84 \\
05 / 28 / 85\end{array}$ & $\begin{array}{l}0001 \\
0001\end{array}$ & $M G / L$ & & $\begin{array}{l}0.13 \\
0.15\end{array}$ & $\begin{array}{l}0.01 \\
0.01\end{array}$ & $\dot{-}$ \\
\hline NICKEL & $\begin{array}{l}04 / 04 / 84 \\
05 / 28 / 85\end{array}$ & $\begin{array}{l}0001 \\
0001\end{array}$ & $M G / L$ & $<$ & $\begin{array}{l}0.04 \\
0.04\end{array}$ & $\begin{array}{l}0.04 \\
0.04\end{array}$ & $\dot{-}$ \\
\hline SULFATE & $\begin{array}{l}04 / 04 / 84 \\
05 / 28 / 85\end{array}$ & $\begin{array}{l}0001 \\
0001\end{array}$ & $M G / L$ & & $\begin{array}{l}366.00 \\
400.00\end{array}$ & $\begin{array}{l}0.1 \\
0.1\end{array}$ & - \\
\hline
\end{tabular}

PARAMETER VALUE INDICATOR (PVI): < - LESS THAN DETECTION LIMIT

SAMPLE ID CODES

0001 - FILTERED SAMPLE (.45 MICRONS)

OTHER PARAMETER VALUE FLAGS:

$J$ - est IMATED VALUE 
GROUNDWATER QUALITY DATA BY LOCATION

SITE: RVTO1 RIVERTON

LOCATION: 0423 DOMESTIC WELL - WHITEMAN

NORTH COORDINATE: 25600.0 FT

EAST COORDINATE: $\quad 28190.0$ FT

06/12/81 TO 01/10/94

REPORT DATE: 09/07/94

FORMATION OF COMPLETION: NO RECOVERY OF DATA FOR CLASSIFYING (NR) HYDRAULIC FLOW RELATIONSHIP: UNKNOWN (N)

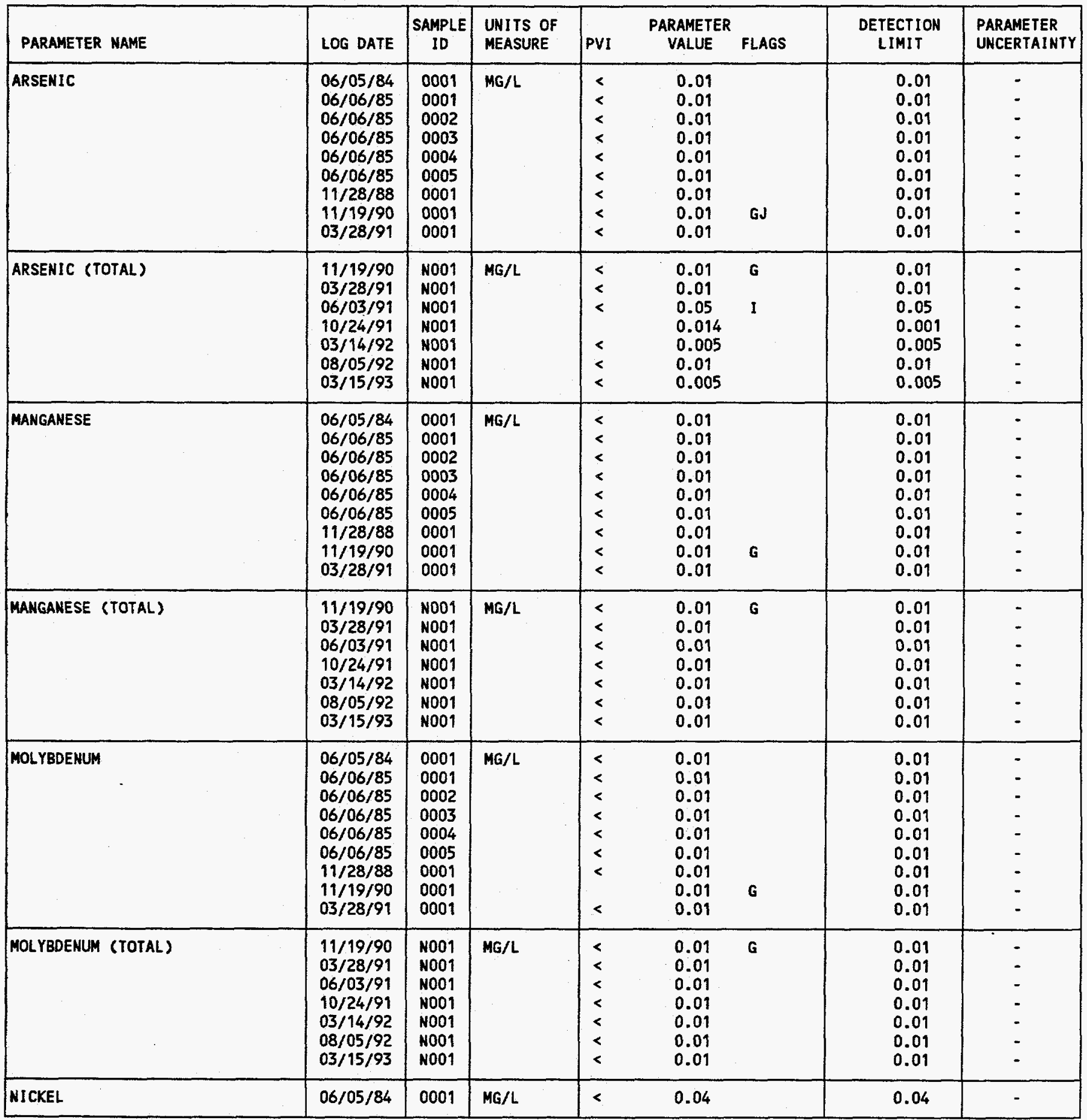

PARAMETER VALUE INDICATOR (PVI): < - LESS THAN DETECTION LIMIT

SAMPLE ID CODES:

OTHER PARAMETER VALUE FLAGS:

G - PH > 9, POSSIBLE GROUT CONTAMINATION

1 - INCREASED DETECTION LIMIT DUE TO REQUIRED OILUTION

$\jmath$ - estihated value 
GROUNDHATER QUALITY DATA BY LOCATION

SITE: RVTO1 RIVERTOH

LOCATION: O423 DOMESTIC WELL - WHITEMAN

HORTH COORDINATE: 25600.0 FT

EAST COORDINATE: $\quad 28190.0$ FT

06/12/81 TO $01 / 10 / 94$

REPORT DATE: $09 / 07 / 94$

FORMATION OF COMPLETION: NO RECOVERY OF DATA FOR CLASSIFYING (NR)

HYDRAULIC FLOW RELATIONSHIP: UNKNOWN (N)

\begin{tabular}{|c|c|c|c|c|c|c|c|c|}
\hline PARAMETER NAME & LOG DATE & $\begin{array}{c}\text { SAMPLE } \\
\text { ID }\end{array}$ & $\begin{array}{l}\text { UNITS OF } \\
\text { MEASURE }\end{array}$ & PVI & $\begin{array}{l}\text { PARAMETER } \\
\text { VALUE }\end{array}$ & FLAGS & $\begin{array}{l}\text { DETECTION } \\
\text { LIMIT }\end{array}$ & $\begin{array}{l}\text { PARAMETER } \\
\text { UNCERTAINTY }\end{array}$ \\
\hline NICKEL & $\begin{array}{l}06 / 06 / 85 \\
06 / 06 / 85 \\
06 / 06 / 85 \\
06 / 06 / 85 \\
06 / 06 / 85 \\
11 / 28 / 88 \\
11 / 19 / 90 \\
03 / 28 / 91\end{array}$ & $\begin{array}{l}0001 \\
0002 \\
0003 \\
0004 \\
0005 \\
0001 \\
0001 \\
0001\end{array}$ & MG/L & $\begin{array}{l}< \\
< \\
< \\
< \\
< \\
< \\
< \\
<\end{array}$ & $\begin{array}{l}0.04 \\
0.04 \\
0.04 \\
0.04 \\
0.04 \\
0.04 \\
0.04 \\
0.04\end{array}$ & G & $\begin{array}{l}0.04 \\
0.04 \\
0.04 \\
0.04 \\
0.04 \\
0.04 \\
0.04 \\
0.04\end{array}$ & $\begin{array}{l}- \\
- \\
- \\
- \\
- \\
-\end{array}$ \\
\hline NICKEL (TOTAL) & $\begin{array}{l}11 / 19 / 90 \\
03 / 28 / 91 \\
06 / 03 / 91 \\
10 / 24 / 91 \\
03 / 14 / 92 \\
08 / 05 / 92 \\
03 / 15 / 93\end{array}$ & $\begin{array}{l}\text { No01 } \\
\text { N001 } \\
\text { N001 } \\
\text { N001 } \\
\text { N001 } \\
\text { N001 } \\
\text { N001 }\end{array}$ & $M G / L$ & $\begin{array}{l}< \\
< \\
< \\
< \\
< \\
< \\
<\end{array}$ & $\begin{array}{l}0.04 \\
0.04 \\
0.04 \\
0.01 \\
0.04 \\
0.04 \\
0.04\end{array}$ & $\mathbf{G}$ & $\begin{array}{l}0.04 \\
0.04 \\
0.04 \\
0.01 \\
0.04 \\
0.04 \\
0.04\end{array}$ & $\begin{array}{l}- \\
- \\
- \\
- \\
- \\
-\end{array}$ \\
\hline SULFATE & $\begin{array}{l}06 / 05 / 84 \\
06 / 06 / 85 \\
06 / 06 / 85 \\
06 / 06 / 85 \\
06 / 06 / 85 \\
06 / 06 / 85 \\
11 / 28 / 88 \\
11 / 19 / 90 \\
03 / 28 / 91\end{array}$ & $\begin{array}{l}0001 \\
0001 \\
0002 \\
0003 \\
0004 \\
0005 \\
0001 \\
0001 \\
0001\end{array}$ & $M G / L$ & & $\begin{array}{l}80.30 \\
167.00 \\
167.00 \\
167.00 \\
167.00 \\
167.00 \\
160 . \\
165 . \\
175 .\end{array}$ & $\mathbf{G}$ & $\begin{array}{c}0.1 \\
0.1 \\
0.1 \\
0.1 \\
0.1 \\
0.1 \\
0.1 \\
0.1 \\
10 .\end{array}$ & $\begin{array}{l}- \\
- \\
- \\
- \\
- \\
- \\
- \\
-\end{array}$ \\
\hline SULFATE (TOTAL) & $\begin{array}{l}11 / 19 / 90 \\
06 / 03 / 91 \\
10 / 24 / 91 \\
03 / 14 / 92 \\
08 / 05 / 92 \\
03 / 15 / 93\end{array}$ & $\begin{array}{l}\text { No01 } \\
\text { No01 } \\
\text { No01 } \\
\text { No01 } \\
\text { No01 } \\
\text { No01 }\end{array}$ & $M G / L$ & & $\begin{array}{l}164 . \\
150 . \\
156 \\
178 . \\
162 . \\
166\end{array}$ & $\mathbf{G}$ & $\begin{array}{c}0.1 \\
0.1 \\
0.1 \\
40 . \\
10 . \\
1\end{array}$ & $\begin{array}{l}- \\
- \\
- \\
- \\
-\end{array}$ \\
\hline URANIUM & $\begin{array}{l}06 / 05 / 84 \\
06 / 06 / 85 \\
06 / 06 / 85 \\
06 / 06 / 85 \\
06 / 06 / 85 \\
06 / 06 / 85 \\
11 / 28 / 88 \\
11 / 19 / 90 \\
03 / 28 / 91\end{array}$ & $\begin{array}{l}0001 \\
0001 \\
0002 \\
0003 \\
0004 \\
0005 \\
0001 \\
0001 \\
0001\end{array}$ & $M G / L$ & $\begin{array}{l}< \\
< \\
< \\
< \\
< \\
<\end{array}$ & $\begin{array}{l}0.0003 \\
0.0018 \\
0.0003 \\
0.0003 \\
0.0003 \\
0.0003 \\
0.0003 \\
0.0005 \\
0.003\end{array}$ & $\begin{array}{l}\mathbf{J} \\
\mathbf{J} \\
\mathbf{J} \\
\mathbf{J} \\
\mathbf{J} \\
\mathbf{J} \\
\mathbf{G}\end{array}$ & $\begin{array}{l}0.0003 \\
0.003 \\
0.003 \\
0.003 \\
0.003 \\
0.003 \\
0.003 \\
0.0003 \\
0.001\end{array}$ & $\begin{array}{l}- \\
- \\
- \\
- \\
- \\
- \\
- \\
-\end{array}$ \\
\hline URANIUM (TOTAL) & $\begin{array}{l}11 / 19 / 90 \\
03 / 28 / 91 \\
06 / 03 / 91 \\
10 / 24 / 91 \\
03 / 14 / 92 \\
08 / 05 / 92 \\
03 / 15 / 93\end{array}$ & $\begin{array}{l}\text { No01 } \\
\text { No01 } \\
\text { NO01 } \\
\text { No01 } \\
\text { N001 } \\
\text { No01 } \\
\text { No01 }\end{array}$ & $M G / L$ & $\begin{array}{l}< \\
< \\
< \\
<\end{array}$ & $\begin{array}{l}0.0003 \\
0.001 \\
0.001 \\
0.0003 \\
0.001 \\
0.001 \\
0.001\end{array}$ & G & $\begin{array}{l}0.0003 \\
0.001 \\
0.001 \\
0.0003 \\
0.001 \\
0.001 \\
0.001\end{array}$ & $\begin{array}{l}- \\
- \\
- \\
- \\
-\end{array}$ \\
\hline VANADIUM & $\begin{array}{l}06 / 05 / 84 \\
06 / 06 / 85 \\
06 / 06 / 85\end{array}$ & $\begin{array}{l}0001 \\
0001 \\
0002\end{array}$ & $M G / L$ & $\begin{array}{l}< \\
< \\
<\end{array}$ & $\begin{array}{l}0.01 \\
0.01 \\
0.01\end{array}$ & & $\begin{array}{l}0.01 \\
0.01 \\
0.01\end{array}$ & $\begin{array}{l}- \\
-\end{array}$ \\
\hline
\end{tabular}

PARAMETER VALUE INOICATOR (PVI): < - LESS THAN DETECTION LIMIT

SAMPLE ID CODES:

0001 - FILTERED SAMPLE (.45 MICRONS)

OTHER PARAMETER VALUE FLAGS:

0002 - FILTERED REPLICATE SAMPLE (.45 MICRONS)

0003 - FILTERED REPLICATE SAMPLE (.45 MICRONS)

0004 - FILTERED REPLICATE SAMPLE (.45 MICRONS)

N001 - UNFILTERED SAMPLE

G - PH $>9$, POSSIBLE GROUT CONTAMINATION

$\mathrm{J}$ - estimated VALUE 
GROUNDWATER QUALITY DATA BY LOCATION

SITE: RVTO1 RIVERTON

LOCATION: 0423 DOMESTIC WELL - WHITEMAN

NORTH COORDINATE: 25600.0 FT

EAST COORDINATE: $\quad 28190.0$ FT

06/12/81 TO $01 / 10 / 94$

REPORT DATE: $09 / 07 / 94$

FORMATION OF COMPLETION: NO RECOVERY OF DATA FOR CLASSIFYING (NR) HYDRAULIC FLOW RELATIONSHIP: UNKNOWN (N)

\begin{tabular}{|c|c|c|c|c|c|c|c|c|}
\hline PARAMETER NAME & LOG DATE & $\begin{array}{c}\text { SAMPLE } \\
\text { ID }\end{array}$ & $\begin{array}{l}\text { UNITS OF } \\
\text { MEASURE }\end{array}$ & PVI & $\begin{array}{l}\text { PARAMETER } \\
\text { VALUE }\end{array}$ & FLAGS & $\begin{array}{l}\text { DETECTION } \\
\text { LIMIT }\end{array}$ & $\begin{array}{l}\text { PARAMETER } \\
\text { UNCERTAINTY }\end{array}$ \\
\hline VANADIUM & $\begin{array}{l}06 / 06 / 85 \\
06 / 06 / 85 \\
06 / 06 / 85 \\
11 / 28 / 88 \\
11 / 19 / 90 \\
03 / 28 / 91\end{array}$ & $\begin{array}{l}0003 \\
0004 \\
0005 \\
0001 \\
0001 \\
0001\end{array}$ & MG $/ L$ & $<$ & $\begin{array}{l}0.01 \\
0.01 \\
0.01 \\
0.01 \\
0.01 \\
0.02\end{array}$ & G & $\begin{array}{l}0.01 \\
0.01 \\
0.01 \\
0.01 \\
0.01 \\
0.01\end{array}$ & $\begin{array}{l}: \\
: \\
:\end{array}$ \\
\hline VANADIUM (TOTAL) & $\begin{array}{l}11 / 19 / 90 \\
03 / 28 / 91 \\
06 / 03 / 91 \\
10 / 24 / 91 \\
03 / 14 / 92 \\
08 / 05 / 92 \\
03 / 15 / 93\end{array}$ & $\begin{array}{l}\text { NOO1 } \\
\text { NO01 } \\
\text { NO01 } \\
\text { NO01 } \\
\text { NO01 } \\
\text { NO01 } \\
\text { NO01 }\end{array}$ & MG/L & $\begin{array}{l}< \\
< \\
< \\
<\end{array}$ & $\begin{array}{l}0.01 \\
0.01 \\
0.01 \\
0.01 \\
0.01 \\
0.01 \\
0.01\end{array}$ & G & $\begin{array}{l}0.01 \\
0.01 \\
0.01 \\
0.01 \\
0.01 \\
0.01 \\
0.01\end{array}$ & $\begin{array}{l}- \\
- \\
- \\
-\end{array}$ \\
\hline
\end{tabular}

PARAMETER VALUE INDICATOR (PVI): < - LESS THAN DETECTION LIMIT

SAMPLE ID CODES:

OTHER PARAMETER VALUE FLAGS:

G - PH > 9, POSSIBLE GROUT CONTAMINATION

0001 - FILTERED SAMPLE (.45 MICRONS)

0003 - FILTERED REPLICATE SAMPLE (.45 MICRONS)

0004 - FILTERED REPLICATE SAMPLE (.45 MICRONS)

NOO1 - UNFILTERED SAMPLE 
GROUNDWATER QUALITY DATA BY LOCATION

SITE: RVTO1 RIVERTON

LOCATION: 0424 DOMESTIC WELL

NORTH COORDINATE: 25520.0 FT

EAST COORDINATE: 28260.0 FT

06/12/81 TO $01 / 10 / 94$

REPORT DATE: 09/07/94

FORMATION OF COMPLETION: NO RECOVERY OF DATA FOR CLASSIFYING (NR) HYDRAULIC FLOW RELATIONSHIP: UNKHOWN (N)

\begin{tabular}{|c|c|c|c|c|c|c|c|}
\hline PARAMETER NAME & LOG DATE & $\underset{\text { ID }}{\text { SAMPLE }}$ & $\begin{array}{l}\text { UNITS OF } \\
\text { MEASURE }\end{array}$ & PVI & $\begin{array}{l}\text { PARAMETER } \\
\text { VALUE FLAGS }\end{array}$ & $\begin{array}{l}\text { DETECTION } \\
\text { LIMIT }\end{array}$ & $\begin{array}{l}\text { PARAMETER } \\
\text { UNCERTAINTY }\end{array}$ \\
\hline ARSENIC & $06 / 05 / 84$ & 0001 & $M G / L$ & $<$ & 0.01 & 0.01 & - \\
\hline MANGANESE & $06 / 05 / 84$ & 0001 & $M G / L$ & & 0.15 & 0.01 & - \\
\hline MOLYBDENUM & $06 / 05 / 84$ & 0001 & MG/L & $<$ & 0.01 & 0.01 & - \\
\hline NICKEL & $06 / 05 / 84$ & 0001 & $M G / L$ & $<$ & 0.04 & 0.04 & - \\
\hline SULFATE & $06 / 05 / 84$ & 0001 & $M G / L$ & & 582.00 & 0.1 & - \\
\hline URANIUM & $06 / 05 / 84$ & 0001 & MG/L & & 0.0079 & 0.0003 & - \\
\hline VANADIUM & $06 / 05 / 84$ & 0001 & MG/L & $<$ & 0.01 & 0.01 & - \\
\hline
\end{tabular}

PARAMETER VALUE INDICATOR (PVI):

< - LESS THAN DETECTION LIMIT

SAMPLE ID CODES

0001 - FILTERED SAMPLE (.45 MICRONS) 
GROUNDWATER QUALITY DATA BY LOCATION

SITE: RVTO1 RIVERTON

LOCATION: 0425 DOMESTIC WELL

NORTH COORDINATE: 24120.0 FT

EAST COORDINATE: 22070.0 FT

06/12/81 TO 01/10/94

REPORT DATE: 09/07/94

FORMATION OF COMPLETION: NO RECOVERY OF DATA FOR CLASSIFYING (NR) HYDRAULIC FLOW RELATIONSHIP: UNKNOWN (N)

\begin{tabular}{|c|c|c|c|c|c|c|c|}
\hline PARAMETER NAME & LOG DATE & $\begin{array}{c}\text { SAMPLE } \\
\text { ID }\end{array}$ & $\begin{array}{l}\text { UNITS OF } \\
\text { MEASURE }\end{array}$ & PVI & $\begin{array}{l}\text { PARAMETER } \\
\text { VALUE FLAGS }\end{array}$ & $\begin{array}{l}\text { DETECTION } \\
\text { LIMIT }\end{array}$ & $\begin{array}{l}\text { PARAMETER } \\
\text { UNCERTAINTY }\end{array}$ \\
\hline ARSENIC & $\begin{array}{l}03 / 30 / 84 \\
05 / 27 / 85\end{array}$ & $\begin{array}{l}0001 \\
0001\end{array}$ & $M G / L$ & $<$ & $\begin{array}{l}0.001 \\
0.01\end{array}$ & $\begin{array}{l}0.001 \\
0.01\end{array}$ & - \\
\hline MANGANESE & $03 / 30 / 84$ & 0001 & MG/L & & 0.04 & 0.01 & - \\
\hline MOLYBDENUM & $\begin{array}{l}03 / 30 / 84 \\
05 / 27 / 85\end{array}$ & $\begin{array}{l}0001 \\
0001\end{array}$ & MG/L & $<$ & $\begin{array}{l}0.001 \\
0.01\end{array}$ & $\begin{array}{l}0.001 \\
0.01\end{array}$ & - \\
\hline NI CKEL & $\begin{array}{l}03 / 30 / 84 \\
05 / 27 / 85\end{array}$ & $\begin{array}{l}0001 \\
0001\end{array}$ & $M G / L$ & $\begin{array}{l}< \\
<\end{array}$ & $\begin{array}{l}0.04 \\
0.04\end{array}$ & $\begin{array}{l}0.04 \\
0.04\end{array}$ & - \\
\hline SULFATE & $\begin{array}{l}03 / 30 / 84 \\
05 / 27 / 85\end{array}$ & $\begin{array}{l}0001 \\
0001\end{array}$ & MG/L & & $\begin{array}{l}341.00 \\
336.00\end{array}$ & $\begin{array}{l}0.1 \\
0.1\end{array}$ & $\dot{-}$ \\
\hline URANIUM & $\begin{array}{l}03 / 30 / 84 \\
05 / 27 / 85\end{array}$ & $\begin{array}{l}0001 \\
0001\end{array}$ & $M G / L$ & $<$ & $\begin{array}{l}0.0008 \\
0.0003\end{array}$ & $\begin{array}{l}0.0003 \\
0.003\end{array}$ & $\dot{-}$ \\
\hline VANADIUM & $\begin{array}{l}03 / 30 / 84 \\
05 / 27 / 85\end{array}$ & $\begin{array}{l}0001 \\
0001\end{array}$ & $M G / L$ & $\begin{array}{l}< \\
<\end{array}$ & $\begin{array}{l}0.004 \\
0.01\end{array}$ & $\begin{array}{l}0.004 \\
0.01\end{array}$ & $\begin{array}{l}- \\
-\end{array}$ \\
\hline
\end{tabular}

PARAMETER VALUE INDICATOR (PVI): < - LESS THAN DETECTION LIMIT

SAMPLE ID CODES:

0001 - FILTERED SAMPLE (.45 MICRONS)

OTHER PARAMETER VALUE FLAGS:

$J$ - ESTIMATED VALUE 


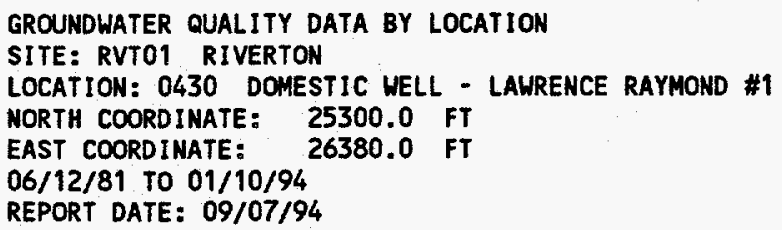

FORMATION OF COMPLETION: NO RECOVERY OF DATA FOR CLASSIFYING (NR) HYDRAULIC FLOW RELATIONSHIP: UNKNOWN (N)

\begin{tabular}{|c|c|c|c|c|c|c|c|c|}
\hline PARAMETER NAME & LOG DATE & $\begin{array}{c}\text { SAMPLE } \\
\text { ID }\end{array}$ & $\begin{array}{l}\text { UNITS OF } \\
\text { MEASURE }\end{array}$ & PVI & $\begin{array}{l}\text { PARAMETER } \\
\text { VALUE }\end{array}$ & FLAGS & $\begin{array}{l}\text { DETECTION } \\
\text { LIMIT }\end{array}$ & $\begin{array}{l}\text { PARAMETER } \\
\text { UNCERTAINTY }\end{array}$ \\
\hline ARSENIC & $\begin{array}{l}12 / 08 / 83 \\
12 / 08 / 83 \\
01 / 10 / 84 \\
01 / 10 / 84 \\
04 / 04 / 84 \\
05 / 27 / 85 \\
11 / 19 / 90 \\
03 / 28 / 91\end{array}$ & $\begin{array}{l}0001 \\
0002 \\
0001 \\
0002 \\
0001 \\
0001 \\
0001 \\
0001\end{array}$ & $M G / L$ & $\begin{array}{l}< \\
< \\
< \\
< \\
<\end{array}$ & $\begin{array}{l}0.001 \\
0.001 \\
0.005 \\
0.005 \\
0.01 \\
0.01 \\
0.01 \\
0.01\end{array}$ & GJ & $\begin{array}{l}0.001 \\
0.001 \\
0.005 \\
0.005 \\
0.01 \\
0.01 \\
0.01 \\
0.01\end{array}$ & $\begin{array}{l}- \\
- \\
- \\
- \\
- \\
-\end{array}$ \\
\hline ARSENIC (TOTAL) & $\begin{array}{l}11 / 19 / 90 \\
03 / 28 / 91 \\
06 / 03 / 91 \\
03 / 14 / 92 \\
08 / 07 / 92 \\
03 / 16 / 93\end{array}$ & $\begin{array}{l}\text { N001 } \\
\text { N001 } \\
\text { N001 } \\
\text { N001 } \\
\text { N001 } \\
\text { N001 }\end{array}$ & $M G / L$ & $\begin{array}{l}< \\
< \\
< \\
<\end{array}$ & $\begin{array}{l}0.01 \\
0.01 \\
0.05 \\
0.005 \\
0.01 \\
0.005\end{array}$ & $\begin{array}{l}G \\
1\end{array}$ & $\begin{array}{l}0.01 \\
0.01 \\
0.05 \\
0.005 \\
0.01 \\
0.005\end{array}$ & $\begin{array}{l}- \\
- \\
- \\
-\end{array}$ \\
\hline MANGANESE (TOTAL) & $\begin{array}{l}11 / 19 / 90 \\
03 / 28 / 91 \\
06 / 03 / 91 \\
03 / 14 / 92 \\
08 / 07 / 92 \\
03 / 16 / 93\end{array}$ & $\begin{array}{l}\text { N001 } \\
\text { N001 } \\
\text { N001 } \\
\text { N001 } \\
\text { N001 } \\
\text { N001 }\end{array}$ & $M G / L$ & $\begin{array}{l}< \\
< \\
<\end{array}$ & $\begin{array}{l}0.01 \\
0.01 \\
0.01 \\
0.01 \\
0.01 \\
0.01\end{array}$ & G & $\begin{array}{l}0.01 \\
0.01 \\
0.01 \\
0.01 \\
0.01 \\
0.01\end{array}$ & $\begin{array}{l}- \\
- \\
- \\
-\end{array}$ \\
\hline MOLYBDENUM & $\begin{array}{l}06 / 12 / 81 \\
12 / 08 / 83 \\
12 / 08 / 83 \\
01 / 10 / 84 \\
01 / 10 / 84 \\
04 / 04 / 84 \\
05 / 27 / 85 \\
11 / 19 / 90 \\
03 / 28 / 91\end{array}$ & $\begin{array}{l}0001 \\
0001 \\
0002 \\
0001 \\
0002 \\
0001 \\
0001 \\
0001 \\
0001\end{array}$ & $M G / L$ & $\begin{array}{l}< \\
< \\
< \\
< \\
< \\
<\end{array}$ & $\begin{array}{l}0.004 \\
0.001 \\
0.001 \\
0.005 \\
0.005 \\
0.01 \\
0.01 \\
0.01 \\
0.01\end{array}$ & G & $\begin{array}{l}- \\
0.001 \\
0.001 \\
0.005 \\
0.005 \\
0.01 \\
0.01 \\
0.01 \\
0.01\end{array}$ & $\begin{array}{l}- \\
- \\
- \\
- \\
- \\
-\end{array}$ \\
\hline NICKEL & $\begin{array}{l}12 / 08 / 83 \\
12 / 08 / 83 \\
01 / 10 / 84 \\
01 / 10 / 84 \\
04 / 04 / 84 \\
05 / 27 / 85 \\
11 / 19 / 90\end{array}$ & $\begin{array}{l}0001 \\
0002 \\
0001 \\
0002 \\
0001 \\
0001 \\
0001\end{array}$ & $M G / L$ & $\begin{array}{l}< \\
< \\
<\end{array}$ & $\begin{array}{l}0.017 \\
0.018 \\
0.04 \\
0.04 \\
0.04 \\
0.04 \\
0.04\end{array}$ & G & $\begin{array}{l}0.001 \\
0.001 \\
0.04 \\
0.04 \\
0.04 \\
0.04 \\
0.04\end{array}$ & $\begin{array}{l}- \\
- \\
- \\
- \\
-\end{array}$ \\
\hline
\end{tabular}

PARAMETER VALUE INDICATOR (PVI): < - LESS THAN DETECTION LIMIT

OTHER PARAMETER VALUE FLAGS:

G - PH > 9, POSSIBLE GROUT CONTAMINATION

I - INCREASED DETECTION LIMIT DUE TO REQUIRED DILUTION

J - ESTIMATED VALUE
SAMPLE ID CODES:

0001 - FILTERED SAMPLE (.45 MICRONS)

0002 - FILTERED REPLICATE SAMPLE (.45 MICRONS)

NO01 - UNFILTERED SAMPLE 
GROUNDWATER QUALITY DATA BY LOCATION

SITE: RVTO1 RIVERTON

LOCATION: 0430 DOMESTIC WELL - LANRENCE RAYMOND \#1

NORTH COORDINATE: 25300.0 FT

EAST COORDINATE: $\quad 26380.0$ FT

06/12/81 TO $01 / 10 / 94$

REPORT DATE : 09/07/94

FORMATION OF COMPLETION: NO RECOVERY OF DATA FOR CLASSIFYING (NR)

HYDRAULIC FLOW RELATIONSHIP: UNKNOWN (N)

\begin{tabular}{|c|c|c|c|c|c|c|c|c|}
\hline PARAMETER NAME & LOG DATE & $\begin{array}{c}\text { SAMPLE } \\
\text { ID }\end{array}$ & $\begin{array}{l}\text { UNITS OF } \\
\text { MEASURE }\end{array}$ & PVI & $\begin{array}{l}\text { PARAMETER } \\
\text { VALUE }\end{array}$ & FLAGS & $\begin{array}{l}\text { DETECTION } \\
\text { LIMIT }\end{array}$ & $\begin{array}{l}\text { PARAMETER } \\
\text { UNCERTAINTY }\end{array}$ \\
\hline NICKEL & $03 / 28 / 91$ & 0001 & $M G / L$ & $<$ & 0.04 & & 0.04 & - \\
\hline NICKEL (TOTAL) & $\begin{array}{l}11 / 19 / 90 \\
03 / 28 / 91 \\
06 / 03 / 91 \\
03 / 14 / 92 \\
08 / 07 / 92 \\
03 / 16 / 93\end{array}$ & $\begin{array}{l}\text { NO01 } \\
\text { N001 } \\
\text { N001 } \\
\text { N001 } \\
\text { N001 } \\
\text { N001 }\end{array}$ & $M G / L$ & $\begin{array}{l}< \\
< \\
< \\
<\end{array}$ & $\begin{array}{l}0.04 \\
0.04 \\
0.04 \\
0.04 \\
0.04 \\
0.04\end{array}$ & G & $\begin{array}{l}0.04 \\
0.04 \\
0.04 \\
0.04 \\
0.04 \\
0.04\end{array}$ & $\begin{array}{l}- \\
- \\
- \\
-\end{array}$ \\
\hline SULFATE & $\begin{array}{l}06 / 12 / 81 \\
12 / 08 / 83 \\
12 / 08 / 83 \\
01 / 10 / 84 \\
01 / 10 / 84 \\
04 / 04 / 84 \\
05 / 27 / 85 \\
11 / 19 / 90 \\
03 / 28 / 91\end{array}$ & $\begin{array}{l}0001 \\
0001 \\
0002 \\
0001 \\
0002 \\
0001 \\
0001 \\
0001 \\
0001\end{array}$ & $M G / L$ & & $\begin{array}{l}205.00 \\
194.00 \\
189.00 \\
180.00 \\
180.00 \\
198.00 \\
192.00 \\
209 . \\
202 .\end{array}$ & G & $\begin{array}{c}- \\
0.1 \\
0.1 \\
- \\
- \\
0.1 \\
0.1 \\
0.1 \\
10 .\end{array}$ & $\begin{array}{l}- \\
- \\
- \\
- \\
- \\
- \\
-\end{array}$ \\
\hline SULFATE (TOTAL) & $\begin{array}{l}11 / 19 / 90 \\
06 / 03 / 91 \\
03 / 14 / 92 \\
08 / 07 / 92 \\
03 / 16 / 93\end{array}$ & $\begin{array}{l}\text { No01 } \\
\text { N001 } \\
\text { N001 } \\
\text { N001 } \\
\text { N001 }\end{array}$ & MG/L & & $\begin{array}{l}209 . \\
185 \\
198 \\
208 \\
212\end{array}$ & G & $\begin{array}{c}0.1 \\
0.1 \\
40 . \\
20 . \\
1\end{array}$ & $\begin{array}{l}- \\
- \\
-\end{array}$ \\
\hline URANIUM & $\begin{array}{l}12 / 08 / 83 \\
12 / 08 / 83 \\
01 / 10 / 84 \\
01 / 10 / 84 \\
04 / 04 / 84 \\
05 / 27 / 85 \\
11 / 19 / 90 \\
03 / 28 / 91\end{array}$ & $\begin{array}{l}0001 \\
0002 \\
0001 \\
0002 \\
0001 \\
0001 \\
0001 \\
0001\end{array}$ & $M G / L$ & $\begin{array}{l}< \\
< \\
< \\
<\end{array}$ & $\begin{array}{l}0.0006 \\
0.0003 \\
0.002 \\
0.002 \\
0.0012 \\
0.0003 \\
0.0003 \\
0.002\end{array}$ & $\begin{array}{l}\text { J } \\
\text { G }\end{array}$ & $\begin{array}{l}0.0003 \\
0.0003 \\
0.002 \\
0.002 \\
0.0003 \\
0.003 \\
0.0003 \\
0.001\end{array}$ & $\begin{array}{l}- \\
- \\
- \\
- \\
-\end{array}$ \\
\hline URANIUM (TOTAL) & $\begin{array}{l}11 / 19 / 90 \\
03 / 28 / 91 \\
06 / 03 / 91 \\
03 / 14 / 92 \\
08 / 07 / 92 \\
03 / 16 / 93\end{array}$ & $\begin{array}{l}\text { No01 } \\
\text { No01 } \\
\text { N001 } \\
\text { NO01 } \\
\text { N001 } \\
\text { NO01 }\end{array}$ & $M G / L$ & $\begin{array}{l}< \\
< \\
< \\
<\end{array}$ & $\begin{array}{l}0.0003 \\
0.001 \\
0.001 \\
0.001 \\
0.001 \\
0.003\end{array}$ & G & $\begin{array}{l}0.0003 \\
0.001 \\
0.001 \\
0.001 \\
0.001 \\
0.001\end{array}$ & $\begin{array}{l}- \\
- \\
- \\
-\end{array}$ \\
\hline VANADIUM & $\begin{array}{l}12 / 08 / 83 \\
12 / 08 / 83 \\
01 / 10 / 84 \\
01 / 10 / 84 \\
04 / 04 / 84 \\
05 / 27 / 85 \\
11 / 19 / 90 \\
03 / 28 / 91\end{array}$ & $\begin{array}{l}0001 \\
0002 \\
0001 \\
0002 \\
0001 \\
0001 \\
0001 \\
0001\end{array}$ & MG/L & $\begin{array}{l}< \\
< \\
< \\
< \\
< \\
< \\
<\end{array}$ & $\begin{array}{l}0.004 \\
0.004 \\
0.004 \\
0.004 \\
0.01 \\
0.01 \\
0.01 \\
0.01\end{array}$ & G & $\begin{array}{l}0.004 \\
0.004 \\
0.004 \\
0.004 \\
0.01 \\
0.01 \\
0.01 \\
0.01\end{array}$ & $\begin{array}{l}- \\
- \\
- \\
- \\
- \\
- \\
-\end{array}$ \\
\hline VANADIUM (TOTAL) & $\begin{array}{l}11 / 19 / 90 \\
03 / 28 / 91 \\
06 / 03 / 91 \\
03 / 14 / 92 \\
08 / 07 / 92 \\
03 / 16 / 93\end{array}$ & $\begin{array}{l}\text { N001 } \\
\text { N001 } \\
\text { N001 } \\
\text { N001 } \\
\text { N001 } \\
\text { N001 }\end{array}$ & MG/L & $\begin{array}{l}< \\
< \\
< \\
< \\
< \\
<\end{array}$ & $\begin{array}{l}0.01 \\
0.01 \\
0.01 \\
0.01 \\
0.01 \\
0.01\end{array}$ & G & $\begin{array}{l}0.01 \\
0.01 \\
0.01 \\
0.01 \\
0.01 \\
0.01\end{array}$ & $\begin{array}{l}- \\
- \\
- \\
-\end{array}$ \\
\hline
\end{tabular}

PARAMETER VALUE INDICATOR (PVI): < - LESS THAN DETECTION LIMIT

J - estimated VALUe 
GROUNDWATER QUALITY DATA BY LOCATION

SITE: RVTO1 RIVERTON

LOCATION: 0430 DOMESTIC WELL - LAWRENCE RAYMOND \#1

NORTH COORDINATE: 25300.0 FT

EAST COORDINATE: $\quad 26380.0$ FT

06/12/81 TO 01/10/94

REPORT DATE: 09/07/94

FORMATION OF COMPLETION: NO RECOVERY OF DATA FOR CLASSIFYING (NR)

HYDRAULIC FLOW RELATIONSHIP: UNKNOWN (N)

\begin{tabular}{|c|c|c|c|c|c|c|c|}
\hline PARAMETER NAME & LOG DATE & $\begin{array}{c}\text { SAMPLE } \\
\text { ID }\end{array}$ & $\begin{array}{l}\text { UNITS OF } \\
\text { MEASURE }\end{array}$ & PVI & $\begin{array}{l}\text { ARAMETER } \\
\text { VALUE FLAGS }\end{array}$ & $\begin{array}{l}\text { DETECTION } \\
\text { LIMIT }\end{array}$ & $\begin{array}{l}\text { PARAMETER } \\
\text { UNCERTAINTY }\end{array}$ \\
\hline
\end{tabular}

PARAMETER VALUE INDICATOR (PVI): < - LESS THAN DETECTION LIMIT SAMPLE ID CODES: 
GROUNDWATER QUALITY DATA BY LOCATION

SITE: RVTO1 RIVERTON

LOCATION: 0431 DOMESTIC HELL - RAYMOND \#2

NORTH COORDINATE: 25440.0 FT

EAST COORDINATE: 26440.0 FT

$06 / 12 / 81$ TO $01 / 10 / 94$

REPORT DATE: 09/07/94

FORMATION OF COMPLETION: NO RECOVERY OF DATA FOR CLASSIFYING (NR)

HYDRAULIC FLOW RELATIONSHIP: UNKNOWN (N)

\begin{tabular}{|c|c|c|c|c|c|c|c|}
\hline PARAMETER NAME & LOG DATE & $\begin{array}{c}\text { SAMPLE } \\
\text { ID }\end{array}$ & $\begin{array}{l}\text { UNITS OF } \\
\text { MEASURE }\end{array}$ & PVI & $\begin{array}{l}\text { PARAMETER } \\
\text { VALUE FLAGS }\end{array}$ & $\begin{array}{l}\text { DETECTION } \\
\text { LIMIT }\end{array}$ & $\begin{array}{l}\text { PARAMETER } \\
\text { UNCERTAINTY }\end{array}$ \\
\hline ARSENIC & $\begin{array}{l}04 / 04 / 84 \\
05 / 27 / 85\end{array}$ & $\begin{array}{l}0001 \\
0001\end{array}$ & MG/L & $\begin{array}{l}< \\
<\end{array}$ & $\begin{array}{l}0.01 \\
0.01\end{array}$ & $\begin{array}{l}0.01 \\
0.01\end{array}$ & - \\
\hline ARSENIC (TOTAL) & $\begin{array}{l}08 / 07 / 92 \\
03 / 16 / 93\end{array}$ & $\begin{array}{l}\text { No01 } \\
\text { N001 }\end{array}$ & $M G / L$ & $<$ & $\begin{array}{l}0.01 \\
0.005\end{array}$ & $\begin{array}{l}0.01 \\
0.005\end{array}$ & - \\
\hline MANGANESE & $\begin{array}{l}04 / 04 / 84 \\
05 / 27 / 85\end{array}$ & $\begin{array}{l}0001 \\
0001\end{array}$ & $M G / L$ & & $\begin{array}{l}0.59 \\
0.27\end{array}$ & $\begin{array}{l}0.01 \\
0.01\end{array}$ & - \\
\hline MANGANESE (TOTAL) & $\begin{array}{l}08 / 07 / 92 \\
03 / 16 / 93\end{array}$ & $\begin{array}{l}\text { No01 } \\
\text { No01 }\end{array}$ & $M G / L$ & & $\begin{array}{l}0.08 \\
0.06\end{array}$ & $\begin{array}{l}0.01 \\
0.01\end{array}$ & - \\
\hline MOL YBDENUM & $\begin{array}{l}04 / 04 / 84 \\
05 / 27 / 85\end{array}$ & $\begin{array}{l}0001 \\
0001\end{array}$ & MG/L & $<$ & $\begin{array}{l}0.01 \\
0.01\end{array}$ & $\begin{array}{l}0.01 \\
0.01\end{array}$ & $=$ \\
\hline MOLYBDENUM (TOTAL) & $\begin{array}{l}08 / 07 / 92 \\
03 / 16 / 93\end{array}$ & $\begin{array}{l}\text { No01 } \\
\text { No01 }\end{array}$ & $M G / L$ & $\begin{array}{l}< \\
<\end{array}$ & $\begin{array}{l}0.01 \\
0.01\end{array}$ & $\begin{array}{l}0.01 \\
0.01\end{array}$ & - \\
\hline NICKEL & $\begin{array}{l}04 / 04 / 84 \\
05 / 27 / 85\end{array}$ & $\begin{array}{l}0001 \\
0001\end{array}$ & MG/L & $<$ & $\begin{array}{l}0.04 \\
0.04\end{array}$ & $\begin{array}{l}0.04 \\
0.04\end{array}$ & - \\
\hline NICKEL (TOTAL) & $\begin{array}{l}08 / 07 / 92 \\
03 / 16 / 93\end{array}$ & $\begin{array}{l}\text { No01 } \\
\text { N001 }\end{array}$ & MG $/ L$ & $\begin{array}{l}< \\
<\end{array}$ & $\begin{array}{l}0.04 \\
0.04\end{array}$ & $\begin{array}{l}0.04 \\
0.04\end{array}$ & - \\
\hline SULFATE & $\begin{array}{l}04 / 04 / 84 \\
05 / 27 / 85\end{array}$ & $\begin{array}{l}0001 \\
0001\end{array}$ & $M G / L$ & & $\begin{array}{l}244.00 \\
199.00\end{array}$ & $\begin{array}{l}0.1 \\
0.1\end{array}$ & - \\
\hline SULFATE (TOTAL) & $\begin{array}{l}08 / 07 / 92 \\
03 / 16 / 93\end{array}$ & $\begin{array}{l}\text { No01 } \\
\text { N001 }\end{array}$ & $M G / L$ & & $\begin{array}{l}282 \\
176\end{array}$ & $\begin{array}{c}30 . \\
1\end{array}$ & - \\
\hline URAHIUM & $\begin{array}{l}04 / 04 / 84 \\
05 / 27 / 85\end{array}$ & $\begin{array}{l}0001 \\
0001\end{array}$ & $M G / L$ & & $\begin{array}{l}0.0077 \\
0.0103\end{array}$ & $\begin{array}{l}0.0003 \\
0.003\end{array}$ & - \\
\hline URANIUM (TOTAL) & $\begin{array}{l}08 / 07 / 92 \\
03 / 16 / 93\end{array}$ & $\begin{array}{l}\text { No01 } \\
\text { N001 }\end{array}$ & $M G / L$ & & $\begin{array}{l}0.010 \\
0.016\end{array}$ & $\begin{array}{l}0.001 \\
0.001\end{array}$ & - \\
\hline VANADIUM & $\begin{array}{l}04 / 04 / 84 \\
05 / 27 / 85\end{array}$ & $\begin{array}{l}0001 \\
0001\end{array}$ & $M G / L$ & $<$ & $\begin{array}{l}0.01 \\
0.01\end{array}$ & $\begin{array}{l}0.01 \\
0.01\end{array}$ & - \\
\hline VANADIUM (TOTAL) & $\begin{array}{l}08 / 07 / 92 \\
03 / 16 / 93\end{array}$ & $\begin{array}{l}\text { No01 } \\
\text { N001 }\end{array}$ & $M G / L$ & $\begin{array}{l}< \\
<\end{array}$ & $\begin{array}{l}0.01 \\
0.01\end{array}$ & $\begin{array}{l}0.01 \\
0.01\end{array}$ & - \\
\hline
\end{tabular}

PARAMETER VALUE INDICATOR (PVI): < - LESS THAN DETECTION LIMIT

SAMPLE ID CODES:

0001 - FILTERED SAMPLE (.45 MICRONS)

NOO1 - UNFILTERED SAMPLE 
GROUNDWATER QUALITY DATA BY LOCATION

SITE: RVTO1 RIVERTON

LOCATION: 0435 DOMESTIC WELL

NORTH COORDINATE: 19120.0 FT

EAST COORDINATE: 22170.0 FT

06/12/81 TO $01 / 10 / 94$

REPORT DATE: $09 / 07 / 94$

FORMATION OF COMPLETION: NO RECOVERY OF DATA FOR CLASSIFYING (NR) HYDRAULIC FLOW RELATIONSHIP: UNKNOWN (N)

\begin{tabular}{|c|c|c|c|c|c|c|c|}
\hline PARAMETER NAME & LOG DATE & $\underset{\text { ID }}{\text { SAMPLE }}$ & $\begin{array}{l}\text { UNITS OF } \\
\text { MEASURE }\end{array}$ & PVI & $\begin{array}{l}\text { PARAMETER } \\
\text { VALUE FLAGS }\end{array}$ & $\begin{array}{l}\text { DETECTION } \\
\text { LIMIT }\end{array}$ & $\begin{array}{l}\text { PARAMETER } \\
\text { UNCERTAINTY }\end{array}$ \\
\hline ARSENIC & $\begin{array}{l}12 / 08 / 83 \\
01 / 10 / 84 \\
06 / 05 / 84\end{array}$ & $\begin{array}{l}0001 \\
0001 \\
0001\end{array}$ & $M G / L$ & $<$ & $\begin{array}{l}0.001 \\
0.005 \\
0.01\end{array}$ & $\begin{array}{l}0.001 \\
0.005 \\
0.001\end{array}$ & - \\
\hline MANGANESE & $\begin{array}{l}12 / 08 / 83 \\
01 / 10 / 84 \\
06 / 05 / 84\end{array}$ & $\begin{array}{l}0001 \\
0001 \\
0001\end{array}$ & $M G / L$ & $<$ & $\begin{array}{l}0.02 \\
0.01 \\
0.01\end{array}$ & $\begin{array}{c}10 . \\
0.01 \\
0.01\end{array}$ & $\begin{array}{l}- \\
-\end{array}$ \\
\hline MOLYBDENUM & $\begin{array}{l}12 / 08 / 83 \\
01 / 10 / 84 \\
06 / 05 / 84\end{array}$ & $\begin{array}{l}0001 \\
0001 \\
0001\end{array}$ & MG/L & $<$ & $\begin{array}{l}0.001 \\
0.005 \\
0.01\end{array}$ & $\begin{array}{l}0.001 \\
0.005 \\
0.01\end{array}$ & - \\
\hline NICKEL & $\begin{array}{l}12 / 08 / 83 \\
01 / 10 / 84 \\
06 / 05 / 84\end{array}$ & $\begin{array}{l}0001 \\
0001 \\
0001\end{array}$ & $M G / L$ & $<$ & $\begin{array}{l}0.024 \\
0.04 \\
0.04\end{array}$ & $\begin{array}{l}0.001 \\
0.04 \\
0.04\end{array}$ & $\begin{array}{l}- \\
-\end{array}$ \\
\hline SULFATE & $\begin{array}{l}12 / 08 / 83 \\
01 / 10 / 84 \\
06 / 05 / 84\end{array}$ & $\begin{array}{l}0001 \\
0001 \\
0001\end{array}$ & $M G / L$ & & $\begin{array}{l}170.00 \\
150.00 \\
168.00\end{array}$ & $\begin{array}{l}0.1 \\
--1\end{array}$ & - \\
\hline URANIUM & $\begin{array}{l}12 / 08 / 83 \\
01 / 10 / 84 \\
06 / 05 / 84\end{array}$ & $\begin{array}{l}0001 \\
0001 \\
0001\end{array}$ & MG/L & $<$ & $\begin{array}{l}0.0003 \\
0.002 \\
0.0003\end{array}$ & $\begin{array}{l}0.0003 \\
0.002 \\
0.0003\end{array}$ & : \\
\hline VANADIUM & $\begin{array}{l}12 / 08 / 83 \\
01 / 10 / 84 \\
06 / 05 / 84\end{array}$ & $\begin{array}{l}0001 \\
0001 \\
0001\end{array}$ & MG/L & $<$ & $\begin{array}{l}0.004 \\
0.004 \\
0.01\end{array}$ & $\begin{array}{l}0.004 \\
0.004 \\
0.01\end{array}$ & - \\
\hline
\end{tabular}

PARAMETER VALUE INDICATOR (PVI): < - LESS THAN DETECTION LIMIT

SAMPLE ID CODES:

0001 - FILTERED SAMPLE (.45 MICRONS)

OTHER PARAMETER VALUE FLAGS:

$J$ - ESTIMATED VALUE 
GROUNDWATER QUALITY DATA BY LOCATION

SITE : RVTO1 RIVERTON

LOCATION: 0436 DOMESTIC WELL - ST STEPHENS MISSION

NORTH COORDINATE: $19000.0 \mathrm{FT}$

EAST COORDINATE: 23600.0 FT

06/12/81 TO $01 / 10 / 94$

REPORT DATE : 09/07/94

FORMATION OF COMPLETION: NO RECOVERY OF DATA FOR CLASSIFYING (NR) HYDRAULIC FLOW RELATIONSHIP: UNKNOWN (N)

\begin{tabular}{|c|c|c|c|c|c|c|c|}
\hline PARAMETER NAME & LOG DATE & $\begin{array}{c}\text { SAMPLE } \\
\text { ID }\end{array}$ & $\begin{array}{l}\text { UNITS OF } \\
\text { MEASURE }\end{array}$ & PVI & $\begin{array}{l}\text { PARAMETER } \\
\text { VALUE FLAGS }\end{array}$ & $\begin{array}{l}\text { DETECTION } \\
\text { LIMIT }\end{array}$ & $\begin{array}{l}\text { PARAMETER } \\
\text { UNCERTAINTY }\end{array}$ \\
\hline ARSENIC (TOTAL) & $\begin{array}{l}06 / 03 / 91 \\
10 / 26 / 91 \\
03 / 14 / 92 \\
08 / 05 / 92\end{array}$ & $\begin{array}{l}\text { N001 } \\
\text { N001 } \\
\text { N001 } \\
\text { N001 }\end{array}$ & $M G / L$ & $\begin{array}{l}< \\
< \\
< \\
<\end{array}$ & $\begin{array}{ll}0.05 & 1 \\
0.001 & \\
0.005 & \\
0.01 & \end{array}$ & $\begin{array}{l}0.05 \\
0.001 \\
0.005 \\
0.01\end{array}$ & $\begin{array}{l}- \\
-\end{array}$ \\
\hline MANGANESE (TOTAL) & $\begin{array}{l}06 / 03 / 91 \\
10 / 26 / 91 \\
03 / 14 / 92 \\
08 / 05 / 92\end{array}$ & $\begin{array}{l}\text { No01 } \\
\text { N001 } \\
\text { N001 } \\
\text { N001 }\end{array}$ & $M G / L$ & $\begin{array}{l}< \\
< \\
<\end{array}$ & $\begin{array}{l}0.01 \\
0.01 \\
0.01 \\
0.01\end{array}$ & $\begin{array}{l}0.01 \\
0.01 \\
0.01 \\
0.01\end{array}$ & $\begin{array}{l}- \\
- \\
-\end{array}$ \\
\hline MOLYBDENUM (TOTAL) & $\begin{array}{l}06 / 03 / 91 \\
10 / 26 / 91 \\
03 / 14 / 92 \\
08 / 05 / 92\end{array}$ & $\begin{array}{l}\text { N001 } \\
\text { N001 } \\
\text { N001 } \\
\text { N001 }\end{array}$ & $M G / L$ & $\begin{array}{l}< \\
< \\
<\end{array}$ & $\begin{array}{l}0.01 \\
0.01 \\
0.01 \\
0.01\end{array}$ & $\begin{array}{l}0.01 \\
0.01 \\
0.01 \\
0.01\end{array}$ & $\begin{array}{l}- \\
- \\
-\end{array}$ \\
\hline NICKEL (TOTAL) & $\begin{array}{l}06 / 03 / 91 \\
10 / 26 / 91 \\
03 / 14 / 92 \\
08 / 05 / 92\end{array}$ & $\begin{array}{l}\text { N001 } \\
\text { N001 } \\
\text { N001 } \\
\text { N001 }\end{array}$ & MG/L & $\begin{array}{l}< \\
< \\
<\end{array}$ & $\begin{array}{l}0.04 \\
0.01 \\
0.04 \\
0.04\end{array}$ & $\begin{array}{l}0.04 \\
0.01 \\
0.04 \\
0.04\end{array}$ & $\begin{array}{l}- \\
- \\
-\end{array}$ \\
\hline SULFATE (TOTAL) & $\begin{array}{l}06 / 03 / 91 \\
10 / 26 / 91 \\
03 / 14 / 92 \\
08 / 05 / 92 \\
03 / 17 / 93\end{array}$ & $\begin{array}{l}\text { No01 } \\
\text { N001 } \\
\text { N001 } \\
\text { N001 } \\
\text { N001 }\end{array}$ & $M G / L$ & & $\begin{array}{l}186 \\
193 \\
235 \\
230 \\
217\end{array}$ & $\begin{array}{c}0.1 \\
0.1 \\
40 . \\
30 . \\
1\end{array}$ & $\begin{array}{l}- \\
- \\
-\end{array}$ \\
\hline URANIUM (TOTAL) & $\begin{array}{l}06 / 03 / 91 \\
10 / 29 / 91 \\
03 / 14 / 92 \\
08 / 05 / 92 \\
03 / 17 / 93\end{array}$ & $\begin{array}{l}\text { N001 } \\
\text { N001 } \\
\text { N001 } \\
\text { N001 } \\
\text { N001 }\end{array}$ & $M G / L$ & $\begin{array}{l}< \\
< \\
<\end{array}$ & $\begin{array}{l}0.001 \\
0.0003 \\
0.001 \\
0.001 \\
0.001\end{array}$ & $\begin{array}{l}0.001 \\
0.0003 \\
0.001 \\
0.001 \\
0.001\end{array}$ & $\begin{array}{l}- \\
- \\
- \\
-\end{array}$ \\
\hline VANADIUM (TOTAL) & $\begin{array}{l}06 / 03 / 91 \\
10 / 26 / 91 \\
03 / 14 / 92 \\
08 / 05 / 92\end{array}$ & $\begin{array}{l}\text { N001 } \\
\text { N001 } \\
\text { N001 } \\
\text { N001 }\end{array}$ & $M G / L$ & $\begin{array}{l}< \\
<\end{array}$ & $\begin{array}{l}0.01 \\
0.01 \\
0.01 \\
0.01\end{array}$ & $\begin{array}{l}0.01 \\
0.01 \\
0.01 \\
0.01\end{array}$ & $\begin{array}{l}- \\
- \\
-\end{array}$ \\
\hline
\end{tabular}

PARAMETER VALUE INDICATOR (PVI): < - LESS THAN DETECTION LIMIT

SAMPLE ID CODES:

NOO1 - UNFILTERED SAMPLE

OTHER PARAMETER VALUE FLAGS:

1 - INCREASED DETECTION LIMIT DUE TO REQUIRED DILUTION 
GROUNDWATER QUALITY DATA BY LOCATION

SITE: RVTO1 RIVERTON

LOCATION: 0437 DOMESTIC WELL

NORTH COORDINATE: 18604.0 FT

EAST COORDINATE: 22487.6 FT

06/12/81 TO $01 / 10 / 94$

REPORT DATE: 09/07/94

FORMATION OF COMPLETION: NO RECOVERY OF DATA FOR CLASSIFYING (NR) HYDRAULIC FLOW RELATIONSHIP: UNKNOWN (N)

\begin{tabular}{|c|c|c|c|c|c|c|c|}
\hline PARAMETER NAME & LOG DATE & $\underset{\text { ID }}{\text { SAMPLE }}$ & $\begin{array}{l}\text { UNITS OF } \\
\text { MEASURE }\end{array}$ & PVI & $\begin{array}{l}\text { PARAMETER } \\
\text { VALUE FLAGS }\end{array}$ & $\begin{array}{l}\text { DETECTION } \\
\text { LIMIT }\end{array}$ & $\begin{array}{l}\text { PARAMETER } \\
\text { UNCERTAINTY }\end{array}$ \\
\hline ARSENIC & $05 / 29 / 85$ & 0001 & $M G / L$ & $<$ & 0.01 & 0.01 & - \\
\hline MOL YBDENUM & $05 / 29 / 85$ & 0001 & MG/L & $<$ & 0.01 & 0.01 & - \\
\hline SULFATE & $05 / 29 / 85$ & 0001 & MG/L & & 83.90 & 0.1 & - \\
\hline URANIUM & $05 / 29 / 85$ & 0001 & $M G / L$ & & $0.0017 \mathrm{~J}$ & 0.003 & - \\
\hline VANADIUM & $05 / 29 / 85$ & 0001 & MG/L & $<$ & 0.01 & 0.01 & - \\
\hline
\end{tabular}

PARAMETER VALUE INDICATOR (PVI): < - LESS THAN DETECTION LIMIT

SAMPLE ID CODES:

0001 - FILTERED SAMPLE (.45 MICRONS)

OTHER PARAMETER VALUE FLAGS:

$J$ - ESTIMATED VALUE 


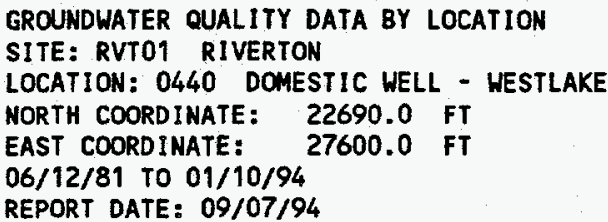

FORMATION OF COMPLETION: NO RECOVERY OF DATA FOR CLASSIFYING (NR) HYDRAULIC FLOW RELATIONSHIP: UNKNOWN (N)

\begin{tabular}{|c|c|c|c|c|c|c|c|c|}
\hline PARAMETER NAME & LOG DATE & $\begin{array}{c}\text { SAMPLE } \\
\text { ID }\end{array}$ & $\begin{array}{l}\text { UNITS OF } \\
\text { MEASURE }\end{array}$ & PVI & $\begin{array}{l}\text { PARAMETER } \\
\text { VALUE }\end{array}$ & FLAGS & $\begin{array}{c}\text { DETECTION } \\
\text { LIMIT }\end{array}$ & $\begin{array}{l}\text { PARAMETER } \\
\text { UNCERTAINTY }\end{array}$ \\
\hline ARSENIC & $\begin{array}{l}06 / 07 / 84 \\
05 / 25 / 85 \\
02 / 20 / 88 \\
04 / 01 / 90 \\
11 / 19 / 90\end{array}$ & $\begin{array}{l}0001 \\
0001 \\
0001 \\
0001 \\
0001\end{array}$ & MG/L & $\begin{array}{l}< \\
< \\
< \\
<\end{array}$ & $\begin{array}{l}0.01 \\
0.01 \\
0.002 \\
0.01 \\
0.01\end{array}$ & $\begin{array}{l}J \\
\text { GJ }\end{array}$ & $\begin{array}{l}0.01 \\
0.01 \\
0.01 \\
0.01 \\
0.01\end{array}$ & $\begin{array}{l}- \\
- \\
- \\
-\end{array}$ \\
\hline ARSENIC (TOTAL) & $\begin{array}{l}04 / 01 / 90 \\
11 / 19 / 90\end{array}$ & $\begin{array}{l}\text { No01 } \\
\text { No01 }\end{array}$ & $M G / L$ & $\begin{array}{l}< \\
<\end{array}$ & $\begin{array}{l}0.01 \\
0.01\end{array}$ & G & $\begin{array}{l}0.01 \\
0.01\end{array}$ & - \\
\hline MANGANESE & $\begin{array}{l}06 / 07 / 84 \\
05 / 25 / 85 \\
02 / 20 / 88 \\
04 / 01 / 90 \\
11 / 19 / 90\end{array}$ & $\begin{array}{l}0001 \\
0001 \\
0001 \\
0001 \\
0001\end{array}$ & MG/L & $\begin{array}{l}< \\
< \\
< \\
<\end{array}$ & $\begin{array}{l}1.32 \\
0.01 \\
0.01 \\
0.01 \\
0.01\end{array}$ & G & $\begin{array}{l}0.01 \\
0.01 \\
0.01 \\
0.01 \\
0.01\end{array}$ & $\begin{array}{l}- \\
- \\
- \\
-\end{array}$ \\
\hline MANGANESE (TOTAL) & $\begin{array}{l}04 / 01 / 90 \\
11 / 19 / 90\end{array}$ & $\begin{array}{l}\text { No01 } \\
\text { No01 }\end{array}$ & $M G / L$ & $\begin{array}{l}< \\
<\end{array}$ & $\begin{array}{l}0.01 \\
0.01\end{array}$ & $\mathbf{G}$ & $\begin{array}{l}0.01 \\
0.01\end{array}$ & - \\
\hline MOL YBDENUM & $\begin{array}{l}06 / 07 / 84 \\
05 / 25 / 85 \\
02 / 20 / 88 \\
04 / 01 / 90 \\
11 / 19 / 90\end{array}$ & $\begin{array}{l}0001 \\
0001 \\
0001 \\
0001 \\
0001\end{array}$ & MG $/ L$ & $\begin{array}{l}< \\
< \\
< \\
<\end{array}$ & $\begin{array}{l}0.01 \\
0.01 \\
0.01 \\
0.01 \\
0.01\end{array}$ & G & $\begin{array}{l}0.01 \\
0.01 \\
0.01 \\
0.01 \\
0.01\end{array}$ & $\begin{array}{l}- \\
- \\
- \\
-\end{array}$ \\
\hline MOLYBDENUM (TOTAL) & $\begin{array}{l}04 / 01 / 90 \\
11 / 19 / 90\end{array}$ & $\begin{array}{l}\text { No01 } \\
\text { No01 }\end{array}$ & $M G / L$ & $<$ & $\begin{array}{l}0.01 \\
0.01\end{array}$ & G & $\begin{array}{l}0.01 \\
0.01\end{array}$ & - \\
\hline NICKEL & $\begin{array}{l}06 / 07 / 84 \\
05 / 25 / 85 \\
02 / 20 / 88 \\
04 / 01 / 90 \\
11 / 19 / 90\end{array}$ & $\begin{array}{l}0001 \\
0001 \\
0001 \\
0001 \\
0001\end{array}$ & $M G / L$ & $\begin{array}{l}< \\
< \\
< \\
<\end{array}$ & $\begin{array}{l}0.04 \\
0.04 \\
0.02 \\
0.04 \\
0.04\end{array}$ & $\begin{array}{l}\mathbf{J} \\
\mathbf{G}\end{array}$ & $\begin{array}{l}0.04 \\
0.04 \\
0.04 \\
0.04 \\
0.04\end{array}$ & $\begin{array}{l}- \\
- \\
- \\
-\end{array}$ \\
\hline NICKEL (TOTAL) & $\begin{array}{l}04 / 01 / 90 \\
11 / 19 / 90\end{array}$ & $\begin{array}{l}\text { No01 } \\
\text { N001 }\end{array}$ & $M G / L$ & $\begin{array}{l}< \\
<\end{array}$ & $\begin{array}{l}0.04 \\
0.04\end{array}$ & G & $\begin{array}{l}0.04 \\
0.04\end{array}$ & - \\
\hline SULFATE & $\begin{array}{l}06 / 07 / 84 \\
05 / 25 / 85 \\
02 / 20 / 88 \\
04 / 01 / 90 \\
11 / 19 / 90\end{array}$ & $\begin{array}{l}0001 \\
0001 \\
0001 \\
0001 \\
0001\end{array}$ & MG /L & & $\begin{array}{l}691.00 \\
310.00 \\
286 . \\
322 . \\
317 .\end{array}$ & G & $\begin{array}{l}0.1 \\
0.1 \\
0.1 \\
0.1 \\
0.1\end{array}$ & $\begin{array}{l}- \\
- \\
- \\
-\end{array}$ \\
\hline SULFATE (TOTAL) & $\begin{array}{l}04 / 01 / 90 \\
11 / 19 / 90\end{array}$ & $\begin{array}{l}\text { No01 } \\
\text { No01 }\end{array}$ & MG/L & & $\begin{array}{l}322 . \\
319 .\end{array}$ & G & $\begin{array}{l}0.1 \\
0.1\end{array}$ & - \\
\hline URANIUM & $\begin{array}{l}06 / 07 / 84 \\
05 / 25 / 85 \\
02 / 20 / 88 \\
04 / 01 / 90 \\
11 / 19 / 90\end{array}$ & $\begin{array}{l}0001 \\
0001 \\
0001 \\
0001 \\
0001\end{array}$ & MG/L & $\begin{array}{l}< \\
< \\
< \\
<\end{array}$ & $\begin{array}{l}0.237 \\
0.0003 \\
0.0003 \\
0.0003 \\
0.0003\end{array}$ & $\begin{array}{l}J \\
J \\
J \\
G\end{array}$ & $\begin{array}{l}0.0003 \\
0.003 \\
0.003 \\
0.003 \\
0.0003\end{array}$ & $\begin{array}{l}- \\
- \\
- \\
- \\
-\end{array}$ \\
\hline URANIUM (TOTAL) & $\begin{array}{l}04 / 01 / 90 \\
11 / 19 / 90\end{array}$ & $\begin{array}{l}\text { No01 } \\
\text { N001 }\end{array}$ & $M G / L$ & & $\begin{array}{l}0.0006 \\
0.0005\end{array}$ & $\begin{array}{l}\mathbf{J} \\
\mathbf{G}\end{array}$ & $\begin{array}{l}0.003 \\
0.0003\end{array}$ & - \\
\hline VANAD IUM & $\begin{array}{l}06 / 07 / 84 \\
05 / 25 / 85\end{array}$ & $\begin{array}{l}0001 \\
0001\end{array}$ & $M G / L$ & $\begin{array}{l}< \\
<\end{array}$ & $\begin{array}{l}0.01 \\
0.01\end{array}$ & & $\begin{array}{l}0.01 \\
0.01\end{array}$ & - \\
\hline
\end{tabular}

PARAMETER VALUE INDICATOR (PVI): < - LESS THAN DETECTION LIMIT

OTHER PARAMETER VALUE FLAGS:

SAMPLE ID CODES:

0001 - FILTERED SAMPLE ( 45 MICRONS)

G - PH $>9$, POSSIBLE GROUT CONTAMINATION

NOO1 - UMFILTERED SAMPLE

J - ESTIMATED VALUE 


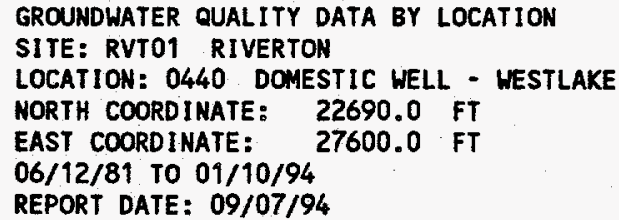

FORMATION OF COMPLETION: NO RECOVERY OF DATA FOR CLASSIFYING (NR) HYDRAULIC FLOW RELATIONSHIP: UNKNOWN (N)

\begin{tabular}{|c|c|c|c|c|c|c|c|c|}
\hline PARAMETER NAME & LOG DATE & $\underset{\text { ID }}{\text { SAMPLE }}$ & $\begin{array}{l}\text { UNITS OF } \\
\text { MEASURE }\end{array}$ & PVI & $\begin{array}{l}\text { PARAMETER } \\
\text { VALUE }\end{array}$ & FLAGS & $\begin{array}{l}\text { DETECTION } \\
\text { LIMIT }\end{array}$ & $\begin{array}{l}\text { PARAMETER } \\
\text { UNCERTAINTY }\end{array}$ \\
\hline VANADIUM & $\begin{array}{l}02 / 20 / 88 \\
04 / 01 / 90 \\
11 / 19 / 90\end{array}$ & $\begin{array}{l}0001 \\
0001 \\
0001\end{array}$ & $M G / L$ & $<$ & $\begin{array}{l}0.02 \\
0.01 \\
0.01\end{array}$ & G & $\begin{array}{l}0.01 \\
0.01 \\
0.01\end{array}$ & : \\
\hline VANADIUM (TOTAL) & $\begin{array}{l}04 / 01 / 90 \\
11 / 19 / 90\end{array}$ & $\begin{array}{l}\text { N001 } \\
\text { N001 }\end{array}$ & $M G / L$ & $<$ & $\begin{array}{l}0.01 \\
0.01\end{array}$ & G & $\begin{array}{l}0.01 \\
0.01\end{array}$ & - \\
\hline
\end{tabular}

PARAMETER VALUE INDICATOR (PVI): < - LESS THAN DETECTION LIMIT

OTHER PARAMETER VALUE FLAGS:

SAMPLE TO CODES:

$G$ - PH > 9, POSSIBLE GROUT CONTAMINATION

SAMPLE ID CODES

NO01 - UNFILTERED SAMPLE 
GROUNDWATER QUALITY DATA BY LOCATION

SITE: RVTO1 RIVERTON

LOCATION: 0441 DOMESTIC HELL - WESTLAKE

NORTH COORDINATE: 22720.0 FT

EAST COORDINATE: 27500.0 FT

06/12/81 TO 01/10/94

REPORT DATE: 09/07/94

FORMATION OF COMPLETION: NO RECOVERY OF DATA FOR CLASSIFYING (NR) HYDRAULIC FLOW RELATIONSHIP: UNKNOWN (N)

\begin{tabular}{|l|c|c|l|l|l|c|c|}
\hline PARAMETER NAME & LOG DATE & $\begin{array}{c}\text { SAMPLE } \\
\text { ID }\end{array}$ & $\begin{array}{l}\text { UNITS OF } \\
\text { MEASURE }\end{array}$ & PVI & $\begin{array}{l}\text { PARAMETER } \\
\text { VALUE }\end{array}$ FLAGS & $\begin{array}{c}\text { DETECTION } \\
\text { LIMIT }\end{array}$ & $\begin{array}{l}\text { PARAMETER } \\
\text { UNCERTAINTYY }\end{array}$ \\
\hline SULFATE & $05 / 25 / 85$ & 0001 & MG/L & 897.00 & 0.1 & - \\
\hline
\end{tabular}

PARAMETER VALUE INDICATOR (PVI):

< - LESS THAN DETECTION LIMIT

SAMPLE ID CODES:

0001 - FILTERED SAMPLE (.45 MICRONS) 
GROUNDHATER QUALITY DATA BY LOCATION

SITE: RVTO1 RIVERTON

LOCATION: 0442 DOMESTIC WELL - RUPERT GOGGLES \#3

NORTH COORDINATE: 22240.0 FT

EAST COORDINATE: $\quad 27000.0$ FT

$06 / 12 / 81$ TO $01 / 10 / 94$

REPORT DATE: 09/07/94

FORMATION OF COMPLETION: NO RECOVERY OF DATA FOR CLASSIFYING (NR) HYDRAULIC FLOW RELATIONSHIP: UNKNOWN (N)

\begin{tabular}{|c|c|c|c|c|c|c|c|}
\hline PARAMETER NAME & LOG DATE & $\begin{array}{c}\text { SAMPLE } \\
\text { ID }\end{array}$ & $\begin{array}{l}\text { UNITS OF } \\
\text { MEASURE }\end{array}$ & PVI & $\begin{array}{l}\text { PARAMETER } \\
\text { VALUE FLAGS }\end{array}$ & $\begin{array}{l}\text { DETECTION } \\
\text { LIMIT }\end{array}$ & $\begin{array}{l}\text { PARAMETER } \\
\text { UNCERTAINTY }\end{array}$ \\
\hline ARSENIC (TOTAL) & $01 / 07 / 94$ & N001 & MG/L & $<$ & 0.005 & 0.005 & - \\
\hline MOLYBDENUM (TOTAL) & $01 / 07 / 94$ & N001 & MG/L & $<$ & 0.01 & 0.01 & - \\
\hline SULFATE & $01 / 07 / 94$ & N001 & $M G / L$ & & 264 & 1 & - \\
\hline URANIUM (TOTAL) & $01 / 07 / 94$ & N001 & MG/L & $<$ & 0.001 & 0.001 & - \\
\hline VANADIUM (TOTAL) & $01 / 07 / 94$ & N001 & MG/L & $<$ & 0.01 & 0.01 & - \\
\hline
\end{tabular}

PARAMETER VALUE INDICATOR (PVI):

< - LESS THAN DETECTION LIMIT

SAMPLE ID CODES:

N001 - UNFILTERED SAMPLE 
GROUNDWATER QUALITY DATA BY LOCATION

SITE: RVTO1 RIVERTON

LOCATION: 0443 DOMESTIC WELL - SARAH BLACKBURN \#1

NORTH COORDINATE: 23180.0 FT

EAST COORDINATE: 29180.0 FT

06/12/81 TO $01 / 10 / 94$

REPORT DATE: $09 / 07 / 94$

FORMATION OF COMPLETION: NO RECOVERY OF DATA FOR CLASSIFYING (NR) HYDRAULIC FLOW RELATIONSHIP: UNKNOWN (N)

\begin{tabular}{|c|c|c|c|c|c|c|c|}
\hline PARAMETER NAME & LOG DATE & $\begin{array}{c}\text { SAMPLE } \\
\text { ID }\end{array}$ & $\begin{array}{l}\text { UNITS OF } \\
\text { MEASURE }\end{array}$ & PVI & $\begin{array}{l}\text { PARAMETER } \\
\text { VALUE FLAGS }\end{array}$ & $\begin{array}{l}\text { DETECTION } \\
\text { LIMIT }\end{array}$ & $\begin{array}{l}\text { PARAMETER } \\
\text { UNCERTAINTY }\end{array}$ \\
\hline ARSENIC (TOTAL) & $01 / 06 / 94$ & N001 & $M G / L$ & $<$ & 0.005 & 0.005 & - \\
\hline MANGANESE (TOTAL) & $01 / 06 / 94$ & N001 & MG/L & & 0.03 & 0.01 & - \\
\hline MOLYBDENUM (TOTAL) & $01 / 06 / 94$ & N001 & $M G / L$ & $<$ & 0.01 & 0.01 & - \\
\hline NICKEL (TOTAL) & $01 / 06 / 94$ & N001 & $M G / L$ & $<$ & 0.04 & 0.04 & $\cdot$ \\
\hline SULFATE & $01 / 06 / 94$ & N001 & $M G / L$ & & 209 & 1 & - \\
\hline URANIUM (TOTAL) & $01 / 06 / 94$ & N001 & $M G / L$ & $<$ & 0.001 & 0.001 & - \\
\hline VANADIUM (TOTAL) & $01 / 06 / 94$ & N001 & MG/L & $<$ & 0.01 & 0.01 & - \\
\hline
\end{tabular}

PARAMETER VALUE INDICATOR (PVI): < - LESS THAN DETECTION LIMIT

SAMPLE ID CODES:

NO01 - UNFILTERED SAMPLE 
GROUNDWATER QUALITY DATA BY LOCATION

SITE: RVTO1 RIVERTON

LOCATION: 0444 DOMESTIC WL - MARGARET BLACKBURN \#2

NORTH COORDINATE: 23000.0 FT

EAST COORDINATE: $\quad 29180.0$ FT

06/12/81 TO $01 / 10 / 94$

REPORT DATE: $09 / 07 / 94$

FORMATION OF COMPLETION: NO RECOVERY OF DATA FOR CLASSIFYING (NR)

HYDRAULIC FLOW RELATIONSHIP: UNKNOWN (N)

\begin{tabular}{|c|c|c|c|c|c|c|c|}
\hline PARAMETER NAME & LOG DATE & $\begin{array}{c}\text { SAMPLE } \\
10\end{array}$ & $\begin{array}{l}\text { UNITS OF } \\
\text { MEASURE }\end{array}$ & PVI & $\begin{array}{l}\text { PARAMETER } \\
\text { VALUE FLAGS }\end{array}$ & $\begin{array}{l}\text { DETECTION } \\
\text { LIMIT }\end{array}$ & $\begin{array}{l}\text { PARAMETER } \\
\text { UNCERTAINTY }\end{array}$ \\
\hline ARSENIC (TOTAL) & $01 / 06 / 94$ & N001 & $M G / L$ & $<$ & 0.005 & 0.005 & - \\
\hline MOLYBDENUM (TOTAL) & $01 / 06 / 94$ & N001 & MG/L & $<$ & 0.01 & 0.01 & - \\
\hline SULFATE & $01 / 06 / 94$ & N001 & $M G / L$ & & 221 & 1 & - \\
\hline URANIUM (TOTAL) & $01 / 06 / 94$ & NoO1 & $M G / L$ & $<$ & 0.001 & 0.001 & - \\
\hline VANADIUM (TOTAL) & $01 / 06 / 94$ & N001 & $M G / L$ & $<$ & 0.01 & 0.01 & - \\
\hline
\end{tabular}

PARAMETER VALUE INDICATOR (PVI): < - LESS THAN DETECTION LIMIT

SAMPLE IO CODES:

NDO1 - UNFILTERED SAMPLE 
GROUNDHATER QUALITY DATA BY LOCATION

SITE: RVT01 RIVERTON

LOCATION: 0445 DOMESTIC WELL - J.BLOMBERT \#2

NORTH COORDINATE: 23390.0 FT

EAST COORDINATE: 29000.0 FT

06/12/81 TO $01 / 10 / 94$

REPORT DATE: 09/07/94

FORMATION OF COMPLETION: NO RECOVERY OF DATA FOR CLASSIFYING (NR) HYORAULIC FLOW RELATIONSHIP: UNKNOWN (N)

\begin{tabular}{|l|c|c|l|c|c|c|c|}
\hline PARAMETER NAME & LOG DATE & $\begin{array}{l}\text { SAMPLE } \\
\text { ID }\end{array}$ & $\begin{array}{l}\text { UNITS OF } \\
\text { MEASURE }\end{array}$ & PVI & $\begin{array}{l}\text { PARAMETER } \\
\text { VALUE }\end{array}$ & $\begin{array}{l}\text { DETECTION } \\
\text { LIMIT }\end{array}$ & $\begin{array}{l}\text { PARAMETER } \\
\text { UNCERTAINTY }\end{array}$ \\
\hline ARSENIC (TOTAL) & $01 / 07 / 94$ & N001 & MG/L & 0.008 & - \\
\hline MANGANESE (TOTAL) & $01 / 07 / 94$ & N001 & MG/L & $<$ & 0.01 & -005 & -01 \\
\hline MOLYBDENUM (TOTAL) & $01 / 07 / 94$ & N001 & MG/L & $<$ & 0.01 & 0.01 & - \\
\hline NICKEL (TOTAL) & $01 / 07 / 94$ & N001 & MG/L & $<$ & 0.04 & 0.04 & - \\
\hline SULFATE & $01 / 07 / 94$ & N001 & MG/L & & 152 & 1 & - \\
\hline URANIUM (TOTAL) & $01 / 07 / 94$ & N001 & MG/L & & 0.016 & - \\
\hline VANADIUM (TOTAL) & $01 / 07 / 94$ & N001 & MG/L & & 0.02 & 0.001 & - \\
\hline
\end{tabular}

PARAMETER VALUE INDICATOR (PVI): < - LESS THAN DETECTION LIMIT

SAMPLE ID CODES:

NOO1 - UNFILTERED SAMPLE 
GROUNDWATER QUALITY DATA BY LOCATION

SITE: RVTO1 RIVERTON

LOCATION: 0446 DOMESTIC WELL - CONNIE HILYARD

NORTH COORDINATE: 25000.0 FT

EAST COORDINATE: 27400.0 FT

$06 / 12 / 81$ To $01 / 10 / 94$

REPORT DATE: 09/07/94

FORMATION OF COMPLETION: NO RECOVERY OF DATA FOR CLASSIFYIHG (NR) HYDRAULIC FLOW RELATIONSHIP: UNKNOWN (N)

\begin{tabular}{|c|c|c|c|c|c|c|c|}
\hline PARAMETER NAME & LOG DATE & $\begin{array}{c}\text { SAMPLE } \\
\text { ID }\end{array}$ & $\begin{array}{l}\text { UNITS OF } \\
\text { MEASURE }\end{array}$ & PVI & $\begin{array}{l}\text { PARAMETER } \\
\text { VALUE FLAGS }\end{array}$ & $\begin{array}{l}\text { DETECTION } \\
\text { LIMIT }\end{array}$ & $\begin{array}{l}\text { PARAMETER } \\
\text { UNCERTAINTY }\end{array}$ \\
\hline ARSEHIC (TOTAL) & $01 / 08 / 94$ & No01 & MG/L & $<$ & 0.005 & 0.005 & - \\
\hline MANGANESE (TOTAL) & $01 / 08 / 94$ & No01 & $M G / L$ & $<$ & 0.01 & 0.01 & - \\
\hline MOLYBDENUM (TOTAL) & $01 / 08 / 94$ & N001 & $M G / L$ & $<$ & 0.01 & 0.01 & - \\
\hline NICKEL (TOTAL) & $01 / 08 / 94$ & NoO1 & MG $/ L$ & $<$ & 0.04 & 0.04 & - \\
\hline SULFATE & $01 / 08 / 94$ & No01 & MG/L & & 138 & 1 & - \\
\hline URANIUM (TOTAL) & $01 / 08 / 94$ & No01 & $M G / L$ & $<$ & 0.001 & 0.001 & - \\
\hline VANADIUM (TOTAL) & $01 / 08 / 94$ & N001 & MG $/ L$ & $<$ & 0.01 & 0.01 & - \\
\hline
\end{tabular}

PARAMETER VALUE IMOICATOR (PVI): < - LESS THAN DETECTION LIMIT

SAMPLE ID CODES:

N001 - UNFILTERED SAMPLE 
GROUNDWATER QUALITY DATA BY LOCATION

SITE: RVTO1 RIVERTON

LOCATION: 0448 DONESTIC WELL - GARY/LORI MARTIN

NORTH COORDINATE: 24300.0 FT

EAST COORDINATE: 27500.0 FT

06/12/81 TO 01/10/94

REPORT DATE: $09 / 07 / 94$

FORMATION OF COMPLETION: NO RECOVERY OF DATA FOR CLASSIFYING (NR)

HYDRAULIC FLOW RELATIONSHIP: UNKNOWN (N)

\begin{tabular}{|c|c|c|c|c|c|c|c|}
\hline PARAMETER NAME & LOG DATE & $\begin{array}{c}\text { SAMPLE } \\
\text { ID }\end{array}$ & $\begin{array}{l}\text { UNITS OF } \\
\text { MEASURE }\end{array}$ & PVI & $\begin{array}{l}\text { PARAMETER } \\
\text { VALUE FLAGS }\end{array}$ & $\begin{array}{l}\text { DETECTION } \\
\text { LIMIT }\end{array}$ & $\begin{array}{l}\text { PARAMETER } \\
\text { UNCERTAINTY }\end{array}$ \\
\hline ARSENIC (TOTAL) & $\begin{array}{l}01 / 08 / 94 \\
01 / 08 / 94\end{array}$ & $\begin{array}{l}\text { N001 } \\
\text { N002 }\end{array}$ & $M G / L$ & $\begin{array}{l}< \\
<\end{array}$ & $\begin{array}{l}0.005 \\
0.005\end{array}$ & $\begin{array}{l}0.005 \\
0.005\end{array}$ & - \\
\hline MANGANESE (TOTAL) & $\begin{array}{l}01 / 08 / 94 \\
01 / 08 / 94\end{array}$ & $\begin{array}{l}\text { N001 } \\
\text { N002 }\end{array}$ & $M G / L$ & $\begin{array}{l}< \\
<\end{array}$ & $\begin{array}{l}0.01 \\
0.01\end{array}$ & $\begin{array}{l}0.01 \\
0.01\end{array}$ & $\dot{-}$ \\
\hline MOLYBDENUM (TOTAL) & $\begin{array}{l}01 / 08 / 94 \\
01 / 08 / 94\end{array}$ & $\begin{array}{l}\text { NoO1 } \\
\text { N002 }\end{array}$ & $M G / L$ & $\begin{array}{l}< \\
<\end{array}$ & $\begin{array}{l}0.01 \\
0.01\end{array}$ & $\begin{array}{l}0.01 \\
0.01\end{array}$ & - \\
\hline HICKEL (TOTAL) & $\begin{array}{l}01 / 08 / 94 \\
01 / 08 / 94\end{array}$ & $\begin{array}{l}\text { No01 } \\
\text { N002 }\end{array}$ & $M G / L$ & $\begin{array}{l}< \\
<\end{array}$ & $\begin{array}{l}0.04 \\
0.04\end{array}$ & $\begin{array}{l}0.04 \\
0.04\end{array}$ & - \\
\hline SULFATE & $\begin{array}{l}01 / 08 / 94 \\
01 / 08 / 94\end{array}$ & $\begin{array}{l}\text { No01 } \\
\text { N002 }\end{array}$ & $M G / L$ & & $\begin{array}{l}173 \\
175\end{array}$ & $\begin{array}{l}1 \\
1\end{array}$ & - \\
\hline URANIUM (TOTAL) & $\begin{array}{l}01 / 08 / 94 \\
01 / 08 / 94\end{array}$ & $\begin{array}{l}\text { NO01 } \\
\text { NOO2 }\end{array}$ & MG/L & $\begin{array}{l}< \\
<\end{array}$ & $\begin{array}{l}0.001 \\
0.001\end{array}$ & $\begin{array}{l}0.001 \\
0.001\end{array}$ & - \\
\hline VANADIUM (TOTAL) & $\begin{array}{l}01 / 08 / 94 \\
01 / 08 / 94\end{array}$ & $\begin{array}{l}\text { NoO1 } \\
\text { N002 }\end{array}$ & $M G / L$ & $\begin{array}{l}< \\
<\end{array}$ & $\begin{array}{r}0.01 \\
0.01\end{array}$ & $\begin{array}{l}0.01 \\
0.01\end{array}$ & - \\
\hline
\end{tabular}

PARAMETER VALUE INDICATOR (PVI): < - LESS THAN DETECTION LIMIT

SAMPLE ID CODES:

NOO1 - UNFILTERED SAMPLE

N002 - UNFILTERED REPLICATE SAMPLE 
GROUNDWATER QUALITY DATA BY LOCATION

SITE: RVT01 RIVERTON

LOCATION: 0451 DOMESTIC WELL - MARY BEAR

MORTH COORDINATE: 23500.0 FT

EAST COORDINATE: $\quad 29400.0$ FT

06/12/81 TO 01/10/94

REPORT DATE: 09/07/94

FORMATION OF COMPLETION: NO RECOVERY OF DATA FOR CLASSIFYING (NR) HYDRAULIC FLOW RELATIONSHIP: UNKNOWN (N)

\begin{tabular}{|l|c|c|l|l|c|c|c|}
\hline PARAMETER NAME & LOG DATE & $\begin{array}{c}\text { SAMPLE } \\
\text { ID }\end{array}$ & $\begin{array}{l}\text { UNITS OF } \\
\text { MEASURE }\end{array}$ & PVI & $\begin{array}{c}\text { PARAMETER } \\
\text { VALUE }\end{array}$ & $\begin{array}{c}\text { DETECTION } \\
\text { LIMIT }\end{array}$ & $\begin{array}{l}\text { PARAMETER } \\
\text { UNCERTAINTY }\end{array}$ \\
\hline ARSENIC (TOTAL) & $01 / 06 / 94$ & N001 & MG/L & $<$ & 0.005 & 0.005 & - \\
\hline MANGANESE (TOTAL) & $01 / 06 / 94$ & N001 & MG/L & $<$ & 0.01 & 0.01 & - \\
\hline MOLYBDENUM (TOTAL) & $01 / 06 / 94$ & N001 & MG/L & $<$ & 0.01 & - \\
\hline NICKEL (TOTAL) & $01 / 06 / 94$ & N001 & MG/L & $<$ & 0.04 & - & 0.04 \\
\hline SULFATE & $01 / 06 / 94$ & N001 & MG/L & & 206 & 1 \\
\hline URANIUM (TOTAL) & $01 / 06 / 94$ & N001 & MG/L & $<$ & 0.001 & - \\
\hline VANADIUM (TOTAL) & $01 / 06 / 94$ & N001 & MG/L & $<$ & 0.01 & 0.001 & - \\
\hline
\end{tabular}

PARAMETER VALUE INDICATOR (PVI):

$<$ - LESS THAN DETECTION LIMIT

SAMPLE ID CODES:

NOO1 - UNFILTERED SAMPLE 
GROUNDWATER QUALITY DATA BY LOCATION

SITE: RVTO1 RIVERTON

LOCATION: 0452 DOMESTIC WELL - KEN BLACKBURN

NORTH COORDINATE: $23590.0 \mathrm{FT}$

EAST COORDINATE: 21900.0 FT

06/12/81 TO 01/10/94

REPORT DATE: 09/07/94

FORMATION OF COMPLETION: NO RECOVERY OF DATA FOR CLASSIFYING (NR) HYDRAULIC FLOW RELATIONSHIP: UNKNOWN (N)

\begin{tabular}{|c|c|c|c|c|c|c|c|}
\hline PARAMETER NAME & LOG DATE & $\begin{array}{c}\text { SAMPLE } \\
\text { ID }\end{array}$ & $\begin{array}{l}\text { UNITS OF } \\
\text { MEASURE }\end{array}$ & PVI & $\begin{array}{l}\text { PARAMETER } \\
\text { VALUE FLAGS }\end{array}$ & $\begin{array}{l}\text { DETECTION } \\
\text { LIMIT }\end{array}$ & $\begin{array}{l}\text { PARAMETER } \\
\text { UNCERTAINTY }\end{array}$ \\
\hline ARSENIC (TOTAL) & $01 / 07 / 94$ & No01 & $M G / L$ & $<$ & 0.005 & 0.005 & - \\
\hline MOLYBDENUM (TOTAL) & $01 / 07 / 94$ & N001 & $M G / L$ & $<$ & 0.01 & 0.01 & - \\
\hline SULFATE & $01 / 07 / 94$ & N001 & MG/L & & 106 & 1 & - \\
\hline URANIUM (TOTAL) & $01 / 07 / 94$ & N001 & $M G / L$ & $<$ & 0.001 & 0.001 & - \\
\hline VANADIUM (TOTAL) & $01 / 07 / 94$ & N001 & $M G / L$ & $<$ & 0.01 & 0.01 & - \\
\hline
\end{tabular}

PARAMETER VALUE INDICATOR (PVI): < - LESS THAN DETECTION LIMIT

SAMPLE ID CODES:

NOO1 - UNFILTERED SAMPLE 
GROUNDWATER QUALITY DATA BY LOCATION

SITE: RVTOI RIVERTON

LOCATION: 0453 DOMESTIC WELL - JOANNE BLACKBURN

NORTH COORDINATE: 23700.0 FT

EAST COORDINATE: 29420.0 FT

06/12/81 TO 01/10/94

REPORT DATE: $09 / 07 / 94$

FORMATION OF COMPLETION: NO RECOVERY OF DATA FOR CLASSIFYING (NR) HYDRAULIC FLOW RELATIONSHIP: UNKNOWN (N)

\begin{tabular}{|c|c|c|c|c|c|c|c|}
\hline PARAMETER NAME & LOG DATE & $\begin{array}{c}\text { SAMPLE } \\
\text { ID }\end{array}$ & $\begin{array}{l}\text { UNITS OF } \\
\text { MEASURE }\end{array}$ & PVI & $\begin{array}{l}\text { PARAMETER } \\
\text { VALUE FLAGS }\end{array}$ & $\begin{array}{l}\text { DETECTION } \\
\text { LIMIT }\end{array}$ & $\begin{array}{l}\text { PARAMETER } \\
\text { UNCERTAINTY }\end{array}$ \\
\hline ARSENIC (TOTAL) & $01 / 07 / 94$ & N001 & $M G / L$ & $<$ & 0.005 & 0.005 & - \\
\hline MOLYBDENUM (TOTAL) & $01 / 07 / 94$ & N001 & $M G / L$ & $<$ & 0.01 & 0.01 & - \\
\hline SULFATE & $01 / 07 / 94$ & N001 & $M G / L$ & & 220 & 1 & - \\
\hline URANIUM (TOTAL) & $01 / 07 / 94$ & N001 & $M G / L$ & $<$ & 0.001 & 0.001 & - \\
\hline VANADIUM (TOTAL) & $01 / 07 / 94$ & No01 & $M G / L$ & $<$ & 0.01 & 0.01 & - \\
\hline
\end{tabular}

PARAMETER VALUE INDICATOR (PVI): < - LESS THAN DETECTION LIMIT

SAMPLE ID CODES:

N001 - UNFILTERED SAMPLE 
GROUNDWATER QUALITY DATA BY LOCATION

SITE : RVTO1 RIVERTON

LOCATION: 0460 KOCH SULFURIC ACID PLANT

NORTH COORDINATE: 24440.0 FT

EAST COORDINATE: 23990.0 FT

06/12/81 TO 01/10/94

REPORT DATE : 09/07/94

FORMATION OF COMPLETION: NO RECOVERY OF DATA FOR CLASSIFYING (NR) HYDRAULIC FLOW RELATIONSHIP: UNKNOWN (N)

\begin{tabular}{|l|c|c|l|l|c|c|c|}
\hline PARAMETER NAME & LOG DATE & $\begin{array}{c}\text { SAMPLE } \\
\text { ID }\end{array}$ & $\begin{array}{l}\text { UNITS OF } \\
\text { MEASURE }\end{array}$ & PVI & $\begin{array}{c}\text { PARAMETER } \\
\text { VALUE }\end{array}$ & $\begin{array}{c}\text { FLAGS } \\
\text { LIMCTION }\end{array}$ & $\begin{array}{l}\text { PARAMETER } \\
\text { UNCERTAINTY }\end{array}$ \\
\hline SULFATE (TOTAL) & $03 / 17 / 93$ & N001 & MG/L & 155 & 1 & - \\
\hline URANIUM (TOTAL) & $03 / 17 / 93$ & N001 & MG/L & $<$ & 0.001 & 0.001 & - \\
\hline
\end{tabular}

PARAMETER VALUE INDICATOR (PVI): < - LESS THAN DETECTION LIMIT SAMPLE ID CODES:

N001 - UNFILTERED SAMPLE 
GROUNDWATER QUALITY DATA BY LOCATION

SITE : RVTO1 RIVERTON

LOCATION: 0951 DOMESTIC WL -BROWN/TENNANT-LONEBEAR

NORTH COORDINATE: 21900.0 . FT

EAST COORDINATE: 24900.0 FT

$06 / 12 / 81$ TO $01 / 10 / 94$

REPORT DATE: 09/07/94

FORMATION OF CONPLETION: NO RECOVERY OF DATA FOR CLASSIFYING (NR) HYDRAULIC FLOW RELATIONSHIP: UNKNOWN (N)

\begin{tabular}{|c|c|c|c|c|c|c|c|}
\hline PARAMETER NAME & LOG DATE & $\begin{array}{l}\text { SAMPLE } \\
\text { ID }\end{array}$ & $\begin{array}{l}\text { UNITS OF } \\
\text { MEASURE }\end{array}$ & PVI & $\begin{array}{l}\text { PARAMETER } \\
\text { VALUE FLAGS }\end{array}$ & $\begin{array}{l}\text { DETECTION } \\
\text { LIMIT }\end{array}$ & $\begin{array}{l}\text { PARAMETER } \\
\text { UNCERTAINTY }\end{array}$ \\
\hline ARSENIC & $11 / 28 / 88$ & 0001 & $M G / L$ & $<$ & 0.01 & 0.01 & - \\
\hline ARSENIC (TOTAL) & $\begin{array}{l}03 / 14 / 92 \\
08 / 06 / 92\end{array}$ & $\begin{array}{l}\text { N001 } \\
\text { N001 }\end{array}$ & MG $/ L$ & $<$ & $\begin{array}{l}0.005 \\
0.01\end{array}$ & $\begin{array}{l}0.005 \\
0.01\end{array}$ & 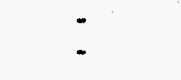 \\
\hline MANGANESE & $11 / 28 / 88$ & 0001 & $M G / L$ & $<$ & 0.01 & 0.01 & - \\
\hline MANGANESE (TOTAL) & $\begin{array}{l}03 / 14 / 92 \\
08 / 06 / 92\end{array}$ & $\begin{array}{l}\text { N001 } \\
\text { N001 }\end{array}$ & $M G / L$ & $<$ & $\begin{array}{l}0.01 \\
0.01\end{array}$ & $\begin{array}{l}0.01 \\
0.01\end{array}$ & - \\
\hline MOL YBDENUN & $11 / 28 / 88$ & 0001 & $M G / L$ & $<$ & 0.01 & 0.01 & - \\
\hline MOLYBDENUM (TOTAL) & $\begin{array}{l}03 / 14 / 92 \\
08 / 06 / 92\end{array}$ & $\begin{array}{l}\text { NO01 } \\
\text { N001 }\end{array}$ & $M G / L$ & $<$ & $\begin{array}{l}0.01 \\
0.01\end{array}$ & $\begin{array}{l}0.01 \\
0.01\end{array}$ & - \\
\hline NICKEL & $11 / 28 / 88$ & 0001 & $M G / L$ & $<$ & 0.04 & 0.04 & - \\
\hline NICKEL (TOTAL) & $\begin{array}{l}03 / 14 / 92 \\
08 / 06 / 92\end{array}$ & $\begin{array}{l}\text { N001 } \\
\text { N001 }\end{array}$ & MG/L & $<$ & $\begin{array}{l}0.04 \\
0.04\end{array}$ & $\begin{array}{l}0.04 \\
0.04\end{array}$ & $\dot{-}$ \\
\hline SULFATE & $11 / 28 / 88$ & 0001 & MG/L & & 92. & 0.1 & - \\
\hline SULFATE (TOTAL) & $\begin{array}{l}03 / 14 / 92 \\
08 / 06 / 92\end{array}$ & $\begin{array}{l}\text { N001 } \\
\text { N001 }\end{array}$ & $M G / L$ & & $\begin{array}{l}239 . \\
248 .\end{array}$ & $\begin{array}{l}40 . \\
30\end{array}$ & - \\
\hline URANIUM & $11 / 28 / 88$ & 0001 & MG/L & $<$ & $0.0003 \mathrm{~J}$ & 0.003 & - \\
\hline URANIUM (TOTAL) & $\begin{array}{l}03 / 14 / 92 \\
08 / 06 / 92\end{array}$ & $\begin{array}{l}\text { N001 } \\
\text { N001 }\end{array}$ & $M G / L$ & $<$ & $\begin{array}{l}0.001 \\
0.001\end{array}$ & $\begin{array}{l}0.001 \\
0.001\end{array}$ & - \\
\hline VANADIUM & $11 / 28 / 88$ & 0001 & $M G / L$ & $<$ & 0.01 & 0.01 & - \\
\hline VANADIUM (TOTAL) & $\begin{array}{l}03 / 14 / 92 \\
08 / 06 / 92\end{array}$ & $\begin{array}{l}\text { N001 } \\
\text { N001 }\end{array}$ & $M G / L$ & $<$ & $\begin{array}{l}0.01 \\
0.01\end{array}$ & $\begin{array}{l}0.01 \\
0.01\end{array}$ & $\dot{-}$ \\
\hline
\end{tabular}

PARAMETER VALUE INDICATOR (PVI): < - LESS THAN DETECTION LIMIT

SAMPLE ID CODES:

OTHER PARAMETER VALUE FLAGS:

0001 - FILTERED SAMPLE (.45 MICRONS)

$J$ - EST IMATED VALUE

N001 - UNFILTERED SAMPLE

DATA FILE NAME: M: LDARTIRVTOTIGWQ10018.DAT 
APPENDIX B2

CONTAMINANTS OF CONCERN IN MONITOR WELLS 
GROUNDWATER QUALITY DATA BY LOCATION

SITE: RVTO 1 RIVERTON

LOCATION: 0101

NORTH COORDINATE: 24105.4 FT

EAST COORDINATE: 24056.0 FT

06/12/81 TO 01/10/94

REPORT DATE: 09/07/94

FORMATION OF COMPLETION: SURFICIAL (SF)

HYORAULIC FLOW RELATIONSHIP: ON-SITE (O)

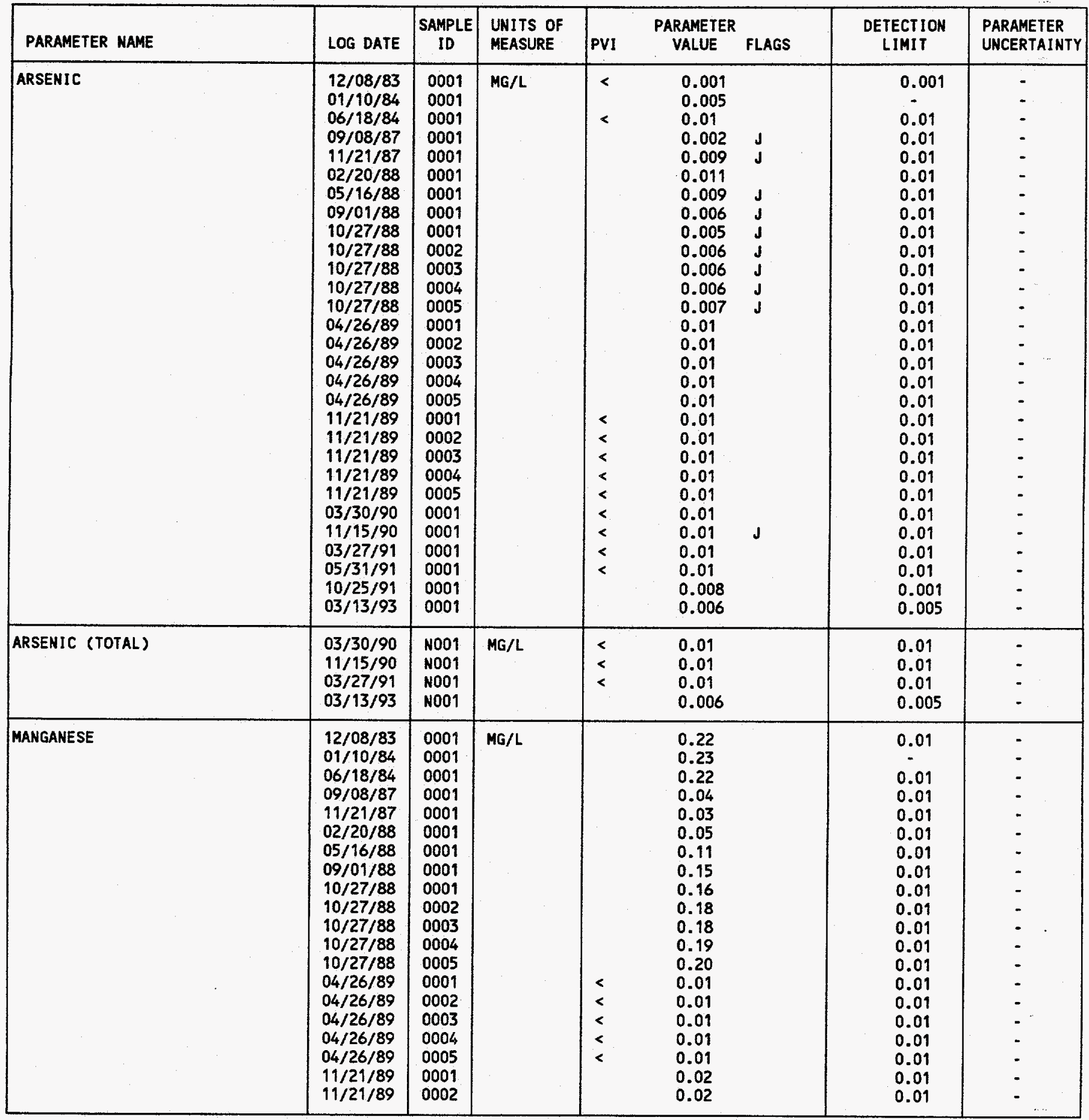

PARAMETER VALUE INDICATOR (PVI): < - LESS THAN DETECTION LIMIT

SAMPLE ID CODES:

0001 - FILTERED SAMPLE (.45 MICRONS)

OTHER PARAMETER VALUE FLAGS:

0002 - FILTERED REPLICATE SAMPLE (.45 MICRONS)

0003 - FILTERED REPLICATE SAMPLE (.45 MICRONS)

0004 - FILTERED REPLICATE SAMPLE (.45 MICRONS)

NOO1 - UNFILTERED SAMPLE 
GROUNDWATER QUALITY DATA BY LOCATION

SITE: RVTOI RIVERTON

LOCATION: 0101

NORTH COORDINATE: $\quad 24105.4$ FT

EAST COORDINATE: $\quad 24056.0$ FT

06/12/81 TO 01/10/94

REPORT DATE: 09/07/94

FORMATION OF COMPLETION: SURFICIAL (SF)

HYDRAULIC FLOW RELATIONSHIP: ON-SITE (O)

\begin{tabular}{|c|c|c|c|c|c|c|c|}
\hline PARAMETER NAME & LOG DATE & $\begin{array}{c}\text { SAMPLE } \\
\text { ID }\end{array}$ & $\begin{array}{l}\text { UNITS OF } \\
\text { MEASURE }\end{array}$ & PVI & $\begin{array}{l}\text { PARAMETER } \\
\text { VALUE FLAGS }\end{array}$ & $\begin{array}{l}\text { DETECT ION } \\
\text { LIMIT }\end{array}$ & $\begin{array}{l}\text { PARAMETER } \\
\text { UNCERTAINTY }\end{array}$ \\
\hline MANGANESE & $\begin{array}{l}11 / 21 / 89 \\
11 / 21 / 89 \\
11 / 21 / 89 \\
03 / 30 / 90 \\
11 / 15 / 90 \\
03 / 27 / 91 \\
05 / 31 / 91 \\
10 / 25 / 91 \\
03 / 13 / 92 \\
08 / 07 / 92 \\
03 / 13 / 93\end{array}$ & $\begin{array}{l}0003 \\
0004 \\
0005 \\
0001 \\
0001 \\
0001 \\
0001 \\
0001 \\
0001 \\
0001 \\
0001\end{array}$ & $M G / L$ & & $\begin{array}{l}0.02 \\
0.02 \\
0.02 \\
0.02 \\
0.02 \\
0.02 \\
0.02 \\
0.04 \\
0.04 \\
0.11 \\
0.12\end{array}$ & $\begin{array}{l}0.01 \\
0.01 \\
0.01 \\
0.01 \\
0.01 \\
0.01 \\
0.01 \\
0.01 \\
0.01 \\
0.01 \\
0.01\end{array}$ & $\begin{array}{l}- \\
- \\
- \\
- \\
- \\
- \\
- \\
- \\
-\end{array}$ \\
\hline MANGANESE (TOTAL) & $\begin{array}{l}03 / 30 / 90 \\
11 / 15 / 90 \\
03 / 27 / 91 \\
03 / 13 / 93\end{array}$ & $\begin{array}{l}\text { No01 } \\
\text { N001 } \\
\text { N001 } \\
\text { N001 }\end{array}$ & $M G / L$ & & $\begin{array}{l}0.02 \\
0.01 \\
0.02 \\
0.12\end{array}$ & $\begin{array}{l}0.01 \\
0.01 \\
0.01 \\
0.01\end{array}$ & $\begin{array}{l}- \\
- \\
-\end{array}$ \\
\hline MOLYBDENUM & $\begin{array}{l}12 / 08 / 83 \\
01 / 10 / 84 \\
06 / 18 / 84 \\
09 / 08 / 87 \\
11 / 21 / 87 \\
02 / 20 / 88 \\
05 / 16 / 88 \\
09 / 01 / 88 \\
10 / 27 / 88 \\
10 / 27 / 88 \\
10 / 27 / 88 \\
10 / 27 / 88 \\
10 / 27 / 88 \\
04 / 26 / 89 \\
04 / 26 / 89 \\
04 / 26 / 89 \\
04 / 26 / 89 \\
04 / 26 / 89 \\
11 / 21 / 89 \\
11 / 21 / 89 \\
11 / 21 / 89 \\
11 / 21 / 89 \\
11 / 21 / 89 \\
03 / 30 / 90 \\
11 / 15 / 90 \\
03 / 27 / 91 \\
05 / 31 / 91 \\
10 / 25 / 91 \\
03 / 13 / 92 \\
08 / 07 / 92 \\
03 / 13 / 93\end{array}$ & $\begin{array}{l}0001 \\
0001 \\
0001 \\
0001 \\
0001 \\
0001 \\
0001 \\
0001 \\
0001 \\
0002 \\
0003 \\
0004 \\
0005 \\
0001 \\
0002 \\
0003 \\
0004 \\
0005 \\
0001 \\
0002 \\
0003 \\
0004 \\
0005 \\
0001 \\
0001 \\
0001 \\
0001 \\
0001 \\
0001 \\
0001 \\
0001\end{array}$ & $M G / L$ & $<$ & $\begin{array}{l}0.03 \\
0.08 \\
0.01 \\
0.04 \\
0.12 \\
0.10 \\
0.06 \\
0.052 \\
0.054 \\
0.050 \\
0.053 \\
0.055 \\
0.050 \\
0.03 \\
0.04 \\
0.03 \\
0.03 \\
0.03 \\
0.07 \\
0.07 \\
0.07 \\
0.07 \\
0.07 \\
0.07 \\
0.07 \\
0.07 \\
0.04 \\
0.04 \\
0.04 \\
0.04 \\
0.05\end{array}$ & 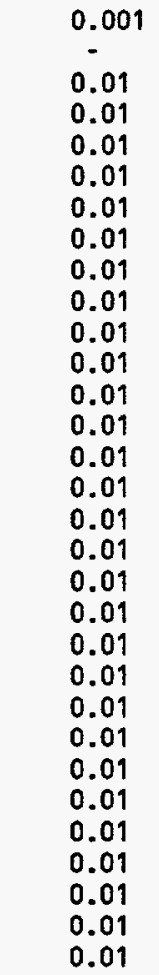 & $\begin{array}{l}- \\
- \\
- \\
- \\
- \\
- \\
- \\
- \\
- \\
- \\
- \\
- \\
- \\
- \\
- \\
- \\
- \\
- \\
- \\
- \\
- \\
- \\
- \\
- \\
- \\
- \\
- \\
- \\
-\end{array}$ \\
\hline MOLYBDENUN (TOTAL) & $\begin{array}{l}03 / 30 / 90 \\
11 / 15 / 90 \\
03 / 27 / 91 \\
03 / 13 / 93\end{array}$ & $\begin{array}{l}\text { No01 } \\
\text { No01 } \\
\text { NO01 } \\
\text { N001 }\end{array}$ & $M G / L$ & & $\begin{array}{l}0.06 \\
0.05 \\
0.05 \\
0.05\end{array}$ & $\begin{array}{l}0.01 \\
0.01 \\
0.01 \\
0.01\end{array}$ & $\begin{array}{l}- \\
- \\
-\end{array}$ \\
\hline NICKEL & $12 / 08 / 83$ & 0001 & $M G / L$ & & 0.10 & 0.001 & - \\
\hline
\end{tabular}

PARAMETER VALUE INDICATOR (PVI): < - LESS THAN DETECTION LIMIT

SAMPLE ID CODES:

0001 - FILTERED SAMPLE (.45 MICRONS)

0002 - FILTERED REPLICATE SAMPLE (.45 MICRONS)

0003 - FILTERED REPLICATE SAMPLE (.45 MICRONS)

0004 - FILTERED REPLICATE SAMPLE (.45 MICRONS)

NOO1 - UNFILTERED SAMPLE 
GROUNDWATER QUALITY DATA BY LOCATION

SITE: RVTO1 RIVERTON

LOCATION: 0101

NORTH COORDINATE: $\quad 24105.4$ FT

EAST COORDINATE: 24056.0 FT

06/12/81 TO 01/10/94

REPORT DATE: 09/07/94

FORMATION OF COMPLETION: SURFICIAL (SF)

HYDRAULIC FLOW RELATIONSHIP: ON-SITE (O)

\begin{tabular}{|c|c|c|c|c|c|c|c|}
\hline PARAMETER MAME & LOG DATE & $\underset{10}{\text { SAMPLE }}$ & $\begin{array}{l}\text { UNITS OF } \\
\text { MEASURE }\end{array}$ & PVI & $\begin{array}{l}\text { PARAMETER } \\
\text { VALUE FLAGS }\end{array}$ & $\begin{array}{l}\text { DETECTION } \\
\text { LIMIT }\end{array}$ & $\begin{array}{l}\text { PARAMETER } \\
\text { UNCERTAINTY }\end{array}$ \\
\hline NICKEL & $\begin{array}{l}01 / 10 / 84 \\
06 / 18 / 84 \\
09 / 08 / 87 \\
11 / 21 / 87 \\
02 / 20 / 88 \\
05 / 16 / 88 \\
09 / 01 / 88 \\
10 / 27 / 88 \\
10 / 27 / 88 \\
10 / 27 / 88 \\
10 / 27 / 88 \\
10 / 27 / 88 \\
04 / 26 / 89 \\
04 / 26 / 89 \\
04 / 26 / 89 \\
04 / 26 / 89 \\
04 / 26 / 89 \\
11 / 21 / 89 \\
11 / 21 / 89 \\
11 / 21 / 89 \\
11 / 21 / 89 \\
11 / 21 / 89 \\
03 / 30 / 90 \\
11 / 15 / 90 \\
03 / 27 / 91 \\
05 / 31 / 91 \\
10 / 25 / 91 \\
03 / 13 / 92 \\
08 / 07 / 92 \\
03 / 13 / 93\end{array}$ & $\begin{array}{l}0001 \\
0001 \\
0001 \\
0001 \\
0001 \\
0001 \\
0001 \\
0001 \\
0002 \\
0003 \\
0004 \\
0005 \\
0001 \\
0002 \\
0003 \\
0004 \\
0005 \\
0001 \\
0002 \\
0003 \\
0004 \\
0005 \\
0001 \\
0001 \\
0001 \\
0001 \\
0001 \\
0001 \\
0001 \\
0001\end{array}$ & $M G / L$ & $\begin{array}{l}< \\
< \\
< \\
< \\
< \\
< \\
< \\
< \\
< \\
< \\
< \\
< \\
< \\
< \\
< \\
< \\
< \\
< \\
< \\
< \\
< \\
< \\
< \\
< \\
<\end{array}$ & $\begin{array}{l}0.04 \\
0.04 \\
0.01 \\
0.01 \\
0.03 \\
0.03 \\
0.02 \\
0.02 \\
0.02 \\
0.02 \\
0.02 \\
0.02 \\
0.04 \\
0.04 \\
0.04 \\
0.04 \\
0.04 \\
0.04 \\
0.04 \\
0.04 \\
0.04 \\
0.04 \\
0.04 \\
0.04 \\
0.04 \\
0.04 \\
0.01 \\
0.04 \\
0.04 \\
0.04\end{array}$ & $\begin{array}{l}0.04 \\
0.04 \\
0.04 \\
0.04 \\
0.04 \\
0.04 \\
0.04 \\
0.04 \\
0.04 \\
0.04 \\
0.04 \\
0.04 \\
0.04 \\
0.04 \\
0.04 \\
0.04 \\
0.04 \\
0.04 \\
0.04 \\
0.04 \\
0.04 \\
0.04 \\
0.04 \\
0.04 \\
0.04 \\
0.04 \\
0.01 \\
0.04 \\
0.04 \\
0.04\end{array}$ & $\begin{array}{l}- \\
- \\
- \\
- \\
- \\
- \\
- \\
- \\
- \\
- \\
- \\
- \\
- \\
- \\
- \\
- \\
- \\
- \\
- \\
- \\
- \\
- \\
-\end{array}$ \\
\hline NICKEL (TOTAL) & $\begin{array}{l}03 / 30 / 90 \\
11 / 15 / 90 \\
03 / 27 / 91 \\
03 / 13 / 93\end{array}$ & $\begin{array}{l}\text { NO01 } \\
\text { NO01 } \\
\text { NO01 } \\
\text { N001 }\end{array}$ & $M G / L$ & $\begin{array}{l}< \\
< \\
<\end{array}$ & $\begin{array}{l}0.04 \\
0.04 \\
0.04 \\
0.04\end{array}$ & $\begin{array}{l}0.04 \\
0.04 \\
0.04 \\
0.04\end{array}$ & : \\
\hline SULFATE & $\begin{array}{l}12 / 08 / 83 \\
01 / 10 / 84 \\
06 / 18 / 84 \\
09 / 08 / 87 \\
11 / 21 / 87 \\
02 / 20 / 88 \\
05 / 16 / 88 \\
09 / 01 / 88 \\
10 / 27 / 88 \\
10 / 27 / 88 \\
10 / 27 / 88 \\
10 / 27 / 88 \\
10 / 27 / 88 \\
04 / 26 / 89 \\
04 / 26 / 89 \\
04 / 26 / 89 \\
04 / 26 / 89 \\
04 / 26 / 89 \\
11 / 21 / 89\end{array}$ & $\begin{array}{l}0001 \\
0001 \\
0001 \\
0001 \\
0001 \\
0001 \\
0001 \\
0001 \\
0001 \\
0002 \\
0003 \\
0004 \\
0005 \\
0001 \\
0002 \\
0003 \\
0004 \\
0005 \\
0001\end{array}$ & $M G / L$ & & $\begin{array}{l}577.00 \\
520.00 \\
360.00 \\
520 . \\
429 . \\
475 . \\
553 . \\
500 . \\
510 . \\
504 . \\
502 . \\
508 . \\
502 . \\
232 . \\
226 . \\
240 . \\
230 . \\
228 . \\
320 .\end{array}$ & $\begin{array}{l}0.1 \\
0.1 \\
0.1 \\
0.1 \\
0.1 \\
0.1 \\
0.1 \\
1 . \\
0.1 \\
0.1 \\
0.1 \\
0.1 \\
0.1 \\
0.1 \\
0.1 \\
0.1 \\
0.1 \\
0.1 \\
0.1\end{array}$ & $\begin{array}{l}- \\
- \\
- \\
- \\
- \\
- \\
- \\
- \\
- \\
- \\
- \\
- \\
- \\
-\end{array}$ \\
\hline
\end{tabular}

PARAMETER VALUE INDICATOR (PVI): < - LESS THAN DETECTION LIMIT

SAMPLE ID COOES:

OTHER PARAMETER VALUE FLAGS:

0001 - FILTERED SAMPLE (.45 MICRONS)

$J$ - estimated VALUE

0002 - FILTERED REPLICATE SAMPLE (.45 MICRONS) 0003 - FILTERED REPLICATE SAMPLE ( 45 MICRONS) 0004 - FILTERED REPLICATE SAMPLE (.45 MICRONS) N001 - UNFILTERED SAMPLE 
GROUNDWATER QUALITY DATA BY LOCATION

SITE: RVTO1 RIVERTON

LOCATION: 0101

NORTH COORDINATE: $\quad 24105.4$ FT

EAST COORDINATE: 24056.0 FT

06/12/81 TO $01 / 10 / 94$

REPORT DATE: $09 / 07 / 94$

FORMATION OF COMPLETION: SURFICIAL (SF)

HYDRAULIC FLOW RELATIONSHIP: ON-SITE (0)

\begin{tabular}{|c|c|c|c|c|c|c|c|}
\hline PARAMETER NAME & LOG DATE & $\begin{array}{c}\text { SAMPLE } \\
\text { ID }\end{array}$ & $\begin{array}{l}\text { UNITS OF } \\
\text { MEASURE }\end{array}$ & PVI & $\begin{array}{l}\text { PARAMETER } \\
\text { VALUE FLAGS }\end{array}$ & $\begin{array}{l}\text { DETECTION } \\
\text { LIMIT }\end{array}$ & $\begin{array}{l}\text { PARAMETER } \\
\text { UNCERTAINTY }\end{array}$ \\
\hline SULFATE & $\begin{array}{l}11 / 21 / 89 \\
11 / 21 / 89 \\
11 / 21 / 89 \\
11 / 21 / 89 \\
03 / 30 / 90 \\
11 / 15 / 90 \\
03 / 27 / 91 \\
05 / 31 / 91 \\
10 / 25 / 91 \\
03 / 13 / 92 \\
08 / 07 / 92\end{array}$ & $\begin{array}{l}0002 \\
0003 \\
0004 \\
0005 \\
0001 \\
0001 \\
0001 \\
0001 \\
0001 \\
0001 \\
0001\end{array}$ & $M G / L$ & & $\begin{array}{l}318 . \\
318 . \\
324 . \\
319 . \\
272 . \\
230 . \\
270 . \\
306 . \\
256 \\
356 . \\
404 .\end{array}$ & $\begin{array}{c}0.1 \\
0.1 \\
0.1 \\
0.1 \\
0.1 \\
0.1 \\
10 . \\
10 . \\
0.1 \\
40 . \\
100 .\end{array}$ & $\begin{array}{l}- \\
- \\
- \\
- \\
- \\
- \\
- \\
- \\
-\end{array}$ \\
\hline SULFATE (TOTAL) & $\begin{array}{l}03 / 30 / 90 \\
11 / 15 / 90 \\
03 / 13 / 93\end{array}$ & $\begin{array}{l}\text { No01 } \\
\text { N001 } \\
\text { N001 }\end{array}$ & $M G / L$ & & $\begin{array}{l}267 \\
221 . \\
432\end{array}$ & $\begin{array}{l}0.1 \\
0.1 \\
1\end{array}$ & - \\
\hline URANIUM & $\begin{array}{l}01 / 10 / 84 \\
06 / 18 / 84 \\
09 / 08 / 87 \\
11 / 21 / 87 \\
02 / 20 / 88 \\
05 / 16 / 88 \\
09 / 01 / 88 \\
10 / 27 / 88 \\
10 / 27 / 88 \\
10 / 27 / 88 \\
10 / 27 / 88 \\
10 / 27 / 88 \\
04 / 26 / 89 \\
04 / 26 / 89 \\
04 / 26 / 89 \\
04 / 26 / 89 \\
04 / 26 / 89 \\
11 / 21 / 89 \\
11 / 21 / 89 \\
11 / 21 / 89 \\
11 / 21 / 89 \\
11 / 21 / 89 \\
03 / 30 / 90 \\
11 / 15 / 90 \\
03 / 27 / 91 \\
05 / 31 / 91 \\
10 / 25 / 91 \\
03 / 13 / 92 \\
03 / 13 / 93\end{array}$ & $\begin{array}{l}0001 \\
0001 \\
0001 \\
0001 \\
0001 \\
0001 \\
0001 \\
0001 \\
0002 \\
0003 \\
0004 \\
0005 \\
0001 \\
0002 \\
0003 \\
0004 \\
0005 \\
0001 \\
0002 \\
0003 \\
0004 \\
0005 \\
0001 \\
0001 \\
0001 \\
0001 \\
0001 \\
0001 \\
0001\end{array}$ & $M G / L$ & & $\begin{array}{l}0.19 \\
0.415 \\
0.122 \\
0.0931 \\
0.103 \\
0.168 \\
0.077 \\
0.132 \\
0.130 \\
0.113 \\
0.098 \\
0.101 \\
0.171 \\
0.154 \\
0.154 \\
0.163 \\
0.171 \\
0.245 \\
0.231 \\
0.257 \\
0.271 \\
0.219 \\
0.147 \\
0\end{array}$ & $\begin{array}{l}{ }^{-} \\
0.0003 \\
0.003 \\
0.003 \\
0.003 \\
0.003 \\
0.003 \\
0.003 \\
0.003 \\
0.003 \\
0.003 \\
0.003 \\
0.003 \\
0.003 \\
0.003 \\
0.003 \\
0.003 \\
0.003 \\
0.003 \\
0.003 \\
0.003 \\
0.003 \\
0.003 \\
0.0003 \\
0.001 \\
0.001 \\
0.0003 \\
0.001 \\
0.001\end{array}$ & $\begin{array}{l}- \\
- \\
- \\
- \\
- \\
- \\
- \\
- \\
- \\
- \\
- \\
- \\
- \\
- \\
- \\
- \\
- \\
- \\
- \\
- \\
- \\
- \\
-\end{array}$ \\
\hline URANIUM (TOTAL) & $\begin{array}{l}03 / 30 / 90 \\
11 / 15 / 90 \\
03 / 27 / 91 \\
03 / 13 / 93\end{array}$ & $\begin{array}{l}\text { No01 } \\
\text { N001 } \\
\text { N001 } \\
\text { N001 }\end{array}$ & $M G / L$ & & $\begin{array}{l}0.146 \\
0.0749 \\
0.153 \\
0.212\end{array}$ & $\begin{array}{l}0.003 \\
0.0003 \\
0.001 \\
0.001\end{array}$ & - \\
\hline VANADIUM & $\begin{array}{l}12 / 08 / 83 \\
01 / 10 / 84 \\
06 / 18 / 84 \\
09 / 08 / 87\end{array}$ & $\begin{array}{l}0001 \\
0001 \\
0001 \\
0001\end{array}$ & $M G / L$ & $<$ & $\begin{array}{l}0.004 \\
0.005 \\
0.01 \\
0.03\end{array}$ & $\begin{array}{l}0.004 \\
- \\
0.01 \\
0.01\end{array}$ & $\begin{array}{l}- \\
- \\
-\end{array}$ \\
\hline
\end{tabular}

PARAMETER VALUE INDICATOR (PVI): < - LESS THAN DETECTION LIMIT

SAMPLE ID CODES:

0001 - FILTERED SAMPLE (. 45 MICRONS)

O002 - FILTERED REPLICATE SAMPLE (.45 MICRONS)

0003 - FILTERED REPLICATE SAMPLE (.45 MICRONS)

0004 - FILTERED REPLICATE SAMPLE (.45 MICRONS)

N001 - UNFILTERED SAMPLE 
GROUNDWATER QUALITY DATA BY LOCATION

SITE: RVTO1 RIVERTON

LOCATION: 0101

NORTH COORDINATE: 24105.4 FT

EAST COORDINATE: $\quad 24056.0$ FT

06/12/81 TO 01/10/94

REPORT DATE: 09/07/94

FORMATION OF COMPLETION: SURFICIAL (SF)

HYDRAULIC FLON RELATIONSHIP: ON-SITE (O)

\begin{tabular}{|c|c|c|c|c|c|c|c|}
\hline PARAMETER NAME & LOG DATE & $\begin{array}{c}\text { SAMPLE } \\
\text { ID }\end{array}$ & $\begin{array}{l}\text { UNITS OF } \\
\text { MEASURE }\end{array}$ & PVI & $\begin{array}{l}\text { PARAMETER } \\
\text { VALUE FLAGS }\end{array}$ & $\begin{array}{l}\text { DETECTION } \\
\text { LIMIT }\end{array}$ & $\begin{array}{l}\text { PARAMETER } \\
\text { UNCERTAINTY }\end{array}$ \\
\hline VANADIUM & $\begin{array}{l}11 / 21 / 87 \\
02 / 20 / 88 \\
05 / 16 / 88 \\
09 / 01 / 88 \\
10 / 27 / 88 \\
10 / 27 / 88 \\
10 / 27 / 88 \\
10 / 27 / 88 \\
10 / 27 / 88 \\
04 / 26 / 89 \\
04 / 26 / 89 \\
04 / 26 / 89 \\
04 / 26 / 89 \\
04 / 26 / 89 \\
11 / 21 / 89 \\
11 / 21 / 89 \\
11 / 21 / 89 \\
11 / 21 / 89 \\
11 / 21 / 89 \\
03 / 30 / 90 \\
11 / 15 / 90 \\
03 / 27 / 91 \\
05 / 31 / 91 \\
10 / 25 / 91 \\
03 / 13 / 92 \\
08 / 07 / 92 \\
03 / 13 / 93\end{array}$ & $\begin{array}{l}0001 \\
0001 \\
0001 \\
0001 \\
0001 \\
0002 \\
0003 \\
0004 \\
0005 \\
0001 \\
0002 \\
0003 \\
0004 \\
0005 \\
0001 \\
0002 \\
0003 \\
0004 \\
0005 \\
0001 \\
0001 \\
0001 \\
0001 \\
0001 \\
0001 \\
0001 \\
0001\end{array}$ & MG/L & $\begin{array}{l}< \\
\\
< \\
< \\
< \\
< \\
< \\
< \\
< \\
< \\
< \\
< \\
<\end{array}$ & $\begin{array}{l}0.03 \\
0.04 \\
0.03 \\
0.01 \\
0.02 \\
0.01 \\
0.01 \\
0.01 \\
0.01 \\
0.01 \\
0.01 \\
0.01 \\
0.01 \\
0.01 \\
0.02 \\
0.03 \\
0.02 \\
0.02 \\
0.02 \\
0.01 \\
0.02 \\
0.01 \\
0.01 \\
0.03 \\
0.01 \\
0.01 \\
0.01\end{array}$ & $\begin{array}{l}0.01 \\
0.01 \\
0.01 \\
0.01 \\
0.01 \\
0.01 \\
0.01 \\
0.01 \\
0.01 \\
0.01 \\
0.01 \\
0.01 \\
0.01 \\
0.01 \\
0.01 \\
0.01 \\
0.01 \\
0.01 \\
0.01 \\
0.01 \\
0.01 \\
0.01 \\
0.01 \\
0.01 \\
0.01 \\
0.01 \\
0.01\end{array}$ & $\begin{array}{l}- \\
- \\
- \\
- \\
- \\
- \\
- \\
- \\
- \\
- \\
- \\
- \\
- \\
- \\
- \\
- \\
- \\
- \\
- \\
- \\
- \\
- \\
-\end{array}$ \\
\hline VANADIUM (TOTAL) & $\begin{array}{l}03 / 30 / 90 \\
11 / 15 / 90 \\
03 / 27 / 91 \\
03 / 13 / 93\end{array}$ & $\begin{array}{l}\text { N001 } \\
\text { N001 } \\
\text { N001 } \\
\text { N001 }\end{array}$ & MG/L & $\begin{array}{l}< \\
< \\
<\end{array}$ & $\begin{array}{l}0.01 \\
0.01 \\
0.01 \\
0.01\end{array}$ & $\begin{array}{l}0.01 \\
0.01 \\
0.01 \\
0.01\end{array}$ & $\begin{array}{l}- \\
-\end{array}$ \\
\hline
\end{tabular}

PARAMETER VALUE INDICATOR (PVI): < - LESS THAN DETECTION LIMIT

SAMPLE ID CODES:

0001 - FILTERED SAMPLE (.45 MICRONS)

0002 - FILTERED REPLICATE SAMPLE (.45 MICRONS)

0003 - FILTERED REPLICATE SAMPLE (.45 MICRONS)

0004 - FILTERED REPLICATE SAMPLE (.45 MICRONS)

N001 - UNFILTERED SAMPLE 
GROUNDWATER QUALITY DATA BY LOCATION

SITE : RVT01 RIVERTON

LOCATION: 0104

NORTH COORDINATE: 24101.7 FT

EAST COORDINATE: 24251.2 FT

06/12/81 TO 01/10/94

REPORT DATE: $09 / 07 / 94$

FORMATION OF COMPLETION: SURFICIAL (SF)

HYDRAULIC FLOW RELATIONSHIP: ON-SITE (O)

\begin{tabular}{|c|c|c|c|c|c|c|c|c|}
\hline PARAMETER NAME & LOG DATE & $\begin{array}{c}\text { SAMPLE } \\
\text { ID }\end{array}$ & $\begin{array}{l}\text { UNITS OF } \\
\text { MEASURE }\end{array}$ & PVI & $\begin{array}{l}\text { PARAMETER } \\
\text { VALUE }\end{array}$ & FLAGS & $\begin{array}{l}\text { DETECTION } \\
\text { LIMIT }\end{array}$ & $\begin{array}{l}\text { PARAMETER } \\
\text { UNCERTAINTY }\end{array}$ \\
\hline ARSENIC & $\begin{array}{l}12 / 08 / 83 \\
01 / 10 / 84 \\
06 / 18 / 84 \\
11 / 15 / 90 \\
03 / 27 / 91 \\
06 / 01 / 91 \\
03 / 13 / 92 \\
08 / 07 / 92 \\
03 / 14 / 93 \\
03 / 14 / 93\end{array}$ & $\begin{array}{l}0001 \\
0001 \\
0001 \\
0001 \\
0001 \\
0001 \\
0001 \\
0001 \\
0001 \\
0002\end{array}$ & $M G / L$ & $\begin{array}{l}< \\
< \\
< \\
< \\
< \\
< \\
<\end{array}$ & $\begin{array}{l}0.001 \\
0.005 \\
0.01 \\
0.01 \\
0.01 \\
0.01 \\
0.005 \\
0.005 \\
0.005 \\
0.005\end{array}$ & $\begin{array}{l}\mathbf{J} \\
\mathbf{W} \\
\mathbf{W}\end{array}$ & $\begin{array}{l}0.001 \\
0.005 \\
0.01 \\
0.01 \\
0.01 \\
0.01 \\
0.005 \\
0.005 \\
0.005 \\
0.005\end{array}$ & $\begin{array}{l}- \\
- \\
- \\
- \\
- \\
- \\
- \\
-\end{array}$ \\
\hline ARSENIC (TOTAL) & $\begin{array}{l}11 / 15 / 90 \\
03 / 27 / 91 \\
10 / 24 / 91 \\
03 / 14 / 93 \\
03 / 14 / 93\end{array}$ & $\begin{array}{l}\text { N001 } \\
\text { N001 } \\
\text { N001 } \\
\text { N001 } \\
\text { N002 }\end{array}$ & MG/L & $\begin{array}{l}< \\
< \\
<\end{array}$ & $\begin{array}{l}0.01 \\
0.01 \\
0.013 \\
0.005 \\
0.005\end{array}$ & $W$ & $\begin{array}{l}0.01 \\
0.01 \\
0.001 \\
0.005 \\
0.005\end{array}$ & $\begin{array}{l}. \\
. \\
.\end{array}$ \\
\hline MANGANESE (TOTAL) & $\begin{array}{l}11 / 15 / 90 \\
03 / 27 / 91 \\
10 / 24 / 91 \\
03 / 14 / 93 \\
03 / 14 / 93\end{array}$ & $\begin{array}{l}\text { No01 } \\
\text { No01 } \\
\text { No01 } \\
\text { No01 } \\
\text { NO02 }\end{array}$ & $M G / L$ & $<$ & $\begin{array}{l}0.02 \\
0.14 \\
0.01 \\
0.04 \\
0.01\end{array}$ & & $\begin{array}{l}0.01 \\
0.01 \\
0.01 \\
0.01 \\
0.01\end{array}$ & $\begin{array}{l}- \\
- \\
-\end{array}$ \\
\hline MOLYBDENUM (TOTAL) & $\begin{array}{l}11 / 15 / 90 \\
03 / 27 / 91 \\
10 / 24 / 91 \\
03 / 14 / 93 \\
03 / 14 / 93\end{array}$ & $\begin{array}{l}\text { N001 } \\
\text { N001 } \\
\text { N001 } \\
\text { N001 } \\
\text { N002 }\end{array}$ & $M G / L$ & & $\begin{array}{l}0.06 \\
0.08 \\
0.14 \\
0.08 \\
0.08\end{array}$ & & $\begin{array}{l}0.01 \\
0.01 \\
0.01 \\
0.01 \\
0.01\end{array}$ & $\begin{array}{l}- \\
- \\
-\end{array}$ \\
\hline NICKEL & $\begin{array}{l}12 / 08 / 83 \\
01 / 10 / 84 \\
06 / 18 / 84 \\
11 / 15 / 90 \\
03 / 27 / 91\end{array}$ & $\begin{array}{l}0001 \\
0001 \\
0001 \\
0001 \\
0001\end{array}$ & MG/L & $\begin{array}{l}< \\
< \\
<\end{array}$ & $\begin{array}{l}0.148 \\
0.04 \\
0.04 \\
0.04 \\
0.04\end{array}$ & & $\begin{array}{l}0.001 \\
0.04 \\
0.04 \\
0.04 \\
0.04\end{array}$ & $\begin{array}{l}- \\
- \\
-\end{array}$ \\
\hline
\end{tabular}

PARAMETER VALUE INDICATOR (PVI): < - LESS THAN DETECTION LIMIT

SAMPLE ID CODES:

OTHER PARAMETER VALUE FLAGS:

$J$ - ESTIMATED VALUE

$W$ - POST-DIGEST SPIKE OUT OF CNTR LIM WHILE SAMP ABS < $50 \%$ SPIKE

0001 - FILTERED SAMPLE (.45 MICRONS)

0002 - FILTERED REPLICATE SAMPLE (.45 MICRONS)

NOO1 - UNFILTERED SAMPLE

NO02 - UNFILTERED REPLICATE SAMPLE 
GROUNDWATER QUALITY DATA BY LOCATION

SITE: RVTO1 RIVERTON

LOCATION: 0104

NORTH COORDINATE: 24101.7 FT

EAST COORDINATE: 24251.2 FT

06/12/81 TO $01 / 10 / 94$

REPORT DATE: 09/07/94

FORMATION OF COMPLETION: SURFICIAL (SF)

HYDRAULIC FLOW RELATIONSHIP: ON-SITE (O)

\begin{tabular}{|c|c|c|c|c|c|c|c|}
\hline PARANETER NAME & LOG DATE & $\begin{array}{l}\text { SAMPLE } \\
\text { ID }\end{array}$ & $\begin{array}{l}\text { UNITS OF } \\
\text { MEASURE }\end{array}$ & PVI & $\begin{array}{l}\text { PARAMETER } \\
\text { VALUE FLAGS }\end{array}$ & $\begin{array}{l}\text { DETECTION } \\
\text { LIMIT }\end{array}$ & $\begin{array}{l}\text { PARAMETER } \\
\text { UNCERTAINTY }\end{array}$ \\
\hline NICKEL & $\begin{array}{l}06 / 01 / 91 \\
03 / 13 / 92 \\
08 / 07 / 92 \\
03 / 14 / 93 \\
03 / 14 / 93\end{array}$ & $\begin{array}{l}0001 \\
0001 \\
0001 \\
0001 \\
0002\end{array}$ & $M G / L$ & $\begin{array}{l}< \\
< \\
< \\
<\end{array}$ & $\begin{array}{l}0.04 \\
0.04 \\
0.04 \\
0.04 \\
0.04\end{array}$ & $\begin{array}{l}0.04 \\
0.04 \\
0.04 \\
0.04 \\
0.04\end{array}$ & $\begin{array}{l}- \\
- \\
-\end{array}$ \\
\hline NICKEL (TOTAL) & $\begin{array}{l}11 / 15 / 90 \\
03 / 27 / 91 \\
10 / 24 / 91 \\
03 / 14 / 93 \\
03 / 14 / 93\end{array}$ & $\begin{array}{l}\text { No01 } \\
\text { N001 } \\
\text { N001 } \\
\text { N001 } \\
\text { N002 }\end{array}$ & $M G / L$ & $\begin{array}{l}< \\
< \\
< \\
<\end{array}$ & $\begin{array}{l}0.04 \\
0.04 \\
0.09 \\
0.04 \\
0.04\end{array}$ & $\begin{array}{l}0.04 \\
0.04 \\
0.01 \\
0.04 \\
0.04\end{array}$ & $\begin{array}{l}- \\
- \\
-\end{array}$ \\
\hline SULFATE & $\begin{array}{l}12 / 08 / 83 \\
01 / 10 / 84 \\
06 / 18 / 84 \\
11 / 15 / 90 \\
03 / 27 / 91 \\
06 / 01 / 91 \\
03 / 13 / 92 \\
08 / 07 / 92\end{array}$ & $\begin{array}{l}0001 \\
0001 \\
0001 \\
0001 \\
0001 \\
0001 \\
0001 \\
0001\end{array}$ & $M G / L$ & & $\begin{array}{l}544.00 \\
520.00 \\
289.00 \\
271 . \\
272 . \\
259 . \\
298 . \\
293 .\end{array}$ & $\begin{array}{c}0.1 \\
- \\
0.1 \\
0.1 \\
10 . \\
10 . \\
30 . \\
100 .\end{array}$ & $\begin{array}{l}- \\
- \\
- \\
- \\
-\end{array}$ \\
\hline SULFATE (TOTAL) & $\begin{array}{l}11 / 15 / 90 \\
10 / 24 / 91 \\
03 / 14 / 93 \\
03 / 14 / 93\end{array}$ & $\begin{array}{l}\text { No01 } \\
\text { N001 } \\
\text { N001 } \\
\text { N002 }\end{array}$ & $M G / L$ & & $\begin{array}{l}275 . \\
267 \\
367 \\
369\end{array}$ & $\begin{array}{l}0.1 \\
0.1 \\
1 \\
1\end{array}$ & :- \\
\hline URANIUM & $\begin{array}{l}01 / 10 / 84 \\
06 / 18 / 84 \\
11 / 15 / 90 \\
03 / 27 / 91 \\
06 / 01 / 91 \\
03 / 13 / 92 \\
03 / 14 / 93 \\
03 / 14 / 93\end{array}$ & $\begin{array}{l}0001 \\
0001 \\
0001 \\
0001 \\
0001 \\
0001 \\
0001 \\
0002\end{array}$ & $M G / L$ & & $\begin{array}{c}140.00 \\
0.159 \\
0.0795 \\
0.131 \\
0.042 \\
0.086 \\
0.095 \\
0.097\end{array}$ & $\begin{array}{l}- \\
0.0003 \\
0.0003 \\
0.001 \\
0.001 \\
0.001 \\
0.001 \\
0.001\end{array}$ & $\begin{array}{l}- \\
- \\
- \\
- \\
-\end{array}$ \\
\hline URANIUM (TOTAL) & $\begin{array}{l}11 / 15 / 90 \\
03 / 27 / 91 \\
10 / 24 / 91 \\
03 / 14 / 93 \\
03 / 14 / 93\end{array}$ & $\begin{array}{l}\text { N001 } \\
\text { N001 } \\
\text { N001 } \\
\text { N001 } \\
\text { N002 }\end{array}$ & $M G / L$ & & $\begin{array}{l}0.0749 \\
0.119 \\
0.0730 \\
0.089 \\
0.100\end{array}$ & $\begin{array}{l}0.0003 \\
0.001 \\
0.0003 \\
0.001 \\
0.001\end{array}$ & $\begin{array}{l}- \\
- \\
-\end{array}$ \\
\hline VANADIUM & $\begin{array}{l}12 / 08 / 83 \\
01 / 10 / 84 \\
06 / 18 / 84 \\
11 / 15 / 90 \\
03 / 27 / 91 \\
06 / 01 / 91 \\
03 / 13 / 92 \\
08 / 07 / 92 \\
03 / 14 / 93 \\
03 / 14 / 93\end{array}$ & $\begin{array}{l}0001 \\
0001 \\
0001 \\
0001 \\
0001 \\
0001 \\
0001 \\
0001 \\
0001 \\
0002\end{array}$ & MG/L & $\begin{array}{l}< \\
< \\
< \\
< \\
< \\
< \\
<\end{array}$ & $\begin{array}{l}0.004 \\
0.005 \\
0.01 \\
0.02 \\
0.01 \\
0.01 \\
0.01 \\
0.04 \\
0.01 \\
0.01\end{array}$ & $\begin{array}{l}0.004 \\
- \\
0.01 \\
0.01 \\
0.01 \\
0.01 \\
0.01 \\
0.01 \\
0.01 \\
0.01\end{array}$ & $\begin{array}{l}- \\
: \\
- \\
- \\
- \\
-\end{array}$ \\
\hline VANADIUM (TOTAL) & $\begin{array}{l}11 / 15 / 90 \\
03 / 27 / 91 \\
10 / 24 / 91 \\
03 / 14 / 93\end{array}$ & $\begin{array}{l}\text { N001 } \\
\text { N001 } \\
\text { N001 } \\
\text { N001 }\end{array}$ & $M G / L$ & $\begin{array}{l}< \\
<\end{array}$ & $\begin{array}{l}0.01 \\
0.01 \\
0.18 \\
0.01\end{array}$ & $\begin{array}{l}0.01 \\
0.01 \\
0.01 \\
0.01\end{array}$ & $\begin{array}{l}- \\
-\end{array}$ \\
\hline
\end{tabular}

PARAMETER VALUE INDICATOR (PVI): < - LESS THAN DETECTION LIMIT SAMPLE ID CODES:

0001 - FILTERED SAMPLE (.45 MICRONS)

0002 - FILTERED REPLICATE SAMPLE (. 45 MICRONS)

NOO1 - UNFILTERED SAMPLE

NO02 - UNFILTERED REPLICATE SAMPLE 
GROUNDWATER QUALITY DATA BY LOCATION

SITE: RVTO1 RIVERTON

LOCATION: 0104

NORTH COORDINATE: $\quad 24101.7$ FT

EAST COORDINATE: 24251.2 FT

06/12/81 TO 01/10/94

REPORT DATE: $09 / 07 / 94$

FORMATION OF COMPLETION: SURFICIAL (SF)

HYDRAULIC FLOW RELATIONSHIP: ON-SITE (O)

\begin{tabular}{|l|c|c|l|l|l|c|c|}
\hline PARAMETER NAME & LOG DATE & $\begin{array}{l}\text { SAMPLE } \\
\text { ID }\end{array}$ & $\begin{array}{l}\text { UNITS OF } \\
\text { MEASURE }\end{array}$ & PVI & $\begin{array}{c}\text { PARAMETER } \\
\text { VALUE }\end{array}$ & $\begin{array}{c}\text { DETECTIION } \\
\text { LIMIT }\end{array}$ & $\begin{array}{l}\text { PARAMETER } \\
\text { UHCERTAINTY }\end{array}$ \\
\hline VANADIUM (TOTAL) & $03 / 14 / 93$ & N002 & MG/L & $<$ & 0.01 & 0.01 & - \\
\hline
\end{tabular}

PARAMETER VALUE INDICATOR (PVI):

< - LESS THAN DETECTION LIMIT

SAMPLE ID COOES:

NO02 - UNFILTERED REPLICATE SAMPLE 
GROUNDWATER QUALITY DATA BY LOCATION

SITE: RVTOI RIVERTON

LOCATION: 0108

NORTH COORDINATE: 24095.4 FT

EAST COORDINATE: 24018.4 FT

06/12/81 TO $01 / 10 / 94$

REPORT DATE: $09 / 07 / 94$

FORMATION OF COMPLETION: SEMICONFINED SANDSTONE (SE)

HYDRAULIC FLOW RELATIONSHIP: ON-SITE (O)

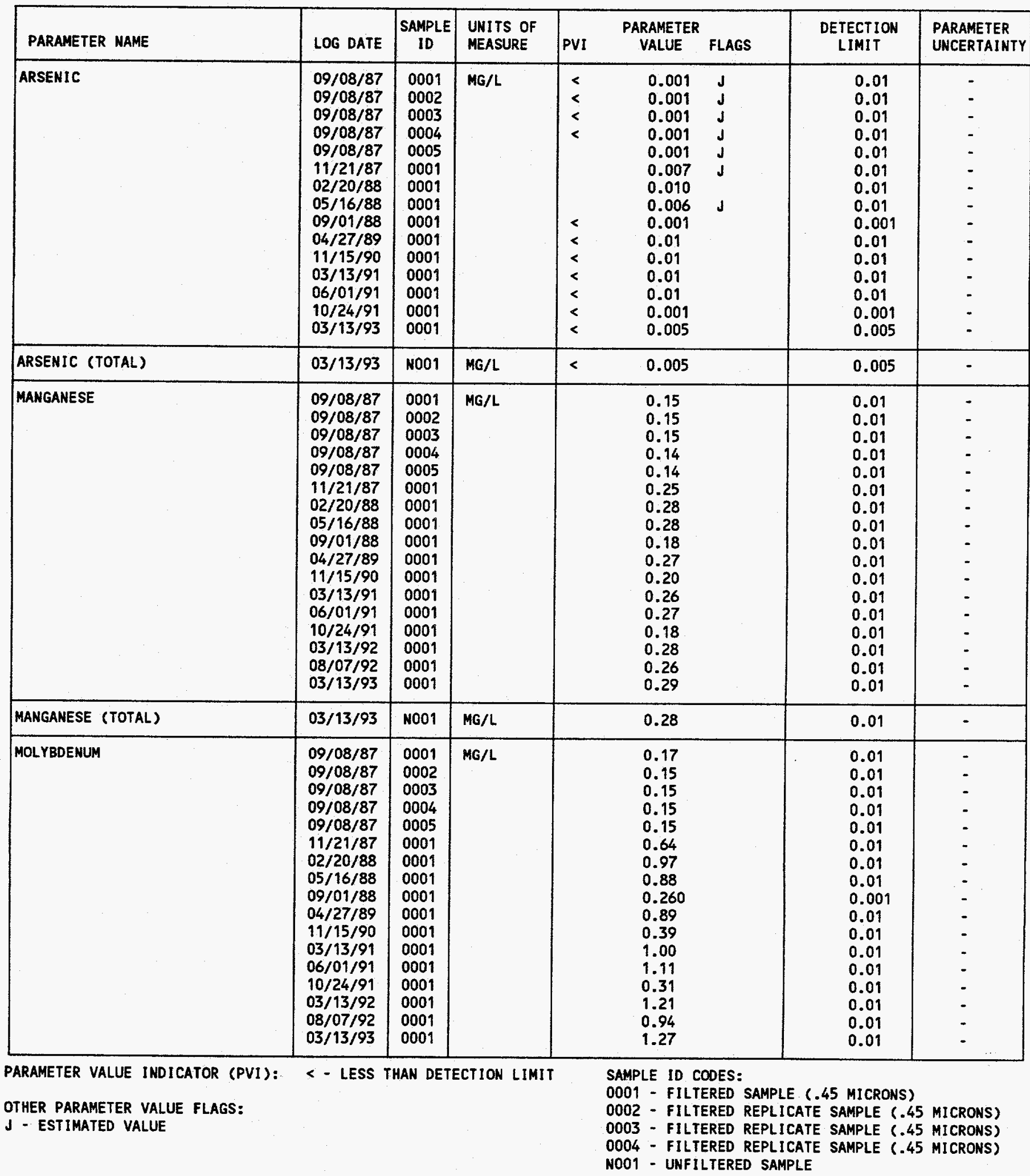


GROUNDWATER QUALITY DATA BY LOCATION

SITE: RVT01 RIVERTON

LOCATION: 0108

NORTH COORDINATE: $\quad 24095.4$ FT

EAST COORDINATE: $\quad 24018.4$ FT

$06 / 12 / 81$ TO $01 / 10 / 94$

REPORT DATE: 09/07/94

FORMATION OF COMPLETION: SEMICONFINED SANDSTONE (SE)

HYDRAULIC FLON RELATIONSHIP: ON-SITE (O)

\begin{tabular}{|c|c|c|c|c|c|c|c|c|}
\hline PARAMETER NAME & LOG DATE & $\begin{array}{c}\text { SAMPLE } \\
\text { ID }\end{array}$ & $\begin{array}{l}\text { UNITS OF } \\
\text { MEASURE }\end{array}$ & PVI & $\begin{array}{l}\text { PARAMETER } \\
\text { VALUE }\end{array}$ & FLAGS & $\begin{array}{l}\text { DETECTION } \\
\text { LIMIT }\end{array}$ & $\begin{array}{l}\text { PARAMETER } \\
\text { UNCERTAINTY }\end{array}$ \\
\hline MOLYBDENUM (TOTAL) & $03 / 13 / 93$ & No01 & $M G / L$ & \multicolumn{3}{|c|}{1.27} & 0.01 & - \\
\hline NICKEL & $\begin{array}{l}09 / 08 / 87 \\
09 / 08 / 87 \\
09 / 08 / 87 \\
09 / 08 / 87 \\
09 / 08 / 87 \\
11 / 21 / 87 \\
02 / 20 / 88 \\
05 / 16 / 88 \\
09 / 01 / 88 \\
04 / 27 / 89 \\
11 / 15 / 90 \\
03 / 13 / 91 \\
06 / 01 / 91 \\
10 / 24 / 91 \\
03 / 13 / 92 \\
08 / 07 / 92 \\
03 / 13 / 93\end{array}$ & $\begin{array}{l}0001 \\
0002 \\
0003 \\
0004 \\
0005 \\
0001 \\
0001 \\
0001 \\
0001 \\
0001 \\
0001 \\
0001 \\
0001 \\
0001 \\
0001 \\
0001 \\
0001\end{array}$ & $M G / L$ & $\begin{array}{l}< \\
< \\
< \\
< \\
< \\
< \\
< \\
< \\
< \\
< \\
< \\
< \\
< \\
< \\
<\end{array}$ & $\begin{array}{l}0.01 \\
0.01 \\
0.01 \\
0.01 \\
0.01 \\
0.01 \\
0.02 \\
0.02 \\
0.02 \\
0.04 \\
0.04 \\
0.04 \\
0.04 \\
0.01 \\
0.04 \\
0.04 \\
0.04\end{array}$ & $\begin{array}{l}\mathbf{J} \\
\mathbf{J} \\
\mathbf{J} \\
\mathbf{J} \\
\mathbf{J} \\
\mathbf{d} \\
\mathbf{J} \\
\mathbf{J} \\
\mathbf{J}\end{array}$ & $\begin{array}{l}0.04 \\
0.04 \\
0.04 \\
0.04 \\
0.04 \\
0.04 \\
0.04 \\
0.04 \\
0.04 \\
0.04 \\
0.04 \\
0.04 \\
0.04 \\
0.01 \\
0.04 \\
0.04 \\
0.04\end{array}$ & $\begin{array}{l}- \\
- \\
- \\
- \\
- \\
- \\
- \\
- \\
- \\
- \\
- \\
- \\
- \\
- \\
-\end{array}$ \\
\hline NICKEL (TOTAL) & $03 / 13 / 93$ & N001 & $M G / L$ & $<$ & 0.04 & & 0.04 & - \\
\hline . & $\begin{array}{l}09 / 08 / 87 \\
09 / 08 / 87 \\
09 / 08 / 87 \\
09 / 08 / 87 \\
09 / 08 / 87 \\
11 / 21 / 87 \\
02 / 20 / 88 \\
05 / 16 / 88 \\
09 / 01 / 88 \\
04 / 27 / 89 \\
11 / 15 / 90 \\
03 / 13 / 91 \\
06 / 01 / 91 \\
10 / 24 / 91 \\
03 / 13 / 92 \\
08 / 07 / 92\end{array}$ & $\begin{array}{l}0001 \\
0002 \\
0003 \\
0004 \\
0005 \\
0001 \\
0001 \\
0001 \\
0001 \\
0001 \\
0001 \\
0001 \\
0001 \\
0001 \\
0001 \\
0001\end{array}$ & $M G / L$ & & $\begin{array}{l}307 . \\
312 . \\
311 . \\
310 . \\
310 . \\
429 . \\
534 . \\
577 . \\
372 . \\
550 . \\
401 . \\
584 . \\
592 . \\
332 \\
630 . \\
543 .\end{array}$ & & $\begin{array}{c}0.1 \\
0.1 \\
0.1 \\
0.1 \\
0.1 \\
0.1 \\
0.1 \\
0.1 \\
1 . \\
0.1 \\
0.1 \\
10 . \\
10 . \\
0.1 \\
60 . \\
100 .\end{array}$ & $\begin{array}{l}- \\
- \\
- \\
- \\
- \\
- \\
- \\
- \\
- \\
- \\
- \\
- \\
- \\
- \\
- \\
-\end{array}$ \\
\hline SULFATE (TOTAL) & $03 / 13 / 93$ & No01 & $M G / L$ & & 632 & & 1 & - \\
\hline URANIUM & $\begin{array}{l}09 / 08 / 87 \\
09 / 08 / 87 \\
09 / 08 / 87 \\
09 / 08 / 87 \\
09 / 08 / 87 \\
11 / 21 / 87 \\
02 / 20 / 88 \\
05 / 16 / 88 \\
09 / 01 / 88 \\
04 / 27 / 89 \\
11 / 15 / 90 \\
03 / 13 / 91 \\
06 / 01 / 91 \\
10 / 24 / 91\end{array}$ & $\begin{array}{l}0001 \\
0002 \\
0003 \\
0004 \\
0005 \\
0001 \\
0001 \\
0001 \\
0001 \\
0001 \\
0001 \\
0001 \\
0001 \\
0001\end{array}$ & MG/L & $\begin{array}{l}< \\
< \\
< \\
<\end{array}$ & $\begin{array}{l}0.0003 \\
0.0003 \\
0.0003 \\
0.0003 \\
0.0020 \\
0.0030 \\
0.0032 \\
0.0030 \\
0.003 \\
0.003 \\
0.0013 \\
0.002 \\
0.003 \\
0.0012\end{array}$ & $\begin{array}{l}\mathbf{J} \\
\mathbf{J} \\
\mathbf{J} \\
\mathbf{J} \\
\mathbf{J}\end{array}$ & $\begin{array}{l}0.003 \\
0.003 \\
0.003 \\
0.003 \\
0.003 \\
0.003 \\
0.003 \\
0.003 \\
0.003 \\
0.003 \\
0.0003 \\
0.001 \\
0.001 \\
0.0003\end{array}$ & $\begin{array}{l}- \\
- \\
- \\
- \\
- \\
- \\
- \\
- \\
- \\
- \\
- \\
- \\
-\end{array}$ \\
\hline
\end{tabular}

PARAMETER VALUE INDICATOR (PVI): < - LESS THAN DETECTION LIMIT

SAMPLE ID CODES:

OTHER PARAMETER VALUE FLAGS:

0001 - FILTERED SAMPLE (.45 MICRONS)

$J$ - ESTIMATED VALUE

0002 - FILTERED REPLICATE SAMPLE (.45 MICRONS)

0003 - FILTERED REPLICATE SAMPLE (.45 MICRONS)

0004 - FILTERED REPLICATE SAMPLE (.45 MICRONS)

NOO1 - UNFILTERED SAMPLE 
GROUNDWATER QUALITY DATA BY LOCATION

SITE: RVTOI RIVERTON

LOCATION: 0108

NORTH COORDINATE: 24095.4 FT

EAST COORDINATE: 24018.4 FT

$06 / 12 / 81$ TO $01 / 10 / 94$

REPORT DATE: 09/07/94

FORMATION OF COMPLETION: SEMICONFINED SANDSTONE (SE)

HYDRAULIC FLOW RELATIONSHIP: ON-SITE (O)

\begin{tabular}{|c|c|c|c|c|c|c|c|}
\hline PARAMETER NAME & LOG DATE & $\begin{array}{c}\text { SAMPLE } \\
\text { ID }\end{array}$ & $\begin{array}{l}\text { UNITS OF } \\
\text { MEASURE }\end{array}$ & PVI & $\begin{array}{l}\text { ARAMETER } \\
\text { VALUE FLAGS }\end{array}$ & $\begin{array}{l}\text { DETECTION } \\
\text { LIMIT }\end{array}$ & $\begin{array}{l}\text { PARAMETER } \\
\text { UNCERTAINTY }\end{array}$ \\
\hline URANIUN & $\begin{array}{l}03 / 13 / 92 \\
08 / 07 / 92 \\
03 / 13 / 93\end{array}$ & $\begin{array}{l}0001 \\
0001 \\
0001\end{array}$ & $M G / L$ & & $\begin{array}{l}0.010 \\
0.005 \\
0.014\end{array}$ & $\begin{array}{l}0.001 \\
0.001 \\
0.001\end{array}$ & $\begin{array}{l}- \\
-\end{array}$ \\
\hline URANIUM (TOTAL) & $03 / 13 / 93$ & No01 & MG/L & & 0.011 & 0.001 & - \\
\hline VANADIUM & $\begin{array}{l}09 / 08 / 87 \\
09 / 08 / 87 \\
09 / 08 / 87 \\
09 / 08 / 87 \\
09 / 08 / 87 \\
11 / 21 / 87 \\
02 / 20 / 88 \\
05 / 16 / 88 \\
09 / 01 / 88 \\
04 / 27 / 89 \\
11 / 15 / 90 \\
03 / 13 / 91 \\
06 / 01 / 91 \\
10 / 24 / 91 \\
03 / 13 / 92 \\
08 / 07 / 92 \\
03 / 13 / 93\end{array}$ & $\begin{array}{l}0001 \\
0002 \\
0003 \\
0004 \\
0005 \\
0001 \\
0001 \\
0001 \\
0001 \\
0001 \\
0001 \\
0001 \\
0001 \\
0001 \\
0001 \\
0001 \\
0001\end{array}$ & $M G / L$ & $\begin{array}{l}< \\
< \\
< \\
<\end{array}$ & $\begin{array}{l}0.02 \\
0.02 \\
0.02 \\
0.02 \\
0.02 \\
0.03 \\
0.04 \\
0.03 \\
0.01 \\
0.01 \\
0.01 \\
0.01 \\
0.03 \\
0.04 \\
0.02 \\
0.02 \\
0.01\end{array}$ & $\begin{array}{l}0.01 \\
0.01 \\
0.01 \\
0.01 \\
0.01 \\
0.01 \\
0.01 \\
0.01 \\
0.01 \\
0.01 \\
0.01 \\
0.01 \\
0.01 \\
0.01 \\
0.01 \\
0.01 \\
0.01\end{array}$ & $\begin{array}{l}- \\
- \\
- \\
- \\
- \\
- \\
- \\
- \\
- \\
- \\
- \\
- \\
- \\
- \\
-\end{array}$ \\
\hline VANADIUM (TOTAL) & $03 / 13 / 93$ & No01 & $M G / L$ & $<$ & 0.01 & 0.01 & - \\
\hline
\end{tabular}

PARAMETER VALUE INDICATOR (PVI): < - LESS THAN DETECTION LIMIT

SAMPLE ID CODES:

0001 - FILTERED SAMPLE (.45 MICRONS)

0002 - FILTERED REPLICATE SAMPLE (.45 MICRONS)

0003 - FILTERED REPLICATE SAMPLE (.45 MICRONS)

0004 - FILTERED REPLICATE SAMPLE (.45 MICRONS)

NO01 - UNFILTERED SAMPLE 
GROUNDWATER QUALITY DATA BY LOCATION

SITE: RVTO1 RIVERTON

LOCATION: 0110

NORTH COORDINATE: 24119.5 FT

EAST COORDINATE: $\quad 24060.8$ FT

06/12/81 TO 01/10/94

REPORT DATE: 09/07/94

FORMATION OF COMPLETION: SANDSTONE (SS)

HYDRAULIC FLOW RELATIONSHIP: ON-SITE (O)

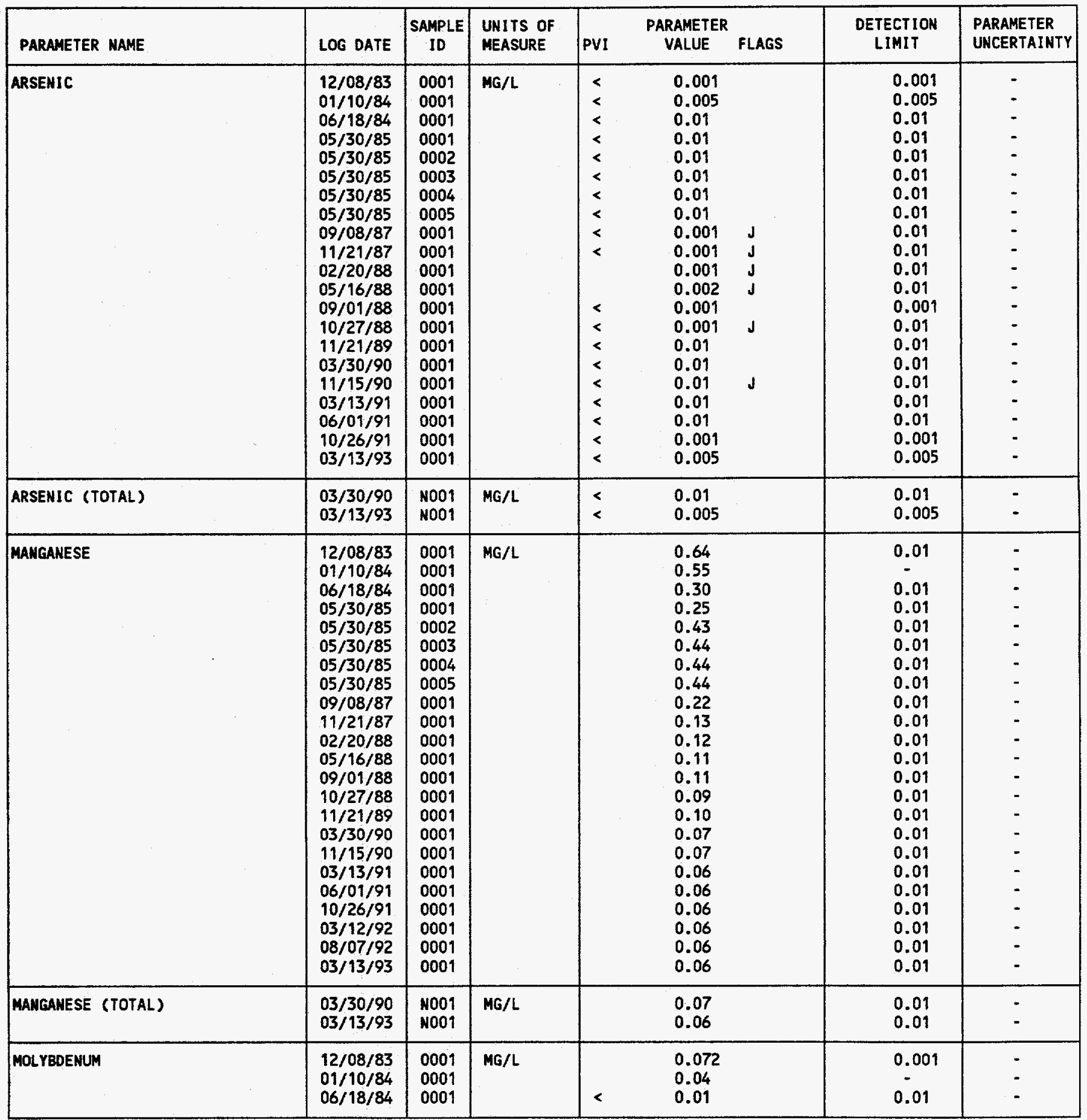

PARAMETER VALUE INDICATOR (PVI): < - LESS THAN DETECTION LIMIT

SAMPLE ID CODES:

OTHER PARAMETER VALUE FLAGS:

0001 - FILTERED SAMPLE (.45 MICRONS)

0002 - FILTERED REPLICATE SAMPLE (.45 MICRONS)

0003 - FILTERED REPLICATE SAMPLE (.45 MICRONS)

$J$ - ESTIMATED VALUE

NOO1 - UNFILTERED SAMPLE 
GROUNDHATER QUALITY DATA BY LOCATIOH

SITE: RVTO1 RIVERTON

LOCATION: 0110

NORTH COORDINATE: 24119.5 FT

EAST COORDINATE: 24060.8 FT

06/12/81 TO 01/10/94

REPORT DATE: 09/07/94

FORMATION OF COMPLETION: SANDSTONE (SS)

HYDRAULIC FLOW RELATIONSHIP: ON-SITE (O)

\begin{tabular}{|c|c|c|c|c|c|c|c|c|}
\hline PARAMETER NAME & LOG DATE & $\begin{array}{c}\text { SAMPLE } \\
\text { ID }\end{array}$ & $\begin{array}{l}\text { UNITS OF } \\
\text { MEASURE }\end{array}$ & PVI & $\begin{array}{l}\text { PARAMETER } \\
\text { VALUE }\end{array}$ & FLAGS & $\begin{array}{l}\text { DETECTION } \\
\text { LIMIT }\end{array}$ & $\begin{array}{l}\text { PARAMETER } \\
\text { UNCERTAINTY }\end{array}$ \\
\hline MOL YBDENUN & $\begin{array}{l}05 / 30 / 85 \\
05 / 30 / 85 \\
05 / 30 / 85 \\
05 / 30 / 85 \\
05 / 30 / 85 \\
09 / 08 / 87 \\
11 / 21 / 87 \\
02 / 20 / 88 \\
05 / 16 / 88 \\
09 / 01 / 88 \\
10 / 27 / 88 \\
11 / 21 / 89 \\
03 / 30 / 90 \\
11 / 15 / 90 \\
03 / 13 / 91 \\
06 / 01 / 91 \\
10 / 26 / 91 \\
03 / 12 / 92 \\
08 / 07 / 92 \\
03 / 13 / 93\end{array}$ & $\begin{array}{l}0001 \\
0002 \\
0003 \\
0004 \\
0005 \\
0001 \\
0001 \\
0001 \\
0001 \\
0001 \\
0001 \\
0001 \\
0001 \\
0001 \\
0001 \\
0001 \\
0001 \\
0001 \\
0001 \\
0001\end{array}$ & MG/L & $\begin{array}{l}< \\
< \\
< \\
< \\
< \\
< \\
< \\
< \\
< \\
< \\
< \\
<\end{array}$ & $\begin{array}{l}0.01 \\
0.01 \\
0.01 \\
0.01 \\
0.01 \\
0.02 \\
0.04 \\
0.01 \\
0.01 \\
0.004 \\
0.002 \\
0.01 \\
0.01 \\
0.01 \\
0.01 \\
0.01 \\
0.01 \\
0.01 \\
0.05 \\
0.01\end{array}$ & J & $\begin{array}{l}0.01 \\
0.01 \\
0.01 \\
0.01 \\
0.01 \\
0.01 \\
0.01 \\
0.01 \\
0.01 \\
0.001 \\
0.01 \\
0.01 \\
0.01 \\
0.01 \\
0.01 \\
0.01 \\
0.01 \\
0.01 \\
0.01 \\
0.01\end{array}$ & $\begin{array}{l}- \\
- \\
- \\
- \\
- \\
- \\
- \\
- \\
- \\
- \\
- \\
- \\
- \\
- \\
- \\
- \\
-\end{array}$ \\
\hline MOLYBDENUM (TOTAL) & $\begin{array}{l}03 / 30 / 90 \\
03 / 13 / 93\end{array}$ & $\begin{array}{l}\text { N001 } \\
\text { N001 }\end{array}$ & $M G / L$ & $<$ & $\begin{array}{l}0.01 \\
0.01\end{array}$ & & $\begin{array}{l}0.01 \\
0.01\end{array}$ & - \\
\hline NICKEL & $\begin{array}{l}12 / 08 / 83 \\
01 / 10 / 84 \\
06 / 18 / 84 \\
05 / 30 / 85 \\
05 / 30 / 85 \\
05 / 30 / 85 \\
05 / 30 / 85 \\
05 / 30 / 85 \\
09 / 08 / 87 \\
11 / 21 / 87 \\
02 / 20 / 88 \\
05 / 16 / 88 \\
09 / 01 / 88 \\
10 / 27 / 88 \\
11 / 21 / 89 \\
03 / 30 / 90 \\
11 / 15 / 90 \\
03 / 13 / 91 \\
06 / 01 / 91 \\
10 / 26 / 91 \\
03 / 12 / 92 \\
08 / 07 / 92 \\
03 / 13 / 93\end{array}$ & $\begin{array}{l}0001 \\
0001 \\
0001 \\
0001 \\
0002 \\
0003 \\
0004 \\
0005 \\
0001 \\
0001 \\
0001 \\
0001 \\
0001 \\
0001 \\
0001 \\
0001 \\
0001 \\
0001 \\
0001 \\
0001 \\
0001 \\
0001 \\
0001\end{array}$ & $M G / L$ & $\begin{array}{l}< \\
< \\
< \\
< \\
< \\
< \\
< \\
< \\
< \\
< \\
< \\
< \\
< \\
< \\
< \\
< \\
< \\
< \\
<\end{array}$ & $\begin{array}{l}0.057 \\
0.04 \\
0.04 \\
0.04 \\
0.04 \\
0.04 \\
0.04 \\
0.04 \\
0.01 \\
0.01 \\
0.02 \\
0.01 \\
0.02 \\
0.02 \\
0.04 \\
0.04 \\
0.04 \\
0.04 \\
0.04 \\
0.01 \\
0.04 \\
0.04 \\
0.04\end{array}$ & $\begin{array}{l}\mathbf{J} \\
\mathrm{J} \\
\mathrm{J} \\
\mathrm{J} \\
\mathrm{J} \\
\mathrm{J}\end{array}$ & $\begin{array}{l}0.001 \\
0.04 \\
0.04 \\
0.04 \\
0.04 \\
0.04 \\
0.04 \\
0.04 \\
0.04 \\
0.04 \\
0.04 \\
0.04 \\
0.04 \\
0.04 \\
0.04 \\
0.04 \\
0.04 \\
0.04 \\
0.04 \\
0.01 \\
0.04 \\
0.04 \\
0.04\end{array}$ & $\begin{array}{l}- \\
- \\
- \\
- \\
- \\
- \\
- \\
- \\
- \\
- \\
- \\
- \\
- \\
- \\
- \\
- \\
- \\
- \\
-\end{array}$ \\
\hline NICKEL (TOTAL) & $\begin{array}{l}03 / 30 / 90 \\
03 / 13 / 93\end{array}$ & $\begin{array}{l}\text { N001 } \\
\text { N001 }\end{array}$ & $M G / L$ & $<$ & $\begin{array}{l}0.04 \\
0.04\end{array}$ & & $\begin{array}{l}0.04 \\
0.04\end{array}$ & - \\
\hline SULFATE & $\begin{array}{l}12 / 08 / 83 \\
01 / 10 / 84 \\
06 / 18 / 84 \\
05 / 30 / 85\end{array}$ & $\begin{array}{l}0001 \\
0001 \\
0001 \\
0001\end{array}$ & $M G / L$ & & $\begin{array}{r}277.00 \\
260.00 \\
88.50 \\
184.00\end{array}$ & & $\begin{array}{l}0.1 \\
- \\
0.1 \\
0.1\end{array}$ & $\begin{array}{l}- \\
- \\
-\end{array}$ \\
\hline
\end{tabular}

PARAMETER VALUE INOICATOR (PVI): < - LESS THAN DETECTION LIMIT

SAMPLE ID CODES:

0001 - FILTERED SAMPLE (.45 MICRONS)

OTHER PARAMETER VALUE FLAGS:

0002 - FILTERED REPLICATE SAMPLE (.45 MICRONS)

0003 - FILTERED REPLICATE SAMPLE (.45 MICRONS)

0004 - FILTERED REPLICATE SAMPLE (.45 MICRONS)

NOO1 - UNFILTERED SAMPLE 
GROUNDWATER QUALITY DATA BY LOCATION

SITE: RVTO1 RIVERTON

LOCATION: 0110

NORTH COORDINATE: 24119.5 FT

EAST COORDINATE: $\quad 24060.8$ FT

06/12/81 TO 01/10/94

REPORT DATE : 09/07/94

FORMATION OF COMPLETION: SAMDSTONE (SS)

HYDRAULIC FLOW RELATIONSHIP: ON-SITE (O)

\begin{tabular}{|c|c|c|c|c|c|c|c|c|}
\hline PARAMETER NAME & LOG DATE & $\underset{\text { ID }}{\text { SAMPLE }}$ & $\begin{array}{l}\text { UNITS OF } \\
\text { MEASURE }\end{array}$ & PVI & $\begin{array}{l}\text { PARAMETER } \\
\text { VALUE }\end{array}$ & FLAGS & $\begin{array}{l}\text { DETECTION } \\
\text { LIMIT }\end{array}$ & $\begin{array}{l}\text { PARAMETER } \\
\text { UNCERTAINTY }\end{array}$ \\
\hline SULFATE & $\begin{array}{l}05 / 30 / 85 \\
05 / 30 / 85 \\
05 / 30 / 85 \\
05 / 30 / 85 \\
09 / 08 / 87 \\
11 / 21 / 87 \\
02 / 20 / 88 \\
05 / 16 / 88 \\
09 / 01 / 88 \\
10 / 27 / 88 \\
11 / 21 / 89 \\
03 / 30 / 90 \\
11 / 15 / 90 \\
03 / 13 / 91 \\
06 / 01 / 91 \\
10 / 26 / 91 \\
03 / 12 / 92 \\
08 / 07 / 92\end{array}$ & $\begin{array}{l}0002 \\
0003 \\
0004 \\
0005 \\
0001 \\
0001 \\
0001 \\
0001 \\
0001 \\
0001 \\
0001 \\
0001 \\
0001 \\
0001 \\
0001 \\
0001 \\
0001 \\
0001\end{array}$ & $M G / L$ & & $\begin{array}{l}335.00 \\
334.00 \\
333.00 \\
335.00 \\
188 . \\
147 . \\
166 . \\
168 . \\
183 . \\
198 . \\
187 . \\
184 . \\
188 . \\
185 . \\
171 . \\
165 \\
182 . \\
178 .\end{array}$ & & $\begin{array}{c}0.1 \\
0.1 \\
0.1 \\
0.1 \\
0.1 \\
0.1 \\
0.1 \\
0.1 \\
1 . \\
0.1 \\
0.1 \\
0.1 \\
0.1 \\
10 . \\
0.1 \\
0.1 \\
10 . \\
20 .\end{array}$ & $\begin{array}{l}- \\
- \\
- \\
- \\
- \\
- \\
- \\
- \\
- \\
- \\
- \\
- \\
- \\
- \\
- \\
-\end{array}$ \\
\hline URANIUM & $\begin{array}{l}01 / 10 / 84 \\
06 / 18 / 84 \\
05 / 30 / 85 \\
05 / 30 / 85 \\
05 / 30 / 85 \\
05 / 30 / 85 \\
05 / 30 / 85 \\
09 / 08 / 87 \\
11 / 21 / 87 \\
02 / 20 / 88 \\
05 / 16 / 88 \\
09 / 01 / 88 \\
10 / 27 / 88 \\
11 / 21 / 89 \\
03 / 30 / 90 \\
11 / 15 / 90 \\
03 / 13 / 91 \\
06 / 01 / 91 \\
10 / 26 / 91 \\
03 / 12 / 92 \\
08 / 07 / 92 \\
03 / 13 / 93\end{array}$ & $\begin{array}{l}0001 \\
0001 \\
0001 \\
0002 \\
0003 \\
0004 \\
0005 \\
0001 \\
0001 \\
0001 \\
0001 \\
0001 \\
0001 \\
0001 \\
0001 \\
0001 \\
0001 \\
0001 \\
0001 \\
0001 \\
0001 \\
0001\end{array}$ & $M G / L$ & $\begin{array}{l}< \\
< \\
< \\
< \\
< \\
< \\
< \\
< \\
< \\
< \\
< \\
<\end{array}$ & $\begin{array}{l}0.005 \\
0.0007 \\
0.0005 \\
0.0062 \\
0.006 \\
0.0063 \\
0.0063 \\
0.0003 \\
0.0003 \\
0.0003 \\
0.0006 \\
0.003 \\
0.003 \\
0.0003 \\
0.0003 \\
0.0003 \\
0.001 \\
0.006 \\
0.0003 \\
0.001 \\
0.001 \\
0.001\end{array}$ & $\begin{array}{l}\mathbf{J} \\
\mathbf{J} \\
\mathbf{J} \\
\mathbf{J}\end{array}$ & $\begin{array}{l}{ }^{-} \\
0.0003 \\
0.003 \\
0.003 \\
0.003 \\
0.003 \\
0.003 \\
0.003 \\
0.003 \\
0.003 \\
0.003 \\
0.003 \\
0.003 \\
0.003 \\
0.003 \\
0.0003 \\
0.001 \\
0.001 \\
0.0003 \\
0.001 \\
0\end{array}$ & $\begin{array}{l}- \\
- \\
- \\
- \\
- \\
- \\
- \\
- \\
- \\
- \\
- \\
- \\
- \\
- \\
- \\
- \\
- \\
- \\
-\end{array}$ \\
\hline URANIUM (TOTAL) & $\begin{array}{l}03 / 30 / 90 \\
03 / 13 / 93\end{array}$ & $\begin{array}{l}\text { N001 } \\
\text { N001 }\end{array}$ & MG/L & $<$ & $\begin{array}{l}0.0003 \\
0.001\end{array}$ & J & $\begin{array}{l}0.003 \\
0.001\end{array}$ & - \\
\hline VANADIUM & $\begin{array}{l}12 / 08 / 83 \\
01 / 10 / 84 \\
06 / 18 / 84 \\
05 / 30 / 85 \\
05 / 30 / 85 \\
05 / 30 / 85 \\
05 / 30 / 85\end{array}$ & $\begin{array}{l}0001 \\
0001 \\
0001 \\
0001 \\
0002 \\
0003 \\
0004\end{array}$ & MG $/ L$ & $\begin{array}{l}< \\
< \\
< \\
< \\
< \\
< \\
<\end{array}$ & $\begin{array}{l}0.004 \\
0.004 \\
0.01 \\
0.01 \\
0.01 \\
0.01 \\
0.01\end{array}$ & & $\begin{array}{l}0.004 \\
0.004 \\
0.01 \\
0.01 \\
0.01 \\
0.01 \\
0.01\end{array}$ & $\begin{array}{l}- \\
- \\
- \\
-\end{array}$ \\
\hline
\end{tabular}

PARAMETER VALUE INDICATOR (PVI): < - LESS THAN DETECTION LIMIT

SAMPLE ID CODES:

OTHER PARAMETER VALUE FLAGS:

0001 - FILTERED SAMPLE (.45 MICRONS)

0002 - FILTERED REPLICATE SAMPLE (.45 MICRONS)

0003 - FILTERED REPLICATE SAMPLE (.45 MICRONS)

0004 - FILTERED REPLICATE SAMPLE (.45 MICRONS)

NO01 - UNFILTERED SAMPLE 
GROUNDWATER QUALITY DATA BY LOCATION

SITE: RVTO1 RIVERTON

LOCATION: 0110

NORTH COORDINATE: 24119.5 FT

EAST COORDINATE: 24060.8 FT

06/12/81 TO 01/10/94

REPORT DATE: 09/07/94

FORMATION OF COMPLETION: SANDSTONE (SS)

HYDRAULIC FLOW RELATIONSHIP: ON-SITE (O)

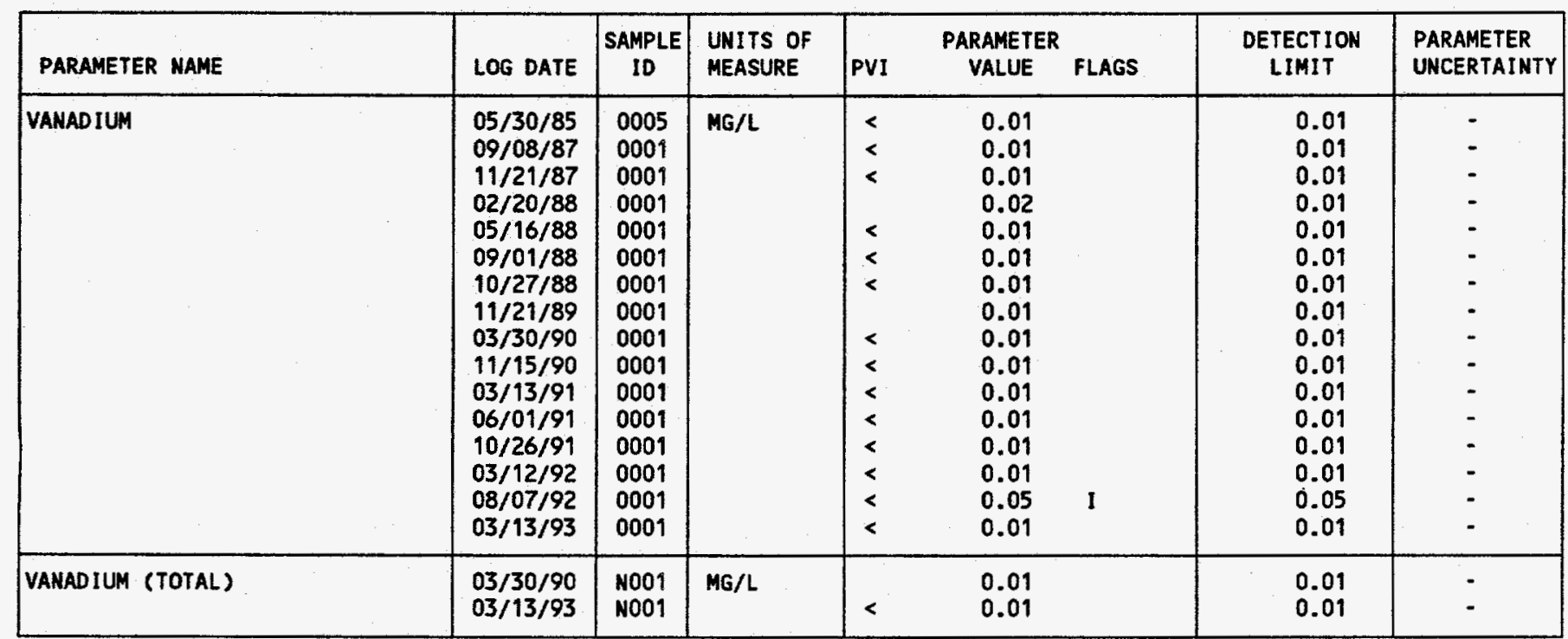

PARAMETER VALUE INDICATOR (PVI): < - LESS THAN DETECTION LIMIT

SAMPLE ID CODES:

OTHER PARAMETER VALUE FLAGS:

1 - INCREASED DETECTION LIMIT DUE TO REQUIRED DILUTION

0001 - FILTERED SAMPLE (.45 MICRONS)

NO01 - UNFILTERED SAMPLE 
GROUNDWATER QUALITY DATA BY LOCATION

SITE: RVTO1 RIVERTON

LOCATION: 0705

NORTH COORDINATE: 21000.8 FT

EAST COORDINATE: 27735.8 FT

$06 / 12 / 81$ TO $01 / 10 / 94$

REPORT DATE: 09/07/94

FORMATION OF COMPLETION: SEMICONFINED SANDSTONE (SE)

HYDRAULIC FLOW RELATIONSHIP: DOWN GRADIENT (D)

\begin{tabular}{|c|c|c|c|c|c|c|c|c|}
\hline PARAMETER NAME & LOG DATE & $\begin{array}{c}\text { SAMPLE } \\
\text { ID }\end{array}$ & $\begin{array}{l}\text { UNITS OF } \\
\text { MEASURE }\end{array}$ & PVI & $\begin{array}{l}\text { PARAMETER } \\
\text { VALUE }\end{array}$ & FLAGS & $\begin{array}{l}\text { DETECTION } \\
\text { LIMIT }\end{array}$ & $\begin{array}{l}\text { PARAMETER } \\
\text { UNCERTAINTY }\end{array}$ \\
\hline ARSENIC & $\begin{array}{l}05 / 28 / 85 \\
11 / 21 / 87 \\
05 / 16 / 88 \\
09 / 01 / 88 \\
10 / 28 / 88 \\
04 / 25 / 89 \\
12 / 02 / 89 \\
04 / 01 / 90 \\
11 / 19 / 90 \\
03 / 11 / 91 \\
06 / 02 / 91 \\
10 / 25 / 91 \\
03 / 31 / 93\end{array}$ & $\begin{array}{l}0001 \\
0001 \\
0001 \\
0001 \\
0001 \\
0001 \\
0001 \\
0001 \\
0001 \\
0001 \\
0001 \\
0001 \\
0001\end{array}$ & $M G / L$ & $\begin{array}{l}< \\
< \\
< \\
< \\
< \\
< \\
< \\
< \\
< \\
<\end{array}$ & $\begin{array}{l}0.01 \\
0.003 \\
0.006 \\
0.002 \\
0.001 \\
0.03 \\
0.01 \\
0.01 \\
0.01 \\
0.01 \\
0.05 \\
0.001 \\
0.005\end{array}$ & $\begin{array}{l}\mathrm{J} \\
\mathrm{J} \\
\mathrm{J}\end{array}$ & $\begin{array}{l}0.01 \\
0.01 \\
0.01 \\
0.001 \\
0.01 \\
0.03 \\
0.01 \\
0.01 \\
0.01 \\
0.01 \\
0.05 \\
0.001 \\
0.005\end{array}$ & $\begin{array}{l}- \\
- \\
- \\
- \\
- \\
- \\
- \\
- \\
-\end{array}$ \\
\hline ARSENIC (TOTAL) & $\begin{array}{l}04 / 01 / 90 \\
03 / 31 / 93\end{array}$ & $\begin{array}{l}\text { NO01 } \\
\text { N001 }\end{array}$ & $M G / L$ & $<$ & $\begin{array}{l}0.01 \\
0.005\end{array}$ & $\mathbf{L}$ & $\begin{array}{l}0.01 \\
0.005\end{array}$ & - \\
\hline MANGANESE (TOTAL) & $\begin{array}{l}04 / 01 / 90 \\
03 / 31 / 93\end{array}$ & $\begin{array}{l}\text { N001 } \\
\text { N001 }\end{array}$ & $M G / L$ & $<$ & $\begin{array}{l}0.01 \\
0.02\end{array}$ & $\mathbf{L}$ & $\begin{array}{l}0.01 \\
0.01\end{array}$ & - \\
\hline MOLYBDENUM (TOTAL) & $\begin{array}{l}04 / 01 / 90 \\
03 / 31 / 93\end{array}$ & $\begin{array}{l}\text { N001 } \\
\text { N001 }\end{array}$ & $M G / L$ & $<$ & $\begin{array}{l}0.01 \\
0.01\end{array}$ & $L$ & $\begin{array}{l}0.01 \\
0.01\end{array}$ & - \\
\hline NICKEL & $05 / 28 / 85$ & 0001 & $M G / L$ & $<$ & 0.04 & & 0.04 & - \\
\hline
\end{tabular}

PARAMETER VALUE INDICATOR (PVI): < - LESS THAN DETECTION LIMIT

SAMPLE ID CODES:

OTHER PARAMETER VALUE FLAGS:

0001 - FILTERED SAMPLE (.45 MICRONS)

I - INCREASED DETECTION LIMIT DUE TO REQUIRED DILUTION

NOO1 - UNFILTERED SAMPLE

J. Est IMATED VALUE

$L$ - LESS THAN THREE BORE VOLUMES REMOVED BEFORE SAMPLING

$W$ - POST-DIGEST SPIKE OUT OF CNTR LIM WHILE SAMP ABS < $50 \%$ SPIKE 
GROUNDHATER QUALITY DATA BY LOCATION

SITE: RVTOI RIVERTON

LOCATION: 0705

NORTH COORDINATE: $\quad 21000.8$ FT

EAST COORDINATE: 27735.8 FT

$06 / 12 / 81$ TO $01 / 10 / 94$

REPORT DATE: 09/07/94

FORMATION OF COMPLETION: SEMICONFINED SANDSTONE (SE) HYDRAULIC FLOW RELATIONSHIP: DOWN GRADIENT (D)

\begin{tabular}{|c|c|c|c|c|c|c|c|c|}
\hline PARAMETER NAME & LOG DATE & $\underset{\text { ID }}{\text { SAMPLE }}$ & $\begin{array}{l}\text { UNITS OF } \\
\text { MEASURE }\end{array}$ & PVI & $\begin{array}{c}\text { PARAMETER } \\
\text { VALUE }\end{array}$ & FLAGS & $\begin{array}{c}\text { DETECTION } \\
\text { LIMIT }\end{array}$ & $\begin{array}{l}\text { PARAMETER } \\
\text { UNCERTAINTY }\end{array}$ \\
\hline NICKEL & $\begin{array}{l}11 / 21 / 87 \\
05 / 16 / 88 \\
09 / 01 / 88 \\
10 / 28 / 88 \\
04 / 25 / 89 \\
12 / 02 / 89 \\
04 / 01 / 90 \\
11 / 19 / 90 \\
03 / 11 / 91 \\
06 / 02 / 91 \\
10 / 25 / 91 \\
03 / 15 / 92 \\
08 / 08 / 92 \\
03 / 31 / 93\end{array}$ & $\begin{array}{l}0001 \\
0001 \\
0001 \\
0001 \\
0001 \\
0001 \\
0001 \\
0001 \\
0001 \\
0001 \\
0001 \\
0001 \\
0001 \\
0001\end{array}$ & $M G / L$ & $\begin{array}{l}< \\
< \\
< \\
< \\
< \\
< \\
< \\
< \\
< \\
< \\
< \\
< \\
<\end{array}$ & $\begin{array}{l}0.01 \\
0.01 \\
0.02 \\
0.02 \\
0.04 \\
0.04 \\
0.04 \\
0.04 \\
0.04 \\
0.04 \\
0.01 \\
0.04 \\
0.04 \\
0.04\end{array}$ & $\begin{array}{l}\mathbf{J} \\
\mathbf{J} \\
\mathbf{J} \\
\mathbf{J}\end{array}$ & $\begin{array}{l}0.04 \\
0.04 \\
0.04 \\
0.04 \\
0.04 \\
0.04 \\
0.04 \\
0.04 \\
0.04 \\
0.04 \\
0.01 \\
0.04 \\
0.04 \\
0.04\end{array}$ & $\begin{array}{l}- \\
- \\
- \\
- \\
- \\
- \\
- \\
- \\
- \\
- \\
- \\
- \\
- \\
-\end{array}$ \\
\hline NICKEL (TOTAL) & $\begin{array}{l}04 / 01 / 90 \\
03 / 31 / 93\end{array}$ & $\begin{array}{l}\text { No01 } \\
\text { N001 }\end{array}$ & $M G / L$ & $<$ & $\begin{array}{l}0.04 \\
0.04\end{array}$ & $L$ & $\begin{array}{l}0.04 \\
0.04\end{array}$ & - \\
\hline SULFATE & $\begin{array}{l}11 / 21 / 87 \\
05 / 16 / 88 \\
09 / 01 / 88 \\
10 / 28 / 88 \\
04 / 25 / 89 \\
12 / 02 / 89 \\
04 / 01 / 90 \\
11 / 19 / 90 \\
03 / 11 / 91 \\
06 / 02 / 91 \\
10 / 25 / 99 \\
03 / 15 / 92 \\
08 / 08 / 92 \\
03 / 31 / 93\end{array}$ & $\begin{array}{l}0001 \\
0001 \\
0001 \\
0001 \\
0001 \\
0001 \\
0001 \\
0001 \\
0001 \\
0001 \\
0001 \\
0001 \\
0001 \\
0001\end{array}$ & MG/L & & $\begin{array}{l}330 . \\
379 . \\
428 . \\
442 . \\
424 . \\
433 . \\
427 . \\
440 . \\
401 . \\
426 . \\
379 \\
432 . \\
413 . \\
369\end{array}$ & . & $\begin{array}{c}0.1 \\
0.1 \\
1 . \\
0.1 \\
0.1 \\
0.1 \\
0.1 \\
0.1 \\
10 . \\
10 . \\
0.1 \\
30 . \\
100 . \\
1\end{array}$ & $\begin{array}{l}- \\
- \\
- \\
- \\
- \\
- \\
- \\
- \\
- \\
- \\
- \\
-\end{array}$ \\
\hline SULFATE (TOTAL) & $04 / 01 / 90$ & No01 & $M G / L$ & & 437. & & 0.1 & - \\
\hline URANIUM & $\begin{array}{l}05 / 28 / 85 \\
11 / 21 / 87 \\
05 / 16 / 88 \\
09 / 01 / 88 \\
10 / 28 / 88 \\
04 / 25 / 89 \\
12 / 02 / 89 \\
04 / 01 / 90 \\
11 / 19 / 90 \\
03 / 11 / 91 \\
06 / 02 / 91 \\
10 / 25 / 91 \\
03 / 15 / 92 \\
08 / 08 / 92 \\
03 / 31 / 93\end{array}$ & $\begin{array}{l}0001 \\
0001 \\
0001 \\
0001 \\
0001 \\
0001 \\
0001 \\
0001 \\
0001 \\
0001 \\
0001 \\
0001 \\
0001 \\
0001 \\
0001\end{array}$ & $M G / L$ & $\begin{array}{l}< \\
< \\
< \\
< \\
< \\
<\end{array}$ & $\begin{array}{l}0.0066 \\
0.0022 \\
0.0030 \\
0.003 \\
0.003 \\
0.005 \\
0.0027 \\
0.0013 \\
0.0021 \\
0.002 \\
0.001 \\
0.0009 \\
0.001 \\
0.001 \\
0.001\end{array}$ & $\begin{array}{l}J \\
\mathbf{J} \\
\mathbf{J}\end{array}$ & $\begin{array}{l}0.003 \\
0.003 \\
0.003 \\
0.003 \\
0.003 \\
0.003 \\
0.003 \\
0.003 \\
0.0003 \\
0.001 \\
0.001 \\
0.0003 \\
0.001 \\
0.001 \\
0.001\end{array}$ & $\begin{array}{l}- \\
- \\
- \\
- \\
- \\
- \\
- \\
- \\
- \\
- \\
- \\
- \\
- \\
- \\
-\end{array}$ \\
\hline URANIUM (TOTAL) & $\begin{array}{l}04 / 01 / 90 \\
03 / 31 / 93\end{array}$ & $\begin{array}{l}\text { No01 } \\
\text { N001 }\end{array}$ & $M G / L$ & $<$ & $\begin{array}{l}0.0045 \\
0.001\end{array}$ & $\mathbf{L}$ & $\begin{array}{l}0.003 \\
0.001\end{array}$ & - \\
\hline VANADIUM & $\begin{array}{l}05 / 28 / 85 \\
11 / 21 / 87\end{array}$ & $\begin{array}{l}0001 \\
0001\end{array}$ & $M G / L$ & $\begin{array}{l}< \\
<\end{array}$ & $\begin{array}{l}0.01 \\
0.01\end{array}$ & & $\begin{array}{l}0.01 \\
0.01\end{array}$ & - \\
\hline
\end{tabular}

PARAMETER VALUE INDICATOR (PVI): < - LESS THAN DETECTION LIMIT

SAMPLE ID COOES:

OTHER PARAMETER VALUE FLAGS:

0001 - FILTERED SAMPLE (.45 MICRONS)

$J$ - EST IMATED VALUE

L - LESS THAN THREE BORE VOLUMES REMOVED BEFORE SAMPLING 
GROUNDWATER QUALITY DATA BY LOCATION

SITE: RVTO1 RIVERTON

LOCATION: 0705

MORTH COORDINATE: 21000.8 FT

EAST COORDINATE: 27735.8 FT

06/12/81 TO 01/10/94

REPORT DATE: $09 / 07 / 94$

FORMATION OF COMPLETION: SEMICONFINED SANDSTONE (SE)

HYORAULIC FLOW RELATIONSHIP: DOWN GRADIENT (D)

\begin{tabular}{|c|c|c|c|c|c|c|c|c|}
\hline PARAMETER NAME & LOG DATE & $\begin{array}{c}\text { SAMPLE } \\
\text { ID }\end{array}$ & $\begin{array}{l}\text { UNITS OF } \\
\text { MEASURE }\end{array}$ & PVI & $\begin{array}{l}\text { PARAMETER } \\
\text { VALUE }\end{array}$ & FLAGS & $\begin{array}{l}\text { DETECTION } \\
\text { LIMIT }\end{array}$ & $\begin{array}{l}\text { PARAMETER } \\
\text { UNCERTAINTY }\end{array}$ \\
\hline VANADIUM & $\begin{array}{l}05 / 16 / 88 \\
09 / 01 / 88 \\
10 / 28 / 88 \\
04 / 25 / 89 \\
12 / 02 / 89 \\
04 / 01 / 90 \\
11 / 19 / 90 \\
03 / 11 / 91 \\
06 / 02 / 91 \\
10 / 25 / 91 \\
03 / 15 / 92 \\
08 / 08 / 92 \\
03 / 31 / 93\end{array}$ & $\begin{array}{l}0001 \\
0001 \\
0001 \\
0001 \\
0001 \\
0001 \\
0001 \\
0001 \\
0001 \\
0001 \\
0001 \\
0001 \\
0001\end{array}$ & $M G / L$ & $\begin{array}{l}< \\
< \\
< \\
< \\
< \\
< \\
< \\
< \\
< \\
< \\
<\end{array}$ & $\begin{array}{l}0.01 \\
0.01 \\
0.01 \\
0.01 \\
0.01 \\
0.01 \\
0.01 \\
0.01 \\
0.01 \\
0.01 \\
0.01 \\
0.01 \\
0.01\end{array}$ & $L$ & $\begin{array}{l}0.01 \\
0.01 \\
0.01 \\
0.01 \\
0.01 \\
0.01 \\
0.01 \\
0.01 \\
0.01 \\
0.01 \\
0.01 \\
0.01 \\
0.01\end{array}$ & $\begin{array}{l}- \\
- \\
- \\
: \\
- \\
- \\
- \\
- \\
-\end{array}$ \\
\hline VANADIUM (TOTAL) & $\begin{array}{l}04 / 01 / 90 \\
03 / 31 / 93\end{array}$ & $\begin{array}{l}\text { N001 } \\
\text { N001 }\end{array}$ & MG/L & $<$ & $\begin{array}{l}0.01 \\
0.01\end{array}$ & $L$ & $\begin{array}{l}0.01 \\
0.01\end{array}$ & $\dot{-}$ \\
\hline
\end{tabular}

PARAMETER VALUE INDICATOR (PVI): < - LESS THAN DETECTION LIMIT

SAMPLE ID CODES:

OTHER PARAMETER VALUE FLAGS:

0001 - FILTERED SAMPLE (.45 MICRONS)

$\downarrow$ - LESS THAN THREE BORE VOLUMES REMOVED BEFORE SAMPLING 


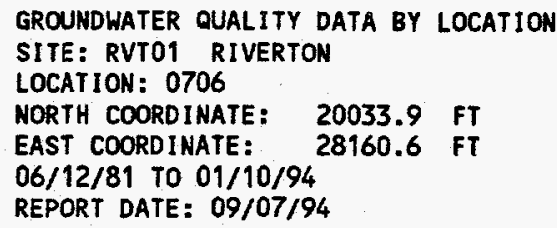

FORMATION OF COMPLETION: SURFICIAL (SF) HYDRAULIC FLOW RELATIONSHIP: DOWN GRADIENT (D)

\begin{tabular}{|c|c|c|c|c|c|c|c|c|}
\hline PARAMETER NAME & LOG DATE & $\begin{array}{c}\text { SAMPLE } \\
\text { ID }\end{array}$ & $\begin{array}{l}\text { UNITS OF } \\
\text { MEASURE }\end{array}$ & PVI & $\begin{array}{l}\text { PARAMETER } \\
\text { VALUE }\end{array}$ & FLAGS & $\begin{array}{l}\text { DETECTION } \\
\text { LIMIT }\end{array}$ & $\begin{array}{l}\text { PARAMETER } \\
\text { UNCERTAINTY }\end{array}$ \\
\hline ARSENIC & $\begin{array}{l}05 / 27 / 85 \\
09 / 08 / 87 \\
11 / 21 / 87 \\
02 / 20 / 88 \\
05 / 16 / 88 \\
09 / 01 / 88 \\
09 / 01 / 88 \\
09 / 01 / 88 \\
09 / 01 / 88 \\
09 / 01 / 88 \\
10 / 26 / 88 \\
04 / 25 / 89 \\
11 / 21 / 89 \\
03 / 30 / 90 \\
11 / 15 / 90 \\
03 / 12 / 91 \\
10 / 26 / 91 \\
03 / 13 / 92 \\
08 / 08 / 92 \\
03 / 11 / 93\end{array}$ & $\begin{array}{l}0001 \\
0001 \\
0001 \\
0001 \\
0001 \\
0001 \\
0002 \\
0003 \\
0004 \\
0005 \\
0001 \\
0001 \\
0001 \\
0001 \\
0001 \\
0001 \\
0001 \\
0001 \\
0001 \\
0001\end{array}$ & $M G / L$ & $\begin{array}{l}< \\
\\
< \\
< \\
< \\
< \\
< \\
< \\
< \\
<\end{array}$ & $\begin{array}{l}0.01 \\
0.001 \\
0.007 \\
0.007 \\
0.006 \\
0.001 \\
0.002 \\
0.002 \\
0.002 \\
0.001 \\
0.001 \\
0.01 \\
0.01 \\
0.01 \\
0.01 \\
0.01 \\
0.001 \\
0.005 \\
0.005 \\
0.005\end{array}$ & $\begin{array}{l}J \\
J \\
J \\
J\end{array}$ & $\begin{array}{l}0.01 \\
0.01 \\
0.01 \\
0.01 \\
0.01 \\
0.001 \\
0.01 \\
0.01 \\
0.01 \\
0.01 \\
0.01 \\
0.01 \\
0.01 \\
0.01 \\
0.01 \\
0.01 \\
0.001 \\
0.005 \\
0.005 \\
0.005\end{array}$ & $\begin{array}{l}- \\
- \\
- \\
- \\
- \\
- \\
- \\
- \\
- \\
- \\
- \\
- \\
- \\
- \\
- \\
- \\
- \\
-\end{array}$ \\
\hline ARSENIC (TOTAL) & $\begin{array}{l}03 / 30 / 90 \\
03 / 11 / 93\end{array}$ & $\begin{array}{l}\text { No01 } \\
\text { N001 }\end{array}$ & $M G / L$ & $<$ & $\begin{array}{l}0.01 \\
0.005\end{array}$ & & $\begin{array}{l}0.01 \\
0.005\end{array}$ & - \\
\hline MANGANESE & $\begin{array}{l}05 / 27 / 85 \\
09 / 08 / 87 \\
11 / 21 / 87 \\
02 / 20 / 88 \\
05 / 16 / 88 \\
09 / 01 / 88 \\
09 / 01 / 88 \\
09 / 01 / 88 \\
09 / 01 / 88 \\
09 / 01 / 88 \\
10 / 26 / 88 \\
04 / 25 / 89 \\
11 / 21 / 89 \\
03 / 30 / 90 \\
11 / 15 / 90 \\
03 / 12 / 91 \\
10 / 26 / 91 \\
03 / 13 / 92 \\
08 / 08 / 92 \\
03 / 11 / 93\end{array}$ & $\begin{array}{l}0001 \\
0001 \\
0001 \\
0001 \\
0001 \\
0001 \\
0002 \\
0003 \\
0004 \\
0005 \\
0001 \\
0001 \\
0001 \\
0001 \\
0001 \\
0001 \\
0001 \\
0001 \\
0001 \\
0001\end{array}$ & MG/L & & $\begin{array}{l}1.05 \\
0.91 \\
1.42 \\
1.20 \\
1.09 \\
1.08 \\
1.05 \\
1.05 \\
1.02 \\
1.03 \\
1.28 \\
1.12 \\
0.98 \\
0.90 \\
0.79 \\
0.55 \\
0.48 \\
0.44 \\
0.31 \\
0.53\end{array}$ & & $\begin{array}{l}0.01 \\
0.01 \\
0.01 \\
0.01 \\
0.01 \\
0.01 \\
0.01 \\
0.01 \\
0.01 \\
0.01 \\
0.01 \\
0.01 \\
0.01 \\
0.01 \\
0.01 \\
0.01 \\
0.01 \\
0.01 \\
0.01 \\
0.01\end{array}$ & $\begin{array}{l}- \\
- \\
- \\
- \\
- \\
- \\
- \\
- \\
- \\
- \\
- \\
- \\
- \\
- \\
- \\
- \\
- \\
- \\
- \\
-\end{array}$ \\
\hline MANGANESE (TOTAL) & $\begin{array}{l}03 / 30 / 90 \\
03 / 11 / 93\end{array}$ & $\begin{array}{l}N 001 \\
N 001\end{array}$ & $\mathrm{MG} / \mathrm{L}$ & & $\begin{array}{l}1.00 \\
0.55\end{array}$ & & $\begin{array}{l}0.01 \\
0.01\end{array}$ & - \\
\hline MOL YBDENUM & $\begin{array}{l}05 / 27 / 85 \\
09 / 08 / 87 \\
11 / 21 / 87 \\
02 / 20 / 88 \\
05 / 16 / 88 \\
09 / 01 / 88 \\
09 / 01 / 88\end{array}$ & $\begin{array}{l}0001 \\
0001 \\
0001 \\
0001 \\
0001 \\
0001 \\
0002\end{array}$ & $M G / L$ & $<$ & $\begin{array}{l}0.01 \\
0.01 \\
0.02 \\
0.05 \\
0.02 \\
0.004 \\
0.002\end{array}$ & 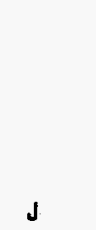 & $\begin{array}{l}0.01 \\
0.01 \\
0.01 \\
0.01 \\
0.01 \\
0.001 \\
0.01\end{array}$ & $\begin{array}{l}- \\
- \\
- \\
- \\
-\end{array}$ \\
\hline
\end{tabular}

PARAMETER VALUE INDICATOR (PVI): < - LESS THAN DETECTION LIMIT

SAMPLE ID CODES:

OTHER PARAMETER VALUE FLAGS:

0001 - FILTERED SAMPLE (.45 MICRONS)

$\downarrow$ - ESTIMATED VALUE

0002 - FILTERED REPLICATE SAMPLE (.45 MICRONS)

0003 - FILTERED REPLICATE SAMPLE (.45 MICRONS)

0004 - FILTERED REPLICATE SAMPLE (.45 MICRONS)

N001 - UNFILTERED SAMPLE 
GROUNDWATER QUALITY DATA BY LOCATION

SITE: RVTO1 RIVERTON

LOCATION: 0706

NORTH COORDINATE: 20033.9 FT

EAST COORDINATE: 28160.6 FT

06/12/81 TO 01/10/94

REPORT DATE: $09 / 07 / 94$

FORMATION OF COMPLETION: SURFICIAL (SF)

HYDRAULIC FLOW RELATIONSHIP: DOWN GRADIENT (D)

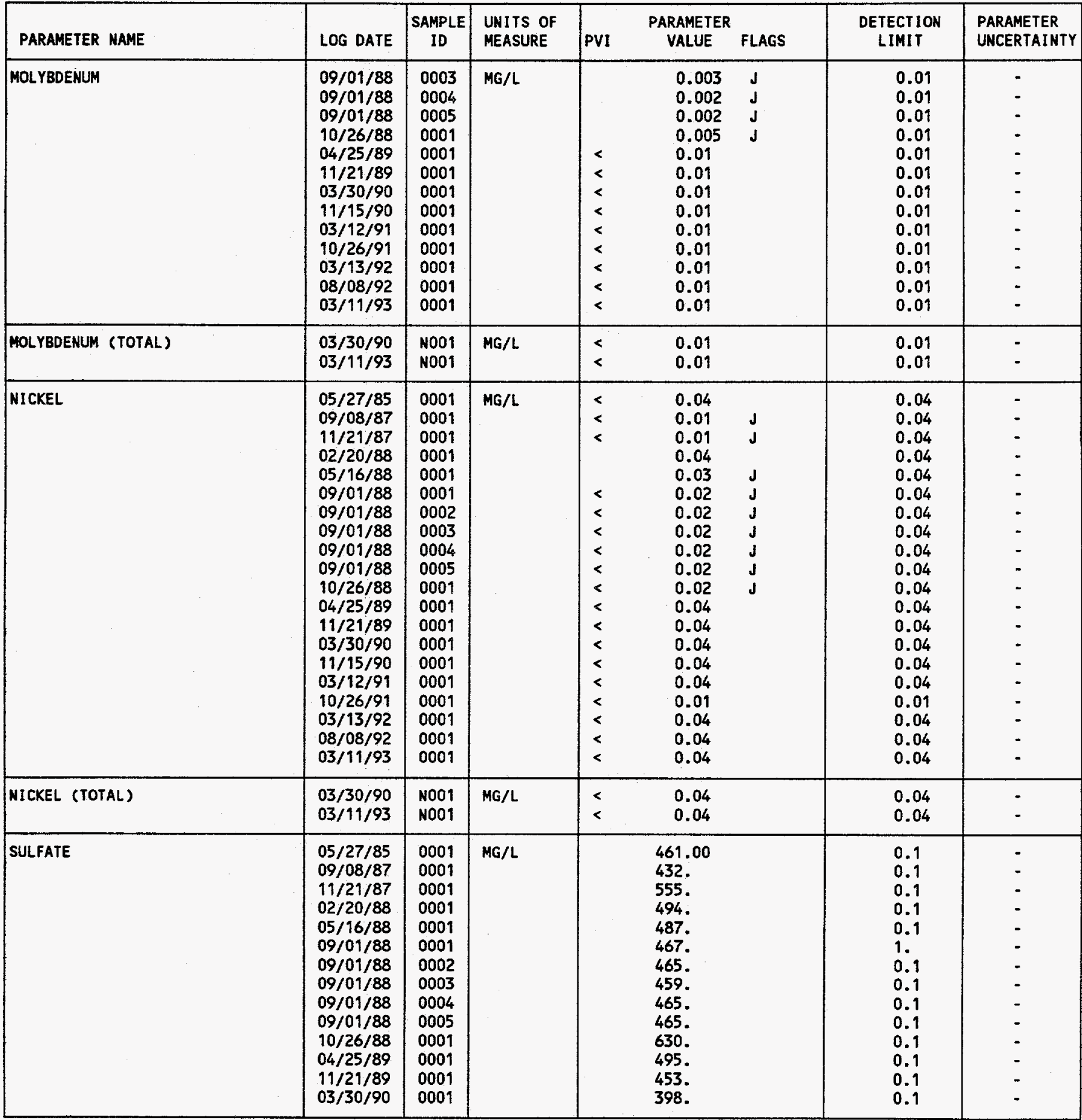

PARAMETER VALUE INDICATOR (PVI): < - LESS THAN DETECTION LIMIT

SAMPLE ID CODES:

OTHER PARAMETER VALUE FLAGS:

d - ESTIMATED VALUE

SAMPL ID CODES: SAMPLE ( 45 MICRONS)

0002 - FILTERED REPLICATE SAMPLE (.45 MICRONS)

0003 - FILTERED REPLICATE SAMPLE (.45 MICRONS)

0004 - FILTERED REPLICATE SAMPLE (.45 MICRONS)

N001 - UNFILTERED SAMPLE 
GROUNDWATER QUALITY DATA BY LOCATION

SITE: RVTO1 RIVERTON

LOCATION: 0706

NORTH COORDINATE: 20033.9 FT

EAST COORDINATE: 28160.6 FT

O6/12/81 TO 01/10/94

REPORT DATE: 09/07/94

FORMATION OF COMPLETION: SURFICIAL (SF)

HYDRAULIC FLOW RELATIONSHIP: DOWN GRADIENT (D)

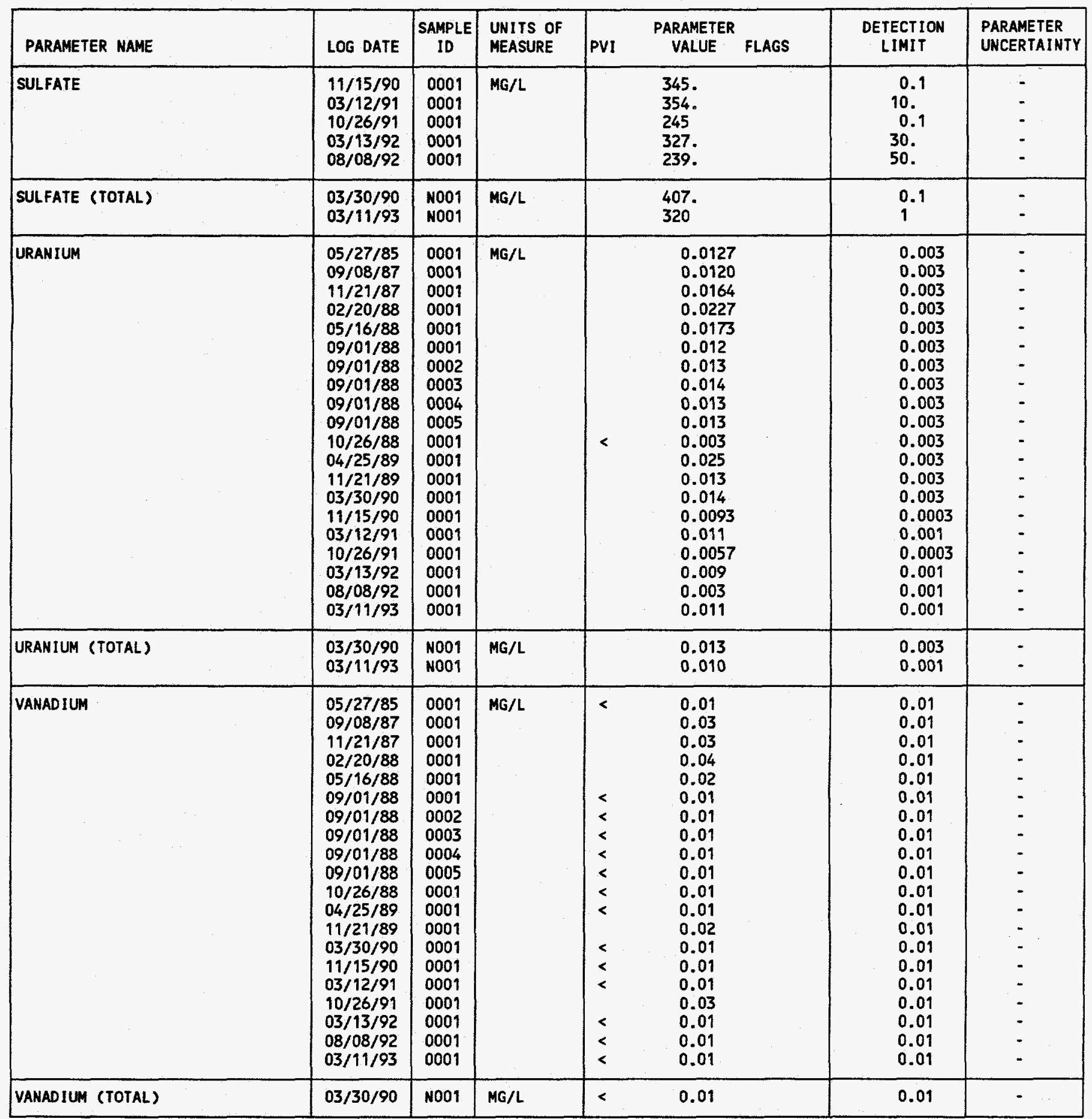

PARAMETER VALUE INDICATOR (PVI): < - LESS THAN DETECTION LIMIT

SAMPLE ID CODES:

0001 - FILTERED SAMPLE (.45 MICRONS)

0002 - FILTERED REPLICATE SAMPLE (.45 MICRONS)

0003 - FILTERED REPLICATE SAMPLE (.45 MICRONS)

0004 - FILTERED REPLICATE SAMPLE (.45 MICRONS)

NOO1 - UNFILTERED SAMPLE 
GROUNDWATER QUALITY DATA BY LOCATION

SITE: RVTO1 RIVERTON

LOCATION: 0706

NORTH COORDINATE: 20033.9 FT

EAST COORDINATE: $\quad 28160.6$ FT

06/12/81 TO 01/10/94

REPORT DATE: $09 / 07 / 94$

FORMATION OF COMPLETION: SURFICIAL (SF)

HYDRAULIC FLOW RELATIONSHIP: DOWN GRADIENT (D)

\begin{tabular}{|l|c|c|l|l|c|c|c|}
\hline PARAMETER NAME & LOG DATE & $\begin{array}{l}\text { SAMPLE } \\
\text { ID }\end{array}$ & $\begin{array}{l}\text { UNITS OF } \\
\text { MEASURE }\end{array}$ & PVI & $\begin{array}{c}\text { PARAMETER } \\
\text { VALUE }\end{array}$ & $\begin{array}{c}\text { DETECTIONS } \\
\text { LIMIT }\end{array}$ & $\begin{array}{c}\text { PARAMETER } \\
\text { UNCERTAINTY }\end{array}$ \\
\hline VANADIUM (TOTAL) & $03 / 11 / 93$ & N001 & MG/L & $<$ & 0.01 & 0.01 & - \\
\hline
\end{tabular}

PARAMETER VALUE INDICATOR (PVI):

< - LESS THAN DETECTION LIMIT

SAMPLE ID CODES:

NOO1 - UNFILTERED SAMPLE 
GROUNDWATER QUALITY DATA BY LOCATION

SITE: RVTO1 RIVERTON

LOCATION: 0707

MORTH COORDINATE: 21008.4 FT

EAST COORDINATE: 27745.2 FT

06/12/81 TO 01/10/94

REPORT DATE: 09/07/94

FORMATION OF COMPLETION: SURFICIAL (SF)

HYDRAULIC FLOW RELATIONSHIP: DOWN GRADIENT (D)

\begin{tabular}{|c|c|c|c|c|c|c|c|c|}
\hline PARAMETER NAME & LOG DATE & $\underset{\text { ID }}{\text { SAMPLE }}$ & $\begin{array}{l}\text { UNITS OF } \\
\text { MEASURE }\end{array}$ & PVI & $\begin{array}{l}\text { PARAMETER } \\
\text { VALUE }\end{array}$ & FLAGS & $\begin{array}{l}\text { DETECTION } \\
\text { LIMIT }\end{array}$ & $\begin{array}{l}\text { PARAMETER } \\
\text { UNCERTAINTY }\end{array}$ \\
\hline ARSENIC & $\begin{array}{l}09 / 08 / 87 \\
11 / 21 / 87 \\
11 / 21 / 87 \\
11 / 21 / 87 \\
11 / 21 / 87 \\
11 / 21 / 87 \\
02 / 20 / 88 \\
02 / 20 / 88 \\
02 / 20 / 88 \\
02 / 20 / 88 \\
02 / 20 / 88 \\
05 / 16 / 88 \\
09 / 01 / 88 \\
10 / 28 / 88 \\
04 / 25 / 89 \\
12 / 02 / 89 \\
04 / 01 / 90 \\
11 / 19 / 90 \\
03 / 12 / 91 \\
06 / 01 / 91 \\
10 / 25 / 91 \\
03 / 31 / 93\end{array}$ & $\begin{array}{l}0001 \\
0001 \\
0002 \\
0003 \\
0004 \\
0005 \\
0001 \\
0002 \\
0003 \\
0004 \\
0005 \\
0001 \\
0001 \\
0001 \\
0001 \\
0001 \\
0001 \\
0001 \\
0001 \\
0001 \\
0001 \\
0001\end{array}$ & $M G / L$ & \begin{tabular}{|l} 
\\
\\
\\
\\
$<$ \\
$<$ \\
$<$ \\
$<$ \\
$<$ \\
$<$ \\
$<$ \\
$<$
\end{tabular} & $\begin{array}{l}0.001 \\
0.019 \\
0.019 \\
0.020 \\
0.020 \\
0.021 \\
0.013 \\
0.018 \\
0.017 \\
0.018 \\
0.018 \\
0.032 \\
0.001 \\
0.001 \\
0.01 \\
0.003 \\
0.02 \\
0.01 \\
0.01 \\
0.05 \\
0.01 \\
0.005\end{array}$ & $\begin{array}{l}\text { J } \\
\text { J } \\
\text { I } \\
\mathbf{l}\end{array}$ & $\begin{array}{l}0.01 \\
0.01 \\
0.01 \\
0.01 \\
0.01 \\
0.01 \\
0.01 \\
0.01 \\
0.01 \\
0.01 \\
0.01 \\
0.01 \\
0.001 \\
0.01 \\
0.01 \\
0.01 \\
0.01 \\
0.01 \\
0.01 \\
0.05 \\
0.01 \\
0.005\end{array}$ & $\begin{array}{l}- \\
- \\
- \\
- \\
- \\
- \\
- \\
- \\
- \\
- \\
- \\
- \\
- \\
- \\
- \\
- \\
- \\
-\end{array}$ \\
\hline ARSENIC (TOTAL) & $\begin{array}{l}04 / 01 / 90 \\
03 / 31 / 93\end{array}$ & $\begin{array}{l}\text { N001 } \\
\text { N001 }\end{array}$ & MG/L & $<$ & $\begin{array}{l}0.05 \\
0.005\end{array}$ & & $\begin{array}{l}0.01 \\
0.005\end{array}$ & - \\
\hline MANGANESE & $\begin{array}{l}09 / 08 / 87 \\
11 / 21 / 87 \\
11 / 21 / 87 \\
11 / 21 / 87 \\
11 / 21 / 87 \\
11 / 21 / 87 \\
02 / 20 / 88 \\
02 / 20 / 88 \\
02 / 20 / 88 \\
02 / 20 / 88 \\
02 / 20 / 88 \\
05 / 16 / 88 \\
09 / 01 / 88 \\
10 / 28 / 88 \\
04 / 25 / 89 \\
12 / 02 / 89 \\
04 / 01 / 90 \\
11 / 19 / 90 \\
03 / 12 / 91 \\
06 / 01 / 91 \\
10 / 25 / 91 \\
03 / 15 / 92 \\
08 / 08 / 92 \\
03 / 31 / 93\end{array}$ & $\begin{array}{l}0001 \\
0001 \\
0002 \\
0003 \\
0004 \\
0005 \\
0001 \\
0002 \\
0003 \\
0004 \\
0005 \\
0001 \\
0001 \\
0001 \\
0001 \\
0001 \\
0001 \\
0001 \\
0001 \\
0001 \\
0001 \\
0001 \\
0001 \\
0001\end{array}$ & $M G / L$ & & $\begin{array}{l}4.69 \\
4.95 \\
5.07 \\
4.99 \\
4.96 \\
4.93 \\
5.39 \\
5.15 \\
5.18 \\
5.04 \\
5.19 \\
4.73 \\
5.10 \\
4.38 \\
4.7 \\
4.73 \\
4.53 \\
5.04 \\
4.83 \\
4.97 \\
6.4 \\
5.08 \\
4.42 \\
4.26\end{array}$ & & $\begin{array}{l}0.01 \\
0.01 \\
0.01 \\
0.01 \\
0.01 \\
0.01 \\
0.01 \\
0.01 \\
0.01 \\
0.01 \\
0.01 \\
0.01 \\
0.01 \\
0.01 \\
0.01 \\
0.01 \\
0.01 \\
0.01 \\
0.01 \\
0.01 \\
0.01 \\
0.01 \\
0.01 \\
0.01\end{array}$ & $\begin{array}{l}- \\
- \\
- \\
- \\
- \\
- \\
- \\
- \\
- \\
- \\
- \\
- \\
- \\
- \\
- \\
- \\
- \\
- \\
-\end{array}$ \\
\hline MANGANESE (TOTAL) & $\begin{array}{l}04 / 01 / 90 \\
03 / 31 / 93\end{array}$ & $\begin{array}{l}\text { N001 } \\
\text { N001 }\end{array}$ & $M G / L$ & & $\begin{array}{l}4.81 \\
3.73\end{array}$ & & $\begin{array}{l}0.01 \\
0.01\end{array}$ & - \\
\hline MOL YBDENUM & $09 / 08 / 87$ & 0001 & $M G / L$ & & 0.77 & & 0.01 & - \\
\hline
\end{tabular}

PARAMETER VALUE INDICATOR (PVI): < - LESS THAN DETECTION LIMIT

SAMPLE ID COOES:

OTHER PARAMETER VALUE FLAGS:

0001 - FILTERED SAMPLE (. 45 MICRONS)

I - INCREASED DETECTION LIMIT DUE TO REQUIRED DILUTION

0002 - FILTERED REPLICATE SAMPLE (.45 MICRONS)

J - ESTIMATED VALUE

0003 - FILTERED REPLICATE SAMPLE (.45 MICRONS)

0004 - FILTERED REPLICATE SAMPLE (.45 MICRONS)

NOO1 - UNFILTERED SAMPLE 
GROUNDWATER QUALITY DATA BY LOCATION

SITE: RVTO1 RIVERTON

LOCATION: 0707

NORTH COORDINATE: $\quad 21008.4$ FT

EAST COORDINATE: 27745.2 FT

06/12/81 TO 01/10/94

REPORT DATE: $09 / 07 / 94$

FORMATION OF COMPLETION: SURFICIAL (SF)

HYDRAULIC FLOW RELATIONSHIP: DOWN GRADIENT (D)

\begin{tabular}{|c|c|c|c|c|c|c|c|}
\hline PARAMETER NAME & LOG DATE & $\underset{\text { ID }}{\text { SAMPLE }}$ & $\begin{array}{l}\text { UNITS OF } \\
\text { MEASURE }\end{array}$ & PVI & $\begin{array}{l}\text { PARAMETER } \\
\text { VALUE FLAGS }\end{array}$ & $\begin{array}{l}\text { DETECTION } \\
\text { LIMIT }\end{array}$ & $\begin{array}{l}\text { PARAMETER } \\
\text { UNCERTAINTY }\end{array}$ \\
\hline MOLYBDEENUM & $\begin{array}{l}11 / 21 / 87 \\
11 / 21 / 87 \\
11 / 21 / 87 \\
11 / 21 / 87 \\
11 / 21 / 87 \\
02 / 20 / 88 \\
02 / 20 / 88 \\
02 / 20 / 88 \\
02 / 20 / 88 \\
02 / 20 / 88 \\
05 / 16 / 88 \\
09 / 01 / 88 \\
10 / 28 / 88 \\
04 / 25 / 89 \\
12 / 02 / 89 \\
04 / 01 / 90 \\
11 / 19 / 90 \\
03 / 12 / 91 \\
06 / 01 / 91 \\
10 / 25 / 91 \\
03 / 15 / 92 \\
08 / 08 / 92 \\
03 / 31 / 93\end{array}$ & $\begin{array}{l}0001 \\
0002 \\
0003 \\
0004 \\
0005 \\
0001 \\
0002 \\
0003 \\
0004 \\
0005 \\
0001 \\
0001 \\
0001 \\
0001 \\
0001 \\
0001 \\
0001 \\
0001 \\
0001 \\
0001 \\
0001 \\
0001 \\
0001\end{array}$ & $M G / L$ & & $\begin{array}{l}1.02 \\
1.04 \\
1.03 \\
1.02 \\
1.02 \\
1.00 \\
0.94 \\
0.91 \\
0.90 \\
0.97 \\
0.81 \\
0.520 \\
0.773 \\
0.70 \\
0.76 \\
0.68 \\
0.83 \\
0.68 \\
0.68 \\
0.96 \\
0.86 \\
0.79 \\
0.83\end{array}$ & $\begin{array}{l}0.01 \\
0.01 \\
0.01 \\
0.01 \\
0.01 \\
0.01 \\
0.01 \\
0.01 \\
0.01 \\
0.01 \\
0.01 \\
0.001 \\
0.01 \\
0.01 \\
0.01 \\
0.01 \\
0.01 \\
0.01 \\
0.01 \\
0.01 \\
0.01 \\
0.01 \\
0.01\end{array}$ & $\begin{array}{l}- \\
- \\
- \\
- \\
- \\
- \\
- \\
- \\
- \\
- \\
- \\
- \\
- \\
- \\
- \\
-\end{array}$ \\
\hline MOLYBDENUM (TOTAL) & $\begin{array}{l}04 / 01 / 90 \\
03 / 31 / 93\end{array}$ & $\begin{array}{l}\text { N001 } \\
\text { N001 }\end{array}$ & MG/L & & $\begin{array}{l}0.70 \\
0.74\end{array}$ & $\begin{array}{l}0.01 \\
0.01\end{array}$ & - \\
\hline NICKEL & $\begin{array}{l}09 / 08 / 87 \\
11 / 21 / 87 \\
11 / 21 / 87 \\
11 / 21 / 87 \\
11 / 21 / 87 \\
11 / 21 / 87 \\
02 / 20 / 88 \\
02 / 20 / 88 \\
02 / 20 / 88 \\
02 / 20 / 88 \\
02 / 20 / 88 \\
05 / 16 / 88 \\
09 / 01 / 88 \\
10 / 28 / 88 \\
04 / 25 / 89 \\
12 / 02 / 89 \\
04 / 01 / 90 \\
11 / 19 / 90 \\
03 / 12 / 91 \\
06 / 01 / 91 \\
10 / 25 / 91 \\
03 / 15 / 92 \\
08 / 08 / 92 \\
03 / 31 / 93\end{array}$ & $\begin{array}{l}0001 \\
0001 \\
0002 \\
0003 \\
0004 \\
0005 \\
0001 \\
0002 \\
0003 \\
0004 \\
0005 \\
0001 \\
0001 \\
0001 \\
0001 \\
0001 \\
0001 \\
0001 \\
0001 \\
0001 \\
0001 \\
0001 \\
0001 \\
0001\end{array}$ & $M G / L$ & $<$ & $\begin{array}{l}0.10 \\
0.11 \\
0.11 \\
0.11 \\
0.10 \\
0.11 \\
0.21 \\
0.22 \\
0.19 \\
0.18 \\
0.19 \\
0.17 \\
0.10 \\
0.08 \\
0.12 \\
0.04 \\
0.17 \\
0.23 \\
0.22 \\
0.22 \\
0.28 \\
0.24 \\
0.20 \\
0.15\end{array}$ & $\begin{array}{l}0.04 \\
0.04 \\
0.04 \\
0.04 \\
0.04 \\
0.04 \\
0.04 \\
0.04 \\
0.04 \\
0.04 \\
0.04 \\
0.04 \\
0.04 \\
0.04 \\
0.04 \\
0.04 \\
0.04 \\
0.04 \\
0.04 \\
0.04 \\
0.01 \\
0.04 \\
0.04 \\
0.04\end{array}$ & $\begin{array}{l}- \\
- \\
- \\
- \\
- \\
- \\
- \\
- \\
- \\
- \\
- \\
- \\
- \\
- \\
- \\
- \\
- \\
-\end{array}$ \\
\hline NICKEL (TOTAL) & $\begin{array}{l}04 / 01 / 90 \\
03 / 31 / 93\end{array}$ & $\begin{array}{l}\text { NOO1 } \\
\text { N001 }\end{array}$ & $M G / L$ & & $\begin{array}{l}0.17 \\
0.14\end{array}$ & $\begin{array}{l}0.04 \\
0.04\end{array}$ & - \\
\hline SULFATE & $09 / 08 / 87$ & 0001 & MG/L & & 3500. & 0.1 & - \\
\hline
\end{tabular}

PARAMETER VALUE INDICATOR (PVI): < - LESS THAN DETECTION LIMIT

SAMPLE ID CODES:

0001 - FILTERED SAMPLE (.45 MICRONS)

0002 - FILTERED REPLICATE SAMPLE (.45 MICRONS)

0003 - FILTERED REPLICATE SAMPLE (.45 MICRONS)

0004 - FILTERED REPLICATE SAMPLE (.45 MICRONS)

NO01 - UNFILTERED SAMPLE 
GROUNDWATER QUALITY DATA BY LOCATION

SITE: RVTO1 RIVERTON

LOCATION: 0707

NORTH COORDINATE: 21008.4 FT

EAST COORDINATE: 27745.2 FT

06/12/81 TO 01/10/94

REPORT DATE: 09/07/94

FORMATION OF COMPLETION: SURFICIAL (SF)

HYDRAULIC FLOW RELATIONSHIP: DOWN GRADIENT (D)

\begin{tabular}{|c|c|c|c|c|c|c|c|}
\hline PARAMETER NAME & LOG DATE & $\begin{array}{c}\text { SAMPLE } \\
\text { ID }\end{array}$ & $\begin{array}{l}\text { UNITS OF } \\
\text { MEASURE }\end{array}$ & PVI & $\begin{array}{l}\text { PARAMETER } \\
\text { VALUE FLAGS }\end{array}$ & $\begin{array}{l}\text { DETECTION } \\
\text { LIMIT }\end{array}$ & $\begin{array}{l}\text { PARAMETER } \\
\text { UNCERTAINTY }\end{array}$ \\
\hline SULFATE & $\begin{array}{l}11 / 21 / 87 \\
11 / 21 / 87 \\
11 / 21 / 87 \\
11 / 21 / 87 \\
11 / 21 / 87 \\
02 / 20 / 88 \\
02 / 20 / 88 \\
02 / 20 / 88 \\
02 / 20 / 88 \\
02 / 20 / 88 \\
05 / 16 / 88 \\
09 / 01 / 88 \\
10 / 28 / 88 \\
04 / 25 / 89 \\
12 / 02 / 89 \\
04 / 01 / 90 \\
11 / 19 / 90 \\
03 / 12 / 91 \\
06 / 01 / 91 \\
10 / 25 / 91 \\
03 / 15 / 92 \\
08 / 08 / 92 \\
03 / 31 / 93\end{array}$ & $\begin{array}{l}0001 \\
0002 \\
0003 \\
0004 \\
0005 \\
0001 \\
0002 \\
0003 \\
0004 \\
0005 \\
0001 \\
0001 \\
0001 \\
0001 \\
0001 \\
0001 \\
0001 \\
0001 \\
0001 \\
0001 \\
0001 \\
0001 \\
0001\end{array}$ & $M G / L$ & & $\begin{array}{l}2950 . \\
2980 . \\
2930 . \\
2920 . \\
2950 . \\
3050 . \\
3050 . \\
3060 . \\
3050 . \\
3060 . \\
3240 . \\
3149 . \\
2999 . \\
3020 . \\
2870 . \\
2570 . \\
2760 . \\
2890 . \\
2910 . \\
4430 \\
3810 . \\
3210 . \\
2970\end{array}$ & $\begin{array}{c}0.1 \\
0.1 \\
0.1 \\
0.1 \\
0.1 \\
0.1 \\
0.1 \\
0.1 \\
0.1 \\
0.1 \\
0.1 \\
1 . \\
0.1 \\
0.1 \\
0.1 \\
0.1 \\
0.1 \\
10 . \\
10 . \\
0.1 \\
10 . \\
10 . \\
1\end{array}$ & $\begin{array}{l}- \\
- \\
- \\
- \\
- \\
- \\
- \\
- \\
- \\
- \\
- \\
- \\
- \\
- \\
- \\
- \\
- \\
-\end{array}$ \\
\hline SULFATE (TOTAL) & $04 / 01 / 90$ & NOO1 & $M G / L$ & & 2880 & 0.1 & - \\
\hline URANIUM & $\begin{array}{l}09 / 08 / 87 \\
11 / 21 / 87 \\
11 / 21 / 87 \\
11 / 21 / 87 \\
11 / 21 / 87 \\
11 / 21 / 87 \\
02 / 20 / 88 \\
02 / 20 / 88 \\
02 / 20 / 88 \\
02 / 20 / 88 \\
02 / 20 / 88 \\
05 / 16 / 88 \\
09 / 01 / 88 \\
10 / 28 / 88 \\
04 / 25 / 89 \\
12 / 02 / 89 \\
04 / 01 / 90 \\
11 / 19 / 90 \\
03 / 12 / 91 \\
06 / 01 / 91 \\
10 / 25 / 91 \\
03 / 15 / 92 \\
08 / 08 / 92 \\
03 / 31 / 93\end{array}$ & $\begin{array}{l}0001 \\
0001 \\
0002 \\
0003 \\
0004 \\
0005 \\
0001 \\
0002 \\
0003 \\
0004 \\
0005 \\
0001 \\
0001 \\
0001 \\
0001 \\
0001 \\
0001 \\
0001 \\
0001 \\
0001 \\
0001 \\
0001 \\
0001 \\
0001\end{array}$ & $M G / L$ & & $\begin{array}{l}1.58 \\
1.35 \\
1.44 \\
1.43 \\
1.43 \\
1.44 \\
1.66 \\
1.61 \\
1.55 \\
1.70 \\
1.70 \\
1.39 \\
1.094 \\
0.719 \\
1.37 \\
1.21 \\
0.998 \\
1.00 \\
0.729 \\
1.02 \\
1.97 \\
1.22 \\
1.08 \\
0.957\end{array}$ & $\begin{array}{l}0.003 \\
0.003 \\
0.003 \\
0.003 \\
0.003 \\
0.003 \\
0.003 \\
0.003 \\
0.003 \\
0.003 \\
0.003 \\
0.003 \\
0.003 \\
0.003 \\
0.003 \\
0.003 \\
0.003 \\
0.0003 \\
0.001 \\
0.001 \\
0.0003 \\
0.001 \\
0.001 \\
0.001\end{array}$ & $\begin{array}{l}- \\
- \\
- \\
- \\
- \\
- \\
- \\
- \\
- \\
- \\
- \\
- \\
- \\
- \\
- \\
- \\
- \\
- \\
-\end{array}$ \\
\hline URANIUM (TOTAL) & $\begin{array}{l}04 / 01 / 90 \\
03 / 31 / 93\end{array}$ & $\begin{array}{l}\text { N001 } \\
\text { N001 }\end{array}$ & $M G / L$ & & $\begin{array}{l}0.974 \\
1.01\end{array}$ & $\begin{array}{l}0.003 \\
0.001\end{array}$ & - \\
\hline VANADIUM & $09 / 08 / 87$ & 0001 & $M G / L$ & & 0.06 & 0.01 & - \\
\hline
\end{tabular}

PARAMETER VALUE INDICATOR (PVI):

< - LESS THAN DETECTION LIMIT

SAMPLE IO COOES:

0001 - FILTERED SAMPLE (.45 MICRONS)

0002 - FILTERED REPLICATE SAMPLE (.45 MICRONS)

0003 - FILTERED REPLICATE SAMPLE (.45 MICRONS)

0004 - FILTERED REPLICATE SAMPLE (.45 MICRONS)

NOO1 - UNFILTERED SAMPLE 
GROUNDWATER QUALITY DATA BY LOCATION

SITE: RVTO1 RIVERTON

LOCATION: 0707

NORTH COORDINATE: $\quad 21008.4$ FT

EAST COORDINATE: 27745.2 FT

06/12/81 TO $01 / 10 / 94$

REPORT DATE: 09/07/94

FORMATION OF COMPLETION: SURFICIAL (SF)

HYDRAULIC FLOW RELATIONSHIP: DOWN GRADIENT (D)

\begin{tabular}{|c|c|c|c|c|c|c|c|c|}
\hline PARAMETER NAME & LOG DATE & $\begin{array}{l}\text { SAMPLE } \\
\text { ID }\end{array}$ & $\begin{array}{l}\text { UNITS OF } \\
\text { MEASURE }\end{array}$ & PVI & $\begin{array}{l}\text { PARAMETE } \\
\text { VALUE }\end{array}$ & FLAGS & $\begin{array}{l}\text { DETECTION } \\
\text { LIMIT }\end{array}$ & $\begin{array}{l}\text { PARAMETER } \\
\text { UNCERTAINTY }\end{array}$ \\
\hline VANADIUM & $\begin{array}{l}11 / 21 / 87 \\
11 / 21 / 87 \\
11 / 21 / 87 \\
11 / 21 / 87 \\
11 / 21 / 87 \\
02 / 20 / 88 \\
02 / 20 / 88 \\
02 / 20 / 88 \\
02 / 20 / 88 \\
02 / 20 / 88 \\
05 / 16 / 88 \\
09 / 01 / 88 \\
10 / 28 / 88 \\
04 / 25 / 89 \\
12 / 02 / 89 \\
04 / 01 / 90 \\
11 / 19 / 90 \\
03 / 12 / 91 \\
06 / 01 / 91 \\
10 / 25 / 91 \\
03 / 15 / 92 \\
08 / 08 / 92 \\
03 / 31 / 93\end{array}$ & $\begin{array}{l}0001 \\
0002 \\
0003 \\
0004 \\
0005 \\
0001 \\
0002 \\
0003 \\
0004 \\
0005 \\
0001 \\
0001 \\
0001 \\
0001 \\
0001 \\
0001 \\
0001 \\
0001 \\
0001 \\
0001 \\
0001 \\
0001 \\
0001\end{array}$ & $M G / L$ & $\begin{array}{l} \\
\\
\\
< \\
< \\
< \\
< \\
< \\
< \\
<\end{array}$ & $\begin{array}{l}0.06 \\
0.06 \\
0.06 \\
0.06 \\
0.06 \\
0.07 \\
0.06 \\
0.06 \\
0.06 \\
0.06 \\
0.06 \\
0.01 \\
0.01 \\
0.01 \\
0.01 \\
0.01 \\
0.01 \\
0.01 \\
0.01 \\
0.14 \\
0.05 \\
0.01 \\
0.01\end{array}$ & I & $\begin{array}{l}0.01 \\
0.01 \\
0.01 \\
0.01 \\
0.01 \\
0.01 \\
0.01 \\
0.01 \\
0.01 \\
0.01 \\
0.01 \\
0.01 \\
0.01 \\
0.01 \\
0.01 \\
0.01 \\
0.01 \\
0.01 \\
0.01 \\
0.01 \\
0.05 \\
0.01 \\
0.01\end{array}$ & $\begin{array}{l}- \\
- \\
- \\
- \\
- \\
- \\
- \\
- \\
- \\
- \\
- \\
- \\
- \\
- \\
- \\
- \\
- \\
- \\
-\end{array}$ \\
\hline VANADIUM (TOTAL) & $\begin{array}{l}04 / 01 / 90 \\
03 / 31 / 93\end{array}$ & $\begin{array}{l}\text { N001 } \\
\text { N001 }\end{array}$ & $M G / L$ & $<$ & $\begin{array}{l}0.02 \\
0.01\end{array}$ & & $\begin{array}{l}0.01 \\
0.01\end{array}$ & 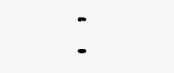 \\
\hline
\end{tabular}

PARAMETER VALUE INDICATOR (PVI): < - LESS THAN DETECTION LIMIT

SAMPLE ID CODES:

OTHER PARAMETER VALUE FLAGS:

0001 - FILTERED SAMPLE (.45 MICRONS)

0002 - FILTERED REPLICATE SAMPLE (.45 MICRONS)

0003 - FILTERED REPLICATE SAMPLE (.45 MICRONS)

0004 - FILTERED REPLICATE SAMPLE (. 45 MICRONS)

N001 - UNFILTERED SAMPLE 
GROUNDWATER QUALITY DATA BY LOCATION

SITE: RVTO1 RIVERTON

LOCATION: 0709

NORTH COORDINATE: 21005.6 FT

EAST COORDINATE: 27748.9 FT

$06 / 12 / 81$ TO $01 / 10 / 94$

REPORT DATE: 09/07/94

FORMATION OF COMPLETION: SANDSTONE (SS)

HYDRAULIC FLOW RELATIONSHIP: DOWN GRADIENT (D)

\begin{tabular}{|c|c|c|c|c|c|c|c|c|}
\hline PARAMETER NAME & LOG DATE & $\begin{array}{c}\text { SAMPLE } \\
\text { ID }\end{array}$ & $\begin{array}{l}\text { UNITS OF } \\
\text { MEASURE }\end{array}$ & PVI & $\begin{array}{c}\text { PARAMETER } \\
\text { VALUE }\end{array}$ & FLAGS & $\begin{array}{l}\text { DETECTION } \\
\text { LIMIT }\end{array}$ & $\begin{array}{l}\text { PARAMETER } \\
\text { UNCERTAINTY }\end{array}$ \\
\hline ARSENIC & $\begin{array}{l}09 / 08 / 87 \\
10 / 28 / 88 \\
04 / 25 / 89 \\
12 / 02 / 89 \\
04 / 01 / 90 \\
11 / 19 / 90 \\
03 / 11 / 91 \\
06 / 02 / 91 \\
10 / 25 / 91 \\
03 / 12 / 93\end{array}$ & $\begin{array}{l}0001 \\
0001 \\
0001 \\
0001 \\
0001 \\
0001 \\
0001 \\
0001 \\
0001 \\
0001\end{array}$ & $M G / L$ & $\begin{array}{l}< \\
< \\
< \\
< \\
< \\
< \\
< \\
< \\
< \\
<\end{array}$ & $\begin{array}{l}0.001 \\
0.001 \\
0.01 \\
0.01 \\
0.01 \\
0.01 \\
0.01 \\
0.01 \\
0.001 \\
0.005\end{array}$ & $\begin{array}{l}\mathbf{J} \\
\mathbf{J} \\
\\
\mathbf{G} \\
\mathbf{G} \\
\mathbf{G} \\
\mathbf{G} \\
\mathbf{L}\end{array}$ & $\begin{array}{l}0.01 \\
0.01 \\
0.01 \\
0.01 \\
0.01 \\
0.01 \\
0.01 \\
0.01 \\
0.001 \\
0.005\end{array}$ & $\begin{array}{l}- \\
- \\
- \\
- \\
- \\
- \\
- \\
- \\
-\end{array}$ \\
\hline ARSENIC (TOTAL) & $\begin{array}{l}04 / 01 / 90 \\
03 / 11 / 93\end{array}$ & $\begin{array}{l}\text { No01 } \\
\text { N001 }\end{array}$ & MG/L & $<$ & $\begin{array}{l}0.01 \\
0.005\end{array}$ & & $\begin{array}{l}0.01 \\
0.005\end{array}$ & - \\
\hline MANGANESE & $\begin{array}{l}09 / 08 / 87 \\
10 / 28 / 88 \\
04 / 25 / 89 \\
12 / 02 / 89 \\
04 / 01 / 90 \\
11 / 19 / 90 \\
03 / 11 / 91 \\
06 / 02 / 91 \\
10 / 25 / 91 \\
03 / 15 / 92 \\
08 / 08 / 92 \\
03 / 12 / 93\end{array}$ & $\begin{array}{l}0001 \\
0001 \\
0001 \\
0001 \\
0001 \\
0001 \\
0001 \\
0001 \\
0001 \\
0001 \\
0001 \\
0001\end{array}$ & MG/L & $\begin{array}{l}< \\
< \\
< \\
< \\
< \\
< \\
< \\
< \\
< \\
<\end{array}$ & $\begin{array}{l}0.01 \\
0.01 \\
0.01 \\
0.01 \\
0.01 \\
0.01 \\
0.01 \\
0.01 \\
0.01 \\
0.01 \\
0.01 \\
0.01\end{array}$ & $\begin{array}{l}\mathbf{G} \\
\mathbf{G} \\
\mathbf{G} \\
\mathbf{G} \\
\mathbf{G} \\
\mathbf{G} \\
\mathbf{L}\end{array}$ & $\begin{array}{l}0.01 \\
0.01 \\
0.01 \\
0.01 \\
0.01 \\
0.01 \\
0.01 \\
0.01 \\
0.01 \\
0.01 \\
0.01 \\
0.01\end{array}$ & $\begin{array}{l}- \\
- \\
- \\
- \\
- \\
- \\
- \\
- \\
- \\
-\end{array}$ \\
\hline MANGANESE (TOTAL) & $\begin{array}{l}04 / 01 / 90 \\
03 / 11 / 93\end{array}$ & $\begin{array}{l}\text { No01 } \\
\text { N001 }\end{array}$ & $M G / L$ & $\begin{array}{l}< \\
<\end{array}$ & $\begin{array}{l}0.01 \\
0.01\end{array}$ & & $\begin{array}{l}0.01 \\
0.01\end{array}$ & - \\
\hline MOL YBDENUM & $\begin{array}{l}09 / 08 / 87 \\
10 / 28 / 88 \\
04 / 25 / 89 \\
12 / 02 / 89 \\
04 / 01 / 90 \\
11 / 19 / 90 \\
03 / 11 / 91 \\
06 / 02 / 91 \\
10 / 25 / 91 \\
03 / 15 / 92 \\
08 / 08 / 92 \\
03 / 12 / 93\end{array}$ & $\begin{array}{l}0001 \\
0001 \\
0001 \\
0001 \\
0001 \\
0001 \\
0001 \\
0001 \\
0001 \\
0001 \\
0001 \\
0001\end{array}$ & $M G / L$ & $<$ & $\begin{array}{l}0.01 \\
0.015 \\
0.02 \\
0.01 \\
0.01 \\
0.02 \\
0.01 \\
0.03 \\
0.02 \\
0.02 \\
0.03 \\
0.03\end{array}$ & $\begin{array}{l}\mathbf{G} \\
\mathbf{G} \\
\mathbf{G} \\
\mathbf{G} \\
\mathbf{G} \\
\mathbf{G} \\
\mathbf{L}\end{array}$ & $\begin{array}{l}0.01 \\
0.01 \\
0.01 \\
0.01 \\
0.01 \\
0.01 \\
0.01 \\
0.01 \\
0.01 \\
0.01 \\
0.01 \\
0.01\end{array}$ & $\begin{array}{l}- \\
- \\
- \\
- \\
- \\
- \\
- \\
- \\
- \\
-\end{array}$ \\
\hline MOLYBDENUM (TOTAL) & $\begin{array}{l}04 / 01 / 90 \\
03 / 11 / 93\end{array}$ & $\begin{array}{l}\text { N001 } \\
\text { N001 }\end{array}$ & $M G / L$ & & $\begin{array}{l}0.01 \\
0.03\end{array}$ & & $\begin{array}{l}0.01 \\
0.01\end{array}$ & - \\
\hline NICKEL & $\begin{array}{l}09 / 08 / 87 \\
10 / 28 / 88 \\
04 / 25 / 89 \\
12 / 02 / 89 \\
04 / 01 / 90 \\
11 / 19 / 90 \\
03 / 11 / 91 \\
06 / 02 / 91 \\
10 / 25 / 91\end{array}$ & $\begin{array}{l}0001 \\
0001 \\
0001 \\
0001 \\
0001 \\
0001 \\
0001 \\
0001 \\
0001\end{array}$ & $M G / L$ & $\begin{array}{l}< \\
< \\
< \\
< \\
< \\
< \\
< \\
<\end{array}$ & $\begin{array}{l}0.01 \\
0.02 \\
0.04 \\
0.04 \\
0.04 \\
0.04 \\
0.04 \\
0.04 \\
0.02\end{array}$ & $\begin{array}{l}\mathbf{G} \\
\mathbf{G} \\
\mathbf{G} \\
\mathbf{G}\end{array}$ & $\begin{array}{l}0.04 \\
0.04 \\
0.04 \\
0.04 \\
0.04 \\
0.04 \\
0.04 \\
0.04 \\
0.01\end{array}$ & $\begin{array}{l}- \\
- \\
- \\
- \\
- \\
- \\
- \\
- \\
-\end{array}$ \\
\hline
\end{tabular}

PARAMETER VALUE IMDICATOR (PVI): < - LESS THAN DETECTION LIMIT

SAMPLE ID CODES:

OTHER PARAMETER VALUE FLAGS:

0001 - FILTERED SAMPLE (.45 MICRONS)

$G$ - $P H>9$, POSSIBLE GROUT CONTAMINATION

NOO1 - UNFILTERED SAMPLE

J - ESTIMATED VALUE

L - LESS THAN THREE BORE VOLUMES REMOVED BEFORE SAMPLING 
FORMATION OF COMPLETION: SANDSTONE (SS)

HYDRAULIC FLOW RELATIONSHIP: DOWN GRADIENT (D)

\begin{tabular}{|c|c|c|c|c|c|c|c|c|}
\hline PARAMETER NAME & LOG DATE & $\begin{array}{c}\text { SAMPLE } \\
\text { ID }\end{array}$ & $\begin{array}{l}\text { UNITS OF } \\
\text { MEASURE }\end{array}$ & PVI & $\begin{array}{l}\text { PARAMETER } \\
\text { VALUE }\end{array}$ & FLAGS & $\begin{array}{l}\text { DETECTION } \\
\text { LIMIT }\end{array}$ & $\begin{array}{l}\text { PARAMETER } \\
\text { UNCERTAINTY }\end{array}$ \\
\hline HICKEL & $\begin{array}{l}03 / 15 / 92 \\
08 / 08 / 92 \\
03 / 12 / 93\end{array}$ & $\begin{array}{l}0001 \\
0001 \\
0001\end{array}$ & $M G / L$ & $\begin{array}{l}< \\
<\end{array}$ & $\begin{array}{l}0.04 \\
0.04 \\
0.04\end{array}$ & $\begin{array}{l}\text { G } \\
\text { G } \\
\text { L }\end{array}$ & $\begin{array}{l}0.04 \\
0.04 \\
0.04\end{array}$ & : \\
\hline NICKEL (TOTAL) & $\begin{array}{l}04 / 01 / 90 \\
03 / 11 / 93\end{array}$ & $\begin{array}{l}\text { N001 } \\
\text { N001 }\end{array}$ & $M G / L$ & $<$ & $\begin{array}{l}0.04 \\
0.04\end{array}$ & & $\begin{array}{l}0.04 \\
0.04\end{array}$ & : \\
\hline SULFATE & $\begin{array}{l}09 / 08 / 87 \\
10 / 28 / 88 \\
04 / 25 / 89 \\
12 / 02 / 89 \\
04 / 01 / 90 \\
11 / 19 / 90 \\
03 / 11 / 91 \\
06 / 02 / 91 \\
10 / 25 / 91 \\
03 / 15 / 92 \\
08 / 08 / 92\end{array}$ & $\begin{array}{l}0001 \\
0001 \\
0001 \\
0001 \\
0001 \\
0001 \\
0001 \\
0001 \\
0001 \\
0001 \\
0001\end{array}$ & MG/L & & $\begin{array}{c}8 . \\
74 . \\
68 . \\
76 . \\
83 . \\
86.4 \\
115 . \\
155 . \\
178 \\
162 . \\
130 .\end{array}$ & $\begin{array}{l}\mathbf{G} \\
\mathbf{G} \\
\mathbf{G} \\
\mathbf{G} \\
\mathbf{G} \\
\mathbf{G}\end{array}$ & $\begin{array}{c}0.1 \\
0.1 \\
0.1 \\
0.1 \\
0.1 \\
0.1 \\
10.1 \\
0.1 \\
0.1 \\
50 . \\
50 .\end{array}$ & $\begin{array}{l}- \\
- \\
- \\
- \\
- \\
- \\
- \\
-\end{array}$ \\
\hline SULFATE (TOTAL) & $\begin{array}{l}04 / 01 / 90 \\
03 / 11 / 93\end{array}$ & $\begin{array}{l}\text { N001 } \\
\text { N001 }\end{array}$ & $M G / L$ & & $\begin{array}{l}91 . \\
112\end{array}$ & & 0.1 & - \\
\hline URANIUM & $\begin{array}{l}09 / 08 / 87 \\
10 / 28 / 88 \\
04 / 25 / 89 \\
12 / 02 / 89 \\
04 / 01 / 90 \\
11 / 19 / 90 \\
03 / 11 / 91 \\
06 / 02 / 91 \\
10 / 25 / 91 \\
03 / 15 / 92 \\
08 / 08 / 92 \\
03 / 12 / 93\end{array}$ & $\begin{array}{l}0001 \\
0001 \\
0001 \\
0001 \\
0001 \\
0001 \\
0001 \\
0001 \\
0001 \\
0001 \\
0001 \\
0001\end{array}$ & $M G / L$ & $\begin{array}{l}< \\
< \\
< \\
< \\
< \\
< \\
< \\
< \\
< \\
< \\
< \\
<\end{array}$ & $\begin{array}{l}0.0003 \\
0.003 \\
0.003 \\
0.0003 \\
0.0003 \\
0.0003 \\
0.001 \\
0.001 \\
0.0003 \\
0.001 \\
0.001 \\
0.001\end{array}$ & $\begin{array}{l}\text { J } \\
\text { J } \\
\text { J } \\
\text { G } \\
\text { G } \\
\text { G } \\
\text { G } \\
\text { L }\end{array}$ & $\begin{array}{l}0.003 \\
0.003 \\
0.003 \\
0.003 \\
0.003 \\
0.0003 \\
0.001 \\
0.001 \\
0.0003 \\
0.001 \\
0.001 \\
0.001\end{array}$ & $\begin{array}{l}- \\
- \\
- \\
- \\
- \\
- \\
- \\
- \\
-\end{array}$ \\
\hline URANIUM (TOTAL) & $\begin{array}{l}04 / 01 / 90 \\
03 / 12 / 93\end{array}$ & $\begin{array}{l}\text { N001 } \\
\text { N001 }\end{array}$ & $M G / L$ & $<$ & $\begin{array}{l}0.0006 \\
0.001\end{array}$ & $\begin{array}{l}\mathrm{J} \\
\mathrm{L}\end{array}$ & $\begin{array}{l}0.003 \\
0.001\end{array}$ & - \\
\hline VANADIUM & $\begin{array}{l}09 / 08 / 87 \\
10 / 28 / 88 \\
04 / 25 / 89 \\
12 / 02 / 89 \\
04 / 01 / 90 \\
11 / 19 / 90 \\
03 / 11 / 91 \\
06 / 02 / 91 \\
10 / 25 / 91 \\
03 / 15 / 92 \\
08 / 08 / 92 \\
03 / 12 / 93\end{array}$ & $\begin{array}{l}0001 \\
0001 \\
0001 \\
0001 \\
0001 \\
0001 \\
0001 \\
0001 \\
0001 \\
0001 \\
0001 \\
0001\end{array}$ & $M G / L$ & $\begin{array}{l}< \\
< \\
< \\
< \\
< \\
<\end{array}$ & $\begin{array}{l}0.06 \\
0.01 \\
0.01 \\
0.02 \\
0.01 \\
0.01 \\
0.01 \\
0.01 \\
0.04 \\
0.01 \\
0.04 \\
0.01\end{array}$ & $\begin{array}{l}\mathbf{G} \\
\mathbf{G} \\
\mathbf{G} \\
\mathbf{G} \\
\mathbf{G} \\
\mathbf{G} \\
\mathbf{L}\end{array}$ & $\begin{array}{l}0.01 \\
0.01 \\
0.01 \\
0.01 \\
0.01 \\
0.01 \\
0.01 \\
0.01 \\
0.01 \\
0.01 \\
0.01 \\
0.01\end{array}$ & $\begin{array}{l}- \\
- \\
- \\
- \\
- \\
- \\
- \\
- \\
- \\
- \\
-\end{array}$ \\
\hline VANADIUM (TOTAL) & $\begin{array}{l}04 / 01 / 90 \\
03 / 11 / 93\end{array}$ & $\begin{array}{l}\text { N001 } \\
\text { N001 }\end{array}$ & $M G / L$ & $<$ & $\begin{array}{l}0.01 \\
0.01\end{array}$ & & $\begin{array}{l}0.01 \\
0.01\end{array}$ & - \\
\hline
\end{tabular}

PARAMETER VALUE INDICATOR (PVI): < - LESS THAN DETECTION LIMIT 
GROUNDWATER QUALITY DATA BY LOCATION

SITE: RVTO1 RIVERTON

LOCATION: 0710

NORTH COORDINATE: 25355.6 FT

EAST COOROINATE: 23982.6 FT

$06 / 12 / 81$ TO $01 / 10 / 94$

REPORT DATE: $09 / 07 / 94$

FORMATION OF COMPLETION: SURFICIAL (SF)

HYDRAULIC FLOW RELATIONSHIP: UPGRADIENT (U)

\begin{tabular}{|c|c|c|c|c|c|c|c|}
\hline PARAMETER NAME & LOG DATE & $\begin{array}{c}\text { SAMPLE } \\
\text { ID }\end{array}$ & $\begin{array}{l}\text { UNITS OF } \\
\text { MEASURE }\end{array}$ & PVI & $\begin{array}{l}\text { PARAMETER } \\
\text { VALUE FLAGS }\end{array}$ & $\begin{array}{l}\text { DETECTION } \\
\text { LIMIT }\end{array}$ & $\begin{array}{l}\text { PARAMETER } \\
\text { UNCERTATHTY }\end{array}$ \\
\hline ARSENIC & $\begin{array}{l}05 / 26 / 85 \\
03 / 13 / 91 \\
06 / 01 / 91 \\
10 / 23 / 91 \\
03 / 12 / 92 \\
08 / 06 / 92 \\
03 / 11 / 93\end{array}$ & $\begin{array}{l}0001 \\
0001 \\
0001 \\
0001 \\
0001 \\
0001 \\
0001\end{array}$ & $M G / L$ & $\begin{array}{l}< \\
< \\
< \\
< \\
< \\
<\end{array}$ & $\begin{array}{l}0.01 \\
0.01 \\
0.01 \\
0.003 \\
0.005 \\
0.005 \\
0.005\end{array}$ & $\begin{array}{l}0.01 \\
0.01 \\
0.01 \\
0.001 \\
0.005 \\
0.005 \\
0.005\end{array}$ & $\begin{array}{l}- \\
- \\
- \\
- \\
- \\
- \\
-\end{array}$ \\
\hline ARSENIC (TOTAL) & $03 / 11 / 93$ & No01 & $M G / L$ & $<$ & $0.005 \quad W$ & 0.005 & - \\
\hline MANGANESE & $\begin{array}{l}05 / 26 / 85 \\
03 / 13 / 91 \\
06 / 01 / 91 \\
10 / 23 / 91 \\
03 / 12 / 92 \\
08 / 06 / 92 \\
03 / 11 / 93\end{array}$ & $\begin{array}{l}0001 \\
0001 \\
0001 \\
0001 \\
0001 \\
0001 \\
0001\end{array}$ & $M G / L$ & $\begin{array}{l}< \\
< \\
< \\
< \\
<\end{array}$ & $\begin{array}{l}0.91 \\
0.01 \\
0.01 \\
0.03 \\
0.01 \\
0.01 \\
0.01\end{array}$ & $\begin{array}{l}0.01 \\
0.01 \\
0.01 \\
0.01 \\
0.01 \\
0.01 \\
0.01\end{array}$ & $\begin{array}{l}- \\
- \\
- \\
- \\
- \\
-\end{array}$ \\
\hline MANGANESE (TOTAL) & $03 / 11 / 93$ & N001 & $M G / L$ & & 0.20 & 0.01 & - \\
\hline MOLYBDENUM & $\begin{array}{l}05 / 26 / 85 \\
03 / 13 / 91 \\
06 / 01 / 91 \\
10 / 23 / 91 \\
03 / 12 / 92 \\
08 / 06 / 92 \\
03 / 11 / 93\end{array}$ & $\begin{array}{l}0001 \\
0001 \\
0001 \\
0001 \\
0001 \\
0001 \\
0001\end{array}$ & $M G / L$ & $\begin{array}{l}< \\
< \\
< \\
< \\
< \\
< \\
<\end{array}$ & $\begin{array}{l}0.01 \\
0.01 \\
0.01 \\
0.01 \\
0.01 \\
0.01 \\
0.01\end{array}$ & $\begin{array}{l}0.01 \\
0.01 \\
0.01 \\
0.01 \\
0.01 \\
0.01 \\
0.01\end{array}$ & $\begin{array}{l}- \\
- \\
- \\
- \\
- \\
-\end{array}$ \\
\hline MOLYBDENUM (TOTAL) & $03 / 11 / 93$ & N001 & $M G / L$ & $<$ & 0.01 & 0.01 & - \\
\hline NICKEL. & $\begin{array}{l}05 / 26 / 85 \\
03 / 13 / 91 \\
06 / 01 / 91 \\
10 / 23 / 91 \\
03 / 12 / 92 \\
08 / 06 / 92 \\
03 / 11 / 93\end{array}$ & $\begin{array}{l}0001 \\
0001 \\
0001 \\
0001 \\
0001 \\
0001 \\
0001\end{array}$ & $M G / L$ & $\begin{array}{l}< \\
< \\
< \\
< \\
< \\
< \\
<\end{array}$ & $\begin{array}{l}0.04 \\
0.04 \\
0.04 \\
0.01 \\
0.04 \\
0.04 \\
0.04\end{array}$ & $\begin{array}{l}0.04 \\
0.04 \\
0.04 \\
0.01 \\
0.04 \\
0.04 \\
0.04\end{array}$ & $\begin{array}{l}- \\
- \\
- \\
- \\
- \\
-\end{array}$ \\
\hline NICKEL (TOTAL) & $03 / 11 / 93$ & NO01 & $M G / L$ & $<$ & 0.04 & 0.04 & - \\
\hline SULFATE & $\begin{array}{l}05 / 26 / 85 \\
03 / 13 / 91 \\
06 / 01 / 91 \\
10 / 23 / 91 \\
03 / 12 / 92 \\
08 / 06 / 92\end{array}$ & $\begin{array}{l}0001 \\
0001 \\
0001 \\
0001 \\
0001 \\
0001\end{array}$ & $M G / L$ & & $\begin{array}{l}363.00 \\
101 . \\
118 . \\
84.7 \\
105 . \\
120 .\end{array}$ & $\begin{array}{c}0.1 \\
10 . \\
0.1 \\
0.1 \\
10 . \\
20 .\end{array}$ & $\begin{array}{l}- \\
- \\
- \\
- \\
-\end{array}$ \\
\hline SULFATE (TOTAL) & $03 / 11 / 93$ & N001 & $M G / L$ & & 120 & 1 & - \\
\hline URANIUM & $\begin{array}{l}05 / 26 / 85 \\
03 / 13 / 91 \\
06 / 01 / 91 \\
10 / 23 / 91 \\
03 / 12 / 92 \\
08 / 06 / 92 \\
03 / 11 / 93\end{array}$ & $\begin{array}{l}0001 \\
0001 \\
0001 \\
0001 \\
0001 \\
0001 \\
0001\end{array}$ & $M G / L$ & $\begin{array}{l}< \\
<\end{array}$ & $\begin{array}{l}0.0156 \\
0.003 \\
0.001 \\
0.0040 \\
0.004 \\
0.001 \\
0.004\end{array}$ & $\begin{array}{l}0.003 \\
0.001 \\
0.001 \\
0.0003 \\
0.001 \\
0.001 \\
0.001\end{array}$ & $\begin{array}{l}- \\
- \\
- \\
- \\
- \\
- \\
=\end{array}$ \\
\hline URANIUM (TOTAL) & $03 / 11 / 93$ & N001 & MG/L & & 0.004 & 0.001 & - \\
\hline
\end{tabular}

PARAMETER VALUE INDICATOR (PVI): < - LESS THAN DETECTION LIMIT

OTHER PARAMETER VALUE FLAGS:

$W$ - POST-DIGEST SPIKE OUT OF CNTR LIM WHILE SAMP ABS < 50\% SPIKE

SAMPLE ID CODES:

0001 - FILTERED SAMPLE (.45 MICRONS)

N001 - UNFILTERED SAMPLE 
GROUNDHATER QUALITY DATA BY LOCATION

SITE: RVT01 RIVERTON

LOCATION: 0710

NORTH COORDINATE: 25355.6 FT

EAST COORDINATE: 23982.6 FT

06/12/81 TO $01 / 10 / 94$

REPORT DATE: 09/07/94

FORMATION OF COMPLETION: SURFICIAL (SF)

HYDRAULIC FLOW RELATIONSHIP: UPGRADIENT (U)

\begin{tabular}{|c|c|c|c|c|c|c|c|}
\hline PARAMETER NAME & LOG DATE & $\begin{array}{c}\text { SAMPLE } \\
\text { ID }\end{array}$ & $\begin{array}{l}\text { UNITS OF } \\
\text { MEASURE }\end{array}$ & PVI & $\begin{array}{l}\text { PARAMETER } \\
\text { VALUE FLAGS }\end{array}$ & $\begin{array}{l}\text { DETECTION } \\
\text { LIMIT }\end{array}$ & $\begin{array}{l}\text { PARAMETER } \\
\text { UNCERTAINTY }\end{array}$ \\
\hline VANADIUM & $\begin{array}{l}05 / 26 / 85 \\
03 / 13 / 91 \\
06 / 01 / 91 \\
10 / 23 / 91 \\
03 / 12 / 92 \\
08 / 06 / 92 \\
03 / 11 / 93\end{array}$ & $\begin{array}{l}0001 \\
0001 \\
0001 \\
0001 \\
0001 \\
0001 \\
0001\end{array}$ & $M G / L$ & $\begin{array}{l}< \\
< \\
< \\
<\end{array}$ & $\begin{array}{l}0.01 \\
0.01 \\
0.01 \\
0.03 \\
0.01 \\
0.02 \\
0.01\end{array}$ & $\begin{array}{l}0.01 \\
0.01 \\
0.01 \\
0.01 \\
0.01 \\
0.01 \\
0.01\end{array}$ & $\begin{array}{l}- \\
- \\
- \\
- \\
-\end{array}$ \\
\hline VANADIUM (TOTAL) & $03 / 11 / 93$ & NOO1 & MG/L & $<$ & 0.01 & 0.01 & - \\
\hline
\end{tabular}

PARAMETER VALUE INDICATOR (PVI)

- LESS THAN DETECTION LIMIT

SAMPLE ID CODES:

0001 - FILTERED SAMPLE (.45 MICRONS)

N001 - UNFILTERED SAMPLE 
GROUNDWATER QUALITY DATA BY LOCATION

SITE: RVTOI RIVERTON

LOCATION: 0711

NORTH COORDINATE: 26088.0 FT

EAST COORDINATE: 24670.9 FT

06/12/81 TO 01/10/94

REPORT DATE : 09/07/94

FORMATION OF COMPLETION: SURFICIAL (SF)

HYDRAULIC FLOW RELATIONSHIP: UPGRADIENT (U)

\begin{tabular}{|c|c|c|c|c|c|c|c|}
\hline PARAMETER NAME & LOG DATE & $\begin{array}{c}\text { SAMPLE } \\
\text { ID }\end{array}$ & $\begin{array}{l}\text { UNITS OF } \\
\text { MEASURE }\end{array}$ & PVI & $\begin{array}{l}\text { PARAMETER } \\
\text { VALUE FLAGS }\end{array}$ & $\begin{array}{l}\text { DETECTION } \\
\text { LIMIT }\end{array}$ & $\begin{array}{l}\text { PARAMETER } \\
\text { UNCERTAINTY }\end{array}$ \\
\hline ARSENIC & $\begin{array}{l}05 / 26 / 85 \\
05 / 26 / 85 \\
05 / 26 / 85 \\
05 / 26 / 85 \\
05 / 26 / 85 \\
11 / 21 / 87 \\
05 / 16 / 88 \\
05 / 16 / 88 \\
05 / 16 / 88 \\
05 / 16 / 88 \\
05 / 16 / 88 \\
09 / 01 / 88 \\
10 / 26 / 88 \\
04 / 26 / 89 \\
11 / 21 / 89 \\
03 / 30 / 90 \\
11 / 15 / 90 \\
03 / 27 / 91 \\
06 / 01 / 91 \\
10 / 23 / 91 \\
03 / 12 / 92 \\
08 / 07 / 92 \\
03 / 18 / 93\end{array}$ & $\begin{array}{l}0001 \\
0002 \\
0003 \\
0004 \\
0005 \\
0001 \\
0001 \\
0002 \\
0003 \\
0004 \\
0005 \\
0001 \\
0001 \\
0001 \\
0001 \\
0001 \\
0001 \\
0001 \\
0001 \\
0001 \\
0001 \\
0001 \\
0001\end{array}$ & $M G / L$ & $\begin{array}{l}< \\
< \\
< \\
< \\
\\
< \\
< \\
< \\
< \\
< \\
< \\
< \\
<\end{array}$ & $\begin{array}{ll}0.01 & \\
0.01 & \\
0.01 & \\
0.01 & \\
0.01 & \\
0.007 & J \\
0.002 & J \\
0.006 & J \\
0.006 & J \\
0.006 & J \\
0.006 & J \\
0.003 & \\
0.003 & J \\
0.01 & \\
0.01 & \\
0.01 & \\
0.01 & J \\
0.01 & \\
0.01 & \\
0.002 & \\
0.005 & \\
0.005 & \\
0.005 & \end{array}$ & $\begin{array}{l}0.01 \\
0.01 \\
0.01 \\
0.01 \\
0.01 \\
0.01 \\
0.01 \\
0.01 \\
0.01 \\
0.01 \\
0.01 \\
0.001 \\
0.01 \\
0.01 \\
0.01 \\
0.01 \\
0.01 \\
0.01 \\
0.01 \\
0.001 \\
0.005 \\
0.005 \\
0.005\end{array}$ & $\begin{array}{l}- \\
- \\
- \\
- \\
- \\
- \\
- \\
- \\
- \\
- \\
- \\
- \\
- \\
- \\
- \\
- \\
- \\
-\end{array}$ \\
\hline ARSENIC (TOTAL) & $\begin{array}{l}03 / 30 / 90 \\
11 / 15 / 90 \\
03 / 27 / 91 \\
03 / 18 / 93\end{array}$ & $\begin{array}{l}\text { No01 } \\
\text { N001 } \\
\text { N001 } \\
\text { N001 }\end{array}$ & $M G / L$ & $\begin{array}{l}< \\
< \\
<\end{array}$ & $\begin{array}{l}0.01 \\
0.01 \\
0.01 \\
0.005\end{array}$ & $\begin{array}{l}0.01 \\
0.01 \\
0.01 \\
0.005\end{array}$ & $\begin{array}{l}- \\
- \\
-\end{array}$ \\
\hline MANGANESE & $\begin{array}{l}05 / 26 / 85 \\
05 / 26 / 85 \\
05 / 26 / 85 \\
05 / 26 / 85 \\
05 / 26 / 85 \\
11 / 21 / 87 \\
05 / 16 / 88 \\
05 / 16 / 88 \\
05 / 16 / 88 \\
05 / 16 / 88 \\
05 / 16 / 88 \\
09 / 01 / 88 \\
10 / 26 / 88 \\
04 / 26 / 89 \\
11 / 21 / 89 \\
03 / 30 / 90 \\
11 / 15 / 90 \\
03 / 27 / 91 \\
06 / 01 / 91 \\
10 / 23 / 91 \\
03 / 12 / 92 \\
08 / 07 / 92 \\
03 / 18 / 93\end{array}$ & $\begin{array}{l}0001 \\
0002 \\
0003 \\
0004 \\
0005 \\
0001 \\
0001 \\
0002 \\
0003 \\
0004 \\
0005 \\
0001 \\
0001 \\
0001 \\
0001 \\
0001 \\
0001 \\
0001 \\
0001 \\
0001 \\
0001 \\
0001 \\
0001\end{array}$ & $M G / L$ & & $\begin{array}{l}0.74 \\
0.23 \\
0.24 \\
0.74 \\
0.74 \\
2.09 \\
1.39 \\
1.40 \\
1.39 \\
1.37 \\
1.38 \\
3.56 \\
1.62 \\
0.87 \\
0.72 \\
0.52 \\
1.08 \\
0.61 \\
0.70 \\
1.4 \\
0.64 \\
0.69 \\
0.77\end{array}$ & $\begin{array}{l}0.01 \\
0.01 \\
0.01 \\
0.01 \\
0.01 \\
0.01 \\
0.01 \\
0.01 \\
0.01 \\
0.01 \\
0.01 \\
0.01 \\
0.01 \\
0.01 \\
0.01 \\
0.01 \\
0.01 \\
0.01 \\
0.01 \\
0.01 \\
0.01 \\
0.01 \\
0.01\end{array}$ & $\begin{array}{l}- \\
- \\
- \\
- \\
- \\
- \\
- \\
- \\
- \\
- \\
- \\
- \\
- \\
- \\
- \\
- \\
- \\
- \\
-\end{array}$ \\
\hline MANGANESE (TOTAL) & $\begin{array}{l}03 / 30 / 90 \\
11 / 15 / 90\end{array}$ & $\begin{array}{l}\text { N001 } \\
\text { N001 }\end{array}$ & MG/L & & $\begin{array}{l}1.04 \\
1.04\end{array}$ & $\begin{array}{l}0.01 \\
0.01\end{array}$ & - \\
\hline
\end{tabular}

PARAMETER VALUE INDICATOR (PVI): < - LESS THAN DETECTION LIMIT

SAMPLE ID CODES:

OTHER PARAMETER VALUE FLAGS:

0001 - FILTERED SAMPLE (.45 MICRONS)

$J$ - ESTIMATED VALUE

0002 - FILTERED REPLICATE SAMPLE (.45 MICRONS)

O003 - FILTERED REPLICATE SAMPLE (.45 MICRONS)

0004 - FILTERED REPLICATE SAMPLE ( 45 MICRONS)

NO01 - UNFILTERED SAMPLE 
GROUNDWATER QUALITY DATA BY LOCATION

SITE: RVTO? RIVERTON

LOCATION: 0711

NORTH COORDINATE: 26088.0 FT

EAST COORDINATE: 24670.9 FT

06/12/81 TO $01 / 10 / 94$

REPORT DATE: 09/07/94

FORMATION OF COMPLETION: SURFICIAL (SF)

HYDRAULIC FLOW RELATIONSHIP: UPGRADIENT (U)

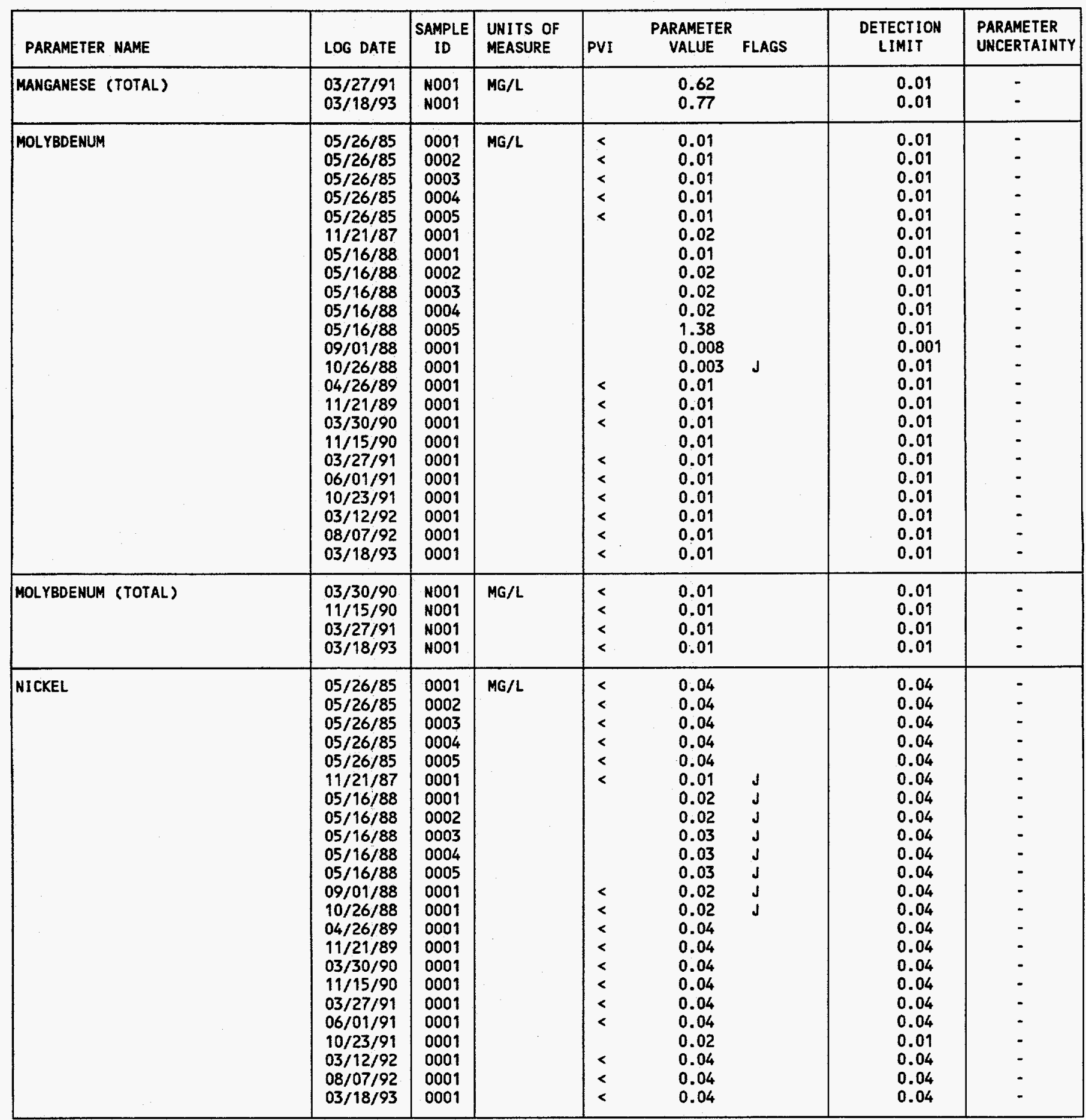

PARAMETER VALUE IMDICATOR (PVI): < - LESS THAN DETECTION LIMIT

SAMPLE ID CODES:

OTHER PARAMETER VALUE FLAGS:

0001 - FILTERED SAMPLE (.45 MICRONS)

0002 - FILTERED REPLICATE SAMPLE (.45 MICRONS)

0003 - FILTERED REPLICATE SAMPLE (.45 MICRONS)

0004 - FILTERED REPLICATE SAMPLE (. 45 MICRONS)

N001 - UNFILTERED SAMPLE 
GROUNDWATER QUALITY DATA BY LOCATION

SITE: RVTO1 RIVERTON

LOCATION: 0711

NORTH COORDINATE: 26088.0 FT

EAST COORDINATE: $\quad 24670.9$ FT

$06 / 12 / 81$ TO $01 / 10 / 94$

REPORT DATE: 09/07/94

FORMATION OF COMPLETION: SURFICIAL (SF)

HYDRAULIC FLOW RELATIONSHIP: UPGRADIENT (U)

\begin{tabular}{|c|c|c|c|c|c|c|c|c|}
\hline PARAMETER NAME & LOG DATE & $\begin{array}{c}\text { SAMPLE } \\
\text { ID }\end{array}$ & $\begin{array}{l}\text { UNITS OF } \\
\text { MEASURE }\end{array}$ & PVI & $\begin{array}{l}\text { PARAMETER } \\
\text { VALUE }\end{array}$ & FLAGS & $\begin{array}{l}\text { DETECTION } \\
\text { LIMIT }\end{array}$ & $\begin{array}{l}\text { PARAMETER } \\
\text { UNCERTAINTY }\end{array}$ \\
\hline HICKEL (TOTAL) & $\begin{array}{l}03 / 30 / 90 \\
11 / 15 / 90 \\
03 / 27 / 91 \\
03 / 18 / 93\end{array}$ & $\begin{array}{l}\text { No01 } \\
\text { N001 } \\
\text { N001 } \\
\text { N001 }\end{array}$ & $M G / L$ & $\begin{array}{l}< \\
< \\
<\end{array}$ & $\begin{array}{l}0.04 \\
0.04 \\
0.04 \\
0.04\end{array}$ & & $\begin{array}{l}0.04 \\
0.04 \\
0.04 \\
0.04\end{array}$ & $\begin{array}{l}- \\
- \\
-\end{array}$ \\
\hline SULFATE & $\begin{array}{l}05 / 26 / 85 \\
05 / 26 / 85 \\
05 / 26 / 85 \\
05 / 26 / 85 \\
05 / 26 / 85 \\
11 / 21 / 87 \\
05 / 16 / 88 \\
05 / 16 / 88 \\
05 / 16 / 88 \\
05 / 16 / 88 \\
05 / 16 / 88 \\
09 / 01 / 88 \\
10 / 26 / 88 \\
04 / 26 / 89 \\
11 / 21 / 89 \\
03 / 30 / 90 \\
11 / 15 / 90 \\
03 / 27 / 91 \\
06 / 01 / 91 \\
10 / 23 / 91 \\
03 / 12 / 92 \\
08 / 07 / 92 \\
03 / 18 / 93\end{array}$ & $\begin{array}{l}0001 \\
0002 \\
0003 \\
0004 \\
0005 \\
0001 \\
0001 \\
0002 \\
0003 \\
0004 \\
0005 \\
0001 \\
0001 \\
0001 \\
0001 \\
0001 \\
0001 \\
0001 \\
0001 \\
0001 \\
0001 \\
0001 \\
0001\end{array}$ & MG/L & & $\begin{array}{l}156.00 \\
155.00 \\
154.00 \\
154.00 \\
155.00 \\
438 . \\
356 . \\
357 . \\
357 . \\
357 . \\
356 . \\
854 . \\
438 . \\
212 . \\
185 . \\
154 . \\
278 . \\
150 . \\
137 . \\
379 \\
157 . \\
93 . \\
106\end{array}$ & & $\begin{array}{c}0.1 \\
0.1 \\
0.1 \\
0.1 \\
0.1 \\
0.1 \\
0.1 \\
0.1 \\
0.1 \\
0.1 \\
0.1 \\
1 . \\
0.1 \\
0.1 \\
0.1 \\
0.1 \\
0.1 \\
10 . \\
0.1 \\
0.1 \\
10 . \\
10 . \\
1\end{array}$ & $\begin{array}{l}- \\
- \\
- \\
- \\
- \\
- \\
- \\
- \\
- \\
- \\
- \\
- \\
- \\
- \\
- \\
- \\
- \\
- \\
- \\
- \\
-\end{array}$ \\
\hline SULFATE (TOTAL) & $\begin{array}{l}03 / 30 / 90 \\
11 / 15 / 90\end{array}$ & $\begin{array}{l}\text { No01 } \\
\text { No01 }\end{array}$ & MG/L & & $\begin{array}{l}161 . \\
281 .\end{array}$ & & $\begin{array}{l}0.1 \\
0.1\end{array}$ & - \\
\hline URANIUM & $\begin{array}{l}05 / 26 / 85 \\
05 / 26 / 85 \\
05 / 26 / 85 \\
05 / 26 / 85 \\
05 / 26 / 85 \\
11 / 21 / 87 \\
05 / 16 / 88 \\
05 / 16 / 88 \\
05 / 16 / 88 \\
05 / 16 / 88 \\
05 / 16 / 88 \\
09 / 01 / 88 \\
10 / 26 / 88 \\
04 / 26 / 89 \\
11 / 21 / 89 \\
03 / 30 / 90 \\
11 / 15 / 90 \\
03 / 27 / 91 \\
06 / 01 / 91 \\
10 / 23 / 91 \\
03 / 12 / 92 \\
08 / 07 / 92 \\
03 / 18 / 93\end{array}$ & $\begin{array}{l}0001 \\
0002 \\
0003 \\
0004 \\
0005 \\
0001 \\
0001 \\
0002 \\
0003 \\
0004 \\
0005 \\
0001 \\
0001 \\
0001 \\
0001 \\
0001 \\
0001 \\
0001 \\
0001 \\
0001 \\
0001 \\
0001 \\
0001\end{array}$ & $M G / L$ & $\begin{array}{l}< \\
< \\
< \\
<\end{array}$ & $\begin{array}{l}0.0007 \\
0.0003 \\
0.0005 \\
0.0003 \\
0.0007 \\
0.0042 \\
0.0044 \\
0.0045 \\
0.0046 \\
0.0042 \\
0.0043 \\
0.008 \\
0.003 \\
0.005 \\
0.0019 \\
0.0020 \\
0.0032 \\
0.004 \\
0.001 \\
0.0046 \\
0.003 \\
0.001 \\
0.002\end{array}$ & $\begin{array}{l}J \\
J \\
J \\
J \\
J\end{array}$ & $\begin{array}{l}0.003 \\
0.003 \\
0.003 \\
0.003 \\
0.003 \\
0.003 \\
0.003 \\
0.003 \\
0.003 \\
0.003 \\
0.003 \\
0.003 \\
0.003 \\
0.003 \\
0.003 \\
0.003 \\
0.0003 \\
0.001 \\
0.001 \\
0.0003 \\
0.001 \\
0.001 \\
0.001\end{array}$ & $\begin{array}{l}- \\
- \\
- \\
- \\
- \\
- \\
- \\
- \\
- \\
- \\
- \\
- \\
- \\
- \\
- \\
- \\
- \\
- \\
- \\
- \\
-\end{array}$ \\
\hline
\end{tabular}

PARAMETER VALUE INDICATOR (PVI): < - LESS THAN DETECTION LIMIT

SAMPLE ID CODES:

0001 - FILTERED SAMPLE (.45 MICRONS)

OTHER PARAMETER VALUE FLAGS:

0002 - FILTERED REPLICATE SAMPLE (.45 MICRONS)

0003 - FILTERED REPLICATE SAMPLE (.45 MICRONS)

$J$ - ESTIMATED VALUE

0004 - FILTERED REPLICATE SAMPLE (.45 MICRONS)

NO01 - UNFILTERED SAMPLE 
GROUNDWATER QUALITY DATA BY LOCATION

SITE: RVTO1 RIVERTON

LOCATION: 0711

NORTH COORDINATE: 26088.0 FT

EAST COORDINATE: 24670.9 FT

$06 / 12 / 81$ TO $01 / 10 / 94$

REPORT DATE: $09 / 07 / 94$

FORMATION OF COMPLETION: SURFICIAL (SF)

HYDRAULIC FLOW RELATIONSHIP: UPGRADIENT (U)

\begin{tabular}{|c|c|c|c|c|c|c|c|}
\hline PARAMETER NAME & LOG DATE & $\begin{array}{c}\text { SAMPLE } \\
\text { ID }\end{array}$ & $\begin{array}{l}\text { UNITS OF } \\
\text { MEASURE }\end{array}$ & PVI & $\begin{array}{l}\text { PARAMETER } \\
\text { VALUE FLAGS }\end{array}$ & $\begin{array}{l}\text { DETECTION } \\
\text { LIMIT }\end{array}$ & $\begin{array}{l}\text { PARAMETER } \\
\text { UNCERTAINTY }\end{array}$ \\
\hline URAMIUM (TOTAL) & $\begin{array}{l}03 / 30 / 90 \\
11 / 15 / 90 \\
03 / 27 / 91 \\
03 / 18 / 93\end{array}$ & $\begin{array}{l}\text { NO01 } \\
\text { NO01 } \\
\text { NO01 } \\
\text { N001 }\end{array}$ & $M G / L$ & $<$ & $\begin{array}{l}0.0020 \quad J \\
0.0027 \\
0.001 \\
0.001\end{array}$ & $\begin{array}{l}0.003 \\
0.0003 \\
0.001 \\
0.001\end{array}$ & : \\
\hline VANADIUM & $\begin{array}{l}05 / 26 / 85 \\
05 / 26 / 85 \\
05 / 26 / 85 \\
05 / 26 / 85 \\
05 / 26 / 85 \\
11 / 21 / 87 \\
05 / 16 / 88 \\
05 / 16 / 88 \\
05 / 16 / 88 \\
05 / 16 / 88 \\
05 / 16 / 88 \\
09 / 01 / 88 \\
10 / 26 / 88 \\
04 / 26 / 89 \\
11 / 21 / 89 \\
03 / 30 / 90 \\
11 / 15 / 90 \\
03 / 27 / 91 \\
06 / 01 / 91 \\
10 / 23 / 91 \\
03 / 12 / 92 \\
08 / 07 / 92 \\
03 / 18 / 93\end{array}$ & $\begin{array}{l}0001 \\
0002 \\
0003 \\
0004 \\
0005 \\
0001 \\
0001 \\
0002 \\
0003 \\
0004 \\
0005 \\
0001 \\
0001 \\
0001 \\
0001 \\
0001 \\
0001 \\
0001 \\
0001 \\
0001 \\
0001 \\
0001 \\
0001\end{array}$ & $M G / L$ & $\begin{array}{l}< \\
< \\
< \\
< \\
< \\
< \\
< \\
< \\
< \\
< \\
< \\
< \\
< \\
<\end{array}$ & $\begin{array}{l}0.01 \\
0.01 \\
0.01 \\
0.01 \\
0.01 \\
0.04 \\
0.02 \\
0.02 \\
0.02 \\
0.03 \\
0.03 \\
0.01 \\
0.01 \\
0.01 \\
0.02 \\
0.01 \\
0.01 \\
0.01 \\
0.01 \\
0.03 \\
0.01 \\
0.01 \\
0.01\end{array}$ & $\begin{array}{l}0.01 \\
0.01 \\
0.01 \\
0.01 \\
0.01 \\
0.01 \\
0.01 \\
0.01 \\
0.01 \\
0.01 \\
0.01 \\
0.01 \\
0.01 \\
0.01 \\
0.01 \\
0.01 \\
0.01 \\
0.01 \\
0.01 \\
0.01 \\
0.01 \\
0.01 \\
0.01\end{array}$ & $\begin{array}{l}- \\
- \\
- \\
- \\
- \\
- \\
- \\
- \\
- \\
- \\
- \\
- \\
- \\
- \\
- \\
- \\
- \\
-\end{array}$ \\
\hline VANADIUM (TOTAL) & $\begin{array}{l}03 / 30 / 90 \\
11 / 15 / 90 \\
03 / 27 / 91 \\
03 / 18 / 93\end{array}$ & $\begin{array}{l}\text { N001 } \\
\text { N001 } \\
\text { N001 } \\
\text { N001 }\end{array}$ & MG/L & $\begin{array}{l}< \\
< \\
<\end{array}$ & $\begin{array}{l}0.01 \\
0.01 \\
0.01 \\
0.01\end{array}$ & $\begin{array}{l}0.01 \\
0.01 \\
0.01 \\
0.01\end{array}$ & $\begin{array}{l}- \\
-\end{array}$ \\
\hline
\end{tabular}

PARAMETER VALUE INDICATOR (PVI): < - LESS THAN DETECTION LIMIT

SAMPLE ID CODES:

O001 - FILTERED SAMPLE (.45 MICRONS)

OTHER PARAMETER VALUE FLAGS:

0002 - FILTERED REPLICATE SAMPLE (.45 MICRONS)

0003 - FILTERED REPLICATE SAMPLE (.45 MICRONS)

0004 - FILTERED REPLICATE SAMPLE (.45 MICRONS)

NOOI - UNFILTERED SAMPLE 
GROUNDWATER QUALITY DATA BY LOCATION

SITE: RVTO1 RIVERTON

LOCATION: 0712

NORTH COORDINATE: 26931.4 FT

EAST COORDINATE: 25462.5 FT

06/12/81 TO $01 / 10 / 94$

REPORT DATE: $09 / 07 / 94$

FORMATION OF COMPLETION: SURFICIAL (SF)

HYDRAULIC FLOW RELATIONSHIP: UPGRADIENT (U)

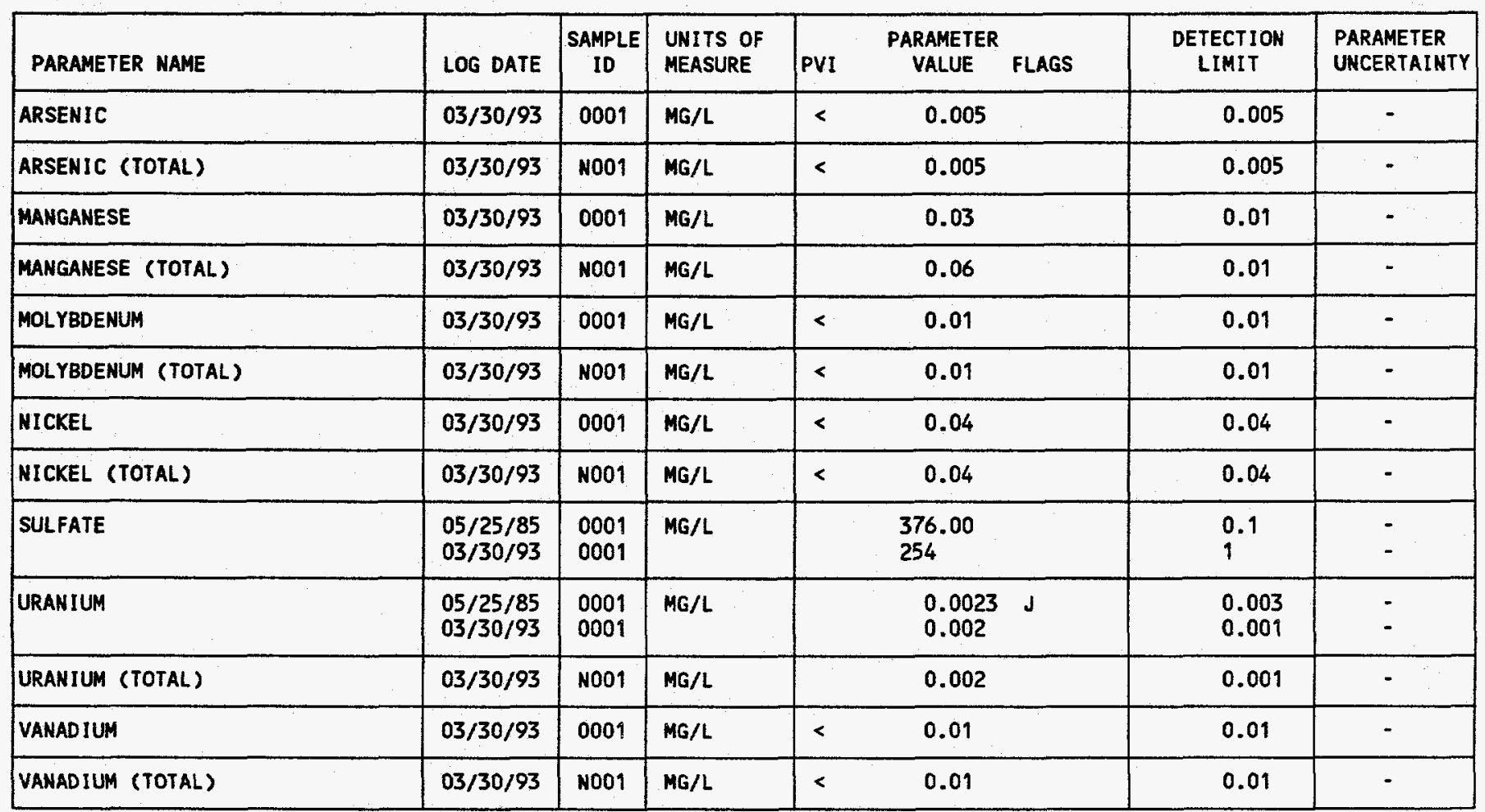

PARAMETER VALUE INDICATOR (PVI): < - LESS THAN DETECTION LIMIT

SAMPLE ID CODES:

OTHER PARAMETER VALUE FLAGS:

O001 - FILTERED SAMPLE (.45 MICRONS)

$J$ - ESTIMATED VALUE

NO01 - UNFILTERED SAMPLE 
GROUNDWATER QUALITY DATA BY LOCATION

SITE: RVTO1 RIVERTON

LOCATION: 0713

NORTH COORDINATE: 27577.4 FT

EAST COORDINATE: 25984.3 FT

06/12/81 TO 01/10/94

REPORT DATE: 09/07/94

FORMATION OF COMPLETION: SURFICIAL (SF)

HYDRAULIC FLOW RELATIONSHIP: UPGRADIENT (U)

\begin{tabular}{|c|c|c|c|c|c|c|c|}
\hline PARAMETER NAME & LOG DATE & $\begin{array}{c}\text { SAMPLE } \\
\text { ID }\end{array}$ & $\begin{array}{l}\text { UNITS OF } \\
\text { MEASURE }\end{array}$ & PVI & $\begin{array}{l}\text { PARAMETER } \\
\text { VALUE FLAGS }\end{array}$ & $\begin{array}{l}\text { DETECTION } \\
\text { LIMIT }\end{array}$ & $\begin{array}{l}\text { PARAMETER } \\
\text { UNCERTAINTY }\end{array}$ \\
\hline ARSENIC & $05 / 25 / 85$ & 0001 & MG/L & $<$ & 0.01 & 0.01 & - \\
\hline MOLYBDENUM & $05 / 25 / 85$ & 0001 & $M G / L$ & $<$ & 0.01 & 0.01 & - \\
\hline SULFATE & $05 / 25 / 85$ & 0001 & MG/L & & 66.70 & 0.1 & - \\
\hline URANIUM & $05 / 25 / 85$ & 0001 & MG/L & & $0.0017 \mathrm{~J}$ & 0.003 & - \\
\hline VANADIUM & $05 / 25 / 85$ & 0001 & $M G / L$ & $<$ & 0.01 & 0.01 & - \\
\hline
\end{tabular}

PARAMETER VALUE INDICATOR (PVI):

< - LESS THAN DETECTION LIMIT

SAMPLE ID CODES:

0001 - FILTERED SAMPLE (.45 MICRONS)

OTHER PARAMETER VALUE FLAGS:

$\mathrm{J}$ - ESTIMATED VALUE 
GROUNDWATER QUALITY DATA BY LOCATION

SITE: RVTO1 RIVERTON

LOCATION: 0714

NORTH COORDINATE: 28193.9 FT

EAST COORDINATE: 26433.9 FT

06/12/81 TO $01 / 10 / 94$

REPORT DATE: 09/07/94

FORMATION OF COMPLETION: SURFICIAL (SF)

HYDRAULIC FLOW RELATIONSHIP: UPGRADIENT (U)

\begin{tabular}{|c|c|c|c|c|c|c|c|}
\hline PARAMETER NAME & LOG DATE & $\begin{array}{l}\text { SAMPLE } \\
\text { ID }\end{array}$ & $\begin{array}{l}\text { UNITS OF } \\
\text { MEASURE }\end{array}$ & PVI & $\begin{array}{l}\text { PARAMETER } \\
\text { VALUE FLAGS }\end{array}$ & $\begin{array}{l}\text { DETECTION } \\
\text { LIMIT }\end{array}$ & $\begin{array}{l}\text { PARAMETER } \\
\text { UNCERTAINTY }\end{array}$ \\
\hline ARSENIC & $05 / 25 / 85$ & 0001 & $\mathrm{MG} / \mathrm{L}$ & $<$ & 0.09 & 0.01 & - \\
\hline MOLYBDENUM & $05 / 25 / 85$ & 0001 & MG/L & $<$ & 0.01 & 0.01 & - \\
\hline SULFATE & $05 / 25 / 85$ & 0001 & $M G / L$ & & 42.80 & 0.1 & - \\
\hline URANIUM & $05 / 25 / 85$ & 0001 & $M G / L$ & $<$ & $0.0003 \mathrm{~J}$ & 0.003 & - \\
\hline VANADIUM & $05 / 25 / 85$ & 0001 & $M G / L$ & $<$ & 0.01 & 0.01 & - \\
\hline
\end{tabular}

PARAMETER VALUE INDICATOR (PVI):

< - LESS THAN DETECTION LIMIT

SAMPLE ID CODES:

0001 - FILTERED SAMPLE (.45 MICRONS)

OTHER PARAMETER VALUE FLAGS:

$\mathrm{J}$ - ESTIMATED VALUE 
GROUNDWATER QUALITY DATA BY LOCATION

SITE: RVTO1. RIVERTON

LOCATION: 0716

NORTH COORDINATE: 22764.49 FT

EAST COORDINATE: $\quad 25873.34$ FT

06/12/81 TO 01/10/94

REPORT DATE: 09/07/94

FORMATION OF COMPLETION: SURFICIAL (SF)

HYDRAULIC FLOW RELATIONSHIP: ON-SITE (O)

\begin{tabular}{|c|c|c|c|c|c|c|c|}
\hline PARAMETER NAME & LOG DATE & $\begin{array}{c}\text { SAMPLE } \\
\text { ID }\end{array}$ & $\begin{array}{l}\text { UNITS OF } \\
\text { MEASURE }\end{array}$ & PVI & $\begin{array}{l}\text { PARAMETER } \\
\text { VALUE FLAGS }\end{array}$ & $\begin{array}{l}\text { DETECTION } \\
\text { LIMIT }\end{array}$ & $\begin{array}{l}\text { PARAMETER } \\
\text { UNCERTAINTY }\end{array}$ \\
\hline ARSENIC & $\begin{array}{l}04 / 01 / 93 \\
01 / 09 / 94\end{array}$ & $\begin{array}{l}0001 \\
0001\end{array}$ & $M G / L$ & $<$ & $\begin{array}{l}0.005 \\
0.005 \quad W\end{array}$ & $\begin{array}{l}0.005 \\
0.005\end{array}$ & - \\
\hline ARSENIC (TOTAL) & $04 / 01 / 93$ & N001 & $M G / L$ & $<$ & 0.005 & 0.005 & - \\
\hline MANGANESE & $\begin{array}{l}04 / 01 / 93 \\
01 / 09 / 94\end{array}$ & $\begin{array}{l}0001 \\
0001\end{array}$ & $M G / L$ & & $\begin{array}{l}0.74 \\
0.74\end{array}$ & $\begin{array}{l}0.01 \\
0.01\end{array}$ & - \\
\hline MANGANESE (TOTAL) & $04 / 01 / 93$ & N001 & MG/L & & 0.68 & 0.01 & - \\
\hline MOLYBDENUM & $\begin{array}{l}04 / 01 / 93 \\
01 / 09 / 94\end{array}$ & $\begin{array}{l}0001 \\
0001\end{array}$ & $M G / L$ & & $\begin{array}{l}0.26 \\
0.24\end{array}$ & $\begin{array}{l}0.01 \\
0.01\end{array}$ & - \\
\hline MOLYBDENUM (TOTAL) & $04 / 01 / 93$ & N001 & $M G / L$ & & 0.23 & 0.01 & - \\
\hline NICKEL & $\begin{array}{l}04 / 01 / 93 \\
01 / 09 / 94\end{array}$ & $\begin{array}{l}0001 \\
0001\end{array}$ & MG/L & $<$ & $\begin{array}{l}0.04 \\
0.04\end{array}$ & $\begin{array}{l}0.04 \\
0.04\end{array}$ & - \\
\hline HICKEL (TOTAL) & $04 / 01 / 93$ & N001 & $M G / L$ & $<$ & 0.04 & 0.04 & $\cdot$ \\
\hline SULFATE & $\begin{array}{l}04 / 01 / 93 \\
01 / 09 / 94\end{array}$ & $\begin{array}{l}0001 \\
0001\end{array}$ & $M G / L$ & & $\begin{array}{l}674 \\
775\end{array}$ & $\begin{array}{l}1 \\
1\end{array}$ & - \\
\hline URANIUM & $\begin{array}{l}04 / 01 / 93 \\
01 / 09 / 94\end{array}$ & $\begin{array}{l}0001 \\
0001\end{array}$ & $M G / L$ & & $\begin{array}{l}0.591 \\
0.718\end{array}$ & $\begin{array}{l}0.001 \\
0.001\end{array}$ & - \\
\hline URANIUM (TOTAL) & $04 / 01 / 93$ & N001 & $M G / L$ & & 0.702 & 0.001 & - \\
\hline VANADIUM & $\begin{array}{l}04 / 01 / 93 \\
01 / 09 / 94\end{array}$ & $\begin{array}{l}0001 \\
0001\end{array}$ & MG/L & $<$ & $\begin{array}{l}0.01 \\
0.01\end{array}$ & $\begin{array}{l}0.01 \\
0.01\end{array}$ & - \\
\hline VAMADIUM (TOTAL) & $04 / 01 / 93$ & NoO1 & $M G / L$ & $<$ & 0.01 & 0.01 & - \\
\hline
\end{tabular}

PARAMETER VALUE INDICATOR (PVI): < - LESS THAN DETECTION LIMIT

SAMPLE ID CODES:

OTHER PARAMETER VALUE FLAGS:

SAPPL - FILTERED SAMPLE (.45 MICRONS)

$W$ - POST-DIGEST SPIKE OUT OF CNTR LIM WHILE SAMP ABS < 50\% SPIKE

N001 - UNFILTERED SAMPLE 
GROUNDWATER QUALITY DATA BY LOCATION

SITE: RVTO1 RIVERTON

LOCATION: 0717

NORTH COORDINATE: 22762.23 FT

EAST COORDINATE: 25889.34 FT

06/12/81 TO 01/10/94

REPORT DATE: 09/07/94

FORMATION OF COMPLETION: SEMICONFINED SANDSTONE (SE)

HYDRAULIC FLOW RELATIONSHIP: ON-SITE (O)

\begin{tabular}{|c|c|c|c|c|c|c|c|}
\hline PARAMETER NAME & LOG DATE & $\underset{\text { SAMPLE }}{\text { ID }}$ & $\begin{array}{l}\text { UNITS OF } \\
\text { MEASURE }\end{array}$ & PVI & $\begin{array}{l}\text { PARAMETER } \\
\text { VALUE FLAGS }\end{array}$ & $\begin{array}{l}\text { DETECTION } \\
\text { LIMIT }\end{array}$ & $\begin{array}{l}\text { PARAMETER } \\
\text { UNCERTAINTY }\end{array}$ \\
\hline ARSENIC & $\begin{array}{l}04 / 01 / 93 \\
01 / 09 / 94\end{array}$ & $\begin{array}{l}0001 \\
0001\end{array}$ & MG/L & $<$ & $\begin{array}{l}0.005 \quad W \\
0.005\end{array}$ & $\begin{array}{l}0.005 \\
0.005\end{array}$ & $\because$ \\
\hline ARSENIC (TOTAL) & $04 / 01 / 93$ & NoO1 & MG/L & $<$ & 0.005 & 0.005 & - \\
\hline MANGANESE & $\begin{array}{l}04 / 01 / 93 \\
01 / 09 / 94\end{array}$ & $\begin{array}{l}0001 \\
0001\end{array}$ & $M G / L$ & & $\begin{array}{l}0.22 \\
0.24\end{array}$ & $\begin{array}{l}0.01 \\
0.01\end{array}$ & - \\
\hline MANGANESE (TOTAL) & $04 / 01 / 93$ & N001 & $M G / L$ & & 0.19 & 0.01 & $\cdot$ \\
\hline MOL YBDENUM & $\begin{array}{l}04 / 01 / 93 \\
01 / 09 / 94\end{array}$ & $\begin{array}{l}0001 \\
0001\end{array}$ & MG/L & $<$ & $\begin{array}{l}0.01 \\
0.01\end{array}$ & $\begin{array}{l}0.01 \\
0.01\end{array}$ & - \\
\hline MOLYBDENUM (TOTAL) & $04 / 01 / 93$ & NOOI & $M G / L$ & $<$ & 0.01 & 0.01 & - \\
\hline NICKEL & $\begin{array}{l}04 / 01 / 93 \\
01 / 09 / 94\end{array}$ & $\begin{array}{l}0001 \\
0001\end{array}$ & $M G / L$ & $<$ & $\begin{array}{l}0.04 \\
0.04\end{array}$ & $\begin{array}{l}0.04 \\
0.04\end{array}$ & - \\
\hline NICKEL (TOTAL) & $04 / 01 / 93$ & N001 & $M G / L$ & $<$ & 0.04 & 0.04 & $\cdot$ \\
\hline SULFATE & $\begin{array}{l}04 / 01 / 93 \\
01 / 09 / 94\end{array}$ & $\begin{array}{l}0001 \\
0001\end{array}$ & $M G / L$ & & $\begin{array}{l}739 \\
707\end{array}$ & $\begin{array}{l}1 \\
1\end{array}$ & $\dot{-}$ \\
\hline URANIUM & $\begin{array}{l}04 / 01 / 93 \\
01 / 09 / 94\end{array}$ & $\begin{array}{l}0001 \\
0001\end{array}$ & $M G / L$ & $<$ & $\begin{array}{l}0.002 \\
0.001\end{array}$ & $\begin{array}{l}0.001 \\
0.001\end{array}$ & - \\
\hline URANIUM (TOTAL) & $04 / 01 / 93$ & NoO1 & $M G / L$ & $<$ & 0.001 & 0.001 & - \\
\hline VANADIUM & $\begin{array}{l}04 / 01 / 93 \\
01 / 09 / 94\end{array}$ & $\begin{array}{l}0001 \\
0001\end{array}$ & $M G / L$ & $<$ & $\begin{array}{l}0.01 \\
0.01\end{array}$ & $\begin{array}{l}0.01 \\
0.01\end{array}$ & - \\
\hline VANADIUM (TOTAL) & $04 / 01 / 93$ & N001 & $M G / L$ & $<$ & 0.01 & 0.01 & - \\
\hline
\end{tabular}

PARAMETER VALUE INDICATOR (PVI): < - LESS THAN DETECTION LIMIT

SAMPLE ID CODES:

OTHER PARAMETER VALUE FLAGS:

OOO1 - FILTERED SAMPLE (.45 MICRONS)

$W$ - POST-DIGEST SPIKE OUT OF CNTR LIM WHILE SAMP ABS < 50\% SPIKE

NOO1 - UNFILTERED SAMPLE 
GROUNDWATER QUALITY DATA BY LOCATION

SITE: RVTO1 RIVERTON

LOCATION: 0718

MORTH COORDINATE: $21673.56 \mathrm{FT}$

EAST COORDINATE: 25406.28 FT

06/12/81 TO 01/10/94

REPORT DATE: 09/07/94

FORMATION OF COMPLETION: SURFICIAL (SF)

HYDRAULIC FLOW RELATIONSHIP: DOWN GRADIENT (D)

\begin{tabular}{|c|c|c|c|c|c|c|c|}
\hline PARAMETER NAME & LOG DATE & $\begin{array}{c}\text { SAMPLE } \\
\text { ID }\end{array}$ & $\begin{array}{l}\text { UNITS OF } \\
\text { MEASURE }\end{array}$ & PVI & $\begin{array}{l}\text { PARAMETER } \\
\text { VALUE FLAGS }\end{array}$ & $\begin{array}{l}\text { DETECTION } \\
\text { LIMIT }\end{array}$ & $\begin{array}{l}\text { PARAMETER } \\
\text { UNCERTAINTY }\end{array}$ \\
\hline ARSENIC & $\begin{array}{l}04 / 01 / 93 \\
01 / 09 / 94\end{array}$ & $\begin{array}{l}0001 \\
0001\end{array}$ & $M G / L$ & $\begin{array}{l}< \\
<\end{array}$ & $\begin{array}{ll}0.005 & W \\
0.005 & W\end{array}$ & $\begin{array}{l}0.005 \\
0.005\end{array}$ & - \\
\hline ARSENIC (TOTAL) & $04 / 01 / 93$ & N001 & $M G / L$ & $<$ & 0.005 & 0.005 & - \\
\hline MANGANESE & $\begin{array}{l}04 / 01 / 93 \\
01 / 09 / 94\end{array}$ & $\begin{array}{l}0001 \\
0001\end{array}$ & $M G / L$ & & $\begin{array}{l}1.85 \\
3.28\end{array}$ & $\begin{array}{l}0.01 \\
0.01\end{array}$ & - \\
\hline MANGANESE (TOTAL) & $04 / 01 / 93$ & N001 & $M G / L$ & & 1.58 & 0.01 & - \\
\hline MOLYBDENUM & $\begin{array}{l}04 / 01 / 93 \\
01 / 09 / 94\end{array}$ & $\begin{array}{l}0001 \\
0001\end{array}$ & $M G / L$ & & $\begin{array}{l}0.13 \\
0.15\end{array}$ & $\begin{array}{l}0.01 \\
0.01\end{array}$ & - \\
\hline MOLYBDENUM (TOTAL) & $04 / 01 / 93$ & NoOI & $M G / L$ & & 0.12 & 0.01 & - \\
\hline NICKEL & $\begin{array}{l}04 / 01 / 93 \\
01 / 09 / 94\end{array}$ & $\begin{array}{l}0001 \\
0001\end{array}$ & $M G / L$ & & $\begin{array}{l}0.04 \\
0.06\end{array}$ & $\begin{array}{l}0.04 \\
0.04\end{array}$ & - \\
\hline NICKEL (TOTAL) & $04 / 01 / 93$ & NoO1 & MG/L & & 0.04 & 0.04 & - \\
\hline SULFATE & $\begin{array}{l}04 / 01 / 93 \\
01 / 09 / 94\end{array}$ & $\begin{array}{l}0001 \\
0001\end{array}$ & $M G / L$ & & $\begin{array}{l}1830 \\
2480\end{array}$ & $\begin{array}{l}1 \\
1\end{array}$ & - \\
\hline URANIUM & $\begin{array}{l}04 / 01 / 93 \\
01 / 09 / 94\end{array}$ & $\begin{array}{l}0001 \\
0001\end{array}$ & $M G / L$ & & $\begin{array}{l}0.202 \\
0.328\end{array}$ & $\begin{array}{l}0.001 \\
0.001\end{array}$ & - \\
\hline URANIUM (TOTAL) & $04 / 01 / 93$ & N001 & $M G / L$ & & 0.195 & 0.001 & - \\
\hline VANADIUM & $\begin{array}{l}04 / 01 / 93 \\
01 / 09 / 94\end{array}$ & $\begin{array}{l}0001 \\
0001\end{array}$ & $M G / L$ & $\begin{array}{l}< \\
<\end{array}$ & $\begin{array}{l}0.01 \\
0.01\end{array}$ & $\begin{array}{l}0.01 \\
0.01\end{array}$ & - \\
\hline VANADIUM (TOTAL) & $04 / 01 / 93$ & N001 & $M G / L$ & $<$ & 0.01 & 0.01 & - \\
\hline
\end{tabular}

PARAMETER VALUE INDICATOR (PVI): < - LESS THAN DETECTION LIMIT

SAMPLE ID CODES:

OTHER PARAMETER VALUE FLAGS:

0001 - FILTERED SAMPLE (.45 MICRONS)

W - POST-DIGEST SPIKE OUT OF CNTR LIM WHILE SAMP ABS < 50\% SPIKE

NO01 - UNFILTERED SAMPLE 
GROUNDWATER QUALITY DATA BY LOCATION

SITE: RVTO1 RIVERTON

LOCATION: 0719

NORTH COORDINATE: 21629.47 FT

EAST COORDINATE: 25392.14 FT

$06 / 12 / 81$ TO $01 / 10 / 94$

REPORT DATE: 09/07/94

FORMATION OF COMPLETION: SEMICONFINED SANDSTONE (SE)

HYDRAULIC FLOW RELATIONSHIP: DOWN GRADIENT (D)

\begin{tabular}{|c|c|c|c|c|c|c|c|c|}
\hline PARAMETER NAME & LOG DATE & $\underset{10}{\text { SAMPLE }}$ & $\begin{array}{l}\text { UNITS OF } \\
\text { MEASURE }\end{array}$ & PVI & $\begin{array}{l}\text { PARAMETER } \\
\text { VALUE }\end{array}$ & FLAGS & $\begin{array}{l}\text { DETECTION } \\
\text { LIMIT }\end{array}$ & $\begin{array}{l}\text { PARAMETER } \\
\text { UNCERTAINTY }\end{array}$ \\
\hline ARSENIC & $\begin{array}{l}04 / 01 / 93 \\
01 / 09 / 94\end{array}$ & $\begin{array}{l}0001 \\
0001\end{array}$ & $M G / L$ & $\begin{array}{l}< \\
<\end{array}$ & $\begin{array}{l}0.005 \\
0.005\end{array}$ & $\begin{array}{l}\text { LW } \\
L\end{array}$ & $\begin{array}{l}0.005 \\
0.005\end{array}$ & - \\
\hline ARSENIC (TOTAL) & $04 / 01 / 93$ & No01 & $M G / L$ & $<$ & 0.005 & $\mathbf{L}$ & 0.005 & - \\
\hline MANGANESE & $\begin{array}{l}04 / 01 / 93 \\
01 / 09 / 94\end{array}$ & $\begin{array}{l}0001 \\
0001\end{array}$ & $M G / L$ & & $\begin{array}{l}0.13 \\
0.22\end{array}$ & $\begin{array}{l}L \\
L\end{array}$ & $\begin{array}{l}0.01 \\
0.01\end{array}$ & - \\
\hline MANGANESE (TOTAL) & $04 / 01 / 93$ & No01 & MG/L & & 0.24 & $L$ & 0.01 & - \\
\hline MOLYBDENUM & $\begin{array}{l}04 / 01 / 93 \\
01 / 09 / 94\end{array}$ & $\begin{array}{l}0001 \\
0001\end{array}$ & $M G / L$ & & $\begin{array}{l}0.04 \\
0.02\end{array}$ & $\begin{array}{l}L \\
L\end{array}$ & $\begin{array}{l}0.01 \\
0.01\end{array}$ & - \\
\hline MOLYBDENUM (TOTAL) & $04 / 01 / 93$ & No01. & $M G / L$ & & 0.03 & $\mathbf{L}$ & 0.01 & - \\
\hline NICKEL & $\begin{array}{l}04 / 01 / 93 \\
01 / 09 / 94\end{array}$ & $\begin{array}{l}0001 \\
0001\end{array}$ & $M G / L$ & $\begin{array}{l}< \\
<\end{array}$ & $\begin{array}{l}0.04 \\
0.04\end{array}$ & $\begin{array}{l}L \\
L\end{array}$ & $\begin{array}{l}0.04 \\
0.04\end{array}$ & - \\
\hline NICKEL (TOTAL) & $04 / 01 / 93$ & $N 001$ & $M G / L$ & $<$ & 0.04 & $\mathbf{L}$ & 0.04 & - \\
\hline SULFATE & $\begin{array}{l}04 / 01 / 93 \\
01 / 09 / 94\end{array}$ & $\begin{array}{l}0001 \\
0001\end{array}$ & $M G / L$ & & $\begin{array}{l}592 \\
512\end{array}$ & $\begin{array}{l}L \\
L\end{array}$ & $\begin{array}{l}1 \\
1\end{array}$ & $\begin{array}{l}- \\
-\end{array}$ \\
\hline URANIUM & $\begin{array}{l}04 / 01 / 93 \\
01 / 09 / 94\end{array}$ & $\begin{array}{l}0001 \\
0001\end{array}$ & $M G / L$ & & $\begin{array}{l}0.017 \\
0.003\end{array}$ & $\begin{array}{l}L \\
L\end{array}$ & $\begin{array}{l}0.001 \\
0.001\end{array}$ & - \\
\hline URANIUM (TOTAL) & $04 / 01 / 93$ & No01 & $M G / L$ & & 0.012 & L & 0.001 & - \\
\hline VANADIUM & $\begin{array}{l}04 / 01 / 93 \\
01 / 09 / 94\end{array}$ & $\begin{array}{l}0001 \\
0001\end{array}$ & $M G / L$ & $<$ & $\begin{array}{l}0.01 \\
0.01\end{array}$ & $\begin{array}{l}L \\
L\end{array}$ & $\begin{array}{l}0.01 \\
0.01\end{array}$ & - \\
\hline VANADIUM (TOTAL) & $04 / 01 / 93$ & No01 & MG/L & & 0.02 & $L$ & 0.01 & - \\
\hline
\end{tabular}

PARAMETER VALUE INDICATOR (PVI): < - LESS THAN DETECTION LIMIT

SAMPLE ID CODES:

OTHER PARAMETER VALUE FLAGS:

0001 - FILTERED SAMPLE (.45 MICRONS)

L - LESS THAN THREE BORE VOLUMES REMOVED BEFORE SAMPLING

NOO1 - UNFILTERED SAMPLE

$W$ - POST-DIGEST SPIKE OUT OF CHTR LIM WHILE SAMP ABS < 50\% SPIKE 
GROUNDWATER QUALITY DATA BY LOCATION

SITE: RVTO1 RIVERTON

LOCATION: 0720

NORTH COORDINATE: $\quad 20729.00$ FT

EAST COORDINATE: $\quad 23677.37$ FT

06/12/81 TO $01 / 10 / 94$

REPORT DATE: $09 / 07 / 94$

FORMATION OF COMPLETION: SURFICIAL (SF)

HYDRAULIC FLOW RELATIONSHIP: CROSS GRADIENT (C)

\begin{tabular}{|c|c|c|c|c|c|c|c|}
\hline PARAMETER NAME & LOG DATE & $\begin{array}{l}\text { SAMPLE } \\
\text { ID }\end{array}$ & $\begin{array}{l}\text { UNITS OF } \\
\text { MEASURE }\end{array}$ & PVI & $\begin{array}{l}\text { PARAMETER } \\
\text { VALUE FLAGS }\end{array}$ & $\begin{array}{l}\text { DETECTION } \\
\text { LIMIT }\end{array}$ & $\begin{array}{l}\text { PARAMETER } \\
\text { UNCERTAINTY }\end{array}$ \\
\hline ARSENIC & $\begin{array}{l}03 / 14 / 93 \\
01 / 09 / 94\end{array}$ & $\begin{array}{l}0001 \\
0001\end{array}$ & $M G / L$ & $<$ & $\begin{array}{l}0.005 \\
0.005\end{array}$ & $\begin{array}{l}0.005 \\
0.005\end{array}$ & - \\
\hline ARSENIC (TOTAL) & $03 / 14 / 93$ & N001 & $M G / L$ & $<$ & 0.005 & 0.005 & - \\
\hline MANGANESE & $\begin{array}{l}03 / 14 / 93 \\
01 / 09 / 94\end{array}$ & $\begin{array}{l}0001 \\
0001\end{array}$ & $M G / L$ & & $\begin{array}{l}0.35 \\
1.15\end{array}$ & $\begin{array}{l}0.01 \\
0.01\end{array}$ & - \\
\hline MANGANESE (TOTAL) & $03 / 14 / 93$ & N001 & $M G / L$ & & 0.32 & 0.01 & - \\
\hline MOLYBDENUM & $\begin{array}{l}02 / 25 / 93 \\
03 / 14 / 93 \\
01 / 09 / 94\end{array}$ & $\begin{array}{l}0001 \\
0001 \\
0001\end{array}$ & MG/L & $<$ & $\begin{array}{l}0.0082 \\
0.01 \\
0.01\end{array}$ & $\begin{array}{l}0.0005 \\
0.01 \\
0.01\end{array}$ & : \\
\hline MOLYBDENUM (TOTAL) & $\begin{array}{l}02 / 25 / 93 \\
03 / 14 / 93\end{array}$ & $\begin{array}{l}\text { N001 } \\
\text { N001 }\end{array}$ & $M G / L$ & $<$ & $\begin{array}{l}0.0082 \\
0.01\end{array}$ & $\begin{array}{l}0.0005 \\
0.01\end{array}$ & $\dot{-}$ \\
\hline NICKEL & $\begin{array}{l}03 / 14 / 93 \\
01 / 09 / 94\end{array}$ & $\begin{array}{l}0001 \\
0001\end{array}$ & $M G / L$ & $<$ & $\begin{array}{l}0.04 \\
0.04\end{array}$ & $\begin{array}{l}0.04 \\
0.04\end{array}$ & - \\
\hline NICKEL (TOTAL) & $03 / 14 / 93$ & N001 & $M G / L$ & $<$ & 0.04 & 0.04 & - \\
\hline SULFATE & $\begin{array}{l}02 / 25 / 93 \\
02 / 25 / 93 \\
01 / 09 / 94\end{array}$ & $\begin{array}{l}0001 \\
\text { N001 } \\
0001\end{array}$ & $M G / L$ & & $\begin{array}{l}406 \\
408 \\
411\end{array}$ & $\begin{array}{l}1.0 \\
1.0 \\
1\end{array}$ & : \\
\hline SULFATE (TOTAL) & $03 / 14 / 93$ & NOOI & $M G / L$ & & 351 & 1 & - \\
\hline URANIUM & $\begin{array}{l}02 / 25 / 93 \\
03 / 14 / 93 \\
01 / 09 / 94\end{array}$ & $\begin{array}{l}0001 \\
0001 \\
0001\end{array}$ & $M G / L$ & & $\begin{array}{l}0.0170 \\
0.010 \\
0.008\end{array}$ & $\begin{array}{l}0.0002 \\
0.001 \\
0.001\end{array}$ & : \\
\hline URANIUM (TOTAL) & $\begin{array}{l}02 / 25 / 93 \\
03 / 14 / 93\end{array}$ & $\begin{array}{l}\text { N001 } \\
\text { N001 }\end{array}$ & $M G / L$ & & $\begin{array}{l}0.0176 \\
0.009\end{array}$ & $\begin{array}{l}0.0002 \\
0.001\end{array}$ & - \\
\hline VANADIUM & $\begin{array}{l}03 / 14 / 93 \\
01 / 09 / 94\end{array}$ & $\begin{array}{l}0001 \\
0001\end{array}$ & $M G / L$ & $<$ & $\begin{array}{l}0.01 \\
0.01\end{array}$ & $\begin{array}{l}0.01 \\
0.01\end{array}$ & $\dot{-}$ \\
\hline VANADIUM (TOTAL) & $03 / 14 / 93$ & N001 & $M G / L$ & $<$ & 0.01 & 0.01 & $\cdot$ \\
\hline
\end{tabular}

PARAMETER VALUE INDICATOR (PVI): < - LESS THAN DETECTION LIMIT

SAMPLE ID CODES:

0001 - FILTERED SAMPLE (.45 MICRONS)

N001 - UNFILTERED SAMPLE 
LOCATION: 0721

NORTH COORDINATE: 20739.68 FT

EAST COORDINATE: 23682.91 FT

06/12/81 TO $01 / 10 / 94$

REPORT DATE: 09/07/94

FORMATION OF COMPLETION: SEMICONFINED SANDSTONE (SE)

HYDRAULIC FLOW RELATIONSHIP: CROSS GRADIENT (C)

\begin{tabular}{|c|c|c|c|c|c|c|c|}
\hline PARAMETER NAME & LOG DATE & $\begin{array}{c}\text { SAMPLE } \\
\text { ID }\end{array}$ & $\begin{array}{l}\text { UNITS OF } \\
\text { MEASURE }\end{array}$ & PVI & $\begin{array}{l}\text { PARAMETER } \\
\text { VALUE FLAGS }\end{array}$ & $\begin{array}{l}\text { DETECTION } \\
\text { LIMIT }\end{array}$ & $\begin{array}{l}\text { PARAMETER } \\
\text { UNCERTAINTY }\end{array}$ \\
\hline ARSENIC & $\begin{array}{l}03 / 14 / 93 \\
01 / 09 / 94\end{array}$ & $\begin{array}{l}0001 \\
0001\end{array}$ & MG/L & $\begin{array}{l}< \\
<\end{array}$ & $\begin{array}{l}0.005 \\
0.005\end{array}$ & $\begin{array}{l}0.005 \\
0.005\end{array}$ & - \\
\hline ARSENIC (TOTAL) & $03 / 14 / 93$ & NoO1 & $M G / L$ & $<$ & 0.005 & 0.005 & - \\
\hline MANGANESE & $\begin{array}{l}03 / 14 / 93 \\
01 / 09 / 94\end{array}$ & $\begin{array}{l}0001 \\
0001\end{array}$ & $M G / L$ & $<$ & $\begin{array}{l}0.01 \\
0.01\end{array}$ & $\begin{array}{l}0.01 \\
0.01\end{array}$ & - \\
\hline MANGANESE (TOTAL) & $03 / 14 / 93$ & No01 & $M G / L$ & & 0.01 & 0.01 & - \\
\hline MOL YBDENUM & $\begin{array}{l}02 / 25 / 93 \\
03 / 14 / 93 \\
01 / 09 / 94\end{array}$ & $\begin{array}{l}0001 \\
0001 \\
0001\end{array}$ & $M G / L$ & $<$ & $\begin{array}{l}0.0025 \\
0.01 \\
0.01\end{array}$ & $\begin{array}{l}0.0005 \\
0.01 \\
0.01\end{array}$ & $\begin{array}{l}- \\
-\end{array}$ \\
\hline MOLYBDEMUM (TOTAL) & $\begin{array}{l}02 / 25 / 93 \\
03 / 14 / 93\end{array}$ & $\begin{array}{l}\text { No01 } \\
\text { No01 }\end{array}$ & $M G / L$ & $<$ & $\begin{array}{l}0.0032 \\
0.01\end{array}$ & $\begin{array}{l}0.0005 \\
0.01\end{array}$ & - \\
\hline NICKEL & $\begin{array}{l}03 / 14 / 93 \\
01 / 09 / 94\end{array}$ & $\begin{array}{l}0001 \\
0001\end{array}$ & $M G / L$ & $<$ & $\begin{array}{l}0.04 \\
0.04\end{array}$ & $\begin{array}{l}0.04 \\
0.04\end{array}$ & - \\
\hline NICKEL (TOTAL) & $03 / 14 / 93$ & N001 & $M G / L$ & $<$ & 0.04 & 0.04 & - \\
\hline SULFATE & $\begin{array}{l}02 / 25 / 93 \\
02 / 25 / 93 \\
01 / 09 / 94\end{array}$ & $\begin{array}{l}0001 \\
N 001 \\
0001\end{array}$ & $M G / L$ & & $\begin{array}{l}230 \\
255 \\
274\end{array}$ & $\begin{array}{l}1.0 \\
1.0 \\
1\end{array}$ & $\begin{array}{l}- \\
-\end{array}$ \\
\hline SULFATE (TOTAL) & $03 / 14 / 93$ & No01 & MG/L & & 287 & 1 & - \\
\hline URANIUH & $\begin{array}{l}02 / 25 / 93 \\
03 / 14 / 93 \\
01 / 09 / 94\end{array}$ & $\begin{array}{l}0001 \\
0001 \\
0001\end{array}$ & $M G / L$ & $\begin{array}{l}< \\
<\end{array}$ & $\begin{array}{l}0.0005 \\
0.001 \\
0.001\end{array}$ & $\begin{array}{l}0.0002 \\
0.001 \\
0.001\end{array}$ & $\begin{array}{l}- \\
-\end{array}$ \\
\hline URANIUM (TOTAL) & $\begin{array}{l}02 / 25 / 93 \\
03 / 14 / 93\end{array}$ & $\begin{array}{l}\text { No01 } \\
\text { N001 }\end{array}$ & $M G / L$ & $<$ & $\begin{array}{l}0.0013 \\
0.001\end{array}$ & $\begin{array}{l}0.0002 \\
0.001\end{array}$ & 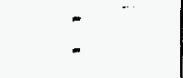 \\
\hline VANADIUM & $\begin{array}{l}03 / 14 / 93 \\
01 / 09 / 94\end{array}$ & $\begin{array}{l}0001 \\
0001\end{array}$ & $M G / L$ & $\begin{array}{l}< \\
<\end{array}$ & $\begin{array}{l}0.01 \\
0.01\end{array}$ & $\begin{array}{l}0.01 \\
0.01\end{array}$ & - \\
\hline VANADIUM (TOTAL) & $03 / 14 / 93$ & No01 & $M G / L$ & $<$ & 0.01 & 0.01 & - \\
\hline
\end{tabular}

PARAMETER VALUE INDICATOR (PVI): < - LESS THAN DETECTION LIMIT

SAMPLE ID CODES:

0001 - FILTERED SAMPLE (.45 MICRONS)

NOO1 - UNFILTERED SANPLE 
GROUNDWATER QUALITY DATA BY LOCATION

SITE: RVTO1 RIVERTON

LOCATION: 0722

NORTH COORDINATE: 22246.56 FT

EAST COORDINATE: 26603.32 FT

06/12/81 TO 01/10/94

REPORT DATE: 09/07/94

FORMATION OF COMPLETION: SURFICIAL (SF)

HYORAULIC FLOW RELATIONSHIP: DOWN GRADIENT (D)

\begin{tabular}{|c|c|c|c|c|c|c|c|}
\hline PARAMETER NAME & LOG DATE & $\begin{array}{c}\text { SAMPLE } \\
\text { ID }\end{array}$ & $\begin{array}{l}\text { UNITS OF } \\
\text { MEASURE }\end{array}$ & PVI & $\begin{array}{l}\text { PARAMETER } \\
\text { VALUE FLAGS }\end{array}$ & $\begin{array}{l}\text { DETECTION } \\
\text { LIMIT }\end{array}$ & $\begin{array}{l}\text { PARAMETER } \\
\text { UNCERTAINTY }\end{array}$ \\
\hline ARSENIC & $\begin{array}{l}03 / 16 / 93 \\
01 / 10 / 94\end{array}$ & $\begin{array}{l}0001 \\
0001\end{array}$ & $M G / L$ & $<$ & $\begin{array}{l}0.005 \\
0.005\end{array}$ & $\begin{array}{l}0.005 \\
0.005\end{array}$ & - \\
\hline ARSENIC (TOTAL) & $03 / 16 / 93$ & N001 & $M G / L$ & $<$ & 0.005 & 0.005 & - \\
\hline MANGANESE & $\begin{array}{l}03 / 16 / 93 \\
01 / 10 / 94\end{array}$ & $\begin{array}{l}0001 \\
0001\end{array}$ & $M G / L$ & & $\begin{array}{l}2.61 \\
2.71\end{array}$ & $\begin{array}{l}0.01 \\
0.01\end{array}$ & - \\
\hline MANGANESE (TOTAL) & $03 / 16 / 93$ & NoO1 & $M G / L$ & & 2.34 & 0.01 & - \\
\hline MOL YBDENUM & $\begin{array}{l}02 / 25 / 93 \\
03 / 16 / 93 \\
01 / 10 / 94\end{array}$ & $\begin{array}{l}0001 \\
0001 \\
0001\end{array}$ & MG $/ L$ & & $\begin{array}{l}0.1440 \\
0.14 \\
0.11\end{array}$ & $\begin{array}{l}0.0005 \\
0.01 \\
0.01\end{array}$ & $\begin{array}{l}- \\
-\end{array}$ \\
\hline MOLYBDENUM (TOTAL) & $\begin{array}{l}02 / 25 / 93 \\
03 / 16 / 93\end{array}$ & $\begin{array}{l}\text { NoO1 } \\
\text { No01 }\end{array}$ & $M G / L$ & & $\begin{array}{l}0.1390 \\
0.12\end{array}$ & $\begin{array}{l}0.0005 \\
0.01\end{array}$ & - \\
\hline HICKEL & $\begin{array}{l}03 / 16 / 93 \\
01 / 10 / 94\end{array}$ & $\begin{array}{l}0001 \\
0001\end{array}$ & MG /L & $<$ & $\begin{array}{l}0.04 \\
0.04\end{array}$ & $\begin{array}{l}0.04 \\
0.04\end{array}$ & - \\
\hline HICKEL (TOTAL) & $03 / 16 / 93$ & NoO1 & $\mathrm{MG} / \mathrm{L}$ & & 0.06 & 0.04 & - \\
\hline SULFATE & $\begin{array}{l}02 / 25 / 93 \\
02 / 25 / 93 \\
03 / 16 / 93 \\
01 / 10 / 94\end{array}$ & $\begin{array}{l}0001 \\
\text { N001 } \\
0001 \\
0001\end{array}$ & $M G / L$ & & $\begin{array}{l}1800 \\
1780 \\
1750 \\
1720\end{array}$ & $\begin{array}{l}1.0 \\
1.0 \\
1 \\
1\end{array}$ & $\begin{array}{l}- \\
- \\
-\end{array}$ \\
\hline URANIUM & $\begin{array}{l}02 / 25 / 93 \\
03 / 16 / 93 \\
01 / 10 / 94\end{array}$ & $\begin{array}{l}0001 \\
0001 \\
0001\end{array}$ & $M G / L$ & & $\begin{array}{l}1.5400 \\
1.39 \\
1.57\end{array}$ & $\begin{array}{l}0.0002 \\
0.001 \\
0.001\end{array}$ & $\begin{array}{l}- \\
-\end{array}$ \\
\hline URANIUM (TOTAL) & $02 / 25 / 93$ & No01 & $M G / L$ & & 1.5700 & 0.0002 & - \\
\hline VANAD IUM & $\begin{array}{l}03 / 16 / 93 \\
01 / 10 / 94\end{array}$ & $\begin{array}{l}0001 \\
0001\end{array}$ & $M G / L$ & $\begin{array}{l}< \\
<\end{array}$ & $\begin{array}{l}0.01 \\
0.01\end{array}$ & $\begin{array}{l}0.01 \\
0.01\end{array}$ & - \\
\hline VANADIUM (TOTAL) & $03 / 16 / 93$ & No01 & $M G / L$ & $<$ & 0.01 & 0.01 & - \\
\hline
\end{tabular}

PARANETER VALUE INDICATOR (PVI): < - LESS THAN DETECTION LIMIT

SAMPLE ID CODES:

0001 - FILTERED SAMPLE (.45 MICRONS)

OTHER PARAMETER VALUE FLAGS:

NOO1 - UNFILTERED SAMPLE

$H$ - POST-DIGEST SPIKE OUT OF CNTR LIM WHILE SAMP ABS < 50\% SPIKE 
GROUNDWATER QUALITY DATA BY LOCATION

SITE: RVTO1 RIVERTON

LOCATION: 0723

NORTH COORDIMATE: 22254.32 FT

EAST COORDINATE: 26616.55 FT

06/12/81 TO $01 / 10 / 94$

REPORT DATE: 09/07/94

FORMATION OF COMPLETION: SEMICONFINED SANDSTONE (SE)

HYDRAULIC FLOW RELATIONSHIP: DOWN GRADIENT (D)

\begin{tabular}{|c|c|c|c|c|c|c|c|}
\hline PARAMETER NAME & LOG DATE & $\underset{\text { SD }}{\text { SAMPLE }}$ & $\begin{array}{l}\text { UNITS OF } \\
\text { MEASURE }\end{array}$ & PVI & $\begin{array}{l}\text { PARAMETER } \\
\text { VALUE FLAGS }\end{array}$ & $\begin{array}{l}\text { DETECTION } \\
\text { LIMIT }\end{array}$ & $\begin{array}{l}\text { PARAMETER } \\
\text { UNCERTAINTY }\end{array}$ \\
\hline ARSENIC & $\begin{array}{l}03 / 16 / 93 \\
01 / 10 / 94\end{array}$ & $\begin{array}{l}0001 \\
0001\end{array}$ & $M G / L$ & 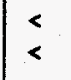 & $\begin{array}{l}0.005 \\
0.005\end{array}$ & $\begin{array}{l}0.005 \\
0.005\end{array}$ & - \\
\hline ARSENIC (TOTAL) & $03 / 16 / 93$ & NOO1 & MG/L & $<$ & 0.005 & 0.005 & - \\
\hline MANGANESE & $\begin{array}{l}03 / 16 / 93 \\
01 / 10 / 94\end{array}$ & $\begin{array}{l}0001 \\
0001\end{array}$ & $M G / L$ & & $\begin{array}{l}0.91 \\
0.72\end{array}$ & $\begin{array}{l}0.01 \\
0.01\end{array}$ & : \\
\hline MANGANESE (TOTAL) & $03 / 16 / 93$ & N001 & $M G / L$ & & 0.87 & 0.01 & - \\
\hline MOL YBDENUM & $\begin{array}{l}02 / 25 / 93 \\
03 / 16 / 93 \\
01 / 10 / 94\end{array}$ & $\begin{array}{l}0001 \\
0001 \\
0001\end{array}$ & $M G / L$ & $<$ & $\begin{array}{l}0.0035 \\
0.01 \\
0.01\end{array}$ & $\begin{array}{l}0.0005 \\
0.01 \\
0.01\end{array}$ & : \\
\hline MOLYBDENUM (TOTAL) & $\begin{array}{l}02 / 25 / 93 \\
03 / 16 / 93\end{array}$ & $\begin{array}{l}\text { N001 } \\
\text { N001 }\end{array}$ & $M G / L$ & $<$ & $\begin{array}{l}0.0023 \\
0.01\end{array}$ & $\begin{array}{l}0.0005 \\
0.01\end{array}$ & - \\
\hline NICKEL & $\begin{array}{l}03 / 16 / 93 \\
01 / 10 / 94\end{array}$ & $\begin{array}{l}0001 \\
0001\end{array}$ & $M G / L$ & $<$ & $\begin{array}{l}0.04 \\
0.04\end{array}$ & $\begin{array}{l}0.04 \\
0.04\end{array}$ & - \\
\hline NICKEL (TOTAL) & $03 / 16 / 93$ & N001 & $M G / L$ & $<$ & 0.04 & 0.04 & - \\
\hline SULFATE & $\begin{array}{l}02 / 25 / 93 \\
02 / 25 / 93 \\
03 / 16 / 93 \\
01 / 10 / 94\end{array}$ & $\begin{array}{l}0001 \\
\text { N001 } \\
0001 \\
0001\end{array}$ & $M G / L$ & & $\begin{array}{l}2060 \\
2070 \\
1860 \\
1740\end{array}$ & $\begin{array}{l}1.0 \\
1.0 \\
1 \\
1\end{array}$ & : \\
\hline URAN IUM & $\begin{array}{l}02 / 25 / 93 \\
03 / 16 / 93 \\
01 / 10 / 94\end{array}$ & $\begin{array}{l}0001 \\
0001 \\
0001\end{array}$ & $M G / L$ & $<$ & $\begin{array}{l}0.0310 \\
0.008 \\
0.001\end{array}$ & $\begin{array}{l}0.0002 \\
0.001 \\
0.001\end{array}$ & $:$ \\
\hline URANIUM (TOTAL) & $\begin{array}{l}02 / 25 / 93 \\
03 / 16 / 93\end{array}$ & $\begin{array}{l}\text { N001 } \\
\text { N001 }\end{array}$ & MG/L & & $\begin{array}{l}0.0164 \\
0.012\end{array}$ & $\begin{array}{l}0.0002 \\
0.001\end{array}$ & - \\
\hline VANADIUM & $\begin{array}{l}03 / 16 / 93 \\
01 / 10 / 94\end{array}$ & $\begin{array}{l}0001 \\
0001\end{array}$ & $M G / L$ & $<$ & $\begin{array}{l}0.01 \\
0.01\end{array}$ & $\begin{array}{l}0.01 \\
0.01\end{array}$ & - \\
\hline VANADIUM (TOTAL) & $03 / 16 / 93$ & N001 & $M G / L$ & $<$ & 0.01 & 0.01 & - \\
\hline
\end{tabular}

PARAMETER VALUE INDICATOR (PVI): < - LESS THAN DETECTION LIMIT

SAMPLE ID CODES:

OTHER PARAMETER VALUE FLAGS:

$W$ - POST-DIGEST SPIKE OUT OF CNTR LIM WHILE SAMP ABS < 50\% SPIKE

0001 - FILTERED SAMPLE (.45 MICRONS)

NDO1 - UNFILTERED SAMPLE 
GROUNDWATER QUALITY DATA BY LOCATION

SITE: RVTO1 RIVERTON

LOCATION: 0724

NORTH COORDINATE: 24896.73 FT

EAST COORDINATE: $\quad 26260.41$ FT

06/12/81 TO 01/10/94

REPORT DATE: $09 / 07 / 94$

FORMATION OF COMPLETION: SURFICIAL (SF)

HYDRAULIC FLOW RELATIONSHIP: UPGRADIENT (U)

\begin{tabular}{|c|c|c|c|c|c|c|c|}
\hline PARAMETER NAME & LOG DATE & $\begin{array}{c}\text { SAMPLE } \\
\text { ID }\end{array}$ & $\begin{array}{l}\text { UNITS OF } \\
\text { MEASURE }\end{array}$ & PVI & $\begin{array}{l}\text { PARAMETER } \\
\text { VALUE FLAGS }\end{array}$ & $\begin{array}{l}\text { DETECTION } \\
\text { LIMIT }\end{array}$ & $\begin{array}{l}\text { PARAMETER } \\
\text { UNCERTAINTY }\end{array}$ \\
\hline ARSENIC & $\begin{array}{l}04 / 02 / 93 \\
01 / 08 / 94\end{array}$ & $\begin{array}{l}0001 \\
0001\end{array}$ & $M G / L$ & $<$ & $\begin{array}{l}0.005 \quad W \\
0.005\end{array}$ & $\begin{array}{l}0.005 \\
0.005\end{array}$ & - \\
\hline ARSENIC (TOTAL) & $04 / 02 / 93$ & N001 & $M G / L$ & $<$ & 0.005 & 0.005 & - \\
\hline MANGANESE & $\begin{array}{l}04 / 02 / 93 \\
01 / 08 / 94\end{array}$ & $\begin{array}{l}0001 \\
0001\end{array}$ & $M G / L$ & & $\begin{array}{l}0.04 \\
0.07\end{array}$ & $\begin{array}{l}0.01 \\
0.01\end{array}$ & - \\
\hline MANGANESE (TOTAL) & $04 / 02 / 93$ & N001 & $M G / L$ & & 0.03 & 0.01 & - \\
\hline MOLYBDENUM & $\begin{array}{l}04 / 02 / 93 \\
01 / 08 / 94\end{array}$ & $\begin{array}{l}0001 \\
0001\end{array}$ & $M G / L$ & $<$ & $\begin{array}{l}0.01 \\
0.01\end{array}$ & $\begin{array}{l}0.01 \\
0.01\end{array}$ & - \\
\hline MOLYBDENUM (TOTAL) & $04 / 02 / 93$ & N001 & $M G / L$ & $<$ & 0.01 & 0.01 & - \\
\hline SULFATE & $\begin{array}{l}04 / 02 / 93 \\
01 / 08 / 94\end{array}$ & $\begin{array}{l}0001 \\
0001\end{array}$ & $M G / L$ & & $\begin{array}{l}214 \\
225\end{array}$ & $\begin{array}{l}1 \\
1\end{array}$ & - \\
\hline URANIUM & $\begin{array}{l}04 / 02 / 93 \\
01 / 08 / 94\end{array}$ & $\begin{array}{l}0001 \\
0001\end{array}$ & $M G / L$ & & $\begin{array}{l}0.031 \\
0.028\end{array}$ & $\begin{array}{l}0.001 \\
0.001\end{array}$ & - \\
\hline URANIUM (TOTAL) & $04 / 02 / 93$ & N001 & $M G / L$ & & 0.028 & 0.001 & - \\
\hline VANADIUM & $\begin{array}{l}04 / 02 / 93 \\
01 / 08 / 94\end{array}$ & $\begin{array}{l}0001 \\
0001\end{array}$ & $M G / L$ & $<$ & $\begin{array}{l}0.01 \\
0.01\end{array}$ & $\begin{array}{l}0.01 \\
0.01\end{array}$ & $\begin{array}{l}- \\
-\end{array}$ \\
\hline VANADIUM (TOTAL) & $04 / 02 / 93$ & No01 & MG/L & $<$ & 0.01 & 0.01 & - \\
\hline
\end{tabular}

PARAMETER VALUE INDICATOR (PVI): < - LESS THAN DETECTION LIMIT

SAMPLE ID CODES:

0001 - FILTERED SAMPLE (.45 MICRONS)

OTHER PARAMETER VALUE FLAGS:

N001 - UNFILTERED SAMPLE

$W$ - POST-DIGEST SPIKE OUT OF CNTR LIM WHILE SAMP ABS < 50\% SPIKE 
GROUNDWATER QUALITY DATA BY LOCATION

SITE: RVTOI RIVERTON

LOCATION: 0725

HORTH COORDINATE: $\quad 24896.73$ FT

EAST COORDINATE: 26260.41 FT

06/12/81 TO 01/10/94

REPORT DATE: 09/07/94

FORMATION OF COMPLETION: SEMICONFINED SANDSTONE (SE)

HYDRAULIC FLOW RELATIONSHIP: UPGRADIENT (U)

\begin{tabular}{|c|c|c|c|c|c|c|c|}
\hline PARAMETER NAME & LOG DATE & $\begin{array}{c}\text { SAMPLE } \\
\text { ID }\end{array}$ & $\begin{array}{l}\text { UNITS OF } \\
\text { MEASURE }\end{array}$ & PVI & $\begin{array}{l}\text { PARAMETER } \\
\text { VALUE FLAGS }\end{array}$ & $\begin{array}{l}\text { DETECTION } \\
\text { LIMIT }\end{array}$ & $\begin{array}{l}\text { PARAMETER } \\
\text { UNCERTAINTY }\end{array}$ \\
\hline ARSENIC & $\begin{array}{l}03 / 14 / 93 \\
01 / 08 / 94\end{array}$ & $\begin{array}{l}0001 \\
0001\end{array}$ & MG/L & $<$ & $\begin{array}{l}0.005 \\
0.005\end{array}$ & $\begin{array}{l}0.005 \\
0.005\end{array}$ & - \\
\hline ARSENIC (TOTAL) & $03 / 14 / 93$ & No01 & $M G / L$ & $<$ & 0.005 & 0.005 & - \\
\hline MANGANESE & $\begin{array}{l}03 / 14 / 93 \\
01 / 08 / 94\end{array}$ & $\begin{array}{l}0001 \\
0001\end{array}$ & $M G / L$ & & $\begin{array}{l}0.06 \\
0.06\end{array}$ & $\begin{array}{l}0.01 \\
0.01\end{array}$ & - \\
\hline MANGANESE (TOTAL) & $03 / 14 / 93$ & No01 & $M G / L$ & & 0.06 & 0.01 & - \\
\hline MOLYBDENUM & $\begin{array}{l}03 / 14 / 93 \\
01 / 08 / 94\end{array}$ & $\begin{array}{l}0001 \\
0001\end{array}$ & $M G / L$ & $<$ & $\begin{array}{l}0.01 \\
0.01\end{array}$ & $\begin{array}{l}0.01 \\
0.01\end{array}$ & - \\
\hline MOL YBDENUM (TOTAL) & $03 / 14 / 93$ & N001. & $M G / L$ & $<$ & 0.01 & 0.01 & - \\
\hline NICKEL & $\begin{array}{l}03 / 14 / 93 \\
01 / 08 / 94\end{array}$ & $\begin{array}{l}0001 \\
0001\end{array}$ & $M G / L$ & $<$ & $\begin{array}{l}0.04 \\
0.04\end{array}$ & $\begin{array}{l}0.04 \\
0.04\end{array}$ & - \\
\hline NICKEL (TOTAL) & $03 / 14 / 93$ & N001 & $M G / L$ & $<$ & 0.04 & 0.04 & - \\
\hline SULFATE & $01 / 08 / 94$ & 0001 & $M G / L$ & & 1940 & 1 & - \\
\hline SULFATE (TOTAL) & $03 / 14 / 93$ & N001 & $M G / L$ & & 207 & 1 & - \\
\hline URANIUM & $\begin{array}{l}03 / 14 / 93 \\
01 / 08 / 94\end{array}$ & $\begin{array}{l}0001 \\
0001\end{array}$ & $M G / L$ & & $\begin{array}{l}0.008 \\
0.009\end{array}$ & $\begin{array}{l}0.001 \\
0.001\end{array}$ & - \\
\hline URANIUM (TOTAL) & $03 / 14 / 93$ & N001 & $M G / L$ & & 0.008 & 0.001 & - \\
\hline VANADIUM & $\begin{array}{l}03 / 14 / 93 \\
01 / 08 / 94\end{array}$ & $\begin{array}{l}0001 \\
0001\end{array}$ & $M G / L$ & $<$ & $\begin{array}{l}0.01 \\
0.01\end{array}$ & $\begin{array}{l}0.01 \\
0.01\end{array}$ & - \\
\hline VANADIUM (TOTAL) & $03 / 14 / 93$ & No01 & MG/L & $<$ & 0.01 & 0.01 & - \\
\hline
\end{tabular}

PARAMETER VALUE INDICATOR (PVI): < - LESS THAN DETECTION LIMIT

SAMPLE ID CODES

0001 - FILTERED SAMPLE (.45 MICRONS)

N001 - UNFILTERED SAMPLE 
GROUNDWATER QUALITY DATA BY LOCATION

SITE: RVTO1 RIVERTON

LOCATION: 0726

NORTH COORDINATE: $\quad 24904.00$ FT

EAST COORDINATE: $26251.00 \mathrm{FT}$

06/12/81 TO 01/10/94

REPORT DATE: $09 / 07 / 94$

FORMATION OF COMPLETION: SANDSTONE (SS)

HYDRAULIC FLOW RELATIONSHIP: UPGRADIENT (U)

\begin{tabular}{|c|c|c|c|c|c|c|c|c|}
\hline PARAMETER NAME & LOG DATE & $\begin{array}{c}\text { SAMPLE } \\
10\end{array}$ & $\begin{array}{l}\text { UNITS OF } \\
\text { MEASURE }\end{array}$ & PVI & $\begin{array}{l}\text { PARAMETER } \\
\text { VALUE }\end{array}$ & FLAGS & $\begin{array}{l}\text { DETECTION } \\
\text { LIMIT }\end{array}$ & $\begin{array}{l}\text { PARAMETER } \\
\text { UNCERTAINTY }\end{array}$ \\
\hline ARSENIC & $\begin{array}{l}04 / 19 / 93 \\
01 / 10 / 94\end{array}$ & $\begin{array}{l}0001 \\
0001\end{array}$ & $M G / L$ & $<$ & $\begin{array}{l}0.005 \\
0.005\end{array}$ & $w$ & $\begin{array}{l}0.005 \\
0.005\end{array}$ & - \\
\hline ARSENIC (TOTAL) & $\begin{array}{l}04 / 02 / 93 \\
04 / 19 / 93 \\
04 / 19 / 93\end{array}$ & $\begin{array}{l}\text { N001 } \\
\text { N001 } \\
\text { N002 }\end{array}$ & MG/L & $<$ & $\begin{array}{l}0.017 \\
0.005 \\
0.005\end{array}$ & $L$ & $\begin{array}{l}0.005 \\
0.005 \\
0.005\end{array}$ & - \\
\hline MANGANESE (TOTAL) & $\begin{array}{l}04 / 02 / 93 \\
04 / 19 / 93 \\
04 / 19 / 93\end{array}$ & $\begin{array}{l}\text { N001 } \\
\text { N001 } \\
\text { N002 }\end{array}$ & $M G / L$ & & $\begin{array}{l}0.37 \\
0.03 \\
0.02\end{array}$ & $\mathbf{L}$ & $\begin{array}{l}0.01 \\
0.01 \\
0.01\end{array}$ & - \\
\hline MOL YBDENUM & $\begin{array}{l}04 / 19 / 93 \\
01 / 10 / 94\end{array}$ & $\begin{array}{l}0001 \\
0001\end{array}$ & $M G / L$ & $<$ & $\begin{array}{l}0.01 \\
0.01\end{array}$ & & $\begin{array}{l}0.01 \\
0.01\end{array}$ & - \\
\hline NICKEL & $\begin{array}{l}04 / 19 / 93 \\
01 / 10 / 94\end{array}$ & $\begin{array}{l}0001 \\
0001\end{array}$ & $M G / L$ & $<$ & $\begin{array}{l}0.04 \\
0.04\end{array}$ & & $\begin{array}{l}0.04 \\
0.04\end{array}$ & - \\
\hline NICKEL (TOTAL) & $\begin{array}{l}04 / 02 / 93 \\
04 / 19 / 93 \\
04 / 19 / 93\end{array}$ & $\begin{array}{l}\text { No01 } \\
\text { No01 } \\
\text { No02 }\end{array}$ & $M G / L$ & $<$ & $\begin{array}{l}0.06 \\
0.04 \\
0.04\end{array}$ & L & $\begin{array}{l}0.04 \\
0.04 \\
0.04\end{array}$ & - \\
\hline SULFATE & $\begin{array}{l}04 / 19 / 93 \\
01 / 10 / 94\end{array}$ & $\begin{array}{l}0001 \\
0001\end{array}$ & $M G / L$ & & $\begin{array}{l}169 \\
159\end{array}$ & & $\begin{array}{l}1 \\
1\end{array}$ & - \\
\hline SULFATE (TOTAL) & $\begin{array}{l}04 / 02 / 93 \\
04 / 19 / 93\end{array}$ & $\begin{array}{l}\text { N001 } \\
\text { N002 }\end{array}$ & $M G / L$ & & $\begin{array}{l}225 \\
162\end{array}$ & $\mathbf{L}$ & $\begin{array}{l}1 \\
1\end{array}$ & - \\
\hline VANADIUM (TOTAL) & $\begin{array}{l}04 / 02 / 93 \\
04 / 19 / 93 \\
04 / 19 / 93\end{array}$ & $\begin{array}{l}\text { N001 } \\
\text { N001 } \\
\text { N002 }\end{array}$ & MG/L & $<$ & $\begin{array}{l}0.07 \\
0.02 \\
0.01\end{array}$ & $\begin{array}{l}\text { L } \\
*\end{array}$ & $\begin{array}{l}0.01 \\
0.01 \\
0.01\end{array}$ & - \\
\hline
\end{tabular}

PARAMETER VALUE INDICATOR (PVI): < - LESS THAN DETECTION LIMIT

SAMPLE ID CODES:

0001 - FILTERED SAMPLE (.45 MICRONS)

OTHER PARAMETER VALUE FLAGS:

* - DUPLICATE aNalysis nOt hithin CONTROL limits

NO01 - UNFILTERED SAMPLE

L - LESS THAN THREE BORE VOLUMES REMOVED BEFORE SAMPLING

NOO2 - UNFILTERED REPLICATE SAMPLE

$W$ - POST-DIGEST SPIKE OUT OF CNTR LIM WHILE SAMP ABS < $50 \%$ SPIKE 
GROUNDWATER QUALITY DATA BY LOCATION

SITE: RVTOI RIVERTON

LOCATION: 0727

NORTH COORDINATE: $24893.70 \mathrm{FT}$

EAST COORDINATE: 23811.24 FT

06/12/81 TO $01 / 10 / 94$

REPORT DATE: 09/07/94

FORMATION OF COMPLETION: SEMICONFINED SANDSTONE (SE)

HYDRAULIC FLOW RELATIONSHIP: UPGRADIENT (U)

\begin{tabular}{|c|c|c|c|c|c|c|c|}
\hline PARAMETER NAME & LOG DATE & $\underset{10}{\text { SAMPLE }}$ & $\begin{array}{l}\text { UNITS OF } \\
\text { MEASURE }\end{array}$ & PVI & $\begin{array}{l}\text { PARAMETER } \\
\text { VALUE FLAGS }\end{array}$ & $\begin{array}{l}\text { DETECTION } \\
\text { LIMIT }\end{array}$ & $\begin{array}{l}\text { PARAMETER } \\
\text { UNCERTAINTY }\end{array}$ \\
\hline ARSENIC & $\begin{array}{l}03 / 31 / 93 \\
01 / 08 / 94\end{array}$ & $\begin{array}{l}0001 \\
0001\end{array}$ & $M G / L$ & $<$ & $\begin{array}{l}0.005 \\
0.005\end{array}$ & $\begin{array}{l}0.005 \\
0.005\end{array}$ & - \\
\hline ARSENIC (TOTAL) & $03 / 31 / 93$ & N001 & $M G / L$ & $<$ & 0.005 & 0.005 & - \\
\hline MANGANESE & $\begin{array}{l}03 / 31 / 93 \\
01 / 08 / 94\end{array}$ & $\begin{array}{l}0001 \\
0001\end{array}$ & $M G / L$ & & $\begin{array}{l}0.02 \\
0.02\end{array}$ & $\begin{array}{l}0.01 \\
0.01\end{array}$ & - \\
\hline MANGANESE (TOTAL) & $03 / 31 / 93$ & NDO1 & MG $/ \mathrm{L}$ & & 0.01 & 0.01 & - \\
\hline MOLYBDENUM & $\begin{array}{l}03 / 31 / 93 \\
01 / 08 / 94\end{array}$ & $\begin{array}{l}0001 \\
0001\end{array}$ & $M G / L$ & $<$ & $\begin{array}{l}0.01 \\
0.01\end{array}$ & $\begin{array}{l}0.01 \\
0.01\end{array}$ & - \\
\hline MOLYBDENUM (TOTAL) & $03 / 31 / 93$ & N001 & MG/L & $<$ & 0.01 & 0.01 & - \\
\hline NICKEL & $\begin{array}{l}03 / 31 / 93 \\
01 / 08 / 94\end{array}$ & $\begin{array}{l}0001 \\
0001\end{array}$ & $M G / L$ & $<$ & $\begin{array}{l}0.04 \\
0.04\end{array}$ & $\begin{array}{l}0.04 \\
0.04\end{array}$ & - \\
\hline NICKEL (TOTAL) & $03 / 31 / 93$ & N001 & $M G / L$ & $<$ & 0.04 & 0.04 & - \\
\hline SULFATE & $\begin{array}{l}03 / 31 / 93 \\
01 / 08 / 94\end{array}$ & $\begin{array}{l}0001 \\
0009\end{array}$ & MG/L & & $\begin{array}{l}170 \\
141\end{array}$ & $\begin{array}{l}1 \\
1\end{array}$ & - \\
\hline URANIUM & $\begin{array}{l}03 / 31 / 93 \\
01 / 08 / 94\end{array}$ & $\begin{array}{l}0001 \\
0001\end{array}$ & $M G / L$ & & $\begin{array}{l}0.002 \\
0.001\end{array}$ & $\begin{array}{l}0.001 \\
0.001\end{array}$ & - \\
\hline URANIUM (TOTAL) & $03 / 31 / 93$ & N001 & MG/L & & 0.002 & 0.001 & - \\
\hline VANADIUM & $\begin{array}{l}03 / 31 / 93 \\
01 / 08 / 94\end{array}$ & $\begin{array}{l}0001 \\
0001\end{array}$ & $M G / L$ & $<$ & $\begin{array}{l}0.01 \\
0.01\end{array}$ & $\begin{array}{l}0.01 \\
0.01\end{array}$ & - \\
\hline VANADIUM (TOTAL) & $03 / 31 / 93$ & N001 & $M G / L$ & $<$ & 0.01 & 0.01 & $=\cdots$ \\
\hline
\end{tabular}

PARAMETER VALUE INDICATOR (PVI): < - LESS THAN DETECTION LIMIT

SAMPLE ID COOES:

OTHER PARAMETER VALUE FLAGS:

0001 - FILTERED SAMPLE (.45 MICRONS)

$W$ - POST-DIGEST SPIKE OUT OF CNTR LIM WHILE SAMP ABS < 50\% SPIKE

N001 - UNFILTERED SAMPLE 
GROUNDWATER QUALITY DATA BY LOCATION

SITE: RVTO 1 RIVERTON

LOCATION: 0728

NORTH COORDINATE: 24893.74 FT

EAST COORDINATE: 24934.93 FT

06/12/81 TO $01 / 10 / 94$

REPORT DATE: 09/07/94

FORMATION OF COMPLETION: SURFICIAL (SF)

HYDRAULIC FLOW RELATIONSHIP: UPGRADIENT (U)

\begin{tabular}{|c|c|c|c|c|c|c|c|}
\hline PARAMETER NAME & LOG DATE & $\begin{array}{c}\text { SAMPLE } \\
10\end{array}$ & $\begin{array}{l}\text { UNITS OF } \\
\text { MEASURE }\end{array}$ & PVI & $\begin{array}{l}\text { PARAMETER } \\
\text { VALUE FLAGS }\end{array}$ & $\begin{array}{l}\text { DETECTION } \\
\text { LIMIT }\end{array}$ & $\begin{array}{l}\text { PARAMETER } \\
\text { UNCERTAINTY }\end{array}$ \\
\hline ARSENIC & $\begin{array}{l}03 / 31 / 93 \\
01 / 08 / 94\end{array}$ & $\begin{array}{l}0001 \\
0001\end{array}$ & $M G / L$ & $<$ & $\begin{array}{ll}0.005 & W \\
0.005 & H\end{array}$ & $\begin{array}{l}0.005 \\
0.005\end{array}$ & $\dot{-}$ \\
\hline ARSENIC (TOTAL) & $03 / 31 / 93$ & N001 & $M G / L$ & $<$ & $0.005 \quad W$ & 0.005 & - \\
\hline MANGANESE & $\begin{array}{l}03 / 31 / 93 \\
01 / 08 / 94\end{array}$ & $\begin{array}{l}0001 \\
0001\end{array}$ & $M G / L$ & $<$ & $\begin{array}{l}0.01 \\
0.01\end{array}$ & $\begin{array}{l}0.01 \\
0.01\end{array}$ & $\dot{-}$ \\
\hline MANGANESE (TOTAL) & $03 / 31 / 93$ & N001 & MG/L & $<$ & 0.01 & 0.01 & - \\
\hline MOLYBDEENUM & $\begin{array}{l}03 / 31 / 93 \\
01 / 08 / 94\end{array}$ & $\begin{array}{l}0001 \\
0001\end{array}$ & MG/L & $<$ & $\begin{array}{l}0.01 \\
0.01\end{array}$ & $\begin{array}{l}0.01 \\
0.01\end{array}$ & - \\
\hline MOLYBDENUM (TOTAL) & $03 / 31 / 93$ & N001 & $M G / L$ & $<$ & 0.01 & 0.01 & - \\
\hline NICKEL & $\begin{array}{l}03 / 31 / 93 \\
01 / 08 / 94\end{array}$ & $\begin{array}{l}0001 \\
0001\end{array}$ & $M G / L$ & $<$ & $\begin{array}{l}0.04 \\
0.04\end{array}$ & $\begin{array}{l}0.04 \\
0.04\end{array}$ & - \\
\hline HICKEL (TOTAL) & $03 / 31 / 93$ & NO01 & $M G / L$ & $<$ & 0.04 & 0.04 & - \\
\hline SULFATE & $\begin{array}{l}03 / 31 / 93 \\
01 / 08 / 94\end{array}$ & $\begin{array}{l}0001 \\
0001\end{array}$ & $M G / L$ & & $\begin{array}{r}106 \\
97\end{array}$ & $\begin{array}{l}1 \\
1\end{array}$ & - \\
\hline URANIUM & $\begin{array}{l}03 / 31 / 93 \\
01 / 08 / 94\end{array}$ & $\begin{array}{l}0001 \\
0001\end{array}$ & MG/L & & $\begin{array}{l}0.015 \\
0.014\end{array}$ & $\begin{array}{l}0.001 \\
0.001\end{array}$ & - \\
\hline URANIUM (TOTAL) & $03 / 31 / 93$ & N001 & MG/L & & 0.015 & 0.001 & - \\
\hline VANADIUM & $\begin{array}{l}03 / 31 / 93 \\
01 / 08 / 94\end{array}$ & $\begin{array}{l}0001 \\
0001\end{array}$ & $M G / L$ & $<$ & $\begin{array}{l}0.01 \\
0.01\end{array}$ & $\begin{array}{l}0.01 \\
0.01\end{array}$ & - \\
\hline VANADIUM (TOTAL) & $03 / 31 / 93$ & No01 & $M G / L$ & $<$ & 0.01 & 0.01 & - \\
\hline
\end{tabular}

PARAMETER VALUE INDICATOR (PVI): < - LESS THAN DETECTION LIMIT

SAMPLE ID CODES:

0001 - FILTERED SAMPLE (.45 MICRONS)

OTHER PARAMETER VALUE FLAGS:

$W$ - POST-DIGEST SPIKE OUT OF CNTR LIM WHILE SAMP ABS < 50\% SPIKE

NOO1 - UNFILTERED SAMPLE 
GROUNDWATER QUALITY DATA BY LOCATION

SITE: RVTO1. RIVERTON

LOCATION: 0729

NORTH COORDINATE: 23228.03 FT

EAST COORDINATE: 28349.91 FT

06/12/81 TO 01/10/94

REPORT DATE: 09/07/94

FORMATION OF COMPLETION: SURFICIAL (SF)

HYDRAULIC FLOW RELATIONSHIP: DOWN GRADIENT (D)

\begin{tabular}{|c|c|c|c|c|c|c|c|}
\hline PARAMETER NAME & LOG DATE & $\underset{10}{\text { SAMPLE }}$ & $\begin{array}{l}\text { UNITS OF } \\
\text { MEASURE }\end{array}$ & PVI & $\begin{array}{l}\text { PARAMETER } \\
\text { VALUE FLAGS }\end{array}$ & $\begin{array}{l}\text { DETECTION } \\
\text { LIMIT }\end{array}$ & $\begin{array}{l}\text { PARAMETER } \\
\text { UNCERTAINTY }\end{array}$ \\
\hline ARSENIC & $\begin{array}{l}04 / 02 / 93 \\
01 / 10 / 94\end{array}$ & $\begin{array}{l}0001 \\
0001\end{array}$ & MG/L & $<$ & $\begin{array}{l}0.005 \\
0.005\end{array}$ & $\begin{array}{l}0.005 \\
0.005\end{array}$ & $\dot{-}$ \\
\hline ARSENIC (TOTAL) & $04 / 02 / 93$ & N001 & MG/L & $<$ & $0.005 \mathrm{~W}$ & 0.005 & - \\
\hline MANGANESE & $\begin{array}{l}04 / 02 / 93 \\
01 / 10 / 94\end{array}$ & $\begin{array}{l}0001 \\
0001\end{array}$ & MG $/ L$ & $<$ & $\begin{array}{l}0.01 \\
0.01\end{array}$ & $\begin{array}{l}0.01 \\
0.01\end{array}$ & - \\
\hline MANGANESE (TOTAL) & $04 / 02 / 93$ & N001 & $M G / L$ & & 0.01 & 0.01 & - \\
\hline MOL YBDENUM & $\begin{array}{l}04 / 02 / 93 \\
01 / 10 / 94\end{array}$ & $\begin{array}{l}0001 \\
0001\end{array}$ & $M G / L$ & $<$ & $\begin{array}{l}0.01 \\
0.01\end{array}$ & $\begin{array}{l}0.01 \\
0.01\end{array}$ & - \\
\hline MOLYBDENUM (TOTAL) & $04 / 02 / 93$ & N001 & $M G / L$ & $<$ & 0.01 & 0.01 & - \\
\hline SULFATE & $\begin{array}{l}04 / 02 / 93 \\
01 / 10 / 94\end{array}$ & $\begin{array}{l}0001 \\
0001\end{array}$ & $M G / L$ & & $\begin{array}{l}168 \\
143\end{array}$ & $\begin{array}{l}1 \\
1\end{array}$ & - \\
\hline URANIUM & $\begin{array}{l}04 / 02 / 93 \\
01 / 10 / 94\end{array}$ & $\begin{array}{l}0001 \\
0001\end{array}$ & $M G / L$ & & $\begin{array}{l}0.015 \\
0.018\end{array}$ & $\begin{array}{l}0.001 \\
0.001\end{array}$ & - \\
\hline URANIUM (TOTAL) & $04 / 02 / 93$ & N001 & MG $/$ & & 0.013 & 0.001 & - \\
\hline VANADIUM & $\begin{array}{l}04 / 02 / 93 \\
01 / 10 / 94\end{array}$ & $\begin{array}{l}0001 \\
0001\end{array}$ & $M G / L$ & $<$ & $\begin{array}{l}0.01 \\
0.01\end{array}$ & $\begin{array}{l}0.01 \\
0.01\end{array}$ & $\dot{-}$ \\
\hline VANADIUM (TOTAL) & $04 / 02 / 93$ & No01 & $M G / L$ & $<$ & 0.01 & 0.01 & - \\
\hline
\end{tabular}

PARAMETER VALUE INDICATOR (PVI): < - LESS THAN DETECTION LIMIT

OTHER PARAMETER VALUE FLAGS:

$W$ - POST-DIGEST SPIKE OUT OF CNTR LIM WHILE SAMP ABS < $50 \%$ SPIKE

SAMPLE ID CODES

0001 - FILTERED SAMPLE (.45 MICRONS)

N001 - UNFILTERED SAMPLE 
GROUNDWATER QUALITY DATA BY LOCATION

SITE: RVTO1 RIVERTON

LOCATION: 0730

HORTH COORDINATE: 23222.16 FT

EAST COORDINATE: 28339.43 FT

06/12/81 TO 01/10/94

REPORT DATE: $09 / 07 / 94$

FORMATION OF COMPLETION: SEMICONFINED SANDSTONE (SE)

HYDRAULIC FLOW RELATIONSHIP: DOWN GRADIENT (D)

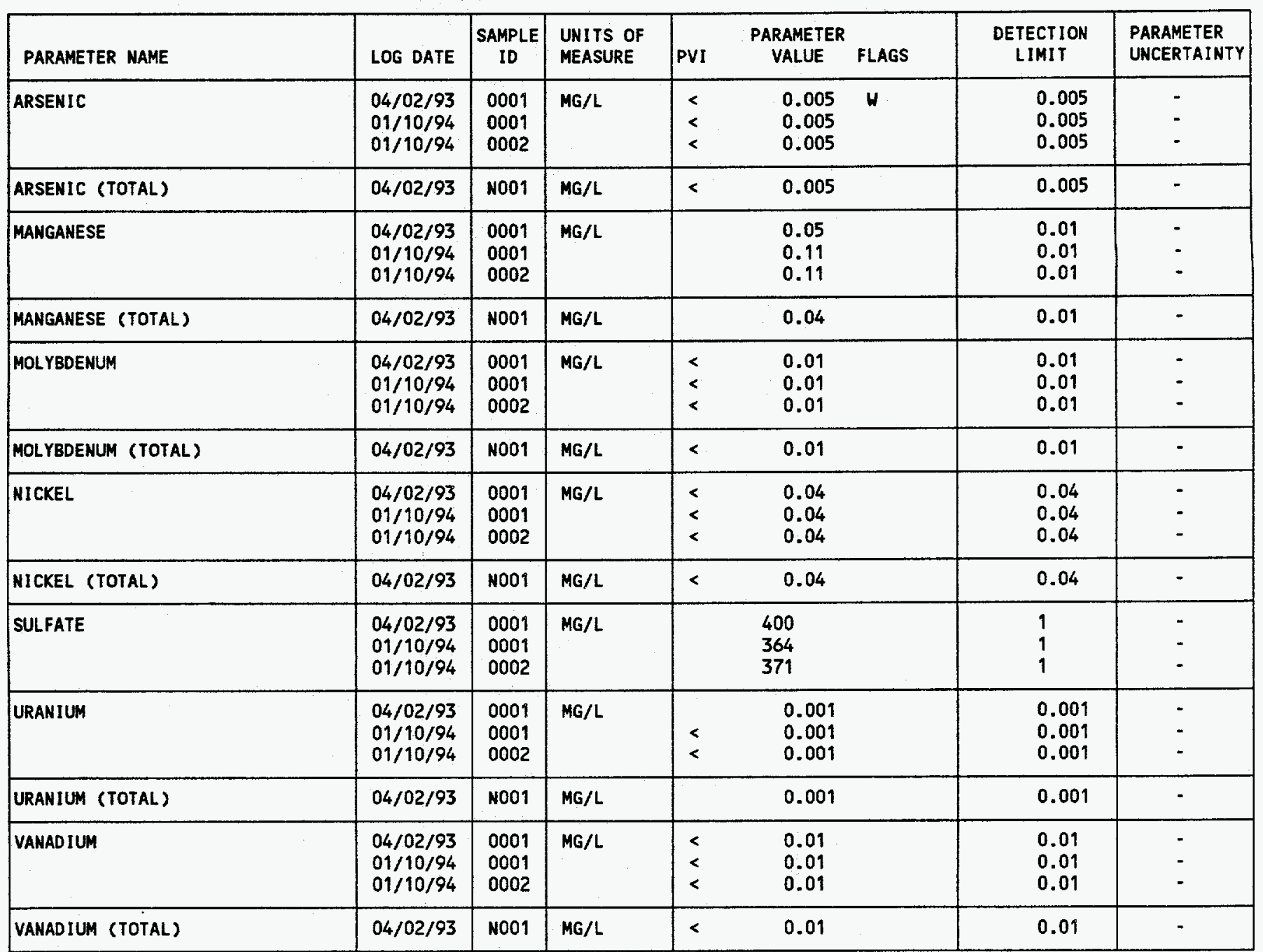

PARAMETER VALUE INDICATOR (PVI): < - LESS THAN DETECTION LIMIT

SAMPLE ID CODES:

0001 - FILTERED SAMPLE (.45 MICRONS)

OTHER PARAMETER VALUE FLAGS:

W - POST-DIGEST SPIKE OUT OF CNTR LIM WHILE SAMP ABS < $50 \%$ SPIKE

O002 - FILTERED REPLICATE SAMPLE (.45 MICRONS)

NOO1 - UNFILTERED SAMPLE 
APPENDIX C

SURFACE WATER AND SEDIMENT ANALYTICAL RESULTS 
SURFACE WATER QUALITY DATA BY LOCATION

SITE: RVTO1 RIVERTON

LOCATION: 0741 RESERVED FOR CDAY

NORTH COORD INATE: UNKNOWN

EAST COORDINATE: UNKNOWN

03/14/93 TO 06/09/93

REPORT DATE: 09/06/94

\begin{tabular}{|c|c|c|c|c|c|c|c|}
\hline PARAMETER NAME & LOG DATE & $\begin{array}{l}\text { SAMPLE } \\
10\end{array}$ & $\begin{array}{l}\text { UNITS OF } \\
\text { MEASURE }\end{array}$ & PVI & $\begin{array}{l}\text { PARAMETER } \\
\text { VALUE FLAGS }\end{array}$ & $\begin{array}{l}\text { DETECTION } \\
\text { LIMIT }\end{array}$ & $\begin{array}{l}\text { PARAMETER } \\
\text { UNCERTAINTY }\end{array}$ \\
\hline CALCIUM (TOTAL) & $\begin{array}{l}06 / 08 / 93 \\
06 / 08 / 93\end{array}$ & $\begin{array}{l}\text { No01 } \\
\text { N003 }\end{array}$ & MG/L & & $\begin{array}{l}46.3 \\
69.8\end{array}$ & $\begin{array}{l}1.0 \\
1.0\end{array}$ & - \\
\hline IRON (TOTAL) & $\begin{array}{l}06 / 08 / 93 \\
06 / 08 / 93\end{array}$ & $\begin{array}{l}\text { NOO1 } \\
\text { N003 }\end{array}$ & $M G / L$ & & $\begin{array}{l}0.43 \\
0.46\end{array}$ & $\begin{array}{l}0.03 \\
0.03\end{array}$ & 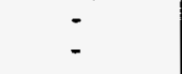 \\
\hline LEAD (TOTAL) & $\begin{array}{l}06 / 08 / 93 \\
06 / 08 / 93\end{array}$ & $\begin{array}{l}\text { NOO1 } \\
\text { N003 }\end{array}$ & $M G / L$ & $<$ & $\begin{array}{l}0.003 \\
0.003\end{array}$ & $\begin{array}{l}0.003 \\
0.003\end{array}$ & - \\
\hline MAGNESIUM (TOTAL) & $\begin{array}{l}06 / 08 / 93 \\
06 / 08 / 93\end{array}$ & $\begin{array}{l}\text { No01 } \\
\text { N003 }\end{array}$ & $M G / L$ & & $\begin{array}{l}13.1 \\
20.1\end{array}$ & $\begin{array}{l}0.1 \\
0.1\end{array}$ & - \\
\hline MANGANESE (TOTAL) & $\begin{array}{l}06 / 08 / 93 \\
06 / 08 / 93\end{array}$ & $\begin{array}{l}\text { NoO1 } \\
\text { N003 }\end{array}$ & $M G / L$ & & $\begin{array}{l}0.05 \\
0.05\end{array}$ & $\begin{array}{l}0.01 \\
0.01\end{array}$ & $\dot{-}$ \\
\hline MOLYBDENUM (TOTAL) & $\begin{array}{l}06 / 08 / 93 \\
06 / 08 / 93\end{array}$ & $\begin{array}{l}\text { NOO1 } \\
\text { N003 }\end{array}$ & $M G / L$ & $<$ & $\begin{array}{l}0.02 \\
0.01\end{array}$ & $\begin{array}{l}0.01 \\
0.01\end{array}$ & : \\
\hline URANIUM (TOTAL) & $\begin{array}{l}06 / 08 / 93 \\
06 / 08 / 93\end{array}$ & $\begin{array}{l}\text { No01 } \\
\text { N003 }\end{array}$ & $M G / L$ & & $\begin{array}{l}0.006 \\
0.006\end{array}$ & $\begin{array}{l}0.001 \\
0.001\end{array}$ & $\dot{-}$ \\
\hline
\end{tabular}

PARAMETER VALUE INDICATOR (PVI):

< - LESS than detection limit

SAMPLE ID CODES:

NOO1 - UNFILTERED SAMPLE

NOO3 - UNFILTERED REPLICATE SAMPLE 
SURFACE WATER QUALITY DATA BY LOCATION

SITE: RVTO1 RIVERTON

LOCATION: 0742 RESERVED FOR CDAY

NORTH COORDINATE: UNKNOWN

EAST COORDINATE: UNKNOWN

03/14/93 TO 06/09/93

REPORT DATE: 09/06/94

\begin{tabular}{|c|c|c|c|c|c|c|c|}
\hline PARAMETER NAME & LOG DATE & $\underset{\text { SAMPLE }}{\text { ID }}$ & $\begin{array}{l}\text { UNITS OF } \\
\text { MEASURE }\end{array}$ & PVI & $\begin{array}{l}\text { PARAMETER } \\
\text { VALUE FLAGS }\end{array}$ & $\begin{array}{l}\text { DETECTION } \\
\text { LIMIT }\end{array}$ & $\begin{array}{l}\text { PARAMETER } \\
\text { UNCERTAINTY }\end{array}$ \\
\hline CALCIUM (TOTAL) & $06 / 08 / 93$ & N001 & $M G / L$ & & 40.7 & 1.0 & - \\
\hline IRON (TOTAL) & $06 / 08 / 93$ & N001 & MG/L & & 1.41 & 0.03 & - \\
\hline LEAD (TOTAL) & $06 / 08 / 93$ & N001 & $M G / L$ & & 0.004 & 0.003 & - \\
\hline MAGNESIUM (TOTAL) & $06 / 08 / 93$ & N001 & $M G / L$ & & 14.1 & 0.1 & - \\
\hline MANGANESE (TOTAL) & $06 / 08 / 93$ & N001 & $M G / L$ & & 0.12 & 0.01 & - \\
\hline MOLYBDENUM (TOTAL) & $06 / 08 / 93$ & N001 & $M G / L$ & $<$ & 0.01 & 0.01 & - \\
\hline URANIUM (TOTAL) & $06 / 08 / 93$ & N001 & $M G / L$ & & 0.025 & 0.001 & - \\
\hline
\end{tabular}

PARAMETER VALUE INDICATOR (PVI):

< - LESS THAN DETECTION LIMIT

SAMPLE ID CODES:

NO01 - UNFILTERED SAMPLE 
SURFACE MATER QUALITY DATA BY LOCATION

SITE: RVTOI RIVERTON

LOCATION: O743 RESERVED FOR COAY

NORTH COORDINATE: UNKNOWN

EAST COORDINATE: UNKNOWN

$03 / 14 / 93$ TO $06 / 09 / 93$

REPORT DATE: 09/06/94

\begin{tabular}{|c|c|c|c|c|c|c|c|}
\hline PARAMETER NAME & LOG DATE & $\begin{array}{c}\text { SAMPLE } \\
\text { ID }\end{array}$ & $\begin{array}{l}\text { UNITS OF } \\
\text { MEASURE }\end{array}$ & PVI & $\begin{array}{l}\text { PARAMETER } \\
\text { VALUE FLAGS }\end{array}$ & $\begin{array}{l}\text { DETECTION } \\
\text { LIMIT }\end{array}$ & $\begin{array}{l}\text { PARAMETER } \\
\text { UNCERTAINTY }\end{array}$ \\
\hline CALCIUM (TOTAL) & $06 / 09 / 93$ & No01 & $M G / L$ & & 160. & 1.0 & - \\
\hline IRON (TOTAL) & $06 / 09 / 93$ & N001 & MG/L & & 0.24 & 0.03 & - \\
\hline LEAD (TOTAL) & $06 / 09 / 93$ & N001 & $M G / L$ & $<$ & 0.003 & 0.003 & - \\
\hline MAGNESIUM (TOTAL) & $06 / 09 / 93$ & N001 & $M G / L$ & & 38.1 & 0.1 & - \\
\hline MANGANESE (TOTAL) & $06 / 09 / 93$ & NO01 & MG/L & & 0.12 & 0.01 & - \\
\hline MOLYBDENUM (TOTAL) & $06 / 09 / 93$ & N001 & $M G / L$ & & 0.01 & 0.01 & - \\
\hline URANIUM (TOTAL) & $06 / 09 / 93$ & N001 & $M G / L$ & & 0.013 & 0.001 & - \\
\hline
\end{tabular}

PARAMETER VALUE INDICATOR (PVI): < - LESS THAN DETECTION LIMIT

SAMPLE ID CODES:

NOO1 - UNFILTERED SAMPLE 
SURFACE WATER QUALITY DATA BY LOCATION

SITE: RVTO1 RIVERTON

LOCATION: 0744 RESERVED FOR CDAY

NORTH COORDINATE: UNKNOWN

EAST COORDINATE: UNKNOWN

03/14/93 TO 06/09/93

REPORT DATE: 09/06/94

\begin{tabular}{|c|c|c|c|c|c|c|c|}
\hline PARAMETER NAME & LOG DATE & $\begin{array}{c}\text { SAMPLE } \\
\text { ID }\end{array}$ & $\begin{array}{l}\text { UNITS OF } \\
\text { MEASURE }\end{array}$ & PVI & $\begin{array}{l}\text { PARAMETER } \\
\text { VALUE FLAGS }\end{array}$ & $\begin{array}{l}\text { DETECTION } \\
\text { LIMIT }\end{array}$ & $\begin{array}{l}\text { PARAMETER } \\
\text { UNCERTAINTY }\end{array}$ \\
\hline CALCIUM (TOTAL) & $06 / 09 / 93$ & N001 & $M G / L$ & & 58.1 & 1.0 & - \\
\hline IRON (TOTAL) & $06 / 09 / 93$ & N001 & $M G / L$ & & 0.13 & 0.03 & - \\
\hline LEAD (TOTAL) & $06 / 09 / 93$ & N001 & $M G / L$ & $<$ & 0.003 & 0.003 & - \\
\hline MANGANESE (TOTAL) & $06 / 09 / 93$ & N001 & $M G / L$ & & 0.02 & 0.01 & - \\
\hline MOLYBDENUM (TOTAL) & $06 / 09 / 93$ & N001 & $M G / L$ & $<$ & 0.01 & 0.01 & - \\
\hline URANIUM (TOTAL) & $06 / 09 / 93$ & N001 & MG/L & & 0.016 & 0.001 & - \\
\hline
\end{tabular}

PARAMETER VALUE INDICATOR (PVI):

< - LESS than DETECTION LIMIT

SAMPLE ID CODES:

N001 - UNFILTERED SAMPLE 
SURFACE WATER QUALITY DATA BY LOCATION

SITE: RVTOI RIVERTON

LOCATION: 0745 RESERVED FOR CDAY

NORTH COORDINATE: UNKNOWN

EAST COORDINATE: UNKNOWN

03/14/93 TO 06/09/93

REPORT DATE: 09/06/94

\begin{tabular}{|c|c|c|c|c|c|c|c|}
\hline PARAMETER NAME & LOG DATE & $\underset{\text { SAMPLE }}{\text { SAMP }}$ & $\begin{array}{l}\text { UWITS OF } \\
\text { MEASURE }\end{array}$ & PVI & $\begin{array}{l}\text { PARAMETER } \\
\text { VALUE FLAGS }\end{array}$ & $\begin{array}{l}\text { DETECTION } \\
\text { LIMIT }\end{array}$ & $\begin{array}{l}\text { PARAMETER } \\
\text { UNCERTAINTY }\end{array}$ \\
\hline CALCIUM (TOTAL) & $06 / 09 / 93$ & NoO1 & MG/L & & 81.0 & 1.0 & - \\
\hline IRON (TOTAL) & $06 / 09 / 93$ & N001 & MG/L & & 0.36 & 0.03 & - \\
\hline LEAD (TOTAL) & $06 / 09 / 93$ & N001 & $M G / L$ & $<$ & 0.003 & 0.003 & - \\
\hline MAGNESIUM (TOTAL) & $06 / 09 / 93$ & No01 & $\mathrm{MG} / \mathrm{L}$ & & 21.9 & 0.1 & - \\
\hline MANGANESE (TOTAL) & $06 / 09 / 93$ & No01 & $M G / L$ & & 0.05 & 0.01 & - \\
\hline MOLYBDEKUM (TOTAL) & $06 / 09 / 93$ & NoO1 & $M G / L$ & $<$ & 0.01 & 0.01 & - \\
\hline URANIUM (TOTAL) & $06 / 09 / 93$ & No01 & $M G / L$ & & 0.008 & 0.001 & - \\
\hline
\end{tabular}

PARAMETER VALUE INDICATOR (PVI): < - LESS THAN DETECTION LIMIT

SAMPLE ID COOES:

NOO1 - UNFILTERED SAMPLE 
SURFACE WATER QUALITY DATA BY LOCATION

SITE: RVTO1 RIVERTON

LOCATION: 0746 RESERVED FOR CDAY

NORTH COORDINATE: UNKNOWN

EAST COORDINATE: UNKNOWN

03/14/93 TO 06/09/93

REPORT DATE: 09/06/94

\begin{tabular}{|c|c|c|c|c|c|c|c|}
\hline PARAMETER NAME & LOG DATE & $\begin{array}{c}\text { SAMPLE } \\
\text { ID }\end{array}$ & $\begin{array}{l}\text { UNITS OF } \\
\text { MEASURE }\end{array}$ & PVI & $\begin{array}{l}\text { PARAMETER } \\
\text { VALUE FLAGS }\end{array}$ & $\begin{array}{l}\text { DETECTION } \\
\text { LIMIT }\end{array}$ & $\begin{array}{l}\text { PARAMETER } \\
\text { UNCERTAINTY }\end{array}$ \\
\hline CALCIUM (TOTAL) & $06 / 09 / 93$ & N001 & $M G / L$ & & 107. & 1.0 & - \\
\hline IRON (TOTAL) & $06 / 09 / 93$ & N001 & $M G / L$ & & 0.09 & 0.03 & - \\
\hline LEAD (TOTAL) & $06 / 09 / 93$ & N001 & $M G / L$ & $<$ & 0.001 & 0.001 & - \\
\hline MAGNESIUM (TOTAL) & $06 / 09 / 93$ & N001 & $M G / L$ & & 39.4 & 0.1 & - \\
\hline MANGANESE (TOTAL) & $06 / 09 / 93$ & N001 & $M G / L$ & & 0.06 & 0.01 & - \\
\hline MOLYBDENUM (TOTAL) & $06 / 09 / 93$ & No01 & $M G / L$ & $<$ & 0.01 & 0.01 & - \\
\hline URANIUM (TOTAL) & $06 / 09 / 93$ & N001 & $M G / L$ & & 0.008 & 0.001 & - \\
\hline
\end{tabular}

PARAMETER VALUE INDICATOR (PVI):

< - Less THAN DETECTION LIMIT

SAMPLE ID CODES:

N001 - UNFILTERED SAMPLE 
SURFACE HATER QUALITY DATA BY LOCATION

SITE: RVTO1 RIVERTON

LOCATION: 0794

NORTH COORD INATE: UNKNOWN

EAST COORDINATE: UNKNOWN

$03 / 14 / 93$ TO $06 / 09 / 93$

REPORT DATE: $09 / 06 / 94$

\begin{tabular}{|c|c|c|c|c|c|c|c|}
\hline PARAMETER NAME & LOG DATE & SAMPLE & $\begin{array}{l}\text { UNITS OF } \\
\text { MEASURE }\end{array}$ & PVI & $\begin{array}{l}\text { PARAMETER } \\
\text { VALUE FLAGS }\end{array}$ & $\begin{array}{l}\text { DETECTION } \\
\text { LIMIT }\end{array}$ & $\begin{array}{l}\text { PARAMETER } \\
\text { UNCERTAINTY }\end{array}$ \\
\hline CALCIUM (TOTAL) & $06 / 09 / 93$ & N001 & $M G / L$ & & 40.9 & 1.0 & - \\
\hline IRON (TOTAL) & $06 / 09 / 93$ & N001 & $M G / L$ & & 1.95 & 0.03 & $\cdot$ \\
\hline LEAD (TOTAL) & $06 / 09 / 93$ & No01 & $M G / L$ & & 0.004 & 0.001 & - \\
\hline MAGNESIUM (TOTAL) & $06 / 09 / 93$ & N001 & $M G / L$ & & 13.8 & 0.1 & - \\
\hline MANGANESE (TOTAL) & $06 / 09 / 93$ & NOO1 & $M G / L$ & & 0.09 & 0.01 & - \\
\hline MOLYBDENUM (TOTAL) & $06 / 09 / 93$ & N001 & $M G / L$ & $<$ & 0.01 & 0.01 & - \\
\hline URANIUM (TOTAL) & $06 / 09 / 93$ & N001 & MG $/ L$ & & 0.002 & 0.001 & - \\
\hline
\end{tabular}

PARAMETER VALUE INDICATOR (PVI): < - LESS THAN DETECTION LIMIT SAMPLE ID CODES:

NO01 - UNFILTERED SAMPLE 
SURFACE WATER QUALITY DATA BY LOCATION

SITE: RVT01 RIVERTON

LOCATION: 0796

NORTH COORDINATE : UNKNOWN

EAST COORDINATE: UNKNOWN

03/14/93 TO 06/09/93

REPORT DATE: 09/06/94

\begin{tabular}{|c|c|c|c|c|c|c|c|}
\hline PARAMETER NAME & LOG DATE & $\underset{\text { ID }}{\text { SAMPLE }}$ & $\begin{array}{l}\text { UNITS OF } \\
\text { MEASURE }\end{array}$ & PVI & $\begin{array}{l}\text { PARAMETER } \\
\text { VALUE FLAGS }\end{array}$ & $\begin{array}{l}\text { DETECTION } \\
\text { LIMIT }\end{array}$ & $\begin{array}{l}\text { PARAMETER } \\
\text { UNCERTAINTY }\end{array}$ \\
\hline CALCIUM (TOTAL) & $06 / 09 / 93$ & N001 & MG/L & & 42.1 & 1.0 & $\cdot$ \\
\hline IRON (TOTAL) & $06 / 09 / 93$ & N001 & MG/L & & 3.12 & 0.03 & - \\
\hline LEAD (TOTAL) & $06 / 09 / 93$ & N001 & MG/L & & 0.004 & 0.001 & - \\
\hline MAGNESIUM (TOTAL) & $06 / 09 / 93$ & N001 & MG/L & & 14.2 & 0.1 & - \\
\hline MANGANESE (TOTAL) & $06 / 09 / 93$ & N001 & MG/L & & 0.14 & 0.01 & - \\
\hline MOLYBDENUM (TOTAL) & $06 / 09 / 93$ & N001 & $M G / L$ & $<$ & 0.01 & 0.01 & - \\
\hline URANIUM (TOTAL) & $06 / 09 / 93$ & N001 & $M G / L$ & & 0.002 & 0.001 & - \\
\hline
\end{tabular}

PARAMETER VALUE INDICATOR (PVI): < - LESS THAN DETECTION LIMIT SAMPLE ID CODES:

N001 - UNFILTERED SAMPLE 
SURFACE WATER QUALITY DATA BY LOCATION

SITE: RVT01 RIVERTON

LOCATION: 0999

NORTH COORD INATE: 11111111.11 FT

EAST COORDINATE: $11111111.11 \mathrm{FT}$

03/14/93 TO 06/09/93

REPORT DATE: 09/06/94

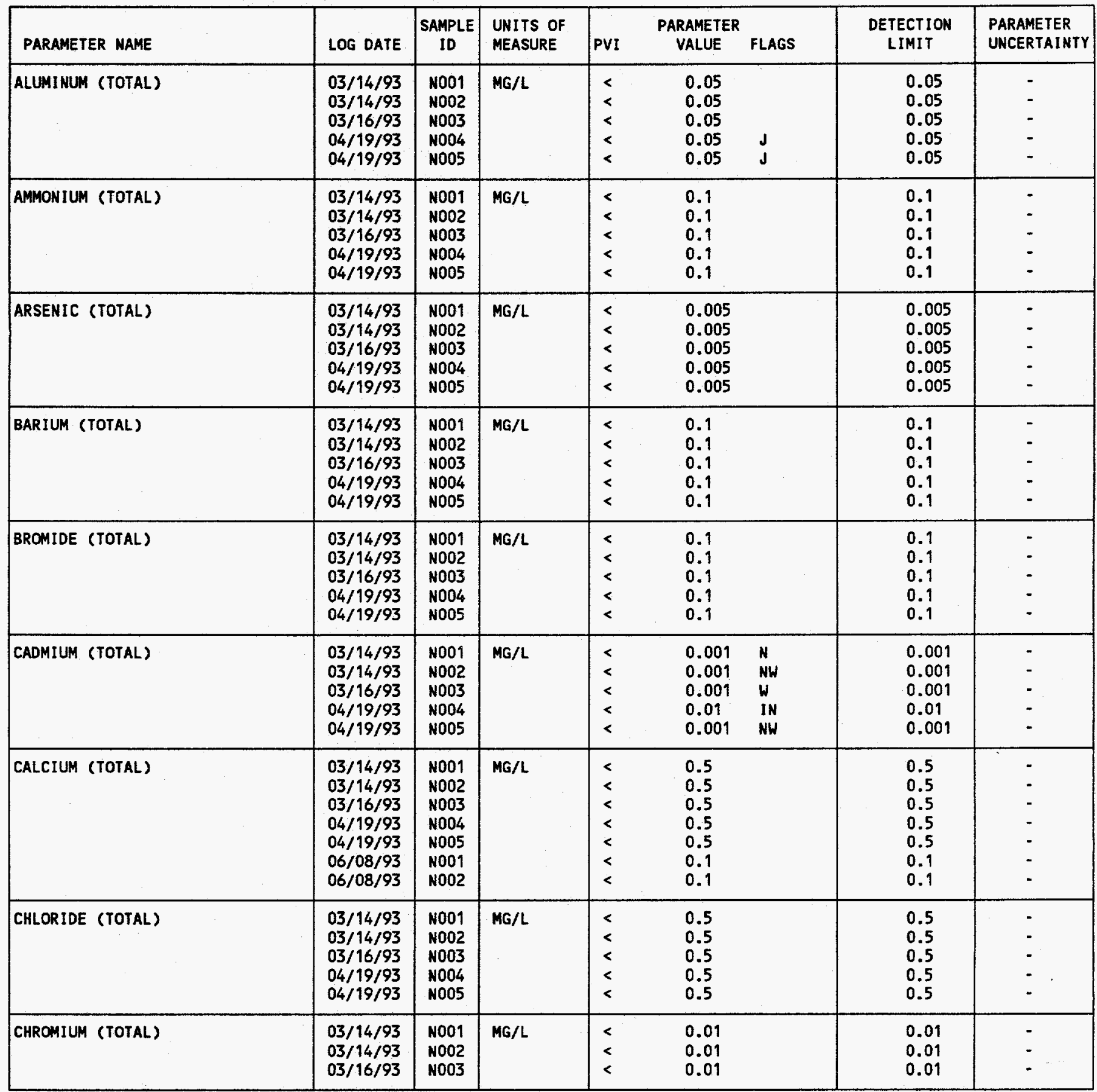

PARAMETER VALUE INDICATOR (PVI): < - LESS THAN DETECTION LIMIT

SAMPLE ID CODES

NOO1 - UNFILTERED SAMPLE

NOO2 - UNFILTERED REPL ICATE SAMPLE NOO3 - UNFILTERED REPLICATE SAMPLE NOO4 - UNFILTERED REPLICATE SAMPLE NOO5 - UNFILTERED REPLICATE SAMPLE

1 - INCREASED DETECTION LIMIT DUE TO REQUIRED DILUTION

$J$ - ESTIMATED VALUE

N - SPIKE SAMPLE RECOVERY NOT WITHIN CONTROL LIMITS

$W$ - POST-DIGEST SPIKE OUT OF CNTR LIM WHILE SAMP ABS < 50\% SPIKE 
SURFACE WATER QUALITY DATA BY LOCATION

SITE: RVTO1 RIVERTON

LOCATION: 0999

NORTH COORDINATE:11111111.11 FT

EAST COORDINATE: $11111111.11 \mathrm{FT}$

$03 / 14 / 93$ T0 06/09/93

REPORT DATE: 09/06/94

\begin{tabular}{|c|c|c|c|c|c|c|c|c|}
\hline PARAMETER NAME & LOG DATE & $\begin{array}{c}\text { SAMPLE } \\
\text { ID }\end{array}$ & $\begin{array}{l}\text { UNITS OF } \\
\text { MEASURE }\end{array}$ & PVI & $\begin{array}{l}\text { ARAMETER } \\
\text { VALUE }\end{array}$ & FLAGS & $\begin{array}{l}\text { DETECTION } \\
\text { LIMIT }\end{array}$ & $\begin{array}{l}\text { PARAMETER } \\
\text { UNCERTAINTY }\end{array}$ \\
\hline CHROMIUM (TOTAL) & $\begin{array}{l}04 / 19 / 93 \\
04 / 19 / 93\end{array}$ & $\begin{array}{l}\text { N004 } \\
\text { N005 }\end{array}$ & $M G / L$ & $\begin{array}{l}< \\
<\end{array}$ & $\begin{array}{l}0.01 \\
0.01\end{array}$ & * & $\begin{array}{l}0.01 \\
0.01\end{array}$ & - \\
\hline DISSOLVED ORGANIC CARBON (TOTAL) & $\begin{array}{l}03 / 14 / 93 \\
03 / 14 / 93 \\
03 / 16 / 93 \\
04 / 19 / 93 \\
04 / 19 / 93\end{array}$ & $\begin{array}{l}\text { No01 } \\
\text { No02 } \\
\text { NO03 } \\
\text { NO04 } \\
\text { N005 }\end{array}$ & $M G / L$ & $\begin{array}{l}< \\
< \\
< \\
< \\
<\end{array}$ & $\begin{array}{l}1 \\
1 \\
1 \\
1 \\
1\end{array}$ & & $\begin{array}{l}1 \\
1 \\
1 \\
1 \\
1\end{array}$ & $\begin{array}{l}- \\
- \\
- \\
-\end{array}$ \\
\hline FLUORIDE (TOTAL) & $\begin{array}{l}03 / 14 / 93 \\
03 / 14 / 93 \\
03 / 16 / 93 \\
04 / 19 / 93 \\
04 / 19 / 93\end{array}$ & $\begin{array}{l}\text { No01 } \\
\text { No02 } \\
\text { No03 } \\
\text { N004 } \\
\text { N005 }\end{array}$ & $M G / L$ & $\begin{array}{l}< \\
< \\
<\end{array}$ & $\begin{array}{l}0.84 \\
0.84 \\
0.1 \\
0.1 \\
0.1\end{array}$ & & $\begin{array}{l}0.1 \\
0.1 \\
0.1 \\
0.1 \\
0.1\end{array}$ & $\begin{array}{l}- \\
- \\
- \\
-\end{array}$ \\
\hline GROSS ALPHA (TOTAL) & $\begin{array}{l}03 / 14 / 93 \\
03 / 14 / 93 \\
03 / 16 / 93 \\
04 / 19 / 93 \\
04 / 19 / 93\end{array}$ & $\begin{array}{l}\text { No01 } \\
\text { NO02 } \\
\text { N003 } \\
\text { N004 } \\
\text { N005 }\end{array}$ & $\mathrm{PCI} / \mathrm{L}$ & & $\begin{array}{l}0.0 \\
0.0 \\
0.0 \\
0.0 \\
0.4\end{array}$ & & $\begin{array}{l}1.9 \\
1.9 \\
1.9 \\
1.9 \\
1.8\end{array}$ & $\begin{array}{l}1.0 \\
0.9 \\
1.1 \\
1.1 \\
1.2\end{array}$ \\
\hline GROSS BETA (TOTAL) & $\begin{array}{l}03 / 14 / 93 \\
03 / 14 / 93 \\
03 / 16 / 93 \\
04 / 19 / 93 \\
04 / 19 / 93\end{array}$ & $\begin{array}{l}\text { No01 } \\
\text { N002 } \\
\text { N003 } \\
\text { N004 } \\
\text { N005 }\end{array}$ & PCI /L & & $\begin{array}{l}0.0 \\
0.0 \\
0.0 \\
0.0 \\
0.0\end{array}$ & & $\begin{array}{l}4.2 \\
4.2 \\
4.3 \\
4.1 \\
4.1\end{array}$ & $\begin{array}{l}2.3 \\
2.3 \\
2.4 \\
2.3 \\
2.2\end{array}$ \\
\hline IRON (TOTAL) & $\begin{array}{l}03 / 14 / 93 \\
03 / 14 / 93 \\
03 / 16 / 93 \\
04 / 19 / 93 \\
04 / 19 / 93 \\
06 / 08 / 93 \\
06 / 08 / 93\end{array}$ & $\begin{array}{l}\text { NO01 } \\
\text { NO02 } \\
\text { NO03 } \\
\text { N004 } \\
\text { N005 } \\
\text { NO01 } \\
\text { N002 }\end{array}$ & MG/L & $\begin{array}{l}< \\
< \\
< \\
< \\
<\end{array}$ & $\begin{array}{l}0.03 \\
0.03 \\
0.03 \\
0.03 \\
0.03 \\
0.70 \\
0.03\end{array}$ & $\begin{array}{l}J \\
J \\
J \\
J\end{array}$ & $\begin{array}{l}0.03 \\
0.03 \\
0.03 \\
0.03 \\
0.03 \\
0.03 \\
0.03\end{array}$ & $\begin{array}{l}- \\
- \\
- \\
- \\
-\end{array}$ \\
\hline LEAD (TOTAL) & $\begin{array}{l}03 / 14 / 93 \\
03 / 14 / 93 \\
03 / 16 / 93 \\
04 / 19 / 93 \\
04 / 19 / 93 \\
06 / 08 / 93 \\
06 / 08 / 93\end{array}$ & $\begin{array}{l}\text { NO01 } \\
\text { N002 } \\
\text { NO03 } \\
\text { NO04 } \\
\text { NO05 } \\
\text { NO01 } \\
\text { NO02 }\end{array}$ & $M G / L$ & $\begin{array}{l}< \\
< \\
< \\
< \\
< \\
< \\
<\end{array}$ & $\begin{array}{l}0.003 \\
0.003 \\
0.003 \\
0.003 \\
0.003 \\
0.001 \\
0.003\end{array}$ & & $\begin{array}{l}0.003 \\
0.003 \\
0.003 \\
0.003 \\
0.003 \\
0.001 \\
0.003\end{array}$ & $\begin{array}{l}- \\
- \\
- \\
- \\
- \\
- \\
-\end{array}$ \\
\hline LEAD-210 (TOTAL) & $\begin{array}{l}03 / 14 / 93 \\
03 / 14 / 93 \\
03 / 16 / 93 \\
04 / 19 / 93 \\
04 / 19 / 93\end{array}$ & $\begin{array}{l}\text { NOO1 } \\
\text { NO02 } \\
\text { N003 } \\
\text { NOO4 } \\
\text { N005 }\end{array}$ & $\mathrm{PCI} / \mathrm{L}$ & & $\begin{array}{l}0.0 \\
0.0 \\
0.5 \\
0.3 \\
0.0\end{array}$ & & $\begin{array}{l}3.6 \\
3.6 \\
3.6 \\
3.0 \\
3.0\end{array}$ & $\begin{array}{l}2.1 \\
2.1 \\
2.2 \\
1.8 \\
1.7\end{array}$ \\
\hline MAGNESIUM (TOTAL) & $\begin{array}{l}03 / 14 / 93 \\
03 / 14 / 93 \\
03 / 16 / 93 \\
04 / 19 / 93\end{array}$ & $\begin{array}{l}\text { No01 } \\
\text { N002 } \\
\text { NO03 } \\
\text { NOO4 }\end{array}$ & $M G / L$ & $\begin{array}{l}< \\
< \\
< \\
<\end{array}$ & $\begin{array}{l}0.1 \\
0.1 \\
0.1 \\
0.1\end{array}$ & $J$ & $\begin{array}{l}0.1 \\
0.1 \\
0.1 \\
0.1\end{array}$ & $\begin{array}{l}- \\
- \\
-\end{array}$ \\
\hline
\end{tabular}

PARAMETER VALUE INDICATOR (PVI): < - LESS THAN DETECTION LIMIT

SAMPLE IO COOES:

OTHER PARAMETER VALUE FLAGS:

N001 - UNFILTERED SAMPLE

* - DUPLICATE ANALYSIS NOT WITHIN CONTROL LIMITS

N002 - UNFILTERED REPLICATE SAMPLE

NOO3 - UNFILTERED REPLICATE SAMPLE

NOO4 - UNFILTERED REPLICATE SAMPLE

N005 - UNFILTERED REPLICATE SAMPLE 
SURFACE WATER QUALITY DATA BY LOCATION

SITE: RVTO1 RIVERTON

LOCATION: 0999

NORTH COORDINATE:11111111.11 FT

EAST COORDINATE: $11111111.11 \mathrm{FT}$

$03 / 14 / 93$ TO 06/09/93

REPORT DATE: 09/06/94

\begin{tabular}{|c|c|c|c|c|c|c|c|}
\hline PARAMETER NAME & LOG DATE & $\begin{array}{c}\text { SAMPLE } \\
\text { ID }\end{array}$ & $\begin{array}{l}\text { UNITS OF } \\
\text { MEASURE }\end{array}$ & PVI & $\begin{array}{l}\text { PARAMETER } \\
\text { VALUE FLAGS }\end{array}$ & $\begin{array}{l}\text { DETECTION } \\
\text { LIMIT }\end{array}$ & $\begin{array}{l}\text { PARAMETER } \\
\text { UNCERTAINTY }\end{array}$ \\
\hline MAGNESIUM (TOTAL) & $\begin{array}{l}04 / 19 / 93 \\
06 / 08 / 93 \\
06 / 08 / 93\end{array}$ & $\begin{array}{l}\text { No05 } \\
\text { N001 } \\
\text { N002 }\end{array}$ & $M G / L$ & $\begin{array}{l}< \\
< \\
<\end{array}$ & $\begin{array}{l}0.1 \\
0.1 \\
0.1\end{array}$ & $\begin{array}{l}0.1 \\
0.1 \\
0.1\end{array}$ & $\begin{array}{l}- \\
-\end{array}$ \\
\hline MANGANESE (TOTAL) & $\begin{array}{l}03 / 14 / 93 \\
03 / 14 / 93 \\
03 / 16 / 93 \\
04 / 19 / 93 \\
04 / 19 / 93 \\
06 / 08 / 93 \\
06 / 08 / 93\end{array}$ & $\begin{array}{l}\text { NoO1 } \\
\text { N002 } \\
\text { No03 } \\
\text { N004 } \\
\text { No05 } \\
\text { NOO1 } \\
\text { NO02 }\end{array}$ & $M G / L$ & $\begin{array}{l}< \\
< \\
< \\
< \\
< \\
< \\
<\end{array}$ & $\begin{array}{l}0.01 \\
0.01 \\
0.01 \\
0.01 \\
0.01 \\
0.01 \\
0.01\end{array}$ & $\begin{array}{l}0.01 \\
0.01 \\
0.01 \\
0.01 \\
0.01 \\
0.01 \\
0.01\end{array}$ & $\begin{array}{l}- \\
- \\
- \\
- \\
- \\
- \\
-\end{array}$ \\
\hline MOLYBDENUM (TOTAL) & $\begin{array}{l}03 / 14 / 93 \\
03 / 14 / 93 \\
03 / 16 / 93 \\
04 / 19 / 93 \\
04 / 19 / 93 \\
06 / 08 / 93 \\
06 / 08 / 93\end{array}$ & $\begin{array}{l}\text { No01 } \\
\text { N002 } \\
\text { NO03 } \\
\text { NO04 } \\
\text { N005 } \\
\text { No01 } \\
\text { NO02 }\end{array}$ & $M G / L$ & $\begin{array}{l}< \\
< \\
< \\
< \\
< \\
< \\
<\end{array}$ & $\begin{array}{l}0.01 \\
0.01 \\
0.01 \\
0.01 \\
0.01 \\
0.01 \\
0.01\end{array}$ & $\begin{array}{l}0.01 \\
0.01 \\
0.01 \\
0.01 \\
0.01 \\
0.01 \\
0.01\end{array}$ & $\begin{array}{l}- \\
- \\
- \\
- \\
- \\
-\end{array}$ \\
\hline NICKEL (TOTAL) & $\begin{array}{l}03 / 14 / 93 \\
03 / 14 / 93 \\
03 / 16 / 93 \\
04 / 19 / 93 \\
04 / 19 / 93\end{array}$ & $\begin{array}{l}\text { NoO1 } \\
\text { No02 } \\
\text { N003 } \\
\text { NO04 } \\
\text { NO05 }\end{array}$ & MG/L & $\begin{array}{l}< \\
< \\
< \\
< \\
<\end{array}$ & $\begin{array}{l}0.04 \\
0.04 \\
0.04 \\
0.04 \\
0.04\end{array}$ & $\begin{array}{l}0.04 \\
0.04 \\
0.04 \\
0.04 \\
0.04\end{array}$ & $\begin{array}{l}- \\
= \\
- \\
=\end{array}$ \\
\hline NITRATE (TOTAL) & $\begin{array}{l}03 / 14 / 93 \\
03 / 14 / 93 \\
03 / 16 / 93 \\
04 / 19 / 93 \\
04 / 19 / 93\end{array}$ & $\begin{array}{l}\text { No01 } \\
\text { No02 } \\
\text { NO03 } \\
\text { No04 } \\
\text { N005 }\end{array}$ & $M G / L$ & $\begin{array}{l}< \\
< \\
< \\
< \\
<\end{array}$ & $\begin{array}{l}1 \\
1 \\
1 \\
1 \\
1\end{array}$ & $\begin{array}{l}1 \\
1 \\
1 \\
1 \\
1\end{array}$ & $\begin{array}{l}- \\
- \\
- \\
-\end{array}$ \\
\hline PHOSPHATE (TOTAL) & $\begin{array}{l}03 / 14 / 93 \\
03 / 14 / 93 \\
03 / 16 / 93 \\
04 / 19 / 93 \\
04 / 19 / 93\end{array}$ & $\begin{array}{l}\text { No01 } \\
\text { No02 } \\
\text { No03 } \\
\text { No04 } \\
\text { N005 }\end{array}$ & $M G / L$ & $\begin{array}{l}< \\
< \\
< \\
<\end{array}$ & $\begin{array}{l}0.1 \\
0.1 \\
0.1 \\
0.1 \\
0.1\end{array}$ & $\begin{array}{l}0.1 \\
0.1 \\
0.1 \\
0.1 \\
0.1\end{array}$ & $\begin{array}{l}- \\
- \\
- \\
-\end{array}$ \\
\hline POLONIUM-210 (TOTAL) & $\begin{array}{l}03 / 14 / 93 \\
03 / 14 / 93 \\
03 / 16 / 93 \\
04 / 19 / 93 \\
04 / 19 / 93\end{array}$ & $\begin{array}{l}\text { No01 } \\
\text { N002 } \\
\text { N003 } \\
\text { N004 } \\
\text { N005 }\end{array}$ & PCI/L & & $\begin{array}{l}0.0 \\
0.0 \\
0.0 \\
1.8 \\
1.2\end{array}$ & $\begin{array}{l}0.9 \\
0.9 \\
0.9 \\
0.9 \\
0.9\end{array}$ & $\begin{array}{l}0.4 \\
0.5 \\
0.5 \\
0.9 \\
0.8\end{array}$ \\
\hline POTASSIUM (TOTAL) & $\begin{array}{l}03 / 14 / 93 \\
03 / 14 / 93 \\
03 / 16 / 93 \\
04 / 19 / 93 \\
04 / 19 / 93\end{array}$ & $\begin{array}{l}\text { No01 } \\
\text { N002 } \\
\text { NO03 } \\
\text { N004 } \\
\text { N005 }\end{array}$ & $M G / L$ & $\begin{array}{l}< \\
< \\
< \\
<\end{array}$ & $\begin{array}{l}0.1 \\
0.1 \\
0.1 \\
0.1 \\
0.1\end{array}$ & $\begin{array}{l}0.1 \\
0.1 \\
0.1 \\
0.1 \\
0.1\end{array}$ & $\begin{array}{l}- \\
- \\
- \\
-\end{array}$ \\
\hline RADIUM-226 (TOTAL) & $\begin{array}{l}03 / 14 / 93 \\
03 / 14 / 93 \\
03 / 16 / 93\end{array}$ & $\begin{array}{l}N 001 \\
N 002 \\
N 003\end{array}$ & $\mathrm{PCI} / \mathrm{L}$ & & $\begin{array}{l}0.4 \\
0.2 \\
0.0\end{array}$ & $\begin{array}{l}0.4 \\
0.4 \\
0.4\end{array}$ & $\begin{array}{l}0.3 \\
0.3 \\
0.2\end{array}$ \\
\hline
\end{tabular}

PARAMETER VALUE INDICATOR (PVI): < - LESS THAN DETECTION LIMIT

SAMPLE ID CODES:

NOO1 - UNFILTERED SAMPLE

OTHER PARAMETER VALUE FLAGS:

$J$ - ESTIMATED VALUE

NOO2 - UNFILTERED REPLICATE SAMPLE

N003 - UNFILTERED REPLICATE SAMPLE

N004 - UNFILTERED REPLICATE SAMPLE

N005 - UNFILTERED REPLICATE SAMPLE 
SURFACE WATER QUALITY DATA BY LOCATION

SITE: RVTO1 RIVERTON

LOCATION: 0999

NORTH COORDINATE: $11111111.11 \mathrm{FT}$

EAST COORDINATE: $11111111.11 \mathrm{FT}$

$03 / 14 / 93$ TO 06/09/93

REPORT DATE: 09/06/94

\begin{tabular}{|c|c|c|c|c|c|c|c|}
\hline PARAMETER NAME & LOG DATE & $\begin{array}{c}\text { SAMPLE } \\
\text { ID }\end{array}$ & $\begin{array}{l}\text { UNITS OF } \\
\text { MEASURE }\end{array}$ & PVI & $\begin{array}{l}\text { PARAMETER } \\
\text { VALUE FLAGS }\end{array}$ & $\begin{array}{l}\text { DETECTION } \\
\text { LIMIT }\end{array}$ & $\begin{array}{l}\text { PARAMETER } \\
\text { UNCERTAINTY }\end{array}$ \\
\hline RADIUM-226 (TOTAL) & $\begin{array}{l}04 / 19 / 93 \\
04 / 19 / 93\end{array}$ & $\begin{array}{l}\text { N004 } \\
\text { N005 }\end{array}$ & $\mathrm{PCl} / \mathrm{L}$ & & $\begin{array}{l}0.0 \\
0.0\end{array}$ & $\begin{array}{l}0.8 \\
0.8\end{array}$ & $\begin{array}{l}0.5 \\
0.4\end{array}$ \\
\hline RAD IUM-228 (TOTAL) & $\begin{array}{l}03 / 14 / 93 \\
03 / 14 / 93 \\
03 / 16 / 93 \\
04 / 19 / 93 \\
04 / 19 / 93\end{array}$ & $\begin{array}{l}N 001 \\
N 002 \\
N 003 \\
N 004 \\
N 005\end{array}$ & $\mathrm{PCl} / \mathrm{L}$ & & $\begin{array}{l}5.7 \\
5.4 \\
1.2 \\
0.2 \\
0.7\end{array}$ & $\begin{array}{l}3.3 \\
3.3 \\
3.3 \\
2.9 \\
2.9\end{array}$ & $\begin{array}{l}2.4 \\
2.4 \\
2.1 \\
1.7 \\
1.8\end{array}$ \\
\hline RADON 222 & $03 / 16 / 93$ & N003 & $\mathrm{PCI} / \mathrm{L}$ & & 6 & - & - \\
\hline SELENIUM (TOTAL) & $\begin{array}{l}03 / 14 / 93 \\
03 / 14 / 93 \\
03 / 16 / 93 \\
04 / 19 / 93 \\
04 / 19 / 93\end{array}$ & $\begin{array}{l}\text { No01 } \\
\text { NO02 } \\
\text { N003 } \\
\text { NO04 } \\
\text { NO05 }\end{array}$ & $M G / L$ & $\begin{array}{l}< \\
< \\
< \\
<\end{array}$ & $\begin{array}{l}0.005 \\
0.005 \\
0.005 \\
0.005 \\
0.005\end{array}$ & $\begin{array}{l}0.005 \\
0.005 \\
0.005 \\
0.005 \\
0.005\end{array}$ & $\begin{array}{l}- \\
- \\
- \\
-\end{array}$ \\
\hline SILICA - SIO2 (TOTAL) & $\begin{array}{l}03 / 14 / 93 \\
03 / 14 / 93 \\
03 / 16 / 93 \\
04 / 19 / 93 \\
04 / 19 / 93\end{array}$ & $\begin{array}{l}\text { No01 } \\
\text { NO02 } \\
\text { NO03 } \\
\text { NO04 } \\
\text { NO05 }\end{array}$ & $M G / L$ & $\begin{array}{l}< \\
< \\
< \\
< \\
<\end{array}$ & $\begin{array}{l}0.5 \\
0.5 \\
0.5 \\
0.5 \\
0.5\end{array}$ & $\begin{array}{l}0.5 \\
0.5 \\
0.5 \\
0.5 \\
0.5\end{array}$ & $\begin{array}{l}- \\
- \\
-\end{array}$ \\
\hline SODIUM (TOTAL) & $\begin{array}{l}03 / 14 / 93 \\
03 / 14 / 93 \\
03 / 16 / 93 \\
04 / 19 / 93 \\
04 / 19 / 93\end{array}$ & $\begin{array}{l}\text { NoO1 } \\
\text { NO02 } \\
\text { NO03 } \\
\text { NO04 } \\
\text { NO05 }\end{array}$ & $M G / L$ & $\begin{array}{l}< \\
< \\
< \\
< \\
<\end{array}$ & $\begin{array}{l}1 \\
1 \\
1 \\
1 \\
1\end{array}$ & $\begin{array}{l}1 \\
1 \\
1 \\
1 \\
1\end{array}$ & $\begin{array}{l}- \\
- \\
- \\
-\end{array}$ \\
\hline STRONTIUM (TOTAL) & $\begin{array}{l}03 / 14 / 93 \\
03 / 14 / 93 \\
03 / 16 / 93 \\
04 / 19 / 93 \\
04 / 19 / 93\end{array}$ & $\begin{array}{l}\text { NoO1 } \\
\text { NOO2 } \\
\text { NO03 } \\
\text { NO04 } \\
\text { NO05 }\end{array}$ & $M G / L$ & $\begin{array}{l}< \\
< \\
< \\
< \\
<\end{array}$ & $\begin{array}{l}0.01 \\
0.01 \\
0.01 \\
0.01 \\
0.01\end{array}$ & $\begin{array}{l}0.01 \\
0.01 \\
0.01 \\
0.01 \\
0.01\end{array}$ & $\begin{array}{l}- \\
- \\
- \\
-\end{array}$ \\
\hline $\begin{array}{c}\text { SULFATE (TOTAL) } \\
-\end{array}$ & $\begin{array}{l}03 / 14 / 93 \\
03 / 14 / 93 \\
03 / 16 / 93 \\
04 / 19 / 93 \\
04 / 19 / 93\end{array}$ & $\begin{array}{l}\text { N001 } \\
\text { N002 } \\
\text { N003 } \\
\text { NO04 } \\
\text { N005 }\end{array}$ & $M G / L$ & $\begin{array}{l}< \\
< \\
< \\
< \\
<\end{array}$ & $\begin{array}{l}1 \\
1 \\
1 \\
1 \\
1\end{array}$ & $\begin{array}{l}1 \\
1 \\
1 \\
1 \\
1\end{array}$ & $\begin{array}{l}- \\
- \\
- \\
-\end{array}$ \\
\hline THORIUM-230 (TOTAL) & $\begin{array}{l}03 / 14 / 93 \\
03 / 14 / 93 \\
03 / 16 / 93 \\
04 / 19 / 93 \\
04 / 19 / 93\end{array}$ & $\begin{array}{l}\text { No01 } \\
\text { NO02 } \\
\text { NO03 } \\
\text { N004 } \\
\text { N005 }\end{array}$ & $\mathrm{PCI} / \mathrm{L}$ & & $\begin{array}{l}2.2 \\
1.4 \\
1.4 \\
0.8 \\
0.1\end{array}$ & $\begin{array}{l}0.8 \\
0.7 \\
0.6 \\
0.7 \\
0.5\end{array}$ & $\begin{array}{l}1.1 \\
1.0 \\
0.9 \\
0.6 \\
0.2\end{array}$ \\
\hline TOTAL DISSOLVED SOLIDS (TOTAL) & $\begin{array}{l}03 / 14 / 93 \\
03 / 14 / 93 \\
03 / 16 / 93 \\
04 / 19 / 93 \\
04 / 19 / 93\end{array}$ & $\begin{array}{l}\text { N001 } \\
\text { N002 } \\
\text { N003 } \\
\text { N004 } \\
\text { N005 }\end{array}$ & $M G / L$ & $\begin{array}{l}< \\
< \\
< \\
<\end{array}$ & $\begin{array}{l}10 \\
10 \\
10 \\
10 \\
10\end{array}$ & $\begin{array}{l}10 \\
10 \\
10 \\
10 \\
10\end{array}$ & $\begin{array}{l}- \\
- \\
- \\
-\end{array}$ \\
\hline TOTAL KJELDAHL NITROGEN (TOTAL). & $03 / 14 / 93$ & N001 & MG/L & $<$ & 1 & 1 & - \\
\hline
\end{tabular}

PARAMETER VALUE INDICATOR (PVI): < - LESS THAN DETECTION LIMIT

SAMPLE ID CODES:

NOO1 - UNFILTERED SAMPLE

OTHER PARAMETER VALUE FLAGS:

H - HOLD TIME EXPIRED, VALUE SUSPECT

NOO2 - UNFILTERED REPLICATE SAMPLE

NO03 - UNFILTERED REPLICATE SAMPLE

N004 - UNFILTERED REPLICATE SAMPLE

N005 - UNFILTERED REPLICATE SAMPLE 
SURFACE WATER QUALITY DATA BY LOCATION

SITE: RVTO1 RIVERTON

LOCATION: 0999

NORTH COORDINATE: $11111111.11 \mathrm{FT}$

EAST COORDINATE: $11111111.11 \mathrm{FT}$

03/14/93 TO 06/09/93

REPORT DATE: $09 / 06 / 94$

\begin{tabular}{|c|c|c|c|c|c|c|c|c|}
\hline PARAMETER NAME & LOG DATE & $\begin{array}{c}\text { SAMPLE } \\
\text { ID }\end{array}$ & $\begin{array}{l}\text { UNITS OF } \\
\text { MEASURE }\end{array}$ & PVI & $\begin{array}{l}\text { PARAMETER } \\
\text { VALUE }\end{array}$ & FLAGS & $\begin{array}{l}\text { DETECTION } \\
\text { LIMIT }\end{array}$ & $\begin{array}{l}\text { PARAMETER } \\
\text { UNCERTAINTY }\end{array}$ \\
\hline TOTAL KJELDAHL NITROGEN (TOTAL) & $\begin{array}{l}03 / 14 / 93 \\
03 / 16 / 93 \\
04 / 19 / 93 \\
04 / 19 / 93\end{array}$ & $\begin{array}{l}\text { NOO2 } \\
\text { NOO3 } \\
\text { NOO4 } \\
\text { N005 }\end{array}$ & $M G / L$ & $\begin{array}{l}< \\
< \\
< \\
<\end{array}$ & $\begin{array}{l}1 \\
1 \\
1 \\
1\end{array}$ & & $\begin{array}{l}1 \\
1 \\
1 \\
1\end{array}$ & $\begin{array}{l}- \\
- \\
-\end{array}$ \\
\hline TOTAL ORGANIC CARBON & $\begin{array}{l}03 / 14 / 93 \\
03 / 14 / 93 \\
03 / 16 / 93 \\
04 / 19 / 93 \\
04 / 19 / 93\end{array}$ & $\begin{array}{l}\text { N001 } \\
\text { N002 } \\
\text { N003 } \\
\text { N004 } \\
\text { N005 }\end{array}$ & $M G / L$ & $\begin{array}{l}< \\
< \\
< \\
< \\
<\end{array}$ & $\begin{array}{l}1 \\
1 \\
1 \\
1 \\
1\end{array}$ & & $\begin{array}{l}1 \\
1 \\
1 \\
1 \\
1\end{array}$ & $\begin{array}{l}- \\
- \\
- \\
-\end{array}$ \\
\hline URANIUM (TOTAL) & $\begin{array}{l}03 / 14 / 93 \\
03 / 14 / 93 \\
03 / 16 / 93 \\
04 / 19 / 93 \\
04 / 19 / 93 \\
06 / 08 / 93 \\
06 / 08 / 93\end{array}$ & $\begin{array}{l}\text { No01 } \\
\text { N002 } \\
\text { N003 } \\
\text { N004 } \\
\text { N005 } \\
\text { NO01 } \\
\text { N002 }\end{array}$ & $M G / L$ & $\begin{array}{l}< \\
< \\
< \\
< \\
< \\
<\end{array}$ & $\begin{array}{l}0.001 \\
0.001 \\
0.001 \\
0.001 \\
0.001 \\
0.001 \\
0.001\end{array}$ & & $\begin{array}{l}0.001 \\
0.001 \\
0.001 \\
0.001 \\
0.001 \\
0.001 \\
0.001\end{array}$ & $\begin{array}{l}- \\
- \\
- \\
- \\
- \\
-\end{array}$ \\
\hline VANADIUM (TOTAL) & $\begin{array}{l}03 / 14 / 93 \\
03 / 14 / 93 \\
03 / 16 / 93 \\
04 / 19 / 93 \\
04 / 19 / 93\end{array}$ & $\begin{array}{l}\text { N001 } \\
\text { N002 } \\
\text { N003 } \\
\text { N004 } \\
\text { N005 }\end{array}$ & MG/L & $\begin{array}{l}< \\
< \\
< \\
< \\
<\end{array}$ & $\begin{array}{l}0.01 \\
0.01 \\
0.01 \\
0.01 \\
0.01\end{array}$ & * & $\begin{array}{l}0.01 \\
0.01 \\
0.01 \\
0.01 \\
0.01\end{array}$ & $\begin{array}{l}- \\
- \\
- \\
-\end{array}$ \\
\hline ZINC (TOTAL) & $\begin{array}{l}03 / 14 / 93 \\
03 / 14 / 93 \\
03 / 16 / 93 \\
04 / 19 / 93 \\
04 / 19 / 93\end{array}$ & $\begin{array}{l}\text { N001 } \\
\text { N002 } \\
\text { N003 } \\
\text { N004 } \\
\text { N005 }\end{array}$ & $M G / L$ & $\begin{array}{l}< \\
<\end{array}$ & $\begin{array}{l}0.006 \\
0.005 \\
0.031 \\
0.005 \\
0.007\end{array}$ & $\begin{array}{l}J \\
J\end{array}$ & $\begin{array}{l}0.005 \\
0.005 \\
0.005 \\
0.005 \\
0.005\end{array}$ & $\begin{array}{l}- \\
- \\
- \\
-\end{array}$ \\
\hline
\end{tabular}

PARAMETER VALUE INDICATOR (PVI): < - LESS THAN DETECTION LIMIT

SAMPLE ID CODES:

OTHER PARAMETER VALUE FLAGS:

* - DUPLICATE ANALYSIS NOT WITHIN CONTROL LIMITS

$\checkmark$ - ESTIMATED VALUE

NOO1 - UNFILTERED SAMPLE

N002 - UNFILTERED REPLICATE SAMPLE

N003 - UNFILTERED REPL ICATE SAMPLE

N004 - UNFILTERED REPLICATE SAMPLE

NO05 - UNFILTERED REPLICATE SAMPLE

DATA FILE NAME: M: \DARTIRVT01\SWQ10003.DAT 


\begin{tabular}{|c|c|c|c|c|c|c|c|c|c|c|c|c|}
\hline \multirow{3}{*}{$\begin{array}{l}\text { Nork Package } \\
\text { (ID) }\end{array}$} & \multicolumn{2}{|c|}{ Project } & \multicolumn{2}{|c|}{$<-$ Horking $\rightarrow$} & \multicolumn{3}{|c|}{$<-$ Trend Baseline -> } & \multicolumn{5}{|c|}{ 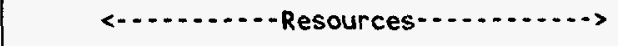 } \\
\hline & Orig & Rem & & & & & & & & Hou & urs & Doll \\
\hline & Dur & Dur & Start & Finish & Start & Finish & Var & Code & Desc. & todt & atcmp & todat \\
\hline
\end{tabular}

S350202-01-T-505 :TAC RESOLVE NRC GEOMORPHIC COMMENTS (350201505,

\$350200-01-T-670E:TAC PREP. FLTSP - CAN (350201670E)

2323 05OCT94 04NOV94

\$350200-01-T-674 :TAC PREP SITE FILE/READINESS REVIEW-BUR (DELETED)

(350201674) 2900 24JAN94A 28AUG94A 22JUN93

$$
29 \text { O 24JAN94A 28AUG94A }
$$

31 MAY94 15JUL94 - 17 ENG ENGINEERING/

$\begin{array}{rrr}0 & 150 & 0 \\ & & \\ 0 & 13 & 7 \\ 1 & 53 & 32 \\ 0 & 18 & 12\end{array}$

S350200-01-T-674C:TAC PREP SITE FILE/READINESS REVIEW-CAN

(350201674C) 66. 66 050CT94 04JAN95

28SEP93

30 JUL93 -394 ENG ENGINEERING/

ENV ENVIRONMENTA

HYD HYDROLOGICAL

$\begin{array}{lll}0 & 0 & 25 \\ 1 & 0 & 54 \\ 0 & 0 & 14\end{array}$
\$350203-01-T-675 :TAC PREPARE \& DELIVER PRELIM SITE FILE
$(350201675)$
$\begin{array}{llllll} & 25 & 01 \text { AUG } 94 & 30 \text { SEP94 } & 01 A U G 94 & 30 \text { SEP9 }\end{array}$

O ENV ENVIRONMENTA

01NOV94 150EC94 D ENG ENGINEERING/

3333 O1NOV94 TSDEC94

S350201-01-T-6T)
(350201675A)

01 NOV94 150EC94

DELIVER FINAL SITE FILE

S350202-01-T-
(350201675A)

$33 \quad 33$ O1NOVO4 15DEC94

S350203-01-T-675A:TAC PREPARE \& DELIVER FINAL SITE FILE (350201675A)
\& DELIVER FINAL SITE FILE
$33 \quad 33$ O1NOV94
01NOV94 15DEC94
O HYD HYDROLOGICAL

0 ENG ENGINEERING/

$\begin{array}{lll}0 & 19 & 3 \\ 0 & 39 & 6 \\ 0 & 10 & 2\end{array}$

$020 \quad 0$

$0 \quad 12 \quad 0$

$0 \quad 40 \quad 0$
$0 \quad 80 \quad 0$ 
SOIL CHEMISTRY DATA BY LOCATION

SITE: RVTO1 RIVERTON

LOCATION: 0741 RESERVED FOR CDAY

NORTH COORDINATE: UNKNOWN

EAST COORDINATE: UNKNOWN

06/08/93 TO 06/09/93

REPORT DATE: 09/06/94

\begin{tabular}{|c|c|c|c|c|c|c|c|c|c|c|}
\hline PARAMETER NAME & LOG DATE & SAMP & $\begin{array}{l}\text { DEPTH RANGE } \\
\text { (FT) }\end{array}$ & $\begin{array}{l}\text { DIG. } \\
\text { CODE }\end{array}$ & $\begin{array}{l}\text { SAMP } \\
\text { DESC }\end{array}$ & $\begin{array}{l}\text { UNITS OF } \\
\text { MEASURE }\end{array}$ & PVI & $\begin{array}{l}\text { PARAMETER } \\
\text { VALUE FLAGS }\end{array}$ & $\begin{array}{l}\text { DETECTION } \\
\text { LIMIT }\end{array}$ & $\begin{array}{l}\text { PARAMETER } \\
\text { UNCERT. }\end{array}$ \\
\hline$\%$ SOLIDS & $\begin{array}{l}06 / 08 / 93 \\
06 / 08 / 93\end{array}$ & $\begin{array}{l}0002 \\
0004\end{array} \mid$ & - & & & $\%$ & & $\begin{array}{l}27.0 \\
80.0\end{array}$ & $\begin{array}{l}0.1 \\
0.1\end{array}$ & - \\
\hline IRON & $\begin{array}{l}06 / 08 / 93 \\
06 / 08 / 93\end{array}$ & $\begin{array}{l}0002 \\
0004\end{array} \mid$ & $\because$ & & & MG/KG & & $\begin{array}{l}10500 . \\
2960 .\end{array}$ & $\begin{array}{l}0.3 \\
0.3\end{array}$ & - \\
\hline LEAD & $\begin{array}{l}06 / 08 / 93 \\
06 / 08 / 93\end{array}$ & $\left|\begin{array}{l}0002 \\
0004\end{array}\right|$ & - & & & MG/KG & & $\begin{array}{r}10.7 \\
3.6\end{array}$ & $\begin{array}{l}0.3 \\
0.3\end{array}$ & $\dot{-}$ \\
\hline MANGANESE & $\begin{array}{l}06 / 08 / 93 \\
06 / 08 / 93\end{array}$ & $\left|\begin{array}{l}0002 \\
0004\end{array}\right|$ & - & & & $M G / K G$ & & $\begin{array}{l}455 . \\
180 .\end{array}$ & 1. & $\ddot{-}$ \\
\hline MOLYYBDENUM & $\begin{array}{l}06 / 08 / 93 \\
06 / 08 / 93\end{array}$ & $\left|\begin{array}{l}0002 \\
0004\end{array}\right|$ & - & & & $M G / K G$ & & 11. & 1. & $\overline{-}$ \\
\hline URANIUM (TOTAL) & $\begin{array}{l}06 / 08 / 93 \\
06 / 08 / 93\end{array}$ & $\left|\begin{array}{l}0002 \\
0004\end{array}\right|$ & - & & & MG/KG & & $\begin{array}{l}7.62 \\
1.94\end{array}$ & $\begin{array}{l}0.001 \\
0.001\end{array}$ & - \\
\hline
\end{tabular}

PARAMETER VALUE INDICATOR (PVI): < - LESS THAN DETECTION LIMIT

SAMPLE DIGESTION TYPE CODES:

SAMPLE DESCRIPTION CODES: 
SOIL CHEMISTRY DATA BY LOCATION

SITE: RVTO1 RIVERTON

OCATION: 0742 RESERVED FOR CDAY

NORTH COORDINATE: UNKNOWI

EAST COORDINATE: UNKNOWM

06/08/93 TO 06/09/93

REPORT DATE: $09 / 06 / 94$

\begin{tabular}{|c|c|c|c|c|c|c|c|c|c|c|}
\hline PARAMETER NAME & LOG DATE & $\begin{array}{c}\text { SAMP } \\
\text { ID }\end{array}$ & $\begin{array}{l}\text { DEPTH RANGE } \\
\text { (FT) }\end{array}$ & $\begin{array}{l}\text { DIG. } \\
\text { CODE }\end{array}$ & $\begin{array}{l}\text { SAMP } \\
\text { DESC }\end{array}$ & $\begin{array}{l}\text { UNITS OF } \\
\text { MEASURE }\end{array}$ & PVI & $\begin{array}{l}\text { PARAMETER } \\
\text { VALUE FLAGS }\end{array}$ & $\begin{array}{l}\text { DETECTION } \\
\text { LIMIT }\end{array}$ & $\begin{array}{l}\text { PARAMETER } \\
\text { UNCERT. }\end{array}$ \\
\hline$\%$ SOLIDS & $06 / 08 / 93$ & 0002 & - & & & $\%$ & & 24.9 & 0.1 & - \\
\hline IRON & $06 / 08 / 93$ & 0002 & - & & & MG/KG & & 21200. & 0.3 & - \\
\hline LEAD & $06 / 08 / 93$ & 0002 & - & & & MG/KG & & 13.6 & 0.3 & - \\
\hline MANGANESE & $06 / 08 / 93$ & 0002 & - & & & MG/KG & & 618. & 1. & - \\
\hline MOLYBDENUM & $06 / 08 / 93$ & 0002 & - & & & $M G / K G$ & $<$ & 4. & 1. & - \\
\hline URANIUM (TOTAL) & $06 / 08 / 93$ & 0002 & - & & & $M G / K G$ & & 10.4 & 0.001 & - \\
\hline
\end{tabular}

PARAMETER VALUE INDICATOR (PVI): < - LESS THAN DETECTION LIMIT

SAMPLE DIGESTION TYPE CODES:

SAMPLE DESCRIPTION CODES: 
SOIL CHEMISTRY DATA BY LOCATIOH

SITE: RVTO1 RIVERTON

LOCATION: 0743 RESERVED FOR CDAY

NORTH COORDINATE: UNKNOWN

EAST COORDINATE: UNKNOWN

06/08/93 TO 06/09/93

REPORT DATE: 09/06/94

\begin{tabular}{|c|c|c|c|c|c|c|c|c|c|c|}
\hline PARAMETER NAME & LOG DATE & $\begin{array}{c}\text { SAMP } \\
\text { ID }\end{array}$ & $\begin{array}{l}\text { DEPTH RANGE } \\
\text { (FT) }\end{array}$ & $\begin{array}{l}\text { DIG. } \\
\text { CODE }\end{array}$ & $\begin{array}{l}\text { SAMP } \\
\text { DESC }\end{array}$ & $\begin{array}{l}\text { UNITS OF } \\
\text { MEASURE }\end{array}$ & PVI & $\begin{array}{l}\text { PARAMETER } \\
\text { VALUE FLAGS }\end{array}$ & $\begin{array}{l}\text { DETECTION } \\
\text { LIMIT }\end{array}$ & $\begin{array}{l}\text { PARAMETER } \\
\text { UNCERT. }\end{array}$ \\
\hline$\%$ SOLIDS & $06 / 09 / 93$ & 0002 & - & & & $\%$ & & 44.7 & 0.1 & - \\
\hline IRON & $06 / 09 / 93$ & 0002 & - & & & $M G / K G$ & & 18000 & 0.3 & - \\
\hline LEAD & $06 / 09 / 93$ & 0002 & - & & & MG/KG & & 21.9 & 0.3 & - \\
\hline MANGANESE & $06 / 09 / 93$ & 0002 & - & & & MG/KG & & 235 . & 1. & - \\
\hline MOLYBDENUM & $06 / 09 / 93$ & 0002 & - & & & $M G / K G$ & & 2. & 1. & - \\
\hline URANIUM (TOTAL) & $06 / 09 / 93$ & 0002 & - & & & MG/KG & & 5.04 & 0.001 & - \\
\hline
\end{tabular}

PARAMETER VALUE INDICATOR (PVI): < - LESS THAN DETECTION LIMIT

SAMPLE DIGESTION TYPE CODES:

SAMPLE DESCRIPTION CODES: 
SOIL CHEMISTRY DATA BY LOCATION

SITE: RVTO1 RIVERTON

LOCATION: 0744 RESERVED FOR CDAY

NORTH COORDINATE: UNKNOWN

EAST COORDINATE: UNKNOWH

06/08/93 TO 06/09/93

REPORT DATE: $09 / 06 / 94$

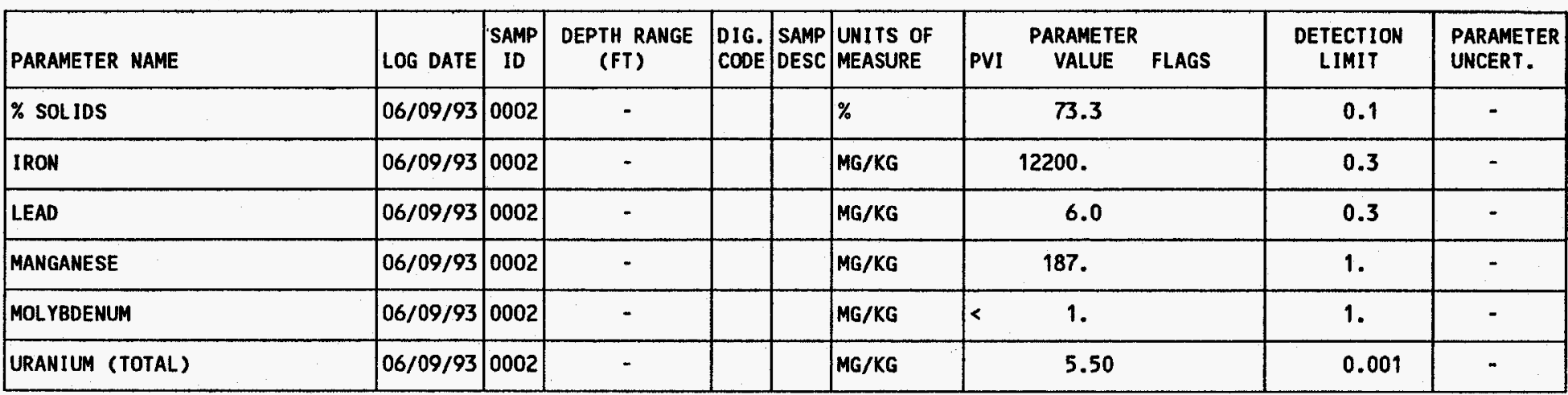

PARAMETER VALUE INDICATOR (PVI): < - LESS THAN DETECTION LIMIT

SAMPLE DIGESTION TYPE CODES:

SAMPLE DESCRIPTION CODES: 
SOIL CHEMISTRY DATA BY LOCATION

SITE: RVT01 RIVERTON

LOCATION: 0745 RESERVED FOR CDAY

NORTH COORDINATE: UNKNOWN

EAST COORDINATE: UNKNOWN

06/08/93 TO 06/09/93

REPORT DATE: 09/06/94

\begin{tabular}{|c|c|c|c|c|c|c|c|c|c|c|}
\hline PARAMETER NAME & LOG DATE & $\begin{array}{l}\text { SAMP } \\
\text { ID }\end{array}$ & $\begin{array}{l}\text { DEPTH RANGE } \\
\text { (FT) }\end{array}$ & $\begin{array}{l}\text { DIG. } \\
\text { CODE }\end{array}$ & $\begin{array}{l}\text { SAMP } \\
\text { DESC }\end{array}$ & $\begin{array}{l}\text { UNITS OF } \\
\text { MEASURE }\end{array}$ & PVI & $\begin{array}{l}\text { PARAMETER } \\
\text { VALUE FLAGS }\end{array}$ & $\begin{array}{l}\text { DETECTION } \\
\text { LIMIT }\end{array}$ & $\begin{array}{l}\text { PARAMETER } \\
\text { UNCERT. }\end{array}$ \\
\hline$\%$ SOLIDS & $06 / 09 / 93$ & 0002 & - & & & $\%$ & & 70.1 & 0.1 & - \\
\hline IRON & $06 / 09 / 93$ & 0002 & - & & & MG/KG & & 3150. & 0.3 & - \\
\hline LEAD & $06 / 09 / 93$ & 0002 & - & & & MG/KG & & 4.8 & 0.3 & - \\
\hline MANGANESE & $06 / 09 / 93$ & 0002 & - & & & MG/KG & & 54. & 1. & - \\
\hline MOL YBDENUM & $06 / 09 / 93$ & 0002 & - & & & MG/KG & & 1. & 1. & - \\
\hline URANIUM (TOTAL) & $06 / 09 / 93$ & 0002 & - & & & $M G / K G$ & & 1.66 & 0.001 & - \\
\hline
\end{tabular}

PARAMETER VALUE INDICATOR (PVI): < - LESS THAN DETECTION LIMIT

SAMPLE DIGESTION TYPE CODES:

SAMPLE DESCRIPTION CODES: 
SOIL CHEMISTRY DATA BY LOCATION

SITE: RVT01 RIVERTON

LOCATION: 0746 RESERVED FOR CDAY

NORTH COORDINATE: UNKNOWN

EAST COORDINATE: UNKNOWN

06/08/93 TO 06/09/93

REPORT DATE: 09/06/94

\begin{tabular}{|c|c|c|c|c|c|c|c|c|c|c|}
\hline PARAMETER NAME & LOG DATE & SAMP & $\begin{array}{l}\text { DEPTH RANGE } \\
\text { (FT) }\end{array}$ & $\begin{array}{l}\text { DIG. } \\
\text { CODE }\end{array}$ & $\begin{array}{l}\text { SAMP } \\
\text { DESC }\end{array}$ & $\begin{array}{l}\text { UNITS OF } \\
\text { MEASURE }\end{array}$ & PVI & $\begin{array}{l}\text { PARAMETER } \\
\text { VALUE FLAGS }\end{array}$ & $\begin{array}{l}\text { DETECTION } \\
\text { LIMIT }\end{array}$ & $\begin{array}{l}\text { PARAMETER } \\
\text { UNCERT. }\end{array}$ \\
\hline$\%$ SOLIDS & $06 / 09 / 93$ & 0002 & - & & & $\%$ & & 22.0 & 0.1 & - \\
\hline IRON & $06 / 09 / 93$ & 0002 & - & & & $M G / K G$ & & 11000. & 0.3 & - \\
\hline LEAD & $06 / 09 / 93$ & 0002 & - & & & MG/KG & & 67.7 & 0.3 & - \\
\hline MANGANESE & $06 / 09 / 93$ & 0002 & - & & & MG/KG & & 314. & 1. & - \\
\hline MOLYYBDENUM & $06 / 09 / 93$ & 0002 & - & & & $M G / K G$ & & 9. & 1. & - \\
\hline URANIUM (TOTAL) & $06 / 09 / 93$ & 0002 & - & & & MG/KG & & 11.3 & 0.001 & - \\
\hline
\end{tabular}

PARAMETER VALUE INDICATOR (PVI)

< - LESS THAN DETECTION LIMIT

SAMPLE DIGESTION TYPE CODES:

SAMPLE DESCRIPTION CODES: 
SOIL CHEMISTRY DATA BY LOCATION

SITE: RVT01 RIVERTON

LOCATION: 0794

NORTH COORDINATE: UNKNOWN

EAST COORDINATE: UNKNOWN

06/08/93 TO 06/09/93

REPORT DATE: $09 / 06 / 94$

\begin{tabular}{|c|c|c|c|c|c|c|c|c|c|c|}
\hline PARAMETER NAME & LOG DATE & $\begin{array}{c}\text { SAMP } \\
\text { ID }\end{array}$ & $\begin{array}{l}\text { DEPTH RANGE } \\
\text { (FT) }\end{array}$ & $\begin{array}{l}\text { DIG. } \\
\text { CODE }\end{array}$ & $\begin{array}{l}\text { SAMP } \\
\text { DESC }\end{array}$ & $\begin{array}{l}\text { UNITS OF } \\
\text { MEASURE }\end{array}$ & PVI & $\begin{array}{l}\text { PARAMETER } \\
\text { VALUE FLAGS }\end{array}$ & $\begin{array}{l}\text { DETECTION } \\
\text { LIMIT }\end{array}$ & $\begin{array}{l}\text { PARAMETER } \\
\text { UNCERT. }\end{array}$ \\
\hline$\%$ SOLIDS & $06 / 09 / 93$ & 0002 & - & & & $\%$ & & 75.6 & 0.1 & - \\
\hline IRON & $06 / 09 / 93$ & 0002 & - & & & $M G / K G$ & & 5860. & 0.3 & - \\
\hline LEAD & $06 / 09 / 93$ & 0002 & - & & & MG/KG & & 4.5 & 0.3 & . \\
\hline MANGANESE & $06 / 09 / 93$ & 0002 & - & & & $M G / K G$ & & 167. & 1. & - \\
\hline MOLYYBDENUM & $06 / 09 / 93$ & 0002 & - & & & MG/KG & $<$ & 1. & 1. & . \\
\hline URANIUM (TOTAL) & |06/09/93 & $|0002|$ & - & & & MG/KG & & 2.03 & 0.001 & - \\
\hline
\end{tabular}

PARAMETER VALUE INDICATOR (PVI): < - LESS THAN DETECTION LIMIT

SAMPLE DIGESTION TYPE CODES:

SAMPLE DESCRIPTION CODES: 
SOIL CHEMISTRY DATA BY LOCATION

SITE: RVTO1 RIVERTON

LOCATION: 0796

NORTH COORDINATE: UNKNOWN

EAST COORDINATE: UNKNOWN

06/08/93 TO 06/09/93

REPORT DATE: 09/06/94

\begin{tabular}{|c|c|c|c|c|c|c|c|c|c|c|}
\hline PARAMETER NAME & LOG DATE & SAMP & $\begin{array}{l}\text { DEPTH RANGE } \\
\text { (FT) }\end{array}$ & $\begin{array}{l}\text { DIG. } \\
\text { CODE }\end{array}$ & SAMP & $\begin{array}{l}\text { UNITS OF } \\
\text { MEASURE }\end{array}$ & PVI & $\begin{array}{l}\text { PARAMETER } \\
\text { VALUE FLAGS }\end{array}$ & $\begin{array}{l}\text { DETECTION } \\
\text { LIMIT }\end{array}$ & $\begin{array}{l}\text { PARAMETER } \\
\text { UNCERT. }\end{array}$ \\
\hline$\%$ SOLIDS & $06 / 09 / 93$ & 0002 & - & & & $\%$ & & 74.1 & 0.1 & $\cdot$ \\
\hline IRON & $06 / 09 / 93$ & 0002 & - & & & MG/KG & & 8530. & 0.3 & - \\
\hline LEAD & $06 / 09 / 93$ & $0002\}$ & - & & & MG/KG & & 3.9 & 0.3 & - \\
\hline MANGANESE & $06 / 09 / 93$ & 0002 & - & & & MG/KG & & 214. & 1. & $\cdot$ \\
\hline MOLYBDEENUM & $06 / 09 / 93$ & 0002 & - & & & MG/KG & & 4. & 1. & - \\
\hline URANIUM (TOTAL) & $06 / 09 / 93$ & 0002 & - & & & MG/KG & & 2.32 & 0.001 & - \\
\hline
\end{tabular}

PARAMETER VALUE INDICATOR (PVI)

< - LESS THAN DETECTION LIMIT

SAMPLE DIGESTION TYPE CODES

SAMPLE DESCRIPTION COOES:

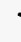

DATA FILE NAME: M: IDARTIRVTO1ISCI10000.DAT 